\title{
ALLIED SOCIAL SCIENCE ASSOCIATIONS
}

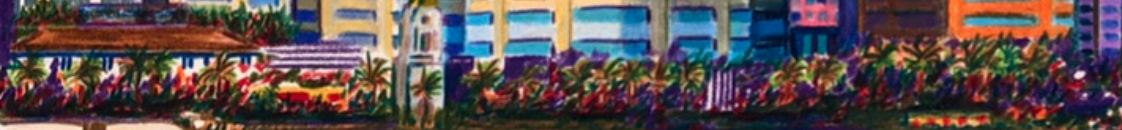

$$
\text { 2) } 20
$$
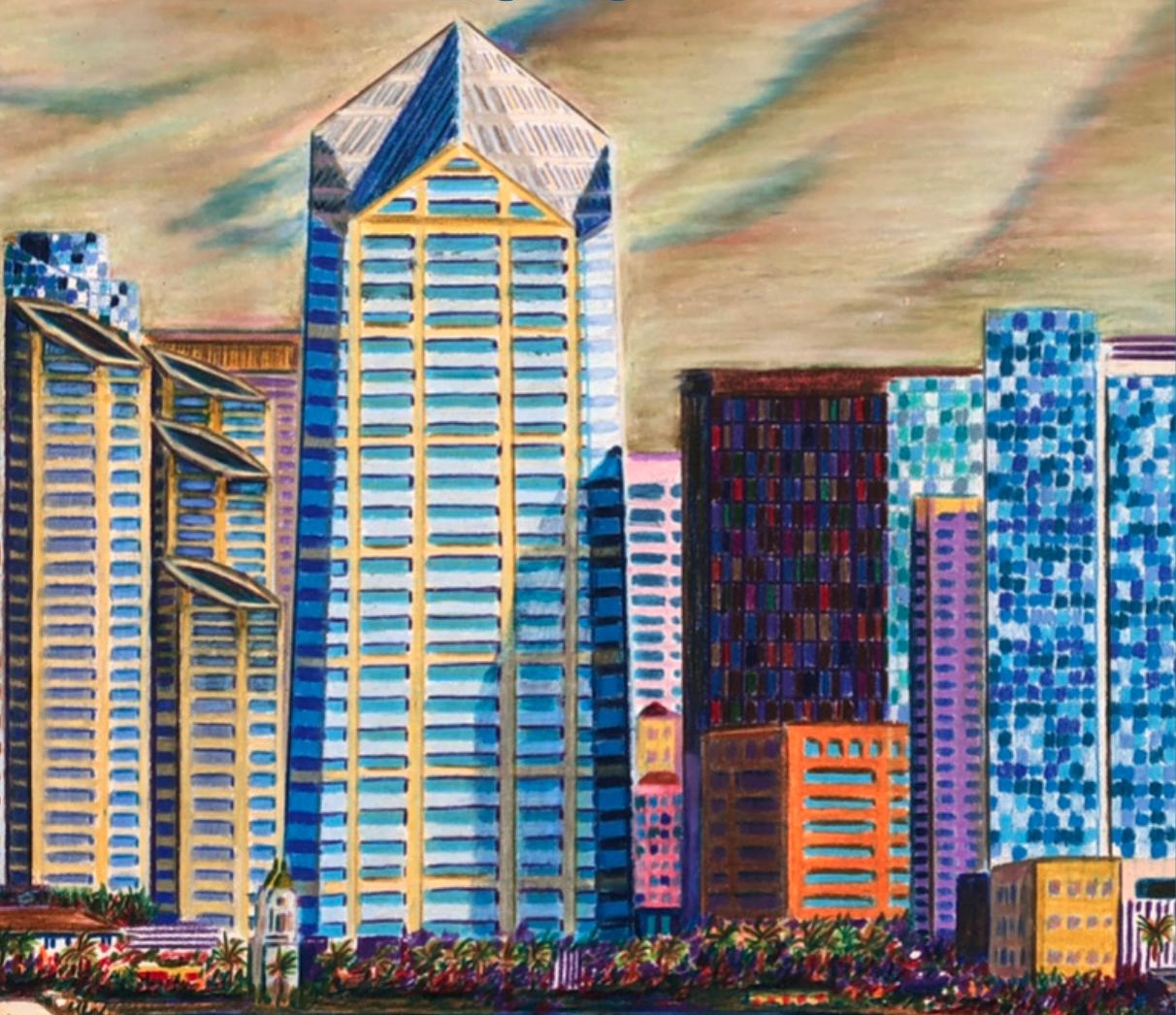
toraces 2. $x^{2}+10$ 325 


\section{Congratulations
to the}

American Economic Association's

2019 Distinquished Fellows:

Olisier Blanchard

Oliver Hart

Edward Lazear

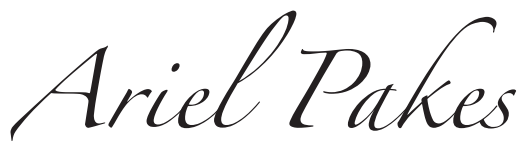

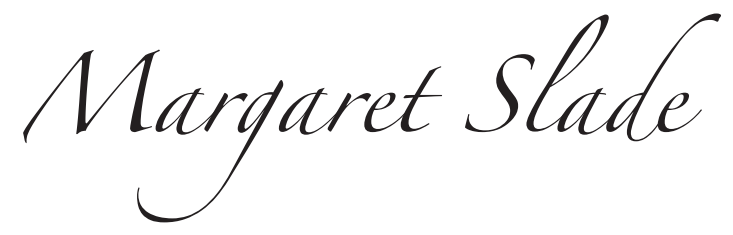

Presentations on January 4, 4:40 PM,

Marriott Marquis San Diego,

Marriott Grand Ballroom 7 - 8 - 9 


\section{Allied Social Science Associations Program}

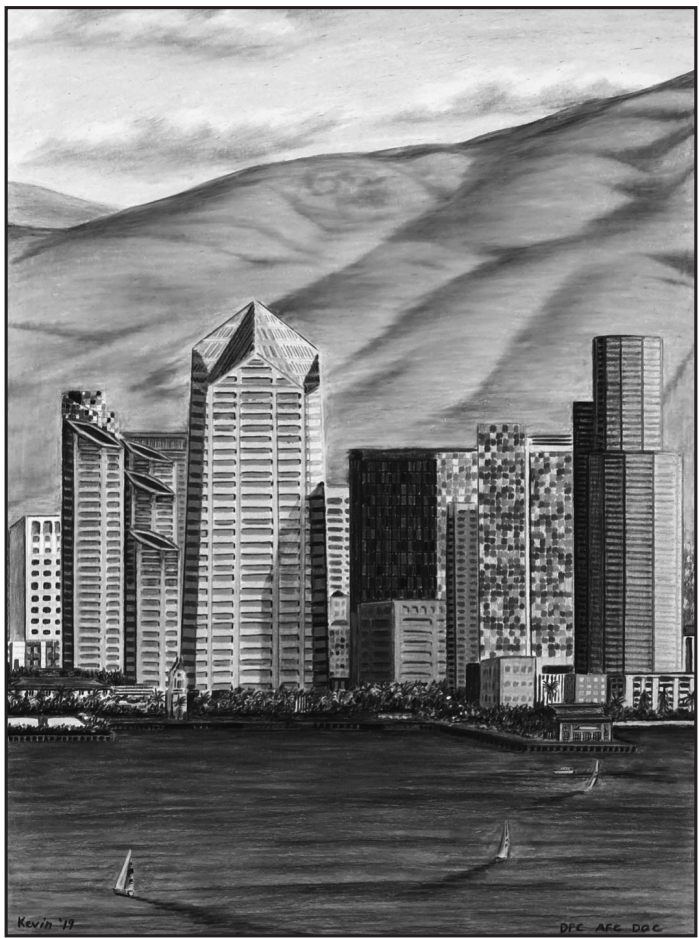

\section{San Diego, CA January 3-5, 2020}

Contract negotiations, management, and meeting arrangements for ASSA meetings are conducted by the American Economic Association. Participants should be aware that the media has open access to all sessions and events at the meetings. 


\title{
Thanks to the 2020 American Economic Association Program Committee Members
}

\author{
Janet Yellen, Chair \\ Joseph Aldy \\ Martha Bailey \\ Leah Boustan \\ Yan Chen \\ Karen Dynan \\ Kristin Forbes \\ Paola Giuliano \\ Rebecca Henderson \\ Lawrence Katz \\ Laurence Kotlikoff \\ Niko Matouschek \\ Andrew Metrick \\ Edward Miguel \\ Dani Rodrik \\ David Romer \\ Fiona Scott Morton \\ Tavneet Suri
}

Cover Art-“San Diego Skyline with Mountains" by Kevin E. Cahill (Colored Pencil, 15" x 20"). Kevin is a partner at ECONorthwest and a research economist at the Center on Aging \& Work at Boston College.

Kevin invites you to visit his personal website at www.kcahillstudios.com. 


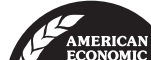 \\ ECONOMIC
ASSOCIATION \\ e \\ ( \\ AEA Code of Professional Conduct}

\section{Adopted April 20, 2018}

The American Economic Association holds that principles of professional conduct should guide economists in academia, government, nonprofit organizations, and the private sector.

The AEA's founding purpose of "the encouragement of economic research" requires intellectual and professional integrity. Integrity demands honesty, care, and transparency in conducting and presenting research; disinterested assessment of ideas; acknowledgement of limits of expertise; and disclosure of real and perceived conflicts of interest.

The AEA encourages the "perfect freedom of economic discussion." This goal requires an environment where all can freely participate and where each idea is considered on its own merits. Economists have a professional obligation to conduct civil and respectful discourse in all forums, including those that allow confidential or anonymous participation.

The AEA seeks to create a professional environment with equal opportunity and fair treatment for all economists, regardless of age, sex, gender identity and expression, race, ethnicity, national origin, religion, sexual orientation, disability, health condition, marital status, parental status, genetic information, political affiliation, professional status, or personal connections.

Economists have both an individual responsibility for their own conduct, and a collective responsibility to promote professional conduct. These responsibilities include developing institutional arrangements and a professional environment that promote free expression concerning economics. These responsibilities also include supporting participation and advancement in the economics profession by individuals from all backgrounds, including particularly those that have been historically underrepresented.

The AEA strives to promote these principles through its activities. 


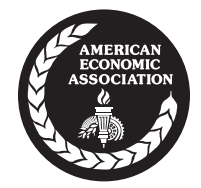

\section{AEA Policy on Harassment and Discrimination}

The AEA does not tolerate harassment or discrimination in any of its activities. Unacceptable behavior includes, but is not limited to:

- Solicitation of emotional or physical intimacy despite expressions or indications that it is unwelcome

- Solicitation of emotional or physical intimacy accompanied by real or implied threat of personal or professional harm

- Intentionally intimidating, threatening, harassing, or abusive actions or remarks (both spoken and in other media)

- Prejudicial actions or comments that undermine the principles of equal opportunity, fair treatment, or free academic exchange

- Deliberate intimidation, stalking, or following

- Harassing photography or recording

- Sustained or aggressive disruption of talks or other activities that undermine free academic exchange

- Physical assault (including unwelcome touching or groping)

- Real or implied threat of physical harm

Individuals violating this policy may be subject to disciplinary action. The AEA reserves the right to take such actions including, but not limited to, removing an individual from an AEA activity without warning, prohibiting an individual from participating in any future AEA activities, terminating an individual's AEA membership, and notifying an individual's employer. Retaliation against any person who files a complaint, or assists in the investigation of such a complaint, is also a violation of this policy and may likewise be subject to disciplinary action.

The AEA views it as the responsibility of each individual member to be proactive in helping to mitigate or avoid harm when the member witnesses any unacceptable behavior. 


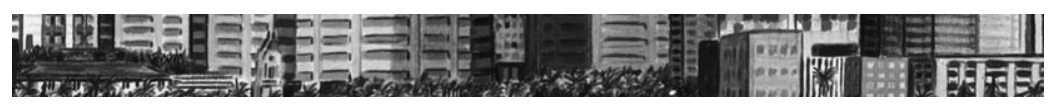

\section{Contents}

General Information. . . . . . . . . . . . . vi

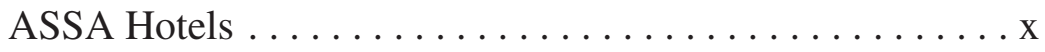

Listing of Advertisers and Exhibitors $\ldots \ldots \ldots \ldots$ xxvi

ASSA Executive Officers................ xxviii

Summary of Sessions by Organization .......... xxxii

Daily Program of Events $\ldots \ldots \ldots \ldots \ldots \ldots \ldots$

AEA Poster Session . . . . . . . . . . . . . . . . . . . . . 29

Program of Sessions

Thursday, January $2 \ldots \ldots \ldots \ldots \ldots \ldots \ldots$

Friday, January $3 \ldots \ldots \ldots \ldots \ldots \ldots \ldots$

Saturday, January 4 . . . . . . . . . . . . . 172

Sunday, January $5 \ldots \ldots \ldots \ldots \ldots \ldots$

Subject Area Index...................... 402

Index of Participants ................... 406 


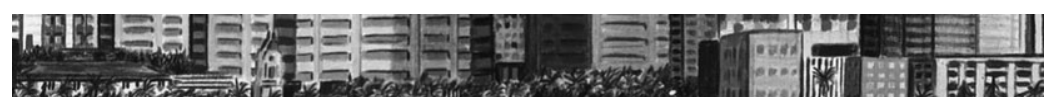

\section{General Information}

\section{PROGRAM SCHEDULES}

A listing of sessions where papers will be presented and another covering activities such as business meetings and receptions are provided in this program. Admittance is limited to those wearing badges. Each listing is arranged chronologically by date and time of the activity. The hotel and room location for each session and function are indicated.

\section{CONVENTION FACILITIES}

Thirty-three hotels are being used for housing. The $\$ 30$ per night premium for the headquarters hotel is rebated to ASSA to help cover the cost of the meetings. Sessions and other convention functions are in the San Diego Marriott Marquis and Marina (headquarters hotel) and the Manchester Grand Hyatt San Diego (co-headquarters hotel). A map of San Diego indicating the locations of the hotels, an alphabetical listing of function rooms within the hotels, and hotel floor plans are in the next section of this book.

Registration and Exhibits are located in the San Diego Marriott Marquis and Marina (headquarters hotel), North Tower, First Floor, Pacific Ballroom. The Interview Tables are located at the Manchester Grand Hyatt San Diego Grand Hall A-C.

\section{REGISTRATION}

Everyone must register including speakers, discussants, and administrators who will be occupying an ASSA hotel room at the convention rate. Identification badges are required for admission to all sessions and activities. On-site and pre-registrants may pick up their registration packets in the San Diego Marriott Marquis and Marina (headquarters hotel), North Tower, First Floor, Pacific Ballroom 14-17. On-site registration fee is $\$ 145$. Full time student registration fee is $\$ 75$. Pre-registration and on-site registration booths are open as follows:

Thursday, January 2
Friday, January 3
Saturday, January 4
Sunday, January 5

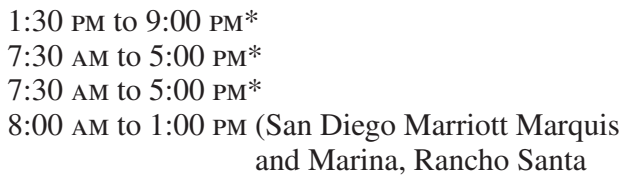

*On-site registration line closes fifteen minutes prior to closing each day.

\section{SPOUSES}

There is no spouse program. Spouses wishing to attend any of the meetings may register as a guest for $\$ 75$. If your spouse needs an affiliation on his/her badge, he/she must register separately and pay the full fee. 


\section{JOB INTERVIEW TABLES}

Interview tables are located in the Manchester Grand Hyatt San Diego, Grand Hall A-C. Hours are January 2-5, from 8:00 AM to 5:00 PM. Everyone admitted to the interviewing tables (including interviewers) must register. Any and all correspondence should take place using email, including interview scheduling, prior to your arrival in San Diego. However, on-site contact can be conducted by using the ASSA on-line hotel directory available at www.vanderbilt.edu/AEA and click on Annual Meeting, or you may download the mobile app. You may also check with the Disclosure Code Booth at the San Diego Marriott Marquis and Marina (headquarters hotel), North Tower, First Floor, Pacific Ballroom 14-17 or in the Manchester Grand Hyatt San Diego, Grand Hall A-C. ASSA does not provide computers on-site.

\section{EXHIBITS}

Exhibits are located in the San Diego Marriott Marquis and Marina (headquarters hotel), North Tower, First Floor, Pacific Ballroom 18-23. The Exhibit area may be visited during the following hours:

$\begin{array}{ll}\text { Friday, January } 3 & 9: 00 \text { AM to 6:00 PM } \\ \text { Saturday, January 4 } & \text { 9:00 AM to 6:00 PM } \\ \text { Sunday, January 5 } & 9: 00 \text { AM to 1:00 PM }\end{array}$

\section{ASSA INFORMATION CENTERS}

The ASSA Information Center is located in the San Diego Marriott Marquis and Marina (headquarters hotel), North Tower, First Floor, Pacific Ballroom 14-17 and is open during the following hours:

$\begin{array}{ll}\text { Thursday, January } 2 & \text { 1:30 PM to 9:00 PM } \\ \text { Friday, January 3 } & \text { 8:00 AM to 5:00 PM } \\ \text { Saturday, January 4 } & \text { 8:00 AM to 5:00 PM } \\ \text { Sunday, January 5 } & \text { 8:00 AM to 2:00 PM }\end{array}$

The number to call is 619-645-6972.

An Information Desk is also located in the Manchester Grand Hyatt San Diego, Second Level, Seaport Foyer. The information table is open Thursday, 2:00 PM until 5:00 PM, Friday and Saturday from 8:00 AM until 4:00 PM and on Sunday from 8:00 AM until 1:00 PM.

\section{FEE AND INVITATION EVENTS}

The "Daily Program of Events" section of this program lists fee and invitation events, membership meetings, and other social functions in chronological order. Events for which a fee is charged or which may be attended by invitation only are noted. Tickets were sold to the following open events:

AEA/AFA Joint Luncheon

ASE Presidential Breakfast
Friday, January 3, 12:30 PM

San Diego Marriott Marquis and Marina, North Tower, Second Floor, Grand Ballroom 7-9

Saturday, January 4, 7:45 AM

Manchester Grand Hyatt San Diego, Fourth

Level, Coronado Ballroom D 
AEA Luncheon Honoring the 2018 Nobel Laureate

AREUEA Presidential Luncheon
Saturday, January 4, 12:30 PM

San Diego Marriott Marquis and Marina,

North Tower, Second Floor, Grand Ballroom 7-9

Saturday, January 4, 12:30 PM

Manchester Grand Hyatt San Diego, Fourth

Level, Coronado Ballroom AB

Tickets to each of these events were ordered on the pre-registration form. Tickets may be available at the door if an event is not sold out.

\section{CONVENTION STAFF HEADQUARTERS}

Headquarters for the ASSA Convention is located in the San Diego Marriott Marquis and Marina, North Tower, Second Floor, Rancho Santa Fe 1. The hours of operation are:

\author{
Thursday, January 2 \\ Friday, January 3 \\ Saturday, January 4 \\ Sunday, January 5
}

$$
\begin{aligned}
& \text { 2:00 PM to } 5: 00 \mathrm{PM} \\
& \text { 7:30 AM to 5:00 PM } \\
& \text { 7:30 AM to 5:00 PM } \\
& \text { 7:30 AM to } 1: 00 \mathrm{PM}
\end{aligned}
$$

Headquarters staff should be alerted to any problems associated with the operation of the convention. Special notices concerning the program and room changes will be posted there. To reach Convention Headquarters by phone call 619-645-6990.

\section{PRESS}

Press Registration is located at the San Diego Marriott Marquis and Marina, North Tower, Second Floor, Rancho Santa Fe 1. Press Registration is open during the following hours:

$\begin{array}{ll}\text { Thursday, January } 2 & \text { 2:00 PM to 5:00 PM } \\ \text { Friday, January 3 } & \text { 7:30 AM to 5:00 PM } \\ \text { Saturday, January 4 } & \text { 7:30 AM to 5:00 PM } \\ \text { Sunday, January 5 } & \text { 7:30 AM to } 12: 00 \text { NOON }\end{array}$

\section{BUSINESS CENTERS}

San Diego Marriott Marquis

Manchester Grand Hyatt

Hilton San Diego Bayfront

Omni San Diego Hotel

The Westin San Diego
Lobby Level

Lobby Level

3rd Floor, Aqua Level

4th Floor

3rd Floor
M-F 7AM-7PM; Sat-Sun 9AM-5PM $7 \mathrm{AM}-7 \mathrm{PM}$

M-F 7AM-7PM; Sat-Sun 8AM-4PM

M-F 8AM-4PM; Sat-Sun 8AM-2PM

24 hours

All other hotels in the room block have business centers located on the Lobby Level and are 24 hours. Above hours are subject to change. 


\section{DISCLOSURE CODES}

The Disclosure Code Information Booths are located in the San Diego Marriott Marquis and Marina (headquarters hotel), North Tower, First Floor, Pacific Ballroom 14-17 and the Manchester Grand Hyatt San Diego, Grand Hall A-C. You must know the disclosure code to obtain the room/suite number, those were distributed by employers. You will find all the information about disclosure codes on the AEA website at www.AEAweb.org, click on Annual Meeting, Disclosure Code Information.

\section{CHILDREN'S PROGRAM}

KiddieCorp will provide a professional children's program at the San Diego Marriott Marquis and Marina (headquarters hotel), South Tower, First Floor, Oceanside/Leucadia. KiddieCorp has been in business since 1986. Team members are qualified child care specialists.

\section{MOTHER'S NURSING ROOM}

There is a mother's nursing room available at the San Diego Marriott Marquis and Marina (headquarters hotel), South Tower, First Floor, Laguna.

\section{SHUTTLE}

ASSA will run several shuttle routes to facilitate the job market and those hotels not within walking distance from the San Diego Marriott Marquis and Marina.

\section{LOST AND FOUND}

Lost and found can be reached through the hotel operator in each hotel. If you lose an item while in the San Diego Marriott Marquis and Marina also check in the Headquarters Office located in San Diego Marriott Marquis and Marina, North Tower, Second Floor, Rancho Santa Fe 1.

NOTE: Any inquiry regarding a disputed payment should be addressed to assa@vanderbilt.edu. 


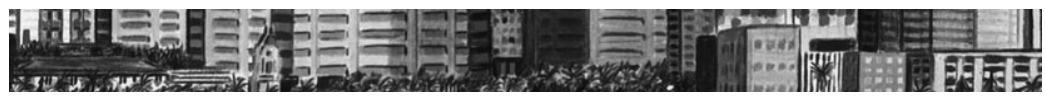 ASSA Hotels}

San Diego Marriott Marquis and Marina (HQ)

333 W Harbor Drive, 92101

(619) 234-1500

Manchester Grand Hyatt San Diego (co-HQ) 1 Market Place, 92101

(619) 232-1234

Andaz San Diego

600 F Street, 92101

(619) 849-1234

Courtyard by Marriott San Diego

Downtown

530 Broadway, 92101

(619) 446-3000

Courtyard by Marriott San Diego Gaslamp/

Convention Center

453 Sixth Avenue, 92101

(619) 544-1004

Embassy Suites San Diego Bay Downtown 601 Pacific Highway, 92101

(619) 239-2400

Four Points by Sheraton San Diego

Downtown Little Italy

1617 First Avenue, 92101

(619) 239-9600

Hampton Inn San Diego Downtown

1531 Pacific Highway, 92101

(619) 233-8408

Hard Rock Hotel

207 Fifth Avenue, 92101

(619) 702-3000

Hilton Garden Inn Downtown/Bayside 2137 Pacific Highway Suite A, 92101 (619) 696-6300
Hilton San Diego Bayfront

One Park Boulevard, 92101

(619) 564-3333

Homewood Suites Downtown/Bayside

2137 Pacific Highway Suite B, 92101

(619) 696-7000

Horton Grand Hotel

311 Island Avenue, 92101

(619) 544-1886

Hotel Indigo San Diego Gaslamp Quarter 509 Ninth Avenue, 92101

(619) 727-4000

Hotel Republic (formerly W San Diego)

421 W B Street, 92101

(619) 398-3100

Kimpton Solamar Hotel

435 Sixth Avenue, 92101

(619) 819-9500

Hotel Z Gaslamp Quarter

521 Sixth Avenue 92101

(619) 330-6401

Omni San Diego

675 L Street, 92101

(619) 231-6664

Palomar San Diego

1047 Fifth Avenue, 92101

(619) 515-3000

Pendry San Diego

550 J Street, 92101

(619) 738-7000

Porto Vista Hotel

1835 Columbia Street, 92101

(619) 544-0164 
Residence Inn San Diego Downtown/ Bayfront

900 Bayfront Court, 92101

(619) 831-0225

Residence Inn San Diego Gaslamp

356 Sixth Avenue, 92101

(619) 487-1200

San Diego Marriott Gaslamp Quarter 660 K Street, 92101

(619) 696-0234

Sheraton San Diego Hotel \& Marina 1380 Harbor Island Drive, 92101

(619) 291-2900

SpringHill Suites by Marriott San Diego Downtown/Bayfront

900 Bayfront Court, 92101

(619) 831-0224
The Bristol Hotel

1055 First Avenue, 92101

(619) 232-6141

The US Grant

326 Broadway, 92101

(619) 232-3121

The Westin San Diego Gaslamp Quarter 910 Broadway Circle, 92101

(619) 239-2200

Westin San Diego

400 W Broadway, 92101

(619) 239-4500

Wyndham San Diego Bayside 1355 N Harbor Drive, 92101

(619) 232-3861 


\section{San Diego}

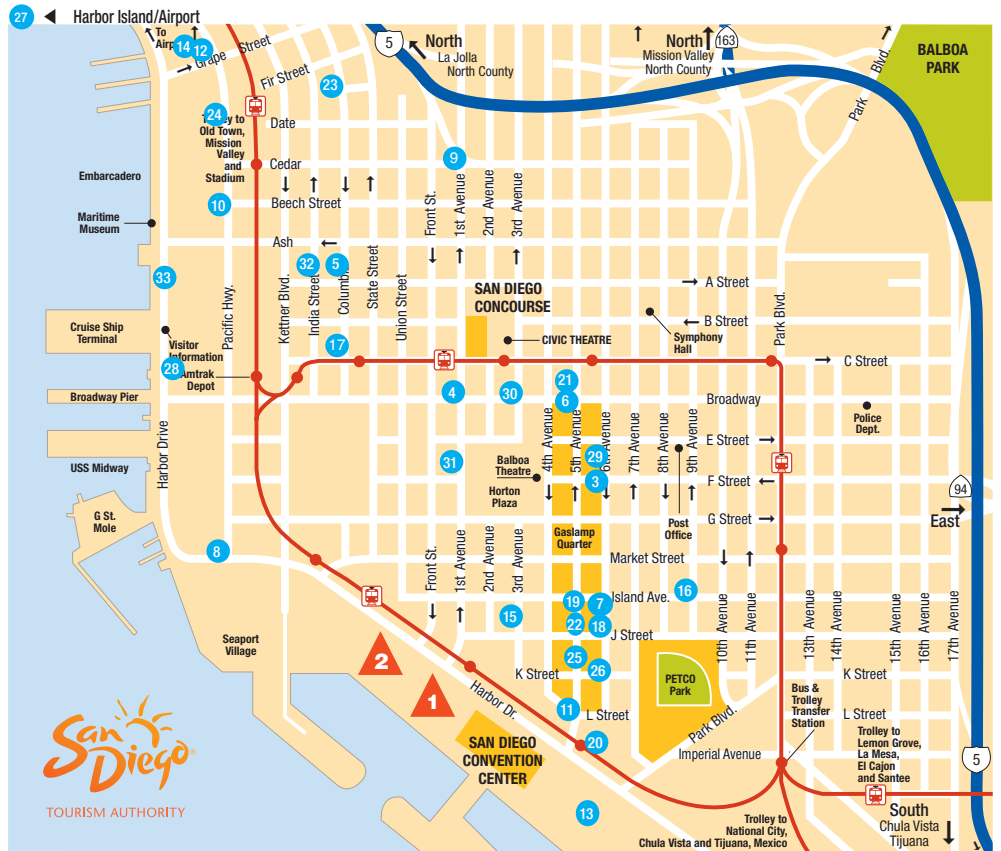

\begin{tabular}{|c|}
\hline Andaz San Diego \\
\hline Bristol Hotel \\
\hline Carté Hotel \\
\hline Courtyard By Marriott San Diego Downtown \\
\hline Courtyard San Diego Gaslamp \\
\hline Embassy Suites \\
\hline Four Points (originally Holiday Inn Downtown) \\
\hline Hampton Inn San Diego \\
\hline Hard Rock Hotel San Diego \\
\hline Hilton Garden Inn San Diego Downtown/Bayside \\
\hline Hilton San Diego Bayfront Hotel \\
\hline Homewood Suites San Diego Downtown Bayside \\
\hline Horton Grand Hotel \\
\hline Hotel Indigo - San Diego Gaslamp Quarter \\
\hline
\end{tabular}
(17) Hotel Republic
18 Hotel Solamar San Diego, a Kimpton Hotel
(19) Hotel Z Gaslamp San Diego
20 Omni San Diego Hotel
21 Palomar San Diego, a Kimpton Hotel
(22) Pendry
23 Porto Vista Hotel
24. Residence Inn San Diego DowntownBayfront
25 Residence Inn San Diego Downtown/Gaslamp Quarter
26 San Diego Marriott Gaslamp Quarter
(27) Sheraton SD Hotel \& Marina
28 SpringHill Suites Downtown/Bayfront
29 The Moxy
30 THE US GRANT - A Luxury Collection Hotel
(31) The Westin Gaslamp Quarter San Diego
(32) The Westin San Diego
(33) Wyndham San Diego Bayside

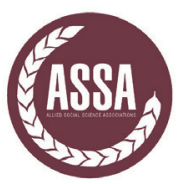




\section{SAN DIEGO MARRIOTT MARQUIS AND MARINA}

Meeting Facilities

\section{ROOM}

Balboa City View

Cardiff Water View

Carlsbad Water View

Catalina Water View

Coronado

Del Mar Water View

Grand Ballroom Foyer $\&$ West Lobby Lounge

La Costa Water View

Laguna Pool View

Leucadia/Oceanside Pool View

Malibu City View

Marina Ballroom D-G

Marriott Grand Ballroom 1-13

Mission Hills City View

Newport Beach Water View

Pacific Ballroom

Point Loma Pool View

Presidio 1-2

Rancho Santa Fe 2

San Diego Ballroom A-C

Santa Rosa

Solana Pool View

Torrey Pines 1-3

Vista

\section{LEVEL}

Floor 3, South Tower

Floor 3, South Tower

Floor 3, South Tower

Floor 4, South Tower

Floor 4, South Tower

Floor 3, South Tower

Lobby level, North Tower

Floor 4, South Tower

Floor 1, South Tower

Floor 1, South Tower

Floor 4, South Tower

Floor 3, South Tower

Lobby level, North Tower

Floor 3, South Tower

Floor 4, South Tower

Floor 1, North Tower

Floor 1, South Tower

Lobby level, North Tower

Lobby level, North Tower

Lobby level, North Tower

Floor 1, South Tower

Floor 1, South Tower

Lobby level, North Tower

Floor 1, South Tower

\section{FUNCTION}

Sessions and Events

Sessions and Events

Sessions and Events

Sessions and Events

Sessions and Events

Sessions and Events

Poster Session

Sessions and Events

Mother's Room

KiddieCorp

Sessions

Sessions and Events

Sessions and Events

Sessions and Events

Sessions and Events

Registration \&

Exhibits \& Info

Sessions and Events

Sessions and Events

Sessions and Events

Sessions and Events Sessions and Events Sessions and Events Sessions and Events Sessions and Events 


\section{SAN DIEGO MARRIOTT MARQUIS AND MARINA}
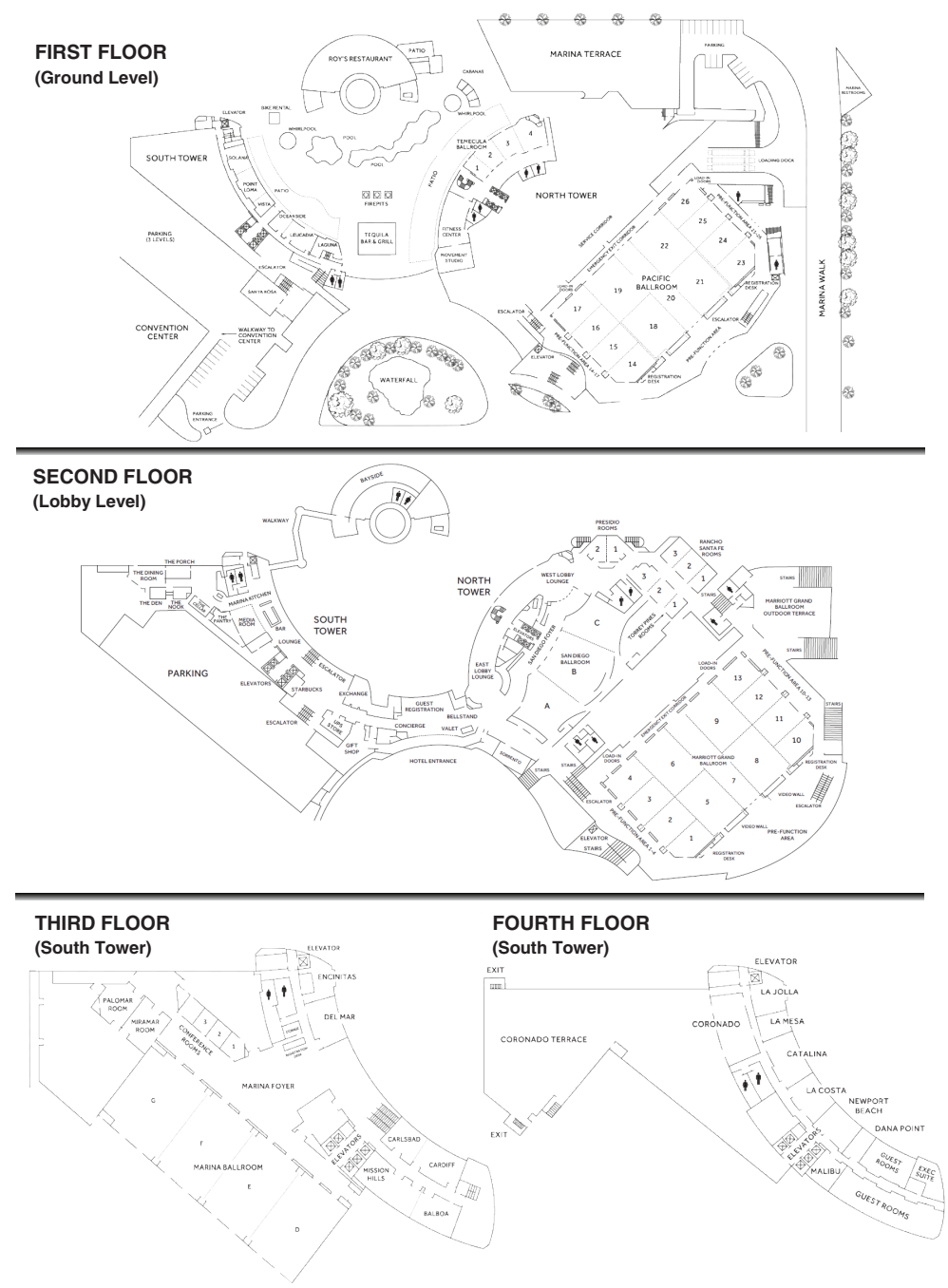


\section{SAN DIEGO MARRIOTT MARQUIS AND MARINA FIRST FLOOR (Ground Level)}

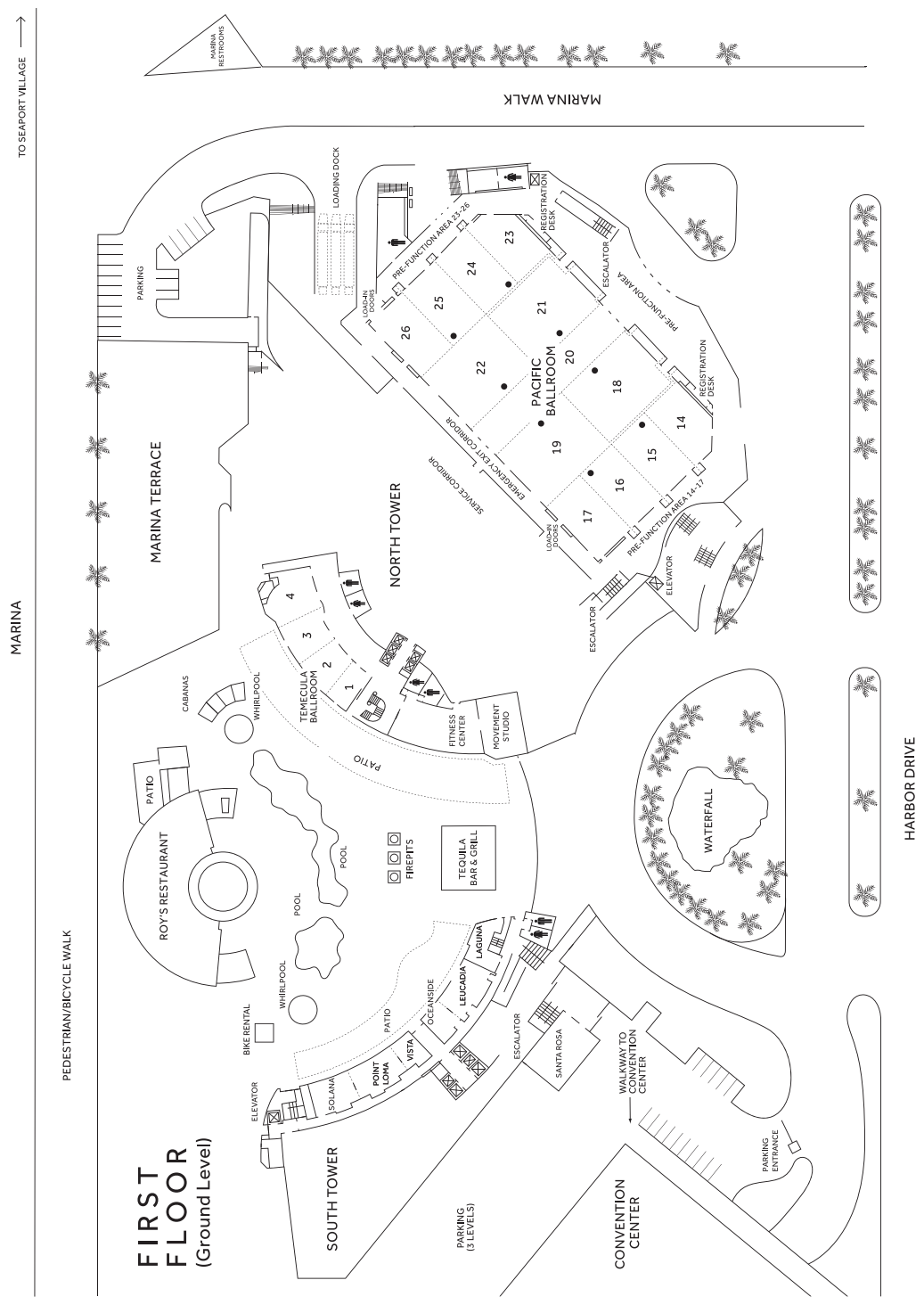




\section{SAN DIEGO MARRIOTT MARQUIS AND MARINA SECOND FLOOR (Lobby Level)}

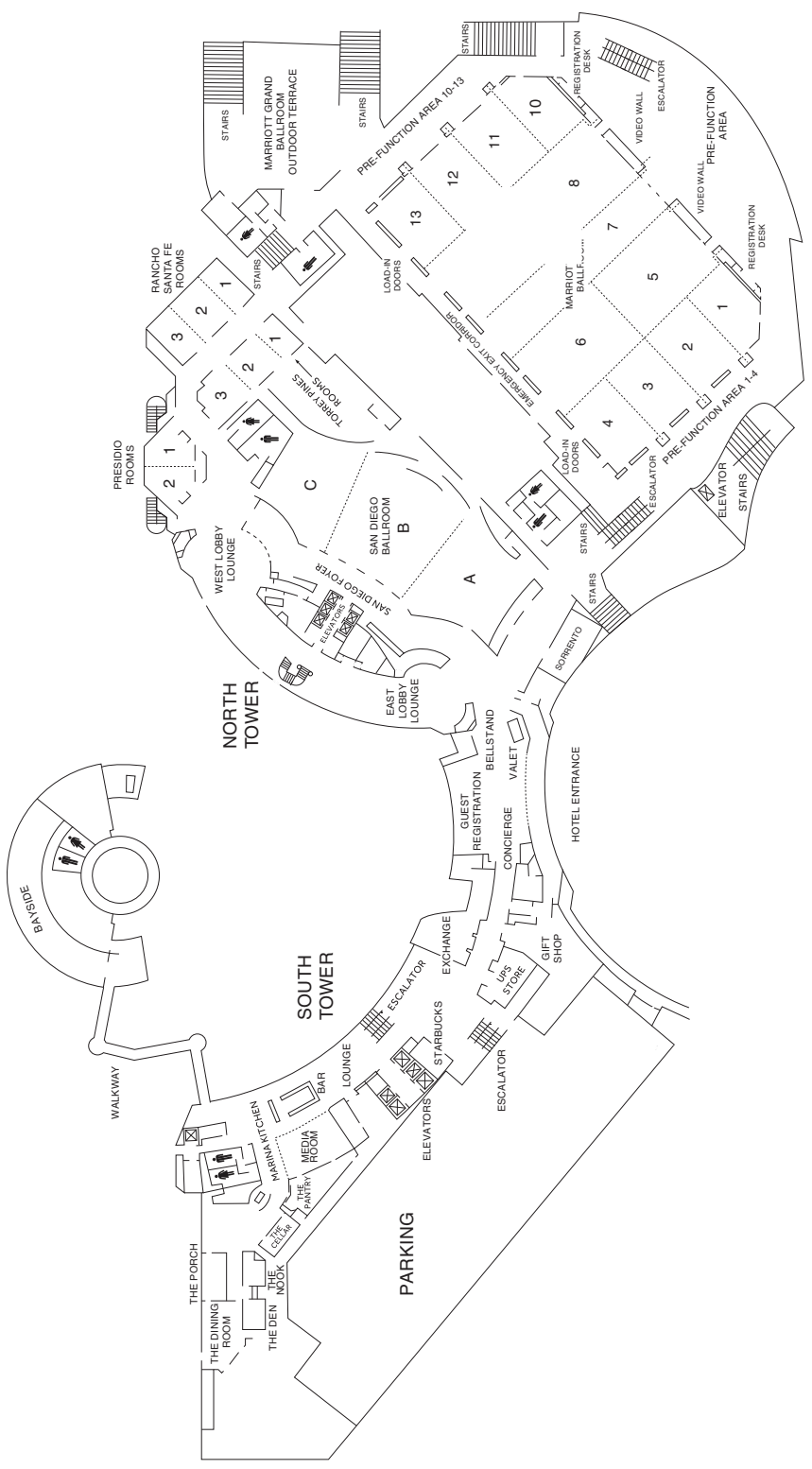




\section{SAN DIEGO MARRIOTT MARQUIS AND MARINA THIRD FLOOR (South Tower)}

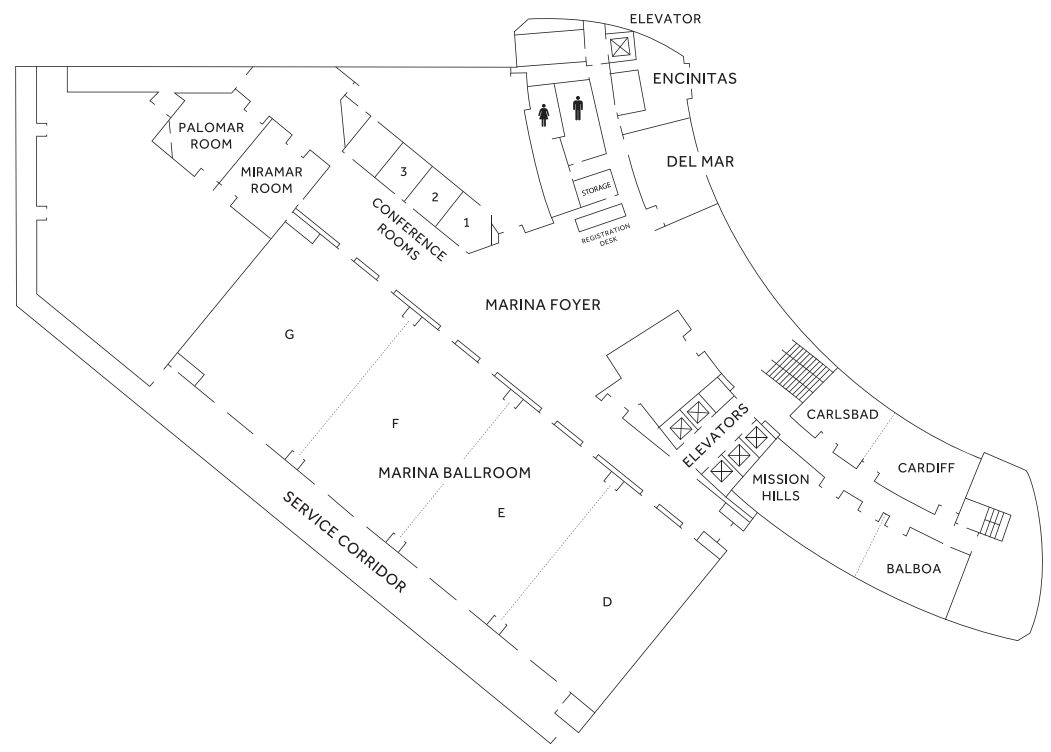




\section{SAN DIEGO MARRIOTT MARQUIS AND MARINA FOURTH FLOOR (South Tower)}

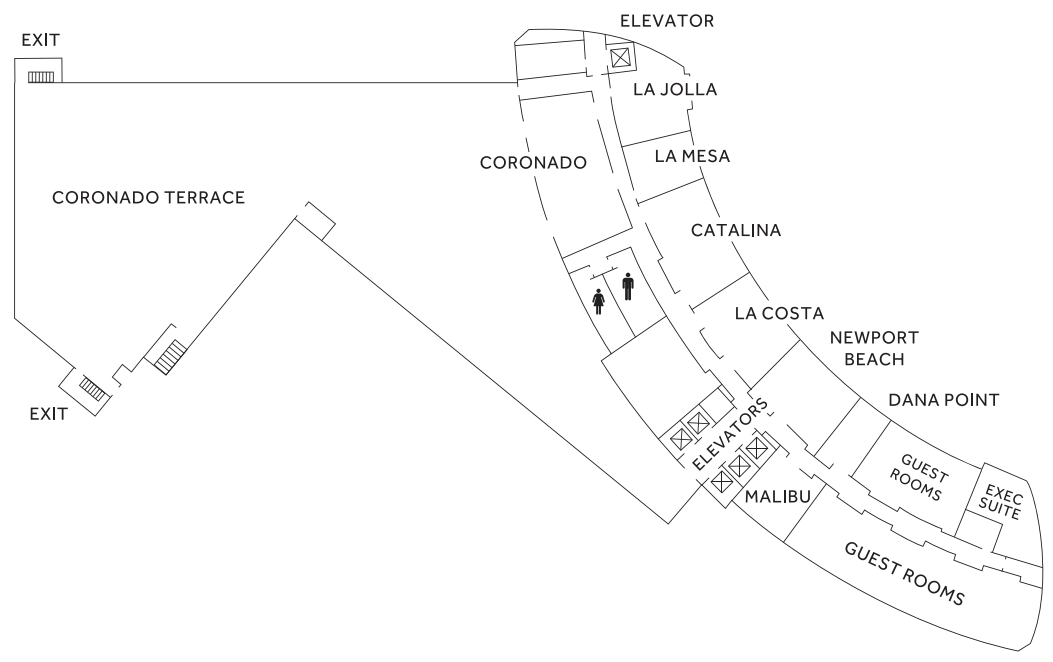




\section{MANCHESTER GRAND HYATT SAN DIEGO}

Meeting Facilities

\section{ROOM}

America's Cup A-D

Balboa C

Boardwalk

Coronado A-E

Cortez Hill A-C

Cove

Gaslamp A-D

Grand Hall C

La Jolla B

Marina

Mission Beach A-C

Nautical

Ocean Beach

Old Town A-B

Palm Foyer

Pier

Promenade A-B

Regatta A-C

Seaport \& Palm Foyers

Seaport A-G

Solana Beach A-B

Torrey Hills A-B

\section{LEVEL}

Fourth Level-Harbor Tower

Second Level-Seaport Tower

Lobby Level

Fourth Level

Third Level-Seaport Tower

Third Level-Harbor Tower

Second Level Seaport Tower

Lobby Level

Second Level-Seaport Tower

Lobby Level

Third Level-Seaport Tower

Fourth Level

Third Level-Seaport Tower

Second Level-Seaport Tower

Second Level-Seaport Tower

Third Level-Harbor Tower

Third Level-Harbor Tower

Fourth Level-Seaport Tower

Second Level-Seaport Tower

Second Level-Seaport Tower

Third Level-Seaport Tower

Third Level-Seaport Tower

\section{FUNCTION}

Sessions and Events

Sessions and Events

Sessions and Events

Sessions and Events

Sessions and Events

Sessions and Events

Sessions and Events

Job Placement

Sessions and Events

Sessions and Events

Sessions and Events

Sessions and Events

Sessions and Events

Sessions and Events

Information Booth

Sessions and Events

Sessions and Events

Sessions and Events

AFA Poster Session

Sessions and Events

Sessions and Events

Sessions and Events 


\section{MANCHESTER GRAND HYATT SAN DIEGO}
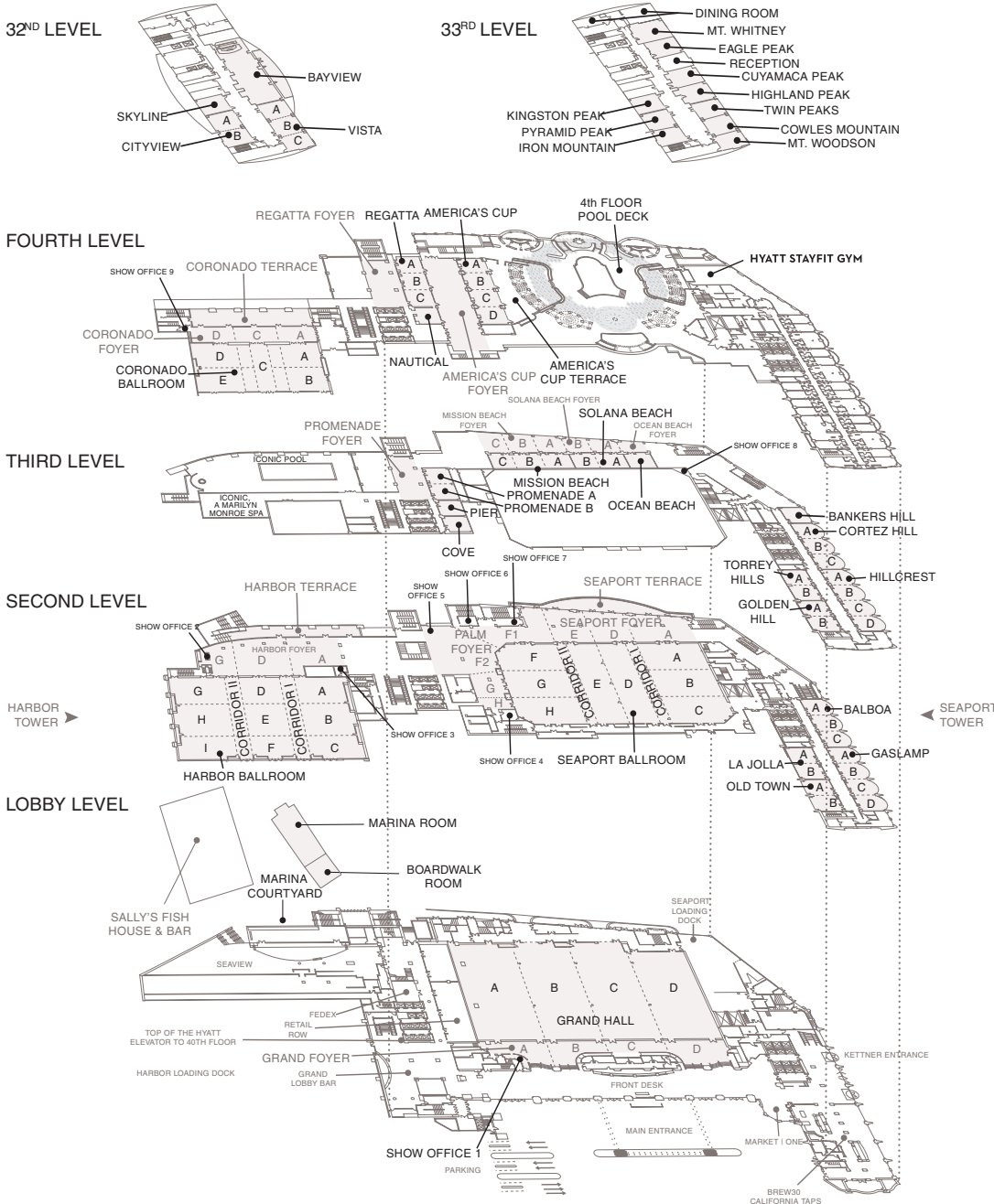


\section{MANCHESTER GRAND HYATT SAN DIEGO LOBBY LEVEL}

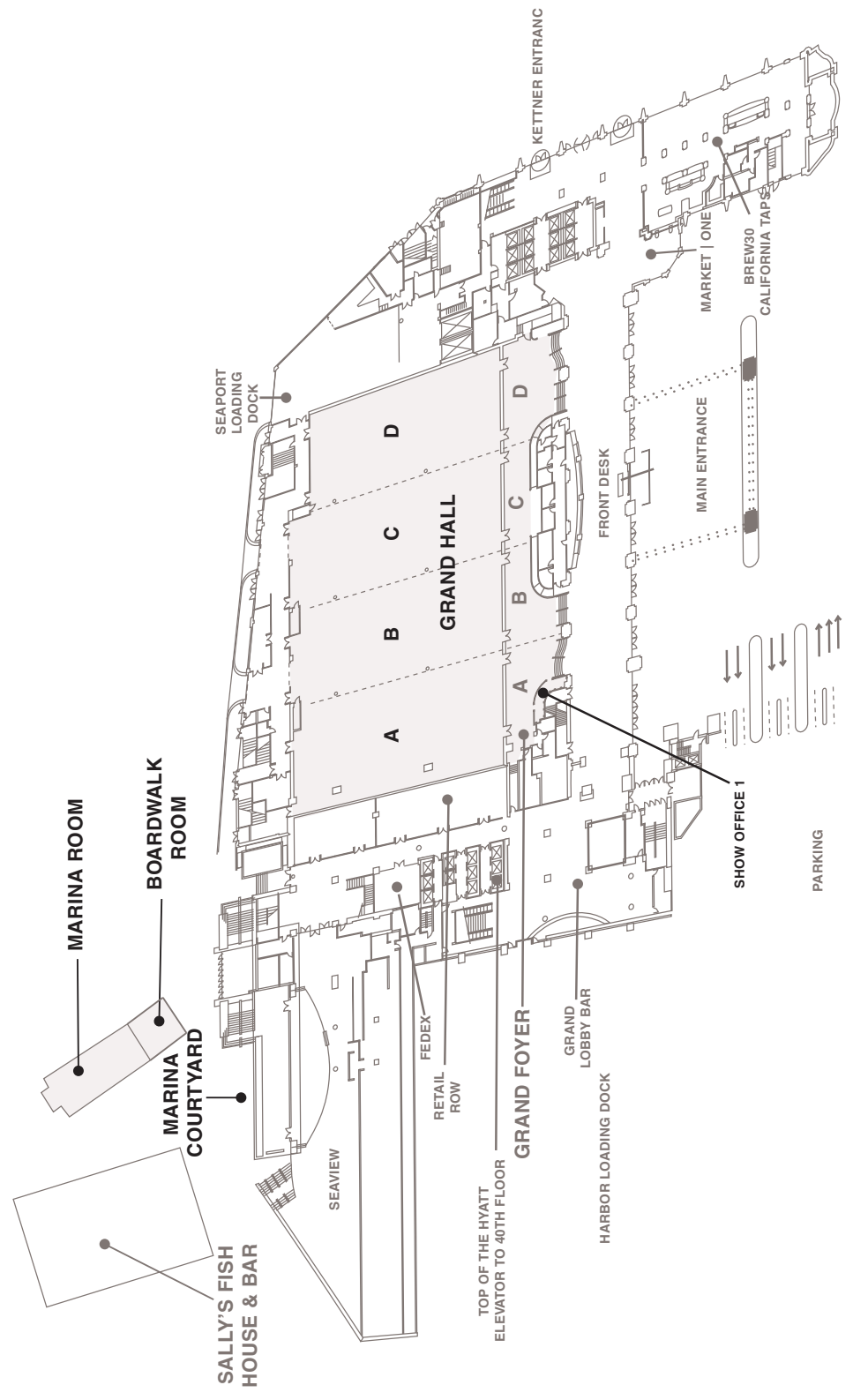




\section{MANCHESTER GRAND HYATT SAN DIEGO SECOND LEVEL}

\section{HARBOR TOWER}

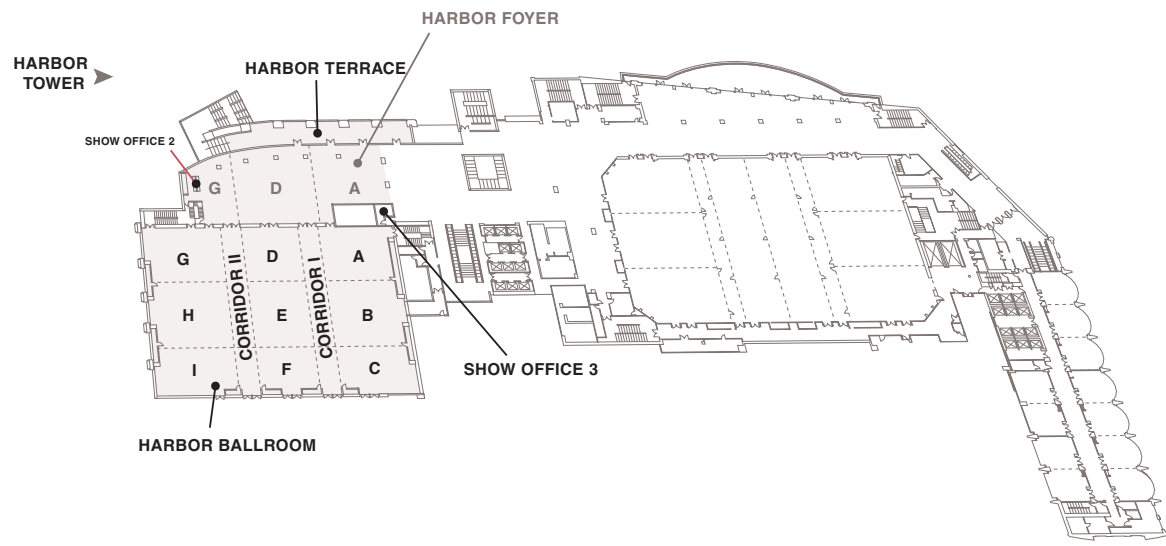

\section{SEAPORT TOWER}

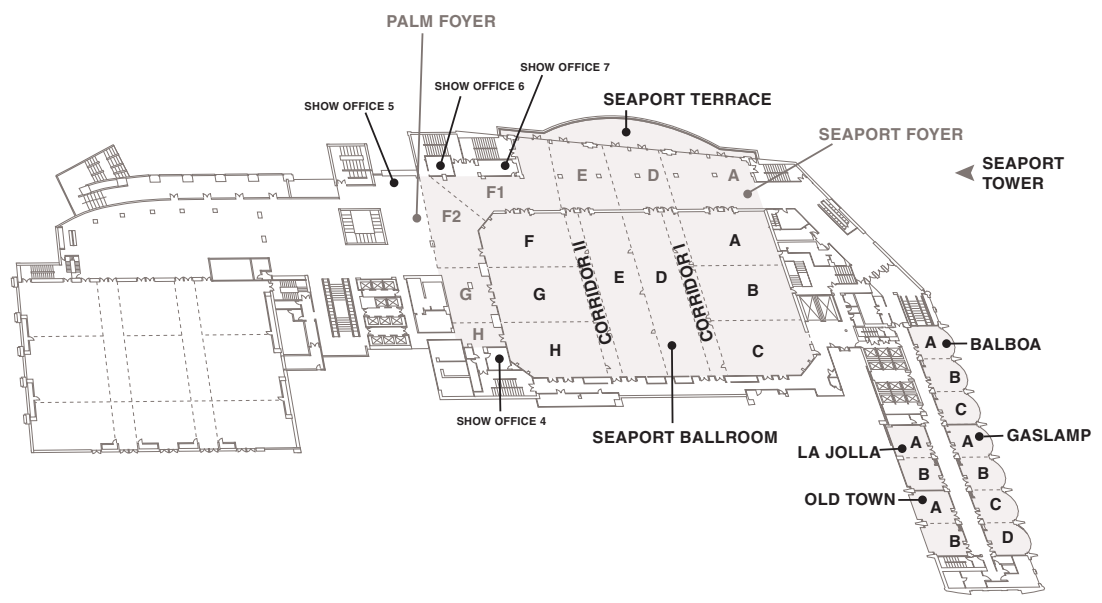




\section{MANCHESTER GRAND HYATT SAN DIEGO THIRD LEVEL}

HARBOR TOWER

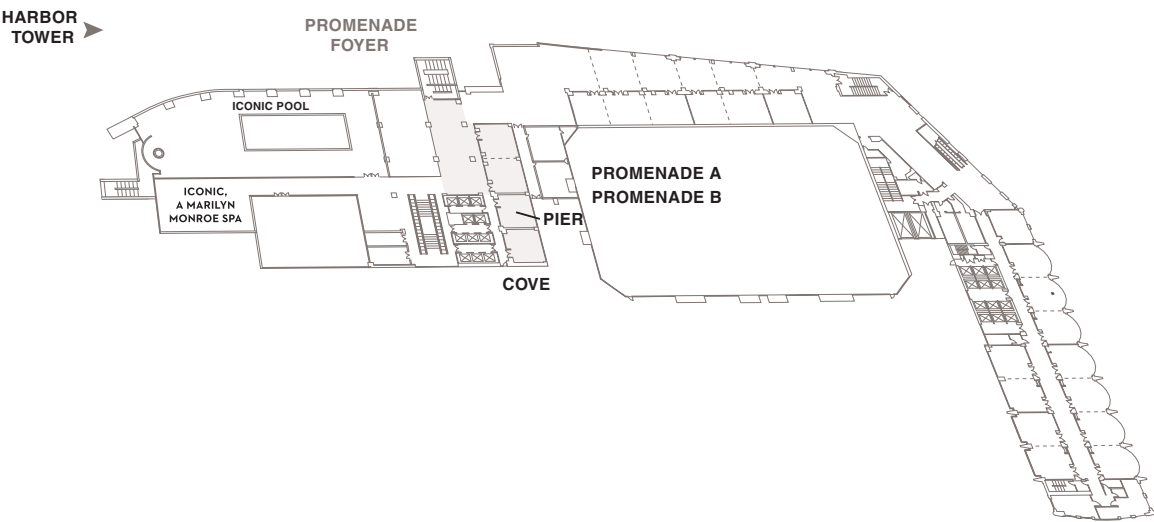

\section{SEAPORT TOWER}

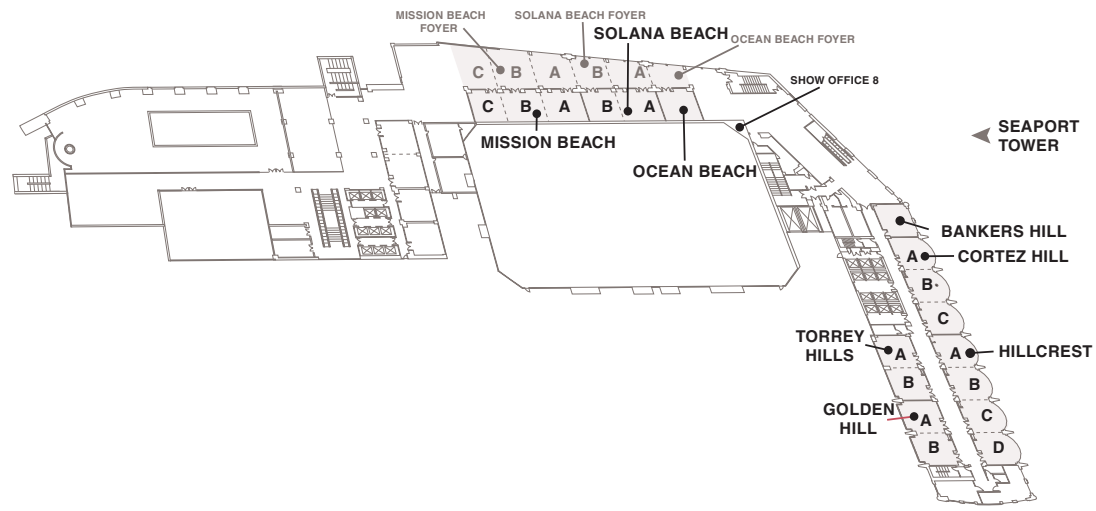




\section{MANCHESTER GRAND HYATT SAN DIEGO FOURTH LEVEL}

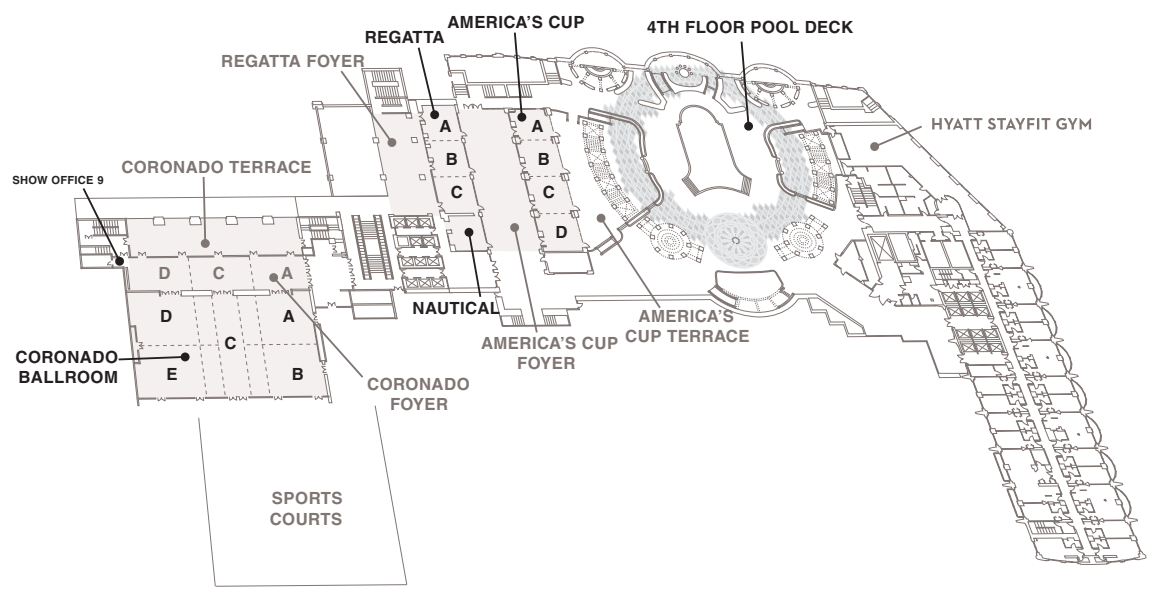




\section{EXHIBIT HALL \\ SAN DIEGO MARRIOTT MARQUIS AND MARINA PACIFIC BALLROOM}

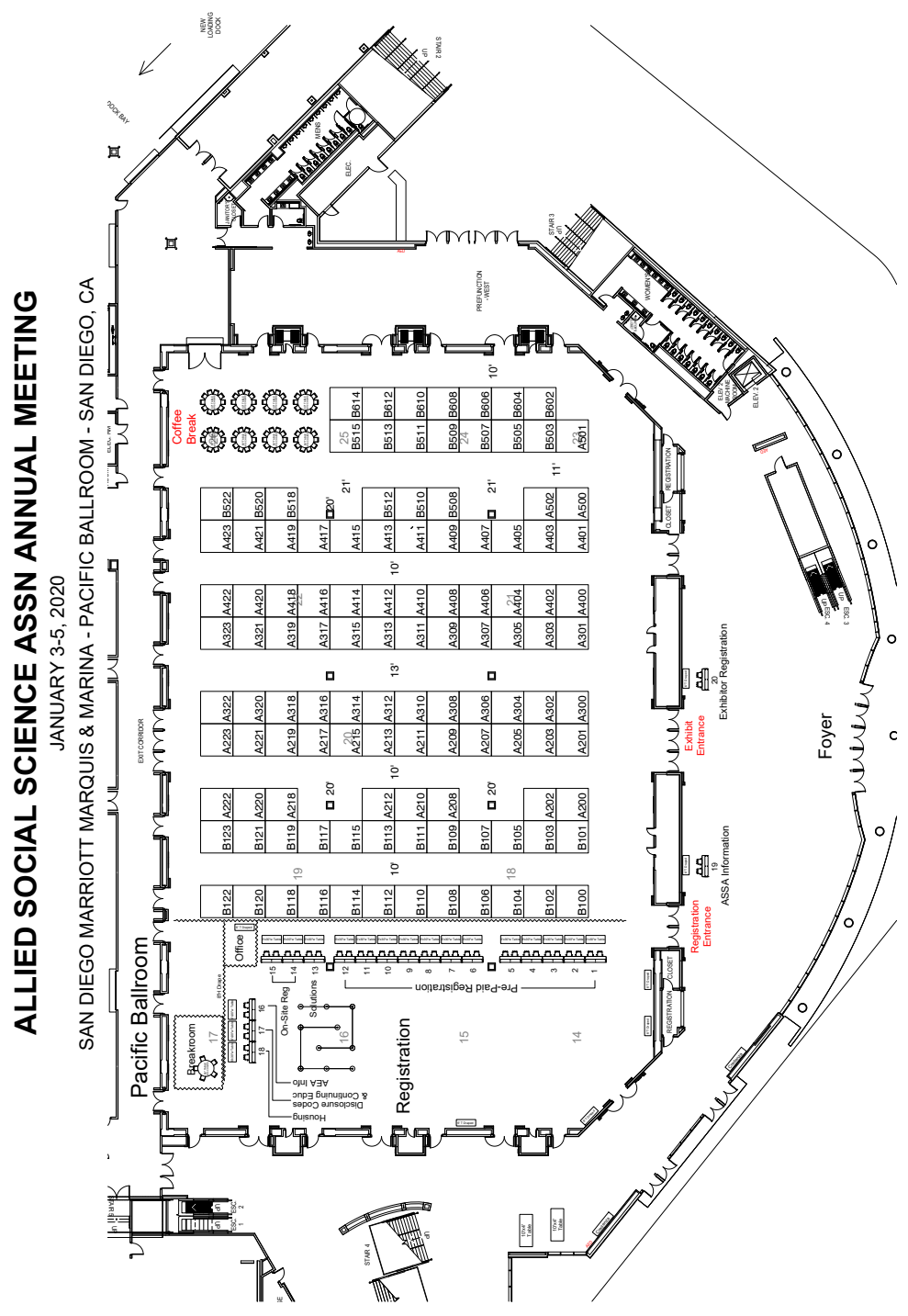




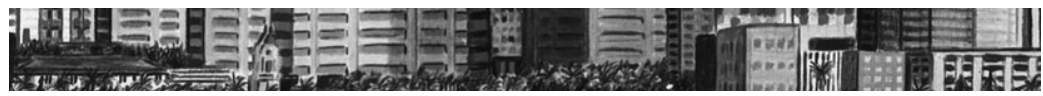 \\ Listing of Advertisers and Exhibitors}

American Economic Association (AEA) (Booths 201 \& 203)

American Finance Association (AFA) (Advertiser)

Amazon (Booth 210)

Analysis Group (Advertiser)

Aptech Systems Inc. (Booth 305)

Bureau of Economic Analysis (Booth 109)

Cambridge University Press (Booths 402, 404, 406)

Cato Institute (Booth 314)

Cengage (Booth 400 and Advertiser)

Center for Retirement Research at Boston College (Advertiser)

Certified Business Economist (NABE) (Booth 303)

China Data Institute (Booth 508 and Advertiser)

Cross-National Equivalent File (Booth 513)

De Gruyter (Booth 520)

Econometric Society (Advertiser)

Edward Elgar Publishing (Booths 304 \& 306)

Federal Housing Finance Agency (Booth 113)

Federal Reserve Bank of St. Louis (Booth 518)

FINRA (Booth 510)

Global Financial Data (Booth 316)

Harvard University Press (Booth 101 and Advertiser)

Haver Analytics (Booth 409)

Hawkes Learning (Booth 522)

Health and Retirement Study (HRS) (Booth 300)

Hoover Institution Press (Booth 411)

ICAPE (Booth 322)

IHS Global Inc. (Booths 103 \& 105)

Independent Publishers Group (Booth 501)

Ingram Academic Services (Booth 408)

Institute for Humane Studies (Booth 502)

Institute for New Economic Thinking (Booths 215 \& 217)

International Labour Organization (Booth 423)

International Monetary Fund (Booth 222 and Advertiser)

JPMorgan Chase Institute (Booth 111)

Kauffman Foundation (Advertiser)

Lexington Books (Booth 106)

Macmillan Learning (Booth 218) 
Marginal Revolution University (Booth 312)

McGraw-Hill Education (Booth 505)

Michigan Retirement and Disability Research Center (MRDRC) (Booth 302)

Minnesota Population Center (Booth 500)

MIT Press (Booths $211 \& 213$ )

MobLab (Booth 407)

National Longitudinal Surveys (Booth 323)

Now Publishers (Booth 100)

Omicron Delta Epsilon (Booth 107 and Advertiser)

Oxford University Press (Booth 507, 509, 511)

Palgrave Macmillan (Booths 315 \& 317)

Panel Study of Income Dynamics (PSID) (Booth 301 and Advertiser)

Pearson (Booth 108)

Post Doctoral Bridge Program (Booth 208)

Princeton University Press (Booths 207 \& 209 and Advertiser)

Research in Germany (Booths 410 \& 412)

Routledge Taylor and Francis Group (Booths $102 \&$ 104)

Russell Sage Foundation (Booth 205 and Advertiser)

Scientists and Environmentalists (Booth 512)

Shanghai University of Finance and Economics (Advertiser)

Sichuan University (Booth 318)

Society of Government Economists (Advertiser)

Springer Nature (Booths 311 \& 313)

Stanford University Press (Advertiser)

StataCorp LLC (Booths 401, 403, 405)

United Nations Publications (Booth 223)

University of Chicago Press (Booth 602 and Advertiser)

University of Toronto Press (Booth 503)

W.W. Norton (Booths 308 \& 310 and Advertiser)

Wanfang Data Canada (Booth 515)

Western Economic Association International (Advertiser)

W.E. Upjohn Institute (Booth 309 and Advertiser)

Wharton Research Data Sources (WRDS) (Booth 422)

Wiley (Booth 614)

World Bank Group (Booths 219 \& 221)

World Scientific Publishing (Booths $200 \& 202$ and Advertiser)

Yale University Press (Booth 212 and Advertiser) 


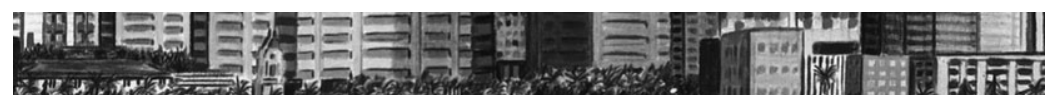

\section{ASSA \\ Executive Officers}

African Finance \& Economics Association (AFEA)

Agricultural \& Applied Economics

Association (AAEA)

American Committee on Asian Economic Studies (ACAES)

American Economic Association (AEA)

American Finance Association (AFA)

American Real Estate \& Urban Economic Association (AREUEA)

American Risk \& Insurance Association (ARIA)

American Society of Health Economists (ASHEcon)

American Society of Hispanic Economists (ASHE)

Association for Comparative Economic Studies (ACES)

Association for Economic \& Development Studies in Bangladesh (AEDSB)

Association for Evolutionary Economics (AFEE)

Association for Social Economics (ASE)

Association for the Study of Generosity in Economics (ASGE)

Association for the Study of Religion, Economics, and Culture (ASREC)

Association for the Study of the Cuban Economy (ASCE)
Samuel Amponsah

Tokyo International University

David Zilberman

University of California-Berkeley

Calla Wiemer

University of the Philippines

Ben Bernanke

Brookings Institution

David Hirshleifer

University of California-Irvine

Crocker H. Liu

Cornell University

Martin Grace

Temple University

Anthony LoSasso

University of Illinois-Chicago

Fernando Lozano

Pomona College

Scott Rozelle

Stanford University

Khawaja Mamun

Sacred Heart University

David Zalewski

Providence College

Julie A. Nelson

University of Massachusetts

Boston

Mark Ottoni-Wilhelm

Indiana University-Purdue

University Indianapolis

Daniel Hungerman

University of Notre Dame

Silvia Pedraza

University of Michigan 
Association of Christian Economists (ACE)

Association of Environmental \& Resource

Economists (AERE)

Association of Financial Economists (AFE)

Association of Indian Economic \& Financial Studies (AIEFS)

Central Bank Research Association (CEBRA)

Chinese Economic Association in North

America (CEANA)

Chinese Economists Society (CES)

Cliometrics Society (CS)

Econometric Society (ES)

Economic History Association (EHA)

Economic Science Association (ESA)

Economics of National Security Association (ENSA)

Economists for Peace \& Security (EPS)

Health Economics Research Organization (HERO)

History of Economics Society (HES)

Industrial Organization Society (IOS)

International Association for Energy

Economics (IAEE)

International Association for Feminist

Economics (IAFFE)

International Association of Applied

Econometrics (IAAE)

International Banking Economics \& Finance Association (IBEFA)
Edd Noell

Westmont College

Daniel Phaneuf

University of Wisconsin-Madison

Anil Makhija

Ohio State University

Amitrajeet A. Batabyal

Rochester Institute of Technology

Raphael Auer

Bank for International

Settlements

Jin-Tan Liu

National Taiwan University

Zongwu Cai

University of Kansas

Melissa Thomasson

Miami University

Stephen Morris

Princeton University

Hugh Rockoff

Rutgers University

Catherine Eckel

Texas A\&M University

Eli Berman

University of California-San

Diego

Linda Bilmes

Harvard University

Donald E. Yett

University of Southern California

Marcel Boumans

University of Utrecht

Kenneth Hendricks

University of Wisconsin-Madison

David Williams

International Association for

Energy Economics

Cheryl Doss

University of Oxford

Hashem Pesaran

University of Southern California

Luisa Lambertini

Swiss Federal Institute of

Technology-Lausanne (EPFL) 
International Economics \& Finance Society (IEFS)

International Health Economics Association (IHEA)

International Network for Economic Method (INEM)

International Society for Inventory Research (ISIR)

International Trade \& Finance Association (ITFA)

Korea-America Economic Association (KAEA)

Labor \& Employment Relations Association (LERA)

Latin American and Caribbean Economic Association (LACEA)

Middle East Economic Association (MEEA)

National Association for Business Economics (NABE)

National Association of Economic Educators (NAEE)

National Association of Forensic Economics (NAFE)

National Economic Association (NEA)

National Tax Association (NTA)

Omicron Delta Epsilon (ODE)

Peace Science Society International (PSSI)

Society for Computational Economics (SCE)

Society for Economic Dynamics (SED)

Society for Institutional and Organizational Economics (SIOE)
Sebnem Kalemli-Ozcan

University of Maryland-College

Park

Winnie Yip

Harvard University

Caterina Marchionni

University of Helsinki

Felipe Schwartzman

Federal Reserve Bank of

Richmond

Pompeo Della Posta

University of Pisa

Jinyong Hahn

University of California-Los

Angeles

Dennis L. Dabney

Kaiser Permanente

Santiago Levy

Inter-American Development

Bank

Wassim Shahin

Lebanese American University

Constance Hunter

KPMG

Julie Heath

University of Cincinnati

Kevin Cahill

Boston College

Omari H. Swinton

Howard University

Andrew Lyon

PwC

Stacey Jones

Seattle University

Glenn Palmer

Pennsylvania State University

Thomas Lubik

Federal Reserve Bank of

Richmond

Ellen McGrattan

University of Minnesota

Francine Lafontaine

University of Michigan 
Society for Nonlinear Dynamics and

Econometrics (SNDE)

Society for Policy Modeling (SPM)

Society for the Advancement of Behavioral Economics (SABE)

Society for the Study of Emerging Markets (SSEM)

Society of Government Economists (SGE)

Transportation \& Public Utilities Group (TPUG)

Union for Radical Political Economists (URPE)
Hilde C. Bjørnland

BI Norwegian Business School

Dominick Salvatore

Fordham University

Shabnam Mousavi

Johns Hopkins University

Meral Kutan

Southern Illinois University-

Edwardsville

Susan Fleck

U.S. Bureau of Labor Statistics

Wesley W. Wilson

University of Oregon

Paddy Quick

St. Francis College 


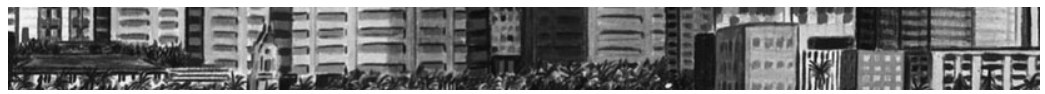 \\ Summary of Sessions by Organization}

\section{AAEA}

\section{January 3rd}

10:15 AM Studying Innovation in Agriculture-New Data and New Tools

2:30 PM Automation and Digitalization in Agriculture

\section{January 4th}

8:00 AM Fertility in a Changing Environment: Climate Change, Migration, and Social Networks

10:15 AM Market Structure and Pricing in Food Markets

12:30 PM Farmer Adaptations to Climate and Environmental Change

2:30 PM Climate Change Adaptation in Developing Countries: Constraints on Adaptation and Mechanisms for Relaxing Them

\section{ACAES}

\section{January 4th}

2:30 PM Economic Inequality in Asia

\section{ACE}

\section{January 4th}

10:15 AM Applied Micro in Economic Development: Natural Disasters, Education, and Technology

2:30 PM New Thinking on Adam Smith and Economics (joint with HES)

\section{ACES}

\section{January 3rd}

8:00 AM The Demand for the State: Evidence from Past and Present

10:15 AM Social Capital and Banking Crises

2:30 PM Skills in College: Cross-National Evidence from China, India, Russia, and the United States

\section{January 4th}

8:00 AM The Institutional Basis of China's Growth and Social Development 
10:15 AM From Culture to Governance: Towards a Comparative Economics of Institutions and Organizations (joint with SIOE)

2:30 PM Improving the Foundations of Human Capital Around the World: Evaluating Early Childhood Development Efforts in China, Brazil, and India

4:45 PM ACES Membership Meeting and Presidential Address

\section{January 5th}

8:00 AM Institutional Setting, Government Policy, and Firm Performance: A Comparative Perspective

10:15 Am Markets and Health Care Quality in Low- and Middle-Income Countries

1:00 PM What Determines Women's Careers: Norms, Organizational Culture, and Institutions

\section{AEA}

\section{January 3rd}

$\begin{aligned} & \text { 8:00 AM } \text { Beyond GDP } \\ & \text { 8:00 AM } \text { Business Cycles } \\ & \text { 8:00 AM } \text { Central Banking } \\ & \text { 8:00 AM } \text { CSMGEP Dissertation Session } \\ & \text { 8:00 AM } \text { Determinants of Student Performance and Proficiencies in Economics } \\ & \text { 8:00 AM } \text { Economic Opportunity and the Impact of Race and Place } \\ & \text { 8:00 AM } \text { Education and Religion } \\ & \text { 8:00 AM } \text { Empirical Research on Automation and "Smart" Technologies } \\ & \text { 8:00 AM } \text { Finance and Politics } \\ & \text { 8:00 AM } \text { From Micro Data to Global Evidence } \\ & \text { 8:00 AM } \text { Gender in the Innovation Economy } \\ & \text { 8:00 AM } \text { Gendered Effects of Social Norms and Institutions } \\ & \text { 8:00 AM } \text { Global Uncertainty: Measurement and Impact } \\ & \text { 8:00 AM } \text { Household Shocks and Crime } \\ & \text { 8:00 AM } \text { Innovation, Productivity, and Regulation } \\ & \text { 8:00 AM } \text { Models of Cryptocurrencies: Pricing and Design } \\ & \text { 8:00 AM } \text { New Approaches for Measuring Poverty } \\ & \text { 8:00 AM } \text { New Directions in Household Saving } \\ & \text { 8:00 AM } \text { Promoting Female Participation in Undergraduate Economics } \\ & \text { 8:00 AM } \text { The Effect of Immigrants on Economic and Political Outcomes in the } \\ & \text { 8:00 AM } \text { The Secular Decline in Real Interest Rates } \\ & \text { 10:15 AM } \text { Carbon Tax Policy } \\ & \text { 10:15 AM } \text { Contraception, Abortion, and Fertility Rates } \\ & \text { 10:15 AM Criminal Behavior, Crime Policy, and Violent Crime } \\ & \text { 10:15 AM Cultural Dynamics of Gender Norms }\end{aligned}$


10:15 AM Economics for Inclusive Prosperity (EfIP): Labor, Technology, and Social Policy

10:15 AM Enhancing Learning in Economics

10:15 AM Household Finance and Race

10:15 AM Life on the Edge: Collaboration and the Production of Ideas at the Scientific Frontier

10:15 AM Monetary Policy

10:15 AM Monetary Policy and Corporate Risk-Taking

10:15 AM Search and Matching in Education Markets

10:15 AM The Economics of Health Epidemics

10:15 AM The National Academies Child Poverty Report

10:15 AM The Supply and Demand of Safe Assets

10:15 AM The United States Economy: Growth, Stagnation, or New Financial Crisis

10:15 AM Unemployment Insurance and the Labor Market

10:15 AM Use of Machine Learning Algorithms

10:15 AM Women in Central Banking

10:15 AM Women's Mobility and Safety in the Public Space

12:30 PM AEA/AFA Joint Luncheon-Fee Event (joint with AFA)

2:30 PM Advances in Measuring Firm-Level Uncertainty

2:30 PM Capital Flows and Policy Dilemmas

2:30 PM Consumer Behavior and Passenger Vehicle Fuel Economy Regulation

2:30 PM Effects of Immigration on American Science and Innovation

2:30 PM Empirical Studies on Physician Quality and Treatment Choice

2:30 PM Employer Market Power: Theory and Evidence

2:30 PM Gender and Entrepreneurship

2:30 PM How Can Economics Solve Its Race Problem?

2:30 PM Inequality

2:30 PM Inequality and Distributional Preferences

2:30 PM International Trade

2:30 PM Investing in the Next Generation-Lessons from History for Economic Policy

2:30 PM Macroprudential Policy and Financial Stability

2:30 PM Monetary Policy, Capital Flows, and Globalization

2:30 PM NBER and the Evolution of Economic Research, 1920-2020

2:30 PM New Approaches to Measuring Technology and Innovation

2:30 PM Provider Decision-Making and Productivity in Health Care

2:30 PM Social Capital

2:30 PM Using Data Analytics and Visualization in Economics Courses

4:45 PM AEA Richard T. Ely Lecture

6:00 PM AEA Business Meeting 


\section{January 4th}

8:00 AM Achievement Tests I: On the Validity of Comparisons across Cohort, Grade, and Subject

8:00 AM Alan Krueger's Contributions to Economics

8:00 AM Consequences of Forced Migration

8:00 AM Countercyclical Fiscal Policy

8:00 AM Crime and Law Enforcement

8:00 AM Differential Treatment: The Role of Gender, Race, Ideology, and Affirmative Action

8:00 AM Fertility Issues

8:00 AM Financial Networks, Regulation, and Systemic Risk

8:00 AM FinTech for Macroeconomists

8:00 AM Gendered Effects on Wages, Employment, and Prices

8:00 AM Has the Global Financial Cycle Changed Since the Crisis?

8:00 AM Identification in Macro-Finance: Recent Advances

8:00 AM Immigration and Assimilation

8:00 AM Machine Learning in Experiments

8:00 AM Matching under Inequality: Implications for Policy

8:00 AM Measuring and Understanding Violence against Women (VAW) in Developing Countries

8:00 AM Physician Behavior

8:00 AM Pink Papers: LGBT Economics

8:00 AM Private and Social Learning in Oil and Gas Extraction

8:00 AM Team-Based Learning in Economics

10:15 AM Achievement Tests II: On the Validity of Comparisons across SES and Place

10:15 AM Algorithmic Fairness and Bias

10:15 AM Economic Measurement Challenges in the Digital Economy

10:15 AM Economics for Inclusive Prosperity (EfIP)

10:15 AM Firms, Trade, and Globalization

10:15 AM Gender and the Economics Profession

10:15 AM Health Care Systems

10:15 AM Interventions to Close Gender Gaps-What Works and What Can Backfire

10:15 AM Liquidity Regulation

10:15 Am New Research on School Choice: The Role of Parental Preferences, Housing Search, and Assignment Mechanisms

10:15 AM Peer Effects and Technology Adoption

10:15 AM Real Effects of Non-Rational Expectations

10:15 AM Superstar Economies: Concentration and Increasing Differences between Firms

10:15 AM Tax Havens, Offshore Issuance, and the Global Financial System

10:15 Am The Consequences of Demonetization: Evidence from the World's Largest Democracy 
10:15 Am The Role of Attitudes and Perceptions on Economic and Political Outcomes

10:15 AM Transforming the Economics Classroom: Diversity and Inclusion

12:30 PM AEA Nobel Laureate Luncheon-Fee Event

12:30 PM European Economic Association Lecture

2:30 PM AEA Committee on Economic Education Poster Session

2:30 PM AEA Report: Best Practices for Improving Equity, Diversity, and the Professional Climate in Economics

2:30 PM AI/Robotics, Labor Markets, and Demography

2:30 PM Behavioral Economics Issues

2:30 PM Central Bank Communication

2:30 PM Child Development and Public Policies

2:30 PM Deaths of Despair and the Future of Capitalism

2:30 PM Digital Financial Services in Africa

2:30 PM Economics of Payments

2:30 PM Funding Financial Intermediaries

2:30 PM Impacts of the Earned Income Tax Credit

2:30 PM Improving the Transparency and Credibility of Economics Research

2:30 PM Is United States Deficit Policy Playing with Fire?

2:30 PM Natural Language Processing and Its Application to Macroeconomics and Macro-Finance

2:30 PM Perspectives on Neoclassical Labor Supply

2:30 PM Stories and Identity in Organizations

2:30 PM Taxation

2:30 PM The Race between Education and Technology Revisited

4:40 PM AEA Awards Ceremony and Presidential Address

8:00 PM 12th Annual Economics Humor Session in Honor of Caroline Postelle Clotfelter

\section{January 5th}

8:00 AM Bank Lending and Real Outcomes

8:00 AM Changes in Occupations and Jobs

8:00 AM Climate Economics

8:00 AM Common Ownership

8:00 AM Comparing Poverty of Refugees and Their Hosts

8:00 AM Crime Prevention in the United States and Abroad

8:00 AM Economic History

8:00 AM Economics of Higher Education

8:00 AM Economics of Voting

8:00 AM Empirical Models of Tacit Collusion

8:00 AM Empirical Practice in Economics: Challenges and Opportunities

8:00 AM Female Leadership in Business and Politics

8:00 AM Financial Economics of Gender Throughout the Firm Lifecycle 
8:00 AM Firm Dynamics

8:00 AM Firms and Wage-Setting

8:00 AM Immigration

8:00 AM Improving Economic Price Statistics through the Use of Alternative Data

8:00 AM Japanification, Secular Stagnation, and Fiscal and Monetary Policy Challenges

8:00 AM Leader Ladies

8:00 AM Macroprudential Policies and Monetary Policy

8:00 AM The Economics and Policy of Automatic Stabilizers

8:00 AM The Economics of Privacy

8:00 AM Using Behavioral Economics to Promote Resource Conservation

10:15 AM Advanced Country Monetary Policy Spillovers to Emerging Markets

10:15 AM Air Pollution: Exposure, Health, and the Labor Market

10:15 AM Banking Under Stress

10:15 AM Building Organizational Culture for Performance

10:15 AM Consumer Credit and Business Cycles

10:15 AM Determinants of Academic Achievement

10:15 AM Economic Consequences of Immigration Policy

10:15 AM Gender Differences in Career Progression

10:15 AM Gender Effects

10:15 AM Housing Markets

10:15 AM Job Polarization: Evidence and Possible Causes

10:15 AM Labor Unions in the United States

10:15 AM Long-Term Effects of Educational Interventions in Developing Countries

10:15 AM Minimum Wages, Taxes, and Low Wage Labor Markets

10:15 Am Monetary Policy Frameworks in a World of Low Interest Rates

10:15 AM Non-Price Collusion

10:15 AM Rising Markups and Monopoly Power

10:15 AM Societal Impacts of Policing and Incarceration

10:15 AM Sources of the Transatlantic Productivity Slowdown

10:15 AM The Puerto Rican Debt Crisis

10:15 AM The Recent Consequences of Trade Wars and Trade Threats

10:15 AM Using Social Media and Blogging to Engage Economists

10:15 AM Wage Dynamics and the Efficiency of Job Separations

1:00 PM Analyzing Firm Behavior Using United States Tax-Returns Data

1:00 PM Behavioral Market Design

1:00 PM Capital Flows, Sovereign Debt, and Risk

1:00 PM Causes of Populism and Its Related Political Preferences

1:00 PM Changes in Family Structures and Consequences

1:00 PM Drivers of the Labor Share of Income

1:00 PM Economic Development in Africa 
1:00 PM Economic Implications of Longevity Risk in an Aging Society:

Challenges and New Insights

1:00 PM Economics for Inclusive Prosperity (EfIP): Finance and Taxation

1:00 PM Explaining Gender Gaps: Role of Competitiveness Versus Perceptions

1:00 PM Foreign Exchange Intervention: Theory and Policy

1:00 PM Information and Sorting in Labor Markets

1:00 PM Local Shocks and Long-Run Persistence

1:00 PM Macroprudential Policies

1:00 PM Political Economy

1:00 PM Relocation and Price Effects of United States Trade Policy

1:00 PM Social Determinants of Health Disparities

1:00 PM Transportation

1:00 PM Wages

\section{AEDSB}

\section{January 4th}

2:30 PM Development Issues of Labor, Agriculture, and Poverty in Bangladesh

\section{AERE}

\section{January 3rd}

8:00 AM Empirical Climate Change Economics

10:15 AM Fisheries Economics

2:30 PM Politics of Environmental Policymaking

\section{January 4th}

8:00 AM Social Costs of Air Pollution

10:15 AM Economics of Water

2:30 PM Environment in a Multisector Economy

January 5th

8:00 AM Implementing Environmental Policy

10:15 AM Natural Resources as Assets

1:00 PM Evolving Electricity Markets

\section{AFA}

\section{January 3rd}

8:00 AM Asset Pricing: Portfolio Choice and Asset Allocation

8:00 AM Contracts and Incentives

8:00 AM Factors, Risk, and the Economy

8:00 AM Firms and Politics

8:00 AM M\&A and Competition 
8:00 AM Mutual Fund Flows and Marketing

8:00 АM New Advances in International Finance

8:00 AM Regulation \& Finance

10:15 AM Common Ownership, Competition, and Innovation

10:15 AM FinTech: Adoption and Consequences

10:15 AM Learning in Asset Markets

10:15 AM Mutual Funds: New Perspectives

10:15 Am New Methods in Asset Pricing

10:15 AM New Perspectives on Raising and Measuring Capital

10:15 AM Shadow Banking: Understanding Private Debt

10:15 AM Shareholder Voting

2:30 PM AFA Panel: Fintech, Financial Stability, and Regulation

2:30 PM Asset Return Dynamics

2:30 PM Debt Financing and Growth

2:30 PM Equity Options and Volatility Derivatives

2:30 PM Financial Intermediation and Liquidity

2:30 PM Gender: Policy, Perception, and Firm Value

2:30 PM Hedge Funds

2:30 PM Intermediaries and Asset Returns

\section{January 4th}

8:00 AM AFA Ph.D. Student Poster Session

8:00 Aм Asset Pricing: Volatility, Tail Risk

8:00 AM Asset Valuation in Economies with Production

8:00 AM Bank and SBA Lending Behavior

8:00 AM Bank Cost of Capital

8:00 AM Frontiers of Corporate Governance

8:00 AM Information Diffusion

8:00 AM Networks, Connections, and Firms

8:00 AM Political Uncertainty and Asset Prices

10:15 AM AFA Panel: Innovating for Financial Health: Are FinTechs, Banks, and Policymakers Addressing the Challenges?

10:15 AM Asset Specificity and Prices

10:15 AM Blockchain and Cryptocurrencies

10:15 AM CEO Effects

10:15 AM Financial Stability

10:15 AM Psychology and Asset Prices

10:15 AM R\&D, Patents, and Innovation

10:15 AM Skill in Mutual Funds

2:30 PM AFA Lecture-Distributed Ledgers: Design and Regulation of Financial Infrastructure and Payment Systems

2:30 PM Bank Lending

2:30 PM Corporate Debt and Liquidity

2:30 PM Corporate Investment in the Modern Economy 
2:30 PM Foreign Exchange Risk Premium

2:30 PM Intermediary Trading, Trading Venues, and Market Liquidity

2:30 PM Structural Models of Credit Risk

2:30 PM The Use (and Misuse) of Private Information in Financial Markets

5:30 PM AFA Business Meeting and Presidential Address

\section{January 5th}

8:00 AM Asset Prices and the Trading Process

8:00 AM Asset Pricing: Cross-section of Returns

8:00 AM Banks and Monetary Policy Transmission

8:00 Ам Finance and Development

8:00 AM Measuring Bond Liquidity

8:00 AM Memory, Perception, and Asset Prices

8:00 AM Mergers and Acquisitions

8:00 AM Shareholder Activism

10:15 AM Analysts, News, and Intermediaries

10:15 AM Asset Pricing: Frictions and Market Efficiency

10:15 AM Corporate Culture and Socially Responsible Investing

10:15 AM Entrepreneurial Finance: Risk and Return

10:15 AM Executive Compensation

10:15 AM Household Finance: Regulation and Intermediation

10:15 AM Intermediation and Asset Prices

10:15 AM Liquidity Risk

1:00 PM Asset Pricing: Cross-section of Returns and Investors

1:00 PM Corporate Disclosure and Incentives

1:00 PM Financial Crises and Transmission of Shocks

1:00 PM Household Debt and Savings

1:00 PM Information Trading in Networks

1:00 PM Labor Markets and Firm Performance

1:00 PM Risk Premia Dynamics in Treasury Bond Markets

\section{AFE}

\section{January 3rd}

10:15 AM Diversity and Career Prospects Up the Corporate Ladder

\section{January 4th}

12:30 PM Beyond Bitcoin (joint with AEA)

2:30 PM Bankruptcy and Efficiency (joint with AFA)

\section{January 5th}

8:00 AM Finance, Money, and Banking in India 


\section{AFEA}

\section{January 3rd}

5:00 PM AFEA Presidential Address and Business Meeting

\section{January 4th}

8:00 AM Health, Human Capital, and Gender Issues in Africa

10:15 AM Infrastructure and Finance in Africa

\section{AFEE}

\section{January 3rd}

8:00 AM Advancing the Progressive Ideal by Reshaping the Role of State and Market (joint with AEA)

10:15 AM Regional Inequality, Industrial Policy, and Land Reform

2:30 PM Contexts of Money and Gift

2:30 PM Economic Policy and the Progressive Idea (joint with ASE)

\section{January 4th}

8:00 AM Is Karl Polanyi's Analysis of the 1930's and 1940's Relevant for Understanding the Global Political Economy of the Present? (joint with ASE)

10:15 AM Institutional Approaches to Women's Economic Empowerment

12:30 PM Institutional Economics in the Calculable Future

2:30 PM John R. Commons's Foundations of Progressive Change

5:00 PM AFEE Presidential Address

\section{January 5 th}

8:00 AM Perspectives on Emergent Financial Systems

10:15 AM Finance and Economic Transition (joint with ASE)

1:00 PM Public Policy toward Business

\section{AIEFS}

\section{January 3rd}

8:00 AM Topics in Output, Income, and Economic Development

12:30 PM Topics in Trade, Innovation, and Economic Development

\section{AREUEA}

\section{January 3rd}

8:00 AM Housing Market and Cycles

8:00 AM Migration and Housing

10:15 AM Commercial Real Estate Investors

10:15 AM Housing Market Segmentation and Sorting

10:15 AM Policies and Regulation in Mortgage Markets 
12:30 PM Real Estate and Housing Finance (joint with AFA)

2:30 PM Agglomeration and Local Public Finance

2:30 PM Housing and Disasters

2:30 PM International Real Estate and Institutions: In Honor of Austin Jaffe

\section{January 4th}

8:00 AM Risk and Delinquency in Mortgage Markets

8:00 AM Women in Economics-Perspectives and New Initiatives from Five Professional Associations (joint with AAEA/AFA)

10:15 AM House Price Dynamics and Indexes

10:15 AM Housing Cost and Supply

12:30 PM AREUEA Presidential Luncheon

2:30 PM Homeownership and Mortgage Access

2:30 PM Housing and the Life Cycle

2:30 PM Transportation

\section{January 5th}

8:00 AM Commercial Real Estate Prices and Cycles

8:00 AM Investors, Purchasers, and House Prices

8:00 AM Machine Learning in Real Estate

10:15 AM Institutional Issues in Mortgage Markets

10:15 AM Pricing (Dis)Amenities

1:00 PM Housing and Cyclical Dynamics

1:00 PM REITs

\section{ARIA}

\section{January 5th}

8:00 AM Topics in Risk and Insurance (joint with AEA)

\section{ASCE}

\section{January 3rd}

8:00 AM The Cuban Economy: Selected Venezuelan Interactions

\section{ASE}

\section{January 2nd}

6:30 PM ASE Plenary Session and Reception

\section{January 3rd}

8:00 AM Policy Lessons for Our Economic Future (joint with AFEE)

10:15 AM Inequality and Fairness

2:30 PM Growth, Wealth, and Finance 
7:45 AM ASE Presidential Breakfast

\section{January 4th}

10:15 AM What Economists Can Do Better?: A Look at the Profession (joint with INEM)

12:30 PM Topics in Social Economics

2:30 PM A Green Light for Public Banks? (joint with AFEE)

January 5th

8:00 AM Seeing Red: Households Awash in Debt

\section{ASGE}

\section{January 3rd}

12:30 PM Voluntarism and the Environment (in Recognition of the 50th Anniversary of Earth Day)

2:30 PM Economics of Philanthropy in Conjunction with Science of Philanthropy Initiative (SPI)

\section{January 4th}

8:00 AM Cash Transfers, Women, and Families: International Perspectives (joint with IAFFE)

\section{ASHE}

\section{January 4th}

8:00 AM Economic Issues of Hispanics in the United States

\section{ASHEcon}

January 4th

10:15 AM The Economics of the Opioid Crisis

\section{ASREC}

\section{January 4th}

10:15 AM Economics of Culture and Religion

\section{CEANA}

\section{January 3rd}

10:15 AM United States-China Trade Relationships

\section{January 4th}

8:00 AM Current Topics in Health and Public Economics 


\section{CEBRA}

\section{January 3rd}

10:15 AM Inflation and Price Setting (joint with AEA)

\section{CES}

\section{January 3rd}

12:30 PM Time Series and Empirical Macroeconomics and Finance

2:30 PM China Environment

January 4th

8:00 AM Entrepreneurship in China

\section{CS}

\section{January 4th}

8:00 AM Human Capital and Public Economics

10:15 AM Banking in Historical Perspective

12:30 PM Knowledge and Technological Change

\section{EHA}

\section{January 3rd}

10:15 AM Migration and Development

12:30 PM Political Economy in Historical Perspective

\section{ENSA}

\section{January 3rd}

2:30 PM Economics of National Security Association

\section{EPS}

\section{January 3rd}

8:00 AM Can MMT Ensure Prosperity and Security?

\section{January 4th}

10:15 AM The Ghost Budget: Paying for the Wars in Iraq and Afghanistan

\section{ES}

\section{January 2nd}

5:30 PM ES Presidential Address 


\section{January 3rd}

8:00 AM Econometrica Session: New Developments in Econometrics

8:00 AM Field Applications and Explorations of Reference-Dependence

8:00 AM Financial Markets with an Emphasis on China

8:00 AM Frontiers in Market Design

8:00 AM Migration and Location Choice

8:00 AM Political Competition and Political Extremism

10:15 AM Learning, Uncertainty, and Choices

10:15 AM Market Design

10:15 AM Market Power and the Aggregate Economy

10:15 AM Social Insurance and Social Safety Net in the United States

10:15 AM Transportation Economics

10:15 AM Treatment Effects and Causal Inference

2:30 PM Advances in Contract and Mechanism Design

2:30 PM Central Bank Communications and Management of Expectations

2:30 PM Econometrics of Decisions and Demand

2:30 PM Econometrics of Networks

2:30 PM Sources and Consequences of Inequality

\section{January 4th}

8:00 AM Analysis of Panel and Clustered Data

8:00 AM Dynamic Incentives

8:00 AM Financial Markets and Monetary Policy

8:00 AM Heterogeneous Beliefs and Asset Pricing

8:00 AM JBES Session: Transparency in Structural Estimation

8:00 AM Poster Session in Econometrics

10:15 AM Advances in Network Theory

10:15 AM Bayesian Persuasion

10:15 AM Gender, Human Capital, and Labor Supply Around the World

10:15 AM Housing Markets and Household Heterogeneity

10:15 AM Journal of Econometrics Panel: Econometrics in the 21st Century, Challenges and Opportunities

10:15 AM Labor Share

2:30 PM Advances and Extensions in Reference-Dependent Models

2:30 PM Declining Business Dynamism

2:30 PM Housing and Financial Stability

2:30 PM Machine Learning and High Dimensional Methods

2:30 PM Quantitative Economics Panel: Design of Randomized Control Trials, Different Perspectives

2:30 PM Recent Advances in International Macro

\section{January 5th}

8:00 AM Exchange Rate Puzzles

8:00 AM Industrial Organization and Financial Markets 
8:00 AM Information Effects and Decision under Uncertainty

8:00 AM Macroeconometrics

8:00 AM Testing in Incomplete and Complete Models

10:15 AM Evolution of Monetary Policymaking

10:15 AM Pricing Algorithms, Competition, and Collusion

10:15 AM Regression Discontinuity Designs

10:15 AM Reputation

10:15 AM Stochastic Choice and Experiments on Decision Making

1:00 PM Advances in Phillips Curve Research

1:00 PM Business Cycles and Labor Markets

1:00 PM Identification and Estimation in Causal Models

1:00 PM Information in Contests

1:00 PM Rare Events

\section{ESA}

\section{January 3rd}

8:00 AM Psychology of Poverty: Preferences, Decision-Making and Productivity

2:30 PM Information (Design), Black Markets, and Congestion

\section{January 4th}

2:30 PM Intervening in Other People's Choices: The Supply and Demand for Decision Rights

\section{HERO}

\section{January 3rd}

8:00 AM Provider Competition, Spillovers, and Health Care Productivity

\section{January 4th}

12:30 PM Physicians, Hospitals, Opioids, and Nutrition

2:30 PM Experimental Evidence: From the ACA to New Drugs (joint with AEA)

\section{January 5th}

8:00 AM Innovation in Healthcare Markets

10:15 AM Innovations in Medicare Regulations

\section{HES}

\section{January 3rd}

8:00 AM Historical Sociology Approaches in History of Economics

10:15 AM Endogenous Preferences: A Historical View

2:30 PM Alternative Traditions in Public Choice 


\section{January 5th}

8:00 AM The Cowles Commission at the Frontiers of Theoretical Economics

\section{IAAE}

\section{January 5th}

10:15 AM Advances in Panel Data Econometrics: Theory and Practice

\section{IAEE}

\section{January 4th}

10:15 Am The Geopolitics of Oil Price Cycles (joint with AEA)

12:30 PM Research in Energy Economics Topics

2:30 PM Taking Stock of the Global Energy Transition (joint with NABE)

\section{IAFFE}

\section{January 3rd}

10:15 AM Intimate Partner Violence: Determinants, Impacts, and Strategies

\section{January 4th}

10:15 AM Testing for Gender Effects Using Natural Experiments

12:30 PM 25 Years of "Feminist Economics": Origins, Achievements, and Challenges

\section{IBEFA}

\section{January 3rd}

10:15 AM Real Estate Credit and Securitization

2:30 PM Culture and Conduct

\section{January 4th}

8:00 AM Cross-Border (Non-)Banking

10:15 AM Corporate Culture and Banking (joint with AEA)

12:30 PM Banks, Markets, and Liquidity

2:30 PM Regulation, Risk, and Lending

\section{IEFS}

\section{January 3rd}

2:30 PM Financial Frictions in the Global Economy

\section{January 4th}

8:00 AM International Trade 


\section{IHEA}

\section{January 3rd}

10:15 AM The Intersection of Private and Public Action in Health and Health Care Internationally

\section{January 4th}

8:00 AM Innovative Programming to Improve Adolescent Health in SubSaharan Africa

\section{INEM}

\section{January 3rd}

8:00 AM Methodology and Social Economics for the 21st Century (joint with ASE)

10:15 AM Are We All Behavioral Economists Now?

\section{IOS}

\section{January 3rd}

10:15 AM Energy and IO

2:30 PM Mark-Ups and Common Ownership: An IO Perspective

\section{January 4th}

12:30 PM Antitrust Policy and Mergers: New Empirical Evidence

\section{ISIR}

\section{January 4th}

10:15 AM Cash Holdings, Investment, and Firm Dynamics

\section{ITFA}

\section{January 4th}

8:00 AM Data Science and AI: The Next Frontier for Evidence-Based PolicyMaking

12:30 PM Topics in International Trade \& Finance, R\&D Investment, and Trade $\&$ Financial Sanctions Against Iran

\section{KAEA}

\section{January 4th}

10:15 AM Machine Learning and Its Applications to Econometrics

12:30 PM From Micro Data To Macro Policy 
2:30 PM Artificial Intelligence, Big Data, and Competition with Algorithms (joint with AEA)

\section{LACEA}

\section{January 4th}

8:00 AM Topics in Emerging Markets (joint with AEA)

\section{LERA}

\section{January 3rd}

8:00 AM Broadening the Minimum Wage Debate Beyond Employment

8:00 AM The Status of Older Workers and the Older Worker Labor Market

10:15 AM The Growth of Alternative Work Arrangements: Measurements and Implications

12:30 PM Worker Participation in the 21st Century

2:30 PM Discussion Panel: Making Global Markets Work for American Workers

2:30 PM Impact of Early and Post-secondary Education Policies on Entry and Outcomes

\section{January 4th}

8:00 AM Gender and Careers

8:00 Am Wage Structure, Covenants Not to Compete, and Nonwage Benefits

10:15 AM Intersectionality of Labor Rights and Gender Inequality

10:15 AM Short-Time Work Arrangements: Recent Developments and Policy Implications

2:30 PM Green New Deal: Labor Market Policies for Sustainability and Equity

2:30 PM Labor Force, Productivity, and Mobility

\section{January 5th}

8:00 AM Labor Market Power

8:00 AM Teacher Labor Markets and Student Achievement

10:15 AM The Evolution and Growth of Occupational Regulation and the Work

Force

10:15 AM Worker Skills, Abilities, and Labor Market Returns: Improving Measurement, Identification, and Policy Responses

1:00 PM Causes and Consequences of Performance Pay

1:00 PM Using Online Job Vacancy Data to Study Labor Market Dynamics

\section{MEEA}

\section{January 4th}

8:00 AM Determinants and Effects of Migration

10:15 AM Policy Session ASSA: Exchange Rate Arrangements, Price Stability and Economic Growth in MENA (joint with AEA) 
12:30 PM Conflict and Stereotypes

2:30 PM Environmental Issues in MENA

\section{NABE}

\section{January 3rd}

12:30 PM Navigating the Crosscurrents: The Outlook for the Global Economy

2:30 PM Tech Economics

\section{NAEE}

\section{January 3rd}

10:15 AM Financial Education: Interventions and Outcomes

2:30 PM Professional Promotion and the Scholarship of Teaching and Learning in Economics

January 5th

10:15 AM Economic Education: Practices and Evidence

\section{NAFE}

\section{January 3rd}

2:30 PM Enslavement, Racial Inequality, and Making Victims Whole (joint with NEA)

\section{January 4th}

8:00 AM Estimating Worklife Expectancy and Earnings Capacity

10:15 AM An Agenda for Future Research in Forensic Economics

2:30 PM Special Topics in Forensic Economics

\section{NEA}

\section{January 3rd}

8:00 AM Discrimination in Labor Markets and Educational Settings:

Experimental Evidence

10:15 AM Disparities across Race and Gender: Economics of Health and WellBeing

12:30 PM Black Women in the Economics Profession

\section{January 4th}

10:15 AM Race, Ethnicity, and the 2020 National Election (joint with ASHE)

6:00 PM NEA Presidential Address

\section{January 5th}

8:00 AM Crime, Financial Shock, Employee Ownership

8:00 AM Relationships among Health, Education, and Inequality 
10:15 AM Crime, Race, and Public Policy

1:00 PM Factors Impacting Emerging African Nations

\section{NTA}

\section{January 5th}

8:00 AM Hot-Button Tax Policy Questions: A Session of New Insights and Evidence Organized by the National Tax Association

\section{ODE}

\section{January 3rd}

8:00 AM Omicron Delta Epsilon Graduate Student Session

12:30 PM Omicron Delta Epsilon John R. Commons Award Lecture

\section{PSSI}

\section{January 4th}

2:30 PM Financial Institutions, Religiosity, and Rebel Conflict in Islamic and Other States

\section{January 5th}

8:00 AM Ethnic Polarization, Displaced People, Governance, and War (joint with AEA)

\section{SABE}

\section{January 4th}

8:00 AM Morality and Social Dilemmas in Society (joint with AEA)

\section{SCE}

\section{January 4th}

10:15 AM Industry Dynamics and Optimal Firm Behavior

\section{SED}

\section{January 3rd}

10:15 AM Information, Reputation, and Optimal Policy

2:30 PM The Political Economy and Economic Development of Non-

Democracies

\section{January 4th}

2:30 PM Risk, Pricing, and Economic Dynamics 
SGE

\section{January 3rd}

10:15 Am Big Data: Value, National Accounts, and Public Policy

2:30 PM Banking Competition: Responding to Social Changes

January 4th

8:00 AM Firms, Growth, and Concentration

10:15 AM Governing, Entrepreneurship, and Innovation

12:30 PM Health Outcomes in the Short and Long Run

2:30 PM Productivity

January 5th

8:00 AM Household Balance Sheet

\section{SIOE}

\section{January 3rd}

8:00 AM Culture and Norms Inside Organizations

\section{SNDE}

\section{January 4th}

10:15 AM Business Cycles, Monetary Policy, and Oil Prices

\section{SPM}

\section{January 4th}

12:30 PM Does Europe Grow More Slowly Than the United States?

2:30 PM The Danger of Collapse of the Rules-Based International Trading

System and How to Prevent It

\section{SSEM}

\section{January 3rd}

8:00 AM Arbitration and the Protection of Foreign Investors Through Investment Treaties

January 4th

2:30 PM Financial Intermediation in Emerging Economies

\section{TPUG}

\section{January 3rd}

10:15 AM Transportation Competition and Externalities 
12:30 PM Safety and the Social Costs of Transportation

\section{January 4th}

10:15 AM Welfare, Pricing, and Market Power in Utility Markets (joint with AEA)

2:30 PM Electricity Markets

\section{URPE}

\section{January 3rd}

8:00 AM Political Economy of the Global Monetary System

10:15 AM Climate Crisis Mitigation: Implementing a Green New Deal and More

10:15 AM Marxist Theory

12:30 PM David Gordon Memorial Lecture

2:30 PM Finance, Post-Keynesian, Sraffian Theory

2:30 PM In Search of a New Social Model for the EU

\section{January 4th}

8:00 AM Gender and Race in Economic Outcomes (joint with IAFFE)

8:00 AM Gendered Labor: Paid and Unpaid Work in Contemporary Capitalism

10:15 AM Monetary Policy in the United States, the Eurozone, and China

10:15 AM Political Economy of China

2:30 PM Political Economy of Immigration: Potential for Deep Divisions and Inclusive Alliances

2:30 PM Socialism in the Twenty-First Century

\section{January 5th}

8:00 AM Feminist Perspectives on Institutions, Norms, and Agency (joint with IAFFE)

8:00 AM Race, Gender, and Economic Security in the 21st Century:

Entrepreneurship, Employment, and Retirement

10:15 AM Feminist Radical Political Economy: Reproduction and Production

1:00 PM Ecology, the Environment, and Energy 


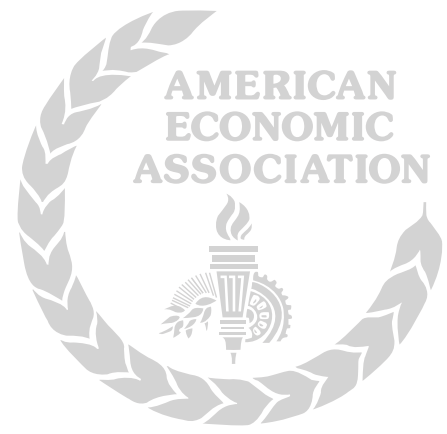




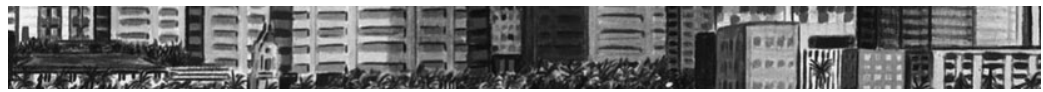 \\ Daily Program of Events \\ Thursday • January 2}

9:30 AM, Marriott Marquis San Diego-Torrey Pines 1-3

American Economic Association (AEA)

Executive Committee Meeting-Invitation Only

12:30 PM, Marriott Marquis San Diego—Rancho Santa Fe 2

American Economic Association (AEA)

Executive Committee Luncheon-Invitation Only

1:00 PM, Marriott Marquis San Diego-Cardiff

National Economic Association (NEA)

Review of Black Political Economy Editorial Board Meeting-Invitation Only

1:00 PM, Manchester Grand Hyatt San Diego-Regatta A-B

American Real Estate and Urban Economics Association (AREUEA)

Board Meeting-Invitation Only

1:00 PM, Manchester Grand Hyatt San Diego-America's Cup C Omicron Delta Epsilon (ODE)

Annual Meeting of the Executive Board-Invitation Only

2:00 PM, Marriott Marquis San Diego-Balboa

National Economic Association (NEA)

Board Meeting-Invitation Only

2:00 PM, Manchester Grand Hyatt San Diego-America's Cup AB Hong Kong Polytechnic University

China Accounting and Finance Review (CAFR) Research WorkshopInvitation Only 


\section{Thursday • January 2}

3:00 PM, Marriott Marquis San Diego-Presidio 1-2

Committee on the Status of Women in the Economics Profession (CSWEP)

Board Meeting-Invitation Only

\section{4:30 PM, Manchester Grand Hyatt San Diego-Seaport A}

American Finance Association (AFA)

Student Travel Grant Panel-Invitation Only

5:00 PM, Marriott Marquis San Diego-Cardiff

Committee on the Status of Minority Groups in the Economics

Profession (CSMGEP)

Annual Meeting-Invitation Only

5:00 PM, Manchester Grand Hyatt San Diego-Coronado D American Real Estate and Urban Economics Association (AREUEA)

Doctoral Session and Reception

5:30 PM, Marriott Marquis San Diego-Marina Ballroom EF Econometric Society (ES)

Presidential Address

Speaker: Stephen Morris, Massachusetts Institute of Technology

Topic: Modelling Incomplete Information: The Misunderstanding of John Harsanyi

5:30 PM, Manchester Grand Hyatt San Diego_-Pier Association for Evolutionary Economics (AFEE)

Annual Board of Directors Meeting. Members and Trustees welcome.

6:00 PM, Manchester Grand Hyatt San Diego-Harbor C Tsinghua University

PBCSF Reception for Financial and Economic Scholars-All are welcome. 


\section{Thursday • January 2}

6:30 PM, Manchester Grand Hyatt San Diego—Coronado AB Association for Social Economics (ASE)

Plenary Session and Reception

Chair: Steven Pressman, Colorado State University

Speaker: Teresa Ghilarducci, New School-A Grey New Deal: The

General Theory of Employment, Retirement, and Money

7:00 PM, Marriott Marquis San Diego-Marriott Grand Ballroom 5-9 Allied Social Science Associations (ASSA)

Welcome Reception

7:00 PM, Manchester Grand Hyatt San Diego-Harbor D

Shanghai Jiao Tong University

Shanghai Advanced Institute of Finance (SAIF) AFA Reception.

All are welcome. 


\section{Friday - January 3}

8:00 АM, Marriott Marquis San Diego_-San Diego Ballroom C Committee on the Status of Women in the Economics Profession (CSWEP)

Mentoring Breakfast for Junior Economists_-Preregistration requiredInvitation Only

8:00 AM, Manchester Grand Hyatt San Diego-Regatta A-B American Real Estate and Urban Economics Association (AREUEA) Hospitality Room

10:15 AM, Manchester Grand Hyatt San Diego-Boardwalk National Association of Forensic Economics (NAFE)

Winter Board of Directors' Meeting-Invitation Only

12:15 PM, Marriott Marquis San Diego-Cardiff American Economic Association (AEA)

AEAStat Working Lunch on Private Sector Data Access-Invitation Only

12:15 PM, Marriott Marquis San Diego-Sorrento Journal of Economic Education

Editor Luncheon-Invitation Only

\section{2:30 PM, Manchester Grand Hyatt San Diego-Harbor B} American Society of Health Economists (ASHEcon)

Tickets may be pre-purchased or purchased onsite. Our special speaker will be Fiona M. Scott Morton, the Theodore Nierenberg Professor of Economics at the Yale University School of Management. Her talk is called The Policy Consequences of Anti-competitive Conduct in Healthcare Markets.

12:30 PM, Manchester Grand Hyatt San Diego-Coronado B Association of Christian Economists (ACE)

Fellowship Luncheon and Business Meeting 


\section{Friday $\cdot$ January 3}

12:30 PM, Marriott Marquis San Diego-Marriott Grand

Ballroom 7-8-9

American Economic Association (AEA)

AEA/AFA Joint Luncheon-Fee Event

Presiding: David A. Hirshleifer, University of California-Irvine

Speaker: David Laibson, Harvard University

Topic: Nudges are Not Enough: The Case for Price-based Paternalism

12:30 PM, Manchester Grand Hyatt San Diego-Promenade AB Association for Evolutionary Economics (AFEE)

Over 50 years of discussion, debate, and scholarship! Please join us in honoring our 2020 Veblen-Commons Award Scholar. Prior RSVP required-Invitation Only

12:30 PM, Marriott Marquis San Diego-San Diego Ballroom C Committee on the Status of Women in the Economics Profession (CSWEP)

Business Meeting and Luncheon to Honor the Recipient of the Carolyn Shaw Bell Award. Pre-registration required-Invitation Only

2:00 PM, Manchester Grand Hyatt San Diego-Balboa C Korea-America Economic Association (KAEA)

EC-AB Meeting-Invitation Only

3:00 PM, Marriott Marquis San Diego-San Diego Ballroom C Committee on the Status of Women in the Economics Profession (CSWEP)

Open Meeting Space. All are welcome to use this space to meet with colleagues or enjoy a quiet moment. Also, stop by for information on CSWEP programming and free copies of CSWEP News.

4:00 PM, Manchester Grand Hyatt San Diego-America's Cup D African Finance and Economics Association (AFEA)

Board Meeting_-Invitation Only 


\title{
Friday • January 3
}

\author{
4:30 PM, Manchester Grand Hyatt San Diego—La Jolla B \\ Union for Radical Political Economics (URPE) \\ Membership Meeting
}

\section{4:30 PM, Marriott Marquis San Diego-Marina Ballroom E Elsevier}

Journal of Econometrics Editorial Board Meeting, followed by Reception. The Journal of Econometrics Editorial Board Meeting will take place from 4:30 to 5:30 PM. The meeting is followed by a reception, taking place from 5:30 to 6:30 PM, in the same location-Invitation Only

\section{4:45 PM, Marriott Marquis San Diego-Marriott Grand Ballroom 7-8-9 \\ American Economic Association (AEA)}

Richard T. Ely Lecture

Presiding: Janet Yellen, Brookings Institution

Speaker: Marianne Bertrand, University of Chicago

Topic: Gender in the 21st Century

\section{4:45 PM, Manchester Grand Hyatt San Diego-Ocean Beach Association for Social Economics (ASE)}

General Membership and Business Meeting

\section{5:00 PM, Manchester Grand Hyatt San Diego-Gaslamp D} National Association of Forensic Economics (NAFE)

Annual General Membership Meeting

\section{5:00 PM, Manchester Grand Hyatt San Diego-Pier} African Finance and Economics Association (AFEA)

Presidential Address and Business Meeting Topic: The State of Africa's Debt: Domestic and Foreign Samuel Amponsah, Tokyo International University Hanan Morsy, African Development Bank Léonce Ndikumana, University of Massachusetts-Amherst Hippolyte Fofack, African Export-Import Bank 


\section{Friday $•$ January 3}

5:00 PM, Marriott Marquis San Diego-Cardiff

American Society of Hispanic Economists (ASHE)

Business Meeting

5:00 PM, Manchester Grand Hyatt San Diego_Cortez Hill A Association for Evolutionary Economics (AFEE)

Please join us for our annual membership meeting, JEI Editor's Prize presentation, and recognition of the Ayre Scholar, Street Scholar, and AFEE Service Award recipients.

5:30 PM, Manchester Grand Hyatt San Diego-Gaslamp AB American Finance Association (AFA)

Board Meeting_-Invitation Only

6:00 PM, Marriott Marquis San Diego-Marriott Grand Ballroom 7-8-9

American Economic Association (AEA)

Business Meeting

6:00 PM, Marriott Marquis San Diego—Catalina TIAA Institute (TIAA)

2019 TIAA Paul A. Samuelson Award

6:00 PM, Manchester Grand Hyatt San Diego-Harbor B American Society of Health Economists (ASHEcon)

Cocktail Reception for Members and Friends of ASHEcon and iHEA.

6:00 PM, Manchester Grand Hyatt San Diego—Old Town B Brown University

Economics Department Cocktail Reception

6:00 PM, Marriott Marquis San Diego-La Costa

Cambridge University Press

Please join the JFQA Editors and Cambridge University Press for drinks and canapés to celebrate another successful year for JFQA. 


\section{Friday • January 3}

6:00 PM, Marriott Marquis San Diego-Marriott Grand Ballroom 10 Committee on the Status of Women in the Economics Profession (CSWEP)

Reception in honor of the recipient of the Carolyn Shaw Bell Award. All are welcome.

\section{6:00 PM, Manchester Grand Hyatt San Diego-Cove}

George Washington University

Please join the Department of Economics for our annual alumni reception.

Network with fellow alumni, meet current students, and connect with faculty. Light hors d'oeuvres and your first drink are free of charge.

\section{6:00 PM, Marriott Marquis San Diego—Santa Rosa University of Colorado Boulder \\ Department of Economics Reception}

6:00 PM, Marriott Marquis San Diego-Mission Hills University of Maryland

Department of Economics reception for alumni and students.

6:00 PM, Marriott Marquis San Diego-Del Mar

AEA Committee on Economic Education

Friends Reception

6:00 PM, Manchester Grand Hyatt San Diego-Coronado A American Real Estate and Urban Economics Association (AREUEA)

Membership Reception

\section{6:00 PM, Manchester Grand Hyatt San Diego-Old Town A} Association of Indian Economic and Financial Studies (AIEFS)

This reception is for friends of the Association of Indian Economic and Financial Studies (AIEFS). AIEFS is a 44-year-old organization of economists that provides a platform for research on India. A special welcome to graduate students interested in the Indian economy. 


\section{Friday $\cdot$ January 3}

6:00 PM, Marriott Marquis San Diego-Torrey Pines 3

Bank of Finland

Reception for Friends of Institute for Economies in Transition (BOFIT) and Research Unit-Invitation Only

6:00 PM, Marriott Marquis San Diego-Torrey Pines 1

Chicago Quantitative Alliance

Members and friends invited to join our Cocktail Reception

6:00 PM, Manchester Grand Hyatt San Diego-Harbor A

Chinese University of Hong Kong

Department of Finance Reception

6:00 PM, Marriott Marquis San Diego-Balboa

Columbia University

Reception

6:00 PM, Manchester Grand Hyatt San Diego_-Promenade AB Cornell University

Alumni and Friends of Dyson School of Applied Economics and Management are invited to meet new and old friends.

6:00 PM, Marriott Marquis San Diego-San Diego Ballroom B Harvard University

Department of Economics and Harvard Business School (HBS) Alumni and Friends Cocktail Reception

6:00 PM, Marriott Marquis San Diego-Marina Ballroom F Institute for Humane Studies

Join IHS staff and fellow scholars for an evening of drinks, hors d'oeuvres, and networking! Friends and colleagues are welcome. 


\section{Friday • January 3}

6:00 PM, Marriott Marquis San Diego-Marina Ballroom G Institute for New Economic Thinking

We welcome our community of scholars, friends, and anyone curious about new economic thinking to join us for a cocktail reception.

\section{6:00 PM, Marriott Marquis San Diego-Coronado Room Jinan University}

Reception hosted by the Institute for Economic and Social Research (IESR). All are welcome.

\section{6:00 PM, Marriott Marquis San Diego_-Point Loma}

Johns Hopkins University

Reception for Alumni and Friends of the Department of Economics

\section{6:00 PM, Marriott Marquis San Diego-San Diego Ballroom A Massachusetts Institute of Technology (MIT)}

Department of Economics 2020 Alumni Reception-Invitation Only

6:00 PM, Marriott Marquis San Diego-Solana

Michigan State University

Department of Economics Alumni Reception

6:00 PM, Manchester Grand Hyatt San Diego-Mission Beach C Middle East Economic Association (MEEA)

Board meeting_-Invitation Only

6:00 PM, Manchester Grand Hyatt San Diego-Gaslamp C National Association of Forensic Economics (NAFE)

Membership \& Guests Cocktail Reception

\section{6:00 PM, Marriott Marquis San Diego-Torrey Pines 2}

New York University

Reception for Alumnae, Alumni, Friends, Students, Members of Stern Economics, Stern Finance, and GSAS Economics 


\section{Friday $•$ January 3}

6:00 PM, Manchester Grand Hyatt San Diego-Mission Beach A Oberlin College

Reception for Alumni and Friends of the Economics Department

6:00 PM, Marriott Marquis San Diego-Marriott Grand Ballroom 13 Shanghai University of Finance and Economics

Reception

6:00 PM, Manchester Grand Hyatt San Diego—Cortez Hill B Transportation and Public Utilities Group (TPUG)

Annual Business Meeting and Cocktail Reception

6:00 PM, Manchester Grand Hyatt San Diego-Harbor E

Union for Radical Political Economics (URPE)

Cocktail Reception for Members and Friends

6:00 PM, Marriott Marquis San Diego-Marriott Grand Ballroom 12 University of California-Berkeley

A reception for alumnae, alumni, friends, and members of the Economics Department.

6:00 PM, Marriott Marquis San Diego-Newport Beach

University of California-Los Angeles

Department of Economics Cocktail Reception for colleagues, faculty, alumni, and friends

6:00 PM, Marriott Marquis San Diego-Carlsbad University of Hong Kong

Faculty of Business and Economics Reception

6:00 PM, Marriott Marquis San Diego-Rancho Santa Fe 2 University of Michigan

Department of Economics Cocktail Reception 


\section{Friday • January 3}

6:00 PM, Manchester Grand Hyatt San Diego-Solana Beach AB University of Pennsylvania

Cocktail Reception sponsored by the School of Arts and Sciences, Department of Economics for the friends of the Department.

6:00 PM, Manchester Grand Hyatt San Diego-Mission Beach B Williams/Amherst/Wesleyan/Wellesley

Reception

6:00 PM, Marriott Marquis San Diego-Marriott Grand Ballroom 11 Yale University

Department of Economics and School of Management Reception

6:00 PM, Marriott Marquis San Diego-Marriott Grand Ballroom 2 Brattle Group

Cocktail Reception-Invitation Only

6:00 PM, Marriott Marquis San Diego-Marriott Grand Ballroom 4 Institute of Labor Economics (IZA)

Annual party. Research Fellows and Affiliates welcome. In addition to the chance for Network members to say hello to each other and to discuss their mutual interests, we will also honor the winner of the 2019 Young Labor Economist Award-Invitation Only

6:00 PM, Manchester Grand Hyatt San Diego-Seaport B Peking University

Guanghua School of Management Reception-Invitation Only

6:00 PM, Manchester Grand Hyatt San Diego-Nautical Peking University

Welcome to National School of Development Alumni Reunion.

\section{6:00 PM, Manchester Grand Hyatt San Diego-Regatta C} Texas A\&M University

Economics Department cocktail reception for faculty, students, and other friends of the Department 


\section{Friday $\cdot$ January 3}

6:15 PM, Manchester Grand Hyatt San Diego-Coronado B Agricultural and Applied Economics Association (AAEA)

T.W. Schultz Memorial Lecture followed by a reception.

6:30 PM, Manchester Grand Hyatt San Diego-Marina American Finance Association (AFA)

AFFECT Reception-Data and Drinks

6:30 PM, Marriott Marquis San Diego-Marriott Grand Ballroom 3 Charles River Associates

You are invited to attend our cocktail reception.

6:30 PM, Manchester Grand Hyatt San Diego-Harbor F

Washington University in St. Louis and Federal Reserve Bank of St. Louis

Department of Economics and Federal Reserve Bank of St. Louis Annual Cocktail Party

6:30 PM, Manchester Grand Hyatt San Diego-Harbor C Xiamen University

Reception for Candidates, Alumni, and Friends of GCCER, WISE, and SOE.

7:00 PM, Manchester Grand Hyatt San Diego_Cortez Hills C University of Wisconsin-Madison

Please join the Department of Economics for an evening reception.

Alumni of the Department and recruitment candidates are encouraged to join our faculty at this event.

7:00 PM, Marriott Marquis San Diego-Marriott Grand Ballroom 1 International Monetary Fund (IMF)

IMF Reception 


\section{Saturday $\cdot$ January 4}

7:00 AM, Manchester Grand Hyatt San Diego—Coronado AB Christian Finance Faculty Association

Meeting

7:00 AM, Manchester Grand Hyatt San Diego_America's Cup AB American Real Estate and Urban Economics Association (AREUEA)

Homer Hoyt Institute (HHI) Breakfast-Invitation Only

7:00 AM, Manchester Grand Hyatt San Diego-Harbor B University of Washington

Editors and Associate Editors Breakfast Meeting

Hosted by: Journal of Financial and Quantitative Analysis-Invitation Only

7:45 AM, Marriott Marquis San Diego-Marina Ballroom G Iowa State University

Chairpersons' Symposium and Breakfast (NSF, CSWEP, CSMGEP, Economic Education, and Labor Market Survey)—Invitation Only

7:45 AM, Manchester Grand Hyatt San Diego-Coronado D Association for Social Economics (ASE)

Presidential Breakfast-Fee Event

Presiding: Steven Pressman, Colorado State University

Speaker: Julie A. Nelson, University of Massachusetts

Topic: Economics For (And By) Humans

8:00 AM, Marriott Marquis San Diego—Vista Review of Industrial Organization (RIO)

Editorial Board Breakfast-Invitation Only

8:00 AM, Marriott Marquis San Diego-Torrey Pines 2 American Economic Journal: Economic Policy

AEJ Policy Editors' Breakfast-Invitation Only 


\section{Saturday $\cdot$ January 4}

8:00 AM, Manchester Grand Hyatt San Diego-Boardwalk American Society of Health Economists (ASHEcon)

ASHEcon Board Meeting-Invitation Only

8:00 AM, Marriott Marquis San Diego-San Diego Ballroom C Committee on the Status of Women in the Economics Profession (CSWEP)

Peer Mentoring Breakfast for Mid-Career Economists. Preregistration required-Invitation Only

8:00 AM, Marriott Marquis San Diego-Torrey Pines 3

Journal of Economic Perspectives (JEP)

Purpose is to brainstorm about topics and authors for future issuesInvitation Only

8:00 AM, Manchester Grand Hyatt San Diego-Regatta A-B American Real Estate and Urban Economics Association (AREUEA) Hospitality Room

8:30 AM, Marriott Marquis San Diego—Encinitas

History of Economics Society (HES)

Executive Committee Meeting-Invitation Only

10:00 AM, Marriott Marquis San Diego-San Diego Ballroom C Committee on the Status of Women in the Economics Profession (CSWEP)

Open Meeting Space. All are welcome to use this space to meet with colleagues or enjoy a quiet moment. Also, stop by for information on CSWEP programming and free copies of CSWEP News.

\section{2:00 PM, Manchester Grand Hyatt San Diego-Harbor B} Association of Environmental and Resource Economists (AERE) Join other AERE members for the AERE Winter Luncheon and Annual Business Meeting-includes the annual AERE Fellow's Address. This event is open only to AERE members-Invitation Only 


\section{Saturday $\cdot$ January 4}

12:15 PM, Marriott Marquis San Diego—Vista

AEA Committee on Economic Education

Member Luncheon-Invitation Only

12:30 PM, Manchester Grand Hyatt San Diego-Coronado AB American Real Estate and Urban Economics Association (AREUEA)

Presidential Luncheon-Fee Event

Presiding: Abdullah Yavas, University of Wisconsin-Madison

Speaker: Crocker Liu, Cornell University

Topic: Thinking Tall: Anchor Tenants, Vertical Agglomeration, and Value Creation

12:30 PM, Marriott Marquis San Diego-Marina Ballroom G National Economic Association (NEA)

50th Anniversary Celebration and Honors Luncheon

12:30 PM, Marriott Marquis San Diego-Santa Rosa

American Economic Association (AEA)

LGBTQ Lunch

12:30 PM, Marriott Marquis San Diego-Marriott Grand Ballroom 7-8-9

American Economic Association (AEA)

Nobel Laureate Luncheon-Fee Event

Presiding: Janet Yellen, Brookings Institution

Lint Barrage, University of California-Santa Barbara

Robert Gordon, Northwestern University

George Akerlof, University of California-Berkeley

Chad Jones, Stanford University

12:30 PM, Manchester Grand Hyatt San Diego-La Jolla A American Finance Association (AFA)

AFFECT Committee Meeting-Invitation Only 


\section{Saturday $\cdot$ January 4}

12:30 PM, Marriott Marquis San Diego-Newport Beach Chinese Economic Association in North America (CEANA)

Research Meeting 2

1:00 PM, Manchester Grand Hyatt San Diego-Coronado D African Finance and Economics Association/African Development Bank (AFEA/AfDB)

Joint Luncheon and Keynote Address

Speaker: Nana Adjoa A. Sifa, Yo!Gate Foods, and Guzakuza-Invitation Only

4:00 PM, Manchester Grand Hyatt San Diego-Coronado AB Review of Radical Political Economics (RRPE)

Editorial Board Meeting-Invitation Only

4:30 PM, Manchester Grand Hyatt San Diego-America's Cup AB American Real Estate and Urban Economics Association (AREUEA) AREUEA Membership Meeting

4:30 PM, Manchester Grand Hyatt San Diego-Promenade A Association for Economic and Development Studies on Bangladesh (AEDSB)

Annual General Meeting (AGM)

Speaker: Khawaja Saeed A. Mamun, Sacred Heart University

4:40 PM, Marriott Marquis San Diego-Marriott Grand Ballroom 7-8-9

American Economic Association (AEA)

Awards Ceremony \& Presidential Address

Presiding: Janet Yellen, Brookings Institution

Speaker: Ben Bernanke, Brookings Institution

Topic: Twenty-first Century Monetary Policy 


\section{Saturday $\cdot$ January 4}

\section{4:45 PM, Manchester Grand Hyatt San Diego-Cove}

American Committee on Asian Economic Studies (ACAES)

The American Committee on Asian Economic Studies extends an open invitation to attend a reception to celebrate the 30 year anniversary of its journal, the Journal of Asian Economics. The reception will follow the ACAES session on "Economic Inequality in Asia."

\section{4:45 PM, Manchester Grand Hyatt San Diego-Harbor D} Association for Comparative Economic Studies (ACES)

Membership Meeting \& Presidential Address

Presiding: Scott Rozelle, Stanford University-Thinking through the Challenges of Middle Income in an Era of Automation, Trade Wars, and Immigration Bans

\section{5:00 PM, Manchester Grand Hyatt San Diego_Cortez Hill A} Association for Evolutionary Economics (AFEE)

Please join us for the annual address from our President. This year David Zalewski will speak on "Confronting the Trilemma: Culture, Institutions, and Macroeconomic Disequilibria." Come for the address and join us later for our cocktail party.

\section{5:00 PM, Manchester Grand Hyatt San Diego-Boardwalk} International Banking, Economics, and Finance Association (IBEFA) Executive Committee Meeting-Invitation Only

5:00 PM, Marriott Marquis San Diego-Marriott Grand Ballroom 3 National Economic Association (NEA)

Business Meeting

5:00 PM, Manchester Grand Hyatt San Diego-Harbor B Korea-America Economic Association (KAEA) Annual Business Meeting 


\section{Saturday $\cdot$ January 4}

5:30 PM, Manchester Grand Hyatt San Diego-Regatta C American Real Estate and Urban Economics Association (AREUEA) WREN Networking Event

\section{5:30 PM, Manchester Grand Hyatt San Diego-Seaport DE} American Finance Association (AFA)

Business Meeting and Presidential Address

\section{5:30 PM, Marriott Marquis San Diego-Point Loma}

Economic Policy Institute

Reception

6:00 PM, Manchester Grand Hyatt San Diego—Cortez Hills C International Banking, Economics, and Finance Association (IBEFA) Membership Meeting-Invitation Only

6:00 PM, Marriott Marquis San Diego-Marriott Grand Ballroom 3 National Economic Association (NEA)

Presidential Address

Omari Swinton, Howard University

6:00 PM, Manchester Grand Hyatt San Diego-Coronado D Agricultural and Applied Economics Association (AAEA)

Network with AAEA Board Members (past and present), mentors and mentees, and other colleagues.

6:00 PM, Manchester Grand Hyatt San Diego-Harbor D Association for Comparative Economic Studies (ACES)

Annual Wine \& Cheese Reception for Members and their Guests.

6:00 PM, Marriott Marquis San Diego-Catalina American Economic Association (AEA)

LGBTQ Reception 


\section{Saturday $\cdot$ January 4}

6:00 PM, Marriott Marquis San Diego-Marriott Grand Ballroom 11 Analysis Group

Reception-Invitation Only

\section{6:00 PM, Manchester Grand Hyatt San Diego-Seaport B} Association of Environmental and Resource Economists (AERE)

Joint Reception with Resources for the Future-AERE members and friends will gather for a reception co-hosted by AERE and Resources for the Future. No pre-registration is required.

\section{6:00 PM, Manchester Grand Hyatt San Diego-Gaslamp C Bank of England}

AEA attendees are welcome to join us for a drinks reception to learn more about Research at the Bank of England, our PhD Research Programme for new researchers, Experienced Researcher roles, and $\mathrm{PhD}$ Intern roles.

6:00 PM, Marriott Marquis San Diego-Mission Hills

Boston University

Economics Department Reception

\section{6:00 PM, Marriott Marquis San Diego-Del Mar Brookings Institution}

Reception in conjunction with Yale University Press for the release of "First Responders: Inside the U.S. Strategy for Fighting the 2007-2009 Global Financial Crisis," edited by Ben S. Bernanke, Timothy F. Geithner, Henry M. Paulson, Jr., with J. Nellie Liang.

6:00 PM, Marriott Marquis San Diego-Torrey Pines 2

Carnegie Mellon University

Tepper School of Business Reception for Faculty, Alumni, and FriendsInvitation Only

6:00 PM, Manchester Grand Hyatt San Diego-Harbor F

Chinese Economists Society (CES)

Business Meeting and Reception 


\section{Saturday • January 4}

6:00 PM, Marriott Marquis San Diego-Marriott Grand Ballroom 1 Cornell University

Department of Economics Cocktail Reception

6:00 PM, Marriott Marquis San Diego-Coronado Room

Economic History Association and Cliometric Society (EHA)

and $(\mathrm{CS})$

We invite friends of economic history to a cocktail reception. Please join us to reminisce about the past with old friends and ponder the future with new acquaintances.

6:00 PM, Manchester Grand Hyatt San Diego-Gaslamp AB Economic Science Association (ESA)

Reception for Members and Friends

6:00 PM, Marriott Marquis San Diego—Cardiff Princeton University

Cocktail Reception

6:00 PM, Manchester Grand Hyatt San Diego-Coronado E European Central Bank

Reception co-hosted with the National Central Banks of the Eurosystem-Invitation Only

6:00 PM, Manchester Grand Hyatt San Diego-Ocean Beach Georgia State University

Department of Economics Cocktail Reception

6:00 PM, Marriott Marquis San Diego-Carlsbad IMPAQ International

Cocktail Reception-Invitation Only 


\section{Saturday $\cdot$ January 4}

6:00 PM, Manchester Grand Hyatt San Diego-Pier

International Economics and Finance Society (IEFS)

Reception

6:00 PM, Manchester Grand Hyatt San Diego-Balboa C

Middle East Economic Association (MEEA)

Business Meeting. All members invited.

\section{6:00 PM, Manchester Grand Hyatt San Diego_-Gaslamp D}

Ohio State University

Department of Economics Cocktail Party and Social Mixer

6:00 PM, Manchester Grand Hyatt San Diego-America's Cup D Omicron Delta Epsilon (ODE)

Reception to honor chapter advisors. All ODE advisors are invited to attend and are welcome to bring any students who are with themInvitation Only

6:00 PM, Marriott Marquis San Diego-Torrey Pines 1

Peking University

HSBC Business School Reception

6:00 PM, Manchester Grand Hyatt San Diego-Old Town B Purdue University

Department of Economics Reception for Alumni and Friends

6:00 PM, Marriott Marquis San Diego-Marina Ballroom E Stanford University

Department of Economics Cocktail Reception

6:00 PM, Manchester Grand Hyatt San Diego—-Old Town A Syracuse University

Department of Economics Cocktail Reception-open to SU faculty, alumni, friends, and invited guests-Invitation Only 


\section{Saturday • January 4}

6:00 PM, Marriott Marquis San Diego-Marriott Grand Ballroom 2 University of Chicago

Kenneth C. Griffin Department of Economics Reception

6:00 PM, Manchester Grand Hyatt San Diego-America's Cup C University of Connecticut

Department of Economics will host a cocktail reception for Faculty, Graduate Students, Alumni, Staff, and Job Candidates.

6:00 PM, Marriott Marquis San Diego—Balboa University of Virginia

Department of Economics and Frank Batten School of Leadership and Public Policy Reception

6:00 PM, Marriott Marquis San Diego—La Costa

History of Economics Society (HES)

Please join us for a cocktail reception.

6:00 PM, Manchester Grand Hyatt San Diego-Seaport C Financial Research Network

Invited guests are welcome to join us at San Diego Wine \& Culinary Center.

For more information about FIRN see firn.org.au—Invitation Only

6:00 PM, Manchester Grand Hyatt San Diego-Mission Beach B Peking University

Reception

6:00 PM, Marriott Marquis San Diego-Newport Beach University of Washington

Department of Economics Reception: Please join our faculty and graduate students for drinks and mingling. 


\section{Saturday - January 4}

6:00 PM, Manchester Grand Hyatt San Diego-Solana Beach AB World Peace Congress

The Life and Work of Genevieve Vaughan and Ravi Batra

Presiding: Rajani Kanth, World Peace Congress

Speakers: Genevieve Vaughan, International Feminists for a Gift Economy

Ravi Batra, Southern Methodist University

\section{6:15 PM, Manchester Grand Hyatt San Diego_Cortez Hill B} Association for Evolutionary Economics (AFEE)

Please join us in celebrating another successful year at our no-host cocktail reception! Immediately following the AFEE presidential address.

6:30 PM, Manchester Grand Hyatt San Diego-Mission Beach C Chapman University

Reception for faculty and friends of Chapman University, hosted by Mark Skousen, Presidential Fellow.

6:30 PM, Manchester Grand Hyatt San Diego-Mission Beach A International Banking, Economics, and Finance Association (IBEFA)

Membership Reception-Invitation Only

6:30 PM, Marriott Marquis San Diego-Marina Ballroom D Australian Universities

Cocktail Reception

6:30 PM, Marriott Marquis San Diego-Marina Ballroom F Committee on the Status of Minority Groups in the Economics Profession, American Society of Hispanic Economists, National Economics Association (CSMGEP, ASHE, NEA)

Cocktail Reception 


\section{Saturday $\cdot$ January 4}

6:30 PM, Marriott Marquis San Diego-Marina Ballroom G University of California-San Diego

Economics Department Reception

6:30 PM, Marriott Marquis San Diego-Marriott Grand Ballroom 4 University of Minnesota-Twin Cities

Cocktail Party

6:30 PM, Manchester Grand Hyatt San Diego-Harbor E

W. P. Carey School of Business

Department of Finance Reception

6:30 PM, Marriott Marquis San Diego_-Vista

California State University-Fullerton

Economics Department and the Woods Center Welcome Reception

6:30 PM, Marriott Marquis San Diego-Marriott Grand Ballroom 12 Ewing Marion Kauffman Foundation

We invite you and your colleagues to join us for an informal and interactive networking reception to engage scholars who are studying entrepreneurship. Cocktails and hors d'oeuvres will be served.

7:00 PM, Marriott Marquis San Diego-Marriott Grand Ballroom 10 Bates White Economic Consulting

Reception-Invitation Only

7:00 PM, Manchester Grand Hyatt San Diego-Harbor A World Bank

Development Research Group Reception-Invitation Only 


\section{Saturday • January 4}

\section{8:00 PM, Marriott Marquis San Diego-San Diego Ballroom A American Economic Association (AEA)}

Annual Economics Humor Session in Honor of Caroline Postelle

Clotfelter

Willingness Toupee:

David McEvoy, Appalachian State University

Ash Morgan, Appalachian State University

John C. Whitehead, Appalachian State University

Ed Van Wesep, University of Colorado Boulder

Yoram Bauman, Standupeconomist.com—-"From Seattle to Salt Lake City" 


\section{Sunday $・$ January 5}

7:30 AM, Marriott Marquis San Diego-Marina Ballroom G ASSA Affiliated Journals

Annual editors breakfast hosted by The American Economist-Invitation Only

\section{8:00 AM, Manchester Grand Hyatt San Diego_La Jolla A}

American Finance Association (AFA)

Nominating Committee-Invitation Only

\section{8:00 AM, Marriott Marquis San Diego-San Diego Ballroom C}

Committee on the Status of Women in the Economics Profession (CSWEP)

Mentoring Breakfast for Junior Economists—Preregistration requiredInvitation Only

8:00 AM, Manchester Grand Hyatt San Diego-Harbor B

Korea-Ameria Economic Association (KAEA)

MK Forum

Ariel Stanley Pakes, Harvard University

\section{8:00 AM, Manchester Grand Hyatt San Diego-America's Cup AB} Peking University

Welcome to the annual gathering of the School of Economics 2020 New Year Forum

\section{8:15 AM, Manchester Grand Hyatt San Diego-Gaslamp AB} Catholic Research Economist Discussion Organization

Annual meeting and breakfast. All are welcome. The meeting and breakfast are preceded by a special 7 AM Mass at St. Joseph Cathedral, 1535 Third Avenue San Diego, CA 92101, a 5-10 minute drive or 25 minute walk from headquarters. 


\section{Sunday $\cdot$ January 5}

10:30 AM, Marriott Marquis San Diego-San Diego Ballroom C Committee on the Status of Women in the Economics Profession (CSWEP)

CSWEP/CSMGEP Panel: Launching a Professional Development

Initiative

Chair: Judy Chevalier, Yale University

Martha Bailey, University of Michigan

Marie T. Mora, University of Missouri-St. Louis

Maya Rossin-Slater, Stanford University

Anna Opoku-Agyeman, Harvard University

12:00 PM, Manchester Grand Hyatt San Diego-Gaslamp AB

Korea-America Economic Association (KAEA)

Mentoring Workshop

12:30 PM, Marriott Marquis San Diego-San Diego Ballroom C Committee on the Status of Women in the Economics Profession (CSWEP)

Open Meeting Space. All are welcome to use this space to meet with colleagues or enjoy a quiet moment. Also, stop by for information on CSWEP programming and free copies of CSWEP News. 


\section{Friday-Sunday • January 3-5}

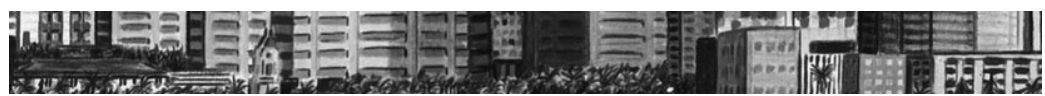 AEA Special Poster Session}

7:00 AM-6:00 PM Marriott Marquis San Diego-2nd Floor (Lobby Level), North Tower, Grand Ballroom Foyer, and West Lobby

Lounge

AEA

JEL Class A (General Economics and Teaching)

OLIVER REHBEIN, University of Bonn-Does Publication Lead to Publication? The Effect of Author Reputation on Publication Success

NIKOLAOS ARTAVANIS, Virginia Tech, and SOUMYA KARRA, University of Massachusetts-Amherst—Financial Literacy and Student Debt

SERGEY V. POPOV, Cardiff University, ALI SINA ÖNDER, University of Portsmouth, and SASCHA SCHWEITZER, University of BayreuthLeadership in Scholarship: Editors' Influence on the Profession's Narrative

\section{JEL Class C (Mathematical and Quantitative Methods)}

MATTHIAS SEBASTIAN HERTWECK, Deutsche BundesbankAgricultural Productivity Shocks and Poverty in India: The Short- and Long-Term Effects of Monsoon Rainfall

KATJA HEINISCH, Halle Institute for Economic Research (IWH), CHRISTOPH SCHULT, Halle Institute for Economic Research (IWH), and CAROLA ENGELKE, University of Cologne-How Forecast Accuracy Depends on Conditioning Assumptions

JAQUESON KINGESKI GALIMBERTI, ETH Zurich-Forecasting GDP Growth from Outer Space

YA-TING CHANG, National Central University, YIN-FENG GAU, National Central University, and CHIH-CHIANG HSU, National Central University_Liquidity Spillover in the Foreign Exchange Market 


\section{Friday-Sunday • January 3-5}

ZUCHAO SHEN, University of Cincinnati, BEN KELCEY, University of Cincinnati, and GANG WANG, Winthrop University-Optimal Allocation of Sample Sizes in Group-Randomized Trials

BIBASWAN CHATTERJEE, Xi' an Jiaotong University, and DOOTI ROY, Boehringer Ingelheim-Predicting Consumer Spending Using Expenditure Micro-Data

LINA LU, Federal Reserve Bank of Boston, and TOMOHIRO ANDO, University of Melbourne-A Spatial Panel Quantile Model with Unobserved Heterogeneity

SANCHARI CHOUDHURY, Saint Xavier University, and JAYJIT ROY, Appalachian State University-Regulatory Races Revisited

KENTARO TOMOEDA, University of Technology Sydney, YAN SONG, Jinan University, and XIAOYU XIA, Chinese University of Hong Kong-Sophistication and Cautiousness in College Applications

\section{JEL Class D (Microeconomics)}

KYLE CHAUVIN, Harvard University-A Misattribution Theory of Discrimination

CHRISTIAN KREKEL, London School of Economics and Political Science, and RETO ODERMATT, University of Basel-Behavioural Spatial Economics: Utility Misprediction in Locational Choices and Spatial Sorting

GUILLAUME ARNOULD, Bank of England, and ANTOINE LALLOUR, Bank of England-Can Banks Use Their Liquid Asset Buffers?

JIAYING CHEN, Hong Kong University of Science and TechnologyFinancial Access and Time Preference: Longitudinal Evidence from Indonesia

ZHI DONG, University of Auckland-Deadweight Loss of the Value of Information with Investors' Temporal Beliefs

KIM SAU CHUNG, Hong Kong Baptist University, and YUJING XU, University of Hong Kong-Dinosaur Judges: Conservative Experts in a Changing Society 


\section{Friday-Sunday $•$ January 3-5}

AHMAD RESHAD OSMANI, University of Memphis, and ALBERT OKUNADE, University of Memphis-Do Supply-Side Incentives Improve the Use of Healthcare Services? New Evidence from a Field Experiment

SANJUKTA BASU, Tulane University—Does the Daylight Savings Time Causes People to Change More Than Their Clock?

MELANIE KOCH, German Institute for Economic Research, THERES KLUEHS, Leibniz University Hannover, and WIEBKE STEIN, Leibniz University Hannover-Don't Expect Too Much: The Effect of Biased Expectations on (Over)-Indebtedness

FELIX RUSCHE, University of Mannheim, and OLGA SLIVKO, Centre for European Economic Research (ZEW) -Emotions and Information Diffusion on Social Networks: Evidence from German Political Twitter

MERADEE TANGVATCHARAPONG, Texas A\&M UniversityEstimating the Impact of Fake News: Evidence from the Anti-Vaccination Movement

HANZHE ZHANG, Michigan State University—A Model of Investmentand-Marriage with Differential Fecundity

YUFENG SUN, Shanghai University of Finance and EconomicsIgnorance Is Bliss

ZHONGHONG KUANG, Tsinghua University, HANGCHENG ZHAO, University of Chicago, and JIE ZHENG, Tsinghua UniversityInformation Design in Simultaneous All-Pay Auction Contests

ROMINA KAZANDJIAN, American University-Information Rigidity and Economic Uncertainty: A New Theory and Stylized Facts

DIMITRI DUBOIS, University of Montpellier, STEFANO FAROLFI, UMR G-eau and CIRAD, PHU NGUYEN-VAN, BETA, CNRS, INRA, University of Strasbourg, and Thang Long University, and JULLIETTE ROUCHIER, LAMSADE, CNRS, and University of DauphineInformation Sharing Is Not Always the Right Option in CPR Extraction Management: Experimental Findings

JIALIANG ZHU, Xiamen University-Is Gift Card Really A Gift? An Empirical Study of Income Elasticity for Special Labeling of Dairy Product 


\section{Friday-Sunday $•$ January 3-5}

JULIANA CHEN PERAZA, RAND Corporation-Long-Term Effects of Child Care Assistance Policies

HUGH HOIKWANG KIM, University of South Carolina, and WENHAO YANG, University of South Carolina-Measuring (In)Attention to Mutual Fund Fees: Evidence from Experiments

MENGHAN XU, Xiamen University, and YUJING XU, University of Hong Kong - Non-Linear Pricing with Reneging

SARAH WOLFOLDS, Cornell University-Nonprofits as Innovators: Profit Status and Competition in the Mixed Microfinance Industry

GAOYANG CAI, Tsinghua University, YONG WANG, Tsinghua University, and DANXIA XIE, Tsinghua University-Optimal Stratification of Platforms: Two-Sided Markets Design with Mechanism Design Approach

AVINASH COLLIS, Massachusetts Institute of Technology, and FELIX EGGERS, University of Groningen-The Impact of Social Media Usage on Productivity and Well-Being: Evidence from a Randomized Controlled Trial

ELISA MOUGIN, Sciences Po-TV in Times of Political Crisis : New Evidence from the 2017 Election in Kenya

AYESHA ALI, Lahore University of Management Sciences, and IHSAN AYYUB QAZI, Lahore University of Management SciencesUnderstanding the Effect of Digital Literacy on the Spread of Misinformation - Evidence from Pakistan

ALEXANDROS THELOUDIS, LISER-Luxembourg and University College London-Family Time Allocations over the Last Half Century

XUEZHONG HE, University of Technology Sydney, LEI SHI, Macquarie University, and MARCO TOLOTTI, Ca' Foscari University of Venice-Welfare Analysis under Probabilistic Choices in a Rational Expectations Equilibrium Model

CHARLENE MARIE KALENKOSKI, Texas Tech University, and THOMAS KORANKYE, Texas Tech University-Effect of Caring for Pets on the Well-being of Older Americans 


\section{Friday-Sunday • January 3-5}

\section{JEL Class E (Macroeconomics and Monetary Economics)}

LINYI CAO, Washington University-St. Louis, and LIJUN ZHU, Peking University-Antitrust Policy in a Globalized Economy

BEN CHAROENWONG, National University of Singapore, RANDALL MORCK, University of Alberta, and YUPANA WIWATTANAKANTANG, National University of Singapore-Asset Prices, Corporate Actions, and Bank of Japan Equity Purchases

ATHANASIOS GEROMICHALOS, University of California-Davis, LUCAS HERRENBRUECK, Simon Fraser University, and SUKJOON LEE, University of California-Davis-Asset Safety Versus Asset Liquidity

MARGARITA RUBIO, University of Nottingham, and FANG YAO, Reserve Bank of New Zealand-Bank Capital, Financial Stability and Basel Regulation in a Low Interest-Rate Environment

SINEM HACIOGLU HOKE, Bank of England-Macroeconomic Effects of Political Risk Shocks

JEREMY BOCCANFUSO, Paris School of Economics-Costly Information Processing and Consumption Dynamics

AKATSUKI SUKEDA, University of California-Santa CruzChallenges of Credible Forward Guidance

ZHESHENG QIU, City University of Hong Kong, and JOSÉ-VÍCTOR RÍOS-RULL, University of Pennsylvania-Directed Search, Nominal Rigidities, and Mark-up Cyclicality

TRISTAN POTTER, Drexel University—Discouragement Traps

PÅL BERGSET ULVEDAL, Norges Bank, FRANCESCO FURLANETTO, Norges Bank, and ØRJAN ROBSTAD, Norges BankEstimating Hysteresis Effects

DAWID ZOCHOWSKI, European Central Bank, IOANA ALEXOPOULOU, European Central Bank, ULRICH BINDSEIL, European Central Bank, AGUEDA SOLIS ALONSO, European Central Bank, and GIACOMO BELTRAME, European Central BankEstimating the Collateral Eligibility Premium: An Euro Area Study 


\section{Friday-Sunday $•$ January 3-5}

FABIAN GREIMEL, University of Mannheim, and MORITZ DRECHSEL-GRAU, University of Mannheim-Falling Behind: Has Rising Inequality Fueled the American Debt Boom 1980-2007?

WEICHENG LIAN, International Monetary Fund-Fundamental and Speculative Demands for Housing

THOMAS WILLETT, Claremont McKenna College and Claremont Graduate University, SHAN XUE, Claremont Graduate University, and ALICE OUYANG, Central University of Finance and EconomicsHong Kong Can Escape the Trilemma in the Short Run

PAWEL KOPIEC, National Bank of Poland-Household Heterogeneity and the Value of Government Spending Multiplier: An Analytical Characterization

ØRJAN ROBSTAD, Norges Bank, FRANCESCO FURLANETTO, Norges Bank, and SAMAD SARFERAZ, ETH Zurich-Immigration and Inequality: New Macroeconomic Evidence

FUTOSHI NARITA, International Monetary Fund, and RUJUN YIN, International Monetary Fund-In Search of Information: Use of Google Trends' Data to Narrow Information Gaps for Low-income Developing Countries

YEVGENIY TERYOSHIN, University of Nevada-Las Vegas-Inflation Target Uncertainty and Monetary Policy

SAM BULLARD, Wells Fargo Securities, LLC, and AZHAR IQBAL, Wells Fargo Securities, LLC-Is the FOMC Overly-Optimistic?

MASAMI IMAI, Wesleyan University-Local Economic Impacts of Political Malapportionment

SYED MUHAMMAD HUSSAIN, James Madison University, and LIN LIU, University of Liverpool-Macroeconomic Effects of Discretionary Tax Changes in Canada: Evidence from a New Narrative Measure of Tax Shocks

THIBAUT DUPREY, Bank of Canada, and ALEXANDER UEBERFELDT, Bank of Canada-Managing GDP Tail Risk

CATALINA MARTINEZ HERNANDEZ, Free University of Berlin and DIW Berlin-Monetary Transmission and Inflation Expectations in the Euro Area 


\section{Friday-Sunday $•$ January 3-5}

TAKAHIRO HATTORI, Ministry of Finance of Japan, and JIRO YOSHIDA, Pennsylvania State University-Return of the Bond-Price Support Regime: Bank of Japan's Dual Bond-Purchase Program

PIETRO DINDO, Ca' Foscari University of Venice, ANDREA MODENA, Ca' Foscari University of Venice, and LORIANA PELIZZON, Goethe University Frankfurt-Risk Pooling, Leverage, and the Business Cycle

XUEHUI HAN, Asian Infrastructure Investment Bank, and YUAN CHENG, Fudan University-Solve the Riddle on Infrastructure-Debt Nexus from Outer Space

LIJUN ZHU, Peking University, MICHELE BOLDRIN, Washington University-St. Louis, and YONG WANG, Peking University-The Cyclical Behavior of Factor Shares

CHRISTIAN FRIEDRICH, Bank of Canada, ALEXANDRA EFFENBERGER, German Federal Ministry for Economics and Energy, and JEROMIN ZETTELMEYER, Peterson Institute for International Economics and CEPR-The Distributional Consequences of Macroeconomic Stabilization Policies

NATALIJA NOVTA, International Monetary Fund, WEICHENG LIAN, International Monetary Fund, EVGENIA PUGACHEVA, International Monetary Fund, YANNICK TIMMER, International Monetary Fund, and PETIA TOPALOVA, International Monetary Fund-The Price of Capital Goods: A Driver of Investment Under Threat

MATHIAS KLEIN, Sveriges Riksbank, and ROLAND WINKLER, University of Antwerp-The Government Spending Multiplier at the Zero Lower Bound: International Evidence from Historical Data

GENE PAUL GERARD AMBROCIO, Bank of Finland-The Real Effects of Fear and Fundamental Uncertainty Shocks

LUIS BRANDAO MARQUES, International Monetary Fund, JEROME VANDENBUSSCHE, International Monetary Fund, PEICHU XIE, International Monetary Fund, and QIANYING CHEN, International Monetary Fund-The Riskiness of Credit Allocation and MacroFinancial Stability

BORA DURDU, Federal Reserve Board, and MOLIN ZHONG, Federal Reserve Board-Understanding Bank and Nonbank Credit Cycles: A Structural Exploration 


\section{Friday-Sunday $•$ January 3-5}

GIOVANNI GANELLI, International Monetary Fund, and JUHA TERVALA, University of Helsinki-Welfare Multiplier of Public Investment

\section{JEL Class F ( International Economics)}

SERGE SHIKHER, United States International Trade Commission, and SUNGHYUN HENRY KIM, Sungkyunkwan University-Can Protectionism Improve the Trade Balance

PEDRO CASTRO, PUC-Rio, and RUY RIBEIRO, PUC-Rio-Currency Returns and Interest Rate Slopes

INGMAR ROEVEKAMP, TU Dresden, and STEFAN EICHLER, TU Dresden-Eurozone Exit Risk

NING CAI, China Development Bank, JINLU FENG, China Development Bank, YONG LIU, China Development Bank, HONG RU, Nanyang Technological University, and ENDONG YANG, University of Macau-Government Credit and Trade War

LOURENCO S. PAZ, Baylor University, ANDRE FILIPE DE AZEVEDO, Unisinos University, and MAGNUS DOS REIS, Federal University of Rio Grande do Sul (UFRGS) - Has WTO Membership Promoted Trade Since the WTO Foundation?

SYED AL-HELAL UDDIN, College of Saint Benedict \& Saint John's University, and AHMED TARIQ AZIZ, Iowa State UniversityImmigration, Product Quality, and Intensive and Extensive Margins of Trade

XIN CHENG, Xiamen University, and YINGGANG ZHOU, Xiamen University-Is Bitcoin a Safe-Haven Currency? Evidence from Conditional Coskewness and Cokurtosis

NATHAN CONVERSE, Federal Reserve Board, and ENRICO MALLUCCI, Federal Reserve Board-Differential Treatment in the Bond Market: Sovereign Risk and Mutual Fund Portfolios

YUKO IMURA, Bank of Canada-Reassessing Trade Barriers with Global Value Chains

BENJAMIN H. LIEBMAN, St. Joseph's University, and YOCHANAN SHACHMUROVE, City University of New York-City College and Graduate Center-Tariffs and Chinese Steel Futures 


\section{Friday-Sunday $\cdot$ January 3-5}

ROGER VICQUERY, London School of Economics-The Common Currency Effect on International Trade: Evidence from an Accidental Monetary Union

JOHN BEGHIN, North Carolina State University, and BYUNG YUL PARKS, North Carolina State University-The Exports of Higher Education Services from OECD Countries to Asian Countries, A Gravity Approach

JESUS ANDRES GORRIN, University of Warwick, JOSE MORALES, Harvard University, and BERNARDO RICCA, London School of Economics-Violence and Growth in the Mexican Drug War

MASSIMO GIOVANNINI, European Commission-Joint Research Centre, STEFAN HOHBERGER, European Commission-Joint Research Centre, ROBERT KOLLMANN, European Centre for Advanced Research in Economics and Statistics (ECARES), Free University of Brussels \& CEPR, MARCO RATTO, European Commission-Joint Research Centre, and WERNER ROEGER, European Commission, DG-ECFIN (Directorate-General for Economic and Financial Affairs) —United States and Euro Area External Adjustment: The Role of Commodity Prices and Emerging Market Shocks

WEI JIAO, University of Wisconsin-Green Bay-Who Disseminates Foreign Information Into Stock Prices?

LINDA FERNANDEZ, Virginia Commonwealth University, and MONICA DAS, Skidmore College—Does the WTO Balance Biosecurity with International Trade?

\section{JEL Class G (Financial Economics)}

TONGBIN ZHANG, Shanghai University of Finance and Economics, and RENBIN ZHANG, Autonomous University of Barcelona-A Natural Experiment Test for Asset Pricing Models

SAMUEL ROSEN, Temple University-Adding Fuel to the Fire Sales: Banks, Capital Regulation, and Systemic Risk

YONG KYU GAM, Southwestern University of Finance and Economics, and CHUNBO LIU, Southwestern University of Finance and Economics-Bank Relationship, Covenant Enforcement, and Creditor Control 


\section{Friday-Sunday $•$ January 3-5}

ERIK J. MAYER, Southern Methodist University—Big Banks, Household Credit Access, and Intergenerational Economic Mobility

JIASHAN WU, University of Illinois-Chicago-CEO Optimism and Net Interest Margin

MANDEEP SINGH, University of New South Wales, and EMDAD ISLAM, University of New South Wales-The Impact of Temperature Shocks on Credit Market

JANIS BERZINS, BI Norwegian Business School, and ALMINAS ZALDOKAS, Hong Kong University of Science and TechnologyConflicts in Private Family Firms

ANDREEA POPESCU, Tilburg University, and CHARLES NOUSSAIR, University of Arizona-Contagion and Return Predictability in Asset Markets: An Experiment with Two Trees

QIZHOU XIONG, Halle Institute for Economic Research (IWH) Credit Surface of Mortgage Loans: Lenders' Belief of Housing Markets

VESA PURSIAINEN, Imperial College London and University of Hong Kong-Cultural Biases in Equity Analysis

LAURIE POUNDER DEMARCO, Federal Reserve Board, and RICARDO CORREA, Federal Reserve Board-Dealer Leverage and Exchange Rates: Heterogeneity Across Intermediaries

THEOFANIS PAPAMICHALIS, University of Oxford, and DIMITRIOS TSOMOCOS, University of Oxford-Default and Liquidity: A Continuous Time Approach

MATTHIJS LOF, Aalto University, and HENRI NYBERG, University of Turku—Discount Rates and Cash Flows: A Local Projection Approach

XIN LIU, University of Bath-Diversification in Lottery-Like Features and Portfolio Pricing Discounts

NGUYEN NGOC THAO VO, RMIT University-Vietnam, THAI VU HONG NGUYEN, RMIT University-Vietnam, and DUC THI HONG PHAN, RMIT University-Australia-Do Investors Exploit Earnings Management Information to Earn Profits in Stock Markets?

ALEKSANDR V. GEVORKYAN, St. John's University—Economics of The Fintech Industry in Small Open Transition Economies: A New Competitive Advantage? 


\section{Friday-Sunday $\cdot$ January 3-5}

PASCAL LETOURNEAU, University of Wisconsin-Whitewater, and SANG BAUM KANG, Illinois Institute of Technology-Exercising Real Options Sooner or Later? New Insights from Quantile-Preserving Spreads on How to Fasten or Delay Exercise

SEBASTIEN DUCHENE, CEE-M, University of Montpellier, CNRS, INRA, SupAgro, ANNA BOTTASSO, University of Genova, ERIC GUERCI, GREDEG and University of Côte d'Azur, NOBUYUKI HANAKI, GREDEG and University of Côte d'Azur, and CHARLES NOUSSAIR, University of Arizona-Financial Market Professionals' Higher Order Risk Attitudes

MATTHEW WYNTER, University of Illinois-Chicago—Frugality and Firms' Financial Flexibility: Evidence from Natural Disasters

RUCHITH DISSANAYAKE, Queensland University of Technology, VIKAS MEHROTRA, University of Alberta, and YANHUI WU, Queensland University of Technology_-Geopolitical Risk and Corporate Investment

MATIAS OSSANDON BUSCH, Halle Institute for Economic Research (IWH) - Income Inequality and Capital Reallocation in the Presence of Financial Frictions

HUGH HOIKWANG KIM, University of South Carolina, and MOHAMMAD (VAHID) IRANI, University of South Carolina-Inertia of Institutional Investors: Rational or Behavioral?

CHARLES O'DONNELL, European Central Bank, and FERGAL MCCANN, Central Bank of Ireland-Information Monopolies and Monetary Policy Pass-through

RENATA HERRERIAS, Technological Autonomous University of Mexico (ITAM), and GUILLERMO ZAMARRIPA, FUNDEFInstitutional Design of Pension Systems and Individual Behavior: How Do Households Respond?

GUIHAI ZHAO, Bank of Canada—Learning, Equilibrium Trend, Cycle, and Spread in Bond Yields

CHAO HUANG, University of Edinburgh, FERNANDO MOREIRA, University of Edinburgh, and THOMAS ARCHIBALD, University of Edinburgh-A Macroeconomic Model with Interbank Markets and Regulated Banks 


\section{Friday-Sunday • January 3-5}

YALIN GUNDUZ, Deutsche Bundesbank, GIORGIO OTTONELLO, Vienna Graduate School of Finance, LORIANA PELIZZON, Goethe University Frankfurt, SAFE, and $\mathrm{Ca}$ ' Foscari University, MICHAEL SCHNEIDER, Deutsche Bundesbank, and MARTI G. SUBRAHMANYAM, New York University—Lighting up the Dark: Liquidity in the German Corporate Bond Market

PETRI JYLHÄ, Aalto University, and MATTHIJS LOF, Aalto University-Mind the Basel Gap

JIAMING ZHANG, China Bohai Bank and Nankai University, XIANGRONG DENG, Nankai University, and XUELIANG FENG, Nankai University-Monetary Policy and Heterogeneity of Bank Risk Taking: Evidence from China

PAUL BELLEFLAMME, Catholic University of Louvain, THOMAS LAMBERT, Erasmus University, and ARMIN SCHWIENBACHER, University of Côte d'Azur-Crowdfunding Dynamics

MARC ARNOLD, University of St. Gallen, MATTHIAS PELSTER, Paderborn University, and MARTI G. SUBRAHMANYAM, New York University-Attention Triggers and Retail Investors' Risk Taking

PETER HEINZ SEVERIN, University of Mannheim, and MARCEL OLBERT, University of Mannheim-Private Equity and Taxes

QI XU, Zhejiang University, ROMAN KOZHAN, University of Warwick, and MARK TAYLOR, Washington University-St. LouisProspect Theory and Currency Returns

FRANCESCO CELENTANO, University of Wisconsin-Madison, and MARK REMPEL, University of Wisconsin-Madison-Public Listing Choice with Persistent Hidden Information

THIAGO DE OLIVEIRA SOUZA, University of Southern DenmarkConsumption, Government Failure, and Asset Prices

CARLOS A. RAMIREZ, Federal Reserve Board—Regulating Financial Networks Under Uncertainty

PATRICK SCHAFFNER, University of St. Gallen, ANGELO RANALDO, University of St. Gallen, and MICHALIS VASIOS, Bank of England-Regulatory Effects on Short-Term Interest Rates

JONATHAN BENCHIMOL, Bank of Israel, and CAROLINE BOZOU, Panthéon-Assas University—Risk Aversion, Credit and Banking 


\section{Friday-Sunday $•$ January 3-5}

BENEDIKT FABIAN BALLENSIEFEN, University of St. Gallen and World Bank Group, and ANGELO RANALDO, University of St. Gallen and Swiss Finance Institute-Safe Asset Carry Trade

KO CHIU YU, National University of Singapore, MANYI YU FAN, National University of Singapore, JINGHAN CAI, University of Scranton, MARCO RICHIONE, University of Scranton, and NATALIE RUSSO, National University of Singapore-Sleeplessness, Distraction and Stock Market Performance: Evidence from the World Cup

SANDRO ANDRADE, University of Miami, ADELPHE EKPONON, Cambridge University, and ALEXANDRE JEANNERET, HEC Montreal-Sovereign Bond Premium and Global Macroeconomic Conditions

XIAOQIAN ZHANG, Zhejiang University-State Ownership, Intellectual Property Protection and M\&A Manipulation: Evidence from China's Mixed-Ownership Reform

SEUNGJOON OH, Peking University, HURSIT CELIL, Peking University, SRINIVASAN SELVAM, Peking University, and XUEYING SHANGI, Peking University-Stock Liquidity and Corporate Diversification: Evidence from Index Reconstitution

CHUNLI CHENG, Sun Yat-Sen University, CHRISTIAN MARTIN HILPERT, Sun Yat-Sen University, AIDIN MIRI LAVASANI, University of Hamburg, and MICK SCHAEFER, University of HamburgSurrender Contagion in Life Insurance: Modeling and Valuation

SHIRIN MOLLAH, Claremont Graduate University-The Impact of an Exogenous Shock on Pharmaceutical Industry Stock Returns: Using the Synthetic Control Methods

GUANMING HE, Durham University, and MENGBING REN, University of Warwick-The Impact of Derivative Disclosures on Managerial Opportunism: Evidence from FASB Statement No. 161

MENGBING REN, University of Warwick-The Impact of FASB Statement No. 161 on Information Asymmetry Between Informed and Uninformed Investors: Evidence from Stock Liquidity

ZORKA SIMON, Goethe University Frankfurt, and ZSUZSA R. HUSZAR, S. P. Jain School of Global Management-The Pricing Implications of the Oligopolistic Securities Lending Market: A Beneficial Owner Perspective 


\section{Friday-Sunday • January 3-5}

VARDGES LEVONYAN, University of Zurich-The Supply Side of Mortgage Lending

YUEXIN LI, Tilburg University, MARSHALL MA, Erasmus University Rotterdam, and LUC RENNEBOOG, Tilburg University-Trust in Art Markets

FRIEDERIKE NIEPMANN, Federal Reserve Board, TIM SCHMIDTEISENLOHR, Federal Reserve Board, and EMILY LIU, Federal Reserve Board-United States Monetary Policy Spillovers to Emerging Markets: The Effect of Stress Tests

PAUL BOROCHIN, University of Miami, and YANHUI ZHAO, University of Wisconsin-Whitewater-What Information Does Risk Neutral Skewness Contain? Evidence From Price Rebounds and Momentum Crashes

ANASTASIA STEPANOVA, Higher School of Economics, and MARIA KOKOREVA, Higher School of Economics-Why Companies Are So Different? Alternative View on The Firms' Financial Design

JAN MUELLER-DETHARD, University of Mannheim, PASCAL KIEREN, University of Mannheim, and MARTIN WEBER, University of Mannheim and CEPR—Why So Negative? Belief Formation in Boom and Bust Markets

\section{JEL Class H (Public Economics)}

SEBASTIAN GARMANN, Ruhr-University Bochum-A Race to the Top? Staggered Electoral Cycles and Strategic Interactions in Business Taxes

QILIN ZHANG, University of Hong Kong, and SAU-HIM PAUL LAU, University of Hong Kong-Public Annuities: Buyers' Behavior and Policy Design

GOHAR S. SEDRAKYAN, Georgia State University-Comparative Studies of M\&A and Greenfield Investments in Response to Changes in Tax Regulations and Administration of Host Economies

MARCEL FISCHER, Copenhagen Business School and University of Konstanz, and BJARNE ASTRUP JENSEN, Copenhagen Business School-Economic Growth and the Debt Tax Shield 


\section{Friday-Sunday $•$ January 3-5}

DAVIDE BELLUCCI, University of Turin, PIERLUIGI CONZO, University of Turin and Carlo Alberto College, and ROBERTO ZOTTI, University of Turin-Immigration, Salience and Electoral Outcomes

ZE SONG, Rutgers University_Long-Term Health Effect of Earned Income Tax Credit

ROBERTO IVO DA ROCHA LIMA FILHO, Federal University of Rio de Janeiro, and SALVADOR ESPINOSA, San Diego State UniversityModeling the Impact of Culture on Trading Behavior and Its Implications for Regulation Reform

NICOLAUS TIDEMAN, Virginia Tech, and FLORENZ PLASSMANN, Binghamton University-Optimal Taxation of Assets

YUKUN SUN, Zhongnan University of Economics and Law-Political Network, Work Experience, and Economic Performance: Evidence from China

TABARÉ CAPITÁN, University of Wyoming, LINDA THUNSTROM, University of Wyoming, KLAAS VAN'T VELD, University of Wyoming, and JONAS NORDSTROM, Lund University and University of Copenhagen-Reference-Dependent Preferences for Information

KEIKO IWASAKI, NLI Research Institute, KUNIO NAKASHIMA, NLI Research Institute, and TOMOKI KITAMURA, Tohoku Gakuin University—Tax Literacy and Personal Investments for Post-Retirement Years

GUANGJUN QU, Birmingham Southern College, KEVIN SYLWESTER, Southern Illinois University-Carbondale, and FENG WANG, Chongqing University-The Effect of Anticorruption on the Structure of Public Revenue and Expenditure

\section{JEL Class I (Health, Education, and Welfare)}

ADAM PILNY, RWI-Leibniz Institute for Economic Research, and FELIX ROESEL, Ifo Institute-Are Private Health Care Providers Politically Discriminated Against? 


\section{Friday-Sunday $•$ January 3-5}

DANIEL R. MORALES, Mother and Teacher Pontifical Catholic University (PUCMM) and IDEICE, CLAUDIA CURIEL, Dominican Institute for Evaluation and Research of Educational Quality (IDEICE), CARLOS SCHMIDT-PADILLA, University of California-Berkeley, and PATRICIA MONES, Dominican Institute for Evaluation and Research of Educational Quality (IDEICE)—Better Management, Better Learning? Evidence from a Sequence of Two RCTs in the Dominican Republic

TATIANA MOCANU, University of Illinois-Urbana-ChampaignBeyond Tuition: Cost of Living and College Affordability

OLESYA FOMENKO, Workers Compensation Research Institute (WCRI), and JONATHAN GRUBER, Massachusetts Institute of Technology—Can Consumers Avoid Cost Sharing by Reclassifying Injuries?

PEDRO CARNEIRO, University College London, MARCUS HOLMLUND, World Bank, MICHELL YOONJEI DONG, World Bank, and SANGHMITRA GAUTAM, Washington University-St. LouisComplementarities in Public and Private Health Service Delivery: Results from a Randomized Controlled Trial in Nigeria

NAIJIA GUO, Chinese University of Hong Kong, ZHAO RONG, Nanjing Audit University, and SHUANGXIN WANG, Chinese University of Hong Kong-Direct and Spillover Effects of Free Compulsory Education on Schooling and Migration

DENI MAZREKAJ, KU Leuven, and SOFIE CABUS, KU LeuvenDoes a High School Diploma Matter? Evidence Using Regression Discontinuity Design

NATALIE MALAK, University of Alabama-Huntsville, and PHIL DECICCA, Ball State University—First, Do No Harm, Second, Say Sorry?

STEFANIE JEANETTE HUBER, University of Amsterdam, and HANNAH PAULE-PALUDKIEWICZ, Goethe University FrankfurtGender Gap in Higher Education and Gender Norms

BJORN TYREFORS, Research Institute of Industrial Economics, and JOAKIM JANSSON, Linnaeus University-Gender Grading Bias at The University: Quasi-Experimental Evidence from an Anonymous Grading Reform 


\section{Friday-Sunday $\cdot$ January 3-5}

SUJEONG PARK, RAND Corporation, and DAVID POWELL, RAND Corporation-Growth of Illicit Drug Markets and Its Effects on Crime Rates

IRMA A. ARTEAGA, University of Missouri, and JULIETA TRIAS, World Bank-Home Visitation or Group Meeting? Effects of Early Stimulation on Child Well-Being: A Cluster Randomized Control Trial in Guatemala

ISABEL MUSSE, University of Illinois-Urbana-Champaign-Is Work Good for Your Health? Evidence from the Purchase of Pain Medications

ALMEDINA MUSIC, World Bank—Love Thy Neighbor? Ethnic Favoritism and Trust in Indonesia

JAMES BAILEY, Providence College, NATHAN BLASCAK, Federal Reserve Bank of Philadelphia, and SLAVA MIKHED, Federal Reserve Bank of Philadelphia-Medicaid Cuts and Consumer Financial Outcomes: Evidence from Missouri

NASIM B. FERDOWS, University of Southern California, and AMIT KUMAR, Northern Arizona University-State Variations in Nurse Practitioners Scope of Practice and Rural-Urban Mortality Gap in the United States

CAMERON KAPLAN, University of Southern California-Price Sensitivity and Substitution Among Prescription Medications: Evidence from the Medicare Part D Donut Hole Closure

NASIM B. FERDOWS, University of Southern California, SOROOSH BAGHBAN FERDOWS, Istanbul Technical University, and AMIT KUMAR, Northern Arizona University-Racial/Ethnic Disparities in Rural-Urban Mortality Gap in the United States: A 24 Years Longitudinal Study

ALICIA MODESTINO, Northeastern University-School's Out: How Summer Youth Employment Programs Impact Academic Outcomes

NIKOLAY ANGELOV, Uppsala Center for Labor Studies, PER JOHANSSON, Uppsala University, MIKAEL LINDAHL, University of Gothenburg, and ARIEL PIHL, University of Gothenburg-Subjective Expectations, Educational Choice Heterogeneity and Gender: Evidence from a Sample of Swedish High School Students 


\section{Friday-Sunday • January 3-5}

CHUANYI GUO, University of Illinois-Chicago-Teacher Quality, Family Inputs, and Student Outcomes: Evidence from Random Assignment of Students to Classrooms

BRIGHAM WALKER, Tulane University-The Cost Effects of a Private Health Insurance Shared Savings Model

JEREMY BAROFSKY, Tulane University-The Effect of Government Health Expenditure on the Income Distribution: A Comparison of Valuation Methods in Ghana

FENG CHEN, Tulane University-The Effects of California's Paid Family Leave Program on Children's Birth Outcomes

NIENKE RUIJS, Dutch Inspectorate of Education, and STAN VERMEULEN, Maastricht University-The Impact of Teacher Teams on Student Achievement

HERDIS STEINGRIMSDOTTIR, Copenhagen Business School, and SNAEBJORN GUNNSTEINSSON, University of Maryland-The Long-Term Impact of Children's Disabilities on Families

BRIGHAM WALKER, Tulane University-The Spillover Effects of a Medicare Payment Reform

MICHAEL DINARDI, University of Rhode Island-Uninsurance and Purchases of Addictive Prescription Drugs: Evidence from the Federal Dependent Coverage Mandate

SILVIA GATTI, University of Bologna-Universality, Equality and Equity in The Italian National Health Service: Highlighting Discrimination Phenomena in Accessing Health Services Using Institutional and Administrative Data

LUNA BELLANI, University of Konstanz-Upward Income Mobility and Legislator Support for Education Policies

CHEN GAO, Texas A\&M University, CHENGCHENG J. FEI, Texas A\&M University, REID STEVENS, Texas A\&M University, and DAVID J. LEATHAM, Texas A\&M University-Using Machine Learning and Big Data to Identify the Food Security Problem in Afghanistan 


\section{Friday-Sunday $•$ January 3-5}

SANTOSH KUMAR, Sam Houston State University, KAUSHALENDRA KUMAR, International Institute for Population SciencesMumbai, RAMANAN LAXMINARAYAN, Center for Disease Dynamics, Economics \& Policy-New Delhi and Princeton University, and ARINDAM NANDI, Center for Disease Dynamics, Economics \& Policy-Washington-The Causal Effect of Birth Weight on Cognitive Development: New Evidence from India

\section{JEL Class J (Labor and Demographic Economics)}

SHIYI CHEN, University of Connecticut-Affirmative Action Policies and Interracial Marriage

KELLY JONES, American University, and BRITNI WILCHER, American University—Balancing Work and Family: The Impact of Paid Family Leave on United States Labor Supply

DESERINA SULAEMAN, Singapore Management University-Birds of a Feather Flock Together (More): Homophily in the Age of Trump

FABIAN SIUDA, Ifo Institute and University of Munich—Childlessness and Inter-Temporal Fertility Choice

JOSHUA MASK, University of Illinois-Chicago-Consequences of Immigrating During a Recession: Evidence from the United States Refugee Resettlement Program

ROMAN L. ZAKHARENKO, National Research University Higher School of Economics-Dead Men Tell No Tales: How the Homo Sapiens Became Homo Economicus

JIN CAO, Norges Bank, HAIYUE YU, Dongbei University of Finance and Economics, JIN CAO, Norges Bank, and SHULONG KANG, Dongbei University of Finance and Economics-Deciphering China's Female Employment Paradox

BEN KLEMENS, U.S. Treasury Department—Domestic Migration: For Money or For Love?

WON FY LEE, University of Minnesota-Effect of Parental Preference for the Sex of a Child on Child Outcomes: Evidence from Korea

IRMA A. ARTEAGA, University of Missouri-Effects of Test Translation on Kindergarten English Learners' Performance on Literacy, Math and Executive Function 


\section{Friday-Sunday $•$ January 3-5}

KENNETH J. MCLAUGHLIN, City University of New York-Hunter College and Graduate Center-Employment Effects of Three Rounds of Federal Minimum Wage Hikes

CHRISTIAN PFEIFER, Leuphana University Lueneburg, and JENS MOHRENWEISER, Bournemouth University—Firms' Wage Structures, Workers' Fairness Perceptions, Job Satisfaction and Turnover Intentions: Evidence from Linked Employer-Employee Data

TUSHAR BHARATI, University of Western Australia, YIWEI QIAN, University of Southern California, and JEONGHWAN YUN, University of Southern California-Fueling the Engines of Liberation with Cleaner Cooking Fuel: Evidence From Indonesia

AHMED ELSAYED, Institute of Labor Economics (IZA), and OLIVIER MARIE, Erasmus University Rotterdam-Gender Biases in Education Investment: The Unexpected Effect of Reduction in Years of Compulsory Schooling in a Developing Country

MICHAELA SLOTWINSKI, ZEW Mannheim and University of Basel, and ANJA ROTH, University of Basel-Gender Norms and Income Misreporting Within Households

ALEXA PRETTYMAN, Georgia State University-Happy 18th Birthday, Now Leave: The Hardships of Aging Out of Foster Care

JULIA BREDTMANN, RWI-Leibniz Institute for Economic ResearchImmigration and Electoral Outcomes: Evidence from the 2015 Refugee Inflow to Germany

ORHUN SEVINC, Central Bank of the Republic of TurkeyImplications of the Occupational Wage-Skill Mismatch in the US

HEE-SEUNG YANG, KDI School of Public Policy and Management, MICHELL YOONJEI DONG, World Bank, and LIANG CHOON WANG, Monash University-International Migration, Gender Imbalances, and Marriage Market Outcomes in the Philippines

JIANBO LUO, State University of New York-Buffalo-Is Work a Burden? The Role of the Living Standard

GREGORY B. UPTON, Louisiana State University, and HAN YU, Texas A\&M University_Local Labor Demand Shocks and Earnings Differentials: Evidence from Shale Oil and Gas Booms 


\section{Friday-Sunday $\cdot$ January 3-5}

XUECHAO QIAN, Ohio State University-Long-term Effects of Childhood Exposure to Persecution: Human Capital, Marriage Market, and Intergenerational Outcomes

OUDOM HEAN, Ohio State University, NATTANICHA CHAIRASSAMEE, Ohio State University, and MARK D. PARTRIDGE, Ohio State University-Migration, Education and Urban Divergence: Evidence from United States Patent Counts

DAFENG XU, University of Minnesota-Natural Disasters, Resettlement, and Population Dynamics in Rural Areas: Evidence from the 1918 Cloquet Fire

FRANK M. FOSSEN, University of Nevada-Reno, and ALINA SORGNER, John Cabot University-Rome-New Digital Technologies and Heterogeneous Employment and Wage Dynamics in the United States: Evidence from Individual-Level Data

MATTHIAS GIESECKE, RWI-Leibniz Institute for Economic Research, and PHILIPP JÄGER, RWI-Leibniz Institute for Economic ResearchPension Incentives and Labor Supply: Evidence from the Introduction of Universal Old-Age Assistance in the UK

RACHEL SEDERBERG, Bowdoin College-Redesigning Unemployment Insurance: Who to Target and How to Trigger

HAIBIN JIANG, Clemson University-The Effect of Child Care Tax Credit on Maternal Labor Supply

ELEANOR JAWON CHOI, Hanyang University, JAEWOO CHOI, Korea Development Institute, and HYELIM SON, University of SeoulThe Long-Term Effects of Labor Market Entry in a Recession: Evidence from the Asian Financial Crisis

HANS GRONQVIST, Uppsala University, JULIEN GRENET, Paris School of Economics, and DANIEL JAHNSON, Uppsala UniversityThe Social Costs of Financial Crisis: Worker Level Evidence

TALI REGEV, IDC Herzliya, TAMAR KRICHELI-KATZ, Tel Aviv University, HAGGAI PORAT, Tel Aviv University, SHAY N. LAVIE, Tel Aviv University, and RONEN AVRAHAM, Tel Aviv UniversityThose Who Tan and Those Who Don't: A Natural Experiment on Race Discrimination 


\section{Friday-Sunday • January 3-5}

DAFENG XU, University of Minnesota, and YUXIN ZHANG, University of Texas-Austin-Within-Population Occupational Segregation by Ethnicity During the Age of Mass Migration: A Machine Learning Approach

\section{JEL Class K (Law and Economics)}

DANIEL BRADLEY, University of South Florida, CONNIE MAO, Temple University, and CHI ZHANG, University of MassachusettsLowell-Do Corporate Taxes Affect Workplace Safety?

HERNAN BOTERO DEGIOVANNI, Scotland's Rural College, and SANTIAGO PINTO, Federal Reserve Bank of Richmond—Does Drug Enforcement Cause Violence? Evidence from Colombia

HANS GRONQVIST, Uppsala University, JULIEN GRENET, Paris School of Economics, and SUSAN NIKNAMI, Stockholm UniversityThe Effect of Electronic Monitoring on Offenders and Their Families

YIXIN LIU, University of New Hampshire, YU LIU, University of Texas-Rio Grande Valley, WILLIAM L. MEGGINSON, University of Oklahoma, and ZUOBAO WEI, University of Texas-El Paso-The Effect of Property Rights on Capital Structure: Evidence from a Chinese Natural Experiment

SANJUKTA BASU, Tulane University, SIOBHAN S. INNES-GAWN, Tulane University, and MARY H. PENN, Tulane University-The Highs and Lows of Medical Marijuana Legalization

AIXA GARCIA-RAMOS, University of Passau-The Mexican Drug War: Elections and Homicides

\section{JEL Code L (Industrial Organization)}

KRISZTINA HORVATH, Boston College-Adverse Selection and Switching Costs in Health Insurance Marketplaces: Using Nudges to Fight the Death Spiral

YOSUKE TAKEDA, Sophia University, and ICHIHIRO UCHIDA, Aichi University—Make or Buy, and/or Cooperate? The Property Rights Approach to Auto Parts Procurement in Japan

JASON WALTER, University of Wisconsin-Stout, and R. SCOTT HILLER, Fairfield University-Music Consumption Decisions with Non-Durable Streaming Options 


\section{Friday-Sunday $\cdot$ January 3-5}

KRIS ZHOU, University of Texas-San Antonio, BRADLEY J. ALLEN, University of Arkansas, RICHARD T. GRETZ, University of Texas-San Antonio, and MARK B. HOUSTON, Texas Christian UniversityOnline Platform for In-Home Healthcare: Customer Defection and Platform Exploitation

MD RAFAYET ALAM, University of Tennessee-Chattanooga, and AKM MAHBUB MORSHED, Southern Illinois University-CarbondalePrice Dispersion Across United States Cities: The Role of Walmart

KEVIN DUCBAO TRAN, DIW Berlin-Partitioned Pricing and Consumer Welfare: Evidence from eBay Germany

YONG WANG, Tsinghua University, TIANZE TANG, Tsinghua University, QIAOQIN XIONG, Tsinghua University, and ZHEN SUN, Tsinghua University-The Achilles Tendon of Dynamic Pricing - The Effect of Consumers' Fairness Preferences on Platform Dynamic Pricing Strategies

KE RONG, Tsinghua University, HUIYI LITAN, Tsinghua University, and DI ZHOU, Tsinghua University-The Competition of PMNCs During the Internationalization: Ecosystem, Informal Institution and Network Effect

AYESHA ALI, Lahore University of Management Sciences, and IHSAN AYYUB QAZI, Lahore University of Management Sciences-The Economic Impact of Internet Censorship

MAXIMILIAN SCHAEFER, DIW Berlin-Data Network Effects: The Example of Internet Search

KAIDA ZHANG, Pennsylvania State University-Too Many Dealerships? The Impact of State Franchise Laws in Automobile Dealerships Distribution

AKIKO NAKAJIMA, Fukuoka University-Total Labor Requirements, Value Relative Prices and Market Prices: Determination of Relative Prices by Input Output Analysis of Japan for 1951, 1960, 1970, 1980, 1990, 2000, and 2011

DAIQIANG ZHANG, State University of New York-AlbanyUncertainty in Procurement Contracting with Time Incentives

GHERARDO GIRARDI, University of St. Mary and Queen Mary University of London-When Does Being Ethical Confer a Profit Advantage Over Rivals? A Theoretical Model of Ecological Awareness 


\section{Friday-Sunday • January 3-5}

ANDY TAO LI, Tsinghua University, and JIE ZHENG, Tsinghua University-When Does the Platform Tell You the Truth? Optimal Design of Persuasion Policy in the Two-Sided Market

XIAOGANG CHE, City University of London, HAJIME KATAYAMA, Waseda University, and PETER LEE, JP Morgan Chase InstituteWillingness to Pay for Brand Reputation: Lessons from the Volkswagen Emissions Scandal

ZHEN SUN, Tsinghua University, JIANPING LIU, Tsinghua University, and TAOXIONG LIU, Tsinghua University_- "Law of One Price" in the Internet Era - Search Cost, Platform Competition and Customer Lock-in

\section{JEL Code M (Business Administration and Business Economics • Marketing • Accounting • Personnel Economics)}

SALIL GADGIL, University of California-Los Angeles, and JASON SOCKIN, University of Pennsylvania-The Value of Firm Reputation in the Labor Market: Evidence from Corporate Scandals

RAICHO BOJILOV, Catholic University of Chile, LALITH MUNASINGHE, Columbia University and Barnard College, TAVIS BARR, Talenteck, and KATE GAUTIER, Talenteck-The Value of Interviewers: Machines Can't Sell Offers

LOUIS R. NEMZER, Nova Southeastern University, and FLORENCE NEYMOTIN, Nova Southeastern University-How Words Matter: Machine Learning \& Movie Success

\section{JEL Code N (Economic History)}

LARS BOERNER, Martin Luther University of Halle-Wittenberg and King's College London, JARED RUBIN, Chapman University, and BATTISTA SEVERGNINI, Copenhagen Business School-A Time to Print, a Time to Reform

GIUSEPPE DI VITA, University of Catania, and FABIO DI VITA, University of Catania-Exploring the Roots of Sicilian Technological Underdevelopment: The Role of Mafia Since the Unification of Italian Kingdom Up to the Present Day 


\section{Friday-Sunday $•$ January 3-5}

\section{JEL Code O (Economic Development, Innovation, Technological Change, and Growth)}

GIORGIO PRESIDENTE, World Bank-Automation in Developing Countries: Plant-Level Evidence and Inter-Industry Spillovers

ASAD ISLAM, Monash University, ABDUL MALEK, Brac University, SAKIBA TASNEEM, Monash University, and LIANG CHOON WANG, Monash University-Can Public Recognition Reward Backfire? Field Experimental Evidence on the Retention and Performance of Volunteers with Social-Image Concerns

MIRIAM JUAREZ-TORRES, Bank of Mexico, and PUIGVERT JONATHAN, Bank of Mexico-Climate and Tropical Cyclone Effects on Economic Activity: Evidence at the Firm Level from Mexico

CLAUDIA BERG, International Monetary Fund, BRIAN BLANKESPOOR, World Bank, and M. SHAHE EMRAN, Columbia University-Does Market Integration Increase Land Inequality in a Rural Economy? Evidence from India

ZHI DONG, University of Auckland-Endogenous Prosperity on Competition: Capital Allocation on Efficient Frontiers

XIAO KE, Peking University, and JUSTIN YIFU LIN, Peking University-High-Speed Rail, Structural Transformation and Inclusive Growth: Quantitative Case Study of the Experimental High-Speed Rail Project in China

YOUJIN HAHN, Yonsei University, JUN SUNG KIM, Monash University, and HEE-SEUNG YANG, KDI School of Public Policy and Management-Multi-Dimensional Social Networks and Employment Opportunities: Evidence from Rural India

OLENA IZHAK, Düsseldorf Institute for Competition Economics, TANJA SAXELL, VATT Institute for Economic Research, and TUOMAS TAKALO, Bank of Finland-Optimal Patent Policy for the Pharmaceutical Industry

ZHE FU, University of International Business and Economics, YANMEI SUN, University of International Business and Economics, and JIANYE YAN, Peking University - Pollution on the Growth Path: The Calibration, Simulation and Prediction of Environmental Kuznets Curve in China 


\section{Friday-Sunday $\cdot$ January 3-5}

JORGE LEMUS, University of Illinois-Urbana-Champaign, and OLGU OZKUL, University of Illinois-Urbana-Champaign-Product Hopping and Innovation Incentives

WOLFGANG DAUTH, University of Wuerzburg and IAB, SEBASTIAN FINDEISEN, University of Mannheim, JENS SUEDEKUM, University of Dusseldorf, and NICOLE WOESSNER, University of DusseldorfRobots and Labor Market Adjustments

SHIN-REN PAN, Taiwan High Prosecutors Office-Taichung BranchThe Consistency of Knowledge Context, Human Capital and Absorptive Capability of Firm

TAKAHIRO YAMADA, Japan Ministry of Finance, and HIROYUKI YAMADA, Keio University-The Long-term Causal Effect of U.S. Bombing Missions on Economic Development: Evidence from Ho Chi Minh Trail and Xieng Khouang Province in Lao P.D.R.

NATALIA LAMBEROVA, University of California-Los AngelesThe Puzzling Politics of R\&D: Signaling Competence Through Risky Projects

GIACOMO DOMINI, Erasmus University Rotterdam, MARCO GRAZZI, Catholic University of the Sacred Heart, DANIELE MOSCHELLA, Sant'Anna School of Advanced Studies, and TANIA TREIBICH, University of Maastricht-Threats and Opportunities in the Digital Era: Automation Spikes and Employment Dynamics

\section{JEL Code $\mathbf{P}$ (Economic Systems)}

N.N. TARUN CHAKRAVORTY, Siberian Federal University, VLADISLAV N. RUTSKIY, Siberian Federal University, and ELENA P. SEVASTYANOVA, Siberian Federal University - Comparative Analysis of Russian Citizens' Well-Being before and after the Collapse of the Soviet Union

\section{JEL Code Q (Agricultural and Natural Resource Economics • Environmental and Ecological Economics)}

ZIGAN WANG, University of Hong Kong, and LUPING YU, University of Hong Kong-Are Firms with Female CEOs More Environmentally Friendly? 


\section{Friday-Sunday $\cdot$ January 3-5}

JOSHUA GRAFF ZIVIN, University of California-San Diego, TONG LIU, Hong Kong University of Science and Technology, YINGQUAN SONG, Peking University, QU TANG, Jinan University, and PENG ZHANG, Hong Kong Polytechnic University—Behind the Flames: Unintended Impacts of Straw Burning on Human Capital

MADELINE WERTHSCHULTE, University of Muenster, and ANDREAS LÖSCHEL, University of Muenster-Cost Misperceptions and Energy Consumption

JOSHUA GRAFF ZIVIN, University of California-San Diego, TONG LIU, Hong Kong University of Science and Technology, and GUOJUN HE, Hong Kong University of Science and Technology-Feel the Burn: Mental and Behavioral Responses to Agricultural Air Pollution in China

JUAN PALACIOS, Maastricht University and IZA, STEFFEN KUENN, Maastricht University, and NICO PESTEL, Institute of Labor Economics (IZA) - The Impact of Indoor Climate on Human Cognition: Evidence from Chess Tournaments

WENJUN WANG, University of Maryland-Trade War and Social Welfare: A Structural Model of the United States Solar Industry

HORATIU A. RUS, University of Waterloo, and HONGXIU LI, University of Waterloo-Water Innovation and Water Governance: Adaptive Responses to Regulatory Change and Extreme Weather Events

\section{JEL Code R (Urban, Rural, Regional, Real Estate, and Transpor- tation Economics)}

CONG PENG, London School of Economics-Can E-Commerce Reduce Traffic Congestion? Evidence from Alibaba Single Day Shopping Event

MINHONG XU, Nanjing Audit University, and YILAN XU, University of Illinois-Urbana-Champaign-Airbnb and Private Investment in Chicago Neighborhoods

DUNCAN H.W. ROTH, Institute for Employment Research-Nuremberg (IAB), GABRIEL AHLFELDT, London School of Economics and Political Science, and TOBIAS SEIDEL, University of DuisburgEssen-Employment-maximising Minimum Wages 


\section{Friday-Sunday • January 3-5}

AIDONG ZHAO, Radboud University, HUUB PLOEGMAKERS, Radboud University, ARY ADRIANSYAH SAMSURA, Radboud University, ERWIN VAN DER KRABBEN, Radboud University, and XIANLEI MA, Nanjing Agricultural University-How Does Market Structure Affect Land Pricing? Evidence from China

LILI WEI, Lanzhou University, JING ZHANG, Lanzhou University, YING YANG, Lanzhou University, HAO-YU CAO, Lanzhou University, and YU-QI HOU, Lanzhou University-Rural-Urban Migration, Family Arrangement and Children's Well-Being: Evidence from China's Rural Areas

HOANG DAO, State University of New York-Buffalo-The Invisible Costs of Promoting Competition in the Airline Industry

VINICIOS SANT'ANNA, University of Illinois-Urbana-Champaign, and GUSTAVO CORTES, University of Florida-The Real Estate Consequences of Immigration Shocks: Evidence from the United States' Mexican Repatriation

\section{JEL Code Z (Other Special Topics)}

GUOYING DENG, Sichuan University, and MANUEL HERNANDEZ, IFPRI-Black-Cat Markets and the Value of Superstition: Evidence from Housing Prices in China 


\section{Thursday • January 2}

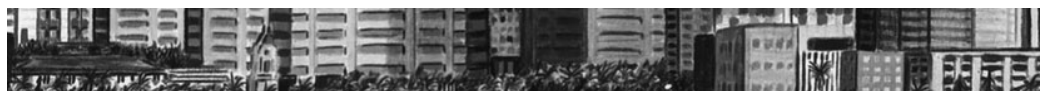 \\ Program of Sessions}

\section{5:30 PM Marriott Marquis San Diego-Marina Ballroom EF}

ES

\section{Presidential Address}

Presiding: STEPHEN MORRIS, Massachusetts Institute of TechnologyModelling Incomplete Information: The Misunderstanding of John Harsanyi

\section{6:30 PM Manchester Grand Hyatt San Diego-Coronado AB} ASE

\section{Plenary Session and Reception}

Presiding: STEVEN PRESSMAN, Colorado State University

TERESA GHILARDUCCI, New School for Social Research-A Grey New Deal: The General Theory of Employment, Retirement, and Money 


\section{Friday $•$ January 3}

\section{8:00 AM Manchester Grand Hyatt San Diego-Harbor D ACES}

The Demand for the State: Evidence from Past and Present (H1)

Presiding: NOAM YUCHTMAN, London School of Economics and Political Science

ANDREAS STEGMANN, Briq Institute on Behavior and Inequality-In Vaccines We Trust? The Effects of the CIA's Vaccine Ruse on Immunization in Pakistan

RAUL SANCHEZ DE LA SIERRA, University of CaliforniaBerkeley-When Formal Contracts Fail

LEANDER HELDRING, Briq Institute on Behavior and Inequality-Environmental Change, the Social Contract and the Origins of the State

Discussants: MIKE CALLEN, University of California-San Diego

AMEET MORJARIA, Northwestern University

DAVID SCHONHOLZER, Stockholm University

\section{8:00 AM Marriott Marquis San Diego—San Diego Ballroom B} AEA

\section{Panel: Beyond GDP (I3)}

Presiding: ERNST BERNDT, Massachusetts Institute of Technology

STEVE LANDEFELD, U.S. Bureau of Economic Analysis-Bureau of Economic Analysis Initiatives for Measuring Social Welfare

PAUL SCHREYER, OECD—International Initiatives for Measuring Social Welfare

ANGUS DEATON, Princeton University

DALE JORGENSON, Harvard University

LISA LYNCH, Brandeis University

LOUISE SHEINER, Brookings Institution

DAN SICHEL, Wellesley College 


\section{Friday $•$ January 3}

\section{8:00 AM Marriott Marquis San Diego-Solana}

\section{AEA}

\section{Business Cycles (E3)}

Presiding: EMILY MARSHALL, Dickinson College

VEGARD HØGHAUG LARSEN, Norges Bank, and LEIF ANDERS THORSRUD, BI Norwegian Business School—Business Cycle Narratives

VINCENZO CUCINIELLO, Bank of Italy-Determinants of Credit Cycle: A Flow Analysis of the Extensive Margin

ERIN MCGUIRE, National Bureau of Economic ResearchReturns to Entrepreneurial Experience over the Business Cycle

CHRISTOS ANDREAS MAKRIDIS, Massachusetts Institute of Technology—Sentimental Business Cycles and the Protracted Great Recession

MATTHIEU GOMEZ, Columbia University-Ups and Downs: How Idiosyncratic Volatility Drives Top Wealth Inequality

CHRIS REDL, Bank of England, ARTHUR TURRELL, Bank of England, ELENI KALAMARA, King's College London, GEORGE KAPETANIOS, King's College London, and SUJIT KAPADIA, European Central Bank-Word2IV: Extracting Instruments from Word Embeddings

\section{8:00 AM Marriott Marquis San Diego-Point Loma}

AEA

\section{Central Banking (E5)}

Presiding: JULIE K. SMITH, Lafayette College

DANIEL LEWIS, Federal Reserve Bank of New YorkAnnouncement-Specific Decompositions of Unconventional Monetary Policy Shocks and Their Macroeconomic Effects

ASHOKA MODY, Princeton University, and MILAN NEDELJKOVIC, FEFA and CESifo-Central Bank Policies and Financial Markets: Lessons from the Euro Crisis

JONATHAN BENCHIMOL, Bank of Israel, SOPHIA KAZINNIK, Federal Reserve Bank of Richmond, and YOSSI SAADON, Bank of Israel-Communication and Transparency Through Central Bank Texts 


\section{Friday $•$ January 3}

ITAI AGUR, International Monetary Fund, ANIL ARI, International Monetary Fund, and GIOVANNI DELL'ARICCIA, International Monetary Fund-Designing Central Bank Digital Currencies

ERIC SIMS, University of Notre Dame, and JING CYNTHIA WU, University of Notre Dame-Evaluating Central Banks' Tool Kit: Past, Present, and Future

\section{8:00 AM Marriott Marquis San Diego-Marriott Grand Ballroom 4 AEA}

\section{CSMGEP Dissertation Session (I0)}

Presiding: KALENA E. CORTES, Texas A\&M University

LEAH SHIFERAW, University of California-Berkeley-The Impact of Food Assistance on Birth Outcomes: Evidence from the Electronic Benefit Transfer (EBT) Card in SNAP

NATALIA CANTET, University of Illinois-Urbana-ChampaignThe Educational Cost of Teenage Pregnancy: Evidence from Urban South Africa

LORISSA PAGÁN, University of North Carolina-Greensboro-Of IVs and IUDs: Assessing the Effect of LARC Use on Pregnancies Using an Instrumental Variables Approach

E. JASON BARON, Florida State University-School Spending and Student Outcomes: Evidence from Revenue Limit Elections in Wisconsin

Discussants: SUSAN DYNARSKI, University of Michigan

MARIE T. MORA, University of Missouri-St. Louis

HEATHER ROYER, University of California-Santa Barbara

LAURA GIULIANO, University of California-Santa Cruz

MANUELA ANGELUCCI, University of Texas-Austin

\section{8:00 AM Marriott Marquis San Diego-Coronado Room} AEA

Determinants of Student Performance and Proficiencies in Economics (A2)

Presiding: JENS SCHUBERT, University of Delaware 


\section{Friday $•$ January 3}

LAURA J. AHLSTROM, Oklahoma State University-Does Participation and Performance on Advanced Placement Economics Exams Predict Undergraduate Economics Degree Completion?

DAVID MAHON, University of Delaware, and JENS SCHUBERT, University of Delaware-Reference-Dependent Study Effort: The Impact of Commitments on Learning Success and Retention in Introductory Economics Courses

TISHA LIN NAKAO EMERSON, Baylor University, and KIMMARIE MCGOLDRICK, University of Richmond-An Investigation of Student Performance in Intermediate Theory Courses

DIEGO MÉNDEZ-CARBAJO, Illinois Wesleyan University, ALEJANDRO E. DELLACHIESA, University of Kentucky, ERIC M. MCDERMOTT, University of Illinois-Urbana-Champaign, and YUHAO YANG, University of Illinois-Urbana-ChampaignSurveying Hansen's Data-Related Proficiencies of Undergraduate Economics Students

Discussants: LAURIE A. MILLER, University of Nebraska-Lincoln

PAUL GRIMES, Pittsburg State University

JULIANNA BUTLER, University of Delaware

CYNTHIA HARTER, Eastern Kentucky University

\section{8:00 AM Marriott Marquis San Diego-Marriott Grand Ballroom 3} AEA

Panel: Economic Opportunity and the Impact of Race and Place (J6)

Presiding: HEATHER BOUSHEY, Washington Center for Equitable Growth RANDALL AKEE, University of California-Los Angeles ELLORA DERENONCOURT, Princeton University PATRICK KLINE, University of California-Berkeley 


\section{Friday $•$ January 3}

\section{8:00 AM Marriott Marquis San Diego-Balboa}

AEA

\section{Education and Religion (I2)}

Presiding: LAURENCE R. IANNACCONE, Chapman University

GHARAD T. BRYAN, London School of Economics, JAMES

J. CHOI, Yale University, and DEAN KARLAN, Northwestern University-Randomizing Religion: The Impact of Protestant Evangelism on Economic Outcomes

BENJAMIN AROLD, Ifo Institute, LUDGER WOESSMANN, Ifo Institute, and LARISSA ZIEROW, Ifo Institute-Can Schools Change Religious Attitudes? Evidence from German State Reforms of Compulsory Religious Education

VICTOR LAVY, University of Warwick and Hebrew University of Jerusalem, EDITH SAND, Bank of Israel, and MOSES SHAYO, Hebrew University of Jerusalem-Charity Begins at Home (and at School): Effects of Religion-Based Discrimination in Education

SASCHA O. BECKER, University of Warwick, VOLKER LINDENTHAL, University of Munich, SHARUN MUKAND, University of Warwick, and FABIAN WALDINGER, University of Munich-Human Capital and the Persecution of Jews in Nazi Germany

Discussants: ABIGAIL PAYNE, University of Melbourne

SAMUEL BAZZI, Boston University

JARED RUBIN, Chapman University

SUSANNA LOEB, Brown University

\section{8:00 AM Marriott Marquis San Diego-Marriott Grand Ballroom 10 AEA}

\section{Empirical Research on Automation and "Smart" Technologies} (O3)

Presiding: JAMES BESSEN, Boston University

DARON ACEMOGLU, Massachusetts Institute of Technology, CLAIRE LELARGE, Paris-Sud University, and PASCUAL RESTREPO, Boston University-Competing with Robots: Micro Evidence from France 


\section{Friday $•$ January 3}

JAMES BESSEN, Boston University, MAARTEN GOOS, University of Utrecht, ANNA SALOMONS, University of Utrecht, and WILJAN VAN DEN BERGE, Bureau for Economic Policy Analysis Netherlands (CPB) - Automatic Reaction - What Happens to Workers at Firms that Automate?

RICHARD FREEMAN, Harvard University, INA GANGULI, University of Massachusetts-Amherst, and MICHAEL HANDEL, Northeastern University-Technological Change in Occupational Attribute Space

AVI GOLDFARB, University of Toronto, FLORENTA TEODORIDIS, University of Southern California, and BLEDI TASKA, Burning Glass Technologies-Machine Learning in Healthcare: Invention of a Method of Invention, General Purpose Technology, or Both?

Discussants: SUSAN R. HELPER, Case Western Reserve University

ROBERT SEAMANS, New York University

DAVID DEMING, Harvard University

DANIEL ROCK, Massachusetts Institute of Technology

\section{8:00 Aм Marriott Marquis San Diego-Newport Beach} AEA

\section{Finance and Politics (G0)}

Presiding: KARSTEN MÜLLER, Princeton University

SEBASTIAN DOERR, Bank for International Settlements, STEFAN GISSLER, Federal Reserve Board, JOSÉ-LUIS PEYDRÓ, ICREA, Pompeu Fabra University, CREI, Barcelona GSE, Imperial College London, and CEPR, and HANS-JOACHIM VOTH, University of Zurich and CEPR-From Finance to Fascism: The Real Effect of Germany's 1931 Banking Crisis

GYOZO GYÖNGYÖSI, Kiel Institute for the World Economy, and EMIL VERNER, Massachusetts Institute of Technology—Financial Crisis, Creditor-Debtor Conflict, and Political Extremism

KARSTEN MÜLLER, Princeton University-Electoral Cycles in Macroprudential Regulation

THIEMO R. FETZER, University of Warwick and CAGE-Did Austerity Cause Brexit? 


\section{Friday $\cdot$ January 3}

Discussants: FRANCESCO D'ACUNTO, Boston College

TOMASZ PISKORSKI, Columbia University

LUIGI ZINGALES, University of Chicago

YURIY GORODNICHENKO, University of California-Berkeley

\section{8:00 AM Marriott Marquis San Diego-Torrey Pines 3}

AEA

\section{From Micro Data to Global Evidence (01)}

Presiding: ANDERS JENSEN, Harvard Business School

PIERRE BACHAS, World Bank, LUCIE GADENNE, University of Warwick, and ANDERS JENSEN, Harvard Business SchoolInformality, Consumption Taxes and Redistribution

TORSTEN FIGUEIREDO WALTER, New York University Abu Dhabi-Misallocation of State Capacity? Evidence from Two Million Primary Schools

KEVIN DONOVAN, Yale University, TODD SCHOELLMAN, Federal Reserve Bank of Minneapolis, and WILL JIANYU LU, Central Bank of Chile_Labor Market Flows and Development TOMMASO PORZIO, Columbia University, and GABRIELA SANTANGELO, University of Cambridge-Does Schooling Cause Structural Transformation

\section{8:00 AM Marriott Marquis San Diego-Marriott Grand Ballroom 11 AEA}

\section{Gender in the Innovation Economy (J1)}

Presiding: JULIAN KOLEV, Southern Methodist University

JANA GALLUS, University of California-Los Angeles, and EMMA HEIKENSTEN, Stockholm School of Economics-Shine a Light (On the Bright): The Effect of Awards on Confidence To Speak Up in Gender-Typed Knowledge Work

MISHA TEPLITSKIY, Harvard University, HARDEEP RANU, Harvard University, GARY GRAY, Harvard University, EVA GUINAN, Harvard University, and KARIM LAKHANI, Harvard Business School and NBER-Experts' Openness to the Opinions of Others: Field Experimental Evidence from Scientific Peer Review 


\section{Friday $•$ January 3}

JULIAN KOLEV, Southern Methodist University, YULY FUENTES-MEDEL, Massachusetts Institute of Technology, and FIONA MURRAY, Massachusetts Institute of Technology-Is Blinded Review Enough? How Gendered Outcomes Arise Even under Anonymous Evaluation

MERCEDES DELGADO, Copenhagen Business School and Massachusetts Institute of Technology, and FIONA MURRAY, Massachusetts Institute of Technology_Driving Inventor Inclusivity in the Innovation Economy: What Is the Role of Universities and Their Top Inventors as Catalysts for Change?

REMBRAND KONING, Harvard Business School, SAMPSA SAMILA, IESE Business School, and JOHN-PAUL FERGUSON, McGill University-Female Inventors and Inventions

Discussants: CATHERINE ECKEL, Texas A\&M University

DANIELLE LI, Massachusetts Institute of Technology

LISA COOK, Michigan State University

JEFF FURMAN, Boston University

ERIN SCOTT, Massachusetts Institute of Technology

\section{8:00 AM Marriott Marquis San Diego-Marriott Grand Ballroom 2} AEA

\section{Gendered Effects of Social Norms and Institutions (J7)}

Presiding: JANET CURRIE, Princeton University

DARA LEE LUCA, Mathematica Policy Research, JACK STEVENS, Ohio State University, and DANA ROTZ, Mathematica Policy Research-Evaluating Teen Options for Preventing Pregnancy: Impacts and Mechanisms

MARIA MICAELA SVIATSCHI, Princeton University, and IVA TRAKO, Paris School of Economics and World Bank-Female Officers, Gender Violence and Human Capital: Evidence from All-Women's Justice Centers in Peru

VICTORIA BARANOV, University of Melbourne, PAULINE GROSJEAN, University of New South Wales, and RALPH DE HAAS, European Bank for Reconstruction and DevelopmentMen. Roots and Consequences of Masculinity Norms 


\section{Friday $•$ January 3}

MICHELA CARLANA, Harvard University-Implicit Stereotypes: Evidence from Teachers' Gender Bias

Discussants: SEEMA JAYACHANDRAN, Northwestern University

ANNA AIZER, Brown University

MARTHA J. BAILEY, University of Michigan

JESSE ROTHSTEIN, University of California-Berkeley

\section{8:00 AM Marriott Marquis San Diego-Marriott Grand Ballroom 13 AEA}

\section{Global Uncertainty: Measurement and Impact (F3)}

Presiding: NICHOLAS BLOOM, Stanford University

BARBARA ROSSI, ICREA and Pompeu Fabra University, TATEVIK SEKHPOSYAN, Texas A\&M University, and MATTHIEU SOUPRE, Pompeu Fabra University-Understanding the Sources of Macroeconomic Uncertainty

AMBROGIO CESA-BIANCHI, Bank of England, M. HASHEM PESARAN, University of Southern California and University of Cambridge, and ALESSANDRO REBUCCI, Johns Hopkins University-Uncertainty and Economic Activity: A Multi-Country Perspective

NANCY XU, Boston College-Global Risk Aversion and International Return Comovements

NICHOLAS BLOOM, Stanford University, and DAVIDE FURCERI, International Monetary Fund-The World Uncertainty Index

Discussants: DAVIDE FURCERI, International Monetary Fund

NANCY XU, Boston College

ALESSANDRO REBUCCI, Johns Hopkins University

BARBARA ROSSI, ICREA and Pompeu Fabra University

\section{8:00 Ам Marriott Marquis San Diego-Marriott Grand Ballroom 1 AEA}

Household Shocks and Crime (K4)

Presiding: ERDAL TEKIN, American University 


\section{Friday $•$ January 3}

ANALISA PACKHAM, Vanderbilt University, and JILLIAN CARR, Purdue University-Do Income Shocks Affect Domestic Violence?

AMANDA AGAN, Rutgers University, and MICHAEL MAKOWSKY, Clemson University-The Minimum Wage, EITC, and Criminal Recidivism

MARK HOEKSTRA, Texas A\&M University, and CHENG CHENG, University of Mississippi-Assessing the Causal Link between Low Incomes and Domestic Violence: Evidence from Random Income Shocks

MICHAEL MUELLER-SMITH, University of Michigan, JANET CURRIE, Princeton University, and MAYA ROSSIN-SLATER, Stanford University-Violence While in Utero: The Impact of Assaults During Pregnancy on Birth Outcomes

Discussants: BENJAMIN HANSEN, University of Oregon

DAVID PHILLIPS, University of Notre Dame

MATTHEW FREEDMAN, University of California-Irvine

KIRSTEN CORNELSON, University of Notre Dame

\section{8:00 AM Marriott Marquis San Diego—San Diego Ballroom A} AEA

\section{Innovation, Productivity and Regulation (O3)}

Presiding: JOHN MICHAEL VAN REENEN, Massachusetts Institute of Technology

JOHN MICHAEL VAN REENEN, Massachusetts Institute of Technology, PHILIPPE AGHION, College of France, and ANTONIN BERGEAUD, Bank of France-The Impact of Regulation on Innovation

UFUK AKCIGIT, University of Chicago, SALOMÉ BASLANDZE, Einaudi Institute for Economics and Finance (EIEF), and FRANCESCA LOTTI, Bank of Italy-Connecting to Power: Political Connections, Innovation, and Firm Dynamics

REBECCA DIAMOND, Stanford University-The Contribution of High-Skilled Immigrants to Innovation in the United States 


\section{Friday $•$ January 3}

JOHN HALTIWANGER, University of Maryland, RUSS COOPER, European University Institute, and JONATHAN WILLIS, Federal Reserve Bank of Kansas City-Declining Business Dynamism: Sources and Productivity Implications

\section{8:00 AM Marriott Marquis San Diego-Marriott Grand Ballroom 12} AEA

\section{Models of Cryptocurrencies: Pricing and Design (G0)}

Presiding: GUILLAUME ROCHETEAU, University of California-Irvine EMILIANO PAGNOTTA, Imperial College London-Bitcoin as Decentralized Money: Prices, Mining, and Network Security JONATHAN CHIU, Bank of Canada, and THORSTEN KOEPPL, Queen's University-The Economics of Cryptocurrencies: Bitcoin and Beyond

ROD GARRATT, University of California-Santa Barbara, and MAARTEN R.C. VAN OORDT, Bank of Canada-Privacy as a Public Good: A Case for Electronic Cash

GUILLAUME ROCHETEAU, University of California-Irvine, and MICHAEL CHOI, University of California-Irvine-Money Mining and Price Dynamics

Discussants: DAVID ANDOLFATTO, Federal Reserve Bank of St. Louis

HARALD UHLIG, University of Chicago

CATHY ZHANG, Purdue University

RANDALL WRIGHT, University of Wisconsin

\section{8:00 AM Marriott Marquis San Diego-Rancho Santa Fe 2 AEA}

New Approaches for Measuring Poverty (I3)

Presiding: DAVID S. JOHNSON, University of Michigan

RICHARD V. BURKHAUSER, Cornell University, KEVIN CORINTH, Council of Economic Advisers, JAMES ELWELL, Cornell University, and JEFF LARRIMORE, Federal Reserve Board-Evaluating the Success of President Johnson's War on Poverty: Revisiting the Historical Record Using a Full-Income Poverty Measure 


\section{Friday $\cdot$ January 3}

LIANA FOX, U.S. Census Bureau, THESIA GARNER, U.S. Bureau of Labor Statistics, JUAN MUNOZ, U.S. Bureau of Labor Statistics, LARYSSA MYKYTA, University of Texas-Rio Grande Valley, and TRUDI RENWICK, U.S. Census Bureau-Potential Improvements to the Census Bureau's Supplemental Poverty Measure for 2021

BRUCE MEYER, University of Chicago, and DEREK WU, University of Chicago-Poverty in the United States Using the Comprehensive Income Dataset

Discussants: DAVID S. JOHNSON, University of Michigan

TIMOTHY SMEEDING, University of Wisconsin-Madison

\section{8:00 AM Marriott Marquis San Diego-Presidio 1 - 2}

AEA

\section{New Directions in Household Saving (D1)}

Presiding: KATHLEEN MCGARRY, University of California-Los Angeles

JEFFREY R. BROWN, University of Illinois, JAMES POTERBA, Massachusetts Institute of Technology and NBER, and DAVID P. RICHARDSON, TIAA—New Evidence on the Choice of Retirement Income Strategies

LAURA FEIVESON, Federal Reserve Board, and JOHN SABELHAUS, Federal Reserve Board-Lifecycle Patterns of Saving and Wealth Accumulation

WILLIAM GALE, Brookings Institution, JASON FICHTNER, Johns Hopkins University, and HILARY GELFOND, Harvard University-Saving Behavior of Millennials

Discussants: OLIVIA S. MITCHELL, University of Pennsylvania

GOPI SHAH GODA, Stanford University

KAREN DYNAN, Harvard University

8:00 Ам Marriott Marquis San Diego-Marina Ballroom G AEA

Promoting Female Participation in Undergraduate Economics (A2)

Presiding: TATYANA AVILOVA, Columbia University 


\section{Friday $•$ January 3}

TATYANA AVILOVA, Columbia University, and CLAUDIA GOLDIN, Harvard University-What UWE Did for Economics

TODD PUGATCH, Oregon State University, and ELIZABETH SCHROEDER, Oregon State University-Motivations to Major in Economics

MOHIT KARNANI, Massachusetts Institute of TechnologyFreshmen Teachers and College Major Choice: Evidence from a Random Assignment in Chile

JOY BUCHANAN, Samford University, and DARWYYN DEYO, San Jose State University-Finance and Economics Women (FEW) Network: Encouraging and Engaging Women in Undergraduate Programs

Discussants: CHER LI, Colorado State University

KASEY BUCKLES, University of Notre Dame

DANILA SERRA, Texas A\&M University

SHELLY LUNDBERG, University of California-Santa Barbara

\section{8:00 AM Marriott Marquis San Diego-Marina Ballroom D} AEA

\section{The Effect of Immigrants on Economic and Political Outcomes in} the United States (J6)

Presiding: PAOLA GIULIANO, University of California-Los Angeles

DAVID FIGLIO, Northwestern University, PAOLA GIULIANO, University of California-Los Angeles, RICCARDO MARCHINGIGLIO, Northwestern University, UMUT OZEK, American Institutes for Research, and PAOLA SAPIENZA, Northwestern University—Diversity in Schools: Immigrants and the Educational Performance of Natives

VASILIKI FOUKA, Stanford University, SOUMYAJIT MAZUMDER, Harvard University, and MARCO TABELLINI, Harvard Business School—Changing In-Group Boundaries: The Role of New Immigrant Waves in the United States

CHRISTIAN DIPPEL, University of California-Los Angeles, and STEPHAN HEBLICH, University of Bristol—Leadership in Social Networks: Evidence from the Forty-Eighters in the Civil War 


\section{Friday $•$ January 3}

KONRAD BURCHARDI, Institute for International Economic Studies (IIES), THOMAS CHANEY, Sciences Po, TAREK HASSAN, Boston University, LISA TARQUINIO, Boston University, and STEPHEN J. TERRY, Boston UniversityImmigration, Innovation and Growth

Discussants: DANIELE PASERMAN, Boston University

GIOVANNI PERI, University of California-Davis

SAUMITRA JHA, Stanford University

OMER OZAK, University of California-Los Angeles

\section{8:00 AM Marriott Marquis San Diego-Santa Rosa AEA}

\section{The Secular Decline in Real Interest Rates (E5)}

Presiding: RAGHURAM RAJAN, University of Chicago

ŁUKASZ RACHEL, Bank of England, and LAWRENCE SUMMERS, Harvard University-On Falling Neutral Real Rates, Fiscal Policy and the Risks of Secular Stagnation

PIERRE-OLIVIER GOURINCHAS, University of CaliforniaBerkeley, and HELENE REY, London Business School-Global Real Rates: A Secular Approach

CARLOS CARVALHO, Central Bank of Brazil, ANDREA FERRERO, University of Oxford, FELIPE MAZIN, University of Pennsylvania, and FERNANDA DA NECHIO, Federal Reserve Bank of San Francisco-Demographics and Real Interest Rates across Countries and over Time

CLAUDIO BORIO, Bank for International Settlements, PITI DISYATAT, Bank for International Settlements, JOHN MIKAEL JUSELIUS, Bank of Finland, and PHURICHAI RUNGCHAROENKITKUL, Bank for International SettlementsWhy So Low for So Long? A Long-Term View of Real Interest Rates

Discussants: BENJAMIN FRIEDMAN, Harvard University

THOMAS LAUBACH, Federal Reserve Board

MARC FLANDREAU, University of Pennsylvania

JAMES D. HAMILTON, University of California-San Diego 


\section{Friday $•$ January 3}

\section{8:00 AM Manchester Grand Hyatt San Diego_-Gaslamp D}

AERE

\section{Empirical Climate Change Economics (Q5)}

Presiding: STEFANO CARATTINI, Georgia State University

RICHARD CARSON, University of California-San Diego, DALIA GHANEM, University of California-Davis, and CHU (ALEX) YU, University of California-San Diego-Estimate the Impact of Climate Change: An Exploration of the Bin Regression Model

MATTHEW NEIDELL, Columbia University, SHINSUKE UCHIDA, Nagoya City University, and MARCELLA VERONESI, University of Verona and ETH Zurich-Be Caution with the Precautionary Principle: Evidence from Fukushima Daiichi Nuclear Accident

IVAN RUDIK, Cornell University, ARIEL ORTIZ-BOBEA, Cornell University, and GARY LYN, Iowa State University-A Microfounded Approach for Estimating the Aggregate Economic Effects of Climate Change

YANJUN LIAO, University of Pennsylvania, and PABLO RUIZ JUNCO, University of California-San Diego-Campaign Finance, Extreme Weather Events, and the Politics of Climate Change

Discussants: JEFFREY WOOLDRIDGE, Michigan State University

KATRINA JESSOE, University of California-Davis

EDWARD BALISTRERI, Iowa State University

STEFANO CARATTINI, Georgia State University

\section{8:00 AM Manchester Grand Hyatt San Diego-Seaport A} AFA

\section{Asset Pricing: Portfolio Choice and Asset Allocation (G1)}

Presiding: RUSSELL WERMERS, University of Maryland

TERRY ZHANG, Australian National University-Trading Opportunities and the Portfolio Choices of Institutional Investors

FRANCISCO GOMES, London Business School, ALEX MICHAELIDES, Imperial College London, and YUXIN ZHANG, Renmin University of China-Tactical Target Date Funds 


\section{Friday $•$ January 3}

LINA LU, Federal Reserve Bank of Boston, MATTHEW PRITSKER, Federal Reserve Bank of Boston, ANDREI ZLATE, Federal Reserve Board, KENECHUKWU ANADU, Federal Reserve Bank of Boston, and JIM BOHN, Federal Reserve Bank of Boston-Reach for Yield by United States Public Pension Funds

ANASTASSIA FEDYK, University of California-Berkeley, and JAMES HODSON, Jozef Stefan Institute-When Can the Market Identify Old News?

Discussants: CHUNHUA LAN, University of New Brunswick

LUBOS PASTOR, University of Chicago

DANIEL BARTH, University of Southern California and CESR

ALAN HUANG, University of Waterloo

\section{8:00 AM Manchester Grand Hyatt San Diego-Seaport B AFA}

\section{Contracts and Incentives (G3)}

Presiding: ALEX EDMANS, London Business School

MARK BORGSCHULTE, University of Illinois, MARIUS GUENZEL, University of California-Berkeley, CANYAO LIU, University of California-Berkeley, and ULRIKE MALMENDIER, University of California-Berkeley-CEO Stress and Life Expectancy: The Role of Corporate Governance and Financial Distress

DAVID DICKS, Baylor University, and PAOLO FULGHIERI, University of North Carolina-Chapel Hill-Uncertainty and Contracting: A Theory of Consensus and Envy in Organizations

JOHN GRAHAM, Duke University, DAWOON KIM, Cornell University, and HYUNSEOB KIM, Cornell University-Executive Mobility in the United States, 1920 to 2011

MEHMET CANAYAZ, Pennsylvania State University, JESS CORNAGGIA, Pennsylvania State University, and KIMBERLY CORNAGGIA, Pennsylvania State University-Choose Your Battles Wisely: The Consequences of Protesting Government Procurement Contracts 


\section{Friday $•$ January 3}

Discussants: CHRISTOPHER PARSONS, University of Southern California

LAURA VELDKAMP, Columbia University

CLAUDIA CUSTODIO, Imperial College London

RAN DUCHIN, University of Washington

\section{8:00 AM Manchester Grand Hyatt San Diego-Seaport DE}

AFA

Factors, Risk and the Economy (G1)

Presiding: JULES VAN BINSBERGEN, University of Pennsylvania

FREDERICO BELO, INSEAD, University of Minnesota and NBER, and ANDRES DONANGELO, University of Texas-AustinPriceless Consumption

NIELS GORMSEN, University of Chicago, and EBEN LAZARUS, Massachusetts Institute of Technology-The Cross-Section of Stock Returns and the Timing of Cash Flows

DAVID SCHREINDORFER, Arizona State UniversityMacroeconomic Tail Risks and Asset Prices

SINA EHSANI, Northern Illinois University, and JUHANI LINNAINMAA, University of Southern California-Factor Momentum and the Momentum Factor

Discussants: TOOMAS LAARITS, New York University

ANDREI GONCALVES, University of North Carolina-Chapel Hill ANDREA TAMONI, Rutgers University

DONG LOU, London School of Economics

\section{8:00 AM Manchester Grand Hyatt San Diego-Seaport F AFA}

\section{Firms and Politics (G3)}

Presiding: JONATHAN KARPOFF, University of Washington APRIL KNILL, Florida State University, BAIXIAO LIU, Florida State University, and JOHN MCCONNELL, Purdue UniversityMedia Partisanship and Fundamental Corporate Decisions 


\section{Friday $•$ January 3}

MATTHEW DENES, Carnegie Mellon University, RAYMOND FISMAN, Boston University, FLORIAN SCHULZ, University of Washington, and VIKRANT VIG, London Business School-Do Political Boundaries Affect Firm Boundaries?

KIZKITZA BIGURI, BI Norwegian Business School, and JÖRG STAHL, Catholic University of Portugal-Who Pays a Visit to

Brussels? Cross-Border Firm Value Effects of Meetings with European Commissioners

Discussants: JOHN LOTT, Crime Prevention Research Center

PAT AKEY, University of Toronto

TRACY WANG, University of Minnesota

\section{8:00 AM Manchester Grand Hyatt San Diego-Seaport G} AFA

\section{M\&A and Competition (G3)}

Presiding: PAVEL SAVOR, DePaul University

ERIC DE BODT, University of Lille, B. ESPEN ECKBO, Dartmouth College, and RICHARD ROLL, California Institute of Technology—Corporate Rivalry and Return Comovement

MIGUEL ANTON, University of Navarra, JOSE AZAR, University of Navarra, MIREIA GINE, University of Navarra and University of Pennsylvania, and LUCA XIANRAN LIN, University of NavarraBeyond the Target: M\&A Decisions and Rival Ownership

ALICE BONAIME, University of Arizona, and YE WANG, University of Arizona-Do Mergers Save Lives?

Discussants: GERARD HOBERG, University of Southern California

ANDREW KOCH, University of Pittsburgh

ALBERT SHEEN, University of Oregon

\section{8:00 AM Manchester Grand Hyatt San Diego-Seaport H} AFA

\section{Mutual Fund Flows and Marketing (G1)}

Presiding: NIKOLAI ROUSSANOV, University of Pennsylvania 


\section{Friday $•$ January 3}

BJARNE FLORENTSEN, Copenhagen Business School, ULF NIELSSON, Copenhagen Business School, PETER RAAHAUGE, Copenhagen Business School, and JESPER RANGVID, Copenhagen Business School-How Important is the Distribution Channel for Mutual Fund Flows?

DUNHONG JIN, Oxford University, MARCIN KACPERCZYK, Imperial College London, BIGE KAHRAMAN, Oxford University, and FELIX SUNTHEIM, International Monetary Fund-Swing Pricing and Fragility in Open-End Mutual Funds

SHANG-JIN WEI, Columbia University, and CHLOE CHUNLIU YANG, Fudan University—Do Internet Finance Platforms Mitigate Conflicts of Interest? The Case of Mutual Fund Investment

ITZHAK BEN-DAVID, Ohio State University and NBER, JIACUI

LI, Stanford University, ANDREA ROSSI, University of Arizona, and YANG SONG, University of Washington-What Do Mutual Fund Investors Really Care About?

Discussants: JONATHAN REUTER, Boston College

ITAY GOLDSTEIN, University of Pennsylvania

HONGXUN RUAN, Peking University

RICHARD EVANS, University of Virginia and Carlo Alberto College

\section{8:00 AM Manchester Grand Hyatt San Diego-Harbor A AFA}

\section{New Advances in International Finance (G1)}

Presiding: PASQUALE DELLA CORTE, Imperial College London

THOMAS MAURER, University of Hong Kong, LUCA PEZZO, University of New Orleans, and MARK TAYLOR, Washington University-St. Louis-Importance of Transaction Costs for Asset Allocations in FX Markets

ZHENGYANG JIANG, Northwestern University, and ROBERT RICHMOND, New York University-Origins of International Factor Structures 


\section{Friday $•$ January 3}

YANG LIU, University of Hong Kong, and IVAN SHALIASTOVICH, University of Wisconsin-Madison-Government Policy Approval and Exchange Rates

ZHENZHEN FAN, Nankai University, JUAN M. LONDONO, Federal Reserve Board, and XIAO XIAO, Erasmus University Rotterdam-United States Equity Tail Risk and Currency Risk Premia

Discussants: BERNARD DUMAS, INSEAD

ROSEN VALCHEV, Boston College

ADRIEN VERDELHAN, Massachusetts Institute of Technology

MIKHAIL CHERNOV, University of California-Los Angeles

\section{8:00 AM Manchester Grand Hyatt San Diego-Seaport C}

\section{AFA}

\section{Regulation \& Finance (G2)}

Presiding: PHILIPP SCHNABL, New York University

KILIAN HUBER, University of Chicago-Are Bigger Banks Better? Firm-Level Evidence from Germany

ALYSSA ANDERSON, Federal Reserve Board, WENXIN DU, University of Chicago, and BERND SCHLUSCHE, Federal Reserve Board-Money Market Fund Reform and Arbitrage Capital

VLADIMIR MUKHARLYAMOV, Georgetown University, and NATASHA SARIN, University of Pennsylvania-Price Regulation in Two-Sided Markets: Empirical Evidence from Debit Cards

JOSE IGNACIO CUESTA, University of Chicago, and ALBERTO SEPULVEDA, Superintendency of Banks and Financial Institutions (SBIF) - Price Regulation in Credit Markets: A Trade-Off between Consumer Protection and Credit Access

Discussants: VICTORIA IVASHINA, Harvard Business School

HANNO LUSTIG, Stanford University

PHILIP STRAHAN, Boston College

ALESSANDRO GAVAZZA, London School of Economics 


\section{Friday $•$ January 3}

\section{8:00 AM Manchester Grand Hyatt San Diego_Cortez Hill A AFEE/AEA}

\section{Advancing the Progressive Ideal by Reshaping the Role of State and Market (B0)}

Presiding: GARY DYMSKI, University of Leeds

FRANCISCO LOUÇÃ, University of Lisbon, and MARIANA MORTÁGUA, National Assembly of Portugal-Green Transformation in Times of Austerity

MASAHIRO YOSHIDA, Komazawa University—The Development of Capital Accumulation in a Former Key Currency Country: The UK's International Balance of Payments and Brexit from a Marxian Viewpoint

AKIRA MATUMOTO, Ritsumeikan University-Considerations on Inequality, Corporate Governance, And Financialization: Insights from Capital, Vol. III, Part V, With Chapter 23 "Interest and Profit of Enterprise" as the Clue

JAN TOPOROWSKI, SOAS University of London-Brecht and Modern Money Theory

RICCARDO BELLOFIORE, University of Bergamo-Minsky's Socialization of Investment: A Schumpeterian Synthesis of Keynes and the New Deal

Discussants: GARY DYMSKI, University of Leeds

JOHN HALL, Portland State University

\section{8:00 AM Manchester Grand Hyatt San Diego-Gaslamp C}

\section{AIEFS}

\section{Topics in Output, Income, and Economic Development (O0)}

Presiding: AMIT BATABYAL, Rochester Institute of Technology

VALERIE CERRA, International Monetary Fund, RUY LAMA, International Monetary Fund, and MAI HAKAMADA, University of California-Santa Cruz-Financial Frictions, Investment Dynamics, and the Lost Recovery

JUSTINE WOOD, Loughborough University-The Effects of Central Bank Transparency on Output Volatility - A Closer Look at Developing Countries 


\section{Friday $•$ January 3}

SRIRAM BALASUBRAMANIAN, International Monetary Fund, RISHABH KUMAR, California State University-San Bernardino, and PRAKASH LOUNGANI, International Monetary FundInequality Dynamics amidst Rapid Growth: A Post Liberalization Indian Perspective

PADMA KADIYALA, Pace University-Liquidity and Price Discovery when Some Participants are Irrational: Evidence from the NSE

AMIT BATABYAL, Rochester Institute of Technology, and HAMID BELADI, University of Texas-San Antonio-Preference Matching, Income, and Population Distribution in Urban and Adjacent Rural Regions

Discussants: SUBHASISH DUGAR, University of Utah

VALERIE CERRA, International Monetary Fund

SUSHANTA K. MALLICK, Queen Mary University of London

SRIRAM BALASUBRAMANIAN, International Monetary Fund JUSTINE WOOD, Loughborough University

\section{8:00 AM Manchester Grand Hyatt San Diego-Nautical AREUEA}

\section{Housing Market and Cycles (R3)}

Presiding: SOPHIA GILBUKH, City University of New York-Baruch College C.Y. CHOI, University of Texas-Arlington-Understanding Comovement of House Prices: Evidence from United States Cities JOSEPH WILLIAMS, Professors Capital-Procyclical Price-Rent Ratios: Theory and Implications

KUN DUAN, Huazhong University of Science and Technology, TAPAS MISHRA, University of Southampton, and SIMON WOLFE, University of Southampton-In Memory: How Do LongMemory Shocks Determine Housing Prices and Macroeconomic Interactions? Evidence from the United States

TINGYU ZHOU, Florida State University, JOHN CLAPP, University of Connecticut, and RAN LU-ANDREWS, California Lutheran University-Is the Behavior of Sellers with Expected Gains and Losses Relevant to Cycles in House Prices? 


\section{Friday $\cdot$ January 3}

Discussants: CHRIS FOOTE, Federal Reserve Bank of Boston LARA LOEWENSTEIN, Federal Reserve Bank of Cleveland JACLENE BEGLEY, Fannie Mae

LAUREN LAMBIE-HANSON, Federal Reserve Bank of Philadelphia

\section{8:00 AM Manchester Grand Hyatt San Diego-Regatta C} AREUEA

\section{Migration and Housing (F2)}

Presiding: MORRIS DAVIS, Rutgers University

TATIANA MOCANU, University of Illinois, and PEDRO TREMACOLDI-ROSSI, University of Illinois-International Student Migration and Local Housing Markets

MAGGIE HU, Chinese University of Hong Kong, YI FAN, National University of Singapore, and XINWEI WAN, University of Cambridge-A Tale of Two Cities: The Impact of Cross-Border Migration on Hong Kong's Housing Market

MARTIJN DROES, University of Amsterdam, and HANS KOSTER, VU University Amsterdam-A World Divided: Refugee Centers, House Prices, and Household Preferences

STUART GABRIEL, University of California-Los Angeles, DANNY BEN-SHAHAR, Tel Aviv University, and RONI GOLAN, Tel Aviv University—Religion, Ideology, and Housing Affordability: Israeli Settlement of the West Bank

Discussants: YONGQIANG CHU, University of North Carolina-Charlotte CHARLES KA YUI LEUNG, City University of Hong Kong MORRIS DAVIS, Rutgers University

DANIEL HARTLEY, Federal Reserve Bank of Chicago

\section{8:00 AM Manchester Grand Hyatt San Diego-Pier ASCE}

The Cuban Economy: Selected Venezuelan Interactions (P2)

Presiding: ROGER R. BETANCOURT, University of Maryland 


\section{Friday $•$ January 3}

ERNESTO HERNANDEZ-CATA, International Monetary Fund (Retired)-Cuba's Petroleum Trade Statistics and the Impact of Cutbacks in Venezuelan Oil

RODOLFO MENDEZ, BBVA Research, JOSE PINEDA, University of British Columbia, and RAFAEL ROMEU, Devtech Systems, Inc-Cuba's Macroeconomic Vulnerabilities to Venezuelan Shocks MONICA GARCIA-PEREZ, St. Cloud State University-Parallel Stories? The Case of Cuban and Venezuelan Migration after Political Regime Changes

Discussants: CARLOS SEIGLIE, Rutgers University-Newark

JOHN DEVEREUX, City University of New York-Queen's College and CGC

ROGER R. BETANCOURT, University of Maryland

\section{8:00 AM Manchester Grand Hyatt San Diego—Cove ASE/AFEE}

\section{Policy Lessons for Our Economic Future (B5)}

Presiding: GIUSEPPE FONTANA, University of Leeds and University of Sannio

THEREZA BALLIESTER REIS, University of Leeds-Does Financial Inclusion Reduce Poverty? The Prescription of the Poor in Brazil

JESUS FERREIRO, University of the Basque Country, and CARMEN GOMEZ, University of the Basque Country-Have Labor Market Reforms Led to More Efficient Labor Markets?

GAËLLE DESPIERRE CORPORON, University of GrenobleConditions for a Relevant Financial Infrastructure to Ensure a Sustainable Development and Reduce Poverty: Lessons from the 2007-2008 Global Turmoil

CHARLES M.A. CLARK, St. John's University, and ALEKSANDR V. GEVORKYAN, St. John's University-Economics of Artificial Intelligence and Integral Human Development

GIUSEPPE FONTANA, University of Leeds and University of Sannio, and MALCOLM SAWYER, University of LeedsDegrowth: An Activist Slogan and Social Movement in Search of an Economic Theory? 


\section{Friday $•$ January 3}

8:00 AM Manchester Grand Hyatt San Diego-Gaslamp AB EPS

Panel: Can MMT Re-envision Financing for Prosperity and Economic Security? (E0)

Presiding: JOHN WATKINS, Westminster College

JASON FURMAN, Harvard University

RANDALL WRAY, Levy Institute

YEVA NERSISYAN, Franklin and Marshall College

ZDRAVKA TODOROVA, Wright State University

\section{8:00 AM Marriott Marquis San Diego-Marina Ballroom F ES}

Panel: Econometrica Session: New Developments in Econometrics (C1)

Presiding: GUIDO IMBENS, Stanford University

AUREO DE PAULA, University College London-Network Analysis

ELENA MANRESA, New York University_Panel Data Analysis

ANNA MIKUSHEVA, Massachusetts Institute of TechnologyIdentification in Time Series

\section{8:00 AM Marriott Marquis San Diego-Del Mar ES}

Field Applications and Explorations of Reference-Dependence (D1)

Presiding: CHARLES SPRENGER, University of California-San Diego MICHAELA PAGEL, Columbia University-The Consumption Effects of the Disposition to Sell Winners and Hold on to Losers NEIL THAKRAL, Brown University, and LINH TÔ, Boston University-Tipping and the Dynamics of Social Norms

LAMAR PIERCE, Washington University-St. Louis, and ALEX REES-JONES, Cornell University-The Negative Consequences of Loss Framing in Performance Incentives 


\section{Friday $•$ January 3}

LORENZ GOETTE, University of Bonn-The Role of Goals in Motivating Behavior: Evidence from a Large-Scale Field Experiment on Resource Conservation

\section{8:00 AM Marriott Marquis San Diego-La Costa ES}

Financial Markets with an Emphasis on China (G1)

Presiding: GIOVANNI COMPIANI, University of California-Berkeley

HAO ZHOU, Tsinghua University—Shadow Banking: China's Dual-Track Interest Rate Liberalization

MATTEO BENETTON, University of California-Berkeley, GIOVANNI COMPIANI, University of California-Berkeley, and ADAIR MORSE, University of California-BerkeleyCryptoMining: Local Evidence from China and the United States

YU SHI, International Monetary Fund, ROBERT TOWNSEND, Massachusetts Institute of Technology, and WU ZHU, University of Pennsylvania-Internal Capital Markets in Business Groups and the Propagation of Credit Supply Shocks

YUANYUAN DENG, University of New South Wales, HANMING FANG, University of Pennsylvania, and KATJA HANEWALD, University of New South Wales-Delaying the Public Pension Age in China: Implications for Labor Force Participation and Individual Welfare

SHENZHE JIANG, Peking University, JIANJUN MIAO, Boston University, and YUZHE ZHANG, Texas A\&M University-China's Housing Bubble, Infrastructure Investment, and Economic Growth

\section{8:00 AM Marriott Marquis San Diego-Catalina ES}

\section{Frontiers in Market Design (D4)}

Presiding: ERIC BUDISH, University of Chicago

DANIEL WALDINGER, New York University-Targeting In-Kind Transfers through Market Design: A Revealed Preference Analysis of Public Housing Allocation 


\section{Friday $•$ January 3}

CLAUDIA ALLENDE, Columbia University and Princeton University, FRANCISCO GALLEGO, Pontifical Catholic University of Chile, and CHRISTOPHER NEILSON, Princeton UniversityApproximating the Equilibrium Effects of Informed School Choice TRACY LIU, Tsinghua University, ZHIXI WAN, Didi Chuxing, and CHENYU YANG, University of Rochester-The Efficiency of A Dynamic Decentralized Two-Sided Matching Market

ERIC BUDISH, University of Chicago, ROBIN LEE, Harvard University, and JOHN SHIM, University of Chicago-Will the Market Fix the Market? A Theory of Stock Exchange Competition and Innovation

HULYA ERASLAN, Rice University, JEREMY FOX, Rice University, YINGHUA HE, Rice University, and YAKYM PIROZHENKO, Rice University—When Do Cardinal Mechanisms Outperform Ordinal Mechanisms?: Operationalizing Pseudomarkets

\section{8:00 Ам Marriott Marquis San Diego-Torrey Pines 1 ES}

\section{Migration and Location Choice (R2)}

Presiding: JESSIE HANDBURY, University of Pennsylvania

JOSEPH-SIMON GOERLACH, Bocconi University-Borrowing Constraints, Migrant Selection, and the Dynamics of Return and Repeat Migration

GREGORIO CAETANO, University of Georgia, and VIKRAM MAHESHRI, University of Houston-A Unified Empirical Framework to Study Segregation

ARMANDO GOMES, Washington University-St. Louis, DAVID SCHOENHERR, Princeton University, JANIS SKRASTINS, Washington University-St. Louis, and BERNARDUS VAN DOORNIK, Central Bank of Brazil-Mobility Constraints and Labor Market Outcomes: Evidence from Credit Lotteries

ALICE KÜGLER, University College London-Residential Segregation and Ethnicity 


\section{Friday $•$ January 3}

\section{8:00 AM Marriott Marquis San Diego-Carlsbad \\ ES}

Political Competition and Political Extremism (D7)

Presiding: ALEXANDER WOLITZKY, Massachusetts Institute of Technology

HANS GERSBACH, ETH Zurich, MATTHEW O. JACKSON,

Stanford University, and ORIOL TEJADA, ETH Zurich-The Optimal Length of Political Terms

LIN HU, Australian National University, and ANQI LI, Washington University-St. Louis-The Politics of Attention

HENG CHEN, University of Hong Kong, and WING SUEN, University of Hong Kong-The Rise of Radicalism: Asymmetric Information and Agenda Escalation

AVIDIT ACHARYA, Stanford University, EDOARDO GRILLO, Carlo Alberto College, TAKUO SUGAYA, Stanford University, and ERAY TURKEL, Stanford University-Dynamic Campaign Spending

DAN BERNHARDT, University of Illinois, STEFAN KRASA, University of Illinois, and MEHDI SHADMEHR, University of Chicago-Demagogues and the Fragility of Democracy

\section{8:00 AM Manchester Grand Hyatt San Diego_-America's Cup AB ESA}

\section{Psychology of Poverty: Preferences, Decision-Making and Productivity (D9)}

Presiding: DIETMAR FEHR, University of Heidelberg

SUPREET KAUR, University of California-Berkeley, SENDHIL MULLAINATHAN, University of Chicago, SUANNA OH, Columbia University, and FRANK SCHILBACH, Massachusetts Institute of Technology-Does Financial Strain Lower Worker Productivity?

DIETMAR FEHR, University of Heidelberg, GUNTHER FINK, Swiss Tropical and Public Health Institute and University of Basel, and B. KELSEY JACK, University of California-Santa BarbaraPoverty, Seasonal Scarcity and Exchange Asymmetries 


\section{Friday $•$ January 3}

GUILHERME LICHAND, Harvard University, and ANANDI MANI, University of Warwick-Cognitive Droughts

VOJTECH BARTOS, University of Munich, MICHAL BAUER, CERGE-EI, JULIE CHYTILOVÁ, Charles University, and IAN LEVELY, Wageningen University \& Research-Effects of Poverty on Impatience: Preferences or Inattention?

Discussants: PAMELA JAKIELA, University of Maryland and Center for Global Development

SANDIP SUKHTANKAR, University of Virginia

LEANDRO CARVALHO, University of Southern California

MARGARET MCCONNELL, Harvard University

\section{8:00 AM Manchester Grand Hyatt San Diego_-Solana Beach AB HERO}

\section{Provider Competition, Spillovers, and Health Care Productivity (I1)}

Presiding: MICHAEL CHERNEW, Harvard University

MICHAEL L. BARNETT, Harvard University, ANDREW OLENSKI, Columbia University, and ADAM SACARNY, Columbia University—Physician Practice Styles, Public Insurance Interventions, and Private Insurance Spillovers

LIRAN EINAV, Stanford University, AMY FINKELSTEIN, Massachusetts Institute of Technology, YUNAN JI, Harvard University, and NEALE MAHONEY, University of ChicagoExternal Effects of Payment Reform: Evidence from a National Randomized Controlled Trial on Bundled Payments

STUART CRAIG, University of Pennsylvania, KEITH MARZILLI ERICSON, Boston University, and AMANDA STARC, Northwestern University-How Important Is Price Variation Between Health Insurers?

Discussants: LAWRENCE BAKER, Stanford University

LEILA AGHA, Dartmouth College

JOSHUA GOTTLIEB, University of Chicago 


\section{Friday $•$ January 3}

\section{8:00 AM Marriott Marquis San Diego-Malibu HES}

Historical Sociology Approaches in History of Economics (B0)

Presiding: ANDREJ SVORENČÍK, University of Mannheim

LOÏC CHARLES, University of Paris 8, and CHRISTINE THÉRÉ, French Institute for Demographic Studies (INED)—Who Was an Economist? The Historical Sociology of Early Economists and Economics (1750-1780)

ANDREJ SVORENČÍK, University of Mannheim, and KEVIN HOOVER, Duke University-Who Runs the AEA? Leadership Hierarchy in American Postwar Economics

PAUL J. PIEPER, University of Illinois-Chicago, and ANDREJ SVORENČÍK, University of Mannheim-Doctoral Origins of Economics Faculty and Job Market Candidates 1993-2019

JOSÉ EDWARDS, Adolfo Ibáñez University, and STEPHEN MEARDON, Texas A\&M International University and Bowdoin College-Factoring "Impact" in the History of Economics

\section{8:00 AM Manchester Grand Hyatt San Diego_America's Cup D INEM/ASE}

\section{Methodology and Social Economics for the 21st Century (B4)}

Presiding: WILFRED DOLFSMA, Wageningen University \& Research

EVELYN FORGET, University of Manitoba-Towards a Caring Economy

MARCEL BOUMANS, University of Utrecht-Simulation and Economic Methodology

LYNNE CHESTER, University of Sydney, ANDREW CUMBERS, University of Glasgow, AMANDA ELLIOT, University of Sydney, and ROBERT MCMASTER, University of Glasgow-Energy Injustice: A Problem of Socio-Economic Stratification

JOHN DAVIS, Marquette University-Individuals' Impaired Capability Development: Stigmatization and Social Stratification

WILFRED DOLFSMA, Wageningen University \& Research, WADE HANDS, Puget Sound University, and ROBERT MCMASTER, University of Glasgow-History, Methodology and Identity for a 21st Century Social Economics 


\section{Friday $•$ January 3}

\section{8:00 AM Manchester Grand Hyatt San Diego-Harbor E LERA}

\section{Breakfast Session: Broadening the Minimum Wage Debate Beyond Employment (J2)}

Presiding: MICHAEL REICH, University of California-Berkeley

LINDSEY BULLINGER, Georgia Institute of Technology, KERRI RAISSIAN, University of Connecticut, and WILL SCHNEIDER, Northwestern University_Does the Minimum Wage Affect Child Maltreatment and Parenting Behaviors? A City-level Analysis

WILLIAM H. DOW, University of California-Berkeley, ANNA GODOY, University of California-Berkeley, CHRISTOPHER LOWENSTEIN, University of California-Berkeley, and MICHAEL REICH, University of California-Berkeley-Can Economic Policies Reduce Deaths of Despair?

DANIEL COOPER, Federal Reserve Bank of Boston, MARIA LUENGO-PRADA, Federal Reserve Bank of Boston, and JONATHAN PARKER, Massachusetts Institute of TechnologyThe Local Aggregate Effects of Minimum Wage Increases

Discussants: AMELIE PETITCLERC, Northwestern University

ANNE CASE, Princeton University

JOSH BIVENS, Economic Policy Institute

\section{8:00 AM Manchester Grand Hyatt San Diego-Harbor F LERA}

\section{Breakfast Session: The Status of Older Workers and the Older Worker Labor Market (J2)}

Presiding: ANTHONY WEBB, New School for Social Research

RICHARD W. JOHNSON, Urban Institute-Racial, Gender, and Educational Disparities in Labor Market Outcomes at Older Ages

DANIELA HOCHFELLNER, New York University, PETER BERG, Michigan State University, MARY HAMMAN, University of Wisconsin-La Crosse, MARISSA ECKROTE, Michigan State University, and MATTHEW PISZCZEK, Wayne State UniversityPension Reforms and Their Implications for Establishment Survivals 


\section{Friday $•$ January 3}

AIDA FARMAND, New School for Social Research, and TERESA GHILARDUCCI, New School for Social Research—Why American Older Workers Have Lost Bargaining Power

Discussants: ANTHONY WEBB, New School for Social Research

KATHARINE G. ABRAHAM, University of Maryland

SIAVASH RADPOUR, New School for Social Research

\section{8:00 AM Marriott Marquis San Diego-Mission Hills NEA}

\section{Discrimination in Labor Markets and Educational Settings: Experimental Evidence (J7)}

Presiding: TIMOTHY DIETTE, Washington and Lee University

SHER AFGHAN ASAD, Iowa State University-Do Workers Discriminate Against Their Out-Group Employers? Evidence from an Online Labor Market

PATRICK BUTTON, Tulane University-Ageist Language in Job Ads and Age Discrimination in Hiring: Evidence from a Field Experiment

DANIA V. FRANCIS, University of Massachusetts-AmherstStatistical Discrimination Versus Implicit Bias: Disentangling the Sources of Gender and Racial Bias in an Educational Setting

DEBORAH RHO, University of St. Thomas, and MARINA MILEO GORSUCH, St. Catherine University-Race, Religion, \& Immigration: Experimental Evidence from the Labor Market

BELINDA ARCHIBONG, Barnard College-Constructing Capital in the Twentieth Century: Prisons and Forced Labor in British Colonial Africa

COLIN CANNONIER, Belmont University-Do Language Restrictions on Obtaining Drivers' License Influence Immigrant Labor Market Outcomes?

Discussants: MACKENZIE ALSTON, Florida State University

ROBYNN COX, University of Southern California

MARCUS CASEY, University of Illinois-Chicago

DANIEL SILVERMAN, Arizona State University

DUHA TORE ALTINDAG, Auburn University 


\section{Friday $•$ January 3}

\section{8:00 AM Manchester Grand Hyatt San Diego_America's Cup C ODE}

\section{Omicron Delta Epsilon Graduate Student Session (A1)}

Presiding: ALI ZADEH, Susquehanna University

HONGCEN WEI, University of Chicago-Financial Friction and Labor Market Dynamics: The Effects of Financial Deregulation on Wage Inequality

ALIREZA MOTAMENI, Howard University-The Impact of Oil Rent, Institutions Quality, and Exchange Rate on Economic Growth: A Heterogeneous Panel Data Study

TIPHANIE MAGNE, University of Delaware-The Effects of the Affordable Care Act Subsidy on Middle Income Households

JULIO ALBERTO RAMOS-PASTRANA, Indiana UniversityRules and Subdividing the Commons: Ejidos in Mexico

Discussants: HONGCEN WEI, University of Chicago

ALIREZA MOTAMENI, Howard University

TIPHANIE MAGNE, University of Delaware

JULIO ALBERTO RAMOS-PASTRANA, Indiana University

\section{8:00 AM Manchester Grand Hyatt San Diego-Torrey Hills AB SIOE}

\section{Panel: Culture and Norms Inside Organizations (L2)}

Presiding: MARIA GUADALUPE, INSEAD

FRANCINE LAFONTAINE, University of Michigan-Session Introduction: SIOE in the AEA

SCOTT E. PAGE, University of Michigan-Institutional Ensembles, Behavioral Spillovers, and Organizational Culture

NAVA ASHRAF, London School of Economics-Altruistic Capital at Work: Field Experiments within Firms

CLAUDINE GARTENBERG, University of PennsylvaniaCorporate Purpose and Firms

ROBERT GIBBONS, Massachusetts Institute of TechnologyCulture and Norms inside Organizations: A SIOE session 


\section{Friday $•$ January 3}

\section{8:00 AM Manchester Grand Hyatt San Diego-Old Town B SSEM}

\section{Arbitration and the Protection of Foreign Investors Through Investment Treaties (F3)}

Presiding: ZDENEK DRABEK, CERGE-EI

CHRISTIAN BELLAK, Vienna University of Economics and Business, and MARKUS LEIBRECHT, University of ReadingMalaysia-The Effect of Economic Crises on the Emergence of Investor-State Arbitration Cases

HENRIK HORN, Research Institute of Industrial Economics, Bruegel, and CEPR, and THOMAS TANGERAS, Research Institute of Industrial Economics-Economics of International Investment Agreements

JOSEF C. BRADA, Arizona State University and CERGE-EI, CHUNDA CHEN, Lamar University, JINGYI JIA, Southern Illinois University-Edwardsville, and ALI KUTAN, Southern Illinois University-Edwardsville-Does Bilateral Investment Treaty Arbitration Have Any Value for Multinational Corporations?

ROBERT HOWSE, New York University, and SARAH LEVIN, New York University-The Right to Regulate and Investor-State Dispute Settlement: Renewable Energy and the Fair and Equitable Treatment Norm

Discussants: M. FABRICIO PEREZ, Wilfrid Laurier University

JOHN BONIN, Wesleyan University

NADIA DOYTCH, City University of New York

ZDENEK DRABEK, CERGE-EI

\section{8:00 AM Manchester Grand Hyatt San Diego_La Jolla B URPE}

\section{Political Economy of the Global Monetary System (F3)}

Presiding: DEVIKA DUTT, University of Massachusetts-Amherst

ALAIN NAEF, University of California-Berkeley-Liberating African Money: Joseph Tchundjang Pouemi and Post-Keynesian Theory 


\section{Friday $•$ January 3}

ALAIN NAEF, University of California-Berkeley-Half a Century on the Market - Bank of England Foreign Exchange Intervention 1952-1993

OLIVER LENINGSTON, University of Sydney-The Political Economy of Federal Reserve Banking: Historical Precedent, Future Possibilities and Possible Responses

DEVIKA DUTT, University of Massachusetts-Amherst—Exorbitant Privilege or Ultimate Responsibility? Access to the International Lender of Last Resort

\section{0:15 AM Manchester Grand Hyatt San Diego-Mission Beach A AAEA}

Studying Innovation in Agriculture - New Data and New Tools (03)

Presiding: GIANCARLO MOSCHINI, Iowa State University

MATTHEW CLANCY, Iowa State University, PAUL HEISEY, USDA Economic Research Service, YONGJIE JI, Iowa State University, and GIANCARLO MOSCHINI, Iowa State UniversityKnowledge Spillovers in Agricultural Innovation: Evidence from Patents

NIKOLAS ZOLAS, U.S. Census Bureau, and TRAVIS LYBBERT, University of California-Davis-How Do Patents Shape Global Value Chains? International and Domestic Patenting and ValueAdded Trade

FELIPE DE FIGUEIREDO SILVA, University of CaliforniaBerkeley, and GREGORY GRAFF, Colorado State UniversityVenture Capital, Startups, and R\&D for Agriculture and Food

Discussant: BRIAN WRIGHT, University of California-Berkeley

\section{0:15 AM Manchester Grand Hyatt San Diego-Harbor D ACES}

\section{Social Capital and Banking Crises (G2)}

Presiding: PAUL WACHTEL, New York University 


\section{Friday $•$ January 3}

ORKUN SAKA, University of Sussex and London School of Economics, and CEVAT GIRAY AKSOY, European Bank for Reconstruction and Development, London School of Economics, and IZA-Financial Crises and Social Capital: Global Evidence EEVA KEROLA, Bank of Finland, ZUZANA FUNGÁC̆OVÁ, Bank of Finland, and LAURENT WEILL, University of StrasbourgDoes Experience of Banking Crises Affect Trust in Banks?

MIKAEL HOMANEN, City University of London and University of Chicago-Depositors Disciplining Banks: The Impact of Scandals

JOSE M. MARTIN-FLORES, CUNEF-Social Capital and Bank Misconduct

Discussants: RALPH DE HAAS, European Bank for Reconstruction and Development, Tilburg University, and Center for Economic and Policy Research

DIANA BONFIM, Bank of Portugal and Católica Lisbon School of Business and Economics

\section{0:15 AM Marriott Marquis San Diego-Marriott Grand Ballroom 5-6 \\ AEA}

\section{Carbon Tax Policy (Q5)}

Presiding: JOSEPH E. ALDY, Harvard University

GILBERT METCALF, Tufts University and NBER, and JAMES STOCK, Harvard University-The Economic Impacts of Carbon Taxes

LINT BARRAGE, University of California-Santa Barbara and NBER-The Fiscal Costs of Climate Change

JOSEPH E. ALDY, Harvard University and NBER, and SARAH ARMITAGE, Harvard University-The Welfare Implications of Carbon Price Certainty

Discussants: MEREDITH FOWLIE, University of California-Berkeley ROBERTON WILLIAMS, University of Maryland and NBER GARTH HEUTEL, Georgia State University and NBER 


\section{Friday $•$ January 3}

\section{0:15 AM Marriott Marquis San Diego—Santa Rosa}

AEA

Contraception, Abortion, and Fertility Rates (J1)

Presiding: MARTHA J. BAILEY, University of Michigan

MARTHA J. BAILEY, University of Michigan, and ERIC CHYN, Dartmouth College-How America Dodged the Draft: The Demographic Legacy of the Vietnam War

SARAH MILLER, University of Michigan, LAURA WHERRY, University of California-Los Angeles, and DIANA FOSTER, University of California-San Francisco-The Economic Consequences of Being Denied an Abortion

JASON M. LINDO, Texas A\&M University-New Evidence on the Effects of Contraception and Abortion Access

JESSAMYN SCHALLER, Claremont McKenna College, PRICE FISHBACK, University of Arizona, and KELLI MARQUARDT, University of Arizona-Local Economic Conditions and Fertility from the Great Depression Through the Great Recession

Discussants: ANALISA PACKHAM, Vanderbilt University

DAVID SLUSKY, University of Kansas

MELANIE GULDI, University of Central Florida

KASEY BUCKLES, University of Notre Dame

\section{0:15 AM Marriott Marquis San Diego-Torrey Pines 3} AEA

Criminal Behavior, Crime Policy and Violent Crime (K4)

Presiding: ANDREA VELASQUEZ, University of Colorado-Denver

CAROLINA ARTEAGA, University of Toronto-The Effects of Marital Rape Laws on Domestic Violence, Homicides and Divorce JONATHAN COLMER, University of Virginia, and JENNIFER DOLEAC, Texas A\&M University-Do Right-to-Carry Laws Mitigate or Exacerbate Violent Crime? Evidence from the Temperature-Violent Crime Relationship 


\section{Friday $•$ January 3}

GAURAV KHANNA, University of California-San Diego, CARLOS MEDINA, Central Bank of Colombia, ANANT NYSHADHAM, Boston College and NBER, JORGE TAMAYO, Harvard University, and CHRISTIAN POSSO, Central Bank of Colombia-Job Loss and Crime in Colombia

MICAELA SVIATSCHI, Princeton University, JUAN F. VARGAS, Del Rosario University, and WILBER BAIRES, Del Rosario University-Should I Stay or Should I Go? The Effect of Residential Voting in a Gang-Controlled Context

Discussants: AMANDA AGAN, Rutgers University

MANISHA SHAH, University of California-Los Angeles

\section{0:15 AM Marriott Marquis San Diego-Marriott Grand Ballroom 12 \\ AEA}

\section{Cultural Dynamics of Gender Norms (Z1)}

Presiding: OWEN OZIER, World Bank

LUCIA CORNO, Catholic University of the Sacred Heart, ELIANA LA FERRARA, Bocconi University, and ALESSANDRA VOENA, University of Chicago-The Historical Roots of Female Genital Cutting

GARANCE GENICOT, Georgetown University, and MARIA HERNANDEZ DE BENITO, Georgetown University-Female First Born and Family Structure in Sub-Saharan Africa

NEHA AGARWAL, University of Otago, and ANNAMARIA MILAZZO, World Bank-Missing Adult Women and Son Preference: Evidence Across Countries

PAMELA JAKIELA, Center for Global Development, LAURA KINCAIDE, Harvard University, and OWEN OZIER, World Bank-Do Daughters Change Fathers' Gender Attitudes?

Discussants: SEEMA JAYACHANDRAN, Northwestern University

SARA LOWES, Bocconi University

RACHEL HEATH, University of Washington

PIETRO BIROLI, University of Zurich 


\section{Friday $•$ January 3}

\section{0:15 AM Marriott Marquis San Diego-Marina Ballroom G AEA}

Economics for Inclusive Prosperity (EfIP): Labor, Technology, and Social Policy (J0)

Presiding: SURESH NAIDU, Columbia University

SANDRA E. BLACK, Columbia University, and JESSE ROTHSTEIN, University of California-Berkeley-An Expanded View of Government's Role in Providing Social Insurance and Investing in Children

ARINDRAJIT DUBE, University of Massachusetts-AmherstUsing Wage Boards to Raise Pay

ANTON KORINEK, University of Virginia-Labor in the Age of Automation and Artificial Intelligence

SURESH NAIDU, Columbia University-Worker Collective Action in the 21st Century Labor Market

Discussants: DAVID AUTOR, Massachusetts Institute of Technology

DAVID DEMING, Harvard University

\section{0:15 AM Marriott Marquis San Diego-Coronado Room AEA}

\section{Enhancing Learning in Economics (A2)}

Presiding: KIMMARIE MCGOLDRICK, University of Richmond RITA BALABAN, University of North Carolina-Chapel Hill, and PATRICK CONWAY, University of North Carolina-Chapel HillEnhancing Learning in Economics through "Nudges"

AMANDA BAYER, Swarthmore College, SYON BHANOT, Swarthmore College, ERIN BRONCHETTI, Swarthmore College, and STEPHEN O'CONNELL, Swarthmore College-Diagnosing the Learning Environment for Diverse Students in Introductory Economics: An Analysis of Relevance, Belonging, and Growth Mindsets

DWAYNE BENJAMIN, University of Toronto, AVI J. COHEN, University of Toronto, and GILLIAN HAMILTON, University of Toronto-A More Pareto-Efficient Way To Teach Principles of Economics? Evidence from the University of Toronto 


\section{Friday $•$ January 3}

BRANDON SHERIDAN, Elon University, and BEN SMITH, University of Nebraska-Omaha-How Often Does Active Learning Occur and Is It Effective? A Quantitative Approach

Discussants: TISHA LIN NAKAO EMERSON, Baylor University

MARTHA L. OLNEY, University of California-Berkeley

WENDY STOCK, Montana State University

GEORG SCHAUR, University of Tennessee

\section{0:15 AM Marriott Marquis San Diego-Marriott Grand} Ballroom 13

AEA

\section{Household Finance and Race (D1)}

Presiding: VICKI BOGAN, Cornell University

JAWAD ADDOUM, Cornell University, CARINA CUCULIZA, University of Miami, ALOK KUMAR, University of Miami, and STUART WEBB, University of Minnesota-Hispanic Culture, Stock Preferences, and Asset Prices

DAMON JONES, University of Chicago-New Evidence on Racial Disparities in Financial Outcomes

DARRICK HAMILTON, Ohio State University—Race, Millennials and Home Ownership in the Aftermath of the Great Recession

RUCKER JOHNSON, University of California-Berkeley-The Impact of Parental Wealth on College Enrollment \& Degree Attainment: Evidence from the Housing Boom \& Bust

Discussants: NGINA CHITEJI, New York University

PETER BLAIR HENRY, New York University

LUISA BLANCO, Pepperdine University

JERMAINE TONEY, Rutgers University 


\section{Friday $•$ January 3}

\section{0:15 AM Marriott Marquis San Diego-Marriott Grand Ballroom 11 \\ AEA}

Life on the Edge: Collaboration and the Production of Ideas at the Scientific Frontier (03)

Presiding: JULIA LANE, New York University

MOHAMMAD AHMADPOOR, Northwestern University, and BENJAMIN F. JONES, Northwestern University and NBERUnraveling Team and Individual Outcomes in Science and Invention MATTHIAS DORNER, IAB Nuremberg, FABIAN GAESSLER, MPI Innovation and Competition, DIETMAR HARHOFF, MPI Innovation and Competition, KARIN HOISL, MPI Innovation and Competition and University of Mannheim, and FELIX PÖGE, MPI Innovation and Competition-Inventor Teams, Invention Quality and Occupational Contexts

RUSSELL FUNK, University of Minnesota, BRITTA GLENNON, University of Pennsylvania, JULIA LANE, New York University, RAVIV MURCIANO-GOROFF, New York University, and MATTHEW B. ROSS, New York University-Money for Something: The Link between Research Funding, Collaboration Networks, and Innovation

KEVIN BOUDREAU, Northeastern University and NBER, and INA GANGULI, University of Massachusetts-Amherst-MultiDisciplinary Scientists: Field Experimental Evidence from a Call for Grant Proposals

MARY KALTENBERG, Brandeis University, ADAM B. JAFFE, Brandeis University, Queensland University of Technology, and NBER, and MARGIE E. LACHMAN, Brandeis University-Fluid Intelligence and Experience in Invention: Complementarity in Age-Heterogeneous Teams

Discussants: PIERRE AZOULAY, Massachusetts Institute of Technology

MATTHEW B. ROSS, New York University

ADAM B. JAFFE, Brandeis University, Queensland University of Technology, and NBER

RUSSELL FUNK, University of Minnesota

INA GANGULI, University of Massachusetts-Amherst 


\section{Friday $•$ January 3}

\section{0:15 AM Marriott Marquis San Diego—Solana}

AEA

\section{Monetary Policy (E3)}

Presiding: THOMAS HOGAN, Rice University

NGOC-KHANH TRAN, Washington University-St. Louis, and THUY TO, University of New South Wales-Cheap TIPS or Expensive Inflation Swaps? Mispricing in Real Asset Markets

MATTEO BENETTON, University of California-Berkeley, and DAVIDE FANTINO, Bank of Italy-Bank Competition and Targeted Monetary Policy

AMBROGIO CESA-BIANCHI, Bank of England, and GARETH ANDERSON, International Monetary Fund-Firm Heterogeneity, Credit Spreads, and Monetary Policy

MOHAMED BAKOUSH, University of Southampton, TAPAS MISHRA, University of Southampton, and SIMON WOLFE, University of Southampton-Securitization, Monetary Policy and Bank Stability

ZIGAN WANG, University of Hong Kong, and LUPING YU, University of Hong Kong-The Effects of Legalizing Open Market Share Repurchases: International Evidence

CRISTIANO CANTORE, Bank of England, FILIPPO FERRONI, Federal Reserve Bank of Chicago, and MIGUEL LEON-LEDESMA, University of Kent-The Missing Link: Monetary Policy and the Labor Share

\section{0:15 AM Marriott Marquis San Diego-Marriott Grand}

\section{Ballroom 2}

AEA

\section{Monetary Policy and Corporate Risk-Taking (E5)}

Presiding: RAGHURAM RAJAN, University of Chicago

DOUGLAS DIAMOND, University of Chicago, and RAGHURAM RAJAN, University of Chicago-The Spillovers from Easy Liquidity and the Implications for Multilateralism

JOSÉ-LUIS PEYDRÓ, University Pompeu Fabra, and FRANK SMETS, European Central Bank-Banking Supervision, Monetary Policy and Risk-Taking: Big Data Evidence from 15 Credit Registers 


\section{Friday $\cdot$ January 3}

CECILIA CAGLIO, Federal Reserve Board, MATT DARST, Federal Reserve Board, and SEBNEM KALEMLI-OZCAN, University of Maryland-Low Interest Rates and Risk Taking Evidence from United States Credit Registry

FRIEDERIKE NIEPMANN, Federal Reserve Board, and TIM SCHMIDT-EISENLOHR, Federal Reserve Board-Institutional Investors, the Dollar, and United States Credit Conditions

Discussants: HYUN SONG SHIN, Bank for International Settlements

THOMAS DRESCHEL, University of Maryland

LUC LAEVEN, European Central Bank

WENXIN DU, University of Chicago

10:15 AM Marriott Marquis San Diego-Rancho Santa Fe 2 AEA

\section{Search and Matching in Education Markets (D8)}

Presiding: ERIC BUDISH, University of Chicago

RAN SHORRER, Pennsylvania State University-Simultaneous Search: Beyond Independent Successes

CHRISTOPHER NEILSON, Princeton University, CLAUDIA ALLENDE, Columbia University, PATRICK AGTE, Princeton University, and ADAM KAPOR, Princeton University-Search Costs, Biased Beliefs and School Choice under Endogenous Consideration Sets

NICOLE IMMORLICA, Microsoft Research, JACOB LESHNO, University of Chicago, IRENE LO, Stanford University, and BRENDAN LUCIER, Microsoft Research-Facilitating Student Information Acquisition in Matching Markets

HESSEL OOSTERBEEK, University of Amsterdam, SANDOR SOVAGO, University of Groningen, and BAS VAN DER KLAAUW, VU University Amsterdam-Why Are Schools Segregated? Evidence from the Secondary-School Match in Amsterdam 


\section{Friday $•$ January 3}

\section{0:15 Aм Marriott Marquis San Diego-Marriott Grand Ballroom 1 \\ AEA}

The Economics of Health Epidemics (I0)

Presiding: IMRAN RASUL, University College London and IFS

JEROME ADDA, Bocconi University-The Spread of Antibiotic Resistance

OEINDRILA DUBE, University of Chicago, DARIN CHRISTENSEN, University of California-Los Angeles, JOHANNES HAUSHOFER, Princeton University, BILAL SIDDIQI, World Bank, and MAARTEN VOORS, Wageningen University \& ResearchHealthcare Delivery During Crisis: Experimental Evidence from Sierra Leone's Ebola Outbreak

IMRAN RASUL, University College London and IFS, and ILDO JUNIOR, University College London-The Anatomy of a Public Health Crisis: Household and Health Sector Responses to the Zika Epidemic in Brazil

CHRISTOPHER M. SNYDER, Dartmouth College, MICHAEL KREMER, Harvard University, and JONATHAN D. LEVIN, Stanford University—Designing Advance Market Commitments for New Vaccines

\section{0:15 Aм Marriott Marquis San Diego-San Diego Ballroom A} AEA

\section{The National Academies Child Poverty Report (I3)}

Presiding: ROBERT T. MICHAEL, University of Chicago

JANET CURRIE, Princeton University, and ROBERT MOFFITT, Johns Hopkins University-The National Academies Child Poverty Report

Discussants: ANGUS DEATON, Princeton University

KAREN DYNAN, Harvard University

LAWRENCE KATZ, Harvard University 


\section{Friday $•$ January 3}

\section{0:15 AM Marriott Marquis San Diego-Marriott Grand Ballroom 10 \\ AEA}

The Supply and Demand of Safe Assets (G2)

Presiding: ANDREW METRICK, Yale University

STEFAN GISSLER, Federal Reserve Board, and BORGHAN NEZAMI NARAJABAD, Federal Reserve Board-Private Supply of Safe Assets: Shadow Banks Versus Traditional Banks

SEBASTIAN INFANTE, Federal Reserve Board, CHARLES PRESS, Federal Reserve Board, and ZACK SARAVAY, Federal Reserve Board-Understanding Collateral Reuse in the United States Financial System

GARY GORTON, Yale University, ANDREW METRICK, Yale University, and CHASE ROSS, Yale University-Who Ran on Repo?

Discussants: YIMING MA, Columbia University

ZOLTAN POZSAR, Credit Suisse

MATHIAS KRUTTLI, Federal Reserve Board

\section{0:15 AM Marriott Marquis San Diego-Marina Ballroom D AEA}

The United States Economy: Growth, Stagnation or New Financial Crisis (E2)

Presiding: DOMINICK SALVATORE, Fordham University

JANICE EBERLY, Northwestern University-Reaping What You Sow: the Changing Composition of Investment

VALERIE A. RAMEY, University of California-San DiegoProductivity Origins of "Secular Stagnation"

KENNETH ROGOFF, Harvard University-The Next Systemic Financial Crisis

ROBERT J. SHILLER, Yale University-Popular Economic Narratives Advancing the Longest U.S. Expansion 2009-2019

LAWRENCE SUMMERS, Harvard University-The Future of American Fiscal Policy

Discussant: DOMINICK SALVATORE, Fordham University 


\section{Friday $•$ January 3}

\section{0:15 AM Marriott Marquis San Diego-Presidio 1-2}

AEA

\section{Unemployment Insurance and the Labor Market (E6)}

Presiding: BENJAMIN SCHOEFER, University of California-Berkeley

CAMILLE LANDAIS, London School of Economics, and JOHANNES SPINNEWIJN, London School of Economics-The Value of Unemployment Insurance

KURT MITMAN, Institute for International Economic Studies (IIES), MARCUS HAGEDORN, University of Oslo, FATIH KARAHAN, Federal Reserve Board, and IOURII MANOVSKII, University of Pennsylvania-Unemployment Benefits and Unemployment in the Great Recession: The Role of Equilibrium Effects

MORITZ KUHN, University of Bonn, PHILIPP JUNG, Technical University of Dortmund, and BENJAMIN HARTUNG, University of Bonn-What Hides behind the German Labor Market Miracle? Unemployment Insurance Reforms and Labor Market Dynamics SIMON JAEGER, Massachusetts Institute of Technology, BENJAMIN SCHOEFER, University of California-Berkeley, SAMUEL YOUNG, Massachusetts Institute of Technology, and JOSEF ZWEIMÜLLER, University of Zurich-Wages and the Value of Nonemployment

\section{0:15 AM Marriott Marquis San Diego-Point Loma} AEA

\section{Use of Machine Learning Algorithms (C5)}

Presiding: YING ZHU, University of California-San Diego

KE TANG, Tsinghua University, KAI FENG, Beihang University, HAN HONG, Stanford University, and JINGYUAN WANG, Beihang University-Decision Making with Machine Learning and ROC Curves

ANDREAS JOSEPH, Bank of England, KRISTINA BLUWSTEIN, Bank of England, MARCUS BUCKMANN, Bank of England, SUJIT KAPADIA, European Central Bank, and OEZGUER SIMSEK, University of Bath-Machine Learning for Financial Crisis Prediction and the Construction of a Coherent Narrative 


\section{Friday $\cdot$ January 3}

DWEEPOBOTEE BRAHMA, Brookings Institution India Center, and DEBASRI MUKHERJEE, Western Michigan UniversityMachine Learning for Predicting "Rare-Events" of Infant and Neo-Natal Mortality and Identifying Leading Indicators for Early Interventions

MODHURIMA DEY AMIN, Washington State University, SYED BADRUDDOZA, Washington State University, and JILL J. MCCLUSKEY, Washington State University-Predicting Access to Healthy Food in the United States with Machine Learning

DARIO SANSONE, Vanderbilt University, and JOAO MONTALVAO, World Bank-Predicting Success Among Female Entrepreneurs: Evidence from Three African Countries

RANAE JABRI, Duke University-Predictive Power at What Cost? Economic and Racial Justice of Data-Driven Algorithms

\section{0:15 Ам Marriott Marquis San Diego-San Diego Ballroom B AEA}

\section{Panel: Women in Central Banking (E5)}

Presiding: CHARLES EVANS, Federal Reserve Bank of Chicago

LAEL BRAINARD, Federal Reserve Board

SARAH BREEDEN, Bank of England

MARY C. DALY, Federal Reserve Bank of San Francisco

CAROLYN A. WILKINS, Bank of Canada

\section{0:15 AM Marriott Marquis San Diego-Marriott Grand Ballroom 4 \\ AEA}

\section{Women's Mobility and Safety in the Public Space (R4)}

Presiding: ERICA FIELD, Duke University

ERICA FIELD, Duke University, and KATE VYBORNY, Duke University—Transport, Urban Labor Markets, and Women's Mobility GIRIJA BORKER, World Bank-Safety First: Perceived Risk of Street Harassment and Educational Choices of Women 


\section{Friday $•$ January 3}

FLORENCE KONDYLIS, World Bank, ASTRID ZWAGER, World Bank, ARIANNA LEGOVINI, World Bank, and KATE VYBORNY, Duke University—Safe Spaces: Avoiding Harassment and Stigma

PETER CHRISTENSEN, University of Illinois, and ADAM OSMAN, University of Illinois-Does Mobility-On-Demand Reduce Frictions in Megacities: Evidence from an Uber Experiment in Cairo

Discussants: GIRIJA BORKER, World Bank

KATE VYBORNY, Duke University

FLORENCE KONDYLIS, World Bank

ADAM OSMAN, University of Illinois

\section{0:15 AM Manchester Grand Hyatt San Diego-Gaslamp D AERE}

\section{Fisheries Economics (Q2)}

Presiding: KAILIN KROETZ, Resources for the Future

CHRISTOPHER C. MOORE, U.S. Environmental Protection Agency, and STEPHEN C. NEWBOLD, U.S. Environmental Protection Agency-Benefits of Ecological Spillovers from Nutrient Management in a Coastal Estuary

MATTHEW REIMER, University of Alaska-Anchorage, JOSHUA ABBOTT, Arizona State University, and ALAN HAYNIE, NOAA Fisheries-Structural Behavioral Models for Rights-Based Fisheries

DAVID KLING, Oregon State University, PAUL FACKLER, North Carolina State University, and MICHAEL SPRINGBORN, University of California-Davis-Measure, Harvest, Learn: Renewable Resource Management under State and Parameter Uncertainty

EYAL FRANK, University of Chicago, and KIMBERLY OREMUS, University of Delaware-Regulating Biological Resources: Lessons from Marine Fisheries in the United States

Discussants: SUNNY JARDINE, University of Washington

LING HUANG, University of Connecticut

DEREK LEMOINE, University of Arizona

KAILIN KROETZ, Resources for the Future 


\section{Friday $•$ January 3}

\section{0:15 AM Manchester Grand Hyatt San Diego-Seaport A}

AFA

\section{Common Ownership, Competition, and Innovation (G3)}

Presiding: JOSE AZAR, University of Navarra

SHRADHA BINDAL, Texas A\&M University-When Does Common Ownership Matter?

JOSEPH J. GERAKOS, Dartmouth College, and JIN XIE, Chinese University of Hong Kong-Institutional Horizontal Shareholdings and Generic Entry in the Pharmaceutical Industry

HADIYE ASLAN, Georgia State University-Common Ownership, Creative Destruction, and Inequality: Evidence from U.S. Consumers MELISSA NEWHAM, KU Leuven and DIW Berlin, JO SELDESLACHTS, KU Leuven and DIW Berlin, and ALBERT BANAL-ESTANOL, Pompeu Fabra University-Common Ownership and Market Entry: Evidence from the Pharmaceutical Industry

Discussants: GORDON PHILLIPS, Dartmouth College

SARA ELLISON, Massachusetts Institute of Technology

MATTHEW WEINBERG, Ohio State University

FIONA SCOTT MORTON, Yale University

\section{0:15 AM Manchester Grand Hyatt San Diego-Seaport B AFA}

\section{FinTech: Adoption and Consequences (G2)}

Presiding: STEPHAN SIEGEL, University of Washington

NICOLAS CROUZET, Northwestern University, APOORV GUPTA, Northwestern University, and FILIPPO MEZZANOTTI, Northwestern University-Shocks and Technology Adoption: Evidence from Electronic Payment Systems

SUDIP GUPTA, Fordham University—FinTech and Credit Scoring for the Millennial Generation

FRANCESCO D'ACUNTO, Boston College, ALBERTO G. ROSSI, University of Maryland, and MICHAEL WEBER, University of Chicago-Crowdsourcing Financial Information to Change Spending Behavior 


\section{Friday $•$ January 3}

MENGMING DONG, Rice University-Consumers' Financial Constraints, Lawsuit Decisions, and the Civil Justice System

Discussants: ABHIROOP MUKHERJEE, Hong Kong University of Science and Technology

TOBIAS BERG, Frankfurt School of Finance \& Management

SAMULI KNÜPFER, BI Norwegian Business School

KELLY SHUE, Yale University

\section{0:15 AM Manchester Grand Hyatt San Diego-Seaport C} AFA

\section{Learning in Asset Markets (G1)}

Presiding: LARS LOCHSTOER, University of California-Los Angeles

JOAO COCCO, London Business School, FRANCISCO GOMES, London Business School, and PAULA LOPES, London School of Economics-Evidence on Expectations of Household Finances

KAI LI, Hong Kong University of Science and Technology, CHI-YANG TSOU, Hong Kong University of Science and Technology, and CHENJIE XU, Hong Kong University of Science and Technology_Learning and the Capital Age Premium

MATTHIJS BREUGEM, Carlo Alberto College, ADRIAN BUSS, INSEAD, and JOEL PERESS, INSEAD-Learning from Interest Rates: Implications for Stock Market Efficiency

ROBIN GREENWOOD, Harvard Business School, SAMUEL HANSON, Harvard Business School, and LAWRENCE JIN, California Institute of Technology—Reflexivity in Credit Markets

Discussants: MICHAELA PAGEL, Columbia University

JACK FAVILUKIS, University of British Columbia

JAROMIR NOSAL, Boston College

PIERRE COLLIN-DUFRESNE, Swiss Federal Institute of Technology-Lausanne (EPFL) 


\section{Friday $•$ January 3}

\section{0:15 AM Manchester Grand Hyatt San Diego-Seaport F}

AFA

\section{Mutual Funds: New Perspectives (G1)}

Presiding: MARCIN KACPERCZYK, Imperial College London ANASTASSIA FEDYK, University of California-Berkeley, SAURIN PATEL, Western University, and SERGEI SARKISSIAN, McGill University-Managerial Structure and Performance Induced Trading

STEFANO GIGLIO, Yale University, YUAN LIAO, Rutgers University, and DACHENG XIU, University of Chicago-Thousands of Alpha Tests

ANDREA BUFFA, Boston University, and APOORVA JAVADEKAR, Indian School of Business-The Allocation of Talent across Mutual Fund Strategies

Discussants: LU ZHENG, University of California-Irvine

ROSSEN VALKANOV, University of California-San Diego

STIJN VAN NIEUWERBURGH, Columbia University

\section{0:15 AM Manchester Grand Hyatt San Diego-Seaport G AFA}

\section{New Methods in Asset Pricing (G1)}

Presiding: SVETLANA BRYZGALOVA, London Business School

RAMAN UPPAL, EDHEC Business School, PAOLO ZAFFARONI, Imperial College London, and IRINA ZVIADADZE, Stockholm School of Economics—Correcting Misspecified Stochastic Discount Factors

AI HE, Emory University, DASHAN HUANG, Singapore Management University, and GUOFU ZHOU, Washington University-St. Louis-New Factors Wanted: Evidence from a Simple Specification Test

GREGORY BROWN, University of North Carolina-Chapel Hill, ERIC GHYSELS, University of North Carolina-Chapel Hill, and OLEG GREDIL, Tulane University-Nowcasting Net Asset Values: The Case of Private Equity 


\section{Friday $•$ January 3}

AMIT GOYAL, University of Lausanne, ZHONGZHI (LAWRENCE) HE, Brock University, and SAHN-WOOK HUH, State University of New York-Buffalo-Distance-Based Metrics: A Bayesian Solution to the Power and Extreme-Error Problems in Asset-Pricing Tests

Discussants: CESARE ROBOTTI, University of Warwick

MIKHAIL CHERNOV, University of California-Los Angeles

SOPHIE SHIVE, University of Notre Dame

ALEXANDER CHINCO, University of Illinois

\section{0:15 AM Manchester Grand Hyatt San Diego-Seaport H AFA}

\section{New Perspectives on Raising and Measuring Capital (G3)}

Presiding: SABRINA T. HOWELL, New York University

RAMIN BAGHAI, Stockholm School of Economics, and RUI SILVA, London Business School-The Impact of Going Public on the Firm's Human Capital

JESS CORNAGGIA, Pennsylvania State University, MATTHEW GUSTAFSON, Pennsylvania State University, JASON KOTTER, Brigham Young University, and KEVIN PISCIOTTA, University of Kansas-Initial Public Offerings and the Local Economy

MICHAEL EWENS, California Institute of Technology, RYAN PETERS, Tulane University, and SEAN WANG, Southern Methodist University-Acquisition Prices and the Measurement of Intangible Capital

RONGBING HUANG, Kennesaw State University, and JAY RITTER, University of Florida-Corporate Cash Shortfalls and Financing Decisions

Discussants: TANIA BABINA, Columbia University

EMANUELE COLONNELLI, University of Chicago

DIMITRIS PAPANIKOLAOU, Northwestern University

RENE STULZ, Ohio State University 


\section{Friday $•$ January 3}

\section{0:15 АM Manchester Grand Hyatt San Diego-Seaport DE}

AFA

Panel: Shadow Banking: Understanding Private Debt (G0)

Presiding: VICTORIA IVASHINA, Harvard Business School

STEVEN KAPLAN, University of Chicago

EDGAR LEE, Oaktree Capital

TODD PULVINO, CNH Partners

JEREMY STEIN, Harvard University

10:15 Ам Manchester Grand Hyatt San Diego-Harbor A AFA

\section{Shareholder Voting (G3)}

Presiding: DORON LEVIT, University of Pennsylvania

NICKOLAY GANTCHEV, Southern Methodist University, and MARIASSUNTA GIANNETTI, Stockholm School of EconomicsThe Costs and Benefits of Shareholder Democracy

VICENTE CUNAT, London School of Economics, YIQING LU, New York University, and HONG WU, Hong Kong Polytechnic University-Managerial Response Under Shareholder Empowerment: Evidence from Majority Voting Legislation Changes RICHARD EVANS, University of Virginia and Carlo Alberto College, OĞUZHAN KARAKAŞ, Cambridge University, RABIH MOUSSAWI, Villanova University, and MICHAEL YOUNG,

University of Virginia-Phantom of the Opera: ETFs and Shareholder Voting

Discussants: JOHN MATSUSAKA, University of Southern California MICHELLE LOWRY, Drexel University ADAM REED, University of North Carolina-Chapel Hill

\section{0:15 AM Manchester Grand Hyatt San Diego-Gaslamp AB AFE}

Diversity and Career Prospects Up the Corporate Ladder (G3)

Presiding: NATALIA REISEL, Fordham University 


\section{Friday $•$ January 3}

ANZHELA KNYAZEVA, U.S. Securities and Exchange Commission, DIANA KNYAZEVA, U.S. Securities and Exchange Commission, and LALITHA NAVEEN, Temple UniversityDiversity in Corporate Teams

SHU HAN, Yeshiva University, and S. ABRAHAM RAVID, Yeshiva University-Diversity in Hollywood: Do Gender and Age Affect Film Directors' Careers?

RENEE ADAMS, Oxford University, and VANITHA RAGUNATHAN, University of Queensland-Lehman Sisters

Discussants: WILL GORNALL, University of British Columbia

JUNGMIN KIM, Hong Kong Polytechnic University

RICK TOWNSEND, University of California-San Diego

\section{0:15 AM Manchester Grand Hyatt San Diego_Cortez Hill A AFEE}

\section{Regional Inequality, Industrial Policy, and Land Reform (01)}

Presiding: KOSTA JOSIFIDIS, University of Novi Sad

JAMES T. PEACH, New Mexico State University, and RICHARD ADKISSON, New Mexico State University-Time, Institutional Change, and Regional Income Distribution in the United States

LUKASZ MAMICA, Cracow University of Economics, and WILFRED DOLFSMA, Wageningen University \& ResearchIndustrial Policy: An Institutional Economic Framework for Assessment

HOWARD STEIN, University of Michigan-Institutional Transformation and Shifting Policy Paradigms: Reflections on Land Reform in Africa

GIOVANNA VERTOVA, University of Bergamo-The State as Innovator of First Resort: A New Approach to the National System of Innovation

BARBARA HOPKINS, Wright State University-Can Co-Determination Help Workers Save Capitalism from the Capitalists?

Discussants: KOSTA JOSIFIDIS, University of Novi Sad

TAE-HEE JO, State University of New York-Buffalo State 


\section{Friday $•$ January 3}

\section{0:15 AM Manchester Grand Hyatt San Diego-Pier AREUEA}

\section{Commercial Real Estate Investors (R3)}

Presiding: ZHONGHUA WU, Florida International University

MELANIE ZHANG, University of Reading, ANUPAM NANDA, University of Reading, and STEVEN DEVANEY, University of Reading-Commercial Real Estate Market Structure and the Transaction Liquidity: A Social Network Analysis

JOSEPH NICHOLS, Federal Reserve Board, JUNG-EUN KIM, University of Texas-Austin, and JOHN KRAINER, Federal Reserve Bank of San Francisco-Slow-Moving Capital and Firesales In Real Estate Markets

CHONGYU WANG, University of Florida, TINGYU ZHOU, Florida State University, and DAVID LING, University of FloridaInstitutional Cross-Ownership, Motivated Investors, and Firm Value: Evidence from Real Estate Investment Trusts

ALEXANDER VAN DE MINNE, Massachusetts Institute of Technology, DRAGANA CVIJANOVIC, University of Warwick, and STANI MILCHEVA, University College London-Institutional Investors and Direct Commercial Real Estate: Evidence from Micro-Data

Discussants: DAVID LING, University of Florida

MICHAEL REHER, University of California-San Diego

ERIK DEVOS, University of Texas-El Paso

JIM CLAYTON, York University

\section{0:15 AM Manchester Grand Hyatt San Diego-Regatta C AREUEA}

\section{Housing Market Segmentation and Sorting (R3)}

Presiding: JENNY SCHUETZ, Brookings Institution

DIONISSI ALIPRANTIS, Federal Reserve Bank of Cleveland, DANIEL CARROLL, Federal Reserve Bank of Cleveland, and ERIC YOUNG, University of Virginia-What Explains Neighborhood Sorting by Income and Race? 


\section{Friday $•$ January 3}

STEVEN BOURASSA, Florida Atlantic University, MARTIJN DROES, University of Amsterdam, and MARTIN HOESLI, University of Geneva-Heterogeneous Households and Market Segmentation in a Hedonic Framework

JONATHAN HALKET, Texas A\&M University, and ABHIMANYU GUPTA, University of Essex-Household Sorting in an Ancient Setting

DAVID ALBOUY, University of Illinois, HEEPYUNG CHO, University of Illinois, and MARIYA SHAPPO, University of Illinois-Immigration and the Pursuit of Amenities

Discussants: JUDITH RICKS, Consumer Financial Protection Bureau (CFPB)

AMANDA ROSS, University of Alabama-Birmingham

MARCUS CASEY, University of Illinois-Chicago

YIJIAO LIU, State University of New York-Stony Brook

\section{0:15 AM Manchester Grand Hyatt San Diego-Nautical AREUEA}

\section{Policies and Regulation in Mortgage Markets (G2)}

Presiding: TESS SCHARLEMANN, Federal Reserve Board

NITZAN TZUR-ILAN, Bank of Israel-Unintended Consequences of Credit Constraints on Housing: The Case of LTV Limit

YONGLIN WANG, Lingnan University, SUMIT AGARWAL, National University of Singapore, and YONGHENG DENG, University of Wisconsin-Madison-Mortgage Brokers and the Effectiveness of Regulatory Oversights

LEI DING, Federal Reserve Bank of Philadelphia, RAPHAEL BOSTIC, University of Southern California, and HYOJUNG LEE, Harvard University-Effects of the Community Reinvestment Act (CRA) on Small Business Lending

YONGQIANG CHU, University of North Carolina-Charlotte, and TENG ZHANG, University of Wyoming - The Political Economy of Mortgage Lending

Discussants: STEPHANIE JOHNSON, Rice University

ANTJE BERNDT, Australian National University

DANIEL RINGO, Federal Reserve Board

STEFAN LEWELLEN, Pennsylvania State University 


\section{Friday $•$ January 3}

\section{0:15 AM Manchester Grand Hyatt San Diego-Cove}

ASE

\section{Inequality and Fairness (B5)}

Presiding: ANITA PENA, Colorado State University

LUKE PETACH, Belmont University, and ANITA PENA, Colorado State University-Local Labor Market Inequality in the Age of Mass Incarceration

EVA SIERMINSKA, LISER, MARKUS GRABKA, DIW Berlin, and DANIELA PIAZZALUNGA, University of VeronaTransitioning Towards More Equality? Wealth Gender Differences and the Changing Role of Explanatory Factors over Time

ROBERT A. MCCAIN, Drexel University-Relative Fairness

PATRICK NÜß, Macroeconomic Policy Institute (IMK) and Christian Albrechts University of Kiel-Firms Resistance to Unionism and Its Determinants: Evidence from a Field Experiment NABAMITA DUTTA, University of Wisconsin-La Crosse, and DANIEL MEIERRIEKS, WZB Berlin Social Science CenterJustifying Income Inequality (or not): Does Subjective Well-Being Matter?

\section{0:15 AM Manchester Grand Hyatt San Diego-Cortez Hills C CEANA}

\section{United States-China Trade Relationships (F1)}

Presiding: HEIWAI TANG, Johns Hopkins University and Hong Kong University

JIANDONG JU, Tsinghua University, HONG MA, Tsinghua University, ZI WANG, Shanghai University of Finance and Economics, and XIAODONG ZHU, Toronto UniversityQuantifying the United States-China Trade Conflicts

LOGAN LEWIS, Federal Reserve Board, RYAN MONARCH, Federal Reserve Board, MICHAEL SPOSI, Southern Methodist University and Federal Reserve Bank of Dallas, and JING ZHANG, Federal Reserve Bank of Chicago-Structural Change and Global Trade 


\section{Friday $•$ January 3}

KYLE HANDLEY, University of Michigan, NUNO LIMAO, University of Maryland, RODNEY LUDEMA, Georgetown University, and ZHI YU, Renmin University of China-Input Trade and Policy Uncertainty: Theory and Evidence from Chinese Firms

ANDREW GREENLAND, Elon University, MIHAI ION, University of Arizona, JOHN LOPRESTI, College of William and Mary, and PETER K. SCHOTT, NBER and Yale University-Using Equity Market Reactions to Infer Exposure to Trade Liberalization

Discussants: FERNANDO PARRO, Pennsylvania State University

TOMASZ SWIECKI, University of British Columbia

DEBORAH SWENSON, University of California-Davis

COLIN HOTTMAN, Federal Reserve Board

\section{0:15 AM Marriott Marquis San Diego-Malibu CEBRA/AEA}

\section{Inflation and Price Setting (E3)}

Presiding: LUCA DEDOLA, European Central Bank

DANIEL GOETZ, University of Toronto, and ALEXANDER RODNYANSKY, University of Cambridge-Exchange Rate Shocks and Quality Adjustments

ALEXIS ANTONIADES, Georgetown University, ROBERT FEENSTRA, University of California-Davis, and MINGZHI XU, Peking University and NBER-Using the Retail Distribution to Impute Expenditure Shares

MARCO BOTTONE, Bank of Italy, and ALFONSO ROSOLIA, Bank of Italy-Monetary Policy, Firms' Inflation Expectations and Prices: Causal Evidence from Firm-Level Data

VEGARD HØGHAUG LARSEN, Norges Bank and BI Norwegian Business School, JULIA ZHULANOVA, BI Norwegian Business School, and LEIF ANDERS THORSRUD, Norges Bank and BI Norwegian Business School-News-Driven Inflation Expectations and Information Rigidities

Discussants: DAVID BERGER, Northwestern University

ALBERTO CAVALLO, Harvard Business School

OLIVIER COIBION, University of Texas-Austin

KRISTOFFER NIMARK, Cornell University 


\section{Friday $•$ January 3}

\section{0:15 AM Marriott Marquis San Diego-Torrey Pines 1 EHA}

\section{Migration and Development (N3)}

Presiding: SUMNER LA CROIX, University of Hawaii

SANTIAGO PEREZ, University of California-Davis-Southern (American) Hospitality: Italians in Argentina and the United States during the Age of Mass Migration

ARIELL ZIMRAN, Vanderbilt University and NBER, and YANNAY SPITZER, Hebrew University of Jerusalem—Like an Ink Blot on Paper: Testing the Diffusion Hypothesis of Mass Migration, Italy $1876-1920$

LEVI BOXELL, Stanford University, JOHN T. DALTON, Wake Forest University, and TOMMY LEUNG, Wake Forest UniversityThe Slave Trade and Conflict in Africa, 1400-2000

IGOR MARTINS, Lund University-More with Less? The Effects of Slave Emancipation on Output and Productivity in the British Cape Colony

Discussants: HISHAM FOAD, San Diego State University

JOHN PARMAN, College of William and Mary

JEAN-LAURENT ROSENTHAL, California Institute of Technology

TREVON LOGAN, Ohio State University

\section{0:15 AM Marriott Marquis San Diego-Mission Hills ES}

\section{Learning, Uncertainty and Choices (D8)}

Presiding: FABIO ANGELO MACCHERONI, Bocconi University

DREW FUDENBERG, Massachusetts Institute of TechnologyLearning in Games and the Interpretation of Natural Experiments PIETRO ORTOLEVA, Princeton University, and DENIS SHISHKIN, Princeton University-Ambiguous Information POOYA MOLAVI, Massachusetts Institute of TechnologyMacroeconomics with Misspecification and Learning: A General Theory and Applications 


\section{Friday $•$ January 3}

JOSE MARIA BARRERO, Technological Autonomous University of Mexico (ITAM), NICHOLAS BLOOM, Stanford University, and IAN WRIGHT, Goldman Sachs-Short and Long Run Uncertainty CARLO BALDASSI, Bocconi University, SIMONE CERREIAVIOGLIO, Bocconi University, FABIO ANGELO MACCHERONI, Bocconi University, and MASSIMO MARINACCI, Bocconi University-A Behavioral Characterization of the Drift Diffusion Model

\section{0:15 AM Marriott Marquis San Diego-Del Mar} ES

\section{Market Design (D8)}

Presiding: SERGEI SEVERINOV, University of British Columbia

FARUK GUL, Princeton University, WOLFGANG PESENDORFER, Princeton University, and MU ZHANG, Princeton UniversityMarket Design and Walrasian Equilibrium

YEON-KOO CHE, Columbia University, JINWOO KIM, Seoul National University, and YOUNGWOO KOH, Hanyang UniversityRepeat Applications in College Admissions

THOMAS MARIOTTI, Toulouse School of Economics-EntryProofness and Market Breakdown under Adverse Selection

SERGEI SEVERINOV, University of British Columbia, and GABOR VIRAG, University of Toronto-Who Wants to Be an Auctioneer?

\section{0:15 AM Marriott Marquis San Diego_Carlsbad ES}

\section{Market Power and the Aggregate Economy (L1)}

Presiding: SINA ATES, Federal Reserve Board

JAN DE LOECKER, KU Leuven, JAN EECKHOUT, University College London and University of Barcelona, and SIMON MONGEY, University of Chicago-Quantifying Market Power and Business Dynamism

UFUK AKCIGIT, University of Chicago, and SINA ATES, Federal Reserve Board-Ten Facts on Declining Business Dynamism and Lessons from Endogenous Growth Theory 


\section{Friday $\cdot$ January 3}

ARIEL BURSTEIN, University of California-Los Angeles, VASCO CARVALHO, University of Cambridge, and BASILE GRASSI, Bocconi University-Bottom-up Markup Fluctuations

PEDRO BENTO, Texas A\&M University, and DIEGO RESTUCCIA, University of Toronto-The Role of Nonemployers in Business Dynamism and Aggregate Productivity

\section{0:15 AM Marriott Marquis San Diego—Catalina ES}

Social Insurance and Social Safety Net in the United States (J2)

Presiding: HAMISH LOW, University of Oxford

LEE LOCKWOOD, University of Virginia-Anti Insurance: The Perverse Targeting of Health Insurance

MATTHEW NOTOWIDIGDO, Northwestern University-Take-Up and Targeting: Experimental Evidence from SNAP

MANASI DESHPANDE, University of Chicago-Disability and Distress: The Effect of Disability Programs on Financial Outcomes HAMISH LOW, University of Oxford, and LUIGI PISTAFERRI, Stanford University—Disability Insurance: Error Rates and Gender Differences

\section{0:15 AM Marriott Marquis San Diego_La Costa ES}

\section{Transportation Economics (R4)}

Presiding: TOBIAS SALZ, Massachusetts Institute of Technology

CEMIL SELCUK, Cardiff University-The Selection of Prices and Commissions in a Spatial Model of Ride-Hailing

GABRIEL KREINDLER, University of Chicago-The Welfare Effect of Road Congestion Pricing: Experimental Evidence and Equilibrium Implications

ELENA BELAVINA, Cornell University, KARAN GIROTRA, Cornell University, PU HE, Columbia University, and FANYIN ZHENG, Columbia University-Customer Preference and Station Network in the London Bike Share System 


\section{Friday $•$ January 3}

NICHOLAS BUCHHOLZ, Princeton University, LAURA DOVAL, California Institute of Technology, JAKUB KASTL, Princeton University, FILIP MATEJKA, Charles University and Academy of Science, and TOBIAS SALZ, Massachusetts Institute of Technology_Platform Design in Ride Hail: An Empirical Investigation

\section{0:15 AM Marriott Marquis San Diego-Marina Ballroom F} ES

\section{Treatment Effects and Causal Inference (C1)}

Presiding: ALBERTO ABADIE, Massachusetts Institute of Technology

SUSAN ATHEY, Stanford University, and GUIDO IMBENS, Stanford University-Design-Based Analysis in Difference-inDifferences Settings with Staggered Adoption

DMITRY ARKHANGELSKY, CEMFI, and GUIDO IMBENS, Stanford University-The Role of the Propensity Score in Fixed Effect Models

AKANKSHA NEGI, Michigan State University, and JEFFREY WOOLDRIDGE, Michigan State University—Revisiting Regression Adjustment in Experiments with Heterogeneous Treatment Effects

MAGNE MOGSTAD, University of Chicago, ALEXANDER TORGOVITSKY, University of Chicago, and CHRISTOPHER WALTERS, University of California-Berkeley-Identification of Causal Effects with Multiple Instruments: Problems and Some Solutions

ALBERTO ABADIE, Massachusetts Institute of TechnologyStatistical Non-Significance in Empirical Economics

\section{0:15 AM Marriott Marquis San Diego-Vista HES}

Endogenous Preferences: A Historical View (B0)

Presiding: MARIO J. RIZZO, New York University

MARIO J. RIZZO, New York University, and MALTE DOLD, Pomona College-Unstable and Endogenous Preferences Are Normal 


\section{Friday $\cdot$ January 3}

DAVID M. LEVY, George Mason University, and SANDRA J. PEART, University of Richmond-Persuasion Endogenizes Preferences in Adam Smith's Work

ROSOLINO CANDELA, George Mason University-The Role of Preferences and Motivations in the Economic Approach to Human Behavior: Becker, Buchanan, and the Austrians

ERIK MATSON, New York University-Sympathy, Preferences, and Commerce in Hume

\section{0:15 AM Manchester Grand Hyatt San Diego_-Old Town B IAFFE}

Intimate Partner Violence: Determinants, Impacts, and Strategies (D1)

Presiding: YASEMIN DILDAR, California State University-San Bernardino SOFIA AMARAL, University of Munich and Ifo Institute-Women in Policing and Domestic Violence Attrition: Evidence from Tracking Calls within the Legal System

YASEMIN DILDAR, California State University-San BernardinoIs Economic Empowerment a Protective Factor against Intimate Partner Violence? Evidence from Turkey

BILGE ERTEN, Northeastern University-Female Employment and Intimate Partner Violence: Evidence from Syrian Refugee Inflows to Turkey

JACQUELINE STRENIO, Southern Oregon UniversityIntimate Partner Violence and Economic Well-Being in Later Life: Longitudinal Evidence from the United States

Discussants: OLGA SHEMYAKINA, Georgia Institute of Technology

GIULIA LA MATTINA, University of South Florida

ALI JALALI, Cornell University

ANA KAREN NEGRETE GARCIA, University of Guanajuato 


\section{Friday $•$ January 3}

\section{0:15 AM Manchester Grand Hyatt San Diego_Cortez Hill B IBEFA}

\section{Real Estate Credit and Securitization (G1)}

Presiding: RICARDO CORREA, Federal Reserve Board

TERRY O'MALLEY, Central Bank of Ireland, CLAIRELABONNE, Federal Reserve Bank of Boston, and FERGAL MCCANN, Central Bank of Ireland-The Market for Mortgage Modification: Evidence from a Large-Scale Renegotiation

CHRISTOPH BASTEN, University of Zurich, and STEVEN ONGENA, University of Zurich-The Geography of Mortgage Lending in Times of FinTech

ARVED FENNER, University of Muenster, PHILIPP KLEIN, University of Muenster, and CARINA MOESSINGER, University of Muenster-Digging into the Black Box of Portfolio Replenishment in Securitization: Evidence from the ABS Loan-Level Initiative

PETER BEDNAREK, Deutsche Bundesbank, CHANG MA, Fudan University, DANIEL MARCEL TE KAAT, University of Groningen, and ALESSANDRO REBUCCI, Johns Hopkins University - Capital Flows, Real Estate, and City Business Cycles: Micro Evidence from the German Boom

Discussants: ISAAC HACAMO, Indiana University

GUSTAVO SUAREZ, Federal Reserve Board

SOFIA JOHAN, Florida Atlantic University

YULIYA DEMYANYK, Federal Reserve Bank of Cleveland

\section{0:15 AM Manchester Grand Hyatt San Diego-America's Cup C IHEA}

The Intersection of Private and Public Action in Health and Health Care Internationally (I1)

Presiding: KAREN N. EGGLESTON, Stanford University

LUCY XIAOLU WANG, Cornell University-Global Drug Diffusion and Innovation with a Patent Pool: The Case of HIV Drug Cocktails 


\section{Friday $•$ January 3}

RADHIKA JAIN, Stanford University, and PASCALINE DUPAS, Stanford University_-Private Hospital Responses to Reimbursement Changes under Insurance in India

MYLENE LAGARDE, London School of Economics, and MOHAMADOU SALL, IPDSR Senegal-Does Pay-forPerformance Improve Quality of Care? Evidence from Senegal HYUNCHEOL BRYANT KIM, Cornell University, SEOLLEE PARK, Harvard University, and YAEEUN HAN, Cornell University-Knowledge, Food Vouchers, and Child Nutrition: Evidence from a Field Experiment in Ethiopia

Discussants: DAVID RIDLEY, Duke University

ANTHONY LOSASSO, University of Illinois-Chicago

WINNIE CHI-MAN YIP, Harvard University

EESHANI KANDPAL, World Bank

\section{0:15 AM Manchester Grand Hyatt San Diego-America's Cup D INEM}

Panel: Are We All Behavioral Economists Now? (B4)

Presiding: MATTHIAS KLAES, University of Buckingham

COLIN CAMERER, California Institute of Technology

CATHERINE HERFELD, University of Zurich

ERIK ANGNER, Stockholm University

BEATRICE CHERRIER, CNRS \& University of Cergy-Pontoise

MATTHIAS KLAES, University of Buckingham

\section{0:15 AM Manchester Grand Hyatt San Diego-America's Cup AB IOS}

\section{Energy and IO (L9)}

Presiding: MAR REGUANT, Northwestern University

JACKSON DORSEY, Indiana University, ASHLEY LANGER, University of Arizona, and SHAUN MCRAE, ITAM-Who Pays at the Pump? Consumer Search in the Gasoline Market 


\section{Friday $•$ January 3}

THOMAS R. COVERT, University of Chicago, and RICHARD L. SWEENEY, Boston College-Innovation in the Wind Power Industry

MATT WOERMAN, University of Massachusetts-AmherstMarket Size and Market Power: Evidence from the Texas Electricity Market

FIONA BURLIG, University of Chicago, AKSHAYA JHA, Carnegie

Mellon University, and LOUIS PREONAS, University of ChicagoCosts of Misallocation in Indian Electricity Supply

Discussants: JEAN-FRANCOIS HOUDE, University of Wisconsin-Madison

JING LI, Massachusetts Institute of Technology

STEVE CICALA, University of Chicago

GASTON ILLANES, Northwestern University

\section{0:15 AM Manchester Grand Hyatt San Diego-Harbor E LERA}

\section{The Growth of Alternative Work Arrangements: Measurements} and Implications (J3)

Presiding: TERESA GHILARDUCCI, New School for Social Research

MICHAEL PAPADOPOULOS, New School for Social ResearchReservation Wages and Nontraditional Work

KATHARINE G. ABRAHAM, University of Maryland, BRAD HERSHBEIN, W.E. Upjohn Institute for Employment Research, and SUSAN HOUSEMAN, W.E. Upjohn Institute for Employment Research-Contract Work and Labor Force Participation at Older Ages

MATTHEW RUTLEDGE, Boston College-Are More Older Workers Moving to Non-Traditional Jobs as Globalization and Automation Spread?

Discussants: MARTHA SUSANA JAIMES BUILES, New School for Public Engagement

TERESA GHILARDUCCI, New School for Social Research

WILLIAM M. RODGERS III, Rutgers University 


\section{Friday $•$ January 3}

\section{0:15 Aм Marriott Marquis San Diego-Newport Beach NAEE}

Financial Education: Interventions and Outcomes (A2)

Presiding: CYNTHIA HARTER, Eastern Kentucky University

PANU KALMI, University of Vaasa, and JAANA RAHKO, University of Vaasa-The Effects of Game-Based Financial Education: New Survey Evidence from Lower Secondary School Students in Finland

CYNTHIA HARTER, Eastern Kentucky University, and JOHN HARTER, Eastern Kentucky University-Impact of Adverse Childhood Experiences on Financial Security in Adulthood

JAMIE WAGNER, University of Nebraska-Omaha, and WILLIAM B. WALSTAD, University of Nebraska-Lincoln-The Effects of Financial Education Received in High School, College, and Employment on the Financial Behaviors of Young Adults

TIM KAISER, University of Koblenz-Landau \& German Institute for Economic Research, and LUKAS MENKHOFF, Humboldt University of Berlin \& German Institute for Economic ResearchFinancial Education in Schools: A Meta-Analysis of Experimental Studies

Discussants: TIM KAISER, University of Koblenz-Landau \& German Institute for Economic Research

PANU KALMI, University of Vaasa

CYNTHIA HARTER, Eastern Kentucky University

WILLIAM B. WALSTAD, University of Nebraska-Lincoln

\section{0:15 AM Marriott Marquis San Diego—Balboa NEA}

Disparities across Race and Gender: Economics of Health and Well-Being (I0)

Presiding: JEVAY GROOMS, Howard University

JEVAY GROOMS, Howard University, and ALBERTO ORTEGA, Indiana University_Examining Racial and Ethnic Differences in Substance Use Treatment 


\section{Friday $•$ January 3}

BRITNI WILCHER, American University-Drug Quality and Gender Parity of Clinical Trial Participants

MARK PAUL, New College of Florida, IMARI SMITH, Duke University, SARAH E. GAITHER, Duke University, and WILLIAM DARITY, Duke University_About Face: Seeing Class and Race

JOAQUIN ALFREDO-ANGEL RUBALCABA, University of North Carolina-Chapel Hill, and CANDIS WATTS SMITH, University of North Carolina-Chapel Hill-Pursuit of Happiness

MINA BALIAMOUNE-LUTZ, University of North Florida and African Center for Economic Transformation-Health Expenditure, Gender and Rent Seeking in the United States and Other OECD Countries

ROBERT WILLIAMS, Guilford College-The Reparations Bill: Adding Late Charges and Securing a Funding Source

Discussants: OLUGBENGA AJILORE, University of Toledo

ALBERTO ORTEGA, Indiana University

JAMEIN CUNNINGHAM, University of Memphis

DANIA V. FRANCIS, University of Massachusetts-Amherst

FAFANYO ASISEH, North Carolina A\&T State University

\section{0:15 AM Manchester Grand Hyatt San Diego_Ocean Beach SED}

\section{Information, Reputation and Optimal Policy (E6)}

Presiding: ALESSANDRO DOVIS, University of Pennsylvania

MARINA HALAC, Yale University, and PIERRE YARED, Columbia University—Fiscal Rules and Discretion under Limited Enforcement

MANUEL AMADOR, University of Minnesota, and CHRIS PHELAN, University of Minnesota-Reputation and Sovereign Default

VARADARAJAN CHARI, University of Minnesota, ALI SHOURIDEH, Carnegie Mellon University, and ARIEL ZETLINJONES, Carnegie Mellon University-Efficiency and Adverse Selection: On Desirability of Mutual Contracts 


\section{Friday $\cdot$ January 3}

ALESSANDRO DOVIS, University of Pennsylvania, and RISHABH KIRPALANI, University of Wisconsin-Madison-Rules without Commitment: Reputation and Incentives

\section{0:15 AM Manchester Grand Hyatt San Diego-Mission Beach B SGE}

Big Data: Value, National Accounts, and Public Policy (O3)

Presiding: GIDEON F. LUKENS, U.S. Office of Management and Budget

WENDY CHUEN-YUEH LI, U.S. Bureau of Economic Analysis, MAKOTO NIREI, University of Tokyo and RIETI, and KAZUFUMI YAMANA, Kanagawa University—Value of Data: There's No Such Thing as a Free Lunch in the Digital Economy

MARSHALL REINSDORF, International Monetary Fund, and JENNIFER RIBARSKY, International Monetary Fund-Measuring the Digital Economy in Macroeconomic Statistics: The Role of Data DAVID NGUYEN, U.K. National Institute of Economic and Social Research, and MARTA PACZOS, U.K. National Institute of Economic and Social Research-Measuring the Economic Value of Data and Data Flows

DIANE COYLE, University of Cambridge-Valuing Data as a Public Good: Implications for Policy

Discussants: DIANE COYLE, University of Cambridge

DYLAN RASSIER, U.S. Bureau of Economic Analysis

MICHAEL MANDEL, Progressive Policy Institute and University of Pennsylvania

LOUISE SHEINER, Brookings Institution

\section{0:15 AM Manchester Grand Hyatt San Diego_-Gaslamp C TPUG}

\section{Transportation Competition and Externalities (L9)}

Presiding: T. EDWARD YU, University of Tennessee

JEFFREY COHEN, University of Connecticut, and FELIX FRIEDT, Macalester College-Perception Versus Reality: The Noise Complaint Effect on Home Values 


\section{Friday $•$ January 3}

ZHENGYI ZHOU, Shanghai University of Finance and Economics, HONGCHANG LI, Beijing Jiao Ton University, and ANMING ZHOU, University of British Columbia-Bike Sharing and House List Prices: Evidence from Micro-Level Data in Shanghai

KENNETH D. BOYER, Michigan State University, and WESLEY W. WILSON, University of Oregon-The Determinants of Railroad Pricing: Elasticity of Demand for Transportation Versus the Profitability of Using the Service

HANMING FANG, University of Pennsylvania, LONG WANG, ShanghaiTech University, and YANG (ZOE) YANG, Chinese University of Hong Kong-Competition and Quality Gains: New Evidence from the High-Speed Rails and Airlines

Discussants: ZHENGYI ZHOU, Shanghai University of Finance and Economics

JEFFREY COHEN, University of Connecticut

CHARLES F. MASON, University of Wyoming

ANMING ZHANG, University of British Columbia

\section{0:15 AM Manchester Grand Hyatt San Diego_La Jolla B}

\section{URPE}

\section{Climate Crisis Mitigation: Implementing a Green New Deal and} More (E6)

Presiding: RON BAIMAN, Benedictine University

RON BAIMAN, Benedictine University-Financial Bailout Spending Would Have Paid for Thirty Years of Climate Crisis Mitigation: Implementing a Global Green New Deal and Marshall Plan

MATHEW FORSTATER, University of Missouri-Kansas City, FADHEL KABOUB, Denison University, and MICHAEL MURRAY, Bemidji State University-Green New Deal: Interdisciplinary Heterodox Approaches

PETER DORMAN, Evergreen State College-Keeping Carbon in the Ground: What a Green New Deal Does and Doesn't Do

JOSEFINA LI, Bemidji State University-Community Currency Powered Job Guarantee (JG): A Way to Full Employment, Sustainability and Gender Equity 


\section{Friday $•$ January 3}

\section{0:15 AM Manchester Grand Hyatt San Diego_-Old Town A}

\section{URPE}

\section{Marxist Theory (B5)}

Presiding: PADDY QUICK, St. Francis College-Brooklyn

CAROLINA ALVES, University of Cambridge-Towards a Critical Framework: Government Bonds as Titles of Fictitious Capital

RICCARDO BELLOFIORE, University of Bergamo-Marx between Schumpeter and Keynes: Augusto Graziani, Marx's Theory of (Surplus) Value, and the Cycle of Money Capital

SERGIO CAMARA IZQUIERDO, Metropolitan Autonomous University (UAM)-Azcapotzalco-Profitability and Accumulation in Mexico: New Estimates and Analysis

BARIS GUVEN, University of Massachusetts-Amherst—Productive Apparatuses of State, Technological Change, and Social Structures of Accumulation Theory

\section{2:30 PM Marriott Marquis San Diego-Marriott Grand} Ballroom 7-8-9

AEA/AFA

\section{Joint Luncheon-Fee Event}

Presiding: DAVID HIRSHLEIFER, University of California-Irvine

DAVID LAIBSON, Harvard University-Nudges are Not Enough: The Ease for Price-based Paternalism

\section{2:30 PM Manchester Grand Hyatt San Diego_Gaslamp C AIEFS}

Topics in Trade, Innovation, and Economic Development (O3)

Presiding: KUSUM MUNDRA, Rutgers University-Newark

HAMID BELADI, University of Texas-San Antonio, NABAMITA DUTTA, University of Wisconsin-La Crosse, and SAIBAL KAR, Centre for Studies in Social Sciences Calcutta-Do Perceived Obstacles Hamper Innovation Efforts of Firms?: The Indian Scenario 


\section{Friday $•$ January 3}

MOSTAK AHAMED, University of Sussex, KUL LUINTEL, Cardiff University, and SUSHANTA K. MALLICK, Queen Mary University of London-Impact of Financing Access and Corporate Governance on Firm Productivity Effect of R\&D Spillover in India: Is It Stock of Innovation or Lack of Local Spill-Over?

RAM UPENDRA DAS, Centre for Regional Trade, ANUP KUMAR JHA, Patliputra University, and MEENAKSHI RISHI, Seattle University-Exports, FDI and Productivity: A Study of Indian Organized Manufacturing since 2000

ANDREW W. HOROWITZ, University of Arkansas, RAJA KALI, University of Arkansas, and HONGWEI SONG, Bellarmine University-Re-Thinking the Aid-Growth Relationship: A Network Approach

DAVID JACHO-CHAVEZ, Emory University, USHA NAIRREICHERT, Georgia Institute of Technology, and ALEJANDRO PUERTA CUARTAS, EAFIT University-An Analysis of Customs Transactions of a Developing Country: The Case of Ecuador

Discussants: RAM UPENDRA DAS, Centre for Regional Trade

SUSHANTA K. MALLICK, Queen Mary University of London

NABAMITA DUTTA, University of Wisconsin-La Crosse

RAJA KALI, University of Arkansas

SUDIPTA SARANGI, Virginia Tech

\section{2:30 PM Manchester Grand Hyatt San Diego-Coronado A AREUEA/AFA}

\section{Real Estate and Housing Finance (G2)}

Presiding: TIMOTHY MCQUADE, Stanford University

TAYLOR BEGLEY, Washington University-St. Louis, and KANDARP SRINIVASAN, Northeastern University-Small Bank Lending Amidst the Ascent of Fintech and Shadow Banking: A Sideshow?

RONEL ELUL, Federal Reserve Bank of Philadelphia, DEEKSHA GUPTA, Carnegie Mellon University, and DAVID MUSTO, University of Pennsylvania-Concentration and Lending in Mortgage Markets 


\section{Friday $\cdot$ January 3}

JAMES CONKLIN, University of Georgia, W. SCOTT FRAME, Federal Reserve Bank of Dallas, KRISTOPHER GERARDI, Federal Reserve Bank of Atlanta, and HAOYANG LIU, Federal Reserve Bank of New York-Villains or Scapegoats? The Role of Subprime Borrowers in Driving the United States Housing Boom

NEIL BHUTTA, Federal Reserve Board, ANDREAS FUSTER, Swiss National Bank, and AUREL HIZMO, Federal Reserve Board-Paying Too Much? Price Dispersion in the United States Mortgage Market

Discussants: GREG BUCHAK, Stanford University

ANTHONY DEFUSCO, Northwestern University

ADAM GUREN, Boston University

CHRISTOPHER PALMER, Massachusetts Institute of Technology

\section{2:30 PM Manchester Grand Hyatt San Diego-Pier ASGE}

Voluntarism and the Environment (in Recognition of the 50th Anniversary of Earth Day) (H4)

Presiding: MARK WILHELM, Indiana University-Purdue University Indianapolis

MICHAEL PRICE, University of Alabama, ANOMITRO CHATTERJEE, London School of Economics, and AHMED ALI KHALIFA, Qatar University-Nudging Energy Conservation in Qatar: Evidence from a Series of Field Experiments

DANIEL HUNGERMAN, University of Notre Dame-Every Day is Earth Day: Studying the Long Term Effects of April 22, 1970

MARTIN KESTERNICH, ZEW Mannheim and University of Kassel, CARLO GALLIER, ZEW Mannheim, ANDREAS LÖSCHEL, University of Muenster, and ISRAEL WAICHMAN, Bard College-Local and Global Public Goods Games

ANDREAS LANGE, University of Hamburg, and CLAUDIA SCHWIRPLIES, University of Hamburg-Prosocial Promises in the Marketplace 


\section{Friday $•$ January 3}

\section{2:30 PM Manchester Grand Hyatt San Diego_-Old Town B CES}

\section{Time Series and Empirical Macroeconomics and Finance (C1)}

Presiding: JUN MA, Northeastern University

YAN LIU, Texas A\&M University, and JING CYNTHIA WU, University of Notre Dame and NBER-Reconstructing the Yield Curve

ANNA CIESLAK, Duke University, and HAO PANG, Duke University-On Common Shocks in Stocks and Bonds

ZONGWU CAI, University of Kansas, HAIYONG LIU, East Carolina University, and XUAN LIU, East Carolina UniversityGHH Preferences on Households' Portfolio Choices: Theoretical Implications and Empirical Evidence

CHANG-JIN KIM, University of Washington, JUN MA, Northeastern University, and CHARLES R. NELSON, University of Washington-A New Approach to Multivariate Beveridge-Nelson Decomposition: The Case of Omitted or Unobservable GrangerCausing Variables

\section{2:30 PM Marriott Marquis San Diego-Malibu EHA}

\section{Political Economy in Historical Perspective (N4)}

Presiding: MICHAEL HAUPERT, University of Wisconsin-La Crosse

BELINDA ARCHIBONG, Barnard College, and NONSO OBIKILI, Economic Research Southern Africa-When Women March: The 1929 Aba Women's Tax Revolt, Prisons and Political Participation in Nigeria

HYUNJOO YANG, Incheon National University, JI YEON HONG, Hong Kong University of Science and Technology, and SUNKYOUNG PARK, Incheon National University-Political Legacy of Dictatorial Development Policy: Evidence from South Korea

CAROLINE FOHLIN, Emory University, and ANDREW TEODORESCU, Emory University-The Value of Cronyism: Insider Trading in the Teapot Dome Affair 


\section{Friday $•$ January 3}

Discussants: SUMNER LA CROIX, University of Hawaii RALF MEISENZAHL, Federal Reserve Bank of Chicago JOE MASON, Louisiana State University

\section{2:30 PM Manchester Grand Hyatt San Diego-Harbor F LERA}

\section{Worker Participation in the 21st Century (J5)}

Presiding: RICHARD FREEMAN, Harvard University

LIWEN CHEN, East China Normal University, ZHONGXING SU, Renmin University of China, and GUANGHUA WANG, Clemson University-Pie-Growing or Pie-Sharing? The Role of China's Democratic Management on Wages, Benefits and Productivity

MAHREEN KHAN, Massachusetts Institute of Technology-Are Worker Management Committees Improving Factory Conditions? A Study of Participation Committees in ILO's Better Work Factories

WILLIAM THOMAS KIMBALL, Massachusetts Institute of Technology, ALEXANDER HERTEL-FERNANDEZ, Columbia University, and THOMAS A. KOCHAN, Massachusetts Institute of Technology—How United States Workers Think About Workplace Democracy: The Structure of Individual Worker Preferences for Labor Representation

SIMON JAEGER, Massachusetts Institute of Technology, BENJAMIN SCHOEFER, University of California-Berkeley, and JOERG HEINING, Institute for Employment Research-Nuremberg (IAB)-Labor in the Boardroom

Discussants: JOHN ADDISON, University of South Carolina

DAVID MADLAND, Center for American Progress PAULINO TEIXEIRA, University of Coimbra 


\section{Friday $•$ January 3}

12:30 PM Marriott Marquis San Diego-San Diego Ballroom A NABE

Panel: Navigating the Crosscurrents: The Outlook for the Global Economy (E6)

Presiding: GEORGE A. KAHN, Federal Reserve Bank of Kansas City

ROBERT S. KAPLAN, Federal Reserve Bank of Dallas

MARY C. DALY, Federal Reserve Bank of San Francisco

JAMES D. HAMILTON, University of California-San Diego

HYUN SONG SHIN, Bank for International Settlements

JUSTIN YIFU LIN, Peking University

\section{2:30 PM Marriott Marquis San Diego-Marriott Grand}

Ballroom 2

NEA

Panel: Black Women in the Economics Profession (J7)

Presiding: MIESHA WILLIAMS, Morehouse College

12:30 PM Manchester Grand Hyatt San Diego-America's

Cup AB

ODE

Omicron Delta Epsilon John R. Commons Award Lecture (A1)

Presiding: STACEY JONES, Seattle University

N. GREGORY MANKIW, Harvard University-The Past and Future of Econ 101 


\section{Friday $•$ January 3}

\section{2:30 PM Manchester Grand Hyatt San Diego_Gaslamp D TPUG}

\section{Safety and the Social Costs of Transportation (L9)}

Presiding: BIJAN VASIGH, Embry Riddle Aeronautical University

CHARLES F. MASON, University of Wyoming-Analyzing the Risk of Transporting Crude Oil by Rail

RICHARD FOWLES, University of Utah, and PETER D. LOEB, Rutgers University-The Marijuana Effect on Motor Vehicle Crashes MISAK AVETISYAN, Texas Tech University, JASPER FABER, CE Delft, DAGMAR NELISSEN, CE Delft, TRISTAN SMITH, University College London, and ISABELLE ROJON, University College London-Assessment of Possible Global Regulatory Measures to Reduce Greenhouse Gas Emissions from International Shipping

LAINGO M. RANDRIANARISOA, University of British Columbia, and DAVID GILLEN, University of British Columbia-Reducing Sulphur Emissions: A Maritime Supply Chain Perspective

Discussants: JAMES PEOPLES, University of Wisconsin-Milwaukee

KENNETH BUTTON, George Mason University

LAINGO M. RANDRIANARISOA, University of British Columbia PATRICK MCCARTHY, Georgia Institute of Technology

\section{2:30 PM Manchester Grand Hyatt San Diego-Harbor A URPE}

\section{Panel: David Gordon Memorial Lecture (B5)}

Presiding: RON BAIMAN, Benedictine University

HEATHER BOUSHEY, Washington Center for Equitable GrowthUnbound: How Inequality Constricts Our Economy and What We Can Do About It

KATHERINE MOOS, University of Massachusetts-AmherstComments on Heather Boushey's "Unbound..." 


\section{Friday $•$ January 3}

\section{2:30 PM Manchester Grand Hyatt San Diego-Mission Beach A}

AAEA

\section{Automation and Digitalization in Agriculture (03)}

Presiding: XIAOXUE DU, University of Idaho

DAVID HENNESSY, Michigan State University-Toward Economic Foundations of Supply and Demand for Automation in Production Agriculture

KARINA GALLARDO, Washington State University, LIANG LU, University of Idaho, and JILL J. MCCLUSKEY, Washington State University-Adoption of Mechanization Solutions for Harvesting Fresh Market Blueberries

XIAOXUE DU, University of Idaho, THOMAS REARDON, Michigan State University, HERNAN TEJEDA, University of

Idaho, and PHILIP WATSON, University of Idaho-A General Equilibrium Model of Technology Adoption-Theory and Evidences from Robotic Milking Systems in Idaho

GENEVIEVE NGUYEN, UMR INRA-AGIR, JULIEN BRAILLY, UMR INRA-AGIR, and FRANÇOIS PURSEIGLE, INP-ENSATNew Outsourced Services and Precision Farming in France

\section{2:30 PM Manchester Grand Hyatt San Diego-Harbor D ACES}

Skills in College: Cross-National Evidence from China, India, Russia, and the United States (I2)

Presiding: SUSAN DYNARSKI, University of Michigan

PRASHANT LOYALKA, Stanford University-Skills in College: China, India, Russia, and the United States

YONG SUK LEE, Stanford University, and DINSHA MISTREE, Stanford University-Management Practices, Faculty Research, and College Student Learning

IGOR CHIRIKOV, University of California-Berkeley-The Effect of Faculty Research on Student Achievement

PAUL GLEWWE, University of Minnesota-Skills in College and Labor Market Outcomes

Discussant: WILLIAM PYLE, Middlebury College 


\section{Friday $•$ January 3}

\section{2:30 PM Marriott Marquis San Diego-Coronado Room AEA}

\section{Advances in Measuring Firm-Level Uncertainty (D8)}

Presiding: DEREK LEMOINE, University of Arizona and NBER

KYLE HANDLEY, University of Michigan, and J. FRANK LI, University of Michigan-Measuring the Effects of Firm Uncertainty on Economic Activity: New Evidence from One Million Documents RUDI BACHMANN, University of Notre Dame, KAI CARSTENSEN, Christian Albrechts University of Kiel, STEFAN LAUTENBACHER, Ifo Institute, and MARTIN SCHNEIDER, Stanford University-Uncertainty Is More Than Risk - Survey Evidence on Knightian and Bayesian Firms

TAREK HASSAN, Boston University, STEPHEN HOLLANDER, Tilburg University, LAURENCE VAN LENT, Frankfurt School of Finance \& Management, and AHMED TAHOUN, London Business School-Firm-Level Risks and Effects of Brexit

ASHLEY LANGER, University of Arizona, and DEREK LEMOINE, University of Arizona and NBER-What Were the Odds? Estimating the Market's Probability of Uncertain Events

Discussants: SCOTT BAKER, Northwestern University

VENKY VENKATESWARAN, Federal Reserve Bank of Minneapolis

JOHN MICHAEL VAN REENEN, Massachusetts Institute of Technology

JUSTIN WOLFERS, University of Michigan

\section{2:30 PM Marriott Marquis San Diego-Solana}

\section{AEA}

Capital Flows and Policy Dilemmas (F0)

Presiding: LOUPHOU COULIBALY, University of Pittsburgh

SCOTT DAVIS, Federal Reserve Bank of Dallas, and MICHAEL DEVEREUX, University of British Columbia-Capital Controls as Macro-Prudential Policy in a Large Open Economy 


\section{Friday $•$ January 3}

FERNANDO ARCE, University of Minnesota, JULIEN BENGUI, University of Montréal, and JAVIER BIANCHI, Federal Reserve Bank of Minneapolis-A Macroprudential Theory of Foreign Reserve Accumulation

LUCA FORNARO, Center for Research in International Economics (CREI) - Monetary Union and Financial Integration

LOUPHOU COULIBALY, University of Pittsburgh-Monetary Policy in Sudden Stops-Prone Economies

Discussants: SUSHANT ACHARYA, Federal Reserve Bank of New York

STEPHANIE SCHMITT-GROHÉ, Columbia University

PABLO OTTONELLO, University of Michigan

ALESSANDRO REBUCCI, Johns Hopkins University

\section{2:30 PM Marriott Marquis San Diego-Torrey Pines 3}

AEA

\section{Consumer Behavior and Passenger Vehicle Fuel Economy Regulation (Q4)}

Presiding: JOSHUA LINN, University of Maryland and Resources for the Future

JIANWEI XING, Peking University-Cars or Trucks? The Impact of Attribute Basing in Fuel Economy Regulations

KENNETH GILLINGHAM, Yale University, SEBASTIEN HOUDE, ETH Zurich, and ARTHUR A. VAN BENTHEM, University of Pennsylvania-Consumer Myopia in Vehicle Purchases: Evidence from a Natural Experiment

ARIK LEVINSON, Georgetown University, and LUTZ SAGER, Georgetown University-Do Car Buyers Undervalue Future Fuel Savings? Post-Purchase Evidence

BENJAMIN LEARD, Resources for the Future, JOSHUA LINN, University of Maryland and Resources for the Future, and KATALIN SPRINGEL, Georgetown University-A Medium-Run Analysis of the 2012-2016 Passenger Vehicle Fuel Economy Standards

Discussants: JAMES SALLEE, University of California-Berkeley

ANTONIO BENTO, University of Southern California

DAVID RAPSON, University of California-Davis

CHRISTY ZHOU, Clemson University 


\section{Friday $•$ January 3}

\section{2:30 PM Marriott Marquis San Diego-Marriott Grand Ballroom 12 \\ AEA}

Effects of Immigration on American Science and Innovation (O3)

Presiding: ETHAN G. LEWIS, Dartmouth College

VASILIKI FOUKA, Stanford University, SHOM MAZUMDER, Harvard University, and MARCO TABELLINI, Harvard University—From Immigrants to Americans: Race and Assimilation During the Great Migration

PIERRE AZOULAY, Massachusetts Institute of Technology, BENJAMIN F. JONES, Northwestern University, J. DANIEL KIM, University of Pennsylvania, and JAVIER MIRANDA, U.S. Census Bureau-Immigration and Entrepreneurship in the United States

SARI PEKKALA KERR, Wellesley College, and WILLIAM KERR, Harvard University-Immigrant Entrepreneurship: Job Creation, Job Quality, and Innovation

PETRA MOSER, New York University, and SHMUEL SAN, New York University-Immigration Quotas and American Science

\section{2:30 PM Marriott Marquis San Diego-Marriott Grand} Ballroom 10

AEA

\section{Empirical Studies on Physician Quality and Treatment Choice} (I1)

Presiding: W. BENTLEY MACLEOD, Columbia University

JANET CURRIE, Princeton University, and W. BENTLEY MACLEOD, Columbia University-Understanding Physician Decision Making: The Case of Depression

JOSEPH DOYLE, Massachusetts Institute of TechnologyMeasuring Physician Quality: Evidence from Physician Availability STACEY H. CHEN, National Graduate Institute for Policy Studies (GRIPS), HONGWEI CHUANG, International University of Japan, and TZU-HSIN LIN, National Taiwan University HospitalPhysicians Treating Physicians: The Relational Advantage in Treatment Choice 


\section{Friday $•$ January 3}

HIROSHI AIURA, Nanzan University, and REO TAKAKU, Hitotsubashi University—Physicians' Responses to Medical Subsidy Programs: Evidence from Japan

\section{2:30 PM Marriott Marquis San Diego-Marriott Grand Ballroom 13 \\ AEA}

Employer Market Power: Theory and Evidence (J2)

Presiding: MATTHEW GIBSON, Williams College

ORLEY ASHENFELTER, Princeton University, and ALAN B. KRUEGER, Princeton University-Theory and Evidence on Employer Collusion in the Franchise Sector

EVAN STARR, University of Maryland, and MICHAEL LIPSITZ,

Miami University-Low Wage Workers and the Enforceability of Covenants Not to Compete

MATTHEW GIBSON, Williams College-Employer Market Power in Silicon Valley

PEDRO MARTINS, Queen Mary University of London-Making Their Own Weather? Estimating Employer Labour-Market Power and Its Wage Effects

JOSE AZAR, University of Navarra, and XAVIER VIVES, University of Navarra-Oligopsony and Government Employment Policy

Discussants: IOANA ELENA MARINESCU, University of Pennsylvania

MATTHEW GIBSON, Williams College

EVAN STARR, University of Maryland

JOSE AZAR, University of Navarra

PEDRO MARTINS, Queen Mary University of London

\section{2:30 PM Marriott Marquis San Diego-Marriott Grand} Ballroom 2

AEA

Gender and Entrepreneurship (O0)

Presiding: REMBRAND KONING, Harvard Business School 


\section{Friday $•$ January 3}

JOSH FENG, National Bureau of Economic Research, and XAVIER JARAVEL, London School of Economics-Innovating for People Like Me: Evidence from Female-Founded Consumer Packaged Goods Startups

RUIQING CAO, Harvard University, REMBRAND KONING, Harvard Business School, and RAMANA NANDA, Harvard Business School-Can Preference Aggregation Bias Product Innovation? Evidence from New Venture Finance

SOLÈNE DELECOURT, Stanford University, and ODYSSIA NG, Stanford University-Do Markets Discriminate Against FemaleOwned Businesses? Evidence from India

OLENKA KACPERCZYK, London Business School, and PETER YOUNKIN, University of Oregon-The Illegitimacy Premium: The Effect of Entrepreneurship on the Future Employment of Women

Discussants: HEATHER SARSONS, University of Chicago

ELIZABETH LYONS, University of California-San Diego

PIAN SHU, Georgia Institute of Technology

REMBRAND KONING, Harvard Business School

\section{2:30 PM Marriott Marquis San Diego-Marriott Grand}

Ballroom 5-6

AEA/CSMGEP

Panel: How Can Economics Solve Its Race Problem? (A1)

Presiding: JANET YELLEN, Brookings Institution

EBONYA WASHINGTON, Yale University

RANDALL AKEE, University of California-Los Angeles

CECILIA CONRAD, Pomona College

TREVON LOGAN, Ohio State University

EDWARD MIGUEL, University of California-Berkeley

MARIE T. MORA, University of Missouri-St. Louis 


\section{Friday $•$ January 3}

\section{2:30 PM Marriott Marquis San Diego-Rancho Santa Fe 2}

AEA

\section{Inequality (D3)}

Presiding: CAROLYN M. SLOANE, University of California-Riverside AIDAY SIKHOVA, University of Wisconsin-Madison-Do Parents Propagate Income Inequality among Children? Evidence from Chinese Twins

SERGE SHIKHER, United States International Trade Commission, ARTHUR GAILES, University of California-Berkeley, TAMARA GUREVICH, United States International Trade Commission, and MARINOS TSIGAS, United States International Trade Commission-Gender and Income Inequality in United States Tariff Burden

MATTHEW O. JACKSON, Stanford University, and ZAFER KANIK, Massachusetts Institute of Technology-How Automation that Substitutes for Labor Affects Production Networks, Growth, and Income Inequality

MATTHEW O. JACKSON, Stanford University, LUKAS BOLTE, Stanford University, and NICOLE IMMORLICA, Microsoft Research-Inequality and Inefficiency Due to Networked Job Referrals

STEFAN SCHNECK, Institute for Small Business Research Bonn (IfM)-The Effect of Self-Employment on Income Inequality

\section{2:30 PM Marriott Marquis San Diego-Balboa}

\section{AEA}

\section{Inequality and Distributional Preferences (H0)}

Presiding: IMRAN RASUL, University College London and IFS

CHRISTINA FONG, Carnegie Mellon University, ILPO KAUPPINEN, VATT Institute for Economic Research, and PANU POUTVAARA, University of Munich, Ifo Institute, CESifo, and IZA-Economic Experiences, Target-specific Beliefs, and Demands for Redistribution 


\section{Friday $•$ January 3}

ALAIN COHN, University of Michigan, LASSE JESSEN, Christian Albrechts University of Kiel, MARKO KLASJNA, Georgetown University, and PAUL SMEETS, Maastricht University-How Do the Rich Think About Redistribution?

ALEXANDER CAPPELEN, Norwegian School of Economics, RANVEIG FALCH, Norwegian School of Economics, and BERTIL TUNGODDEN, Norwegian School of Economics-The Boy Crisis: Experimental Evidence on the Acceptance of Males Falling Behind DIETMAR FEHR, University of Heidelberg, HANNES RAU, University of Heidelberg, YILONG XU, University of Heidelberg, and STEFAN TRAUTMANN, Tilburg University-Inequality, Fairness and Social Capital

Discussants: ERZO F.P. LUTTMER, Dartmouth College

PAMELA JAKIELA, University of Maryland

IMRAN RASUL, University College London

GABRIELE CAMERA, Chapman University

\section{2:30 PM Marriott Marquis San Diego-Torrey Pines 1 AEA}

International Trade (F1)

Presiding: RICHARD POMFRET, University of Adelaide

HYE RYOUNG JUNG, KDI School of Public Policy and Management-Causal Mechanism of Inequality on Civil Conflict: Evidence from a Quasi-Experiment in Trade and Factor-Based Income Distribution

ALESSANDRA BONFIGLIOLI, Queen Mary University of London, ROSARIO CRINOे, Catholic University of the Sacred Heart, and GINO GANCIA, Queen Mary University of LondonFirms and Economic Performance: A View from Trade

BO BIAN, University of British Columbia-Globally Consistent Creditor Protection, Reallocation, and Productivity

SUPRABHA BANIYA, Clark University, NADIA ROCHA, World Bank, and MICHELE RUTA, World Bank-Trade Effects of the New Silk Road 


\section{Friday $•$ January 3}

YIHONG TANG, Central University of Finance and Economics, and WENXIAO WANG, Zhongnan University of Economics and Law-Trade Liberalisation, Export Quality and Wage Inequality: Evidence from China

ERWIN WINKLER, University of Wuerzburg-Trade, Establishment Wage Premiums, and Wage Inequality: Worker-Level Evidence

\section{2:30 PM Marriott Marquis San Diego-Marriott Grand Ballroom 1 AEA}

Investing in the Next Generation - Lessons from History for Economic Policy (N3)

Presiding: FRANCESCO CINNIRELLA, University of Southern Denmark, CEPR and CESifo

ADRIANA LLERAS-MUNEY, University of California-Los Angeles, ANNA AIZER, Brown University, SHARI ELI, University of Toronto, KEYOUNG H. LEE, University of California-Los Angeles, and BARBARA A. SMITH, Social Security Administration-Do Youth Employment Programs Work? Evidence from the New Deal

KJELL SALVANES, Norwegian School of Economics, DARON ACEMOGLU, Massachusetts Institute of Technology, TUOMAS PEKKARINEN, VATT Institute for Economic Research, and MATTI SARVIMÄKI, Aalto University-The Making of Social Democracy: The Economic and Electoral Consequences of Norway's 1935 School Reform

BHASH MAZUMDER, Federal Reserve Bank of Chicago, DANIEL AARONSON, Federal Reserve Bank of Chicago, and MARTHA STINSON, U.S. Census Bureau-The Intergenerational Effects of the Rosenwald Schools

PHILIPP AGER, University of Southern Denmark, and FRANCESCO CINNIRELLA, University of Southern DenmarkFroebel's Gifts: How the Kindergarten Movement Changed the American Family

Discussants: MELISSA THOMASSON, Miami University

KATRINE LOKEN, Norwegian School of Economics

MARIANNE WANAMAKER, University of Tennessee

DOUGLAS ALMOND, Columbia University 


\section{Friday $•$ January 3}

\section{2:30 PM Marriott Marquis San Diego-Marina Ballroom G AEA}

\section{Macroprudential Policy and Financial Stability (G2)}

Presiding: LUC LAEVEN, European Central Bank and CEPR

DAVID AIKMAN, Bank of England, JONATHAN BRIDGES, Bank of England, ANIL K. KASHYAP, University of Chicago, and CASPAR SIEGERT, Bank of England-Macroprudential Policy in the Post-Crisis World: How Is It Being Used and What Impact Is It Having?

LUC LAEVEN, European Central Bank and CEPR, MARIA DOLORES GADEA-RIVAS, University of Zaragoza, and GABRIEL PEREZ-QUIROS, European Central Bank and CEPRIn Macroprudential Policies We Trust

DONALD KOHN, Brookings Institution, and NELLIE LIANG, Brookings Institution-Understanding the Effects of United States Bank Stress Tests

CATERINA LEPORE, Bank of England, JAMIE COEN, London School of Economics, and ERIC SCHAANNING, European Systemic Risk Board-Taking Regulation Seriously: Fire Sales under Solvency and Liquidity Constraints

Discussants: HELENE REY, London Business School

OSCAR JORDA, Federal Reserve Bank of San Francisco

TIL SCHUERMAN, Oliver Wyman

FILIP ZIKES, Federal Reserve Board

\section{2:30 PM Marriott Marquis San Diego-Marriott Grand} Ballroom 11

AEA

\section{Monetary Policy, Capital Flows and Globalization (F2)}

Presiding: LINDA GOLDBERG, Federal Reserve Bank of New York CHENZI XU, Harvard University-The Information Role of Banks in Long-Term Debt 


\section{Friday $•$ January 3}

JUDIT TEMESVARY, Federal Reserve Board, and ELOD TAKATS, Bank for International Settlements-How Does the Interaction of Macroprudential and Monetary Policies Affect Cross-Border Bank Lending

ERIN WOLCOTT, Middlebury College-Impact of Foreign Official Purchases of United States Treasuries on the Yield Curve

ANNA WONG, Federal Reserve Board, and NATHANCONVERSE, Federal Reserve Board-United States Housing as Global Safe Haven Asset: The Case of a China Shock

Discussants: LESLIE SHENG SHEN, Federal Reserve Board

FRIEDERIKE NIEPMANN, Federal Reserve Board

BURCU DUYGAN-BUMP, Federal Reserve Board

INA SIMONOVSKA, University of California-Davis

\section{2:30 PM Marriott Marquis San Diego-San Diego Ballroom B AEA}

NBER and the Evolution of Economic Research, 1920-2020 (B2)

Presiding: JAMES POTERBA, Massachusetts Institute of Technology and NBER

CHRISTINA ROMER, University of California-Berkeley, and DAVID ROMER, University of California-Berkeley-NBER Business Cycle Dating: Contributions, Limitations, and Prospects

HUGH ROCKOFF, Rutgers University-National Income and Economic Measurement

EMI NAKAMURA, University of California-Berkeley, and JON STEINSSON, University of California-Berkeley-Monetary Economics at the NBER

CLAUDIA GOLDIN, Harvard University, and LAWRENCE KATZ, Harvard University-The Incubator of Human Capital Research

Discussants: ROBERT HALL, Stanford University

KATHARINE G. ABRAHAM, University of Maryland

MICHAEL BORDO, Rutgers University

JAMES J. HECKMAN, University of Chicago 


\section{Friday $•$ January 3}

\section{2:30 PM Marriott Marquis San Diego-Presidio 1-2}

AEA

\section{New Approaches to Measuring Technology and Innovation (O3)}

Presiding: ELLEN HUGHES-CROMWICK, University of Michigan

DAVID BEEDE, U.S. Census Bureau, ERIK BRYNJOLFSSON, Massachusetts Institute of Technology, CATHY BUFFINGTON, U.S. Census Bureau, EMIN DINERSLOV, U.S. Census Bureau, LUCIA FOSTER, U.S. Census Bureau, NATHAN GOLDSCHLAG, U.S. Census Bureau, KRISTINA MCELHERAN, University of Toronto, and NIKOLAS ZOLAS, U.S. Census Bureau-Measuring Technology Adoption in Enterprise-Level Surveys: The Annual Business Survey

DEAN ALDERUCCI, Carnegie Mellon University, LEE BRANSTETTER, Carnegie Mellon University, ED HOVY, Carnegie Mellon University, ANDREW RUNGE, Carnegie Mellon University, and NIKOLAS ZOLAS, U.S. Census Bureau-Quantifying the Impact of AI on Productivity and Labor Demand: Evidence from United States Census Microdata

NANCY GREEN LEIGH, Georgia Institute of Technology, BEN KRAFT, Georgia Institute of Technology, and HEON YEONG LEE, Georgia Institute of Technology_Data Development and Measurement of the Economic Geography of Robotics

Discussants: PASCUAL RESTREPO, Boston University

ENGHIN ATALAY, University of Wisconsin

SUSAN R. HELPER, Case Western Reserve University

\section{2:30 PM Marriott Marquis San Diego-Marriott Grand Ballroom 4} AEA

\section{Provider Decision-Making and Productivity in Health Care (I1)}

Presiding: DAVID CHAN, Stanford University

BENJAMIN HANDEL, University of California-Berkeley, JONATHAN KOLSTAD, University of California-Berkeley, and MICHAEL WHINSTON, Massachusetts Institute of TechnologyOutcomes-Based Payments and Physician Productivity: Evidence from Diabetes Care in Hawaii 


\section{Friday $\cdot$ January 3}

ABE DUNN, U.S. Bureau of Economic Analysis, JOSHUA GOTTLIEB, University of Chicago, ADAM SHAPIRO, Federal Reserve Bank of San Francisco, and PIETRO TEBALDI, University of Chicago-What Does Health Care Billing Cost, and Why Does It Matter?

DAVID CHAN, Stanford University, and JONATHAN GRUBER, Massachusetts Institute of Technology-Triage Judgments in the Emergency Department

LAWRENCE JIN, National University of Singapore, RUI TANG, Princeton University, HAN YE, National University of Singapore, JUNJIAN YI, National University of Singapore, and SONGFA ZHONG, National University of Singapore-Path Dependency in Physician Decision-Making

Discussants: ROBERT GIBBONS, Massachusetts Institute of Technology

MARK SHEPARD, Harvard University

DAVID SILVER, Princeton University

ALICE CHEN, University of Southern California

\section{2:30 PM Marriott Marquis San Diego-Vista}

AEA

\section{Social Capital (D9)}

Presiding: LUIGI ZINGALES, University of Chicago

MEHDI SHADMEHR, University of Chicago, and STEPHEN MORRIS, Princeton University-Inspiring Regime Change

HANGCHENG ZHAO, University of Chicago, JIE ZHENG, Tsinghua University, and JAIMIE LIEN, Chinese University of Hong Kong-Perception Bias in Tullock Contests

LINDA THUNSTROM, University of Wyoming-Thoughts and Prayers - Do They Crowd out Charity Donations?

ARNSTEIN AASSVE, Bocconi University, PIERLUIGI CONZO, University of Turin and Carlo Alberto College, and FRANCESCO MATTIOLI, Bocconi University-Was Banfield Right? New Insights from a Nationwide Laboratory Experiment

XUEZHU SHI, London School of Economics-The Role of Social Norms in Old-Age Support: Evidence from China 


\section{Friday $•$ January 3}

LARS HORNUF, University of Bremen, MARC RIEGER, University of Trier, and SVEN HARTMANN, IAAEU-Can Television Reduce Xenophobia? The Case of East Germany

\section{2:30 PM Marriott Marquis San Diego-Point Loma} AEA

\section{Panel: Using Data Analytics and Visualization in Economics Courses (A2)}

Presiding: WENDY STOCK, Montana State University

GREGORY BRUICH, Harvard University and RAJ CHETTY, Harvard University-Diversifying the Pool of Undergraduate Students who Study Economics: Insights from a New Applications Course for Freshmen at Harvard

JONATHAN SCHWABISH, Urban Institute-Elevate the Debate: Teaching Tomorrow's Researchers How to Communicate to Different Audiences

RICHARD DAVIES, London School of Economics-From Data to Impact: Lessons for Teachers from Journalism and Policy

JOHN ERIC HUMPHRIES, Yale University-Econometrics Meets Data Science: Updating Yale's Undergraduate Curriculum

\section{2:30 PM Manchester Grand Hyatt San Diego_Gaslamp D}

\section{AERE}

\section{Politics of Environmental Policymaking (Q5)}

Presiding: TERRENCE IVERSON, Colorado State University

STEPHIE FRIED, Arizona State University, KEVIN NOVAN, University of California-Davis, and WILLIAM PETERMAN, Federal Reserve Board-The Macro Effects of Anticipating Climate Policy

NATHAN W. CHAN, University of Massachusetts-Amherst-Yea or Nay for Carbon Taxes: Political Economy and Willingness to Pay for Carbon Reduction in Washington 


\section{Friday $•$ January 3}

TAMARA L. SHELDON, University of South Carolina, J.R. DESHAZO, University of California-Los Angeles, and BRONWYN LEWIS FRISCIA, University of California-Los Angeles-Microtargeting Consumers' Group Identities to Improve Consumptive Efficiency

FELIX MEIER, Leipzig University, and CHRISTIAN TRAEGER, University of Oslo-Solar Geoengineering in a Regional Analytic Climate Economy

Discussants: ROBERTON WILLIAMS, University of Maryland

YORAM BAUMAN, Standupeconomist.com

ERICA MYERS, University of Illinois

IVAN RUDIK, Cornell University

2:30 PM Manchester Grand Hyatt San Diego-Seaport DE AFA

\section{Panel: Fintech, Financial Stability and Regulation (G0)}

Presiding: HYUN SONG SHIN, Bank for International Settlements

TOBIAS ADRIAN, International Monetary Fund

HYUN SONG SHIN, Bank for International Settlements

THOMAS PHILIPPON, New York University

ANTOINETTE SCHOAR, Massachusetts Institute of Technology

SUSAN ATHEY, Stanford University

\section{2:30 PM Manchester Grand Hyatt San Diego-Seaport A}

AFA

\section{Asset Return Dynamics (G1)}

Presiding: DORON AVRAMOV, IDC Herzliya

CHRISTOPHER PARSONS, University of Washington, RICCARDO SABBATUCCI, Stockholm School of Economics, and SHERIDAN TITMAN, University of Texas-Austin-Geographic Lead-Lag Effects 


\section{Friday $\cdot$ January 3}

STEPHAN FLORIG, Karlsruhe Institute of Technology, MAXIM ULRICH, Karlsruhe Institute of Technology, and CHRISTIAN WUCHTE, Karlsruhe Institute of Technology—A Model-Free Term Structure of United States Dividend Premiums

THUMMIM CHO, London School of Economics, and ARGYRIS TSIARAS, Harvard University-Global Capital and the CrossSection of International Equity Return Comovement

ANDREAS NEUHIERL, University of Notre Dame, and RASMUS VARNESKOV, Copenhagen Business School-Frequency Dependent Risk

Discussants: TOBIAS MOSKOWITZ, Yale University

JULES VAN BINSBERGEN, University of Pennsylvania

NANCY XU, Boston College

MARKUS PELGER, Stanford University

\section{2:30 PM Manchester Grand Hyatt San Diego-Seaport B} AFA

\section{Debt Financing and Growth (G3)}

Presiding: HUI CHEN, Massachusetts Institute of Technology

ROBIN DÖTTLING, Erasmus University, TOMISLAV LADIKA, University of Amsterdam, and ENRICO PEROTTI, University of Amsterdam-Creating Intangible Capital

THOMAS GEELEN, Copenhagen Business School and Danish Finance Institute, JAKUB HAJDA, University of Lausanne, and ERWAN MORELLEC, Swiss Federal Institute of TechnologyLausanne (EPFL) —Debt, Innovation, and Growth

LORIANA PELIZZON, Goethe University Frankfurt, MAX RIEDEL, Goethe University Frankfurt, ZORKA SIMON, Goethe University Frankfurt, and MARTI SUBRAHMANYAM, New York University-The Collateral Framework of the ECB and the Structure of Corporate Debt in the Eurozone

MICHAEL WITTRY, Ohio State University-(Debt) Overhang: Evidence from Resource Extraction 


\section{Friday $•$ January 3}

Discussants: ADRIANO RAMPINI, Duke University

CHRISTIAN OPP, University of Pennsylvania

ZHIGUO HE, University of Chicago

MICHAEL SCHWERT, University of Pennsylvania

\section{2:30 PM Manchester Grand Hyatt San Diego-Seaport C}

AFA

\section{Equity Options and Volatility Derivatives (G1)}

Presiding: ING-HAW CHENG, Dartmouth College

PETER VAN TASSEL, Federal Reserve Bank of New York-The Law of One Price in Equity Volatility Markets

BJORN ERAKER, University of Wisconsin-Madison-The Price of

Higher Order Catastrophe Insurance: The Case of VIX Options

MARK CLEMENTS, Research Affiliates, VITALI KALESNIK, Research Affiliates, and JUHANI LINNAINMAA, University of Southern California-Older and Wiser: Informed Traders and the Choice of Option Maturity

AURELIO VASQUEZ, Technological Autonomous University of Mexico (ITAM), and XIAO XIAO, Erasmus University RotterdamDefault Risk and Option Returns

Discussants: TRAVIS JOHNSON, University of Texas-Austin

JESSICA WACHTER, University of Pennsylvania

TURAN BALI, Georgetown University

ALESSIO SARETTO, University of Texas-Dallas

\section{2:30 PM Manchester Grand Hyatt San Diego-Seaport F AFA}

\section{Financial Intermediation and Liquidity (G2)}

Presiding: ARVIND KRISHNAMURTHY, Stanford University

SCOTT MURRAY, Georgia State University, and STANISLAVA NIKOLOVA, University of Nebraska-The Bond Pricing Implications of Rating-Based Capital Requirements

MAHYAR KARGAR, University of Illinois-Heterogeneous Intermediary Asset Pricing 


\section{Friday $•$ January 3}

YIMING MA, Columbia University-Passthrough of Treasury Supply to Bank Deposit Funding

SEBASTIAN INFANTE, Federal Reserve Board, and ALEXANDROS VARDOULAKIS, Federal Reserve BoardCollateral Runs

Discussants: BO BECKER, Stockholm School of Economics, CEPR \& ECGI WENHAO LI, Stanford University

MARK EGAN, Harvard University

WILLIAM DIAMOND, University of Pennsylvania

\section{2:30 PM Manchester Grand Hyatt San Diego-Seaport G}

AFA

Gender: Policy, Perception and Firm Value (G3)

Presiding: HEATHER TOOKES, Yale University

MARIASSUNTA GIANNETTI, Stockholm School of Economics, and TRACY WANG, University of Minnesota-Public Attention to Gender Equality and the Demand for Female Directors

FELIX VON MEYERINCK, University of St. Gallen, ALEXANDRA NIESSEN-RUENZI, University of Mannheim, MARKUS SCHMID, University of St. Gallen, and STEVEN SOLOMON, University of California-Berkeley-As California Goes, so Goes the Nation? Board Gender Quotas and the Legislation of Non-Economic Values

BENJAMIN BENNETT, Ohio State University, ISIL EREL, Ohio State University, LEA STERN, University of Washington, and ZEXI WANG, Lancaster University-Feminist Firms: Are They Worth More?

SHAUN DAVIES, University of Colorado, EDWARD VAN WESEP, University of Colorado, and BRIAN WATERS, University of Colorado-On the Glass Ceiling: Small Biases, Large Disparities, and Important Decisions

Discussants: GEOFFREY TATE, University of Maryland

DANIEL FERREIRA, London School of Economics

MARGARITA TSOUTSOURA, Cornell University

LAURA VELDKAMP, Columbia University 


\section{Friday $•$ January 3}

\section{2:30 PM Manchester Grand Hyatt San Diego-Seaport H}

AFA

\section{Hedge Funds (G1)}

Presiding: CHRIS SCHWARZ, University of California-Irvine

GREGORY BROWN, University of North Carolina-Chapel Hill, OLEG GREDIL, Tulane University, and PREETESH KANTAK, Indiana University-Finding Fortune: How Do Institutional Investors Pick Asset Managers?

VIKAS AGARWAL, Georgia State University, STEFAN RUENZI, University of Mannheim, and FLORIAN WEIGERT, University of St. Gallen-Unobserved Performance of Hedge Funds

MATHIAS KRUTTLI, Federal Reserve Board, PHILLIP MONIN, U.S. Treasury Department, and SUMUDU WATUGALA, Cornell

University-Prime Broker Exposures, Collateral, and Resilience in Hedge Fund Credit Networks

GEORGE ARAGON, Arizona State University, VIKRAM NANDA, University of Texas-Dallas, and HAIBEI ZHAO, Lehigh University-Investor Protection and Capital Fragility: Evidence from Hedge Funds Around the World

Discussants: NICOLE BOYSON, Northeastern University

NICOLAS BOLLEN, Vanderbilt University

GEORGE ARAGON, Arizona State University

WILLIAM GERKEN, University of Kentucky

\section{2:30 PM Manchester Grand Hyatt San Diego-Harbor A} AFA

\section{Intermediaries and Asset Returns (G1)}

Presiding: DIMITRIS PAPANIKOLAOU, Northwestern University

SEMYON MALAMUD, Swiss Federal Institute of TechnologyLausanne (EPFL), and EGEMEN EREN, Bank for International Settlements-Dominant Currency Debt

WENXIN DU, University of Chicago, BENJAMIN HEBERT, Stanford University, and AMY WANG HUBER, Stanford University-Are Intermediary Constraints Priced? 


\section{Friday $•$ January 3}

JIAFEI HU, University of Queensland, and HAISHAN YUAN, University of Queensland-Interest Arbitrage under Capital Controls: Evidence from Reported Entrepôt Trades

Discussants: ZHENGYANG JIANG, Northwestern University

VALENTIN HADDAD, University of California-Los Angeles

LORENA KELLER, University of Pennsylvania

LAWRENCE SCHMIDT, Massachusetts Institute of Technology

\section{2:30 PM Manchester Grand Hyatt San Diego-Cortez Hill B}

\section{AFEE}

\section{Contexts of Money and Gift (E4)}

Presiding: ZDRAVKA TODOROVA, Wright State University

SCOTT MCCONNELL, Eastern Oregon University-Rai Stones and Banknotes: An Institutionalist Understanding of Micronesian Stone Money

KAROL GIL-VÁSQUEZ, Nichols College-Re-embedding the Economy - El Tumin, a Complementary Currency in Mexican Communities

ALLA SEMENOVA, State University of New York-Potsdam-The Origins of Money in Ancient Greece

KALPANA KHANAL, Nichols College, and RUCHIRA SEN, Jindal Global University-Dowry in South Asia: The Efflorescence of a Non-Reciprocal Gift System

Discussants: ANN E. DAVIS, Marist College

ZDRAVKA TODOROVA, Wright State University

\section{2:30 PM Manchester Grand Hyatt San Diego-Cortez Hill A AFEE/ASE}

\section{Economic Policy and the Progressive Idea (B5)}

Presiding: CHRISTOPHER BROWN, Arkansas State University

PAOLO RAMAZZOTTI, University of Macerata-Economic Policy and the Progressive Idea 


\section{Friday $•$ January 3}

F. GREGORY HAYDEN, University of Nebraska-LincolnMulti-Criteria Analysis Applied to the Instrumental-Ceremonial Dichotomy for Progressive Change

JANICE PETERSON, California State University-Fresno-Welfare Policy and Precarious Lives: "Welfare Reform" Revisited

ANNA KLIMINA, St. Thomas More College and University of Saskatchewan-Defining and Defending a Progressive Market Square: Bringing Institutionalist Development Discourse in Line with the Reality of Post-Soviet Transition Experiences

FELIPE ALMEIDA, Federal University of Paraná, and GUSTAVO GOULART, Federal University of Paraná-Recontextualizing Clarence Ayers's "The Theory of Economic Progress"

Discussants: CHRISTOPHER BROWN, Arkansas State University

WILLIAM WALLER, Hobart and William Smith Colleges

\section{2:30 PM Manchester Grand Hyatt San Diego-Nautical AREUEA}

\section{Agglomeration and Local Public Finance (R0)}

Presiding: MATTHEW FREEDMAN, University of California-Irvine

WILLIAM STRANGE, University of Toronto, GIULIA FAGGIO, City University of London, and OLMO SILVA, London School of Economics-Tales of the City: What Do Agglomeration Cases Tell Us About Agglomeration in General?

SHIMENG LIU, Jinan University, and XI YANG, University of North Texas-Property Tax Limits and Female Labor Supply: Evidence from the Housing Boom and Bust

CARLIANNE PATRICK, Georgia State University, and MARK D. PARTRIDGE, Ohio State University-Identifying Agglomeration Spillovers: New Evidence from Large Plant Openings

CARLOS HURTADO, University of Richmond-Behavioral Responses to Spatial Tax Notches in the Retail Gasoline Market

Discussants: GILLES DURANTON, University of Pennsylvania

KEVIN MUMFORD, Purdue University

RICHARD HORNBECK, University of Chicago

THOMAS HOLMES, University of Minnesota 


\section{Friday $•$ January 3}

\section{2:30 PM Manchester Grand Hyatt San Diego—Regatta C AREUEA}

\section{Housing and Disasters (R2)}

Presiding: JESSIE HANDBURY, University of Pennsylvania

MARCEL FISCHER, University of Konstanz, NATALIA KHORUNZHINA, Copenhagen Business School, and JULIE MARX, Copenhagen Business School-Who Buys Homes When Prices Fall?

INGRID GOULD ELLEN, New York University, XIAODI LI, New York University, and RACHEL MELTZER, New School for Social Research-How Much Does Nearby Blight Affect Real Estate Prices? The Case of Hurricane Sandy

SHAWN ROHLIN, University of Akron, JUSTIN GALLAGHER, Case Western Reserve University, and DANIEL HARTLEY, Federal Reserve Bank of Chicago-The Effect of Federal Assistance on Household Finance and Business Survival after a Natural Disaster

DAVID PHILLIPS, University of Notre Dame-Measuring Housing Stability with Consumer Reference Data

Discussants: JUNGSOO YOO, University of Pennsylvania

JESSE GREGORY, University of Wisconsin

EVAN MAST, W.E. Upjohn Institute for Employment Research ERIC CHYN, University of Virginia

\section{2:30 PM Manchester Grand Hyatt San Diego-Coronado A AREUEA}

\section{International Real Estate and Institutions: In Honor of Austin Jaffe (R2)}

Presiding: BRENT AMBROSE, Pennsylvania State University

JING WU, Tsinghua University, WENLAN QIAN, National University of Singapore, HONG TU, Nankai University, and WEIBIAO XU, Nankai University-Sticky Expectations in the Housing Market: Evidence from the Housing Purchase Restriction Policy 


\section{Friday $•$ January 3}

WANG LONG, National University of Singapore, SUMIT AGARWAL, National University of Singapore, WEIDA KUANG, Renmin University of China, and YANG (ZOE) YANG, Chinese University of Hong Kong-Yin-Yang Contracts in China's Housing Market

DAXUAN ZHAO, Renmin University of China, YONGQIANG CHU, University of North Carolina-Charlotte, WEIDA KUANG, Renmin University of China, and XIAOXIA ZHOU, Shanghai University of Finance and Economics-Inside Job: Evidence from the Chinese Housing Market

SHIHE FU, Xiamen University, YIZHEN GU, Jinan University, and YING LONG, Tsinghua University-The Effects of Urban Growth Boundaries on Urban Development: Evidence from Beijing

Discussants: LYNN FISHER, Federal Housing Finance Agency

JAMES CONKLIN, University of Georgia

LILY SHEN, Clemson University

MOUSSA DIOP, University of Southern California

\section{2:30 PM Manchester Grand Hyatt San Diego-Cove ASE}

\section{Growth, Wealth and Finance (B5)}

Presiding: MONA ALI, State University of New York-New Paltz

KARSTEN KOHLER, Kingston University, LOUIS DAUMAS, Kingston University, and ENGELBERT STOCKHAMMER, King's College London-Growth Models Before and After the Crisis: The Financial Cycle, Austerity and Competitiveness

HANNA SZYMBORSKA, Birmingham City University-Wealth Structures and Income Distribution of United States Households Before and After the Great Recession

LIZETHE MENDEZ, Metropolitan Autonomous University (UAM), and DIEGO LINTHON, University of Guayaquil-Measuring WellBeing Beyond GDP: Comparing Two Metrics for OCDE Countries MONA ALI, State University of New York-New Paltz-AngloAmerican Capitalism and the International Economic (Dis)order 


\section{Friday $\cdot$ January 3}

DANIELE TAVANI, Colorado State University, and LUKE PETACH, Belmont University_Firm Beliefs and Long-Run Demand Effects in a Labor-Constrained Model of Growth and Distribution

\section{2:30 PM Manchester Grand Hyatt San Diego_-Pier ASGE}

Economics of Philanthropy in Conjunction with Science of Philanthropy Initiative (SPI) (H4)

Presiding: DANIEL HUNGERMAN, University of Notre Dame

ANYA SAMEK, University of Southern California, and CHUCK LONGFIELD, Blackbaud Inc-Do Thank-You Calls Increase Charitable Giving? Expert Forecasts and Field Experimental Evidence

MARTA SERRA-GARCIA, University of California-San Diego, and JAMES ANDREONI, University of California-San DiegoPledges as Screening Devices

MARCO CASTILLO, Texas A\&M University, and RAGAN PETRIE, Texas A\&M University-Sophistication and Giving

Discussants: JANA GALLUS, University of California-Los Angeles

ADRIAAN SOETEVENT, University of Groningen

MARK WILHELM, Indiana University-Purdue University Indianapolis

\section{2:30 PM Manchester Grand Hyatt San Diego-Old Town B CES}

\section{China Environment (Q5)}

Presiding: YING FANG, Xiamen University

MENGMENG GUO, Southwestern University of Finance and Economics, HUANG LIN, Southwestern University of Finance and Economics, and MENGXIN WEI, Southwestern University of Finance and Economics-Does Air Pollution Influence Investor Trading Behavior? Evidence from China 


\section{Friday $•$ January 3}

ZHI LI, Xiamen University, LIU PENGFEI, University of Rhode Island, and STEPHEN SWALLOW, University of ConnecticutSupporting Private Provision of Ecosystem Services Through Contracts in Environmental Markets: Evidence from Lab and Pilot Field Experiments

BING ZHANG, Nanjing University, and MENGDI LIU, Nanjing University - Voice of the Masses and Responsive Authoritarianism in China: Online Environmental Complain and Government Response ANDRES ARCILA, University of Waterloo, TAO CHEN, University of Waterloo, and XIAOLAN LU, Jianghan UniversityThe Effectiveness of Consumption Tax on the Reduction of Car Pollution in China

Discussants: JUNFU ZHANG, Clark University

YAZHEN GONG, Renmin University of China

ZIJUN LUO, Sam Houston State University

ZHAO RONG, Zhongnan University of Economics and Law

\section{2:30 PM Manchester Grand Hyatt San Diego_Gaslamp AB ENSA}

\section{Economics of National Security (H0)}

Presiding: ELI BERMAN, University of California-San Diego

GAURAV KHANNA, University of California-San Diego, CARLOS MEDINA, Central Bank of Colombia, ANANT NYSHADHAM, Boston College and NBER, and JORGE TAMAYO, Harvard Business School-Formal Employment and Organized Crime: Regression Discontinuity Evidence from Colombia

JOSHUA BLUMENSTOCK, University of California-Berkeley, TAREK GHANI, Washington University-St. Louis, SYLVAN HERSKOWITZ, International Food Policy Research Institute, THOMAS SCHERER, University of California-San Diego, and OTT TOOMET, University of Washington-How Do Firms Respond to Insecurity? Evidence from Afghan Phone Records

JUSTICE TEI MENSAH, Swedish University of Agricultural Sciences, and KWEKU OPOKU-AGYEMANG, Cornell University-Innocent until Stereotyped Guilty? Terrorism and United States Immigration Court Decisions 


\section{Friday $\cdot$ January 3}

RESUL CESUR, University of Connecticut, NBER and IZA, JOSEPH SABIA, San Diego State University and University of New Hampshire, and W. DAVID BRADFORD, University of GeorgiaDid the War on Terror Ignite a Veteran Opioid Epidemic?

\section{2:30 PM Marriott Marquis San Diego—Carlsbad} ES

\section{Advances in Contract and Mechanism Design (D8)}

Presiding: VASILIKI SKRETA, University of Texas-Austin and University College London

BENJAMIN BROOKS, University of Chicago, and SONGZI DU, University of California-San Diego-Optimal Auction Design with Common Values: An Informationally Robust Approach

HUIYIGUO, Texas A\&M University_Coalition-Proof Mechanisms under Correlated Information

RAN EILAT, Ben Gurion University, KFIR ELIAZ, Tel-Aviv University, and XIAOSHENG MU, Columbia University-Optimal Privacy-Constrained Mechanisms

LAURA DOVAL, California Institute of Technology, and VASILIKI SKRETA, University of Texas-Austin and University College London-Optimal Mechanism for The Sale of a Durable Good

GEORGE GEORGIADIS, Northwestern University, and MICHAEL POWELL, Northwestern University-Optimal Incentives under Moral Hazard: From Theory to Practice

\section{2:30 PM Marriott Marquis San Diego-Del Mar ES}

Central Bank Communications and Management of Expectations (D8)

Presiding: MICHAEL MCMAHON, University of Oxford

LENA DRÄGER, Leibniz University Hannover, MICHAEL LAMLA, University of Essex, and DAMJAN PFAJFAR, Federal Reserve Board-The Hidden Heterogeneity of Inflation Expectations and Its Implications 


\section{Friday $•$ January 3}

MICHAEL LAMLA, University of Essex, and DMITRI VINOGRADOV, University of Glasgow-Central Bank Announcements: Big News for Little People?

MICHAEL WEBER, University of Chicago, OLIVIER COIBION, University of Texas-Austin, and YURIY GORODNICHENKO, University of California-Berkeley-Monetary Policy Communications and Their Effects on Household Inflation Expectations

GEORGE-MARIOS ANGELETOS, Massachusetts Institute of Technology, and KARTHIK SASTRY, Massachusetts Institute of Technology-Managing Expectations Without Rational Expectations

MICHAEL MCMAHON, University of Oxford-Does the Public Understand Policy Uncertainty?

\section{2:30 PM Marriott Marquis San Diego-Catalina ES}

\section{Econometrics of Decisions and Demand (C1)}

Presiding: JOERG STOYE, Cornell University

LEVON BARSEGHYAN, Cornell University, MAURA COUGHLIN, Cornell University, FRANCESCA MOLINARI, Cornell University, and JOSHUA TEITELBAUM, Georgetown University-Heterogeneous Choice Sets and Preferences

ROY ALLEN, University of Western Ontario, and JOHN REHBECK, Ohio State University-Revealed Stochastic Choice with Attributes VICTOR AGUIAR, University of Western Ontario-Does Random Consideration Explain Behavior When Choice is Hard? Evidence from a Large-Scale Experiment

VICTOR AGUIAR, University of Western Ontario, ROY ALLEN, University of Western Ontario, and NAIL KASHAEV, University of Western Ontario-Prices, Profits, and Production: Identification and Counterfactuals

STEFAN HODERLEIN, Boston College, and ALEXANDER MEISTER, University of Rostock-A Panel Data Estimator for the Distribution and Quantiles of Marginal Effects in Nonlinear Structural Models with an Application to the Demand for Junk Food 


\section{Friday $•$ January 3}

YUICHI KITAMURA, Yale University, and JOERG STOYE, Cornell University-Nonparametric Counterfactuals in Random Utility Models

\section{2:30 PM Marriott Marquis San Diego-La Costa ES}

\section{Econometrics of Networks (C2)}

Presiding: ARTHUR LEWBEL, Boston College

MINGLICHEN, University of Warwick, IVÁN FERNÁNDEZ-VAL, Boston University, and MARTIN WEIDNER, University College London-Nonlinear Factor Models for Network and Panel Data

KIRILL EVDOKIMOV, Massachusetts Institute of TechnologyMeasurement Errors in Large Nonlinear Panels and Networks

MICHAEL LEUNG, University of Southern California-Inference in Models of Discrete Choice with Social Interactions Using Network Data

DENIS KOJEVNIKOV, University of British Columbia, VADIM MARMER, University of British Columbia, and KYUNGCHUL (KEVIN) SONG, University of British Columbia-Limit Theorems for Network Dependent Random Variables

HULYA ERASLAN, Rice University, and XUN TANG, Rice University-Identification and Estimation of Large Network Games with Private Link Information

ARTHUR LEWBEL, Boston College, XI QU, Shanghai Jiao Tong University, and XUN TANG, Rice University-Social Networks with Misclassified or Unobserved Links 


\section{Friday $•$ January 3}

\section{2:30 PM Marriott Marquis San Diego-Marina Ballroom F ES}

Panel: Sources and Consequences of Inequality (D3)

Presiding: RICHARD BLUNDELL, University College London ANGUS DEATON, Princeton University PINELOPI GOLDBERG, Yale University ORAZIO ATTANASIO, University College London TIM BESLEY, London School of Economics

2:30 PM Manchester Grand Hyatt San Diego-Torrey Hills AB ESA

\section{Information (Design), Black Markets, and Congestion (D9)}

Presiding: DOROTHEA KUEBLER, WZB Berlin Social Science Center

MARINA AGRANOV, California Institute of Technology, AHRASH DIANAT, University of Essex, LARRY SAMUELSON, Yale University, and LEEAT YARIV, Princeton UniversityAn Experimental Study of Matching Markets with Incomplete Information

YAN CHEN, University of Michigan, MOHAMED MOSTAGIR, University of Michigan, and IMAN YECKEHZAARE, University of Michigan-Information Design in Dynamic Contests: An Experimental Study

RUSTAMDJAN HAKIMOV, University of Lausanne, C.-PHILIPP HELLER, NERA Economic Consulting, DOROTHEA KUEBLER, WZB Berlin Social Science Center, and MORIMITSU KURINO, Keio University-How to Avoid Black Markets for Appointments with Online Booking Systems

YINGHUA HE, Rice University, and THIERRY MAGNAC, Toulouse School of Economics-Application Costs and Congestion in Matching Markets

Discussants: CHRISTIAN BASTECK, ECARES Brussels

LIONEL PAGE, University of Technology Sydney

ROBERT HAMMOND, University of Alabama

AHRASH DIANAT, University of Essex 


\section{Friday $•$ January 3}

\section{2:30 PM Marriott Marquis San Diego-Malibu HES}

\section{Alternative Traditions in Public Choice (B0)}

Presiding: WILLIAM SHUGHART, Utah State University

DAVID COKER, George Mason University, and ROSS EMMETT, Arizona State University_Frank Knight and the Origins of Public Choice

JULIEN GRANDJEAN, University of Lorraine-Gordon Tullock About Simple Majority Voting Rule: The Making of a Conviction

RAFAEL GALVÃO DE ALMEIDA, Federal University of Minas Gerais-A Macroeconomic View of Public Choice

GORDON BRADY, University of North Carolina-Greensboro, and FRANCESCO FORTE, Sapienza University of Rome-Duncan Black's Theories of Voting and Special Interest Legislation in Public Finance

\section{2:30 PM Manchester Grand Hyatt San Diego_Cortez Hills C IBEFA}

\section{Culture and Conduct (G2)}

Presiding: LARRY WALL, Federal Reserve Bank of Atlanta

OLIVER REHBEIN, University of Bonn, and SIMON ROTHER, University of Bonn-Why Distance Matters: The Role of Social Connectedness and Culture in Bank Lending

MARK JANSEN, University of Utah-Spillover Effects of the Opioid Epidemic on Consumer Finance

MICHAEL GOEDDE-MENKE, University of Münster, and PETERHENDRIK INGERMANN, University of Münster-The Impact of Organizational Downsizing on Loan Officer Specialization and Credit Defaults

Discussants: ELENA LOUTSKINA, University of Virginia

PAIGE OUIMET, University of North Carolina-Chapel Hill MARTIEN LAMERS, Ghent University 


\section{Friday $•$ January 3}

\section{2:30 PM Manchester Grand Hyatt San Diego-America's Cup C IEFS}

Financial Frictions in the Global Economy (F3)

Presiding: SEBNEM KALEMLI-OZCAN, University of Maryland

MARK AGUIAR, Princeton University, MANUEL AMADOR, Federal Reserve Bank of Minneapolis, and STELIOS FOURAKIS, University of Minnesota-On the Welfare Losses from External Sovereign Borrowing

KINDA HACHEM, University of Virginia, and ZHENG MICHAEL SONG, Chinese University of Hong Kong-Liquidity Rules and Credit Booms

LESLIE SHENG SHEN, University of California-Berkeley-Global Versus Local Banking: A Double Adverse Selection Problem

ALBERTO MARTIN, European Central Bank, CREI, and Barcelona GSE, FERNANDO BRONER, CREI and Pompeu Fabra University, DARAGH CLANCY, European Stability Mechanism, and AITOR ERCE, European Stability Mechanism-Fiscal Multipliers and Foreign Holdings of Public Debt

\section{2:30 PM Manchester Grand Hyatt San Diego_America's Cup AB IOS}

\section{Mark-Ups and Common Ownership: An IO Perspective (L1)}

Presiding: JULIE HOLLAND MORTIMER, Boston College

MATTHEW R. BACKUS, Columbia University, CHRISTOPHER T. CONLON, New York University, and MICHAEL SINKINSON, Yale University-Common Ownership and Competition in the Ready-To-Eat Cereal Industry

ALON EIZENBERG, Hebrew University of Jerusalem, and DALIA SHILIAN, Israel Federal Trade Administration-Structure, Conduct, and Contact: Competition in Closely-Related Markets

PAUL GRIECO, Pennsylvania State University, CHARLES MURRY, Boston College, and ALI YURUKOGLU, Stanford University-The Evolution of Market Power in the United States Auto Industry

DEVESH RAVAL, Federal Trade Commission-Testing the Production Approach to Markup Estimation 


\section{Friday $•$ January 3}

Discussants: AMIT GHANDI, University of Pennsylvania JONATHAN WILLIAMS, University of North Carolina-Chapel Hill

MATTHEW WEINBERG, Ohio State University

DANIEL ACKERBERG, University of Texas-Austin

\section{2:30 PM Manchester Grand Hyatt San Diego-Harbor E LERA}

\section{Discussion Panel: Making Global Markets Work for American}

Workers (F1)

Presiding: AARON SOJOURNER, University of Minnesota

JOSH BIVENS, Economic Policy Institute-Everybody Wins, Except for Most of Us

KIMBERLY CLAUSING, Reed College-Open: The Progressive Case for Free Trade, Immigration, and Global Capital

DANI RODRIK, Harvard University-Straight Talk on Trade: Ideas for a Sane World Economy

Discussants: JOSEPH E. STIGLITZ, Columbia University

JASON FURMAN, Harvard University

\section{2:30 PM Manchester Grand Hyatt San Diego-Harbor F LERA}

\section{Impact of Early and Post-secondary Education Policies on Entry and Outcomes (J2)}

Presiding: ELIZABETH DHUEY, University of Toronto

TINGTING ZHANG, Western New England University, and ELIZABETH DHUEY, University of Toronto-The Impact of Full-Day Kindergarten on Maternal Labor Supply and Welfare Transfers: New Evidence from Tax Records

ANDRIA SMYTHE, Howard University-Economic Conditions at College Entry and College Outcomes 


\section{Friday $•$ January 3}

JEAN-WILLIAM LALIBERT, University of Calgary, MITRA AKHTARI, AirBnB, and NATALIE BAU, University of California-Los Angeles-Affirmative Action and Student Effort Discussants: NATALIE BAU, University of Toronto

KOURTNEY KOEBEL, University of Toronto

\section{2:30 PM Marriott Marquis San Diego-San Diego Ballroom A NABE}

\section{Tech Economics (L1)}

Presiding: MICHAEL LUCA, Harvard Business School

JIAN JIA, Illinois Institute of Technology, GINGER JIN, University of Maryland, and LIAD WAGMAN, Illinois Institute of Technology_GDPR and the Home Bias of Venture Investment

VICTOR CHERNOZHUKOV, Massachusetts Institute of Technology, and PATRICK BAJARI, Amazon-New Goods, Productivity and the Measurement of Inflation: Using Machine Learning to Improve Quality Adjustments

GUIDO IMBENS, Stanford University, and PATRICK BAJARI, Amazon—Double Randomized Online Experiments

\section{2:30 PM Marriott Marquis San Diego-Newport Beach}

NAEE

\section{Panel: Professional Promotion and the Scholarship of Teaching and Learning in Economics (A2)}

Presiding: DIEGO MENDEZ-CARBAJO, Illinois Wesleyan University

JANE S. LOPUS, California State University-East Bay-A Director of Center for Economics Education Perspective

DIEGO MENDEZ-CARBAJO, Illinois Wesleyan University-A Full Professor Perspective

LAURIE A. MILLER, University of Nebraska-Lincoln-An Associate Professor of Practice Perspective

KAREN GEBHARDT, University of Colorado-Boulder-An Instructor and Textbook Author Perspective 


\section{Friday $•$ January 3}

\section{2:30 PM Manchester Grand Hyatt San Diego-Marina NAFE/NEA}

Enslavement, Racial Inequality and Making Victims Whole (K1)

Presiding: JEROME S. PAIGE, Jerome S. Paige \& Associates

CHARLES BETSEY, Howard University-Compensating Versus Making One Whole

RICHARD AMERICA, Georgetown University-CARICOM: Unjust Enrichment and the Case for Restitution

WILLIAM DARITY, Duke University, and KIRSTEN MULLEN, Artefactual-From Here to Equality: A Framework for Restitution for Black Descendants of American Slavery

Discussants: SIBYLLE SCHOLZ, Forensic Economist

DANIA V. FRANCIS, University of Massachusetts-Amherst

JEROME S. PAIGE, Jerome S. Paige \& Associates

\section{2:30 PM Manchester Grand Hyatt San Diego_Ocean Beach SED}

\section{The Political Economy and Economic Development of Non- Democracies (01)}

Presiding: NANCY QIAN, Northwestern University

LEONARDO BURSZTYN, University of Chicago, GEORGY EGOROV, Northwestern University, RUBEN ENIKOLOPOV, New Economic School, and MARIA PETROVA, Pompeu Fabra University-Social Media and Xenophobia: Evidence from Russia ALEXEY MAKARIN, Northwestern University-Trading with the Enemy: The Impact of Conflict on Trade

NOAM YUCHTMAN, University of California-Berkeley, and DAVID YANG, Harvard University-Fundamental Determinants MONICA MARTINEZ BRAVO, CEMFI, GERARD PADRÓ I MIQUEL, London School of Economics, NANCY QIAN, Northwestern University, and YANG YAO, Peking University-The Rise and Fall of Local Elections in China 


\section{Friday $•$ January 3}

\section{2:30 PM Manchester Grand Hyatt San Diego-Mission Beach B SGE}

\section{Banking Competition: Responding to Social Changes (E0)}

Presiding: ALEXANDER B. UFIER, Federal Deposit Insurance Corporation

W. BLAKE MARSH, Federal Reserve Bank of Kansas City, and RAJDEEP SENGUPTA, Federal Reserve Bank of Kansas CityCompetition and Bank Fragility

DASOL KIM, U.S. Treasury Department, and ALLEN BERGER, University of South Carolina, University of Pennsylvania, and European Banking Center-Market Competition, Production Technologies, and Regulatory Frictions: Evidence from the Banking Industry

JUSTIN VITANZA, Temple University, SUDIPTA BASU, Temple

University, and WEI WANG, Temple University-Walking the Walk: CSR Disclosures and Bank Practices

JONATHAN POGACH, Federal Deposit Insurance Corporation, CLAIRE BRENNECKE, Federal Deposit Insurance Corporation, and STEFAN JACEWITZ, Federal Deposit Insurance CorporationSmall Banks and Big Boxes: Real Sector Industrial Organization and Financial Concentration

Discussants: GIOVANNI CALICE, Loughborough University

EDUARDO DAVILA, Yale University

ALEXANDER B. UFIER, Federal Deposit Insurance Corporation STEFAN LEWELLEN, Pennsylvania State University

\section{2:30 PM Manchester Grand Hyatt San Diego_-Old Town A URPE}

Finance, Post-Keynesian, Sraffian Theory (E1)

Presiding: PAUL COONEY, National University of General Sarmiento and URPE

FAHD ALI, Information Technology University-The Political Economy of Macro-Imbalances: Kalecki in a Small Open Econoomy ANDRES CANTILLO, Kaleidoscope Economic Research-The Financial Structure Implicit in the Sraffa-Pasinetti Framework 


\section{Friday $•$ January 3}

JONATHAN GOLDSTEIN, Bowdoin College-A Three Class Predator-Prey Model with Financial Super-Predators: The Financial Profit Squeeze

GOKCER OZGUR, Gettysburg College-Shadow Banking and Financial Intermediation

\section{2:30 PM Manchester Grand Hyatt San Diego_La Jolla B URPE}

\section{In Search of a New Social Model for the EU (D7)}

Presiding: PASCAL PETIT, University of Paris 13

MARIO PIANTA, Normal Superior School Florence-Can Europe Reshape Its Production Activities towards Convergence and Sustainability?

CHARLIE DANNREUTHER, University of Leeds-Beyond an Enterprise Economy

ANDREW WATT, IMK Institute Hans-Bockler FoundationTaking Stock of the Debate about Positive and Negative Integration in the EU

PASCAL PETIT, University Paris 13-To What Extent Could a Global Governance More Centered on UN ASDGs Help to Revamp the EU Project?

Discussants: GARY DYMSKI, University of Leeds

ESTHER JEFFERS, University of Amiens

DOMINIQUE PLIHON, University Paris 13

JACQUES MAZIER, University Paris 13

\section{4:45 PM Marriott Marquis San Diego-Marriott Grand} Ballroom 7-8-9

AEA

\section{Richard T. Ely Lecture}

Presiding: JANET YELLEN, Brookings Institution

Speaker: MARIANNE BERTRAND, University of Chicago-Gender in the 21st Century 


\section{Friday $•$ January 3}

\section{5:00 PM Manchester Grand Hyatt San Diego-Pier}

AFEA

Presidential Address and Business Meeting

Presiding: SAMUEL AMPONSAH, Tokyo International University

Speakers: HANAN MORSY, African Development Bank, LÉONCE NDIKUMANA, University of Massachusetts-Amherst, HIPPOLYTE FOFACK, African Export-Import Bank-The State of Africa's Debt: Domestic and Foreign

6:00 PM Marriott Marquis San Diego-Marriott Grand Ballroom 7-8-9

AEA

Business Meeting 


\section{Saturday $•$ January 4}

7:45 AM Manchester Grand Hyatt San Diego-Coronado D ASE

\section{Presidential Breakfast}

Presiding: STEVEN PRESSMAN, Colorado State University

Speaker: JULIE NELSON, University of Massachusetts-Boston

Topic: Economics For (And By) Humans

\section{8:00 AM Manchester Grand Hyatt San Diego-Mission Beach A} AAEA

Fertility in a Changing Environment: Climate Change, Migration, and Social Networks (Q0)

Presiding: JOYCE CHEN, Ohio State University

BRIAN THIEDE, Pennsylvania State University, JOYCE CHEN, Ohio State University, VALERIE MUELLER, International Food Policy Research Institute, and YUANYUAN JIA, Ohio State University-It's Raining Babies? Flooding and Fertility Choices in Bangladesh

KATERINE RAMIREZ NIETO, Ohio State University-Mobility Effects on Fertility Decisions: A Case Study Using the Mexico Family Life Survey

S. ANUKRITI, Boston College, CATALINA HERRERAALMANZA, Northeastern University, MAHESH KARRA, Boston University, and PRAVEEN PATHAK, University of Delhi-Social Networks and Women's Reproductive Health Choices in India Discussant: MARK ROSENZWEIG, Yale University

\section{8:00 AM Manchester Grand Hyatt San Diego-Harbor D ACES}

The Institutional Basis of China's Growth and Social Development (P3)

Presiding: RUIXUE JIA, University of California-San Diego CHENGGANG XU, Cheung Kong Graduate School of BusinessInstitutional Genes of China's Socio-Economic Development 


\section{Saturday • January 4}

WEI XIONG, Princeton University-The Mandarin Model of Growth

CHANG-TAI HSIEH, University of Chicago-The Growth of Conglomerates in China

HONGBIN LI, Stanford University—Student Quality, College Selectivity, and the Birth of Firms

Discussants: SCOTT D. ROZELLE, Stanford University

CHENGGANG XU, Cheung Kong Graduate School of Business

WEI XIONG, Princeton University

NOAM YUCHTMAN, London School of Economics

\section{8:00 AM Marriott Marquis San Diego-Rancho Santa Fe 2}

AEA

\section{Achievement Tests I: On the Validity of Comparisons across Cohort, Grade, and Subject (I2)}

Presiding: KEVIN LANG, Boston University

JOHN B. KLOPFER, University of Hong Kong and United States

Naval Academy-Learning Time and Achievement: Evidence from

a Nationwide Natural Experiment

DOUGLAS O. STAIGER, Dartmouth College, and ELIZABETH U. CASCIO, Dartmouth College-Knowledge, Tests, and Fadeout in Educational Interventions

TIMOTHY N. BOND, Purdue University, KEVIN LANG, Boston University, SIRUI WAN, University of California-Irvine, DOUGLAS H. CLEMENTS, University of Denver, and JULIE SARAMA, University of Denver-Is Intervention Fadeout a Scaling Artefact?

ERIC A. HANUSHEK, Stanford University, PAUL E. PETERSON, Harvard University, LAURA M. TALPEY, Stanford University, and LUDGER WOESSMANN, Ifo Institute and CESifo-The Unwavering SES Achievement Gap: Trends in United States Student Performance 


\section{Saturday $•$ January 4}

\section{8:00 AM Marriott Marquis San Diego-Marriott Grand Ballroom 5-6 \\ AEA}

\section{Panel: Alan Krueger's Contributions to Economics (A1)}

Presiding: DAVID CARD, University of California-Berkeley

ALEXANDRE MAS, Princeton University

DIANE WHITMORE SCHANZENBACH, Northwestern University

LAWRENCE KATZ, Harvard University

LISA LYNCH, Brandeis University

DAVID CARD, University of California-Berkeley

\section{8:00 Ам Marriott Marquis San Diego-Marriott Grand Ballroom 1 AEA}

\section{Consequences of Forced Migration (F2)}

Presiding: PANU POUTVAARA, University of Munich

PAULINE A. GROSJEAN, University of New South Wales, SASCHA O. BECKER, University of Warwick, IRENA GROSFELD, Paris School of Economics, NICO VOIGTLÄNDER, University of California-Los Angeles, and EKATERINA ZHURAVSKAYA, Paris School of Economics-Forced Migration and Human Capital: Evidence from Post-WWII Population Transfers

SANDRA ROZO, University of Southern California, and JUAN F. VARGAS, Del Rosario University-Brothers or Invaders? How Crises-Driven Migrants Shape Voting Behaviour

THOMAS GINN, Stanford University, RAGUI ASSAAD, University of Minnesota, and MOHAMED SALEH, Toulouse School of Economics-Impact of Syrian Refugees on Education Outcomes in Jordan

CEVAT GIRAY AKSOY, European Bank for Reconstruction and Development, NICOLAS AJZENMAN, Inter-American Development Bank, and SERGEI GURIEV, European Bank for Reconstruction and Development—Refugee Crisis, Flight to Safety and Entrepreneurship 


\section{Saturday $\cdot$ January 4}

Discussants: PANU POUTVAARA, University of Munich

DANY BAHAR, Brookings Institution

SEMIH TUMEN, TED University

SASCHA O. BECKER, Monash University

\section{8:00 AM Marriott Marquis San Diego-San Diego Ballroom A} AEA

\section{Countercyclical Fiscal Policy (E6)}

Presiding: WENDY EDELBERG, U.S. Congressional Budget Office

VALERIE A. RAMEY, University of California-San Diego, and SARAH ZUBAIRY, Texas A\&M University-Which Fiscal Levers Are Most Effective in Combating a Recession?

ALAN AUERBACH, University of California-Berkeley, YURIY GORODNICHENKO, University of California-Berkeley, and DANIEL MURPHY, University of Virginia-Effects of Fiscal Policy on Credit Markets

OLIVIER BLANCHARD, Peterson Institute for International Economics, and LAWRENCE SUMMERS, Harvard University-

Stabilizers: Automatic and Semi-Automatic

KAREN DYNAN, Harvard University, and DOUGLAS ELMENDORF, Harvard University-Fiscal Policy to Reduce Cyclical Volatility in United States

Discussants: JANICE EBERLY, Northwestern University

GABRIEL CHODOROW-REICH, Harvard University

\section{8:00 AM Marriott Marquis San Diego-Balboa} AEA

\section{Crime and Law Enforcement (D7)}

Presiding: DAVID RIVERS, Western University

ANNA E. KYRIAZIS, University of Illinois-Urbana-ChampaignDo Concealed Carry Laws Affect Police Shootings? 


\section{Saturday $\cdot$ January 4}

CHRISTOPHE BELLÉGO, CREST-ENSAE, and JOEFFREY DROUARD, University of Rennes 1 and CREM-Does It Pay to Fight Crime? Evidence from the Pacification of Slums in Rio de Janeiro

CAMILO GARCIA-JIMENO, Federal Reserve Bank of Chicago, and ALBERTO CIANCIO, University of Pennsylvania-The Political Economy of Immigration Enforcement: Conflict and Cooperation under Federalism

ALAN BARTLEY, Transylvania University, and GEOFFREY WILLIAMS, Transylvania University-Young Men, Cheap Guns, and the Crime Wave of the 1960s and 1970s

EMILY NIX, University of Southern California, MARTTI KAILA, University of Helsinki, KRISTIINA HUTTUNEN, VATT Institute for Economic Research, and TUOMAS KOSONEN, Labour Institute for Economic Research-The Impact of Punishments on Defendants and Their Families

EVGENIA DECHTER, University of New South Wales, PHILIPPE BELLEY, Kansas State University, and GONZALO CASTEX, University of New South Wales-The Changing Determinants of Juvenile Crime: Evidence from Micro Data

\section{8:00 AM Marriott Marquis San Diego-Newport Beach} AEA

Differential Treatment: The Role of Gender, Race, Ideology, and Affirmative Action (J1)

Presiding: GARY HOOVER, University of Oklahoma

AMANDA BAYER, Swarthmore College, GARY HOOVER, University of Oklahoma, and EBONYA WASHINGTON, Yale University—How to Increase Racial/Ethnic Diversity in Economics MOHSEN JAVDANI, University of British Columbia, and HA-JOON CHANG, Cambridge University-Who Said or What Said? Estimating Ideological Bias in Views among Economists

SHALISE AYROMLOO, University of Illinois-Chicago-Losers Weepers? The Impact of Local Labor Demand Shocks on Gender Attitudes

EMIL TEMNYALOV, University of Technology Sydney-An Economic Theory of Differential Treatment 


\section{Saturday $\cdot$ January 4}

Discussants: GARY HOOVER, University of Oklahoma

MOHSEN JAVDANI, University of British Columbia

SHALISE AYROMLOO, University of Illinois-Chicago

EMIL TEMNYALOV, University of Technology Sydney

\section{8:00 AM Marriott Marquis San Diego-Solana}

AEA

\section{Fertility Issues (J1)}

Presiding: ANALISA PACKHAM, Vanderbilt University

AURELIA LEPINE, University College London, BEN D'EXELLE, University of East Anglia, RICHARD BAKYONO, Centre Muraz, and LUDOVIC TAPSOBA, Centre Muraz-Polygyny, Men's Involvement and Fertility: Evidence from a Field Experiment in Rural Burkina Faso

JASON M. LINDO, Texas A\&M University, and MAYRA BELINDA PINEDA TORRES, Texas A\&M University-Reassessing the Effects of Mandatory Waiting Periods for Abortion

NATALIA CANTET, University of Illinois-Urbana-Champaign-

The Causal Effects of Adolescent Pregnancy: Evidence from South Africa

RONEN BAR-EL, Open University of Israel, YOSSEF TOBOL, Jerusalem College of Technology, and YUVAL ARBEL, Western Galilee College-The Demand for Private Deliveries and the Willingness to Pay for Cesarean Sections

ANDREW W. STEVENS, University of Wisconsin-Madison, and BETTY THOMAS, Mississippi State University-The Effects of Mandatory Sex-Education on Teenage Birth Rates in Mississippi

\section{8:00 Ам Marriott Marquis San Diego-Marriott Grand Ballroom 13 \\ AEA}

Financial Networks, Regulation, and Systemic Risk (G1)

Presiding: MICHAEL KILEY, Federal Reserve Board 


\section{Saturday $•$ January 4}

MATTHEW O. JACKSON, Stanford University, and AGATHE PERNOUD, Stanford University-Optimal Regulation and Bailouts in Financial Networks

BENJAMIN BERNARD, National Taiwan University, AGOSTINO CAPPONI, Columbia University, and JOSEPH E. STIGLITZ, Columbia University-Bail-ins and Bail-outs: Incentives, Connectivity, and Systemic Stability

CARLOS A. RAMIREZ, Federal Reserve Board-Regulating Financial Networks Under Uncertainty

CELSO BRUNETTI, Federal Reserve Board, JEFFREY $\mathrm{H}$. HARRIS, American University, and SHAWN MANKAD, Cornell University-Bank Holdings and Systemic Risk

Discussants: CO-PIERRE GEORG, University of Cape Town, Deutsche Bundesbank, \& Massachusetts Institute of Technology

ANA BABUS, Washington University-St. Louis

ALIREZA TAHBAZ-SALEHI, Northwestern University

FILIP ZIKES, Federal Reserve Board

\section{8:00 AM Marriott Marquis San Diego-Coronado Room AEA}

\section{FinTech for Macroeconomists (E2)}

Presiding: FRANCESCO D'ACUNTO, Boston College

MICHAELAPAGEL, Columbia University, and ARNA OLAFSSON, Copenhagen Business School-Borrowing in Response to Windfalls SUMIT AGARWAL, National University of Singapore, WENLAN QIAN, National University of Singapore, YUAN REN, National University of Singapore, and BERNARD YEUNG, National University of Singapore-The Value of Mobile Payment Technology FRANCESCO D'ACUNTO, Boston College, THOMAS RAUTER, University of Chicago, CHRISTOPH SCHEUCH, Vienna University of Economics and Business, and MICHAEL WEBER, University of Chicago-Perceived Precautionary Savings Motives: Evidence from FinTech 


\section{Saturday $\cdot$ January 4}

Discussants: ALBERTO G. ROSSI, Georgetown University

FILIPPO MEZZANOTTI, Northwestern University

MARCO DIMAGGIO, Harvard University

\section{8:00 AM Marriott Marquis San Diego-Marina Ballroom D AEA}

Gendered Effects on Wages, Employment, and Prices (J7)

Presiding: JENNIFER DOLEAC, Texas A\&M University

BARBARA BIASI, Yale University, and HEATHER SARSONS, University of Toronto-Flexible Pay, Bargaining, and the Gender Gap

VALENTIN BOLOTNYY, Harvard University, and NATALIA EMANUEL, Harvard University-Why Do Women Earn Less Than Men? Evidence from Bus and Train Operations

LAURA GEE, Tufts University, AMANDA AGAN, Rutgers University, and BO COWGILL, Columbia University-Salary Disclosure and Hiring: Field Experimental Evidence from a Two-Sided Audit Study

MARGARITA MACHELETT, Bank of Spain-Gender Price Gaps and Competition: Evidence from a Correspondence Study

Discussants: NICOLE FORTIN, University of British Columbia

THOMAS LEMIEUX, University of British Columbia

JENNIFER DOLEAC, Texas A\&M University

MATTHEW NOTOWIDIGDO, Northwestern University

8:00 AM Marriott Marquis San Diego-Marriott Grand Ballroom 2 AEA

\section{Has the Global Financial Cycle Changed Since the Crisis? (F3)}

Presiding: SILVIA MIRANDA-AGRIPPINO, Bank of England and Northwestern University

KRISTIN FORBES, Massachusetts Institute of Technology-The Global Financial Cycle and Capital Flows: Ripples instead of Waves 


\section{Saturday $\cdot$ January 4}

PRACHI MISHRA, Goldman Sachs, and RAGHURAM RAJAN, University of Chicago-Financial Sector Spillovers from Monetary Policies at the Core

HELENE REY, London Business School, and SILVIA MIRANDAAGRIPPINO, Bank of England and Northwestern UniversityAnatomy of the Global Financial Cycle

BURCU ERIK, Bank for International Settlements, MARCO LOMBARDI, Bank for International Settlements, DUBRAVKO MIHALJEK, Bank for International Settlements, and HYUN SONG SHIN, Bank for International Settlements-Nowcasting Economic Activity with Indicators of Global Financial Conditions

Discussants: RICHARD CLARIDA, Federal Reserve Board

EDUARD LEVY-YEYATI, Harvard University

\section{8:00 AM Marriott Marquis San Diego-Marina Ballroom F AEA}

\section{Identification in Macro-Finance: Recent Advances (E0)}

Presiding: EMI NAKAMURA, University of California-Berkeley

ADAM GUREN, Boston University, ALISDAIR MCKAY, Federal Reserve Bank of Minneapolis, EMI NAKAMURA, University of California-Berkeley, and JON STEINSSON, University of California-Berkeley-What Do We Learn from Cross-Sectional Empirical Estimates in Macroeconomics?

SYDNEY LUDVIGSON, New York University, SAI MA, Federal Reserve Board, and SERENA NG, Columbia University-Shock Restricted Structural Vector Autoregressions

PAUL GOLDSMITH-PINKHAM, Yale University, ISAAC SORKIN, Stanford University, and HENRY SWIFT, Independent Researcher-Bartik Instruments: What, When, Why, and How?

XAVIER GABAIX, Harvard University, and RALPH KOIJEN, University of Chicago_-Granular Instrumental Variables

Discussants: ADRIEN AUCLERT, Stanford University

HARALD UHLIG, University of Chicago

RODRIGO ADAO, University of Chicago

GUIDO IMBENS, Stanford University 


\section{Saturday $•$ January 4}

8:00 АM Marriott Marquis San Diego-Marriott Grand Ballroom 3 AEA

\section{Immigration and Assimilation (J1)}

Presiding: LEAH BOUSTAN, Princeton University

ALBERTO ALESINA, Harvard University, and STEFANIE STANTCHEVA, Harvard University-Perceptions of Immigrants and Support for Immigration

EDWARD LAZEAR, Stanford University-Rationing Determines Immigrant Composition and Outcomes

RAN ABRAMITZKY, Stanford University, LEAH BOUSTAN, Princeton University, KATHERINE ERIKSSON, University of California-Davis, and STEPHANIE HAO, Princeton UniversityDiscrimination, Assimilation and Immigrant Outcomes in the Age of Mass Migration

Discussant: MICHAEL CLEMENS, Center for Global Development

\section{8:00 AM Marriott Marquis San Diego-Marriott Grand}

Ballroom 12

AEA

\section{Machine Learning in Experiments (C9)}

Presiding: JEFFREY NAECKER, Wesleyan University

ANNIE LIANG, University of Pennsylvania, and DREW FUDENBERG, Massachusetts Institute of Technology—Predicting and Understanding Initial Play

COLIN CAMERER, California Institute of Technology, JUAN PABLO FRANCO, University of Melbourne, GIDEON NAVE, University of Pennsylvania, and ALEC SMITH, Virginia TechMachine Learning of Behavior and Biomarkers to Predict Outcomes and Hidden States in Bargaining

JOHN CLITHERO, University of Oregon, JAE JOON LEE, Claremont Graduate University, and JOSHUA TASOFF, Claremont Graduate University-Supervised Machine Learning for Eliciting Individual Demand 


\section{Saturday $•$ January 4}

B. DOUGLAS BERNHEIM, Stanford University, CHRISTINE EXLEY, Harvard Business School, JEFFREY NAECKER, Wesleyan University, and CHARLES SPRENGER, University of California-San Diego-The Model You Know: Benchmarks for Models of Risk Preferences

Discussants: MONICA CAPRA, Claremont Graduate University

GREG DEANGELO, Claremont Graduate University

BEN GILLEN, Claremont McKenna College

ALEC SMITH, Virginia Tech

\section{8:00 AM Marriott Marquis San Diego-Marriott Grand Ballroom 4 AEA}

Matching under Inequality: Implications for Policy (D4)

Presiding: RAJ CHETTY, Harvard University

RYAN KIM, Johns Hopkins University, and JONATHAN VOGEL, University of California-Los Angeles-Trade and Inequality across Local Labor Markets: The Margins of Adjustment

RAJ CHETTY, Harvard University, DAVID DEMING, Harvard University, and JOHN N. FRIEDMAN, Brown University-College Admissions at Selective Schools

MOHAMMAD AKBARPOUR, Stanford University, PIOTR DWORCZAK, Northwestern University, and SCOTT DUKE KOMINERS, Harvard Business School-Redistribution in Matching Markets

RAVI JAGADEESAN, Harvard Business School-Capital Mismatch and the Form of Capital Taxation

Discussants: COSTAS MEGHIR, Yale University

LAWRENCE BLUME, Cornell University

PIOTR DWORCZAK, Northwestern University 


\section{Saturday $•$ January 4}

\section{8:00 AM Marriott Marquis San Diego-Marriott Grand}

Ballroom 10

AEA

Measuring and Understanding Violence against Women (VAW) in Developing Countries (O0)

Presiding: VERONICA FRISANCHO, Inter-American Development Bank

ERICA FIELD, Duke University, JORGE AGUERO, University of Connecticut, URSULA ALDANA, Institute of Peruvian Studies, VERONICA FRISANCHO, Inter-American Development Bank, and JAVIER ROMERO HAAKER, Duke University-Measurement Error in Self-Reported Data: Experimental Evidence for Intimate Partner Violence

MANUELA ANGELUCCI, University of Texas-Austin, and RACHEL HEATH, University of Washington-Women Empowerment Programs and Domestic Violence

DONALD P. GREEN, Columbia University, ANNA WILKE, Columbia University, and JASPER COOPER, Columbia University-Countering Violence against Women at Scale: A Mass Media Experiment in Rural Uganda

JOHANNES HAUSHOFER, Princeton University, CHARLOTTE RINGDAL, Norwegian School of Economics, JEREMY P. SHAPIRO, Busara Center for Behavioral Economics, and XIAO YU WANG, Duke University-Income Changes and Intimate Partner Violence: Evidence from Unconditional Cash Transfers in Kenya

Discussants: JOHANNES HAUSHOFER, Princeton University

DONALD P. GREEN, Columbia University

MANUELA ANGELUCCI, University of Texas-Austin

ERICA FIELD, Duke University

\section{8:00 AM Marriott Marquis San Diego-Torrey Pines 1 AEA}

Physician Behavior (I1)

Presiding: MARIANA CARRERA, Montana State University

BECKY STAIGER, Yale University-Better than Random Matching of Patients to Physicians and Its Effects on Utilization and Health Outcomes 


\section{Saturday $\cdot$ January 4}

MYLENE LAGARDE, London School of Economics and Political Science, and DUANE BLAAUW, University of WitwatersrandDo Pro-Social and Financial Concerns Reduce the Provision of Unnecessary Medical Treatment? Evidence from South Africa

ALEXANDER L.P. WILLEN, Norwegian School of Economics, JULIE RIISE, University of Bergen, and BARTON WILLAGE, Louisiana State University-Do Same-Sex Role Models Matter outside the Classroom? Evidence from Doctor-Patient Interactions

ARMANDO N. MEIER, University of Chicago, ZIAD OBERMEYER, University of California-Berkeley, DEVIN G. POPE, University of Chicago, and KEVIN VOLPP, University of Pennsylvania-Medical Guidelines and Doctor Behavior

JOSHUA TIBBITTS, Washington State University, JILL J. MCCLUSKEY, Washington State University, RON MITTELHAMMER, Washington State University, and JONATHAN YODER, Washington State University-The Economics of Pain and Addiction

\section{8:00 AM Marriott Marquis San Diego-Marriott Grand Ballroom 11 \\ AEA}

\section{Pink Papers: LGBT Economics (J7)}

Presiding: LEE BADGETT, University of Massachusetts-Amherst

IAN BURN, Stockholm University, and MICHAEL MARTELL, Bard College-The Effect of Gender Nonconformity on Labor Market and Health Outcomes

MIGUEL SARZOSA, Purdue University-Unobserved Heterogeneity and Labor Market Discrimination against Homosexuals

DARIO SANSONE, Vanderbilt University-LGBT Students: New Evidence on Demographics and Educational Outcomes

SCOTT DELHOMMER, University of Texas-Austin-Sexual Orientation Discrimination in the Workplace

Discussants: MICHAEL MARTELL, Bard College

CHER HSUEH-HSIANG LI, Colorado State University

JOSEPH SABIA, San Diego State University

CHRISTOPHER SCOTT CARPENTER, Vanderbilt University 


\section{Saturday $\cdot$ January 4}

\section{8:00 AM Marriott Marquis San Diego-Presidio 1-2}

AEA

\section{Private and Social Learning in Oil and Gas Extraction (Q4)}

Presiding: MARK AGERTON, University of California-Davis

T. ROBERT FETTER, Duke University, ANDREW STECK, University of Toronto, CHRISTOPHER TIMMINS, Duke University, and DOUGLAS H. WRENN, Pennsylvania State UniversityLearning by Viewing? Social Learning, Regulatory Disclosure and Firm Productivity in Shale Gas

THOMAS R. COVERT, University of Chicago, and RICHARD L. SWEENEY, Boston College-Well Confidentiality Laws and Oil and Gas Investment

ANDREW STECK, University of Toronto-Industry Dynamics with Social Learning: Evidence from Hydraulic Fracturing

CHARLES HODGSON, Yale University-Information Externalities, Free Riding, and Optimal Exploration in the UK Oil Industry

MARK AGERTON, University of California-Davis-Learning Where to Drill: Drilling Decisions and Geological Quality in the Haynesville Shale

Discussants: TIMOTHY FITZGERALD, Texas Tech University

PETER MANILOFF, Colorado School of Mines

PETER THOMPSON, Georgia Institute of Technology

KENNETH HENDRICKS, University of Wisconsin-Madison

LUCIJA MUEHLENBACHS, University of Calgary

\section{8:00 AM Marriott Marquis San Diego-Del Mar AEA}

\section{Team-Based Learning in Economics (A2)}

Presiding: WILLIAM GOFFE, Pennsylvania State University

PHIL RUDER, Pacific University, MARK MAIER, Glendale Community College, and SCOTT SIMKINS, North Carolina A\&T State University—Getting the Incentives Right: Learning Science and Team-Based Learning in Economics 


\section{Saturday $•$ January 4}

ALAN GREEN, Stetson University—TBL Fridays: Using Policy Applications for Effective Team-Based Learning in an Introductory Class

MARCELO CLERICI-ARIAS, Stanford University-Underrepresented Groups in the Economics Major: The Impact of Using Team-Based Learning in the Principles Course

KATHERINE SILZ-CARSON, United States Air Force AcademyResults of a Multi-Site Evaluation of Team-Based Learning

Discussants: WILLIAM GOFFE, Pennsylvania State University

W. EDWARD CHI, Cerritos College

AMBER CASOLARI, Riverside City College

JENNIFER IMAZEKI, San Diego State University

\section{8:00 AM Manchester Grand Hyatt San Diego-Gaslamp D}

\section{AERE}

\section{Social Costs of Air Pollution (Q5)}

Presiding: PATRICK BAYLIS, University of British Columbia

BRIAN PREST, Resources for the Future, and ALAN KRUPNICK, Resources for the Future-How Clean is "Refined Coal"? An Empirical Assessment of a Billion-Dollar Tax Credit

YAZHEN GONG, Renmin University of China, SHANJUN LI, Cornell University, NICHOLAS J. SANDERS, Cornell University, and GUANG SHI, Development Research Center of the State Council-The Mortality Impact of Fine Particulate Matter in China ALEX HOLLINGSWORTH, Indiana University, and IVAN RUDIK, Cornell University-The Social Cost of Leaded Gasoline: Evidence from Regulatory Exemptions

YIREN WANG, Duke University-The Impact of Ambient Air Pollution on Chinese Expressed Happiness through Social Media

Discussants: GLENN SHERIFF, Arizona State University

JESSAMYN SCHALLER, Claremont McKenna College

KAREN CLAY, Carnegie Mellon University

PATRICK BAYLIS, University of British Columbia 


\section{Saturday $\cdot$ January 4}

8:00 AM Manchester Grand Hyatt San Diego-Seaport \& Palm Foyers

AFA

\section{AFA Ph.D. Student Poster Session (G0)}

Presiding: JOHN GRAHAM, Duke University

OLIVIER DAVID ZERBIB, Tilburg University-A Sustainable Capital Asset Pricing Model (S-CAPM): Evidence from Green Investing and Sin Stock Exclusion

TENGFEI ZHANG, Louisiana State University, JUNBO WANG, Louisiana State University, KUNTARA PUKTHUANTHONG, University of Missouri, and RICHARD ROLL, California Institute of Technology-A Tool Kit for Factor-Mimicking Portfolios

XIANGSHANG CAI, University of Manchester, AMEDEO DE DESARI, University of Manchester, NING GAO, University of Manchester, and NI PENG, Queen Mary University of LondonAcquisitions and Technology Value Revision

VESA PURSIAINEN, Imperial College London and University of Hong Kong-Alternative Facts in Peer-to-Peer Loans? Borrower Misreporting Dynamics and Implications

ERIC THAM, EDHEC-Ambiguous Text

ANDREAS KNETSCH, RWTH Aachen University-An Empirical Investigation of Short-Termist Investment: The Case of Corporate Investment Horizons

DEXIN HOU, Tsinghua University, JIE LI, Shanghai Jiao Tong University, LI LIAO, Tsinghua University, and HONG ZHANG, Tsinghua University-Asset Pricing on Blockchain: Slow Moving Capital, Crypto-Momentum, and Bubbles

OLGA BRIUKHOVA, University of Zurich and Swiss Finance Institute, MICHELE PELLI, University of Zurich and Swiss Finance Institute, and CHRISTOPH BASTEN, University of Zurich-Bank Capital Requirements and Asset Prices: Evidence from the Swiss Real Estate Market

KERRY SIANI, Columbia University-Bank Intermediation in Corporate Bond Issuance

GAZI KABAS, University of Zurich and Swiss Finance Institute, and SEBASTIAN DOERR, University of Zurich-Banking on Demography: Population Aging and Financial Integration 


\section{Saturday $•$ January 4}

WENQIAN HUANG, Bank for International Settlements, ALBERT MENKVELD, VU University Amsterdam, and SHIHAO YU, VU University Amsterdam-Central Counterparty Exposure in Stressed Markets

TARUN PATEL, University of Washington-Commissions and Investment Adviser Misconduct

EYUB YEGEN, University of Toronto-Common-Ownership and Portfolio Rebalancing

QIANQIAN HUANG, City University of Hong Kong, and BIN YANG, City University of Hong Kong-Competition and Product Development Innovation: The Case of Newly Launched Trademarks SCOTT GUERNSEY, University of Cambridge-Competition, Non-Patented Innovation, and Firm Value

KONSTANTIN BRÄUER, Goethe University Frankfurt, ANDREAS HACKETHAL, Goethe University Frankfurt, and TOBIN HANSPAL, Goethe University Frankfurt-Consuming Dividends

DAVID XIAOYU XU, University of Texas-Costly Information Acquisition and Investment Decisions: Quasi-Experimental Evidence HWAGYUN (HAGEN) KIM, Texas A\&M University, JU HYUN KIM, Sungkyunkwan University, and HEUNGJU PARK, Sungkyunkwan University-Credit Information Uncertainty and Corporate Bond Prices

MAXIMILLIAN LITTLEJOHN, University of California-IrvineCredit Supply Decomposition and Real Activity

MANUEL AMMANN, University of St. Gallen, and MATHIS MOERKE, University of St. Gallen-Credit Variance Risk Premiums

DANIEL TUT, York University-Creditor Rights, Debt Capacity and Securities Issuance: Evidence from Anti-recharacterization Laws

CONSTANTINOS ANTONIOU, University of Warwick, CARINA CUCULIZA, University of Miami, ALOK KUMAR, University of Miami, and LIZHENGBO YANG, University of WarwickCultural Distance in Family and Corporate Risk-taking 


\section{Saturday $\cdot$ January 4}

DANIELA SCHOCH, LMU Munich-Data Economy and M\&A

MATTHEW HENRIKSSON, University of South FloridaDisastrous Selling Decisions: The Disposition Effect and Natural Disasters

NAGIHAN MIMIROGLU, Maastricht University-Distance Effects in CMBS Loan Pricing: Banks versus NonBanks

BAO DOAN, University of New South Wales-Distinct Roles of Risk and Uncertainty: Evidence from Trading around U.S. Macro News

SHUYI CHENG, City University of Hong Kong-Do Banks Help Corporate Tax Avoidance? Evidence from Simultaneous DebtEquity Holding

ROBERT BIRD, University of Connecticut, PAUL BOROCHIN, University of Miami, JOHN KNOPF, University of Connecticut, and LUCHUN MA, University of Connecticut-Do Boards Have Style? Evidence from Director Style Divergence and Board Turnover

NEGAR GHANBARI, Norwegian School of Economics-Do Creditor Rights affect Financial Contracts? Evidence from the AntiRecharacterization Statute

JINFEI SHENG, University of California-Irvine, YUKUN LIU,

University of Rochester, and WANYI WANG, University of California-Irvine-Do Digital Coins Have Fundamental Values? Evidence from Machine Learning

SUNNY (SEUNG YEON) YOO, University of Southern CaliforniaDo Firms Leave Workers in the Dark Before Wage Negotiations?

BALBINDER SINGH GILL, Temple University-Do Natural Disasters Bias Creditors?

RUMPA BISWAS, University of New Orleans-Does Economic Policy Uncertainty Affect Analyst Forecast Accuracy?

TUNG NGUYEN, University of Surrey, DIMITRIS PETMEZAS, University of Surrey, and NIKOLAOS KARAMPATSAs, University of Surrey-Does Safety Uncertainty Affect Acquisitions?

CHRISTINA E. BANNIER, Justus Liebig University Giessen, YANNIK BOFINGER, Justus Liebig University Giessen, and BJOERN ROCK, Justus Liebig University Giessen-Doing Safe by Doing Good: Risk and Return of ESG Investing in the U.S. and Europe 


\section{Saturday $•$ January 4}

VINCENT TENA, Toulouse School of Management-Dynamic Contracting with a Forthcoming Technology of Automation

JUAN CHEN, London School of Economics-Dynamic Financing and Pricing of the Platform Market

ZHANGKAI HUANG, Tsinghua University, GORDON PHILLIPS, Dartmouth College, and JIALUN YANG, Tsinghua UniversityEducation and Innovation: The Long Shadow of the Cultural Revolution

PEDRO TREMACOLDI-ROSSI, University of Illinois-UrbanaChampaign-Electronic Trading and Traders

HONGWEI ZHANG, Tilburg University and Central University of Finance and Economics-Ensemble Machine Learning and Stock Return Predictability

JIE CAO, Chinese University of Hong Kong, SHERIDAN TITMAN, University of Texas-Austin, XINTONG ZHAN, Chinese University of Hong Kong, and WEIMING ZHANG, Chinese University of Hong Kong-ESG Preference and Market Efficiency: Evidence from Mispricing and Institutional Trading

CHONG MENG, University of Alberta-Excess Proceeds in the Equity Financing Process

MORITZ DRECHSEL-GRAU, University of Mannheim, and FABIAN GREIMEL, University of Mannheim-Falling Behind: Has Rising Inequality Fueled the American Debt Boom 1980-2007? JONATHAN ZANDBERG, Boston College-Family Comes First: Reproductive Rights and the Gender Gap in Entrepreneurship

STEFAN MORKOETTER, University of St. Gallen, TOBIAS SCHORI, University of St. Gallen, and THOMAS ZELLWEGER, University of St. Gallen-Family Ties and Insider Trading: A Closer Look at Family Firms

ISHITA SEN, Harvard University, and VARUN SHARMA, London Business School—Financial Constraints and Pricing Flexibility

SHIQI CHEN, University of Cambridge, and BART LAMBRECHT, University of Cambridge-Financial Policies and Internal Governance with Heterogeneous Risk Preferences

MINJAE KOO, University of Houston-Fire Sales, Fair Value Estimation, and Impairment Recognition of Downgraded Securities 


\section{Saturday $•$ January 4}

YE WANG, University of Arizona-Firm Reputation and the Cost of Bank Debt

EMESE LAZAR, University of Reading, and XIAOHAN XUE, University of Reading-Forecasting Risk Measures Using Intraday Data in a Generalized Autoregressive Score (GAS) Framework

AZI BEN-REPHAEL, Rutgers University, XI DONG, City University of New York-Baruch College, MASSIMO MASSA, INSEAD, and CHANGYUN ZHOU, City University of New YorkBaruch College-Foreign Sentiment

OZGUR ARSLAN-AYAYDIN, University of Illinois-Chicago, PRABAL SHRESTHA, KU Leuven, JAMES THEWISSEN, KU Leuven, and WOUTER TORSIN, KU Leuven-Formal Institutions, Culture, and Initial Coin Offerings: A Cross-Country Analysis

LUCA X. LIN, IESE Business School, University of NavarraFriends with Threats: Credit Risk Under Common Ownership

SUMIT AGARWAL, National University of Singapore, YU QIN, National University of Singapore, TIEN FOO SING, National University of Singapore, and XIAOYU ZHANG, National University of Singapore-Golfing for Information: Social Interactions and Economic Consequences

YENAN WANG, Duke University-High-Frequency Trading, Endogenous Capital Commitment and Market Quality

LU LIU, Imperial College London-House Price Risks and Mortgage Choice

DANYING FU, University of Oxford, TIM JENKINSON, University of Oxford, and CHRISTIAN RAUCH, Goethe University Frankfurt-How do Financial Contracts Evolve for New Ventures?

ABENA OWUSU, Rensselaer Polytechnic Institute-How Have Stock Markets Responded to 35 Years of Analyst Reports? Evidence from Machine Learning and Textual Analysis

HANS DEGRYSE, KU Leuven and CEPR, YALIN GUNDUZ, Deutsche Bundesbank, KUCHULAIN O'FLYNN, University of Zurich, and STEVEN ONGENA, University of Zurich-Identifying Empty Creditors with a Shock and Micro-Data

BENNY HARTWIG, Deutsche Bundesbank, CHRISTOPH MEINERDING, Deutsche Bundesbank, and YVES SCHUELER, Deutsche Bundesbank-Identifying Indicators of Systemic Risk 


\section{Saturday $•$ January 4}

IVAN BRICK, Rutgers University, DARIUS PALIA, Rutgers University, and YANKUO QIAO, Rutgers University-Impact of Internal Governance on a CEO's Investment Cycle

STEVEN WEI HO, Columbia University, and MINGRUI ZHANG, Columbia University-Information Leakage Prior to SEC Form Filings - Evidence from TAQ Millisecond Data

ANDREY PANKRATOV, USI Lugano and Swiss Finance Institute-Information Leakages, Distribution of Profits from Informed Trading, and Last Mover Advantage

SUNGJOUNG KWON, Drexel University-Inorganic Growth in Innovative Firms: Evidence from Patent Acquisitions

ZIHAN YE, Pennsylvania State University-Inter-county Economic Growth and Municipal Access to Finance: Does Your Neighbor's Credit Rating Matter?

ZHI DA, University of Notre Dame, JIAN HUA, City University of New York-Baruch College, CHIH-CHING HUNG, City University of New York-Baruch College, and LIN PENG, City University of New York-Baruch College-Investor Attention and Market Return Predictability

CHANGTAI LI, Nanyang Technological University, SOOK REI TAN, Nanyang Technological University, SY HA HO, Nanyang Technological University, and WAI MUN CHIA, Nanyang Technological University-Investor Sentiment, Behavioral Heterogeneity and Stock Market Dynamics

JUN MA, University of Auckland-Is Anti-herding Always a Smart Choice? Evidence from Mutual Funds

STEFAN LEE, EAESP-FGV, and WILLIAM EID JR., FGV/ EAESP-Is Cross-hedging an Optimal Hedging Strategy for Commodity Currencies?

CHANG SUK BAE, University of Pittsburgh-Is Innovation Always Beneficial? Externalities of Innovation on Product Market Relationship

GE YANG, National University of Singapore-Is Mandatory Board Gender Quota Costly? Insights from Insiders' Trades

ANUP AGRAWAL, University of Alabama, and MEHRAN AZIMI, University of Alabama-Is Positive Sentiment in Corporate Annual Reports Informative? Evidence from Deep Learning 


\section{Saturday $•$ January 4}

SPENCER BARNES, Florida State University-Is There Value in Employee Opinion? The Effect of CEO Employee Approval on Financial Outcomes

NICOLE BRANGER, University of Muenster, RENÉ FLACKE, University of Muenster, and FREDERIK MIDDELHOFF, University of Muenster-Jumps and the Correlation Risk Premium: Evidence from Equity Options

ROB BAUER, Maastricht University, JEROEN DERWALL, Maastricht University, and COLIN TISSEN, Maastricht UniversityLegal Origins and Institutional Investors' Support for CSR

MONICA BILLIO, Università Ca' Foscari Venezia, ALFONSO DUFOUR, University of Reading, ANA SINA, University of Reading, and SIMONE VAROTTO, University of ReadingLeveraged Loans, Systemic Risk and Network Interconnectedness

REED DOUGLAS, University of Southern California-Linear Betas in the Cross-Section of Asset Returns

MARCEL FISCHER, Copenhagen Business School, ROLAND FÜSS, University of St. Gallen, and SIMON STEHLE, University of Konstanz-Local House Price Comovements

HAN MA, Georgia State University-Local Spillover of M\&As

KRISTY JANSEN, Tilburg University-Long-term Investors and the Yield Curve

DÉSIRÉE-JESSICA PÉLY, Ludwig-Maximilians-Universität München-Managerial Bullshitting and Shareholders' Cognitive Processing Abilities: Evidence from M\&As

TRI VI DANG, Columbia University, YOUAN WANG, University of Hong Kong, and ZIGAN WANG, University of Hong KongMandatory Pollution Abatement, Environmental Awareness, and Firm Investment

JINMING XUE, University of Maryland-College Park-Measuring Customer Liquidity Provision in the Corporate Bond Market

QINGJIE DU, Hong Kong Polytechnic University-Moonshots: Speculative Trading, Bitcoin, and Stock Returns

YUSHI PENG, University of Zurich-Mortgage Credit and Housing Markets

JEFFREY BUSSE, Emory University, JING DING, Tsinghua University, LEI JIANG, Tsinghua University, and KE WU, Renmin University of China-Mutual Fund Market Timing: Daily Evidence 


\section{Saturday $•$ January 4}

KHALADDIN RZAYEV, University of Edinburgh-Need for Speed? International Transmission Latency, Liquidity and Volatility YA KANG, National University of Singapore-On the Effect of Institution of Racial Inequality: Trump Election and Minority CEO Pessimism

XIAOTIAN LIU, City University of Hong Kong-One Man's Meat, Another's Poison: Spillover Effect of Bank-Firm Common Ownership

URBAN ULRYCH, University of Zurich and Swiss France Institute, and NIKOLA VASILJEVIĆ, University of Zurich-Optimal Currency Exposure Under Risk and Ambiguity Aversion

STEVEN WEI HO, Columbia University, and YUTONG HU, London Business School—Option Return Predictability, a MachineLearning Approach

FRANCESCA BASTIANELLO, Harvard University, and PAUL FONTANIER, Harvard University_Partial Equilibrium Thinking in General Equilibrium

XIAO ZHONG, University of Utah-Performance-vesting Compensation and Firm Investment/Financing Decisions

THUONG HARVISON, University of Arizona-Political Connections and Insider Trading

TIANYUE ZHAO, University of Pittsburgh—Predatory Trading in Mutual Funds

FARSHID ABDI, University of Massachusetts-Amherst, and BOTAO WU, New York University-Pre-FOMC Information Asymmetry

SHIYANG HUANG, University of Hong Kong, TSE-CHUN LIN, University of Hong Kong, and HONG XIANG, University of Hong Kong-Psychological Barrier and Cross-firm Return Predictability JINGZHI HUANG, Pennsylvania State University, XIN LI, University of Cincinnati, MEHMET SAGLAM, University of Cincinnati, and TONG YU, University of Cincinnati-Rainy Day Liquidity

GREG TINDALL, Florida Atlantic University—Real Effects of Shareholder Proposals in the Context of Climate Change

KHALED ALSABAH, University of Colorado-Regulation and Initial Capital Structure: Evidence from the JOBS Act 


\section{Saturday $\cdot$ January 4}

CHASE ROSS, Yale University-Safe Asset Migration

BENJAMIN LOOS, University of Mannheim, STEFFEN MEYER, University of Southern Denmark \& Danish Finance Institute, CHARLINE UHR, Goethe University Frankfurt, and ANDREAS HACKETHAL, Goethe University Frankfurt-Same Bank, Same Client but Different Costs: How do Flat-fees for Mutual Funds affect Retail Investor Portfolios?

DENNIS VINK, Nyenrode Business Universiteit, MIKE NAWAS, Nyenrode Business Universiteit, and VIVIAN VAN BREEMEN, De Nederlandsche Bank-Security Design and Credit Rating Risk in the CLO Market

MOHAMMAD GHADERI, University of Houston, METE KILIC, University of Southern California, and SANG BYUNG SEO, University of Houston-Slowly Unfolding Disasters

AN (ALLEN) HU, Yale University, and SONG MA, Yale University—Social Psychology Determinants of VC Investment: A Study Using Video Data and Machine Learning

YUJING GONG, University of Warwick-Speculator Spreading Pressure and the Commodity Futures Risk Premium

DIANA MIKHAIL, Carnegie Mellon University-Speed of

Financial Contagion and Optimal Timing for Intervention

RUSTAM JAMILOV, London Business School—Systemic Cyber Risk

LI-TING CHIU, SUNY-Buffalo-The Bond Investor's Trading Horizon and the Cost of Debt

LIRA MOTA, Columbia University-The Corporate Supply of (Quasi) Safe Assets

SABINE BERNARD, University of Mannheim, BENJAMIN LOOS, University of Technology Sydney, and MARTIN WEBER, University of Mannheim-The Disposition Effect in Boom and Bust Markets

MRINAL MISHRA, University of Zurich and Swiss Finance Institute, and STEVEN ONGENA, University of Zurich-The Effect of Conflict on Lending: Empirical Evidence from Indian Border Areas

ROMORA SITORUS, University of Oklahoma-The Effect of Policy Uncertainty on VC Investments Around the World 


\section{Saturday $\cdot$ January 4}

HEINER BECKMEYER, University of Muenster, NICOLE BRANGER, University of Muenster, and THOMAS GRÜNTHALER, University of Muenster-The Fed Call: FOMC Announcements and Stock Market Uncertainty

ROMULO ALVES, Erasmus University Rotterdam, and MARTA SZYMANOWSKA, Erasmus University Rotterdam-The Information Content of Commodity Futures Markets

VALERIYA DINGER, University of Osnabrueck, CHRISTIAN SCHMIDT, University of Mannheim, and ERIK THEISSEN, University of Mannheim-The Real Effects of Distressed Bank Mergers

THOMAS CHEMMANUR, Boston College, KAREN SIMONYAN, Suffolk University, YU WANG, Boston College, and XIANG ZHENG, Boston College-The Role of Investor Attention in Seasoned Equity Offerings: Theory and Evidence

EFE COTELIOGLU, USI Lugano and Swiss Finance Institute-The Term Structure of Credit Spreads and Institutional Equity Trading

DAVID MCLEAN, Georgetown University, JEFFREY PONTIFF, Boston College, and CHRISTOPHER REILLY, Boston CollegeThe Trinity of Market Participants: Taking Sides on Return Predictability

ALEXANDER KRONIES, Copenhagen Business School-The Value of Renewable Energy and Subsidies: An Investor's Perspective AXEL KIND, Universität Konstanz, MARCO POLTERA, Universität Basel, and JOHANNES ZAIA, Universität KonstanzThe Value Of Say On Pay

TURAN BALI, Georgetown University, LUCA DEL VIVA, ESADE Business School, MENATALLA EL HEFNAWY, ESADE Business School, and LENOS TRIGEORGIS, University of Cyprus, King's College London and MIT_-The Value Uncertainty Premium

TATJANA SCHULZE, University of Oxford, and DIMITRIOS TSOMOCOS, University of Oxford-The Zero Lower Bound and Financial Stability: A Role for Central Banks

CARINA CUCULIZA, University of Miami-Ticket to Heaven: Beliefs in the Afterlife, Portfolio Choice, and Asset Prices

LI LIAO, Tsinghua University, ZHENGWEI WANG, Tsinghua University, and CONGYI ZHOU, Tsinghua University-Tit for Tat? The Consequence of Private Information Misuse in Debt Collection 


\section{Saturday $•$ January 4}

ISABELLA WOLFSKEIL, Bocconi University-Tweeting in the Dark: Corporate Tweeting and Information Diffusion

HYEYOON JUNG, New York University-Understanding the Onshore versus Offshore Forward Rate Basis: The Role of FX Position Limits and Margin Constraints

SHIJIA WU, University of California-Irvine-Visuals and Attention to Earnings News on Twitter

BHARAT PARAJULI, University of Utah-Wealth Effects and Predictability of Firms' Government Sales Dependency

MUSTAFA EMIN, University of Florida-What do Private Equity Firms do in the Credit Markets?

THOMAS CHEMMANUR, Boston College, DONGMEI LI, University of South Carolina, KEVIN TSENG, University of Kansas, and YU WANG, Boston College-What is the Value of an Innovation? Theory and Evidence on the Stock Market's Reaction to Innovation Announcements

SHIDA LIU, Tsinghua University, and HAO WANG, Tsinghua University-What Shapes Credit Rating Effectiveness in China? Evidence from the Upgrading in the Banking Sector

FABRICIUS SOMOGYI, University of St. Gallen, and PAUL SÖDERLIND, University of St. Gallen-When Does Liquidity Matter?

RAN TAO, University of Reading, CHRIS BROOKS, University of Reading, and ADRIAN BELL, University of Reading - When is a MAX not the MAX? How News Resolves Information Uncertainty

DENNIS HAMILTON, University of Iowa-Which Post-Crisis Regulations are Constraining Banks' Market Making? Evidence from Strategic Accounting Classifications

JIANFENG HU, Singapore Management University, ANTONIA KIRILOVA, Singapore Management University, SEONGKYU (GILBERT) PARK, Hong Kong Polytechnic University, and DOOJIN RYU, Sungkyunkwan University-Who Has Skills in Trading Options?

YANRAN LIU, University of Pittsburgh-Why Do Institutional Investors Oppose Shareholder Activism? Evidence from Voting in Proxy Contests 


\section{Saturday $•$ January 4}

KORNELIA FABISIK, Ecole Polytechnique Fédérale de Lausanne (EPFL) and Swiss Finance Institute (SFI) — Why do U.S. CEOs Pledge their own Company's Stock?

AMANJOT SINGH, Deakin University, SAIKAT SOVAN DEB, Deakin University, and HARMINDER SINGH, Deakin University-Why US Firms use more Long-term Debt Post Activist Interventions?

XIAO REN, University of Georgia-Within-firm Labor Heterogeneity and Firm Performance: Evidence from Employee Political Ideology Conflicts

ANNE HANSEN, University of Copenhagen-Yield Curve Volatility and Macro Risks

\section{8:00 AM Manchester Grand Hyatt San Diego-Seaport DE AFA}

\section{Asset Pricing: Volatility, Tail Risk (G1)}

Presiding: BRYAN KELLY, Yale University

GRACE XING HU, University of Hong Kong, JUN PAN, Massachusetts Institute of Technology, JIANG WANG, Massachusetts Institute of Technology, and HAOXIANG ZHU, Massachusetts Institute of Technology-Premium for Heightened Uncertainty: Solving the FOMC Puzzle

JIE CAO, Chinese University of Hong Kong, AURELIO VASQUEZ, Technological Autonomous University of Mexico (ITAM), XIAO XIAO, Erasmus University Rotterdam, and XINTONG ZHAN, Chinese University of Hong Kong - Volatility Uncertainty and the Cross-Section of Option Returns

NIELS GORMSEN, University of Chicago, and CHRISTIAN SKOV JENSEN, Bocconi University-Higher-Moment Risk

Discussants: TOOMAS LAARITS, New York University

DMITRIY MURAVYEV, Boston College

MATHIEU FOURNIER, HEC Montreal 


\section{Saturday $•$ January 4}

\section{8:00 AM Manchester Grand Hyatt San Diego-Seaport B}

AFA

\section{Asset Valuation in Economies with Production (G1)}

Presiding: MARTIN SCHNEIDER, Stanford University

ANDREA EISFELDT, University of California-Los Angeles, ANTONIO FALATO, Federal Reserve Board, and MINDY XIAOLAN, University of Texas-Austin-Human Capitalists

ALEXANDRE CORHAY, University of Toronto, HOWARD KUNG, London Business School, and LUKAS SCHMID, Duke University-Q: Risk, Rents, or Growth?

M. CECILIA BUSTAMANTE, University of Maryland-Supply Chain Bargaining and Asset Prices

JULES VAN BINSBERGEN, University of Pennsylvania, and CHRISTIAN OPP, University of Pennsylvania-Exactly Solved Economies with Heterogeneity

Discussants: ANMOL BHANDARI, University of Minnesota

GAUTI EGGERTSSON, Brown University

GILL SEGAL, University of North Carolina-Chapel Hill

STEPHEN J. TERRY, Boston University

\section{8:00 AM Manchester Grand Hyatt San Diego-Seaport C AFA}

\section{Bank and SBA Lending Behavior (G2)}

Presiding: MANJU PURI, Duke University and NBER

ALEJANDRO DREXLER, Federal Reserve Bank of Chicago, ANDRE GUETTLER, Ulm University, DANIEL PARAVISINI, London School of Economics, and AHMET ALI TASKIN, Ulm University-Competition Between Arm's Length and Relational Lenders: Who Wins the Contest?

JOAO GRANJA, University of Chicago, CHRISTIAN LEUZ, University of Chicago, and RAGHURAM RAJAN, University of Chicago-Going the Extra Mile: Distant Lending and Credit Cycles NATALIE BACHAS, Princeton University, ERNEST LIU, Princeton University, and CONSTANTINE YANNELIS, University of Chicago-Market Power in Small Business Lending 


\section{Saturday $•$ January 4}

Discussants: SASHA INDARTE, Northwestern University

STEVEN ONGENA, University of Zurich

MARK EGAN, Harvard University

\section{8:00 AM Manchester Grand Hyatt San Diego-Seaport F}

AFA

\section{Bank Cost of Capital (G2)}

Presiding: JULIANE BEGENAU, Stanford University

JENS DICK-NIELSEN, Copenhagen Business School, JACOB GYNTELBERG, Nordea Group, and CHRISTOFFER THIMSEN, Aarhus University-The Cost of Capital for Banks

ITZHAK BEN-DAVID, Ohio State University and NBER, AJAY PALVIA, U.S. Office of the Comptroller of the Currency, and RENE STULZ, Ohio State University-Do Distressed Banks Really Gamble for Resurrection?

VICTOR LYONNET, Ohio State University, and JOHAN HOMBERT, HEC Paris-Can Risk Be Shared Across Investor Cohorts? Evidence from a Popular Savings Product

Discussants: MALCOLM BAKER, Harvard Business School

LAURA BLATTNER, Stanford University

MOTOHIRO YOGO, Princeton University

\section{8:00 AM Manchester Grand Hyatt San Diego-Seaport G} AFA

\section{Frontiers of Corporate Governance (G3)}

Presiding: KELLY SHUE, Yale University

TRAVIS JOHNSON, University of Texas-Austin, and NATHAN SWEM, Federal Reserve Board-Reputation and Investor Activism: A Structural Approach

RYAN BUBB, New York University, and EMILIANO CATAN, New York University-The Party Structure of Mutual Funds 


\section{Saturday $\cdot$ January 4}

DANIEL FERREIRA, London School of Economics, JIN LI, University of Hong Kong, and RADOSLAWA NIKOLOWA, Queen Mary University of London-Corporate Capture of Blockchain Governance

HONG RU, Nanyang Technological University-How Do Individual Politicians Affect Privatization? Evidence from China

Discussants: ARTHUR KORTEWEG, University of Southern California

MICHAEL WEISBACH, Ohio State University

BARRY NALEBUFF, Yale University

DIRK JENTER, London School of Economics

\section{8:00 AM Manchester Grand Hyatt San Diego-Seaport H} AFA

\section{Information Diffusion (G1)}

Presiding: LAURA VELDKAMP, Columbia University

GEORGE MALIKOV, University of Michigan-Information, Participation, and Passive Investing

WILL CONG, University of Chicago, and YIZHOU XIAO, Chinese

University of Hong Kong-Information Cascade and Threshold Implementation

PETER KONDOR, London School of Economics, and GABOR PINTER, Bank of England-Clients' Connections: Measuring the Role of Private Information in Decentralised Markets

Discussants: BRADYN BREON-DRISH, University of California-San Diego VALENTIN HADDAD, University of California-Los Angeles AMIR KERMANI, University of California-Berkeley

\section{8:00 AM Manchester Grand Hyatt San Diego-Harbor A AFA}

Networks, Connections, and Firms (G3)

Presiding: MARK SEASHOLES, Arizona State University

HANNAN ZHENG, Boston University, and GUSTAVO SCHWENKLER, Boston University-The Network of Firms Implied by the News 


\section{Saturday $•$ January 4}

AMANDA HEITZ, Tulane University, YOUAN WANG, University of Hong Kong, and ZIGAN WANG, University of Hong KongPolitical Connections and Selective EPA Enforcement

QUOC-ANH DO, Sciences Po, and BANG NGUYEN, University of Cambridge-Political Connections and Firm Value: Evidence from Close Gubernatorial Elections

Discussants: ANNA SCHERBINA, Brandeis University

CESARE FRACASSI, University of Texas-Austin

ILONA BABENKO, Arizona State University

\section{8:00 AM Manchester Grand Hyatt San Diego-Seaport A} AFA

Political Uncertainty and Asset Prices (G1)

Presiding: STEFANO GIGLIO, Yale University

LUBOS PASTOR, University of Chicago, and PIETRO VERONESI, University of Chicago-Inequality Aversion, Populism, and the Backlash Against Globalization

MATTHIAS FLECKENSTEIN, University of Delaware, PRIYANK GANDHI, Rutgers University, and PENGJIE GAO, University of Notre Dame-Tax Policy Uncertainty and Asset Prices: Evidence from Dual-class Corporate Bonds in Early 20th Century

KEWEI HOU, Ohio State University, KE TANG, Tsinghua University, and BOHUI ZHANG, Chinese University of Hong Kong-Political Uncertainty and Commodity Markets

Discussants: HANNO LUSTIG, Stanford University

CLEMENS SIALM, University of Texas-Austin and NBER JONATHAN BROGAARD, University of Utah

8:00 AM Manchester Grand Hyatt San Diego-Promenade A AFEA

Health, Human Capital, and Gender Issues in Africa (I1)

Presiding: JEAN-CLAUDE MASWANA, Ritsumeikan University 


\section{Saturday $\cdot$ January 4}

BORIS HOUENOU, Washington State University-Infectious Disease Control and Human Health Investment: Learning by Controlling

DAVID CANNING, Harvard University, MARIE CHRISTELLE MABEU, University of Ottawa, and ROLAND PONGOU, University of Ottawa-Colonial Origins and Fertility

SAMUEL AMPONSAH, Tokyo International University, and KYOKO KOGA, Kochi University—Does Akan Literacy Influence One's Income?

BELINDA ARCHIBONG, Barnard College, FRANCIS ANNAN, Georgia State University, and UCHE EKHATOR-MOBAYODE, University of Pittsburgh-Bradford-Pricing Daughters and the Economic Burden of Disease: Evidence from the Meningitis Belt

HANAN MORSY, African Development Bank, AMIRA EL-SHAL, African Development Bank, and ANDINET WOLDEMICHAEL, African Development Bank-Perceived Glass Ceiling? Women SelfSelection out of the Credit Market in Africa

EVELYN WAMBOYE, Pennsylvania State University-China's Finance in Africa: What and How Much?

MINA BALIAMOUNE-LUTZ, University of North Florida-Trade with China and the Impacts of Infrastructure and Human Capital on Africa's Industrial Development

Discussants: BICHAKA FAYISSA, Middle Tennessee State University

AKPAN EKPO, African Development Bank

BEDASSA TADESSE, University of Minnesota-Duluth

KWABENA GYIMAH-BREMPONG, National Science Foundation JEAN-CLAUDE MASWANA, Ritsumeikan University

BONIFACE YEMBA, Marshall University

\section{8:00 Aм Manchester Grand Hyatt San Diego—Cortez Hill A AFEE/ASE}

Panel: Is Karl Polanyi's Analysis of the 1930's and 1940's Relevant for Understanding the Global Political Economy of the Present? (B5)

Presiding: ANN E. DAVIS, Marist College 


\section{Saturday $\cdot$ January 4}

FRED L. BLOCK, University of California-Davis-Based on his recent book, Capitalism, the Future of an Illusion, 2018, Block will address the implications of Polanyi's analysis for the current economic situation.

ANN E. DAVIS, Marist College-Labor as Fictitious Commodity

DAVID ZALEWSKI, Providence College-Class Structure in Polanyi's "The Mechanism of the World Crisis"

GARY DYMSKI, University of Leeds-Uncertainty, Irreversible Investment, and the Double Movement

\section{8:00 AM Manchester Grand Hyatt San Diego-Nautical AREUEA}

\section{Risk and Delinquency in Mortgage Markets (G2)}

Presiding: KRISTOPHER GERARDI, Federal Reserve Bank of Atlanta

ANURAG MEHROTRA, University of Georgia, and HENRY MUNNEKE, University of Georgia-Loan Servicing and Management of Delinquent Loans

FRANCO ZECCHETTO, Technological Autonomous University of Mexico (ITAM), PEDRO GETE, IE University, ATHENA TSOUDEROU, IE University, and SUSAN M. WACHTER, University of Pennsylvania-Quantifying Mortgage Credit Risk: Evidence from a Natural Experiment

MARIYA LETDIN, Florida State University, and MEAGAN MCCOLLUM, University of Tulsa-Harping on about HARP: Consequences of Ineligibility for the Home Affordable Refinance Program

ROBERT VAN ORDER, George Washington University, and ROSE LAI, University of Macau-Credit Risk Transfers: Optimal Structuring

Discussants: THAO LE, Georgia State University

W. SCOTT FRAME, Federal Reserve Bank of Dallas

STEPHEN H. SHORE, Georgia State University

PAUL WILLEN, Federal Reserve Bank of Boston

JANET KOHLHASE, University of Houston 


\section{Saturday $•$ January 4}

\section{8:00 AM Manchester Grand Hyatt San Diego-Coronado E AREUEA/AAEA/AFA/CSWEP/EEA}

\section{Panel: Women in Economics-Perspectives and New Initiatives from Five Professional Associations (A1)}

Presiding: JUSTIN WOLFERS, University of Michigan

KAREN PENCE, Federal Reserve Board and WREN

RENEE ADAMS, University of Oxford and AFFECT

SIMANTI BANERJEE, University of Nebraska-Lincoln and CWAE VICKI BOGAN, Cornell University and CSMGEP

JUDITH CHEVALIER, Yale University and CSWEP

GUIDO FRIEBEL, Geothe University and WinE

\section{8:00 AM Manchester Grand Hyatt San Diego-Pier ASGE/IAFFE}

Cash Transfers, Women, and Families: International Perspectives (H4)

Presiding: MARK OTTONI-WILHELM, Indiana University-Purdue University Indianapolis

TANIMA AHMED, American University-Child Support, Foster Care, Dependency Grants, and Time Use in South Africa

FAREENA MALHI, American University-Unconditional Cash Transfers, Aspirations, and Children's Schooling: Evidence from Pakistan

ALMAZ ZELLEKE, New York University Shanghai-Designing a Basic Income that Works for Women and Children

ASHLEY WHILLANS, Harvard Business School, and COLIN WEST, University of California-Los Angeles-Alleviating Time Poverty Among the Working Poor: A Pre-Registered Longitudinal Field Experiment

Discussants: ABIGAIL PAYNE, University of Melbourne

SUSAN PARKER, University of Maryland

NANCY FOLBRE, University of Massachusetts-Amherst ANYA SAMEK, University of Southern California 


\section{Saturday $•$ January 4}

\section{8:00 AM Marriott Marquis San Diego-Cardiff ASHE}

Economic Issues of Hispanics in the United States (J1)

Presiding: SUSAN POZO, Western Michigan University

RANDALL AKEE, University of California-Los Angeles, MAGGIE R. JONES, U.S. Census Bureau, SONYA R. PORTER, U.S. Census Bureau, and EMILIA SIMEONOVA, Johns Hopkins UniversityEarnings Inequality for Asians and Hispanics: An Examination of Variation across Subgroups

MARY LOPEZ, Occidental College, CATALINA AMUEDODORANTES, University of California-Merced, and MANUEL PASTOR, University of Southern California-Immigration Policy, Immigrant Detention, and the United States Correctional System

ROBERT SANTILLANO, Mathematica Policy Research, STEPHANIE POTOCHNICK, University of Missouri, and JADE JENKINS, University of California-Irvine-Immigration Raids and Hispanic Head Start Enrollment

SANDRA OROZCO-ALEMAN, Mississippi State University, and HERIBERTO GONZALEZ-LOZANO, Mississippi State University-Interior Enforcement, Deterrence, and Crime

STEPHEN TREJO, University of Texas-Austin, and BRIAN DUNCAN, University of Colorado-Denver-The Educational Progress of United States-Born Mexican Americans

Discussants: FERNANDO LOZANO, Pomona College

LUISA BLANCO, Pepperdine University

MONICA GARCIA-PEREZ, Saint Cloud State University

CATALINA AMUEDO-DORANTES, University of California-Merced JUAN DE LA CRUZ, City University of New York-Lehman College

\section{8:00 AM Manchester Grand Hyatt San Diego_Cortez Hills C CEANA}

Current Topics in Health and Public Economics (I1)

Presiding: CHING-TO ALBERT MA, Boston University 


\section{Saturday $•$ January 4}

UNDRAL BYAMBADALAI, Boston University, CHING-TO ALBERT MA, Boston University, and DANIEL WIESEN, University of Cologne-Changing Preferences: An Experiment and Estimation of Market-Incentive Effects on Altruism

CHIH-SHENG HSIEH, National Taiwan University, and XU LIN, Virginia Tech-Social Interactions and Social Preferences in Social Networks

SEAN SHENG-HSIU HUANG, Georgetown University, and JOHN R. BOWBLIS, Miami University-The Impacts of Medicare Advantage on Skilled Nursing Facility Deficiencies and Staffing

JASON HOCKENBERRY, Emory University, and HEFEI WEN, University of Kentucky - Health Insurance Parity for Behavioral Health Treatment and Labor Market Outcomes

Discussants: KOSALI SIMON, Indiana University

ERNEST LAI, Lehigh University

HSIEN-CHANG LIN, Indiana University

SHIN-YI CHOU, Lehigh University

\section{8:00 AM Manchester Grand Hyatt San Diego-Gaslamp C CES}

\section{Entrepreneurship in China (D7)}

Presiding: XIAOBO ZHANG, Peking University and IFPRI

JIANWEI XING, Peking University-The Industry Choice of Firsttime Entrepreneurs

LOREN BRANDT, University of Toronto-Serial Entrepreneurship in China

TIANYANG XI, Peking University-Moving "Umbrella": Bureaucratic Transfers, Collusion, and Rent-seeking in China

RUOCHEN DAI, Peking University—Detecting Shell Companies in China 


\section{Saturday $•$ January 4}

\section{8:00 AM Marriott Marquis San Diego-Malibu \\ CS}

\section{Human Capital and Public Economics (N3)}

Presiding: MARTIN SAAVEDRA, Oberlin College

D. MARK ANDERSON, Montana State University, KERWIN CHARLES, University of Chicago, and DANIEL REES, University of Colorado-Denver-Public Health Efforts and the Decline in Urban Mortality

JONATHAN CHAPMAN, New York University Abu Dhabi-Rural Elites and Redistribution: Evidence from the English Poor Law

ZACHARY WARD, Baylor University-Intergenerational Mobility in American History: Accounting for Race and Measurement Error MAGGIE JONES, University of Victoria, and DONNA FEIR, Center for Indian Country Development-The Missionary Imposition? The Long-Run Impact of Indian Missions in the United States

Discussants: BRIAN BEACH, Vanderbilt University

WALKER HANLON, New York University

JAMES FEIGENBAUM, Boston University

SUMNER LA CROIX, University of Hawaii

\section{8:00 AM Marriott Marquis San Diego-Mission Hills ES}

\section{Analysis of Panel and Clustered Data (C2)}

Presiding: DOUGLAS STEIGERWALD, University of California-Santa Barbara

GEORGE KAPETANIOS, King's College London, M. HASHEM PESARAN, University of Southern California and Trinity College Cambridge, and SIMON REESE, University of Southern California-Detection of Units with Pervasive Effects in Large Panel Data Models

RODRIGO ADAO, University of Chicago, MICHAL KOLESAR, Princeton University, and EDUARDO MORALES, Princeton University—Shift-Share Designs: Theory and Inference 


\section{Saturday $•$ January 4}

WAYNE YUAN GAO, Yale University, and MING LI, Yale University-Robust Semiparametric Estimation in Panel Multinomial Choice Models

ANDRES SANTOS, University of California-Los Angeles, IVAN CANAY, Northwestern University, and AZEEM SHAIKH, University of Chicago-The Wild Bootstrap with a "Small" Number of "Large" Clusters

JIANFEI CAO, University of Chicago, CHRISTIAN HANSEN, University of Chicago, DAMIAN KOZBUR, University of Zurich, and LUCCIANO VILLACORTA, Central Bank of Chile-Inference for Dependent Data with Cluster Learning

DOUGLAS STEIGERWALD, University of California-Santa Barbara, and ANDREW CARTER, University of California-Santa Barbara-Testing for Treatment Effects in Randomized Control Trials: The Effect of Differing Cluster Sizes

\section{8:00 AM Marriott Marquis San Diego—Carlsbad ES}

\section{Dynamic Incentives (C7)}

Presiding: GONZALO CISTERNAS, Massachusetts Institute of Technology ALESSANDRO BONATTI, Massachusetts Institute of Technology, ESAT DORUK CETEMEN, University of Rochester, and JUUSO TOIKKA, University of Pennsylvania-Optimal Project Management

DANIEL BIRD, Tel Aviv University, and ALEX FRUG, Pompeu Fabra University-Monotone Contracts

YI CHEN, Cornell University-Optimal Dynamic Contract of Influence

DILIP ABREU, New York University, BENJAMIN BROOKS, University of Chicago, and YULIY SANNIKOV, Stanford University-A "Pencil-Sharpening" Algorithm for Two Player Stochastic Games with Perfect Monitoring

GONZALO CISTERNAS, Massachusetts Institute of Technology, and AARON KOLB, Indiana University-Signaling with Private Monitoring 


\section{Saturday $•$ January 4}

\section{8:00 AM Marriott Marquis San Diego—La Costa \\ ES}

\section{Financial Markets and Monetary Policy (E5)}

Presiding: ERIC SWANSON, University of California-Irvine

ERIC SWANSON, University of California-Irvine-A Macroeconomic Model of Equities and Real, Nominal, and Defaultable Debt

SANDEEP DAHIYA, Georgetown University, BARDIA KAMRAD, Georgetown University, VALERIO POTI, University College Dublin, and AKHTARUR SIDDIQUE, U.S. Office of the Comptroller of the Currency-The Greenspan Put

ROBERT DITTMAR, University of Michigan, ALEX HSU, Georgia Institute of Technology, GUILLAUME ROUSSELLET, McGill University, and PETER SIMASEK, Georgia Institute of Technology_Default Risk and the Pricing of United States Sovereign Bonds

MICHAEL BAUER, Federal Reserve Bank of San Francisco, AEIMIT LAKDAWALA, Michigan State University, and PHILIPPE MUELLER, University of Warwick-Market-Based Monetary Policy Uncertainty

\section{8:00 AM Manchester Grand Hyatt San Diego-Regatta C ES}

\section{Heterogeneous Beliefs and Asset Pricing (G1)}

Presiding: EFSTATHIOS AVDIS, University of Alberta

CHRISTIAN HEYERDAHL-LARSEN, Indiana University, and PHILIPP ILLEDITSCH, Carnegie Mellon University-Demand Disagreement

ALLY ZHANG, Lancaster University-The Arbitrage Cycle and the Business Cycle-Limited Arbitrage in a Production Economy

KAI LI, Macquarie University, and JUN LIU, University of California-San Diego-Extrapolative Asset Pricing 


\section{Saturday $•$ January 4}

THEODOROS EVGENIOU, INSEAD, JULIEN HUGONNIER,

Swiss Federal Institute of Technology-Lausanne (EPFL), and RODOLFO PRIETO, INSEAD—Costly Short Sales and Nonlinear Asset Pricing

Discussants: MATTHIEU GOMEZ, Columbia University

ESTER FAIA, Goethe University Frankfurt

LAWRENCE JIN, California Institute of Technology

ITAMAR DRECHSLER, University of Pennsylvania

\section{8:00 Ам Marriott Marquis San Diego—Catalina ES}

JBES Session: Transparency in Structural Estimation (C1)

Presiding: CHRISTIAN HANSEN, University of Chicago

MATTHEW GENTZKOW, Stanford University, ISAIAH ANDREWS, Harvard University, and JESSE M. SHAPIRO, Brown University-Transparency in Structural Estimation

Discussants: ELIE TAMER, Harvard University

CHRISTOPHER TABER, University of Wisconsin-Madison

STEPHANE BONHOMME, University of Chicago

\section{8:00 AM Marriott Marquis San Diego-Marina Ballroom E ES}

\section{Poster Session in Econometrics (C1)}

Presiding: MATIAS CATTANEO, Princeton University

YOON-JAE WHANG, Seoul National University-Testing Stochastic Dominance with Many Conditioning Variables

YOONSEOK LEE, Syracuse University, and YULONG WANG, Syracuse University-Nonparametric Sample Splitting

ADRIANA LLERAS-MUNEY, University of California-Los Angeles, SHUYANG SHENG, University of California-Los Angeles, and VERONICA SOVERO, Wake Forest University-Party on: The Labor Market Returns to Social Networks and Socializing 


\section{Saturday $•$ January 4}

PEDRO H. C. SANT'ANNA, Vanderbilt University, XIAOJUN SONG, Peking University, and QI XU, Vanderbilt UniversityCovariate Distribution Balance Via Propensity Scores

ILYA ARCHAKOV, University of Vienna, and PETER HANSEN, University of North Carolina-Chapel Hill-A New Parametrization of Correlation Matrices

BEN DEANER, Massachusetts Institute of TechnologyNonparametric Estimation and Identification in Non-Separable Models Using Panel Data

SANDER BARENDSE, Oxford University, and ANDREW PATTON, Duke University-Comparing Predictive Accuracy in the Presence of a Loss Function Shape Parameter

DAVID CHILDERS, Carnegie Mellon University-Automated Solution of Heterogeneous Agent Models

RUOYAO SHI, University of California-Riverside-An Averaging Estimator for Two Step M Estimation In Semiparametric Models

KIRILL EVDOKIMOV, Massachusetts Institute of Technology, and ILZE KALNINA, North Carolina State University-Improved Estimation by Simulated Maximum Likelihood

PAOLO ZAFFARONI, Imperial College London-Factor Models for Asset Pricing

LIANG CHEN, Shanghai University of Finance and Economics, JUAN DOLADO, University Carlos III of Madrid, and JESUS GONZALO, University Carlos III of Madrid-Quantile Factor Models

SIDA PENG, Microsoft Research, and MATTHEW R. BACKUS, Columbia University-On Testing Continuity and the Detection of Failures

RICHARD SPADY, Johns Hopkins University, and SAMI STOULI, University of Bristol—Simultaneous Mean-Variance Regression

BONSOO KOO, Monash University, DAVIDE LA VECCHIA, University of Geneva, and OLIVER LINTON, University of Cambridge_Estimation of a Nonparametric Model for Bond Prices from Cross-Section and Time Series Information

DESIRE KEDAGNI, Iowa State University-Identification of Treatment Effects with Mismeasured Imperfect Instruments 


\section{Saturday $\cdot$ January 4}

YUYA SASAKI, Vanderbilt University, and YULONG WANG, Syracuse University-Robust Inference about Conditional Tail Properties: A Panel Data Approach

FLORIAN GUNSILIUS, Brown University-Bounds on Causal Effects in Continuous Instrumental Variable Models

VALENTINA CORRADI, University of Surrey, and DANIEL GUTKNECHT, University of Mannheim-Testing for Sample Selection

M. HASHEM PESARAN, University of Southern California, and CYNTHIA YANG, Florida State University-Estimation and Inference in Spatial Models with Dominant Units

NICCOLO LOMYS, Toulouse School of Economics, LORENZO MAGNOLFI, University of Wisconsin-Madison, and CAMILLA RONCORONI, University of Warwick-Dynamic Foundations for Empirical Static Games

YAO LUO, University of Toronto, and RULI XIAO, Indiana University-Identification of Auction Models Using Order Statistics ANDERS KOCK, Aarhus University, DAVID PREINERSTORFER, Free University of Brussels, and BEZIRGEN VELIYEV, Aarhus University-Functional Sequential Treatment Allocation

ANDRÉS F. GARCÍA-SUAZA, EIA University, MIGUEL A. DELGADO, University Carlos III of Madrid, and PEDRO H. C. SANT'ANNA, Vanderbilt University-Distribution Regression in Duration Analysis: an Application to Unemployment Spells

PIETRO BONALDI, Carnegie Mellon University-Synthetic Regression Discontinuity-Estimating Treatment Effects using Machine Learning

YAROSLAV MUKHIN, Massachusetts Institute of TechnologyOn Counterfactual Analysis of Differentiable Functionals

JOHN LAZAREV, New York University—Blacklisted

AMANDA ELLEN KOWALSKI, University of MichiganCounting Defiers

MASSIMO GUIDOLIN, Bocconi University, and MANUELA PEDIO, Bocconi University-A Markov Switching Cointegration Analysis of the CDS-Bond Basis Puzzle 


\section{Saturday $•$ January 4}

\section{8:00 AM Manchester Grand Hyatt San Diego_Cortez Hill B IBEFA}

\section{Cross-Border (Non-)Banking (G2)}

Presiding: DIANA BONFIM, Bank of Portugal and Catholic University of Portugal

RICARDO CORREA, Federal Reserve Board, and LINDA GOLDBERG, Federal Reserve Bank of New York-Bank Complexity, Governance, and Risk

JIN CAO, Norges Bank, and VALERIYA DINGER, University of Osnabrück-Financial Globalization and Bank Lending: The Limits of Domestic Monetary Policy?

ASLI DEMIRGUC-KUNT, World Bank, BALINT HORVATH, University of Bristol, and HARRY HUIZINGA, Tilburg University and CEPR-Regulatory Arbitrage and Cross-Border Syndicated Loans

SI CHENG, Chinese University of Hong Kong, MASSIMO MASSA, INSEAD, and HONG ZHANG, Tsinghua University-Catering through Globalization: Cross-Border Expansion and Misallocation in the Global Mutual Fund Industry

Discussants: KATHERYN RUSS, University of California-Davis

LINDA GOLDBERG, Federal Reserve Bank of New York

WILKO BOLT, De Nederlandsche Bank

TENG WANG, Federal Reserve Board

\section{8:00 AM Manchester Grand Hyatt San Diego_America's Cup C IEFS}

International Trade (F1)

Presiding: JEFFREY BERGSTRAND, University of Notre Dame

TRISTAN KOHL, University of Groningen, JAMES LAKE, Southern Methodist University, and SHUSHANIK HAKOBYAN, International Monetary Fund-Lobbying for Tariff Phase-Outs in United States Free Trade Agreements

POL ANTRAS, Harvard University, EVGENII FADEEV, Harvard University, TERESA C. FORT, Dartmouth College, and FELIX TINTELNOT, University of Chicago-Global Sourcing and Assembly with Scale Economies 


\section{Saturday $•$ January 4}

PETER K. SCHOTT, Yale University, XIANG DING, Harvard University, TERESA C. FORT, Dartmouth College, and STEPHEN J. REDDING, Princeton University-Structural Change Within Versus Across Firms: Evidence from the United States

MARCELO BIANCONI, Tufts University, FEDERICO ESPOSITO, Tufts University, and MARCO SAMMON, Northwestern University-Trade Policy Uncertainty and Stock Returns

\section{8:00 AM Manchester Grand Hyatt San Diego_Ocean Beach IHEA}

\section{Innovative Programming to Improve Adolescent Health in Sub- Saharan Africa (I1)}

Presiding: KATHLEEN BEEGLE, World Bank

MANISHA SHAH, University of California-Los Angeles and NBER, and JENNIFER MUZ, George Washington UniversityIncluding Males: Improving Sexual and Reproductive Health for Female Adolescents

BERK ÖZLER, World Bank, SUSAN ATHEY, Stanford University, and JULIAN JAMISON, University of Exeter-Increasing the Uptake of Long-Acting Reversible Contraceptives (LARCs) among Adolescent Females and Young Women in Cameroon

SARAH BAIRD, George Washington University, and BERK ÖZLER, World Bank-Incorporating Mental Health Programming into Adolescent Empowerment Programming: The Role of GroupBased Interpersonal Psychotherapy (IPT-G)

SARAH BAIRD, George Washington University, JOAN HAMORY HICKS, University of Oklahoma, MICHAEL KREMER, Harvard University and NBER, and EDWARD MIGUEL, University of California-Berkeley and NBER-Worms and Wellbeing: 20 Year Economic Impacts from Kenya

Discussants: JOE CUMMINS, University of California-Riverside

KELLY JONES, American University

PAMELA JAKIELA, Center for Global Development

JENNIFER MUZ, George Washington University 


\section{Saturday $•$ January 4}

\section{8:00 AM Manchester Grand Hyatt San Diego-Gaslamp AB ITFA}

\section{Data Science and AI: The Next Frontier for Evidence-Based Policy-Making (H1)}

Presiding: THIERRY WARIN, SKEMA Business School

CESAR A. HIDALGO, Massachusetts Institute of TechnologyFrom Public Data to Responsible A.I.: The Next Generation of Public Data Distribution Platforms

CLIFTON VAN DER LINDEN, McMaster University-On the Measurement of Public Opinion in the Age of Big Data

MARTA BENGOA, City University of New York-City College, and THIERRY WARIN, SKEMA Business School-Health Outcomes in China for the Hukou Migrants: How Algorithms May Inform Public Policymakers

ANN BACKUS, Harvard University, and NATHALIE DE MARCELLIS, Polytechnique Montreal \& CIRANO (Montreal)-Evidence-Based Health and Environmental Policies and the Potential Mismatch with Citizens' Perceptions: A Data Science Perspective

Discussants: JOSEPH PELZMAN, George Washington University

GINA PIETERS, University of Chicago

ALEKSANDAR STOJKOV, Ss. Cyril and Methodius University

CESAR A. HIDALGO, Massachusetts Institute of Technology

\section{8:00 AM Manchester Grand Hyatt San Diego-Promenade B LACEA/AEA}

\section{Topics in Emerging Markets (F0)}

Presiding: CARMEN REINHART, Harvard University

ANUSHA CHARI, University of North Carolina-Chapel Hill and NBER, and JENNIFER RHEE, Federal Deposit Insurance Corporation-The Return to Capital in Capital Scare Countries LAURA ALFARO, Harvard University, MAURICIO CALANI, Central Bank of Chile, and LILIANA VARELA, London School of Economics-Currency Hedging in Emerging Markets: Managing Cash Flow Exposure 


\section{Saturday $•$ January 4}

ALBERTO CAVALLO, Harvard University-Measuring Inflation: Using Crowdsourcing and Mobile Phones

Discussants: UGO PANIZZA, Graduate Institute Geneve

JESSE SCHREGER, Columbia University

FABIO KANCZUK, World Bank \& University of São Paulo

\section{8:00 Aм Manchester Grand Hyatt San Diego-Harbor E LERA}

\section{Breakfast Session: Gender and Careers (M5)}

Presiding: MARIANNE BERTRAND, University of Chicago

PATRICIA CORTES, Boston University, JESSICA PAN, National University of Singapore, and BASIT ZAFAR, Arizona State University-Information Provision and Gender Differences in Negotiation: Evidence from Business Majors

YUKIKO ASAI, University of Chicago, and DMITRI K. KOUSTAS, University of Chicago-Temporary Work Contracts and Female Labor Market Outcomes

ANDERS FREDERIKSEN, Aarhus University, TAKAO KATO,

Colgate University, and NINA SMITH, Aarhus UniversityWorking Hours and the Gender Gap in Career Success: Evidence from Linked Employer-Employee Data

COLLEEN F. MANCHESTER, University of Minnesota, MYLES SHAVER, University of Minnesota, and ALAN BENSON, University of Minnesota-Marrying for Love or Mobility? DualCareer Couples and High-Risk Job Opportunities

Discussants: MELANIE WASSERMAN, University of California-Los Angeles DORA GICHEVA, University of North Carolina-Greensboro

\section{8:00 AM Manchester Grand Hyatt San Diego-Harbor F LERA}

Breakfast Session: Wage Structure, Covenants Not to Compete, and Nonwage Benefits (J3)

Presiding: ERICA GROSHEN, Cornell University 


\section{Saturday $\cdot$ January 4}

OREN DANIELI, Tel Aviv University, and SYDNEE CALDWELL, Microsoft Research-Outside Options in the Labor Market

MICHAEL CARR, University of Massachusetts-Boston, RANDY ALBELDA, University of Massachusetts-Boston, and EMILY WIEMERS, University of Massachusetts-Boston-The Long-Run Impact of Temporary Disability Insurance on Social Security Disability Insurance Claims (SSDI) in the United States

NATARAJAN BALASUBRAMANIAN, Syracuse University, JIN WOO CHANG, University of Michigan, MARIKO SAKAKIBARA, University of California-Los Angeles, JAGADEESH SIVADASAN, University of Michigan, and EVAN STARR, University of Maryland-Locked In? The Enforceability of Covenants Not to Compete and the Careers of High-Tech Workers

Discussants: IOANA ELENA MARINESCU, University of Pennsylvania

HYE JIN RHO, Massachusetts Institute of Technology

YULYA TRUSKINSOVSKY, Wayne State University

\section{8:00 Aм Manchester Grand Hyatt San Diego-Balboa C MEEA}

\section{Determinants and Effects of Migration (F6)}

Presiding: RAHEL M. SCHOMAKER, CUAS Villach/FOEV Speyer AYESHA MEHTAB, COMSATS University-Islamabad-How Immigration Can Raise Wages in Pakistan

AYSUN AYGUN, Istanbul Technical University, and MURAT KIRDAR, Bogazici University-The Impact of Syrian Refugees on Native Mortality in Turkey

INES TROJETTE, ESPI Paris, and DOSLALO MILLOGO, University of Norbert-Zongo-Do French Migration Policies Affect Immigrants Inflows in the MENA Region?

HISHAM FOAD, San Diego State University_Comparing Middle Eastern Migration to Europe, Latin America, and North America 


\section{Saturday $•$ January 4}

\section{8:00 AM Manchester Grand Hyatt San Diego-Marina \\ NAFE}

Estimating Worklife Expectancy and Earnings Capacity (K2)

Presiding: CONSTANTINE M. BOUKIDIS, VWM Analytics

DAVID ROSENBAUM, University of Nebraska-Lincoln, and KALANA JAYANETTI, University of Nebraska-LincolnUnemployment Biases in Worklife Expectancy

CHARLES L. BAUM, Middle Tennessee State UniversityEmployee Tenure Projections for Calculating Economic Losses in Wrongful Termination Cases

NIKANOR I. VOLKOV, Mercer University, THOMAS RONEY, Thomas Roney LLC, and BRITTANY PEARCE, Thomas Roney LLC_Estimating the Present Value of Earning Capacity for an Undocumented Worker

Discussants: GARY SKOOG, Legal Econometrics, Inc.

CRAIG ALLEN, Commonwealth Research Group

STEPHEN HORNER, Consulting Economist

\section{8:00 AM Manchester Grand Hyatt San Diego-Cove SABE/AEA}

Morality and Social Dilemmas in Society (D9)

Presiding: ANGELA C. M. DE OLIVEIRA, University of MassachusettsAmherst

JAMES COX, Georgia State University, VJOLLCA SADIRAJ, Georgia State University, and SUSAN XU TANG, Georgia State University-Rational Choice in Games with Externalities and Contractions

ABHIJIT RAMALINGAM, Appalachian State University, NOR IZZATINA ABDUL AZIZ, University of East Anglia, and ROBERT SUGDEN, University of East Anglia-Status and Trust in Representative Leaders: A Lab-in-the-Field Experiment in Rural Sarawak

DANILA SERRA, Texas A\&M University, VINCENZO DI MARO, World Bank, STEFAN LEEFFERS, Nova University of Lisbon, and PEDRO VICENTE, Nova University of Lisbon-Information and Collective Action in Angolan Schools 


\section{Saturday $•$ January 4}

LOUIS PUTTERMAN, Brown University, JEAN-ROBERT TYRAN, University of Vienna, and KENJU KAMEI, Durham University—Civic Engagement as a Second Order Public Good: An Experiment

Discussants: NATHAN CHAN, University of Massachusetts-Amherst

IRENE MUSSIO, McMaster University

SHEHERYAR BANURI, University of East Anglia

BILLUR AKSOY, Rensselaer Polytechnic Institute

\section{8:00 AM Manchester Grand Hyatt San Diego-Mission Beach B SGE}

\section{Firms, Growth and Concentration (E0)}

Presiding: CHAD SYVERSON, University of Chicago

NICHOLAS BLOOM, Stanford University, AUDREY GUO, Stanford University, and BRIAN LUCKING, Stanford UniversityOutsourcing, Occupational and Industrial Concentration

ESTEBAN ROSSI-HANSBERG, Princeton University, PIERREDANIEL SARTE, Federal Reserve Bank of Richmond, and NICHOLAS TRACHTER, Federal Reserve Bank of RichmondDiverging Trends in National and Local Concentration

UFUK AKCIGIT, University of Chicago, EMIN DINLERSOZ, U.S. Census Bureau, JEREMY GREENWOOD, University of Pennsylvania, and VERONIKA PENCIAKOVA, University of Maryland-Synergizing Ventures

TOSHI MUKOYAMA, Georgetown University, DAN CAO, Georgetown University, HENRY HYATT, U.S. Census Bureau, and ERICK SAGER, Federal Reserve Board-Firm Growth through New Establishments

Discussants: DOMINIC SMITH, U.S. Bureau of Labor Statistics

RYAN A. DECKER, Federal Reserve Board

DEVESH RAVAL, Federal Trade Commission

SINA ATES, Federal Reserve Board 


\section{Saturday $•$ January 4}

\section{8:00 AM Manchester Grand Hyatt San Diego-Old Town A URPE/IAFFE}

\section{Gender and Race in Economic Outcomes (J3)}

Presiding: ELISSA BRAUNSTEIN, Colorado State University

ROBIN BARTLETT, Denison University, ZARRINA JURAQULOVA, Denison University, and ANDREA ZIEGERT, Denison University-Did the Unique Team Mentoring of CCOFFE Work? Evidence from 20 Years Later

MARLENE KIM, University of Massachusetts-Boston-The Intersection of Gender and Race: African American and Asian American Women in the United States, 1980-2018 and Gendered Racism

CRISTINA PEREIRA VIECELI, Federal University of Rio Grande do Sul (UFRGS), and CARLOS VASCONCELLO, Federal University of Rio Grande do Sul (UFRGS)_Domestic Employment in Brazil: Two Decades of Continuity and Change

HANNA SZYMBORSKA, Birmingham City UniversityUnderstanding the Structural Determinants of Wealth Inequality across Gender and Race

\section{8:00 AM Manchester Grand Hyatt San Diego-Old Town B URPE}

\section{Gendered Labor: Paid and Unpaid Work in Contemporary Capitalism (B5)}

Presiding: KATHERINE MOOS, University of Massachusetts-Amherst

KATHERINE MOOS, University of Massachusetts-Amherst, and HAO QI, Renmin University of China-How Neoliberal Is China's Welfare State? Comparing the Chinese and United States Net Social Wage 1992-2016

LUIZA NASSIF PIRES, New School for Social Research-The Impact of Gender and Race Segregation on Labor Organization in a Social Interaction Model

LYGIA SABBAG FARES GIBB, Getulio Vargas Foundation-The Gendered Impact of Working Time Flexibilization

JENNY BROWN, National Women's Liberation-Longevity: Crisis or Blessing 


\section{Saturday $•$ January 4}

\section{0:15 AM Manchester Grand Hyatt San Diego-Mission Beach A}

AAEA

\section{Market Structure and Pricing in Food Markets (L1)}

Presiding: STEPHEN HAMILTON, California Polytechnic State UniversitySan Luis Obispo

METIN CAKIR, University of Minnesota, CLARE CHO, USDA Economic Research Service, and XIANGWEN KONG, University of Minnesota-Food Retailing in Rural America: Growth of National Chains and the Viability of Independent Stores

CHRISTOPH BAUNER, University of Massachusetts-Amherst, and EMILY WANG, University of Massachusetts-Amherst-The Effect of Competition on Pricing and Product Positioning: Evidence from Wholesale Club Entry

JINHO JUNG, Purdue University, JUAN SESMERO, Purdue University, and RALPH SIEBERT, Purdue University-Spatial Competition and Pricing in Agricultural Procurement Markets: Evidence from the Corn Market in Indiana

TIMOTHY RICHARDS, Arizona State University, JOHN LOWERY, Ohio State University, and STEPHEN HAMILTON, California Polytechnic State University-San Luis Obispo-Food Waste, Food Banks, and Damaged Goods

\section{0:15 AM Manchester Grand Hyatt San Diego-America's Cup C ACE}

\section{Applied Micro in Economic Development: Natural Disasters, Education, and Technology (O1)}

Presiding: STEPHEN SMITH, Hope College

LEAH BEVIS, Ohio State University, and KIRA VILLA, University of New Mexico-The Intergenerational Health Impact of Early Life Climate Variablity and its Implications for Child Recovery from Natural Disasters: Evidence from Indonesia 


\section{Saturday $•$ January 4}

GARRICK BLALOCK, Cornell University, THERESA BELTRAMO, United Nations High Commissioner for Refugees, STEPHEN HARRELL, University of California-Berkeley, DAVID I. LEVINE, University of California-Berkeley, and ANDREW M. SIMONS, Fordham University-The Effects of Fuel-Efficient Cook Stoves on Fuel Use, Particulate Matter, and Cooking Practices: Results from a Randomized Trial in Rural Uganda

PAUL GLEWWE, University of Minnesota, ZOE JAMES, University College London, JONGWOOK LEE, University of Minnesota, CAINE ROLLESTON, University College London, and KHOA VU, University of Minnesota-What Explains Vietnam's Exceptional Performance in Education Relative to Other Countries? Analysis of the Young Lives Data from Ethiopia, Peru, India (Andhra Pradesh), and Vietnam

JEFFREY BLOEM, University of Minnesota, and BRUCE WYDICK, University of San Francisco-All I Really Need to Know I Learned in Kindergarten? Evidence from the Philippines

Discussants: SARAH E. HAMERSMA, Syracuse University

RUSSELL D. TOTH, University of Sydney

RUTH UWAIFO OYELERE, Agnes Scott College

DENISE STANLEY, California State University-Fullerton

\section{0:15 AM Manchester Grand Hyatt San Diego_-Harbor D ACES/SIOE}

\section{From Culture to Governance: Towards a Comparative Economics of Institutions and Organizations (H1)}

Presiding: ROBERT GIBBONS, Massachusetts Institute of Technology

VASILIKI FOUKA, Stanford University, and ALAIN SCHLAEPFER, Santa Clara University-Culture Clash: Incompatible Reputation Systems and Intergroup Conflict

DEVESH RUSTAGI, Goethe University Frankfurt-The Interdependence of Culture and Institutions in Commons Management

XIAO YU WANG, Duke University, JUAN CARLOS SUÁREZ SERRATO, Duke University, and SHUANG ZHANG, University of Colorado-Boulder-The Limits of Meritocracy: Screening Bureaucrats under Imperfect Verifiability 


\section{Saturday $•$ January 4}

DIANA MOREIRA, University of California-Davis, JONAS HJORT, Columbia University, and GAUTAM RAO, Harvard University-Do Research Findings Influence Policy? Experimental Evidence from 2,145 Brazilian Municipalities

Discussants: KARLA HOFF, World Bank

GERARD PADRÓ I MIQUEL, Yale University

ROBERT GIBBONS, Massachusetts Institute of Technology

\section{0:15 AM Marriott Marquis San Diego-Rancho Santa Fe 2} AEA

\section{Achievement Tests II: On the Validity of Comparisons across SES and Place (I2)}

Presiding: JOHN B. KLOPFER, University of Hong Kong and United States Naval Academy

ERIC NIELSEN, Federal Reserve Board-Test Questions, Economic Outcomes, and Inequality

DEV PATEL, Harvard University, and JUSTIN SANDEFUR, Center for Global Development-Standardizing "Standardized" Tests: A New Global Measure of Human Capital

ERIC A. HANUSHEK, Stanford University, ANNIKA B. BERGBAUER, Ifo Institute, and LUDGER WOESSMANN, Ifo Institute and CESifo-Testing

\section{0:15 AM Marriott Marquis San Diego-Marriott Grand Ballroom 1}

AEA

\section{Algorithmic Fairness and Bias (J7)}

Presiding: BO COWGILL, Columbia University

SUSAN ATHEY, Stanford University, KEVIN BRYAN, University of Toronto, and JOSHUA GANS, University of Toronto-Designing Organizations and Incentives with Human and Artificial Intelligence Agents 


\section{Saturday $\cdot$ January 4}

BO COWGILL, Columbia University, and FABRIZIO DELL'AQUA, Columbia University-Biased Programmers? Or Biased Training Data? A Field Experiment About Algorithmic Bias

JON KLEINBERG, Cornell University, JENS LUDWIG, University of Chicago, SENDHIL MULLAINATHAN, University of Chicago, ASHESH RAMBACHAN, Harvard University, and CASS SUNSTEIN, Harvard University-Regulating Discrimination in the Presence of Algorithms

MEGAN STEVENSON, George Mason University, and JENNIFER DOLEAC, Texas A\&M University-Algorithmic Risk Assessment in the Hands of Humans

Discussants: JOSHUA GANS, University of Toronto

AVI GOLDFARB, University of Toronto

JORGE GUZMÁN, Columbia University

SHANE GREENSTEIN, Harvard Business School

\section{0:15 AM Marriott Marquis San Diego-Marriott Grand Ballroom 10 \\ AEA}

Economic Measurement Challenges in the Digital Economy (O3)

Presiding: JOHN HALTIWANGER, University of Maryland

ERIK BRYNJOLFSSON, Massachusetts Institute of Technology, AVINASH COLLIS, Massachusetts Institute of Technology, W. ERWIN DIEWERT, University of British Columbia, FELIX EGGERS, University of Groningen, and KEVIN FOX, University of New South Wales-GDP-B: Accounting for the Value of New and Free Goods in the Digital Economy

HUNT ALLCOTT, New York University, LUCA BRAGHIERI, Stanford University, SARAH EICHMEYER, Stanford University, and MATTHEW GENTZKOW, Stanford University-The Welfare Effects of Social Media

CAROL CORRADO, Conference Board, DAVID MARTIN, M-Cam International, and QIANFAN WU, M-Cam InternationalInnovation-a: What Does an Intangibles-intensive Stock Price Index Tell Us about Business Profitability and Productivity? 


\section{Saturday $•$ January 4}

DIANA FARRELL, JP Morgan Chase Institute, FIONA GREIG, JP Morgan Chase Institute, and ERICA DEADMAN, JP Morgan Chase Institute-Estimating Family Income from Administrative Banking Data: A Machine Learning Approach

\section{0:15 Am Marriott Marquis San Diego-Marriott Grand} Ballroom 5-6

AEA

Economics for Inclusive Prosperity (EfIP) (A1)

Presiding: DANI RODRIK, Harvard University

SURESH NAIDU, Columbia University, DANI RODRIK, Harvard University, and GABRIEL ZUCMAN, University of CaliforniaBerkeley-Can Economics Rise to the Challenge?

SAMUEL BOWLES, Santa Fe Institute, and WENDY CARLIN, University College London-Economic Foundations of Real Freedom for All

LUIGI ZINGALES, University of Chicago-The Political Limits of Economics

\section{0:15 AM Marriott Marquis San Diego_Point Loma} AEA

\section{Firms, Trade and Globalization (F6)}

Presiding: NINA PAVCNIK, Dartmouth College

TIANYUE RUAN, National University of Singapore-Financial Globalization and the Growth-Stability Trade-Off

NITYA PANDALAI-NAYAR, University of Texas-Austin-Local Shocks and the Origins of Granular Fluctuations

ERHAN ARTUC, World Bank, PAULO BASTOS, World Bank, and EUNHEE LEE, University of Maryland-Trade, Jobs, and Worker Welfare

RACHA MOUSSA, International Monetary Fund, ANUSHA CHARI, University of North Carolina-Chapel Hill and NBER, and PETER BLAIR HENRY, New York University and Brookings Institution-Does Capital Scarcity Matter? 


\section{Saturday $\cdot$ January 4}

Discussants: YAN BAI, University of Rochester

KALINA MANOVA, University College London

NINA PAVCNIK, Dartmouth College

INA SIMONOVSKA, University of California-Davis

\section{0:15 АM Marriott Marquis San Diego-San Diego Ballroom A AEA}

\section{Gender and the Economics Profession (J7)}

Presiding: BETSEY STEVENSON, University of Michigan

ALICIA MODESTINO, Northeastern University, PASCALINE DUPAS, Stanford University, MURIEL NIEDERLE, Stanford University, and JUSTIN WOLFERS, University of MichiganGender and the Dynamics of Economics Seminars

DONNA GINTHER, University of Kansas, JANET CURRIE, Princeton University, FRANCINE BLAU, Cornell University, and RACHEL CROSON, Michigan State University-Can Mentoring Help Female Assistant Professors in Economics? An Evaluation by Randomized Trial

BEATRICE CHERRIER, University of Cergy-Pontoise and CNRS, CLEO CHASSONNERY-ZAIGOUCHE, University of Cambridge, and JOHN SINGLETON, University of Rochester-Economics Is

Not a Man's Field: A History of CSWEP and of the First Gender Reckoning in the Economics Profession

DANIELLE H. SANDLER, U.S. Census Bureau, LUCIA FOSTER, U.S. Census Bureau, JULIA MANZELLA, U.S. Census Bureau, and ERIKA MCENTARFER, U.S. Census Bureau-Employment Dynamics for Economists: Empirical Evidence by Gender and Race

Discussants: SANDRA E. BLACK, Columbia University

SUSAN DYNARSKI, University of Michigan

MARIANNE WANAMAKER, University of Tennessee

BHASH MAZUMDER, Federal Reserve Bank of Chicago 


\section{Saturday $•$ January 4}

\section{0:15 AM Marriott Marquis San Diego-Torrey Pines 1}

AEA

\section{Health Care Systems (I1)}

Presiding: DAVID FRISVOLD, University of Iowa

DANIEL KALISKI, University of London-Does Insurance for Treatment Crowd Out Prevention? Evidence from Diabetics' Insulin Usage

MANUEL HOFFMANN, Texas A\&M University-Private Health Insurance under Universal Health Care: Health, Labor, and Budget Considerations

GABOR KEZDI, University of Michigan, TAMAS HAJDU, Hungarian Academy of Sciences, GABOR KERTESI, Hungarian Academy of Sciences, and AGNES SZABO-MORVAI, Hungarian Academy of Sciences-The Effect of a Neonatal Intensive Care System on Neonatal and Infant Mortality: Evidence from Expanding the System through 25 years in Hungary

BARIS K. YORUK, State University of New York-Albany, PINKA CHATTERJI, State University of New York-Albany, and XIANGSHI LIU, Southwestern University of Finance and Economics-The Effects of the 2010 Affordable Care Act Dependent Care Provision on Family Structure and Public Program Participation among Young Adults

MOON JOON KIM, Duke Kunshan University-Unintended Impacts of the Abolition of Copayment on Outpatient Utilization in South Korea: Evidence from a Regression Discontinuity in Time

FANGWEN LU, Renmin University of China, and YILEI LUO, Renmin University of China-Why Are the Elderly Vulnerable to Cheating? Evidence from a Survey Experiment

\section{0:15 AM Marriott Marquis San Diego-Marriott Grand Ballroom 3 \\ AEA}

Interventions to Close Gender Gaps - What Works and What Can Backfire (C9)

Presiding: RAGAN PETRIE, Texas A\&M University 


\section{Saturday $•$ January 4}

DANY KESSEL, Södertörn University, JOHANNA MOLLERSTROM, George Mason University, and ROEL VAN VELDHUIZEN, Lund University-Simple Advice Eliminates the Gender Gap in Willingness to Compete

GAURI KARTINI SHASTRY, Wellesley College, OLGA SHURCHKOV, Wellesley College, and LINGJUN (LOTUS) XIA, Wellesley College_Luck or Skill: How Women and Men React to Noisy Feedback

KATHERINE COFFMAN, Harvard Business School, MANUELA COLLIS, Harvard Business School, and LEENA KULKARNI, Harvard University-Stereotypes and Belief Updating

KATHERINE COFFMAN, Harvard Business School, CLIO BRYANT FLIKKEMA, Wellesley College, and OLGA SHURCHKOV, Wellesley College-Gender Stereotypes in Deliberation and Team Decisions

RANIA GIHLEB, University of Pittsburgh, RACHEL LANDSMAN, Bucknell University, and LISE VESTERLUND, University of Pittsburgh-Banning Negotiation: Is Wage Dispersion Maintained When Left to Manager Discretion?

Discussants: ANAT BRACHA, Federal Reserve Bank of Boston

ELIF DEMIRAL, George Mason University

CORINNE LOW, University of Pennsylvania

MARIA RECALDE, University of Melbourne

ANYA SAMEK, University of Wisconsin-Madison

\section{0:15 AM Marriott Marquis San Diego-Del Mar} AEA

\section{Liquidity Regulation (G2)}

Presiding: CHRISTA H.S. BOUWMAN, Texas A\&M University

ERIC MONNET, Bank of France, Paris School of Economics and CEPR, and MIKLOS VARI, International Monetary FundLiquidity Ratios as Monetary Policy Tools: Some Historical Lessons for Macroprudential Policy 


\section{Saturday $\cdot$ January 4}

STEPHAN IMHOF, Swiss National Bank, CYRIL MONNET, Bank for International Settlements, and SHENGXING ZHANG, London School of Economics-The Risk-Taking Channel of Liquidity Regulations and Monetary Policy

CHRISTOPHER J. CURFMAN, University of Texas-Austin, and JOHN KANDRAC, Federal Reserve Board-The Costs and Benefits of Liquidity Regulations: Lessons from an Idle Monetary Policy Tool

DANIEL ROBERTS, Harvard University, ASANI SARKAR, Federal Reserve Bank of New York, and OR SHACHAR, Federal Reserve Bank of New York-Bank Liquidity Creation, Systemic Risk and Basel Liquidity Regulations

Discussants: MORTEN L. BECH, Bank for International Settlements

KINDA HACHEM, University of Virginia

GLENN SCHEPENS, European Central Bank

CHRISTA H.S. BOUWMAN, Texas A\&M University

\section{0:15 AM Marriott Marquis San Diego-Marriott Grand Ballroom 4 \\ AEA}

\section{New Research on School Choice: The Role of Parental \\ Preferences, Housing Search, and Assignment Mechanisms (H4)}

Presiding: JUSTINE HASTINGS, Brown University

CAMILLE TERRIER, HEC Lausanne, and PARAG PATHAK, Massachusetts Institute of Technology-Banning the Boston Assignment Mechanism: Effects on School Segregation and Student Achievement

PETER BERGMAN, Columbia University, ERIC CHAN, Babson College, and ADAM KAPOR, Princeton University-Housing Search Frictions: Evidence from Detailed Search Data and a Field Experiment

DAMON CLARK, University of California-Irvine, PACO MARTORELL, University of California-Davis, and MATTHEW WISWALL, University of Wisconsin-Madison-What Do Families Want from Schools? Evidence from Real Choices and a Survey of Choosers 


\section{Saturday $\cdot$ January 4}

JULIEN GRENET, CNRS and Paris School of Economics, GABRIELLE FACK, Paris Dauphine University, and YINGHUA HE, Rice University-The Effects of Affirmative Action on Targeted and Non-Targeted Students: Evidence from Low-Income Priorities in Paris High School

Discussants: ADAM KAPOR, Princeton University

YUSUKE NARITA, Yale University

DOUGLAS O. STAIGER, Dartmouth College

CHRISTOPHER WALTERS, University of California-Berkeley

\section{0:15 AM Marriott Marquis San Diego-Balboa} AEA

\section{Peer Effects and Technology Adoption (O3)}

Presiding: THERESA KUCHLER, New York University

DANIEL BJORKEGREN, Brown University-Competition in Network Industries: Evidence from Mobile Telecommunication in Rwanda

SEAN HIGGINS, University of California-Berkeley-Financial Technology Adoption

CHRISTOPHER TONETTI, Stanford University, TREB ALLEN,

Dartmouth College, and KAMRAN BILIR, University of

Wisconsin-Knowledge Diffusion through Networks

THERESA KUCHLER, New York University, JOHANNES STROEBEL, New York University, MICHAEL C. BAILEY, Facebook, ARLENE WONG, Princeton University, and DREW JOHNSTON, New York University-Peer Effects in Product Adoption

\section{0:15 AM Marriott Marquis San Diego-Marriott Grand Ballroom 13}

AEA

\section{Real Effects of Non-Rational Expectations (E7)}

Presiding: DAVID THESMAR, Massachusetts Institute of Technology JOSE MARIA BARRERO, Technological Autonomous University of Mexico (ITAM) - The Micro and Macro of Managerial Beliefs 


\section{Saturday $•$ January 4}

YUERAN MA, University of Chicago, TIZIANO ROPELE, Bank of Italy, DAVID SRAER, University of California-Berkeley, and DAVID THESMAR, Massachusetts Institute of Technology-Do Managerial Forecasting Biases Matter?

HUSEYIN GULEN, Purdue University, MIHAI ION, University of Arizona, and STEFANO ROSSI, Bocconi University-Credit Cycles and Corporate Investment

PEDRO BORDALO, University of Oxford, NICOLA GENNAIOLI, Bocconi University, ANDREI SHLEIFER, Harvard University, and STEPHEN J. TERRY, Boston University-Real Credit Cycles

Discussants: TONI WHITED, University of Michigan

OLIVIER COIBION, University of Texas-Austin

BIGE KAHRAMAN, University of Oxford

JULIANA SALOMAO, University of Minnesota

\section{0:15 AM Marriott Marquis San Diego-Solana AEA}

Superstar Economies: Concentration and Increasing Differences between Firms (D2)

Presiding: CHIARA CRISCUOLO, OECD

JOHN MICHAEL VAN REENEN, Massachusetts Institute of Technology —Changes in Firm Inequality and Market Power THOMAS PHILIPPON, New York University—Global Stars

MATEJ BAJGAR, OECD, GIUSEPPE BERLINGIERI, ESSEC Business School and OECD, SARA CALLIGARIS, OECD, CHIARA CRISCUOLO, OECD, and JONATHAN TIMMIS, OECD-Industry Concentration in Europe and North America

UFUK AKCIGIT, University of Chicago, SINA ATES, Federal Reserve Board, and SEBNEM KALEMLI-OZCAN, University of Maryland-Diverging Productivity of Best and the Rest: The Role of Globalization 


\section{Saturday $\cdot$ January 4}

\section{0:15 AM Marriott Marquis San Diego-Marina Ballroom D}

AEA

\section{Tax Havens, Offshore Issuance and the Global Financial System} (F3)

Presiding: HYUN SONG SHIN, Bank for International Settlements

BORIS HOFMANN, Bank for International Settlements, HYUN SONG SHIN, Bank for International Settlements, and MAURICIO VILLAMIZAR-VILLEGAS, Central Bank of Colombia-FX Intervention and Domestic Credit: Evidence from High-frequency Micro Data

ANTONIO COPPOLA, Harvard University, MATTEO MAGGIORI, Harvard University, JESSE SCHREGER, Columbia University, and BRENT NEIMAN, University of Chicago-Redrawing the Map of Global Capital Flows: The Role of Cross-Border Financing and Tax Havens

RICARDO CORREA, Federal Reserve Board, WENXIN DU, University of Chicago, GORDON LIAO, Federal Reserve Board, and LUKE PETTIT, Federal Reserve Board-United States Banks and Global Liquidity

Discussants: HANNO LUSTIG, Stanford University

KRISTIN FORBES, Massachusetts Institute of Technology

TYLER MUIR, University of California-Los Angeles

\section{0:15 AM Marriott Marquis San Diego-Marriott Grand} Ballroom 12

AEA

The Consequences of Demonetization: Evidence from the World's Largest Democracy (01)

Presiding: PRASHANT BHARADWAJ, University of California-San Diego ABHIJIT BANERJEE, Massachusetts Institute of Technology, EMILY BREZA, Harvard University, ARUN CHANDRASEKHAR, Stanford University, and BENJAMIN GOLUB, Harvard UniversityWhen Less is More: Experimental Evidence on Information Delivery during India's Demonetization 


\section{Saturday $•$ January 4}

GAURAV KHANNA, University of California-San Diego, and PRIYA MUKHERJEE, College of William and Mary-Political Punishment and Financial Safety Nets: Evidence from India's Demonetization

GAUTAM NAIR, Yale University-The Political Economy of Demonetization

Discussants: CYNTHIA KINNAN, Tufts University

MARTIN KANZ, World Bank Group

YUSUF NEGGERS, University of Michigan-Ann Arbor

CESI CRUZ, University of British Columbia

\section{0:15 Am Marriott Marquis San Diego-Marriott Grand Ballroom 11}

AEA

The Role of Attitudes and Perceptions on Economic and Political Outcomes (A1)

Presiding: PAOLA GIULIANO, University of California-Los Angeles

ODED GALOR, Brown University, OMER OZAK, Southern Methodist University, and ASSAF SARID, University of HaifaLinguistic Traits and Human Capital Formation

PAOLA GIULIANO, University of California-Los Angeles, and PAOLA SAPIENZA, Northwestern University-The Happiness Cost of Being Patient

ANKE BECKER, Harvard University, BENJAMIN ENKE, Harvard University, and ARMIN FALK, Behavior and Inequality Research Institute (BRIQ) - Ancient Origins of the Global Variation in Economic Preferences

ALBERTO ALESINA, Harvard University, and STEFANIE STANTCHEVA, Harvard University-Perception Versus Reality in Trump Voters' Minds 


\section{Saturday $\cdot$ January 4}

10:15 AM Marriott Marquis San Diego-Presidio 1-2

AEA

Panel: Transforming the Economics Classroom: Diversity and Inclusion (A2)

Presiding: MARTHA L. OLNEY, University of California-Berkeley

AMANDA BAYER, Swarthmore College

LISA COOK, Michigan State University

WILLIAM DARITY, Duke University

GARY HOOVER, University of Oklahoma

KIMMARIE MCGOLDRICK, University of Richmond

NANCY L. ROSE, Massachusetts Institute of Technology

10:15 АM Manchester Grand Hyatt San Diego_Gaslamp D AERE

\section{Economics of Water (Q2)}

Presiding: OLIVIER DESCHENES, University of California-Santa Barbara MUYANG GE, Nanjing Audit University, ERIC EDWARDS, North Carolina State University, and REZA OLADI, Utah State University-Water Trade in General Equilibrium: Theory and Evidence

ANDREW AYRES, Environmental Defense Fund, and RENATO MOLINA, University of Miami-Water Market Dynamics in the Presence of Environmental Variability

ELLEN MARIE BRUNO, University of California-Berkeley, KATRINA JESSOE, University of California-Davis, and MICHAEL HANEMANN, Arizona State University - Water Prices, Water Use, and Adoption of Water-saving Technology: Evidence from California Agriculture

STEVEN M. SMITH, Colorado School of Mines, and ERIC EDWARDS, North Carolina State University-Technological Change and Climatic Resiliency: Evidence from Irrigation in the United States 


\section{Saturday $•$ January 4}

Discussants: DAVID SUNDING, University of California-Berkeley

SHEILA OLMSTEAD, University of Texas

YUSUKE KUWAYAMA, Resources for the Future

OLIVIER DESCHENES, University of California-Santa Barbara

\section{0:15 AM Manchester Grand Hyatt San Diego-Seaport DE} AFA

Panel: Innovating for Financial Health: Are FinTechs, Banks and Policymakers Addressing the Challenges? (G0)

Presiding: AMIT SERU, Stanford University

KENNETH SINGLETON, Stanford University

ADRIENNE HARRIS, Financial Health Network

SHLOMO BENARTZI, University of California-Los Angeles

RYAN FALVEY, Financial Venture Studio

\section{0:15 AM Manchester Grand Hyatt San Diego-Seaport A} AFA

\section{Asset Specificity and Prices (G1)}

Presiding: LIYAN YANG, University of Toronto

HUI CHEN, Massachusetts Institute of Technology, ZHUO CHEN, Tsinghua University, ZHIGUO HE, University of Chicago, JINYU LIU, University of International Business and Economics, and RENGMING XIE, CITIC Securities-Pledgeability and Asset Prices: Evidence from the Chinese Corporate Bond Markets

TURAN BALI, Georgetown University, DAVID HIRSHLEIFER, University of California-Irvine, LIN PENG, City University of New York-Baruch College, and YI TANG, Fordham UniversityAttention, Social Interaction, and Investor Attraction to Lottery Stocks

JOHN GRIFFIN, University of Texas-Austin, NICHOLAS HIRSCHEY, London Business School, and SAMUEL KRUGER, University of Texas-Austin-Do Municipal Bond Dealers Give Their Customers Best Execution or Opportunistic Pricing? 


\section{Saturday $\cdot$ January 4}

Discussants: JAEWON CHOI, University of Illinois

JOSEPH ENGELBERG, University of California-San Diego

ZHAOGANG SONG, Johns Hopkins University

\section{0:15 AM Manchester Grand Hyatt San Diego_Seaport B} AFA

\section{Blockchain and Cryptocurrencies (G2)}

Presiding: GERRY TSOUKALAS, University of Pennsylvania

WILL CONG, University of Chicago, YE LI, Ohio State University, and NENG WANG, Columbia University-Tokenomics and Platform Finance

BRUNO BIAIS, HEC Paris, CHRISTOPHE BISIERE, Toulouse School of Economics, MATTHIEU BOUVARD, McGill University, CATHERINE CASAMATTA, Toulouse School of Economics, and ALBERT MENKVELD, VU University Amsterdam-Equilibrium Bitcoin Pricing

FRANZ HINZEN, New York University, KOSE JOHN, New York University, and FAHAD SALEH, McGill University-Proof-ofWork's Limited Adoption Problem

Discussants: EMILIANO PAGNOTTA, Imperial College London

MARKUS BRUNNERMEIER, Princeton University

DAVID MUSTO, University of Pennsylvania

\section{0:15 AM Manchester Grand Hyatt San Diego-Seaport C AFA}

\section{CEO Effects (G3)}

Presiding: DIRK JENTER, London School of Economics

ANTOINETTE SCHOAR, Massachusetts Institute of Technology, KELVIN YEUNG, Cornell University, and LUO ZUO, Cornell University-The Effects of Managers on Systematic Risk

CLARK LIU, Tsinghua University, TAO SHU, Chinese University of Hong Kong, JOHAN SULAEMAN, National University of Singapore, and ERIC YEUNG, Cornell University-Life Is Too Short? Bereaved Managers and Investment Decisions 


\section{Saturday $•$ January 4}

CLAUDIA CUSTODIO, Imperial College London, DIOGO MENDES, Nova Business School, and DANIEL METZGER, Rotterdam School of Management-The Impact of Financial Literacy on Medium and Large Enterprises - Evidence from a Randomized Controlled Trial in Mozambique

Discussants: PAVEL SAVOR, DePaul University

FRANCISCO PEREZ, Autonomous Technological University of Mexico (ITAM)

BILAL ZIA, World Bank

\section{0:15 AM Manchester Grand Hyatt San Diego-Seaport F AFA}

\section{Financial Stability (G2)}

Presiding: STACEY SCHREFT, U.S. Office of Financial Research

VIRAL ACHARYA, Reserve Bank of India, CEPR, and NBER, KATHARINA BERGANT, Trinity College Dublin, MATTEO CROSIGNANI, University of Michigan, TIM EISERT, Erasmus University Rotterdam, and FERGAL MCCANN, Central Bank of Ireland-The Anatomy of the Transmission of Macroprudential Policies

ANTONIO FALATO, Federal Reserve Board, DIANA IERCOSAN, Federal Reserve Board, and FILIP ZIKES, Federal Reserve BoardBanks as Regulated Traders

AGOSTINO CAPPONI, Columbia University, and MARKO WEBER, Columbia University-Systemic Portfolio Diversification

Discussants: TOMASZ PISKORSKI, Columbia University

MARK FLANNERY, University of Florida

SELMAN EROL, Carnegie Mellon University

\section{0:15 AM Manchester Grand Hyatt San Diego-Seaport G AFA}

Psychology and Asset Prices (G1)

Presiding: CAMELIA KUHNEN, University of North Carolina-Chapel Hill 


\section{Saturday $\cdot$ January 4}

HONGYE GUO, University of Pennsylvania, and JESSICA WACHTER, University of Pennsylvania- “Superstitious" Investors NICHOLAS BARBERIS, Yale University, LAWRENCE JIN, California Institute of Technology, and BAOLIAN WANG, University of Florida-Prospect Theory and Stock Market Anomalies

JINGCHI LIAO, Shenzhen Stock Exchange, and CAMERON PENG, London School of Economics-Price and Volume Dynamics in Bubbles

Discussants: IAN DEW-BECKER, Northwestern University

IAN MARTIN, London School of Economics

CARY FRYDMAN, University of Southern California

\section{0:15 AM Manchester Grand Hyatt San Diego-Seaport H}

AFA

\section{R\&D, Patents, and Innovation (G3)}

Presiding: SHAI BERNSTEIN, Stanford University

DAVIDHSU, University of Pennsylvania, PO-HSUAN HSU, National Tsing Hua University, TONG ZHOU, Sun Yat-Sen University, and ARVIDS ZIEDONIS, Boston University-Benchmarking United States University Technology Commercialization Efforts: A New Approach

JAN BENA, University of British Columbia, HERNAN ORTIZMOLINA, University of British Columbia, and ELENA SIMINTZI, University of North Carolina-Chapel Hill—Shielding Firm Value: Employment Protection and Process Innovation

GERARD HOBERG, University of Southern California, BRUCE LI, University of Southern California, and GORDON PHILLIPS, Dartmouth College-United States Innovation and Chinese Competition for Innovation Production

SABRINA T. HOWELL, New York University, and FILIPPO MEZZANOTTI, Northwestern University-Financing Entrepreneurship through the Tax Code: Angel Investor Tax Credits

Discussants: DANIELLE LI, Massachusetts Institute of Technology

GUSTAVO MANSO, University of California-Berkeley

ADRIEN MATRAY, Princeton University

SABRINA T. HOWELL, New York University 


\section{Saturday $•$ January 4}

\section{0:15 AM Manchester Grand Hyatt San Diego-Harbor A}

AFA

\section{Skill in Mutual Funds (G1)}

Presiding: LUCIAN TAYLOR, University of Pennsylvania

MARKUS IBERT, Federal Reserve Board-What Do Mutual Fund Managers' Private Portfolios Tell Us About Their Skills?

NIKOLAI ROUSSANOV, University of Pennsylvania, HONGXUN RUAN, Peking University, and YANHAO WEI, University of Southern California-Mutual Fund Flows and Performance in (Imperfectly) Rational Markets?

JUN KYUNG AUH, Georgetown University, and JENNIE BAI, Georgetown University-Cross-Asset Information Synergy in Mutual Fund Families

Discussants: JUHANI LINNAINMAA, University of Southern California JONATHAN BERK, Stanford University

CLEMENS SIALM, University of Texas-Austin and NBER

\section{0:15 AM Manchester Grand Hyatt San Diego_Promenade A AFEA}

\section{Infrastructure and Finance in Africa (O1)}

Presiding: BORIS HOUENOU, Washington State University

CHRISTIAN NSIAH, Baldwin Wallace University, BICHAKA FAYISSA, Middle Tennessee State University, and HERMAN SAHNI, Baldwin Wallace University-Nonlinearities in the Impact of Infrastructure Investments on Long-Run Economic Growth: Evidence from African Countries

AKPAN EKPO, African Development Bank, ANTHONY SIMPASA, African Development Bank, and CHUKU CHUKU, African Development Bank-Greasing the Wheels of Regional Integration: Infrastructure as a Catalyst for Trade, Innovation, and Growth in Africa

BEDASSA TADESSE, University of Minnesota-Duluth, BICHAKA FAYISSA, Middle Tennessee State University, and ELIAS SHUKRALLA, Siena College-Infrastructure, Transaction Costs, and Trade: The Imperatives for African Economies 


\section{Saturday $\cdot$ January 4}

ADUGNA LEMI, University of Massachusetts-Boston, LIYAN LIU, Beijing Institute of Petrochemical Technology, and IAN WRIGHT, University of Miami-Where and Why Do Chinese Firms Invest in Africa: Application of a Spatial Analysis

JEAN-CLAUDE MASWANA, Ritsumeikan University, BONIFACE YEMBA, Marshall University, ERICK KITENGE, Central State University, and CHRISTIAN OTCHIA, Nagoya UniversityAfrica's Manufacturing Development under the Rise of China: Threat or Opportunity

AMIRA EL-SHAL, African Development Bank, HANAN MORSY, African Development Bank, and ANDINET WOLDEMICHAEL, African Development Bank-Explaining Firm-level Productivity Gender Differential in Africa

Discussants: DAVID CANNING, Harvard University

BELINDA ARCHIBONG, Barnard College

HANAN MORSY, African Development Bank

MINA BALIAMOUNE-LUTZ, University of North Florida

ADUGNA LEMI, University of Massachusetts-Boston

KYOKO KOGA, Kochi University

\section{0:15 AM Manchester Grand Hyatt San Diego_Cortez Hill A} AFEE

\section{Institutional Approaches to Women's Economic Empowerment} (B5)

Presiding: EUGENIA CORREA, National Autonomous University of Mexico (UNAM)-Mexico City

MELISSA LANGWORTHY, Tulane University, and TONIA WARNECKE, Rollins College-Capabilities and Women's Entrepreneurship in Kuwait

ELLEN MUTARI, Stockton University-Feminist Institutional Economics: A Cross-Fertilization of Congruent Approaches

SCOTT ALAN CARSON, University of Texas-Permian BasinNet Nutrition and the Female-Male Transition to Social Feminism: Assessing Body Mass Index Change with Differences in Decompositions 


\section{Saturday $•$ January 4}

JOHN HALL, Portland State University, and MANUEL RAMON DE SOUZA LUZ, Federal University of ABC-São Paulo-Thorstein Veblen as Evolutionary Feminist for the Progressive Movement

Discussants: EUGENIA CORREA, National Autonomous University of Mexico (UNAM)-Mexico City

KALPANA KHANAL, Nichols College

\section{0:15 AM Manchester Grand Hyatt San Diego-Regatta C AREUEA}

\section{House Price Dynamics and Indexes (R3)}

Presiding: CHRIS REDFEARN, University of Southern California

HAN LIU, George Washington University-The Reversal of Housing Price Gradient: Theory and Empirical Evidence

DORINTH VAN DIJK, Netherlands Bank-Local ConstantQuality Housing Market Liquidity Indices

ALINA AREFEVA, University of Wisconsin-Madison-How Auctions Amplify House-Price Fluctuations

ERLING ROED LARSEN, Oslo Metropolitan University, and ANDRE ANUNDSEN, Oslo Metropolitan University-The Most Wonderful Time of the Year? Thin Markets, House Price Seasonality, and the December Discount

Discussants: SHAWN ROHLIN, Kent State University

STEVEN BOURASSA, Florida Atlantic University

KATHERINE KIEL, College of the Holy Cross

RONAN LYONS, Trinity College Dublin

\section{0:15 AM Manchester Grand Hyatt San Diego-Nautical AREUEA}

\section{Housing Cost and Supply (R3)}

Presiding: TSUR SOMERVILLE, University of British Columbia

CHRISTOS ANDREAS MAKRIDIS, Massachusetts Institute of Technology_-(Why) Are Housing Costs Rising? 


\section{Saturday $\bullet$ January 4}

CHANDLER LUTZ, University of California-Los Angeles, and BEN SAND, York University-Highly Disaggregated Land Unavailability

XIAODI LI, New York University—Do More Housing Units Reduce Nearby Rents?

THAO LE, Georgia State University, EDWARD COULSON, University of California-Irvine, and LILY SHEN, Clemson University—Landlord Rights, Evictions, and Rent Affordability

Discussants: DESEN LIN, University of Pennsylvania

JOSEPH WILLIAMS, Professors Capital

RANDAL VERBRUGGE, Federal Reserve Bank of Cleveland

INGRID GOULD ELLEN, New York University

\section{0:15 AM Manchester Grand Hyatt San Diego-Cove ASE/INEM}

What Can Economists Do Better?: A Look at the Profession (B4)

Presiding: STEVEN PRESSMAN, Colorado State University

WILL MILBERG, New School for Social Research-The Return of "Capitalism" and the Limits of Economics

GEORGE DEMARTINO, University of Denver-Should Economists Tell the Truth? Pro-Social Lying, Paternalism, and the $10: 15$ Ben Bernanke Problem

RHONDA VONSHAY SHARPE, Women's Institute for Science, Equity and Race-Diversity and Inclusion at the Intersection of Race, Ethnicity and Gender

JACQUELINE STRENIO, Southern Oregon University-Mentoring Matters: A Patch for the Leaky Pipeline

\section{0:15 AM Manchester Grand Hyatt San Diego_-Solana Beach AB ASHEcon}

The Economics of the Opioid Crisis (I1)

Presiding: M. KATE BUNDORF, Stanford University 


\section{Saturday $\cdot$ January 4}

ALICIA ATWOOD, Vassar College, LINDSAY ALLEN, West Virginia University, RACHEL HARRINGTON, National Committee for Quality Assurance, NATHAN PAULY, West Virginia University, and SABRINA YOUNG, University of IllinoisChicago-The Impact of Staggered Benefit Disbursement on Opioid Use, Hospitalizations, and Mortality

DANIEL SACKS, Indiana University, ALEX HOLLINGSWORTH, Indiana University, THUY NGUYEN, Indiana University, and KOSALI SIMON, Indiana University-Reducing Opioids Dispensed to New Users: Initial Prescription Limits and MustAccess Prescription Drug Monitoring Programs

KEITH TELTSER, Georgia State University, STACY DICKERTCONLIN, Michigan State University, TODD ELDER, Michigan State University, and BETHANY LEMONT, Ohio UniversityOpioids and Organs: How Overdoses Affect the Supply of Donors, Waiting Lists, and Transplant Outcomes

ABBY ALPERT, University of Pennsylvania, WILLIAM N. EVANS, University of Notre Dame, ETHAN M.J. LIEBER, University of Notre Dame, and DAVID POWELL, RAND Corporation-Origins of the Opioid Crisis and Its Enduring Impacts

Discussants: CHRISTOPHER RUHM, University of Virginia

MIREILLE JACOBSON, University of Southern California

JOSEPH SABIA, San Diego State University

MATHEW HARRIS, University of Tennessee

\section{0:15 AM Manchester Grand Hyatt San Diego_-Pier ASREC}

\section{Economics of Culture and Religion (Z0)}

Presiding: JARED RUBIN, Chapman University

SASCHA O. BECKER, Monash University, JARED RUBIN, Chapman University, and STEVE PFAFF, University of Washington-Ideological Entrepreneurs and the Diffusion of Radical Institutional Innovation: Martin Luther's Personal Ties and the Early Reformation

ANNE SOFIE BECK KNUDSEN, Lund University-Those Who Stayed: Individualism, Self-Selection and Cultural Change during the Age of Mass Migration 


\section{Saturday $•$ January 4}

FELIPE VALENCIA CAICEDO, University of British Columbia, and JUAN FELIPE RIAÑO RODRÍGUEZ, University of British Columbia-Collateral Damage: The Legacy of Laos Secret War

Discussants: JEAN-PAUL CARVALHO, University of California-Irvine

JARED RUBIN, Chapman University

JEANET BENTZEN, University of Copenhagen

\section{0:15 AM Marriott Marquis San Diego-Malibu}

CS

\section{Banking in Historical Perspective (N2)}

Presiding: JONATHAN ROSE, Federal Reserve Bank of Chicago

DAVID C. WHEELOCK, Federal Reserve Bank of St. Louis, CHARLES W. CALOMIRIS, Columbia University, and MATTHEW JAREMSKI, Utah State University-Interbank Connections, Contagion and Bank Distress in the Great Depression

EUGENE WHITE, Rutgers University, and ELLIS TALLMAN, Federal Reserve Bank of Cleveland-Why Was There No Banking Panic in 1920-1921? The Federal Reserve Banks and the Recession

PAMFILI ANTIPA, Sciences Po, and QUOC-ANH DO, Sciences Po-Charity Begins At Home - Why Britain Resumed the Gold Standard After the French Wars

CHENZI XU, Harvard University and Dartmouth College, and HE YANG, Harvard University-National Banks and the Liabilities Channel of Local Economic Development

Discussants: ANGELA VOSSMEYER, Claremont McKenna College

KILIAN RIEDER, Oesterreichische Nationalbank

CHRISTOPHER M. MEISSNER, University of California-Davis SARAH QUINCY, Vanderbilt University 


\section{Saturday $•$ January 4}

\section{0:15 AM Manchester Grand Hyatt San Diego-Gaslamp AB}

EPS

\section{Panel: The Hidden Costs of War and Sanctions (N4)}

Presiding: JAMES GALBRAITH, University of Texas

LINDA BILMES, Harvard University

TIMOTHY K. MACKEY, University of California-San Diego

TOPHER MCDOUGAL, University of San Diego

MARK WEISBROT, Center for Economic and Policy Research

\section{0:15 AM Marriott Marquis San Diego-Cardiff}

ES

\section{Advances in Network Theory (D8)}

Presiding: ALEXANDER WOLITZKY, Massachusetts Institute of Technology MATTHEW O. JACKSON, Stanford University, SURAJ MALLADI, Stanford University, and DAVID MCADAMS, Duke UniversityLearning Through the Grapevine: The Impact of Message Mutation, Transmission Failure, and Deliberate Bias

JUNJIE ZHOU, National University of Singapore-Networks in Conflict: A Variational Inequality Approach

PIERPAOLO BATTIGALLI, Bocconi University, FABRIZIO PANEBIANCO, Catholic University of the Sacred Heart-Milano, and PO PAOLIN, Bocconi University_Learning and Selfconfirming Equilibria in Network Games

\section{0:15 AM Marriott Marquis San Diego_Carlsbad}

\section{ES}

\section{Bayesian Persuasion (D8)}

Presiding: FEI LI, University of North Carolina-Chapel Hill

SIMONE GALPERTI, University of California-San Diego, and JACOPO PEREGO, Columbia University—Belief Meddling in Social Networks: An Information-Design Approach 


\section{Saturday $\cdot$ January 4}

ANTON KOLOTILIN, University of New South Wales, TYMOFIY MYLOVANOV, University of Pittsburgh, and ANDRIY ZAPECHELNYUK, University of St. Andrews-Optimal Persuasion with an Application to Media Censorship

ANH NGUYEN, Carnegie Mellon University, and TECK YONG TAN, Nanyang Technological University-Bayesian Persuasion with Costly Messages

PEICONG HU, University of California-San Diego, and JOEL SOBEL, University of California-San Diego-Simultaneous Versus Sequential Disclosure

FEI LI, University of North Carolina-Chapel Hill, and PETER NORMAN, University of North Carolina-Chapel Hill-Sequential Persuasion

\section{0:15 AM Marriott Marquis San Diego-Mission Hills} ES

Gender, Human Capital and Labor Supply Around the World (J1)

Presiding: ERICA FIELD, Duke University

ERICA FIELD, Duke University, CHARITY MOORE, Harvard University, ROHINI PANDE, Harvard University, NATALIA RIGOL, Harvard University, and SIMONE SCHANER, University of Southern California-On Her Own Account: How Strengthening Women's Financial Control Impacts Labor Supply and Gender Norms

ABI ADAMS, University of Oxford, and ALISON ANDREW, Institute for Fiscal Studies-Preferences and Beliefs in the Marriage Market for Young Brides

SITIAN LIU, Queen's University-Incarceration of African American Men and the Impacts on Women and Children

CHRISTOPHER FLINN, New York University, PETRA TODD, University of Pennsylvania, and WEILONG ZHANG, University of Cambridge-Personality Traits, Job Search Strategies and Gender Wage Gap 


\section{Saturday $•$ January 4}

\section{0:15 AM Marriott Marquis San Diego_La Costa}

ES

\section{Housing Markets and Household Heterogeneity (D1)}

Presiding: KAIJI CHEN, Emory University

JACK FAVILUKIS, University of British Columbia, PIERRE MABILLE, New York University, and STIJN VAN NIEUWERBURGH, Columbia University-Affordable Housing and City Welfare

CARLOS GARRIGA, Federal Reserve Bank of St. Louis, PEDRO GETE, IE University, and ATHENA TSOUDEROU, IE UniversityThe Dynamic Effects of Investors in Housing Markets

SAROJ BHATTARAI, University of Texas-Austin, FELIPE SCHWARTZMAN, Federal Reserve Bank of Richmond, and CHOONGRYUL YANG, University of Texas-Austin-The Persistent Employment Effects of the 2006-09 United States Housing Wealth Collapse

KAIJI CHEN, Emory University-Aggregate and Distributional Impacts of Housing Policy: China's Experiment

\section{0:15 AM Marriott Marquis San Diego-Marina Ballroom F ES}

Journal of Econometrics Panel: Econometrics in the 21st Century, Challenges and Opportunities (C1)

Presiding: SERENA NG, Columbia University

LARS HANSEN, University of Chicago

CHRISTOPHER SIMS, Princeton University

ANGUS DEATON, Princeton University

DANIEL MCFADDEN, University of California-Berkeley and University of Southern California

GARY CHAMBERLAIN, Harvard University

GUIDO IMBENS, Stanford University

ROSA MATZKIN, University of California-Los Angeles 


\section{Saturday $\cdot$ January 4}

\section{0:15 AM Marriott Marquis San Diego—Catalina \\ ES}

\section{Labor Share (D3)}

Presiding: GILBERT CETTE, Bank of France

GILBERT CETTE, Bank of France, LORRAINE KOEHL, INSEE, and THOMAS PHILIPPON, New York University-Labor Share

DARON ACEMOGLU, Massachusetts Institute of Technology, and PASCUAL RESTREPO, Boston University-Automation and New Tasks: How Technology Displaces and Reinstates Labor

MATTHIAS KEHRIG, Duke University, and NICOLAS VINCENT, HEC Montreal-Decline in the Labor Share and Product Differentiation

CYRILLE SCHWELLNUS, OECD—Labour Share Developments over the Past Two Decades: The Role of Technological Progress, Globalisation and "Winner-Takes-Most" Dynamics

BARIS KAYMAK, University of Montreal, and IMMO SCHOTT, University of Montreal-Corporate Tax Cuts and the Decline of the Manufacturing Labor Share

Discussants: DAVIDE FURCERI, International Monetary Fund

DANNY YAGAN, University of California-Berkeley

JEFFREY CAMPBELL, Federal Reserve Bank of Chicago

GORDON HANSON, University of California-San Diego

NICOLAS VINCENT, HEC Montreal

\section{0:15 AM Marriott Marquis San Diego-Coronado Room} IAEE/AEA

\section{Panel: The Geopolitics of Oil Price Cycles (Q4)}

Presiding: CHRISTIAN VON HIRSCHHAUSEN, Technical University of Berlin

DANIEL AHN, BNP Paribas-Disentangling the Economic Effects of Sanctions vs. Oil Prices: The Case of Russia Sanctions

HELEN CURRIE, Conoco Phillips-Oil Market Outlook: A Producer's Perspective on Key Issues in the Next Decade and Beyond MAHMOUD EL-GAMAL, Rice University-The NEW Coupled Cycles of Oil Prices, Financial Markets, and Middle East Geopolitics 


\section{Saturday $•$ January 4}

AMY JAFFE, Council on Foreign Relations-America's Energy Bounty: Geopolitical and Commodity Pricing Implications

\section{0:15 AM Manchester Grand Hyatt San Diego_-Old Town B IAFFE}

\section{Testing for Gender Effects Using Natural Experiments (J1)}

Presiding: CHERYL DOSS, University of Oxford

MIRIAM BEBLO, University of Hamburg, LUISE GEORGES, University of Hamburg, and EVA MARKOWSKY, University of Hamburg-Speaking of Gender: Does Children's Experience with Gender Equality Affect Their Labor Market Outcomes as Adults?

MAIK HAMJEDIERS, Humboldt University of Berlin-The Distant Cause of Gender Pay Gaps: How Gender Ideology Accounts for Regional Variation of Income Disparities Between Men and Women in Germany

OLUWASHEYI OLADIPO, State University of New York-Old Westbury_-Gender Difference in Labor Demand Behavior

MAXIMILIAN SPRENGHOLZ, Humboldt University of Berlin, ANNA WIEBER, German Pension Insurance Association, and ELKE HOLST, DIW Berlin-Gender Identity and Wives' Labor Market Outcomes in West and East Germany between 1984 and 2016 Discussants: SARA SOLNICK, University of Vermont

DAN HAMERMESH, University of Texas-Austin

\section{0:15 AM Manchester Grand Hyatt San Diego-Torrey Hills AB IBEFA/AEA}

\section{Panel: Corporate Culture and Banking (G3)}

Presiding: DIANA HANCOCK, Federal Reserve Board

MARY C. DALY, Federal Reserve Bank of San FranciscoCorporate Culture and Banking: A Regulator Perspective

GARY B. GORTON, Yale University-Corporate Culture and Banking: What Helps Make a Progressive Corporate Culture?

RENE STULZ, Ohio State University-Corporate Culture and Banking: Culture, Risk Management, and Finance 


\section{Saturday $•$ January 4}

\section{0:15 AM Manchester Grand Hyatt San Diego-Ocean Beach ISIR}

Cash Holdings, Investment, and Firm Dynamics (E0)

Presiding: PABLO OTTONELLO, University of Michigan

JULIANE BEGENAU, Stanford University, and BERARDINO PALAZZO, Federal Reserve Board-Firm Selection and Corporate Cash Holdings

MINDY XIAOLAN, University of Texas-Austin, and LEI ZHANG, University of Hong Kong-Intangible Dynamics

PETER KLENOW, Stanford University, LIRAN EINAV, Stanford University, JONATHAN D. LEVIN, Stanford University, and RAVIV MURCIANO-GOROFF, Boston University-Customers and Retailer Growth

\section{0:15 AM Manchester Grand Hyatt San Diego-Harbor C KAEA}

\section{Machine Learning and Its Applications to Econometrics (C1)}

Presiding: HYUNGSIK ROGER MOON, University of Southern California SUKJIN HAN, University of Texas-Austin, and KRISTEN GRAUMAN, University of Texas-Austin-Market-Based Learning:

Differentiated Products with Visual Attributes

CHRISTIAN HANSEN, University of Chicago, VICTOR CHERNOZHUKOV, Massachusetts Institute of Technology, YUAN LIAO, Rutgers University, and YINCHU ZHU, University of Oregon-Inference for Heterogeneous Effects Using Low-Rank Estimation

VASILIS SYRGKANIS, Microsoft Research-New England, and DYLAN FOSTER, Massachusetts Institute of Technology-A Statistical Learning Approach to Semi-Parametric Inference

WHITNEY NEWEY, Massachusetts Institute of Technology, VICTOR CHERNOZHUKOV, Massachusetts Institute of Technology, and RAHUL SINGH, Massachusetts Institute of Technology_Debiased Machine Learning of Treatment and Structural Regression Effects 


\section{Saturday $•$ January 4}

\section{0:15 AM Manchester Grand Hyatt San Diego-Harbor F}

LERA

Intersectionality of Labor Rights and Gender Inequality (J1)

Presiding: BILL SPRIGGS, Howard University

CHLOE TOUZET, OECD, and SANDRINE CAZES, OECDLabor Union Representation of Women in Non-standard Forms of Work: The Intersection of Gender and Worker Voice Across Advanced Economies

ELISSA BRAUNSTEIN, Colorado State University, and STEPHANIE SEGUINO, University of Vermont-Gender Job Segregation, Labor Regulation and the Labor Share of Income

ERIC HOYT, University of Massachusetts-Amherst-Wrongful Discharge, Union Representation and Women's Wages: A CrossState Analysis

Discussants: JEANNETTE WICKS-LIM, University of MassachusettsAmherst

JEVAY GROOMS, Howard University

\section{0:15 AM Manchester Grand Hyatt San Diego-Harbor E LERA}

Short-Time Work Arrangements: Recent Developments and Policy Implications (J2)

Presiding: ETIENNE LALÉ, University of Quebec-Montreal

ANNE POLIVKA, U.S. Bureau of Labor Statistics-The Effect of Structural and Cyclical Changes on Trends across Time in the Number of Workers in Contingent and Alternative Work Arrangements

ROBERT VALLETTA, Federal Reserve Bank of San FranciscoInvoluntary Part-Time Work and the Gig Economy: Boon or Bane?

LONNIE GOLDEN, Pennsylvania State University-Abington-Part Time Pay Penalties are Persisting

FRANCIS KRAMARZ, CREST-ENSAE, and SANDRA NEVOUX, Bank of France-When Short-Time Work Works 


\section{Saturday $\cdot$ January 4}

Discussants: SUSAN HOUSEMAN, W.E. Upjohn Institute for Employment Research

JAMES R. SPLETZER, U.S. Census Bureau

STUART GLOSSER, University of Wisconsin-Whitewater

SHAIMAA YASSIN, McGill University

\section{0:15 AM Manchester Grand Hyatt San Diego-Balboa C MEEA/AEA}

Panel: Policy Session ASSA: Exchange Rate Arrangements, Price Stability and Economic Growth in MENA (E0)

Presiding: WASSIM SHAHIN, Lebanese American University

WASSIM SHAHIN, Lebanese American University-The Monetary Policy of Exchange Rate Arrangements in MENA countries: A Critical Analysis

SHIREEN ALAZZAWI, Santa Clara University-Cost of Living Changes after a Large Scale Devaluation (joint paper with Vladimír Hlásny)

DIAA NOURELDIN, American University in Cairo-How does the Monetary Policy Regime Impact the Relative Price Variability: Evidence from a Large Panel of Countries (joint with Nadine Abdelraouf)

AKBAR TORBAT, California State University-Los AngelesProblems of Economic Liberalization in Iran

\section{0:15 AM Manchester Grand Hyatt San Diego-Marina NAFE}

\section{An Agenda for Future Research in Forensic Economics (K2)}

Presiding: STEVEN J. SHAPIRO, New York Institute of Technology

JOHN O. WARD, University of Missouri-Kansas City-An Agenda for Future Research in Forensic Economics: Setting Standards of Validity and Reliability in Measuring Progress

FRANK L. SLESNICK, Bellarmine University, and MICHAEL BROOKSHIRE, Brookshire Barrett \& Associates LLC-An Agenda for Future Research in Forensic Economics: Topics from NAFE Surveys 


\section{Saturday $•$ January 4}

STEVEN J. SHAPIRO, New York Institute of Technology-An Agenda for Future Research in Forensic Economics: New Approaches to Viewing Controversial Topics

Discussant: KEVIN E. CAHILL, Boston College

\section{0:15 AM Marriott Marquis San Diego-Marriott Grand Ballroom 2 NEA/ASHE}

\section{Race, Ethnicity and the 2020 National Election (J4)}

Presiding: MARK HUGO LOPEZ, Pew Research Center

CATALINA AMUEDO-DORANTES, University of CaliforniaMerced, and JOSÉ R. BUCHELI, New Mexico State University-A Look Ahead at the 2020 Elections: How Important is Diversity in the Candidate Pool?

DARRICK HAMILTON, Ohio State University-Federal Job Guarantee, Baby Bond and Reparations: A Three-Legged Stool of Racial Economic Justice

J. DAVID BROWN, U.S. Census Bureau, MISTY HEGGENESS, U.S. Census Bureau, SUZANNE M. DORINSKI, U.S. Census Bureau, LAWRENCE WARREN, U.S. Census Bureau, and MOISES YI, U.S. Census Bureau-Predicting the Effect of Adding a Citizenship Question to the 2020 Census

TREVON LOGAN, Ohio State University-Whitelashing: Black Politicians, Taxes, and Violence

JOAQUIN ALFREDO-ANGEL RUBALCABA, University of North Carolina-Chapel Hill—Communities under Siege: Ethnic Profiling under Auspices of 287(g) in North Carolina

DANIA V. FRANCIS, University of Massachusetts-AmherstEstimating the Present Value of Black Agricultural Land Loss in the United States, 1910-1977

\section{0:15 AM Manchester Grand Hyatt San Diego_Cortez Hill B SCE}

Industry Dynamics and Optimal Firm Behavior (L1)

Presiding: HERBERT DAWID, Bielefeld University 


\section{Saturday $•$ January 4}

ADAM DEARING, Ohio State University, and JASON BLEVINS, Ohio State University_Efficient and Convergent Sequential PseudoLikelihood Estimation of Dynamic Discrete Games

ULRICH DORASZELSKI, University of Pennsylvania, and JOAO F. GOMES, University of Pennsylvania-Dynamic Strategic Corporate Finance: A Tug of War with Financial Constraints

MARIA LAVRUTICH, Norwegian University of Science and Technology, and JACCO THIJSSEN, University of York-Predatory Pricing under Uncertainty: Revisiting the Deep Pocket Argument

ANNE BALTER, Tilburg University, KUNO HUISMAN, Tilburg University, and PETER M. KORT, Tilburg University—Finite Project

Life and Strategic Interactions in Investment under Uncertainty

Discussants: VICTOR AGUIRREGABIRIA, University of Toronto

VOJISLAV MAKSIMOVIC, University of Maryland

KUNO HUISMAN, Tilburg University

HERBERT DAWID, Bielefeld University

\section{0:15 AM Manchester Grand Hyatt San Diego_-Mission Beach B SGE}

\section{Governing, Entrepreneurship, and Innovation (H0)}

Presiding: BARBARA M. FRAUMENI, Central University of Finance and Economics and NBER

JOAO PEREIRA DOS SANTOS, Nova University of Lisbon, MIGUEL FERREIRA, Nova University of Lisbon, and ANA VENANCIO, Nova University of Lisbon-Collateral Value and Entrepreneurship: Evidence from a Property Tax Reform

CHAOPENG WU, Xiamen University, LILLY FANG, INSEAD, JOSH LERNER, Harvard University, and QI ZHANG, Xiamen University-Corruption, Government Subsidies, and Innovation: Evidence from China

YAQIN SU, Hunan University, and CHENG CHENG, Hunan University-Women in Power: Female City Leaders and Regional Economic Performance in China 


\section{Saturday $•$ January 4}

DANIEL B. JONES, University of Pittsburgh, BRIAN BEACH, Vanderbilt University, TATE TWINAM, College of William and Mary, and RANDALL WALSH, University of Pittsburgh-Minority Representation in Local Government

Discussants: R. JAY KAHN, University of Michigan

SOFIA JOHAN, Florida Atlantic University

DRAGANA CVIJANOVIC, University of Warwick

KATE ANTONOVICS, University of California-San Diego

\section{0:15 AM Manchester Grand Hyatt San Diego-Promenade B SNDE}

\section{Business Cycles, Monetary Policy and Oil Prices (E3)}

Presiding: HILDE C. BJØRNLAND, BI Norwegian Business School

DIEGOR. KANZIG, London Business School-The Macroeconomic Effects of Oil Supply News: Evidence from OPEC Announcements

SAMI ALPANDA, University of Central Florida, ELEONORA GRANZIERA, Norges Bank, and SARAH ZUBAIRY, Texas A\&M University—State Dependence of Monetary Policy Across Business, Credit and Interest Rate Cycles

MARCIN BIELECKI, Narodowy Bank Polski and University of Warsaw, MICHAL BRZOZA-BRZEZINA, Narodowy Bank Polski and SGH Warsaw School of Economics, and MARCIN PAWEL KOLASA, Narodowy Bank Polski and SGH Warsaw School of Economics-Distributional Consequences of Conventional and Unconventional Monetary Policy

MAXIMO CAMACHO, University of Murcia, MARIA DOLORES GADEA, University of Zaragoza, and ANA GOMEZ LOSCOS, Bank of Spain-A New Approach to Dating the Reference Cycle

Discussants: JAMES D. HAMILTON, University of California-San Diego

OSCAR JORDA, Federal Reserve Bank of San Francisco

FRANCESCO FURLANETTO, Norges Bank

MARCELLE CHAUVET, University of California-Riverside 


\section{Saturday $•$ January 4}

10:15 AM Manchester Grand Hyatt San Diego-Gaslamp C TPUG/AEA

Welfare, Pricing, and Market Power in Utility Markets (L9)

Presiding: FRANK A. WOLAK, Stanford University

YI JIANG, Asian Development Bank, RENZ ADRIAN T. CALUB, Asian Development Bank, and XIAOTING ZHENG, Jinan University-Water Tariff Setting and Its Welfare Implications: Evidence from Chinese Cities

JOSEPH CULLEN, Amazon, NICOLAS SCHUTZ, University of Mannheim, and OLEKSANDR SHCHERBAKOV, Bank of Canada-Welfare Analysis of Equilibria with and without Early Termination Fees in the United States Wireless Industry

SHAUN D. MCRAE, ITAM, and FRANK A. WOLAK, Stanford University-Market Power and Incentive-Based Capacity Payment Mechanisms

GRANT MCDERMOTT, University of Oregon-Hydro Power Market Might

Discussants: WESLEY W. WILSON, University of Oregon

JOHN MAYO, Georgetown University

EDWARD RUBIN, University of Oregon

FRANK A. WOLAK, Stanford University

\section{0:15 AM Manchester Grand Hyatt San Diego-Coronado E URPE}

Monetary Policy in the United States, the Eurozone, and China (G0)

Presiding: ESTHER JEFFERS, University of Picardie

GARY DYMSKI, University of Leeds, and MARIA GAVRIS, University of Leeds-The Transformation of the Central Banking Policy Template in the Neoliberal Era: The United States-EU Financial Paradox and Global Financial Crises

NINA EICHACKER, University of Rhode Island-Special Drawing Rights, Target2 Balances, and European Monetary Policy, before and after the Eurozone Crisis 


\section{Saturday $•$ January 4}

GERALD EPSTEIN, University of Massachusetts-AmherstFinancing the "Green New Deal": The Role of the Federal Reserve and the Limits of the Global Dollar

ESTHER JEFFERS, University of Picardie, and DOMINIQUE PLIHON, University Paris 13-Monetary Policy in the Eurozone: Limits of ECB Policy on the Financial Crisis and Climate Change JACQUES MAZIER, University Paris 13-China, United States and the EU: Varying Capacities to Meet the Challenges

Discussants: JACQUES MAZIER, University Paris 13

PASCAL PETIT, University Paris 13

DOMINIQUE PLIHON, University Paris 13

10:15 AM Manchester Grand Hyatt San Diego_-Old Town A URPE

\section{Political Economy of China (O0)}

Presiding: PADDY QUICK, St. Francis College-Brooklyn

BANGXI LI, Tsinghua University, and CHONG LIU, Tsinghua University-Fixed Capital, Accelerated Depreciation, and Economic Growth: Mathematical and Empirical Studies Based on Political Economy

BRIAN CHI-ANG LIN, National Chengchi University-China: Rich Country, Poor People? The Expansion of Economic Nationalism HANLIN QIANG, Tsinghua University-Population and Capital Flows in Metropolitan Beijing: Empirical Evidence from the Past 30 Years

ZHUN XU, Howard University, and WEI ZHANG, Tsinghua University-Gender Norm and Household Labor: Time Use in the Context of Class Differentiation in China

\section{2:30 PM Manchester Grand Hyatt San Diego-Mission Beach A} AAEA

Farmer Adaptations to Climate and Environmental Change (Q5)

Presiding: ROBERT CHAMBERS, University of Maryland-College Park 


\section{Saturday $\cdot$ January 4}

FRANCES MOORE, University of California-Davis, and JESUS ARELLANO GONZALEZ, University of CaliforniaDavis-Security of Property Rights and Long-Term Agricultural Investments: Drought, Water Rights, and Perennial Cropping Decisions in California

PIERRE MEREL, University of California-Davis, MATTHEW GAMMANS, University of California-Davis, and XIAOMENG CUI, Jinan University—Do Climate Signals Matter? Evidence from Agriculture

SIMONE PIERALLI, Massey University New Zealand, and ARIEL ORTIZ-BOBEA, Cornell University_Are Yields Slowing Down Due to Recent Climate Trends? Evidence from a Farm-level Panel in France?

\section{2:30 PM Marriott Marquis San Diego-Marriott Grand} Ballroom 7-8-9

AEA

AEA Nobel Laureate Luncheon - Fee Event

Presiding: JANET YELLEN, Brookings Institution

LINT BARRAGE, University of California-Santa Barbara

ROBERT GORDON, Northwestern University

GEORGE AKERLOF, University of California-Berkeley

CHAD JONES, Stanford University

\section{2:30 PM Marriott Marquis San Diego-Marriott Grand} Ballroom 2

AEA

\section{European Economic Association Lecture}

Presiding: IMRAN RASUL, University College London

ULRIKE MALMENDIER, University of California-BerkeleyExperience, Bias, and Expertise - How Experience Effects Bias Decision-making Even Among Experts 


\section{Saturday $•$ January 4}

\section{2:30 PM Manchester Grand Hyatt San Diego-Torrey Hills AB}

AFE/AEA

\section{Beyond Bitcoin (G2)}

Presiding: ZHIGUO HE, University of Chicago

AMIN SHAMS, Ohio State University-What Drives the Covariation of Cryptocurrency Returns?

TETIANA DAVYDIUK, Carnegie Mellon University, DEEKSHA GUPTA, Carnegie Mellon University, and SAMUEL ROSEN, Temple University-De-crypto-ing Signals in Initial Coin Offerings: Evidence of Rational Token Retention

TAO LI, University of Florida, DONGHWA SHIN, University of North Carolina-Chapel Hill, and BAOLIAN WANG, University of Florida-Cryptocurrency Pump-And-Dump Schemes

Discussants: FAHAD SALEH, McGill University

SABRINA T. HOWELL, New York University

LIN WILLIAM CONG, Cornell University

\section{2:30 PM Manchester Grand Hyatt San Diego_Cortez Hill A AFEE}

\section{Institutional Economics in the Calculable Future (B4)}

Presiding: TAE-HEE JO, State University of New York-Buffalo State

LYNNE CHESTER, University of Sydney-Pluralism, Interdisciplinarity, and Institutional Economics

GEOFFREY E. SCHNEIDER, Bucknell University-Institutional Economics and the Promise of Pluralism

ZDRAVKA TODOROVA, Wright State University, and TAE-HEE JO, State University of New York-Buffalo State-Promotion and Development of Original Institutional Economics

WILLIAM WALLER, Hobart and William Smith Colleges-The Journal of Economic Issues in the Calculable Future of Original Institutional Economics

EMILIA ORMAECHEA, University of Litoral-Latin American Development: What about the State, Conflict and Power? 


\section{Saturday $\cdot$ January 4}

Discussants: JAMES T. PEACH, New Mexico State University

MANUEL RAMON DE SOUZA LUZ, Federal University of ABC

\section{2:30 PM Manchester Grand Hyatt San Diego—Coronado AB} AREUEA

\section{AREUEA Presidential Luncheon}

Presiding: ABDULLAH YAVAS, University of Wisconsin-Madison

Speaker: CROCKER LIU, Cornell University

Topic: Thinking Tall: Anchor Tenants, Vertical Agglomeration, and Value Creation

\section{2:30 PM Manchester Grand Hyatt San Diego—Cove}

ASE

\section{Topics in Social Economics (B5)}

Presiding: CHRIS JEFFORDS, Indiana University of Pennsylvania

GIORGOS GALANIS, Goldsmiths University of London, and ROBERTO VENEZIANI, Queen Mary University of LondonSocial Status and Intergenerational Equality of Opportunity

YING ZHEN, Wesleyan College-The Well-Being of Musicians in the United States

PAOLO RAMAZZOTTI, University of Macerata-Racism and

Economic Policy: Recent Trends

STEFANO SOLARI, University of Padova-A Socially and Environmentally Sustainable Growth: The Non-Obsolete View of Social Liberalism

CHRIS JEFFORDS, Indiana University of Pennsylvania—-Trends in Human Rights Research within Economics Journals

\section{2:30 PM Marriott Marquis San Diego-Malibu CS}

Knowledge and Technological Change (N3)

Presiding: EDWARD KOSACK, Xavier University 


\section{Saturday $\cdot$ January 4}

PAUL SHARP, Southern Denmark University, and NINA BOBERGFAZLIC, Southern Denmark University-Immigrant Communities and Knowledge Spillovers: Danish-Americans and the Development of the Dairy Industry

ALEXANDER J. FIELD, Santa Clara University-War Mobilization and Its Impact on Patenting in the United States: 1941-48

KARINE VAN DER BEEK, Ben-Gurion University of the Negev, JOEL MOKYR, Northwestern University, and ASSAF SARID, University of Haifa-The Wheels of Change: Human Capital, Millrights, and Industrialization in Eighteenth-Century England

Discussants: ARTHI VELLORE, University of California-Irvine

ENRICO G. BERKES, Ohio State University

ROWENA GRAY, University of California-Merced

\section{2:30 PM Manchester Grand Hyatt San Diego-Gaslamp AB HERO}

\section{Physicians, Hospitals, Opioids, and Nutrition (I1)}

Presiding: KOSALI SIMON, Indiana University

IAN MCCARTHY, Emory University, HAIZHEN LIN, Indiana University, and MICHAEL RICHARDS, Baylor UniversityOwning the Agent: Hospital Influence on Physician Behaviors

CAITLIN CARROLL, University of Minnesota, DAVID CUTLER, Harvard University, and ANUPAM JENA, Harvard UniversityPhysician Responses to Malpractice Allegations: Evidence from Florida Emergency Departments

SUMEDHA GUPTA, Indiana University-Purdue University Indianapolis, THUY NGUYEN, Indiana University, PATRICIA FREEMAN, University of Kentucky, and KOSALI SIMON, Indiana University-Effect of United States Drug Enforcement Administration (DEA)'s "Scheduling" of Tramadol Products on Opioid Prescribing

MARIANNE BITLER, University of California-Davis, JANET CURRIE, Princeton University, HILARY HOYNES, University of California-Berkeley, LISA SCHULKIND, University of North Carolina-Charlotte, and BARTON WILLAGE, Louisiana State University-The Impact of Childhood Nutrition Assistance on Child Health and Well-Being: Lessons from WIC 


\section{Saturday $•$ January 4}

\section{2:30 PM Marriott Marquis San Diego—Coronado Room}

IAEE

Research in Energy Economics Topics (Q4)

Presiding: ALBERTO J. LAMADRID, Lehigh University

PAIGE WEBER, University of California-Santa Barbara and University of North Carolina-Chapel Hill-Dynamic Responses to Carbon Pricing in the Electricity Sector

NICOLAS ASTIER, Stanford University-Second Best Pricing for Incomplete Market Segments: Applications to Electricity Pricing

DAIRE MCCOY, London School of Economics, and GREER GOSNELL, London School of Economics-Smart-Meter Adoption: Valuing Drivers and Barriers in the United Kingdom

SHAUN D. MCRAE, ITAM-Market Power in Cost-Based Wholesale Electricity Markets: Evidence from Mexico

Discussants: GREGORY B. UPTON, Louisiana State University

PAUL JOSKOW, Massachusetts Institute of Technology

ERIN BAKER, University of Massachusetts

TODD GERARDEN, Cornell University

\section{2:30 PM Manchester Grand Hyatt San Diego_-Old Town B}

\section{IAFFE}

Panel: 25 Years of "Feminist Economics": Origins, Achievements, and Challenges (B5)

Presiding: ELISSA BRAUNSTEIN, Colorado State University

CECILIA CONRAD, John D. and Catherine T. MacArthur Foundation

NANCY FOLBRE, University of Massachusetts-Amherst

CARMEN DIANA DEERE, University of Florida

JANE HUMPHRIES, University of Oxford

GÜNSELI BERIK, University of Utah

DIANA STRASSMANN, Rice University

ABENA D. ODURO, University of Ghana 


\section{Saturday $•$ January 4}

\section{2:30 PM Manchester Grand Hyatt San Diego_Cortez Hill B IBEFA}

\section{Banks, Markets, and Liquidity (C6)}

Presiding: JOHN C. DRISCOLL, Federal Reserve Board

RAINER HASELMANN, Goethe University and SAFE, THOMAS KICK, Deutsche Bundesbank, SHIKHAR SINGLA, London Business School, and VIKRANT VIG, London Business SchoolCapital Regulation, Market-Making, and Liquidity

VIKRAM NANDA, University of Texas-Dallas, MUNHEE HAN, University of Texas-Dallas, and SANGHYUN (HUGH) KIM, University of Texas-Dallas-Institutional Brokerage Networks: Facilitating Liquidity Provision

ANDRIY SHKILKO, Wilfrid Laurier University-Insider Trading Under the Microscope

TARIK ROUKNY, KU Leuven, and MARCO D'ERRICO, European Central Bank-Compressing Over-the-Counter Markets

Discussants: RAN DUCHIN, University of Washington

IMAN VAN LELYVELD, Central Bank of the Netherlands

JEFF COLES, University of Utah

DAVID SKEIE, Warwick University

\section{2:30 PM Manchester Grand Hyatt San Diego-Solana Beach AB IOS}

\section{Antitrust Policy and Mergers: New Empirical Evidence (L4)}

Presiding: NANCY L. ROSE, Massachusetts Institute of Technology

THOMAS WOLLMANN, University of Chicago-How to Get Away with Merger: Stealth Consolidation and its Real Effects on US Healthcare

NATHAN MILLER, Georgetown University, GLORIA SHEU, Federal Reserve Board, and MATTHEW WEINBERG, Ohio State University-Oligopolistic Price Leadership and Mergers: The United States Beer Industry

COLLEEN CUNNINGHAM, London Business School, FLORIAN EDERER, Yale University, and SONG MA, Yale University-Killer Acquisitions 


\section{Saturday $\cdot$ January 4}

Discussants: JUDITH CHEVALIER, Yale University

JAN DE LOECKER, KU Leuven

KATE HO, Princeton University

\section{2:30 PM Manchester Grand Hyatt San Diego-Harbor E ITFA}

Topics in International Trade \& Finance, R\&D Investment, and Trade \& Financial Sanctions Against Iran (F6)

Presiding: JOSEPH PELZMAN, George Washington University

MARTA BENGOA, City University of New York and University of Johannesburg, ERIKA KRAEMER-MBULA, University of Johannesburg, and FIONA TREGENNA, University of Johannesburg-R\&D Tax Credit Effectiveness: Evidence from South African Manufacturing Firms

JOSEPH PELZMAN, George Washington University-The Economic Effects of the Re-Imposed United States Sanctions on Iran and Its Spillover on MENA, the PRC, Russia and Turkey

MURAT ISSABAYEV, Narxoz University, HAYOT BERK SAYDALIYEV, Suleyman Demirel University, and VEYSEL AVSAR, Texas A\&M University-The Nexus between Remittances, Institutional Quality and Financial Inclusion

AHMED MOHAMED TAWFICK ROSTOM, World Bank and ERF, and LEILA AGHABARARI, World Bank-After a Decade of Turbulence, Do Banks in MENA Sound Sound? A Tale of Two

Shocks Oil and Social Unrest

Discussants: JOSEPH PELZMAN, George Washington University

MARIA E. DE BOYRIE, New Mexico State University

\section{2:30 PM Manchester Grand Hyatt San Diego-Harbor C KAEA}

From Micro Data To Macro Policy (E2)

Presiding: YOOSOON CHANG, Indiana University

REGIS BARNICHON, Federal Reserve Bank of San Francisco and CEPR, and GEERT MESTERS, Pompeu Fabra UniversityIdentifying Modern Macro Equations with Old Shocks 


\section{Saturday $•$ January 4}

LAURA VELDKAMP, Columbia University-A Growth Model of the Data Economy

STEPHEN J. REDDING, Princeton University, STEPHAN HEBLICH, University of Bristol, and DANIEL M. STURM, London School of Economics-The Making of the Modern Metropolis: Evidence from London

OLIVIER COIBION, University of Texas-Austin-Expectations and Firms' Decision-Making: New Evidence

Discussants: HIE JOO AHN, Federal Reserve Board

HYUNJU LEE, Ryerson University

EUNHEE LEE, University of Maryland

YOOSOON CHANG, Indiana University

\section{2:30 PM Manchester Grand Hyatt San Diego_Balboa C MEEA}

\section{Conflict and Stereotypes (Z1)}

Presiding: MARCUS MARKTANNER, Kennesaw State University

ALMUT MERKEL, Kennesaw State University-The Third Revolutionary's Socioeconomic Trace in the Arab Uprising RONIA HAWASH, Butler University, and SHIREEN ALAZZAWI, Santa Clara University-Happily Ever After? Did Life Satisfaction Increase After the Arab Spring?

ISLAM ABDELBARY, Plymouth University, and RASHA ELSHAWA, United Nations High Commissioner for RefugeesThe Impact of Economic Sanctions on Managing the International Conflict: A Case Study on the Iran-West Conflict

MEHMET BALCILAR, Eastern Mediterranean University, and JEFFREY NUGENT, University of Southern CaliforniaCasualties in Syria and the Physical and Mental Health Status of Syrian Refugees in Turkey

MOHAMED EL KOMI, American University in Cairo, and SHEHERYAR BANURI, University of East Anglia-Stereotyping and Micro-Aggression in the Workplace: An Experimental Comparison Between Arabs and Europeans 


\section{Saturday $\cdot$ January 4}

\section{2:30 PM Manchester Grand Hyatt San Diego-Mission Beach B SGE}

Health Outcomes in the Short and Long Run (I1)

Presiding: SABRINA WULFF PABILONIA, U.S. Bureau of Labor Statistics

LEWIS H. WARREN, U.S. Census Bureau, and STEPHEN A. WOODBURY, Michigan State University-The Long-Run Effects of Poverty and Food Insecurity

AUSTIN NICHOLS, Abt Associates, IAN BREUNIG, Abt Associates, and SAM DASTRUP, Abt Associates-Comparing the PRA Program to Other Housing Options for People with Disabilities

FARAH FARAHATI, University of Maryland-Baltimore CountyOpioid-Related Hospitalizations and Emergency Department Visits among Americans by Sociodemographic Characteristics

LAKSHMI K. RAUT, University of Chicago-Health Outcomes in Mid-Ages: Multistate Time to Event Statistical Models Versus Long Short Term Memory (LSTM) Recurrent Neural Network (RNN) Models

Discussants: THESIA GARNER, U.S. Bureau of Labor Statistics

JOHN ROMLEY, University of Southern California

ANNE HALL, U.S. Treasury Department

GARY CORNWALL, U.S. Bureau of Economic Analysis

\section{2:30 PM Marriott Marquis San Diego-Marina Ballroom D SPM}

\section{Does Europe Grow More Slowly Than the United States? (E2)}

Presiding: DOMINICK SALVATORE, Fordham University

MORENO BERTOLDI, European Commission, and KRISTIAN ORSINI, European Commission-United States and Euro Area Growth Performances: Are They So Different?

ANASTASIOS MALLIARIS, Loyola University ChicagoWhy Does Europe Grow More Slowly Than the United States? Comparisons Before and After the Global Financial Crisis 


\section{Saturday $•$ January 4}

LUCJAN ORLOWSKI, Sacred Heart University-Integration of Capital Markets and Economic Growth in the European Union FRED CAMPANO, Fordham University, and DOMINICK SALVATORE, Fordham University-When and How Will Europe's Growth Crisis End?

Discussants: FRED CAMPANO, Fordham University

PELLEGRINO MANFRA, City University of New York DOMINICK SALVATORE, Fordham University

\section{2:30 PM Manchester Grand Hyatt San Diego-Mission Beach A} AAEA

Climate Change Adaptation in Developing Countries: Constraints on Adaptation and Mechanisms for Relaxing Them (Q5)

Presiding: VIS TARAZ, Smith College

JOYCE CHEN, Ohio State University, and JON EINAR FLATNES,

Ohio State University-Credit Access, Migration, and Climate Change Adaptation in Rural Bangladesh

VALERIE MUELLER, Arizona State University, CLARK GRAY, University of North Carolina-Chapel Hill, SUDHANSHU HANDA, University of North Carolina-Chapel Hill, and DAVID SEIDENFELD, American Institutes for Research-Do Social Protection Programs Foster Short-Term and Long-Term Migration Adaptation Strategies?

MAGGIELIU, Smith College, YOGITA SHAMDASANI, University of Pittsburgh, and VIS TARAZ, Smith College-Climate Change, Structural Transformation, and Infrastructure: Evidence from India Discussant: JOHN HODDINOTT, Cornell University

\section{2:30 PM Manchester Grand Hyatt San Diego-Cove ACAES}

Economic Inequality in Asia (D3)

Presiding: CALLA WIEMER, American Committee on Asian Economic Studies 


\section{Saturday $・$ January 4}

SHI LI, Beijing Normal University_-Income Inequality in China in the 21st Century

OLIVER HOLTEMÖLLER, Halle Institute for Economic Research (IWH), and YANQUN ZHANG, Chinese Academy of Social Sciences-International Trade and Income Distribution: Evidence from China

MUHAMMAD AAMIR KHAN, COMSATS University, TERRIE WALMSLEY, ImpactECON LLC, and KAKALI MUKHOPADHYAY, McGill University-Trade Liberalization and Income Inequality: The Case of Pakistan

ARSENIO BALISACAN, Philippine Competition CommissionToward a Fairer Society: Inequality and Competition Policy in Developing Asia

Discussants: BARRY NAUGHTON, University of California-San Diego

ANGELA LYONS, University of Illinois-Urbana-Champaign

TOMOO KIKUCHI, Korea University

WILLIAM VIOLETTE, U.S. Federal Trade Commission

\section{2:30 PM Manchester Grand Hyatt San Diego_America's Cup C ACE/HES}

\section{New Thinking on Adam Smith and Economics (B3)}

Presiding: EDD NOELL, Westmont College

MARY HIRSCHFELD, Villanova University-Aristotle, Thomas Aquinas, and Adam Smith

PAUL OSLINGTON, Alphacrucis College-Sydney-Smith and Hume on Religious Markets

ROSS EMMETT, Arizona State University-Economists on Adam Smith on Economics and Religion

DEIRDRE MCCLOSKEY, University of Illinois-Chicago-Work in the World: A Smithian Sermon 


\section{Saturday $•$ January 4}

\section{2:30 PM Manchester Grand Hyatt San Diego-Harbor D ACES}

Improving the Foundations of Human Capital Around the World: Evaluating Early Childhood Development Efforts in China, Brazil and India (I3)

Presiding: SCOTT D. ROZELLE, Stanford University

JAMES J. HECKMAN, University of Chicago, and JIN ZHOU, University of Chicago-Interactions as Investments

FLAVIO CUNHA, Rice University-Implementation and Evaluation of a Parenting Program in Rural Northeast Brazil: The Case of PADIN

ORAZIO ATTANASIO, University College London-From 6 Months to 60: Sequential Interventions to Improve Child Development

SEAN SYLVIA, University of North Carolina-Chapel Hill-Early Childhood Development in Rural China: Evidence from the Qinling Cohort Study

Discussant: NELE WARRINNIER, Queen Mary University of London

\section{2:30 PM Marriott Marquis San Diego-Marina Ballroom E} AEA

\section{AEA Committee on Economic Education Poster Session (A2)}

Presiding: WILLIAM GOFFE, Pennsylvania State University

STEPHEN ERFLE, Dickinson College-An Active-Learning Exercise for Syllabus Day in Intermediate Microeconomics

JAMES R. BRUEHLER, Eastern Illinois University, WILLIAM D. CAMPBELL, University of Wyoming, and ALAN P. GRANT, Baker University-An Alternative Grading Scheme

TAREK H. SELIM, American University in Cairo, and KAREMAN M. SHOAIR, American University in Cairo-Classroom Competition Games: Learning Strategy

AREERAT KICHKHA, Lindenwood University—Cognitive Load Reduction with Cognitive Aids 


\section{Saturday $•$ January 4}

G. DIRK MATEER, University of Arizona-Crazy Rich Economics THOMAS GROLL, Columbia University-EconPractice: An Open Source Learning Toolkit for Economics

SYLWIA E. STARNAWSKA, State University of New York-Empire State College-Executive Dashboards for Commercial and Central Banking-Complementary Views for Decision-Making

JACK MARLEY-PAYNE, Financial Life Cycle Education, PHILIP DITURI, Financial Life Cycle Education and Fordham University, and ANDREW DAVIDSON, Financial Life Cycle EducationHarnessing Spreadsheets to Model Retirement Savings

JENNJOU CHEN, National Chengchi University, TSUI-FANG LIN, National Taipei University, and CHEN-HSUAN LIAO, National Chengchi University-Flipped Classroom Teaching in Microeconomics Recitation Sessions

HELEN SCHNEIDER, University of Texas-Austin-Incorporating Writing and Independent Inquiry into Econometrics Courses

BRIAN W. SLOBODA, University of Phoenix, and YAYA SISSOKO, Indiana University of Pennsylvania-Inside the Classroom: Learning from the 2008 Financial Crisis and the Subprime Meltdown

BENJAMINARTZ, University of Wisconsin-Oshkosh, MARIANNE JOHNSON, University of Wisconsin-Oshkosh, DENISE ROBSON, University of Wisconsin-Oshkosh, and SARINDA TAENGNOI SIEMERS, University of Wisconsin-Oshkosh-Notetaking and Lectures in the Digital Age

KATHRYN BIRKELAND, University of South Dakota, and MANDIE WEINANDT, University of South Dakota—One Talking Head Is Better Than None

EIICHIRO KAZUMORI, University of Massachusetts-Dartmouth, and DEVON LYNCH, University of Massachusetts-DartmouthRe-imagining Introductory Economics: Developing a Low-Cost Instructional Framework

COLIN CANNONIER, Belmont University, BRAD D. CHILDS, Belmont University, HOWARD H. COCHRAN, Belmont University, LUKE PETACH, Belmont University, LAKISHA SIMMONS, Belmont University, and MARIETA V. VELIKOVA, Belmont University—Show-And-Tell Economics Using Selfies 


\section{Saturday $\cdot$ January 4}

CALVIN BLACKWELL, College of Charleston, JAMES MALM, College of Charleston, NORMAN MAYNARD, College of Charleston, MARK PYLES, College of Charleston, MARCIA SNYDER, College of Charleston, and MARK WITTE, College of Charleston-Skepticism Education and Personality

SEDEFKA BECK, Valparaiso University-Teaching Econometrics with an Empirical Focus: Research Project Assignment

DMITRIY CHULKOV, Indiana University-Kokomo, and DMITRI NIZOVTSEV, Washburn University-Teaching Managerial Economics: Case-Based Learning Versus Problem-Based Learning MARIANNE JOHNSON, University of Wisconsin-Oshkosh, and MARTIN MEDER, Nicholls State University-Technology Interventions in Collegiate Economics Classes

MANDIE WEINANDT, University of South Dakota, and KATHRYN BIRKELAND, University of South Dakota-The Digital Dilemma: Using Digital Tools in the Online or Face-to-Face Classroom to Foster Participation and Encourage Student Learning ROD D. RAEHSLER, Duquesne University and Clarion UniversityThe Econometric Mini-Games: Does Competition Help in Learning Econometrics?

LINDA S. GHENT, Eastern Illinois University, JAMES R. BRUEHLER, Eastern Illinois University, and ALAN P. GRANT, Baker University-Using "Dollar Street" to Show Income Inequality Across the World

SCOTT WOLLA, Federal Reserve Bank of St. Louis-Yours, Mine, and the Truth: Using a Structured Minimum Wage Debate in the Economics Classroom

2:30 PM Marriott Marquis San Diego-Marriott Grand Ballroom 11

AEA

AEA Report: Best Practices for Improving Equity, Diversity, and the Professional Climate in Economics

Presiding: AMANDA BAYER, Swarthmore College

LETO COPELEY, AEA Ombudsperson

SEBNEM KALEMLI-OZCAN, University of Maryland

ROHINI PANDE, Yale University 


\section{Saturday $\cdot$ January 4}

CECILIA ROUSE, Princeton University

JUAN CARLOS SUÁREZ SERRATO, Duke University

TONY SMITH, Yale University

DAVID WILCOX, Federal Reserve Board-retired

\section{2:30 PM Marriott Marquis San Diego-Marriott Grand} Ballroom 10

AEA

AI/Robotics, Labor Markets and Demography (O3)

Presiding: KAREN N. EGGLESTON, Stanford University and NBER

HAL R. VARIAN, Google-Automation Versus Procreation, aka Bots Versus Tots

TOSHIAKI IIZUKA, University of Tokyo, YONG SUK LEE, Stanford University, and KAREN N. EGGLESTON, Stanford University and NBER-The Impact of Robots on Staffing in Nursing Homes

YONG SUK LEE, Stanford University, BENJAMIN LARSEN, Copenhagen Business School, MICHAEL WEBB, Stanford University, and MARIANO-FLORENTINO CUÉLLAR, California Supreme Court and Stanford University-How Would AI Regulation Change Firms' Behavior? Evidence from Thousands of Managers

Discussants: RAMIN TOLOUI, Stanford University

ROBERT SEAMANS, New York University

KRISTINA MCELHERAN, University of Toronto

\section{2:30 PM Marriott Marquis San Diego-Solana} AEA

\section{Behavioral Economics Issues (D9)}

Presiding: ISABEL TREVINO, University of California-San Diego

YEHUDA IZHAKIAN, Baruch College, and JAIME ZENDER, University of Colorado-Boulder-Ambiguity and Beliefs in the Principal Agent Model

QUYEN NGUYEN, Utah State University-Bayesian Persuasion: Evidence from the Laboratory 


\section{Saturday $•$ January 4}

SIMAS KUCINSKAS, Humboldt University of Berlin, and FLORIAN PETERS, University of Amsterdam-Measuring Biases in Expectation Formation

HAIMANTI BHATTACHARYA, University of Utah, and SUBHASISH DUGAR, University of Utah-Superstitious Belief Versus Nudge as Contract-Enforcing Mechanisms: Evidence from a Field Experiment

ZACHARY BREIG, University of Queensland, MATTHEW GIBSON, Williams College, and JEFFREY SHRADER, Columbia University—Why Do We Procrastinate? Present Bias and Optimism

\section{2:30 PM Marriott Marquis San Diego-San Diego Ballroom A AEA}

\section{Central Bank Communication (E5)}

Presiding: HYUN SONG SHIN, Bank for International Settlements

OLIVIER COIBION, University of Texas-Austin, DIMITRIS GEORGARAKOS, European Central Bank, YURIY GORODNICHENKO, University of California-Berkeley, and MICHAEL WEBER, University of Chicago-Forward Guidance Communication

ANNETTE VISSING-JORGENSEN, University of CaliforniaBerkeley-Central Banking with Many Voices: The Communications Arms Race

ANNA CIESLAK, Duke University, SEMYON MALAMUD, Swiss Federal Institute of Technology-Lausanne (EPFL), and ANDREAS SCHRIMPF, Bank for International SettlementsPolicy Announcement Design

STEPHEN HANSEN, Imperial College London, MICHAEL MCMAHON, University of Oxford, and MATTHEW TONG, Bank of England-The Long-Run Information Effect of Central Bank Communication

Discussants: NARAYANA KOCHERLAKOTA, University of Rochester

JEREMY STEIN, Harvard University

STEPHEN MORRIS, Princeton University

SAMUEL HANSON, Harvard Business School 


\section{Saturday $\cdot$ January 4}

\section{2:30 PM Marriott Marquis San Diego-Rancho Santa Fe 2}

AEA

Child Development and Public Policies (I3)

Presiding: FRANCESCO AGOSTINELLI, University of Pennsylvania

DANIELA DEL BOCA, University of Torino, CHRISTOPHER FLINN, New York University, EWOUT VERRIEST, New York University, and MATTHEW WISWALL, University of WisconsinMadison-Actors in the Child Development Process

FRANCESCO AGOSTINELLI, University of Pennsylvania, and GIUSEPPE SORRENTI, University of Zurich-Money Versus Time: Family Income, Maternal Labor Supply, and Child Development JORGE RODRIGUEZ, University of the Andes-Understanding the Effects of a Work-Based Welfare Policy on Child Human Capital

MARTHA J. BAILEY, University of Michigan, SHUQIAO SUN, University of Michigan, and BRENDEN TIMPE, University of Michigan-"Prep School for Poor Kids": The Long-Run Impact of Head Start on Human Capital and Productivity

Discussants: MATTHEW WISWALL, University of Wisconsin-Madison

KATRINE LOKEN, Norwegian School of Economics

JEFFREY GROGGER, University of Chicago

JOHN ERIC HUMPHRIES, Yale University

\section{2:30 PM Marriott Marquis San Diego-Marriott Grand} Ballroom 5-6

AEA

Panel: Deaths of Despair and the Future of Capitalism (G3)

Presiding: ANGUS DEATON, Princeton University

ANNE CASE, Princeton University

ROBERT D. PUTNAM, Harvard University

RAGHURAM RAJAN, University of Chicago

KENNETH ROGOFF, Harvard University 


\section{Saturday $•$ January 4}

2:30 PM Marriott Marquis San Diego-Marriott Grand Ballroom 1 AEA

\section{Digital Financial Services in Africa (O1)}

Presiding: TAVNEET SURI, Massachusetts Institute of Technology

PRASHANT BHARADWAJ, University of California-San Diego, and TAVNEET SURI, Massachusetts Institute of TechnologyImproving Financial Inclusion Through Digital Savings and Credit

JENNY C. AKER, Tufts University, SILVIA PRINA, Northwestern University, and C. JAMILAH WELCH, Tufts UniversityMigration, Money Transfers and Mobile Money: Evidence from Niger

CATIA BATISTA, Nova University of Lisbon, and PEDRO VICENTE, Nova University of Lisbon-Is Mobile Money Changing Rural Africa? Evidence from a Field Experiment

SHILPA AGGARWAL, Indian School of Business, VALENTINA BRAILOVSKAYA, IDinsight, and JONATHAN ROBINSON, University of California-Santa Cruz-Cashing In (and Out): Experimental Evidence on the Effects of Mobile Money in Malawi

\section{2:30 PM Marriott Marquis San Diego-Del Mar AEA}

\section{Economics of Payments (L8)}

Presiding: MARC S. RYSMAN, Boston University

SERGEI KOULAYEV, Consumer Financial Protection Bureau (CFPB), and DANIEL GRODZICKI, Pennsylvania State University and Consumer Financial Protection Bureau (CFPB) - Sustained Credit Card Borrowing

CHUN-YU HO, State University of New York-Albany, LI XU, Shanghai Jiao Tong University, and DAIQIANG ZHANG, State University of New York-Albany-Price Negotiation with Merchant Heterogeneity in the Payment Card Industry

ZHU WANG, Federal Reserve Bank of Richmond, BIN GRACE LI, International Monetary Fund, and JAMES MCANDREWS, TNB USA Inc.-Two-Sided Market, R\&D and Payments System Evolution 


\section{Saturday $\cdot$ January 4}

OLEKSANDR SHCHERBAKOV, Bank of Canada, KIM P. HUYNH, Bank of Canada, and GRADON NICHOLLS, Bank of Canada-Explaining the Interplay between Merchant and Consumer Decisions in Two-Sided Market For Payment Methods

Discussants: OLEKSANDR SHCHERBAKOV, Bank of Canada

SERGEI KOULAYEV, Consumer Financial Protection Bureau (CFPB)

CHUN-YU HO, State University of New York-Albany

ZHU WANG, Federal Reserve Bank of Richmond

\section{2:30 PM Marriott Marquis San Diego-Marriott Grand} Ballroom 12

AEA

Funding Financial Intermediaries (G2)

Presiding: JOSE SCHEINKMAN, Columbia University

KRISTIAN BLICKLE, Federal Reserve Bank of New York, MARKUS BRUNNERMEIER, Princeton University, and STEPHAN LUCK, Federal Reserve Bank of New York-Microevidence from a Systemwide Financial Meltdown: The German Crisis of 1931

EDUARDO DAVILA, Yale University, and ITAY GOLDSTEIN, University of Pennsylvania-Optimal Deposit Insurance

YUERAN MA, University of Chicago, and JOSE SCHEINKMAN, Columbia University-Going-Concern Debt of Financial Intermediaries

Discussants: MATTHIEU GOMEZ, Columbia University

DOUGLAS DIAMOND, University of Chicago

MARTIN OEHMKE, London School of Economics and Political Science

\section{2:30 PM Marriott Marquis San Diego-Torrey Pines 1} AEA

Impacts of the Earned Income Tax Credit (H2)

Presiding: RILEY WILSON, Brigham Young University 


\section{Saturday $•$ January 4}

JACOB BASTIAN, University of Chicago, and MAGGIE R. JONES, U.S. Census Bureau-Do EITC Expansions Pay for Themselves? Effects on Tax Revenue and Public Assistance Spending KATHERINE MICHELMORE, Syracuse University, NATASHA PILKAUSKAS, University of Michigan, and RICK RODEMS, University of Michigan-Who's Minding the Kids? The Earned Income Tax Credit and Child Care Arrangements

RILEY WILSON, Brigham Young University-The Impact of Social Networks on EITC Claiming Behavior

JESSAMYN SCHALLER, University of Arizona, ANN HUFF STEVENS, University of California-Davis, and CHLOE N. EAST, University of Colorado-Denver-The Dynamics of Earned Income Tax Credit Eligibility

Discussants: REAGAN BAUGHMAN, University of New Hampshire

AMANDA AGAN, Rutgers University

DAVID SIMON, University of Connecticut

SARA LALUMIA, Williams College

\section{2:30 PM Marriott Marquis San Diego-Marriott Grand} Ballroom 13

AEA

\section{Improving the Transparency and Credibility of Economics} Research (B4)

Presiding: EDWARD MIGUEL, University of California-Berkeley

DAVID BIRKE, University of California-Berkeley, GARRET CHRISTENSEN, U.S. Census Bureau, REBECCA LITTMAN, Massachusetts Institute of Technology, EDWARD MIGUEL, University of California-Berkeley, ELIZABETH LEVY PALUCK, Princeton University, NICHOLAS SWANSON, University of California-Berkeley, and ZENAN WANG, University of CaliforniaBerkeley-Open Science Practices Are on the Rise in Economics ABEL BRODEUR, University of Ottawa, NIKOLAI COOK, University of Ottawa, and ANTHONY HEYES, University of Ottawa-Rising Up the Ranks: Rejecting the Null Hypothesis and Impact Factor 


\section{Saturday $\cdot$ January 4}

GEORGE OFOSU, London School of Economics, and DANIEL POSNER, University of California-Berkeley-Evidence on the Use of Pre-analysis Plans in Economics and Political Science

STEFANO DELLAVIGNA, University of California-Berkeley, NICHOLAS OTIS, University of California-Berkeley, and EVA VIVALT, Australian National University-Forecasting the Results of Economic Research

Discussants: FIONA BURLIG, University of Chicago

MICHAEL GECHTER, Pennsylvania State University

DAVID MCKENZIE, World Bank

\section{2:30 PM Marriott Marquis San Diego-Marriott Grand Ballroom 3} AEA

Is United States Deficit Policy Playing with Fire? (H6)

Presiding: LAURENCE KOTLIKOFF, Boston University

RICHARD EVANS, University of Chicago-Public Debt, Low Interest Rates, and Rare Events

N. GREGORY MANKIW, Harvard University-A Skeptic's Guide to Modern Monetary Theory

MICHAEL BOSKIN, Stanford University-How, Why and When Deficits and Debt Are Dangerous

JASMINA HASANHODZIC, Babson College-Simulating the Blanchard-Summers Conjecture in a Multi-Period Life-Cycle Model JOHANNES BRUMM, Karlsruhe Institute of Technology, LAURENCE KOTLIKOFF, Boston University, and FELIX KUBLER, University of Zurich—Leveraging Posterity's Prosperity?

Discussant: ALAN AUERBACH, University of California-Berkeley

SETH BENZELL, Massachusetts Institute of Technology

2:30 PM Marriott Marquis San Diego-Marriott Grand Ballroom 2 AEA

Natural Language Processing and Its Application to

Macroeconomics and Macro-Finance (E1)

Presiding: NELLIE LIANG, Brookings Institution 


\section{Saturday $•$ January 4}

RICARDO CORREA, Federal Reserve Board, JUAN M. LONDONO, Federal Reserve Board, and STIJN CLAESSENS, Bank for International Settlements-Financial Stability Governance and Communication

DAVID-JAN JANSEN, Central Bank of the Netherlands, ARINA WISCHNEWSKY, Trier University, and MATTHIAS NEUENKIRCH, Trier University and CESifo-Financial Stability and the Fed: Evidence from Congressional Hearings

SEUNG JUNG LEE, Federal Reserve Board, MARY CHEN, Federal Reserve Board, MATTHEW DEININGER, Federal Reserve Board, and MARTIN SICILIAN, Federal Reserve Board-Identifying Financial Crises Using Textual Data

ARTHUR TURRELL, Bank of England, ELENI KALAMARA, King's College London, CHRIS REDL, Bank of England, GEORGE KAPETANIOS, King's College London, and SUJIT KAPADIA, European Central Bank-Making Text Count for Macroeconomics: What Newspaper Text Can Tell Us about the Economy

Discussants: MARTIN CIHAK, International Monetary Fund

JONATHAN ROSE, Federal Reserve Bank of Chicago

CASPAR SIEGERT, Bank of England

LELAND CRANE, Federal Reserve Board

\section{2:30 PM Marriott Marquis San Diego-Point Loma AEA}

\section{Perspectives on Neoclassical Labor Supply (E2)}

Presiding: BENJAMIN SCHOEFER, University of California-Berkeley

TIMO BOPPART, IIES Stockholm, PER KRUSELL, IIES Stockholm, and JONNA OLSSON, IIES Stockholm-Labor Supply in the Past, Present, and Future: The Post-War United States

PRESTON MUI, University of California-Berkeley, and BENJAMIN SCHOEFER, University of California-Berkeley-The Aggregate Labor Supply Curve at the Extensive Margin: A Reservation Wedge Approach

SEBASTIAN DYRDA, University of Toronto, GREG KAPLAN, University of Chicago, and JOSÉ-VÍCTOR RÍOS-RULL, University of Pennsylvania—Living Arrangements and Labor Market Volatility of Young Workers 


\section{Saturday $\cdot$ January 4}

MICHAEL ELSBY, University of Edinburgh, RYAN MICHAELS, Federal Reserve Board, DAVID RATNER, Federal Reserve Board, and MATTHEW SHAPIRO, University of Michigan-The Wages of Nonemployment

2:30 PM Marriott Marquis San Diego-Marriott Grand Ballroom 4 AEA

Stories and Identity in Organizations (D2)

Presiding: NIKO MATOUSCHEK, Northwestern University

ROBERT GIBBONS, Massachusetts Institute of Technology, and LAURENCE PRUSAK, Columbia University-Stories as Knowledge in Organizations

MARIA GUADALUPE, INSEAD, ZOE KINIAS, INSEAD, and FLORIAN SCHLODERER, INSEAD-Individual Identity and Organizational Attachment: Evidence from a Field Experiment

ROBERT AKERLOF, University of Warwick, NIKO MATOUSCHEK, Northwestern University, and LUIS RAYO, Northwestern University-Stories in Organizations

\section{2:30 PM Marriott Marquis San Diego-Balboa}

AEA

Taxation (H2)

Presiding: DANNY YAGAN, University of California-Berkeley

RENKE SCHMACKER, DIW Berlin, and SINNE SMED, University of Copenhagen-Can Sin Taxes Help Consumers with

Low Self-Control? Evidence from Danish Soft Drink Tax Reforms

TERRY MOON, Princeton University and University of British Columbia-Capital Gains Taxes and Real Corporate Investment

GABRIELA MUNDACA, World Bank, and JON STRAND, World Bank-Carbon Pricing of International Transport Fuels: Impacts on Carbon Emissions and Trade Activity

SEBASTIAN BEER, International Monetary Fund, MARIA COELHO, International Monetary Fund, and SÉBASTIEN LEDUC, International Monetary Fund-Hidden Treasures: The Impact of Automatic Exchange of Information on Cross-Border Tax Evasion 


\section{Saturday $•$ January 4}

JAN-EMMANUEL DE NEVE, University of Oxford, CLEMENT IMBERT, University of Warwick, JOHANNES SPINNEWIJN, London School of Economics, TEODORA TSANKOVA, University of Warwick, and MAARTEN LUTS, Federal Public Service Finance-Belgium-How to Improve Tax Compliance? Evidence from Population-Wide Experiments in Belgium

ZHIYONG AN, Fannie Mae-Tax Policy and Price-To-Rent Ratio: Evidence from the Tax Cuts and Jobs Act of 2017 (TCJA)

\section{2:30 PM Marriott Marquis San Diego-San Diego Ballroom B AEA}

The Race between Education and Technology Revisited (J3)

Presiding: LAWRENCE KATZ, Harvard University

DAVID AUTOR, Massachusetts Institute of Technology, CLAUDIA GOLDIN, Harvard University, and LAWRENCE KATZ, Harvard University-The Race between Education and Technology Revisited BRAD HERSHBEIN, W.E. Upjohn Institute for Employment Research, and MELISSA KEARNEY, University of MarylandIncreasing Educational Attainment to Reduce Economic Insecurity and Income Inequality

DARON ACEMOGLU, Massachusetts Institute of Technology, and PASCUAL RESTREPO, Boston University-Automation, New Tasks, and Inequality

DAVID DEMING, Harvard University-Direct Measures of the Skill Bias of Technological Change

Discussants: JOHN MICHAEL VAN REENEN, Massachusetts Institute of Technology

SANDRA E. BLACK, Columbia University

CHAD JONES, Stanford University

NICOLE FORTIN, University of British Columbia 


\section{Saturday $•$ January 4}

\section{2:30 PM Manchester Grand Hyatt San Diego-Promenade A AEDSB}

Development Issues of Labor, Agriculture and Poverty in Bangladesh (01)

Presiding: FAHAD KHALIL, University of Washington

ASAD ISLAM, Monash University, MARCEL FAFCHAMPS, Stanford University, ABDUL MALEK, University of Tsukuba, and DEBAYAN PAKRASHI, Indian Institute of Technology (IIT)Kanpur-Can Referral Improve Targeting? Evidence from an Agricultural Training Experiment

LAURA BOUDREAU, Columbia University-Multinational Enforcement of Labor Law: Experimental Evidence from Bangladesh's Apparel Sector

CAITLIN BROWN, Central European University, ROSSELLA CALVI, Rice University, and JACOB PENGLASE, University of Bordeaux-Sharing the Pie: Undernutrition, Intra-household Allocation, and Poverty

MAITREESH GHATAK, London School of Economics, CLARE BALBONI, London School of Economics, ORIANA BANDIERA, London School of Economics, and ROBIN BURGESS, London School of Economics-Why Do People Stay Poor?

Discussants: RESHMAAN HUSSAM, Harvard Business School

KHAWAJA SAEED MAMUN, Sacred Heart University

ABU SHONCHOY, Florida International University

AHMED MUSHFIQ MOBARAK, Yale University

\section{2:30 PM Manchester Grand Hyatt San Diego_Gaslamp D} AERE

\section{Environment in a Multisector Economy (Q5)}

Presiding: KRISTLE ROMERO CORTÉS, University of New South Wales

DON FULLERTON, University of Illinois, and CHI LAN TA, University of Illinois-Effects of Tightening Renewable Energy Standards: Analytical General Equilibrium Model and Empirical Tests 


\section{Saturday $\cdot$ January 4}

GARTH HEUTEL, Georgia State University, and XIN ZHANG, Georgia State University-Efficiency Wages, Unemployment, and Environmental Policy

FANNY MOFFETTE, University of Wisconsin, MARIN SKIDMORE, University of Wisconsin, and HOLLY GIBBS, University of Wisconsin-Deforestation Policies: A Tool to Shape Productivity?

JUSTIN GALLAGHER, Montana State University, and DANIEL HARTLEY, Federal Reserve Bank of Chicago-Local Bank Lending Following a Natural Disaster

Discussants: KAREN PALMER, Resources for the Future

STEPHIE FRIED, Arizona State University

JILL CAVIGLIA-HARRIS, Salisbury University

KRISTLE ROMERO CORTÉS, University of New South Wales

\section{2:30 PM Manchester Grand Hyatt San Diego-Seaport DE} AFA

\section{AFA Lecture-Distributed Ledgers: Design and Regulation of Financial Infrastructure and Payment Systems (G0)}

Presiding: ROBERT TOWNSEND, Massachusetts Institute of Technology

\section{2:30 PM Manchester Grand Hyatt San Diego-Seaport A AFA}

\section{Bank Lending (G2)}

Presiding: JUSTIN MURFIN, Cornell University

ROBERT PRILMEIER, Tulane University, and RENE STULZ, Ohio State University-Securities Laws and the Choice Between Loans and Bonds for Highly Levered Firms

TAYLOR BEGLEY, Washington University-St. Louis, UMIT GURUN, University of Texas-Dallas, AMIYATOSH PURNANANDAM, University of Michigan, and DANIEL WEAGLEY, Georgia Institute of Technology-Disaster Lending: "Fair" Prices, but "Unfair" Access 


\section{Saturday $\cdot$ January 4}

CEM DEMIROGLU, Koc University, CHRISTOPHER JAMES, University of Florida, and GUNER VELIOGLU, Loyola University Chicago-Why Are Commercial Loan Rates So Sticky?

Discussants: GREGORY NINI, Drexel University

ELIZABETH BERGER, Cornell University

RYAN PRATT, Brigham Young University

\section{2:30 PM Manchester Grand Hyatt San Diego-Seaport B}

AFA

\section{Corporate Debt and Liquidity (G3)}

Presiding: MICHAEL ROBERTS, University of Pennsylvania

CANDACE JENS, Tulane University, and BEAU PAGE, Tulane University-Corporate Cash and Political Uncertainty

MARIA CHADERINA, Carnegie Mellon University-Rollover Risk and the Dynamics of Debt

JACK FAVILUKIS, University of British Columbia, XIAOJI LIN, University of Minnesota, NENG WANG, Columbia University, and XIAOFEI ZHAO, Georgetown University-The Impact of Labor Market Frictions on Corporate Liquidity Management

Discussants: HEITOR ALMEIDA, University of Illinois

ZHIGUO HE, University of Chicago

TONI WHITED, University of Michigan

\section{2:30 PM Manchester Grand Hyatt San Diego-Seaport C} AFA

\section{Corporate Investment in the Modern Economy (G3)}

Presiding: ANDREA EISFELDT, University of California-Los Angeles

ANIL K. KASHYAP, University of Chicago, NATALIA KOVRIJNYKH, Arizona State University, JIAN LI, University of Chicago, and ANNA PAVLOVA, London Business School-The Benchmark Inclusion Subsidy

GERARD HOBERG, University of Southern California, and VOJISLAV MAKSIMOVIC, University of Maryland-Product Life Cycles in Corporate Finance 


\section{Saturday $•$ January 4}

MEGHANA AYYAGARI, George Washington University, ASLI DEMIRGUC-KUNT, World Bank, and VOJISLAV MAKSIMOVIC, University of Maryland-The Rise of Star Firms: Intangible Capital and Competition

PAIGE OUIMET, University of North Carolina-Chapel Hill, ELENA SIMINTZI, University of North Carolina-Chapel Hill, and KAILEI YE, University of North Carolina-Chapel Hill-The Impact of the Opioid Crisis on Firm Value and Investment

Discussants: JULES VAN BINSBERGEN, University of Pennsylvania

MINDY XIAOLAN, University of Texas-Austin

NICOLAS CROUZET, Northwestern University

WILLIAM MANN, University of California-Los Angeles

\section{2:30 PM Manchester Grand Hyatt San Diego-Seaport F AFA}

\section{Foreign Exchange Risk Premium (G1)}

Presiding: WENXIN DU, University of Chicago

INGOMAR KROHN, Copenhagen Business School, PHILIPPE MUELLER, University of Warwick, and PAUL WHELAN, Copenhagen Business School-FX Premia Around the Clock XIANG FANG, University of Pennsylvania-Intermediary Leverage and Currency Risk Premium

PASQUALE DELLA CORTE, Imperial College London, ALEXANDRE JEANNERET, HEC Montreal, and ELLA PATELLI, HEC Montreal-A Credit-Based Theory of the Currency Risk Premium

SAI MA, Federal Reserve Board, and SHAOJUN ZHANG, Ohio State University-Housing Cycles and Exchange Rates

Discussants: ALAIN CHABOUD, Federal Reserve Board

CAROLIN PFLUEGER, University of British Columbia

LUKAS KREMENS, London School of Economics

NANCY XU, Boston College 


\section{Saturday $\cdot$ January 4}

\section{2:30 PM Manchester Grand Hyatt San Diego-Seaport G}

AFA

Intermediary Trading, Trading Venues, and Market Liquidity (G1)

Presiding: YAJUN WANG, City University of New York-Baruch College AGOSTINO CAPPONI, Columbia University, ALBERT MENKVELD, VU University Amsterdam, and HONGZHONG ZHANG, Columbia University-Large Orders in Small Markets: On Optimal Execution with Endogenous Liquidity Supply

GIDEON SAAR, Cornell University, JIAN SUN, Massachusetts Institute of Technology, RON YANG, Harvard University, and HAOXIANG ZHU, Massachusetts Institute of Technology and NBER_From Market Making to Matchmaking: Does Banking Regulation Harm Market Liquidity?

CHAOJUN WANG, University of Pennsylvania, and TOMY LEE, University of Toronto-Why Trade Over-the-Counter? When Investors Want Price Discrimination

Discussants: KERRY BACK, Rice University

ALBERT KYLE, University of Maryland

CECILIA PARLATORE, New York University

\section{2:30 PM Manchester Grand Hyatt San Diego-Harbor A}

AFA

Structural Models of Credit Risk (G1)

Presiding: PIERRE COLLIN-DUFRESNE, Swiss Federal Institute of Technology-Lausanne (EPFL)

JINGZHI HUANG, Pennsylvania State University, YOSHIO NOZAWA, Hong Kong University of Science and Technology, and ZHAN SHI, Tsinghua University-The Global Credit Spread Puzzle ZHIYAO CHEN, Chinese University of Hong Kong, DIRK HACKBARTH, Boston University, and ILYA STREBULAEV, Stanford University-A Unified Model of Distress Risk Puzzles

RYAN LEWIS, University of Colorado Boulder-Same Firm, Different Betas 


\section{Saturday $•$ January 4}

YANG LIU, University of Hong Kong, LUKAS SCHMID, Duke University, and AMIR YARON, University of Pennsylvania-The Risks of Safe Assets

Discussants: PETER FELDHüTTER, Copenhagen Business School

KENT DANIEL, Columbia University

ANTJE BERNDT, Australian National University

LARS LOCHSTOER, University of California-Los Angeles

\section{2:30 PM Manchester Grand Hyatt San Diego-Seaport H} AFA

The Use (and Misuse) of Private Information in Financial Markets (G1)

Presiding: SNEHAL BANERJEE, University of California-San Diego

SHIYANG HUANG, University of Hong Kong, YAN XIONG, Hong Kong University of Science and Technology, and LIYAN YANG, University of Toronto-Skill Acquisition and Information Sales

EMRE OZDENOREN, London Business School, KATHY YUAN, London School of Economics, and SHENGXING ZHANG, London School of Economics-Dynamic Coordination with Flexible Security Design

MARCIN KACPERCZYK, Imperial College London, and EMILIANO PAGNOTTA, Imperial College London-Becker Meets Kyle: Inside Insider Trading

Discussants: NADYA MALENKO, Boston College

JESSE DAVIS, University of North Carolina-Chapel Hill

KENNETH AHERN, University of Southern California

\section{2:30 PM Manchester Grand Hyatt San Diego-Torrey Hills AB} AFE/AFA

\section{Bankruptcy and Efficiency (G3)}

Presiding: KOSE JOHN, New York University

KATHERINE WALDOCK, Georgetown University-Four Facts About Corporate Bankruptcy in the United States 


\section{Saturday $•$ January 4}

WINSTON WEI DOU, University of Pennsylvania, LUCIAN A. TAYLOR, University of Pennsylvania, WEI WANG, Queen's University, and WENYU WANG, Indiana University—Dissecting Bankruptcy Frictions

B. ESPEN ECKBO, Dartmouth College, KAI LI, University of British Columbia, and WEI WANG, Queen's University-Rent Extraction by Super-Priority Lenders

BO LI, Tsinghua University, and JACOPO PONTICELLI, Northwestern University-Going Bankrupt in China

Discussants: DAVID C. SMITH, University of Virginia

SERGEI DAVYDENKO, University of Toronto

SANDEEP DAHIYA, Georgetown University

HAITIAN LU, Hong Kong Polytechnic University

\section{2:30 PM Manchester Grand Hyatt San Diego-Cortez Hill A AFEE}

\section{John R. Commons's Foundations of Progressive Change (B5)}

Presiding: DAVID ZALEWSKI, Providence College

KOTA KITAGAWA, Kansai University-From Judicial Sovereignty to Collective Democracy: J.R. Commons' Developing View of Progressive Institutional Change

SHINGO TAKAHASHI, Tokyo College of Transport StudiesToward Reasonable Capitalism: The Role of John R. Commons's Price and Business Cycle Theories

GLEN ATKINSON, University of Nevada-Reno, ERIC HAKE, Catawba College, and STEPHEN PASCHALL, Lovett Bookman

Harmon Marks LLP-John R. Commons, Subsidiarity and the Corporation

CHARLES WHALEN, State University of New York-BuffaloJohn R. Commons and Government as Employer of Last Resort: Three Paths to a Progressive Right to Work

PHILIPPE BRODA, Novancia Business School-Institutions, the Economy and Politics: The Debate between Commons and North

Discussants: F. GREGORY HAYDEN, University of Nebraska-Lincoln

DAVID ZALEWSKI, Providence College 


\section{Saturday $•$ January 4}

\section{2:30 PM Manchester Grand Hyatt San Diego-Promenade B AREUEA}

\section{Homeownership and Mortgage Access (R3)}

Presiding: PAUL WILLEN, Federal Reserve Bank of Boston

JAMES CONKLIN, University of Georgia, BRENT AMBROSE, Pennsylvania State University, and LUIS LOPEZ, Pennsylvania State University-Preferential Treatment in Financial Contracts: Does Borrower and Broker Race Affect Mortgage Prices

ZHENGUO LIN, Florida International University, YINGCHUN LIU, University of North Texas, and JIA XIE, California State University-Fullerton—Credit Supply and the American Dream

CLAES BÄCKMAN, Lund University, and NATALIA KHORUNZHINA, Copenhagen Business School-Interest-Only Mortgages, Household Consumption, Housing Wealth Effects

SUSAN WACHTER, University of Pennsylvania, ARTHUR ACOLIN, University of Washington, and DESEN LIN, University of Pennsylvania-Endowments and Minority Homeownership

Discussants: AUREL HIZMO, Federal Reserve Board

RALUCA ROMAN, Federal Reserve Bank of Philadelphia

CLAIRE LABONNE, Federal Reserve Bank of Boston

STEVE ROSS, University of Connecticut

\section{2:30 PM Manchester Grand Hyatt San Diego-Nautical AREUEA}

\section{Housing and the Life Cycle (R2)}

Presiding: MIKE ERIKSEN, University of Cincinnati

JING LI, Singapore Management University, NAQUN HUANG, Nanjing Audit University, and AMANDA ROSS, University of Alabama-Do Elderly Individuals Delay Claiming Social Security and Cash-out Home Equity When House Prices Appreciate?

CHARLES KA YUI LEUNG, City University of Hong Kong, and YIFAN GONG, University of Western Ontario-When Education Policy and Housing Policy Interact: Can We Correct for the Externalities? 


\section{Saturday $•$ January 4}

JIRO YOSHIDA, Pennsylvania State University, MIKI SEKO, Musashino University, and KAZUTO SUMITA, Toyo UniversityThe Inheritance Tax and Household Mobility: An Exploration of Empty Nest Problem

NADIA GREENHALGH-STANLEY, Kent State University, and LOCKWOOD REYNOLDS, Kent State University-Housing Wealth, Bequests, and the Elderly

Discussants: SITA SLAVOV, George Mason University

ALVIN MURPHY, Arizona State University

ANIL KUMAR, Federal Reserve Bank of Dallas

SEWIN CHAN, New York University

\section{2:30 PM Manchester Grand Hyatt San Diego—Regatta C AREUEA}

\section{Transportation (R4)}

Presiding: EDWARD COULSON, University of California-Irvine

YU QIN, National University of Singapore, YATANG LIN, Hong Kong University of Science and Technology, JOHAN SULAEMAN, National University of Singapore, JUBO YAN, Nanyang Technological University, and JIALIANG ZHANG, Peking University—Facilitating Investment Flows: Evidence from China's High-Speed Passenger Rail Network

YI FAN, National University of Singapore, XINWEI WAN, University of Cambridge, and HO PIN TEO, National University of Singapore-Public Transport, Noise Complaints, and Housing: Evidence from Sentiment Analysis in Singapore

YANG (ZOE) YANG, Chinese University of Hong Kong, HANMING FANG, University of Pennsylvania, and LONG WANG, ShanghaiTech University-Competition and Quality Gains: New Evidence from the High-Speed Rails and Airlines

WEIHUA ZHAO, University of Louisville-The Long Run Effects of Uber on Public Transit, Sprawl, Energy Consumption, and Carbon Emissions 


\section{Saturday $•$ January 4}

Discussants: JANET KOHLHASE, University of Houston

JEFFREY COHEN, University of Connecticut

JAN BRUECKNER, University of California-Irvine

JEFFREY LIN, Federal Reserve Bank of Philadelphia

\section{2:30 PM Manchester Grand Hyatt San Diego-Pier ASE/AFEE}

\section{A Green Light for Public Banks? (B5)}

Presiding: LOUIS-PHILIPPE ROCHON, Laurentian University

DEBORAH FIGART, Stockton University-Public Banks: A Source for Infrastructure Funding and Potential Economic Impact THOMAS HERNDON, Loyola Marymount University, and MARK PAUL, New College of Florida-A Public Banking Option

MARIO SECCARECCIA, University of Ottawa-Banking as a Public Good, or Why the Public Banking Option Is Desirable in Contemporary Economies

MASSIMO CINGOLANI, European Investment Bank-Public and Private Financing of the Sustainable Development Goals (SDG)

WESLEY MARSHALL, Autonomous University of MexicoIztapalapa, and LOUIS-PHILIPPE ROCHON, Laurentian University—Beyond Fiscal and Monetary Policies: A Post-Keynesian Case for Public Banks

\section{2:30 PM Marriott Marquis San Diego-Mission Hills ES}

\section{Advances and Extensions in Reference-Dependent Models (D1)}

Presiding: CHARLES SPRENGER, University of California-San Diego ORI HEFFETZ, Cornell University and Hebrew University of Jerusalem, and MATTHEW RABIN, Harvard UniversityExperimental Expectations and Expectations-Based Reference Dependence

BEN BUSHONG, Michigan State University-Misattribution of Reference Dependence: Evidence from Real-Effort Experiments 


\section{Saturday $•$ January 4}

ERIK SNOWBERG, California Institute of Technology, and JONATHAN CHAPMAN, New York University-Loss Attitudes in the United States Population: Evidence from Dynamically Optimized Sequential Experimentation (DOSE)

CHARLES SPRENGER, University of California-San DiegoHeterogeneity of Gain-Loss Attitudes and Expectations-Based Reference Points

\section{2:30 PM Marriott Marquis San Diego-Catalina} ES

\section{Declining Business Dynamism (04)}

Presiding: UFUK AKCIGIT, University of Chicago

JOHN HALTIWANGER, University of Maryland, and ZOLTAN WOLF, U.S. Census Bureau-Declining Reallocation in the United States: Implications for Productivity Growth?

UFUK AKCIGIT, University of Chicago, and SINA ATES, Federal Reserve Board-What Happened to United States Business Dynamism?

CHAD SYVERSON, University of Chicago-The Productivity J-Curve: How Intangibles Complement General Purpose Technologies

JASON FURMAN, Harvard University, and PETER ORSZAG, Brookings Institution-Slower Productivity and Higher Inequality: Are They Related?

\section{2:30 PM Marriott Marquis San Diego-Cardiff ES}

Housing and Financial Stability (R5)

Presiding: REBECCA DIAMOND, Stanford University

REBECCA DIAMOND, Stanford University, ADAM GUREN, Boston University, and ROSE TAN, Stanford University-The Effect of Foreclosures on Homeowners, Tenants, and Landlords

ROBERT COLLINSON, University of Notre Dame-The Effects of Evictions on Low-Income Families 


\section{Saturday $\cdot$ January 4}

WINNIE VAN DIJK, University of Chicago, JOHN ERIC HUMPHRIES, Yale University, DANIEL TANNENBAUM, University of Nebraska-Lincoln, and NICHOLAS MADER, University of Chicago-Does Eviction Have Spillovers on Children?

PASCAL NOEL, University of Chicago, and PETER GANONG, University of Chicago-Why Do Borrowers Default on Mortgages?

A New Test Using High-Frequency Data

Discussants: MATTHEW NOTOWIDIGDO, Northwestern University

MICHAEL MUELLER-SMITH, University of Michigan

ANNA AIZER, Brown University

JOAO COCCO, London Business School

\section{2:30 PM Marriott Marquis San Diego-Presidio 1-2}

ES

\section{Machine Learning and High Dimensional Methods (C1)}

Presiding: WHITNEY NEWEY, Massachusetts Institute of Technology

YING-YING LEE, University of California-Irvine, and KYLE COLANGELO, University of California-Irvine-Double Debiased Machine Learning Nonparametric Inference with Continuous Treatments

JESUS FERNANDEZ-VILLAVERDE, University of Pennsylvania, and STEPHEN HANSEN, Imperial College London-Structural Estimation of Dynamic Equilibrium Models with Unstructured Data VICTOR CHERNOZHUKOV, Massachusetts Institute of Technology, JERRY HAUSMAN, Massachusetts Institute of Technology, and WHITNEY NEWEY, Massachusetts Institute of Technology_Demand Analysis with Many Prices

VIRA SEMENOVA, Harvard University-Machine Learning for Dynamic Discrete Choice

PHILIPPE GOULET COULOMBE, University of Pennsylvania, MAXIME LEROUX, University of Quebec-Montreal, DALIBOR STEVANOVIC, University of Quebec-Montreal, and STEPHANE SURPRENANT, University of Quebec-Montreal-How Is Machine Learning Useful for Macroeconomic Forecasting? 


\section{Saturday $•$ January 4}

KARUN ADUSUMILLI, University of Pennsylvania, FRIEDRICH GEIECKE, London School of Economics, and CLAUDIO SCHILTER, London School of Economics-Dynamically Optimal Treatment Allocation Using Reinforcement Learning

\section{2:30 PM Marriott Marquis San Diego-Marina Ballroom F ES}

\section{Quantitative Economics Panel: Design of Randomized Control} Trials, Different Perspectives (C1)

Presiding: CHRISTOPHER TABER, University of Wisconsin-Madison

AZEEM SHAIKH, University of Chicago

SYLVAIN CHASSANG, New York University

KARTHIK MURALIDHARAN, University of California-San Diego

\section{2:30 PM Marriott Marquis San Diego_La Costa}

\section{ES}

\section{Recent Advances in International Macro (F4)}

Presiding: LOUKAS KARABARBOUNIS, University of Minnesota

GABRIEL CHODOROW-REICH, Harvard University, LOUKAS KARABARBOUNIS, University of Minnesota, and ROHAN KEKRE, University of Chicago-The Macroeconomics of the Greek Depression

STEPHANIE SCHMITT-GROHÉ, Columbia University, and MARTIN URIBE, Columbia University-Exchange Rates and

Uncovered Interest Differentials: The Role of Permanent Monetary Shocks

CRISTINA ARELLANO, Federal Reserve Bank of Minneapolis, YAN BAI, University of Rochester, and LUIGI BOCOLA, Stanford University-Sovereign Default Risk and Firm Heterogeneity

PIERRE-OLIVIER GOURINCHAS, University of CaliforniaBerkeley, PHILIPPE MARTIN, Sciences Po, and TODD MESSER, University of California-Berkeley-The Economics of Sovereign Debt, Bailouts and the Eurozone Crisis 


\section{Saturday $•$ January 4}

\section{2:30 PM Manchester Grand Hyatt San Diego_-Gaslamp AB ESA}

\section{Intervening in Other People's Choices: The Supply and Demand for Decision Rights (C9)}

Presiding: CHLOE TERGIMAN, Pennsylvania State University

CHLOE TERGIMAN, Pennsylvania State University, and ELENA PIKULINA, University of British Columbia-Preferences for Power AYELET GNEEZY, University of California-San Diego, ALEX IMAS, Carnegie Mellon University, and ANIA JAROSZEWICZ, Harvard University-The Impact of Agency on Time and Risk Preferences

AMBUEHL SANDRO, University of Toronto, B. DOUGLAS BERNHEIM, Stanford University, and AXEL OCKENFELS, University of Cologne-Projective Paternalism

JOAO FERREIRA, University of Rennes 1, HANAKI NOBUYUKI, University of Côte d'Azur, and BENOIT TARROUX, University of Rennes 1-On the Roots of the Intrinsic Value of Decision Rights: Evidence from France and Japan

Discussants: JAMES COX, Georgia State University

EMANUEL VESPA, University of California-Santa Barbara

TRISTAN GAGNON-BARTSCH, Harvard University

MARINA AGRANOV, California Institute of Technology

\section{2:30 PM Manchester Grand Hyatt San Diego_-Solana Beach AB HERO/AEA}

Experimental Evidence: From the ACA to New Drugs (I1)

Presiding: DONALD YETT, University of Southern California

KEITH MARZILLI ERICSON, Boston University, TIM LAYTON, Harvard University, ADRIANNA MCINTYRE, Harvard University, and ADAM SACARNY, Columbia University-Nudging Take-up of Subsidized Insurance: Evidence from Massachusetts

ITHAI LURIE, U.S. Treasury Department, JANET MCCUBBIN, U.S. Treasury Department, and JACOB GOLDIN, Stanford University - Health Insurance, Taxes, and Mortality: Evidence from Outreach to the Uninsured 


\section{Saturday $•$ January 4}

AMANDA ELLEN KOWALSKI, University of Michigan-A Model of a Randomized Experiment with an Application to the PROWESS Clinical Trial

Discussants: JOSEPH DOYLE, Massachusetts Institute of Technology

MARK SHEPARD, Harvard University

JONATHAN KOLSTAD, University of California-Berkeley

\section{2:30 PM Marriott Marquis San Diego-Coronado Room IAEE/NABE}

\section{Panel: Taking Stock of the Global Energy Transition (Q4)}

Presiding: MINE YUCEL, Federal Reserve Bank of Dallas

REDA CHERIF, International Monetary Fund-Riding the Energy Transition

FUAD HASANOV, International Monetary Fund and Georgetown University-Riding the Energy Transition

DEBORAH BYERS, Ernst and Young-Driving the New Energy Transition: Balancing Growth and Sustainability in China, India, and Brazil

CHRISTIAN VON HIRSCHHAUSEN, Berlin University of Technology and DIW Berlin-The Low-carbon Energy Transformation in Europe: Status Quo and Perspectives

\section{2:30 PM Manchester Grand Hyatt San Diego—Cortez Hills C IBEFA}

Regulation, Risk, and Lending (G3)

Presiding: MICHAEL KOETTER, Leibniz Institute for Economic Research and Otto-von-Guericke University

LARS NORDEN, Getulio Vargas Foundation, GREGORY F. UDELL, Indiana University, and TENG WANG, Federal Reserve Board-Do Bank Bailouts Affect the Provision of Trade Credit?

TONI AHNERT, Bank of Canada and CEPR, and MAHMOUD ELAMIN, Consultant—Bank Runs, Portfolio Choice, and Liquidity Provision 


\section{Saturday $\cdot$ January 4}

YIJIA (EDDIE) ZHAO, University of Massachusetts, DONGHANG ZHANG, University of South Carolina, and ALLEN BERGER, University of South Carolina-Tests of the New Intermediary Asset Pricing Theory: The Role of Lead Bank Capital in the Liquidity of Syndicated Loans

FREDERICO MOURAD, Central Bank of Brazil, RAFAEL SCHIOZER, Getulio Vargas Foundation, and TONI SANTOS, Central Bank of Brazil—Bank Loan Forbearance: Evidence from a Million Restructured Loans

Discussants: SANTIAGO CARBÓ VALVERDE, CUNEF and Bangor University

FLORIAN HEIDER, European Central Bank

GALINA HALE, Federal Reserve Bank of San Francisco

SASCHA STEFFEN, Frankfurt School of Finance \& Management

\section{2:30 PM Manchester Grand Hyatt San Diego-Harbor C KAEA/AEA}

\section{Artificial Intelligence, Big Data, and Competition with Algorithms (C8)}

Presiding: JAY PIL CHOI, Michigan State University

SUSAN ATHEY, Stanford University, VITOR HADAD, Stanford University, IMANOL IBARRA, Stanford University, and GUIDO IMBENS, Stanford University-Designing Experiments with Contextual Bandits

YEON-KOO CHE, Columbia University, KYUNGMIN KIM, Emory University, and WEIJIE ZHONG, Stanford UniversityRatings-Guided Markets

JOSEPH HARRINGTON, University of Pennsylvania-Competition Law and Pricing Algorithms

ALEXANDRE DE CORNIÈRE, Toulouse School of Economics, and GREG TAYLOR, University of Oxford-Data and Competition

Discussants: SOKBAE LEE, Columbia University

JOSHUA GANS, University of Toronto

ILWOO HWANG, University of Miami

HYOJIN SONG, Microsoft Research 


\section{Saturday $•$ January 4}

\section{2:30 PM Manchester Grand Hyatt San Diego-Harbor E LERA}

\section{Green New Deal: Labor Market Policies for Sustainability and Equity (J0)}

Presiding: SANFORD M. JACOBY, University of California-Los Angeles

CLAIR BROWN, University of California-Berkeley-Sustainable Shared-Prosperity Policy Index: How Nations Create a Sustainable, Prosperous, Equitable Economy

JISUNG PARK, University of California-Los Angeles, and PATRICK BEHRER, Harvard University-Will We Adapt? Temperature, Labor, and Adaptation to Climate Change

CAROL ZABIN, University of California-Berkeley_Legislatively Mandated Analysis on How to Support Workers and Improve Job Quality and Job Access - Including Workers and Good Jobs in Climate Policy - Lessons from California

BASAV SEN, Institute for Policy Studies-Just and Equitable Transition to a Clean Energy Future: Transformative Potential Exists, but So Do Challenges

Discussants: MICAH MITROSKY, IBEW 569

JOSHUA GRAFF ZIVIN, University of California-San Diego

\section{2:30 PM Manchester Grand Hyatt San Diego-Harbor F LERA}

Labor Force, Productivity, and Mobility (J2)

Presiding: ABIGAIL WOZNIAK, Federal Reserve Bank of Minneapolis

DIDEM TUZEMEN, Federal Reserve Bank of Kansas CityDisappearing Routine Jobs and Declining Prime-Age Labor Force Participation

HYE JIN RHO, Massachusetts Institute of Technology, and ANDREW WEAVER, University of Illinois-Urbana-ChampaignHow Skill Demands Affect Time-To-Hire: Evidence from Applicant Tracking Data

SHULAMIT KAHN, Boston University, ALICIA MODESTINO, Northeastern University, and YESEUL HYUN, Boston UniversityThe Structural Decline in Job Turnover since 2000: Disequilibrium or New Normal? 


\section{Saturday $•$ January 4}

Discussants: DALE BELMAN, Michigan State University

EVAN STARR, University of Maryland

MICHAEL CARR, University of Massachusetts-Boston

\section{2:30 PM Manchester Grand Hyatt San Diego-Balboa C MEEA}

\section{Environmental Issues in MENA (Q5)}

Presiding: MAHDI MAJBOURI, Babson College

GHASSAN DIBEH, Lebanese American University, ALI FAKIH, Lebanese American University, WALID MARROUCH, Lebanese American University, and GHIDA MATAR, Lebanese American University-Who Cares about Environmental Quality? Evidence amongst Youth in the MENA

MINE CINAR, Loyola University Chicago, NATHALIE HILMI, Scientific Center of Monaco, STACY NEIER BERAN, Loyola University Chicago, ALAIN SAFAA, Skill Partners, and DENIS ALLEMAND, Scientific Center of Monaco-How Do Different Disciplines Perceive the Environment? Survey Results from the Mediterranean and MENA

MOHAMMAD AHMADIZADEH, University of Illinois-UrbanaChampaign, and AMIRHOSSEIN AMINI BEHBAHANI, Howard University—Dust Storms, Migration and Housing Markets

MD TANVIR PAVEL, Florida International University-Natural Hazards and Internal Migration: The Role of Transient Versus Permanent Shocks

\section{2:30 PM Manchester Grand Hyatt San Diego-Marina}

NAFE

\section{Special Topics in Forensic Economics (K2)}

Presiding: WILLIAM G. BRANDT, Brandt Forensic Economics

WILLIAM H. ROGERS, W H Rogers, LLC-Testing the Boundaries of Synthetic Cohort Techniques on Lifetime Earnings 


\section{Saturday $•$ January 4}

SCOTT DALE GILBERT, Southern Illinois UniversityCarbondale-Economic Damages in Price Fixing Cases: A Difference-in-Difference Estimation Approach

LAWRENCE M. SPIZMAN, State University of New York-Oswego, and JOHN KANE, State University of New York-Oswego-The Impact of Race on a Child's Educational Attainment and Life Time Earnings

Discussants: SCOTT DALE GILBERT, Southern Illinois UniversityCarbondale

CHRISTOPHER YOUNG, Rutgers University

KEVIN E. CAHILL, Boston College

\section{2:30 PM Manchester Grand Hyatt San Diego-Cortez Hill B PSSI}

Financial Institutions, Religiosity, and Rebel Conflict in Islamic and Other States (F5)

Presiding: CARLOS SEIGLIE, Rutgers University-Newark

PAUL COLLIER, University of Oxford, NEIL GREGORY, World Bank, and ALEXANDROS RAGOUSSIS, World BankPioneering Firms in Fragile and Conflict-Affected States: Why and How Development Finance Institutions Should Support Them

ROLAND HODLER, University of St. Gallen, University of Oxford, and CESifo, PAUL RASCHKY, Monash University, and ANTHONY STRITTMATTER, University of St. Gallen-Religiosity and Terrorism: Evidence from Ramadan Fasting

LAURA ARMEY, Naval Postgraduate School, THOMAS KNIESNER, Claremont Graduate University, JOHN LEETH, Bentley University, and RYAN SULLIVAN, Naval Postgraduate School-Combat, Casualties, and Compensation: Evidence from Iraq and Afghanistan

KONSTANTIN SONIN, University of Chicago, JARNICKAE WILSON, University of Chicago, and AUSTIN WRIGHT, University of Chicago-Rebel Capacity and Combat Tactics 


\section{Saturday $•$ January 4}

Discussants: TIRTHATANMOY DAS, Indian Institute of Management Bangalore and IZA

LEILA SALARPOUR GOODARZI, University of Victoria

CURTIS SIMON, Clemson University

JOHN DEVEREUX, City University of New York

\section{2:30 PM Manchester Grand Hyatt San Diego_Ocean Beach SED}

Risk, Pricing, and Economic Dynamics (E2)

Presiding: THOMAS WINBERRY, University of Chicago

THOMAS WINBERRY, University of Chicago, and MIKHAIL GOLOSOV, University of Chicago-The Price of Risk and Investment Dynamics

ROBERT HALL, Stanford University, and SEBASTIAN DI TELLA, Stanford University-Business Cycles Driven by Risk Premiums

DIMITRIS PAPANIKOLAOU, Northwestern University, BRYAN KELLY, Yale University, AMIT SERU, Stanford University, and MATT TADDY, Amazon-Measuring Technological Innovation over the Long Run

ALP SIMSEK, Massachusetts Institute of Technology, and RICARDO CABALLERO, Massachusetts Institute of TechnologyPrudential Monetary Policy

\section{2:30 PM Manchester Grand Hyatt San Diego-Mission Beach B SGE}

\section{Productivity (F0)}

Presiding: LUCY ELDRIDGE, U.S. Bureau of Labor Statistics

JON D. SAMUELS, U.S. Bureau of Economic Analysis, and KOJI NOMURA, Keio University-The Impact of Industry Productivity Level Differences on the United States-Japan Real Exchange Rate T. KIRK WHITE, U.S. Census Bureau-Measuring Cross-Country Differences in Misallocation 


\section{Saturday • January 4}

RYAN A. DECKER, Federal Reserve Board, MEAGAN MCCOLLUM, University of Tulsa, and GREGORY B. UPTON, Louisiana State University-Firm Dynamics and Local Economic Shocks: Evidence from the Shale Oil and Gas Boom

SABRINA WULFF PABILONIA, U.S. Bureau of Labor Statistics, and SUSAN FLECK, U.S. Bureau of Labor Statistics-Knowledge Capital and United States State-Level Differences in Labor Productivity

Discussants: VALERIE CERRA, International Monetary Fund

CIAN RUANE, International Monetary Fund

J. ANTHONY COOKSON, University of Colorado-Boulder

ERIC A. HANUSHEK, Stanford University

\section{2:30 PM Marriott Marquis San Diego-Marina Ballroom D SPM}

The Danger of Collapse of the Rule-Based International Trading System and How to Prevent It (F1)

Presiding: DOMINICK SALVATORE, Fordham University

CHAD P. BOWN, Peterson Institute for International EconomicsWill the Trade War End WTO Dispute Settlement as We Knew It?

BARRY EICHENGREEN, University of California-Berkeley-The Trade War: Missing Macroeconomic Effects

ROBERT KOOPMAN, World Trade Organization-The Value of the Multilateral Trading Systems

JONATHAN OSTRY, International Monetary Fund-Macroeconomic Effects of Tariffs

Discussant: DOMINICK SALVATORE, Fordham University

\section{2:30 PM Manchester Grand Hyatt San Diego-Old Town B SSEM}

Financial Intermediation in Emerging Economies (G2)

Presiding: SERGIO SCHMUKLER, World Bank 


\section{Saturday $\cdot$ January 4}

VIVIANE AZEVEDO, Industrial Internet Consortium, JEANNE LAFORTUNE, Pontifical Catholic University of Chile and Jameel Poverty Action Lab, and JOSÉ A. TESSADA, Pontifical Catholic University of Chile and Jameel Poverty Action Lab-Does Formal Credit Lead to More Financial Inclusion or Distress? Results Using a Strict Scoring Rule Amongst the Poor in Paraguay

PABLO SLUTZKY, University of Maryland, MAURICIO VILLAMIZAR-VILLEGAS, Central Bank of Colombia, and TOMAS WILLIAMS, George Washington University-Drug Money and Bank Lending: The Unintended Consequences of AntiMoney Laundering Policies

PIERRE BACHAS, World Bank, PAUL GERTLER, University of California-Berkeley, SEAN HIGGINS, Northwestern University, and ENRIQUE SEIRA, Technological Autonomous University of Mexico (ITAM) - How Debit Cards Enable the Poor to Save More

SUMIT AGARWAL, National University of Singapore, THOMAS KIGABO, National Bank of Rwanda, CAMELIA MINOIU, Federal Reserve Board, ANDREA PRESBITERO, International Monetary Fund and MoFiR, and ANDRE F. SILVA, Federal Reserve BoardFinancial Access Under the Microscope

Discussants: XAVI GINE, World Bank

JULIO RIUTORT, Adolfo Ibáñez University

JAIME RUIZ-TAGLE, University of Chile

RALPH DE HAAS, European Bank for Reconstruction and Development

\section{2:30 PM Manchester Grand Hyatt San Diego-Gaslamp C TPUG}

\section{Electricity Markets (L9)}

Presiding: MEREDITH FOWLIE, University of California-Berkeley

MEREDITH FOWLIE, University of California-Berkeley, EDWARD RUBIN, University of Oregon, and CATHERINE WRIGHT, University of California-Berkeley-Declining Power Plant Emissions, Co-benefits, and Regulatory Rebound 


\section{Saturday $\cdot$ January 4}

STEPHEN JARVIS, University of California-Berkeley, OLIVIER DESCHENES, University of California-Santa Barbara, and AKSHAYA JHA, Carnegie Mellon University-Machine Learning the Equilibrium Impacts of Nuclear Shutdowns in Germany: Prices, Profits, Pollution, and Politics

MARK JAMISON, University of Florida, THEODORE J. KURY, University of Florida, and MICHELLE A. PHILLIPS, University of Florida-Solar Impacts: Does Distributed Production Affect Consumption Choices?

AKSHAYA JHA, Carnegie Mellon University, and GORDON LESLIE, Monash University-Dynamic Costs and Market Power: The Rooftop Solar Transition in Western Australia

Discussants: AKSHAYA JHA, Carnegie Mellon University

GRANT MCDERMOTT, University of Oregon

GORDON LESLIE, Monash University

THEODORE J. KURY, University of Florida

\section{2:30 PM Manchester Grand Hyatt San Diego_-Old Town A URPE}

Political Economy of Immigration: Potential for Deep Divisions and Inclusive Alliances (J6)

Presiding: ANN DAVIS, Marist College

MIKE DAVIS, University of California-Riverside-No One Is Illegal: Treatment of Migrants at the Southern Border

MANUEL PASTOR, University of Southern CaliforniaOrganizing for Immigrant Integration and Racial Justice: Scaling From Local to State to National

GAURAV KHANNA, University of California-San Diego-What Counts: Skill Level or Country of Origin? The (In) Coherence of U.S. Immigration Policy

GARY DYMSKI, University of Leeds, ANN DAVIS, Marist College, and NICOLE CERPA VIELMA, University of Leeds-Assymetries of Political Power and the Mexican Immigration Crisis 


\section{Saturday $•$ January 4}

\section{2:30 PM Manchester Grand Hyatt San Diego-Coronado E URPE}

Socialism in the Twenty-First Century (P2)

Presiding: ROBIN HAHNEL, American University

ROBIN HAHNEL, American University, and ALLISON KERKHOFF, University of British Columbia-Integrating LongTerm and Short-Term Participatory Planning

MIHNEA TUDOREANU, University of Massachusetts-Amherst, and DAVID KOTZ, University of Massachusetts-Amherst-Stable Job or iPhones? The Dilemma of Innovation in Socialism

DANIEL SAROS, Valparaiso University-Information Technology and the Socialist Mode of Production: A Simulation of the Point Allocation System

PETER DORMAN, Evergreen State College-Social Funds in a Pluralist Socialism

\section{4:40 PM Marriott Marquis San Diego-Marriott Grand Ballroom 7-8-9 \\ AEA}

\section{AEA Awards Ceremony and Presidential Address}

Presiding: JANET YELLEN, Brookings Institution

BEN BERNANKE, Brookings Institution-Twenty-first Century Monetary Policy

\section{4:45 PM Manchester Grand Hyatt San Diego-Harbor D ACES}

\section{ACES Membership Meeting and Presidential Address}

Presiding: SCOTT ROZELLE, Stanford University-Thinking through the Challenges of Middle Income in an Era of Automation, Trade Wars, and Immigration Bans 


\section{Saturday $•$ January 4}

5:00 PM Manchester Grand Hyatt San Diego-Cortez Hill A AFEE

\section{AFEE Presidential Address}

Presiding: DAVID ZALEWSKI, Providence College-Confronting the Trilemma: Culture, Institutions, and Macroeconomic Disequilibria

5:30 PM Manchester Grand Hyatt San Diego-Seaport DE AFA

AFA Business Meeting and Presidential Address

Presiding: DAVID HIRSHLEIFER, University of California-Irvine

6:00 PM Marriott Marquis San Diego-Marriott Grand Ballroom 3 NEA

NEA Presidential Address

Presiding: OMARI SWINTON, Howard University

8:00 PM Marriott Marquis San Diego-San Diego Ballroom A AEA

12th Annual Economics Humor Session in Honor of Caroline Postelle Clotfelter

Presiding: MANDIE WEINANDT, University of South Dakota

Willingness Toupee: DAVID MCEVOY, Applachian State University, ASH MORGAN, Appalachian State University, JOHN C. WHITEHEAD, Appalachian State University

ED VAN WESEP, University of Colorado-Boulder

YORAM BAUMAN, Standupeconomist.com-From Seattle to Salt Lake City 


\section{Sunday $\cdot$ January 5}

\section{8:00 AM Manchester Grand Hyatt San Diego-Harbor D ACES}

Institutional Setting, Government Policy and Firm Performance: A Comparative Perspective (H3)

Presiding: ISTVAN P. SZEKELY, European Commission

JOANNA TYROWICZ, University of Warsaw and IZA, JAKUB MAZUREK, University of Warsaw, and KARSTEN STAEHR, Eestipank and Tallinn University of Technology_Corporate Income Taxation and Firm Efficiency

HONG MA, Tsinghua University, and QING LIU, Renmin University of China-Trade Policy Uncertainty and Innovation: Firm Level Evidence from China's WTO Accession

VELIMIR BOLE, University of Ljubljana, MIHA DOMINKO, University of Ljubljana, MILAN LAKIĆEVIĆ, University of Montenegro-Podgorica, ANA OBLAK, University of Ljubljana, and JANEZ PRAŠNIKAR, University of Ljubljana-Disentangling External Flows (External Shocks) and Policy and Regulation Effects on the Credit Activities of Banks in Three Emerging Countries during the Great Recession

JAN HANOUSEK, CERGE-EI, ANASTASIYA SHAMSHUR, University of East Anglia, JAN SVEJNAR, Columbia University and CERGE-EI, and JIRI TRESL, University of Mannheim and CERGE-EI-Corruption Environment and Investment in Private Firms

Discussants: JOSEF C. BRADA, Arizona State University

POLONA DOMADENIK, University of Ljubljana

JOHN BONIN, Wesleyan University

MICHAEL LANDESMANN, Vienna Institute for International Economic Studies

8:00 Ам Marriott Marquis San Diego-Torrey Pines 3

AEA

Bank Lending and Real Outcomes (G2)

Presiding: DALIDA KADYRZHANOVA, Georgia State University 


\section{Sunday $\cdot$ January 5}

YUNZHI HU, University of North Carolina-Chapel Hill, and FELIPE VARAS, Duke University-A Dynamic Theory of Learning and Relationship Lending

ANNA CORORATON, Southern Methodist University-Banking on the Firm Objective

JULAPA JAGTIANI, Federal Reserve Bank of Philadelphia, and RAMAN QUINN MAINGI, New York University-How Important Are Local Community Banks to Small Business Lending? Evidence from Mergers and Acquisitions

HENG GENG, Victoria University of Wellington, CHENG ZHANG, Victoria University of Wellington, and FRANK ZHOU, University of Pennsylvania-The Economic Consequences of Audit Market Competition: Evidence from Cost of Bank Financing

JULAPA JAGTIANI, Federal Reserve Bank of Philadelphia, JOSEPH HUGHES, Rutgers University, and CHOON-GEOL MOON, Hanyang University-Consumer Lending Efficiency: Traditional Bank Lenders Versus Lending Club

\section{8:00 Aм Marriott Marquis San Diego-Presidio 2 AEA}

\section{Changes in Occupations and Jobs (J2)}

Presiding: PETER MCHENRY, College of William and Mary

SHULAMIT KAHN, Boston University, ALICIA MODESTINO, Northeastern University, and YESEUL HYUN, Boston UniversityOccupational Mobility in a Changing Labor Market: Upward Climbs or Crooked Paths?

MATTHIAS PAREY, University of Surrey-Tasks and Technology: The Labor Market Effects of Innovation

PAUL MOHNEN, University of Michigan-The Impact of the Retirement Slowdown on the United States Youth Labor Market

ELIJAH NEILSON, Clemson University-Unskill Biased Technological Change and Educational Attainment: Evidence from the Fracking Boom

KRISTINE KOUTOUT, Vanderbilt University-Worker Beliefs and the Job Application Decision: A Large-Scale Lab-in-the-Field Experiment 


\section{Sunday $\cdot$ January 5}

CARLOS CARRILLO-TUDELA, University of Essex, FRASER SUMMERFIELD, St. Francis Xavier University, and LUDO VISSCHERS, University of Edinburgh-Workers' Task and Employer Mobility over the Business Cycle

\section{8:00 Ам Marriott Marquis San Diego-Torrey Pines 1}

\section{AEA}

\section{Climate Economics (Q5)}

Presiding: J. SCOTT HOLLADAY, University of Tennessee

CHRISTOPH MAXIMILIAN SCHILLER, University of Toronto, and NORA PANKRATZ, Maastricht University-Climate Change and Adaptation in Global Supply-Chain Networks

BRIGITTE ROTH TRAN, Federal Reserve Board, and DANIEL J. WILSON, Federal Reserve Bank of San Francisco-Local Economic Impact of Natural Disasters

EUGENIE DUGOUA, London School of Economics, and MARION DUMAS, London School of Economics-Supply Chain Networks and Green Innovations: An Empirical Investigation

JAKOB MIETHE, Humboldt University of Berlin and DIW BerlinThe Elusive Banker. Using Hurricanes to Uncover (Non-) Activity in Offshore Financial Centers

SIMON DIETZ, London School of Economics, JAMES RISING, London School of Economics, THOMAS STOERK, European Commission, and GERNOT WAGNER, New York UniversityTipping Points in the Climate System and the Economics of Climate Change

KENNETH CASTELLANOS, Georgia State University, and GARTH HEUTEL, Georgia State University-Unemployment, Labor Mobility, and Climate Policy

\section{8:00 AM Marriott Marquis San Diego-Marriott Grand Ballroom 13 \\ AEA}

Common Ownership (L1)

Presiding: MATTHEW R. BACKUS, Columbia University 


\section{Sunday $\cdot$ January 5}

MICHAEL SINKINSON, Yale University, MATTHEW R. BACKUS, Columbia University, and CHRISTOPHER T. CONLON, New York University_Common Ownership in America: 1980-2017 XAVIER VIVES, IESE Business School, JO SELDESLACHTS, KU Leuven and DIW Berlin, and ALBERT BANAL-ESTANOL, Pompeu Fabra University_Financial Markets, Common Ownership and Product Market Outcomes

FIONA SCOTT MORTON, Yale University, and LYSLE BOLLER, Duke University-Testing the Theory of Common Stock Ownership OZ SHY, Federal Reserve Bank of Atlanta, and RUNE STENBACKA, Hanken School of Economics-Common Ownership, Institutional Investors, and Welfare

JOSEPH J. GERAKOS, Dartmouth College, and JIN XIE, Chinese University of Hong Kong-Institutional Horizontal Shareholdings and Generic Entry in the Pharmaceutical Industry

Discussants: JAN DE LOECKER, KU Leuven

CHRISTOPHER T. CONLON, New York University

LEVON BARSEGHYAN, Cornell University

JOSEPH HARRINGTON, University of Pennsylvania

\section{8:00 Ам Marriott Marquis San Diego-Marriott Grand Ballroom 10 \\ AEA}

Comparing Poverty of Refugees and Their Hosts (D6)

Presiding: PAOLO VERME, World Bank

SAMUEL LEONE, University of California-Berkeley, EDWARD MIGUEL, University of California-Berkeley, SANDRA ROZO, University of Southern California, and EMMA SMITH, Harvard University—The Syrian Refugee Life Study 


\section{Sunday $•$ January 5}

C. AUSTIN DAVIS, American University, AHMED MUSHFIQ MOBARAK, Yale University, and PAULA LÓPEZ-PEÑA, Yale University-Collecting Representative Panel Data in a Refugee Setting - Evidence from Bangladesh

THERESA BELTRAMO, United Nations High Commissioner for Refugees, IBRAHIMA SARR, World Bank, PAOLO VERME, World Bank, and HAI-ANH DENG, World Bank-Is Imputing Poverty Efficient? An Example from Refugee Data in Chad

Discussants: GIACOMO DE GIORGI, University of Geneva

GIOVANNI PERI, University of California-Davis

\section{8:00 AM Marriott Marquis San Diego-Marriott Grand Ballroom 3} AEA

Crime Prevention in the United States and Abroad (K4)

Presiding: JENNIFER DOLEAC, Texas A\&M University

BRITTANY STREET, Texas A\&M University-The Impact of Economic Opportunity on Criminal Behavior: Evidence from the Fracking Boom

SARA HELLER, University of Michigan, MARIANNE BERTRAND, University of Chicago, MONICA BHATT, University of Chicago, CHRISTOPHER BLATTMAN, University of Chicago, and MAX KAPUSTIN, University of Chicago-Predicting and Preventing Gun Violence: An Experimental Evaluation of READI Chicago

LELYS DINARTE, World Bank-Peer Effects on Violence. Experimental Evidence in El Salvador

MARIA MICAELA SVIATSCHI, Princeton University, NIKITA MELNIKOV, Princeton University, and CARLOS SCHMIDTPADILLA, University of California-Berkeley-Gangs, State Capacity, and Development

Discussants: STEVEN RAPHAEL, University of California-Berkeley

EMILY OWENS, University of California-Irvine

JENS LUDWIG, University of Chicago

JOHN DONOHUE, Stanford University 


\section{Sunday $\cdot$ January 5}

\section{8:00 AM Marriott Marquis San Diego-Torrey Pines 2}

AEA

\section{Economic History (N0)}

Presiding: JOHN PARMAN, College of William and Mary

FRANCISCA M. ANTMAN, University of Colorado-Boulder-For Want of a Cup: The Rise of Tea in England and the Impact of Water Quality on Economic Development

MARINA TKALEC, Institute of Economics-Zagreb-Long-Run Persistence of Habsburg Military Colonialism on Institutions in Post-Transition Europe

CHRISTOPHER ANDREW HARTWELL, Bournemouth University-Unstable Tsar, Stable Markets? Political Instability as Financial Information in Tsarist Russia

ROK SPRUK, University of Ljubljana, and ROBBERT MASELAND, University of Groningen-The Benefits of Statehood: An Analysis of the Growth Effects of Joining the United States of America

STEPHAN LUCK, Federal Reserve Bank of New York, MARK CARLSON, Federal Reserve Board, and SERGIO CORREIA, Federal Reserve Board-The Effects of Banking Competition on Growth and Financial Stability: Evidence from the National Banking Era

PRIYA MUKHERJEE, College of William and Mary, and THIEMO R. FETZER, University of Warwick-The Long-Run Effects of Private Rule in the Colonial Era: Evidence from Java

\section{8:00 AM Marriott Marquis San Diego-Malibu}

AEA

\section{Economics of Higher Education (I2)}

Presiding: SCOTT CARRELL, University of California-Davis

ARNAUD MAUREL, Duke University and NBER, ESTEBAN AUCEJO, Arizona State University, PETER ARCIDIACONO, Duke University and NBER, and TYLER RANSOM, University of Oklahoma-College Attrition and the Dynamics of Information Revelation 


\section{Sunday $\cdot$ January 5}

PAUL BARREIRA, Harvard University, MATTHEW BASILICO, Harvard University, and VALENTIN BOLOTNYY, Harvard University_Graduate Student Mental Health: Lessons from American Economics Departments

NICOLAS DE ROUX, University of the Andes, and EVAN RIEHL, Cornell University-Isolating Peer Effects in the Returns to College Selectivity

ANA GAZMURI, Toulouse School of Economics, and ELENA PRAGER, Northwestern University-Peer Learning in College Applications

DEVEN CARLSON, University of Oklahoma, ALEX SCHMIDT, University of Wisconsin-Madison, and BARBARA L. WOLFE, University of Wisconsin-Madison-The Effects of Need-Based Financial Aid on Employment, Earnings, and Receipt of Public Benefits

XIN JIN, University of South Florida, and SUZANA KARIM, University of South Florida-The Returns to Specialization: Evidence from Education-Occupation Match in the United States

\section{8:00 AM Marriott Marquis San Diego—Carlsbad} AEA

\section{Economics of Voting (D7)}

Presiding: ETHAN KAPLAN, University of Maryland

DAVIDE CIPULLO, Uppsala University, and ANDRÉ RESLOW, Uppsala University and Sveriges Riksbank-Biased Forecasts to Affect Voting Decisions? The Brexit Case

KIM LEONIE KELLERMANN, University of Muenster, and SIMON WINTER, University of Muenster-Fear of the Unknown? Anti-Immigrant Voting in the 2017 Parliamentary Elections in France, Germany and the Netherlands

LUIS ROBERTO MARTINEZ, University of Chicago, MARIELLA GONZALES, University of Chicago, and GIANMARCO LEON, University Pompeu Fabra-Monetary Incentives to Vote: Evidence from a Nationwide Policy 


\section{Sunday $\cdot$ January 5}

THOMAS LE BARBANCHON, Bocconi University, and JULIEN SAUVAGNAT, Bocconi University-Voter Bias and Women in Politics

SOMDEEP CHATTERJEE, Indian Institute of ManagementLucknow, and JAI KAMAL, Indian Institute of ManagementLucknow-Voting for the Underdog or Jumping on the Bandwagon? Evidence from India's Exit Poll Ban

\section{8:00 AM Marriott Marquis San Diego-Presidio 1} AEA

\section{Empirical Models of Tacit Collusion (L1)}

Presiding: MATTHEW WEINBERG, Ohio State University

MATTHEW WEINBERG, Ohio State University, NATHAN MILLER, Georgetown University, and MARC REMER, Swarthmore College-A Study of the Market Impact of a Cartel: The Case of Canned Tuna

YING FAN, University of Michigan, and CHRISTOPHER JOHN SULLIVAN, University of Wisconsin-Madison-Measuring Competition with a Flexible Model of Supply

MITSURU IGAMI, Yale University, and TAKUO SAGAYA, Stanford University-Measuring the Incentive to Collude: The Vitamins Cartel, 1990-1999

\section{8:00 AM Marriott Marquis San Diego—San Diego Ballroom A AEA}

\section{Empirical Practice in Economics: Challenges and Opportunities} (C1)

Presiding: GUIDO IMBENS, Stanford University

JANET CURRIE, Princeton University-Polarization in Economics: The Great Methods Divide

DAVID ROMER, University of California-Berkeley-In Praise of

Confidence Intervals 


\section{Sunday $\cdot$ January 5}

RYAN HILL, Massachusetts Institute of Technology, CAROLYN STEIN, Massachusetts Institute of Technology, and HEIDI WILLIAMS, Stanford University-Internalizing Externalities: Designing Effective Data Policies

Discussants: LAWRENCE KATZ, Harvard University

GUIDO IMBENS, Stanford University

BENJAMIN F. JONES, Northwestern University

\section{8:00 AM Marriott Marquis San Diego-Santa Rosa AEA}

\section{Female Leadership in Business and Politics (J1)}

Presiding: OLGA STODDARD, Brigham Young University

LEI GAO, Iowa State University, XIAOHU DENG, University of Tasmania, and JIANLEI HAN, Macquarie University-Are Female Executives Better Innovators?

BENJAMIN POSMANICK, Clemson University-Women in the Boardroom and Their Impact on Corporate Governance and Performance: An Extended Analysis and Replication

THOMAS KRAUSE, Halle Institute for Economic Research (IWH), and NEEL U. SUKHATME, Georgetown University-Does Female Political Leadership Enhance Innovation in United States Cities?

THUSHYANTHAN BASKARAN, University of Siegen, and ZOHAL HESSAMI, University of Konstanz-Does the Entry of a Woman into Political Office Affect Policy Choices?

TOMMASO NANNICINI, Bocconi University, and VINCENZO GALASSO, Bocconi University-Persuasion and Gender: Experimental Evidence from Two Political Campaigns

OLUWASHEYI OLADIPO, State University of New York-College at Old Westbury, KASIA PLATT, State University of New YorkCollege at Old Westbury, and HYOUNG SUK SHIM, City University of New York-College of Staten Island-The Effects of Workplace Flexibility on Managerial Performance of a Female-Owned Firm 


\section{Sunday $\cdot$ January 5}

8:00 АM Marriott Marquis San Diego-Marriott Grand Ballroom 4 AEA

Financial Economics of Gender Throughout the Firm Lifecycle (G3)

Presiding: KATHRYN SHAW, Stanford University

WILL GORNALL, University of British Columbia, and ILYA STREBULAEV, Stanford University-Gender, Race, and Entrepreneurship: A Randomized Field Experiment on Venture Capitalists and Angels

SABRINA T. HOWELL, New York University, and RAMANA NANDA, Harvard Business School-Networking Frictions in Venture Capital, and the Gender Gap in Entrepreneurship

MORTEN BENNEDSEN, INSEAD, ELENA SIMINTZI, University of North Carolina-Chapel Hill, MARGARITA TSOUTSOURA, Cornell University, and DANIEL WOLFENZON, Columbia University-Do Firms Respond to Gender Pay Gap Transparency?

DENIS SOSYURA, Arizona State University, RAN DUCHIN, University of Washington, and MIKE SIMUTIN, University of Toronto-The Origins and Real Effects of the Gender Gap: Evidence from CEOs' Formative Years

Discussants: DAVID MCKENZIE, World Bank

ALICIA ROBB, Next Wave Impact

GEOFFREY TATE, University of Maryland

ALEX HE, University of Maryland

\section{8:00 AM Marriott Marquis San Diego_-Vista}

AEA

Firm Dynamics (E2)

Presiding: JAMES TYBOUT, Pennsylvania State University

MARIA FRANCISCA PEREZ, University of Chile-Estimated Dynamic Industry Equilibrium Model with Firing Costs and Subcontracting 


\section{Sunday $\cdot$ January 5}

MINA KIM, U.S. Bureau of Labor Statistics, JOOYOUN PARK, Kent State University, GEORG SCHAUR, University of Tennessee, and T. CLAY MCMANUS, University of Tennessee-Import Exposure and Skill Content: Plant-Level Evidence from the United States

CHENG CHEN, University of Hong Kong and Clemson University, CHANG SUN, University of Hong Kong, and HONGYONG ZHANG, Research Institute of Economy, Trade and Industry (RIETI) - Learning from Siblings within Multinational Firms

FEDERICO ESPOSITO, Tufts University-Risk Diversification and Input Sourcing

MING XU, Queen's University, MONS CHAN, University of Toronto, and SERGIO SALGADO, University of PennsylvaniaThe Distribution and Evolution of Firm Productivity

ANDREA CIANI, Düsseldorf Institute for Competition Economics, ALEXANDROS RAGOUSSIS, World Bank, and TRANG THU TRAN, World Bank-The "Missing Top" of the Firm-Size Distribution in Developing Countries: What Is the Evidence?

\section{8:00 Ам Marriott Marquis San Diego-Solana} AEA

\section{Firms and Wage-Setting (J3)}

Presiding: SYDNEE CALDWELL, Massachusetts Institute of Technology JONAS HJORT, Columbia University, XUAN LI, Columbia University, and HEATHER SARSONS, University of ChicagoUniform Across-Country Wage-Setting in Multinationals

ANDRES DRENIK, Columbia University, SIMON JAEGER, Massachusetts Institute of Technology, and BENJAMIN SCHOEFER, University of California-Berkeley-Temporary Work Agencies, Outsourcing, and Wage Inequality: Evidence from Administrative Data

ELLORA DERENONCOURT, Princeton University, DAVID WEIL, Brandeis University, and CLEMENS NOELKE, Brandeis University—Do Wage Setting Shocks Propagate through the Labor Market? Evidence from Private and Public Wage Policy Changes in the United States 


\section{Sunday $\cdot$ January 5}

SYDNEE CALDWELL, Massachusetts Institute of Technology, and OREN DANIELI, Harvard University_-Outside Options and Wages

\section{8:00 AM Marriott Marquis San Diego-Mission Hills}

\section{AEA}

\section{Immigration (J6)}

Presiding: KATHERINE ERIKSSON, University of California-Davis

JIANHAO CHEN, University of Illinois-Chicago-A Teacher Likes Having Me in Class: Do Migrant Students Leave Behind?

CHAN YU, University of Texas-Austin-Do Immigrants Equilibrate Labor Market Outcomes from Chinese Import Competition?

ANICA KRAMER, University of Bamberg, RWI, and IZA-Forced Migration and the Educational Attainment of Second and Third Generations

ARNAUD CHEVALIER, Royal Holloway University of London, BENJAMIN ELSNER, University College Dublin, ANDREAS LICHTER, University of Duesseldorf, and NICO PESTEL, Institute of Labor Economics (IZA) - Immigrant Voters, Taxation and the Size of the Welfare State

KATHLEEN KUERSCHNER RAUCK, Otto von Guericke University Magdeburg, and MICHAEL KVASNICKA, Otto von Guericke University Magdeburg-The 2015 European Refugee Crisis and Residential Housing Rents in Germany

IFTEKHAR HASAN, Fordham University, INCHEOL KIM, University of Texas-Rio Grande Valley, and XIAOJING YUAN, University of Massachusetts-Lowell-Unauthorized Immigration Regulation and Labor Productivity: Evidence from EstablishmentLevel Data

8:00 AM Marriott Marquis San Diego-Coronado Room AEA

Improving Economic Price Statistics through the Use of Alternative Data (E3)

Presiding: ERICA GROSHEN, Cornell University 


\section{Sunday $\cdot$ January 5}

BRETT MATSUMOTO, U.S. Bureau of Labor Statistics, JOHN BIELER, U.S. Bureau of Labor Statistics, BRIAN PARKER, U.S. Bureau of Labor Statistics, DANIEL WANG, U.S. Bureau of Labor Statistics, and CALEB CHO, U.S. Bureau of Labor StatisticsUsing Insurance Claims Data in the Medical Price Indexes

JOHN BIELER, U.S. Bureau of Labor Statistics, SARAH NIEDERGALL, U.S. Bureau of Labor Statistics, DAVID POPKO, U.S. Bureau of Labor Statistics, and ILMO SUNG, U.S. Bureau of Labor Statistics-A Nontraditional Data Approach to the CPI Gasoline Index: CPI Crowd-Sourced Motor Fuels Data Analysis Project

JEFFREY HILL, U.S. Bureau of Labor Statistics, BONNIE MURPHY, U.S. Bureau of Labor Statistics, MELANIE SANTIAGO, U.S. Bureau of Labor Statistics, and WILLIAM THOMPSON, U.S. Bureau of Labor Statistics-Implementing an Alternative Data Source to Estimate Producer Price Indexes within Selected Financial Services Industries

SUSAN FLECK, U.S. Bureau of Labor Statistics, and DON FAST, U.S. Bureau of Labor Statistics-Using Administrative Data to Calculate Export Price Indexes

Discussants: LOUISE SHEINER, Brookings Institution

ROBERT FEENSTRA, University of California-Davis EMI NAKAMURA, University of California-Berkeley HAL R. VARIAN, University of California-Berkeley

\section{8:00 AM Marriott Marquis San Diego-Marriott Grand Ballroom 5-6}

AEA

Panel: Japanification, Secular Stagnation, and Fiscal and Monetary Policy Challenges (E0)

Presiding: OLIVIER BLANCHARD, Peterson Institute for International Economics

OLIVIER BLANCHARD, Peterson Institute for International Economics 


\section{Sunday $\cdot$ January 5}

LAWRENCE SUMMERS, Harvard University

JANET YELLEN, Brookings Institution

ADAM POSEN, Peterson Institute for International Economics

\section{8:00 AM Marriott Marquis San Diego-Rancho Santa Fe 2 AEA}

\section{Leader Ladies (J1)}

Presiding: NATALYA VOLCHKOVA, New Economic School

LUCIA DEL CARPIO, INSEAD, and MARIA GUADALUPE, INSEAD-More Women in Tech? Evidence from a Field Experiment Addressing Social Identity

OLGA KUZMINA, New Economic School, and VALENTINA MELENTYEVA, University of Mannheim-Gender Diversity in Corporate Boards: Evidence from a Natural Experiment

MANUEL BAGUES, University of Warwick, and PAMELA CAMPA, Stockholm Institute for Transition Economics-Gender and Government Formation

EVA RANEHILL, University of Gothenburg, and ROBERTO A. WEBER, University of Zurich-Do Gender Preference Gaps Impact Policy Outcomes?

Discussants: KATHERINE COFFMAN, Harvard Business School

EGLE KARMAZIENE, Vrije University Amsterdam

EVA RANEHILL, University of Gothenburg

PAOLA PROFETA, Bocconi University

8:00 AM Marriott Marquis San Diego-Marriott Grand Ballroom 2 AEA

\section{Macroprudential Policies and Monetary Policy (E5)}

Presiding: NELLIE LIANG, Brookings Institution

MARK GERTLER, New York University, NOBUHIRO KIYOTAKI, Princeton University, and ANDREA PRESTIPINO, Federal Reserve Board-Credit Booms, Financial Crises and Macroprudential Policy 


\section{Sunday $\cdot$ January 5}

TOBIAS ADRIAN, International Monetary Fund, FERNANDO DUARTE, Federal Reserve Bank of New York, NELLIE LIANG, Brookings Institution, and PAWEL ZABCYZK, International Monetary Fund-Monetary and Macroprudential Policy with Endogenous Risk

ANIL K. KASHYAP, University of Chicago, and GUIDO LORENZONI, Northwestern University-Borrower and Lender Resilience

Discussants: JULIANE BEGENAU, Stanford University

SYLVAIN LEDUC, Federal Reserve Bank of San Francisco

EMMANUEL FARHI, Harvard University

\section{8:00 AM Marriott Marquis San Diego-Point Loma} AEA

The Economics and Policy of Automatic Stabilizers (E6)

Presiding: JAY SHAMBAUGH, Brookings Institution and George Washington University and HEATHER BOUSHEY, Washington Center for Equitable Growth

DIANE WHITMORE SCHANZENBACH, Northwestern University, and HILARY HOYNES, University of CaliforniaBerkeley-Strengthening SNAP as an Automatic Stabilizer

CLAUDIA SAHM, Federal Reserve Board-Direct Stimulus Payments to Individuals

GABRIEL CHODOROW-REICH, Harvard University, and JOHN COGLIANESE, Federal Reserve Board-Unemployment Insurance and Macroeconomic Stabilization

Discussants: JAY SHAMBAUGH, Brookings Institution and George Washington University

HEATHER BOUSHEY, Washington Center for Equitable Growth NOAH SMITH, Bloomberg 


\section{Sunday $\cdot$ January 5}

\section{8:00 AM Marriott Marquis San Diego-Marriott Grand}

Ballroom 12

AEA

The Economics of Privacy (D8)

Presiding: LEONARDO BURSZTYN, University of Chicago

BENJAMIN GOLUB, Harvard University, ARUN CHANDRASEKHAR, Stanford University, and HE YANG, Harvard University_-Signaling, Shame, and Silence in Social Learning

ZOE CULLEN, Harvard Business School, and RICARDO PEREZTRUGLIA, University of California-Los Angeles-The Salary Taboo: Privacy Norms and the Diffusion of Information

JAMES ANDREONI, University of California-San Diego, and ALISON SANCHEZ, University of California-San Diego-Fooling Myself or Fooling Observers?

ROBERT METCALFE, Boston University, DMITRY TAUBINSKY, University of California-Berkeley, and LUIGI BUTERA, University of Chicago-The Deadweight Loss of Social Recognition

Discussants: MORITZ MEYER-TER-VEHN, University of California-Los Angeles

BOBBY PAKZAD-HURSON, Brown University

NICOLAS BOTTAN, Cornell University

BO COWGILL, Columbia University

\section{8:00 AM Marriott Marquis San Diego-Marriott Grand Ballroom 1} AEA

\section{Using Behavioral Economics to Promote Resource Conservation} (Q4)

Presiding: LORENZ GOETTE, University of Bonn

MARK ANDOR, RWI Essen and Ifo Institute, ANDREAS GERSTER, University of Mannheim, JORG PETERS, RWI-Leibniz Institute for Economic Research and University of Passau, and CHRISTOPH SCHMIDT, RWI-Leibniz Institute for Economic Research and Ruhr-University Bochum-Information Provision and the Potential of Targeting - Evidence from Residential Energy Conservation 


\section{Sunday $\cdot$ January 5}

BRYAN BOLLINGER, Duke University, JESSE BURKHARDT, Colorado State University, and KENNETH GILLINGHAM, Yale University and NBER-Peer Effects in Water Conservation: Evidence from Consumer Migration

SUMIT AGARWAL, National University of Singapore, XIMENG FANG, University of Bonn, LORENZ GOETTE, University of Bonn, SAMUEL SCHOEB, University of Bamberg, and TIEN FOO SING, National University of Singapore-The Role of Goals in Motivating Behavior: Evidence from a Large-Scale Field Experiment

KATRINA JESSOE, University of California-Davis, GABRIEL LADE, Iowa State University, FRANK LOGE, University of California-Davis, and EDWARD SPANG, University of CaliforniaDavis-Experimental Evidence on the Effects of Targeted Behavioral Treatments and Their Persistence

Discussants: RALF MARTIN, Imperial College London

MICHAEL PRICE, University of Alabama and NBER

ANDREAS GERSTER, University of Mannheim

KENNETH GILLINGHAM, Yale University and NBER

\section{8:00 АM Manchester Grand Hyatt San Diego_-Gaslamp D AERE}

\section{Implementing Environmental Policy (Q5)}

Presiding: LALA MA, University of Kentucky

ANA ESPINOLA-ARREDONDO, Washington State University, FELIX MUNOZ-GARCIA, Washington State University, and ELENI STATHOPOULOU, Nottingham Trent UniversityRegulators and Environmental Groups: Better Together than Apart? MEERA MAHADEVAN, University of California-Santa BarbaraThe Price of Power: Costs of Political Corruption in Indian Electricity WESLEY BLUNDELL, California State University-East BayWhen Threats Become Credible: A Natural Experiment of Environmental Enforcement from Florida

GLENN SHERIFF, Arizona State University, and ERIN MANSUR, Dartmouth College_-Do Pollution Markets Harm Low Income and Minority Communities? Ranking Emissions Distributions Generated by California's RECLAIM Program 


\section{Sunday $\cdot$ January 5}

Discussants: LAURA GRANT, Claremont McKenna College

SUBHRENDU K. PATTANAYAK, Duke University

KATHERINE GROOMS, Southwestern University

LALA MA, University of Kentucky

\section{8:00 AM Manchester Grand Hyatt San Diego-Seaport A}

AFA

\section{Asset Prices and the Trading Process (G1)}

Presiding: HAOXIANG ZHU, Massachusetts Institute of Technology

RUI ALBUQUERQUE, Boston College, SHIYUN SONG, University of Warwick, and CHEN YAO, Chinese University of Hong Kong-The Price Effects of Liquidity Shocks: A Study of SEC's Tick-Size Experiment

JONATHAN BROGAARD, University of Utah, HUONG NGUYEN, University of Technology Sydney, TALIS PUTNINS, University of Technology Sydney, and ELIZA WU, University of Sydney-What Moves Stock Prices? The Role of News, Noise, and Information

EDUARDO DAVILA, Yale University, and CECILIA PARLATORE, New York University-Identifying Price Informativeness

Discussants: INGRID WERNER, Ohio State University

JOEL HASBROUCK, New York University

HARRY MAMAYSKY, Columbia University

\section{8:00 АM Manchester Grand Hyatt San Diego-Seaport DE AFA}

\section{Asset Pricing: Cross-section of Returns (G1)}

Presiding: SERHIY KOZAK, University of Maryland

MATTI KELOHARJU, Aalto University, JUHANI LINNAINMAA, University of Southern California, and PETER NYBERG, Aalto University—Long-Term Discount Rates Do not Vary Across Firms

ALEXANDER CHINCO, University of Illinois, ANDREAS NEUHIERL, University of Notre Dame, and MICHAEL WEBER, University of Chicago-Estimating the Anomaly Baserate 


\section{Sunday $\cdot$ January 5}

LEONID KOGAN, Massachusetts Institute of Technology, JUN LI, University of Texas-Dallas, and HAROLD ZHANG, University of Texas-Dallas-A Production-Based Economic Explanation for the Gross Profitability Premium

ANDREI GONCALVES, University of North Carolina-Chapel Hill-The Short Duration Premium

Discussants: SHRIHARI SANTOSH, University of Maryland

FRANCISCO BARILLAS, University of New South Wales

ERIK LOUALICHE, University of Minnesota

MICHAEL WEBER, University of Chicago

\section{8:00 AM Manchester Grand Hyatt San Diego-Seaport C AFA}

\section{Banks and Monetary Policy Transmission (G2)}

Presiding: DAVID THESMAR, Massachusetts Institute of Technology

CARLO ALTAVILLA, European Central Bank, LORENZO BURLON, European Central Bank, MARIASSUNTA GIANNETTI, Stockholm School of Economics, and SARAH HOLTON, European Central Bank-Is There a Zero Lower Bound? The Effects of Negative Policy Rates on Banks and Firms

YIFEI WANG, University of Michigan, TONI WHITED, University of Michigan, YUFENG WU, University of Illinois, and KAIRONG XIAO, Columbia University—Bank Market Power and Monetary Policy Transmission: Evidence from a Structural Estimation

DAVID ELLIOTT, Bank of England, RALF MEISENZAHL, Federal Reserve Board, JOSÉ-LUIS PEYDRÓ, ICREA, Pompeu Fabra University, CREI, and Barcelona GSE, and BRYCE TURNER, Federal Reserve Board-Nonbanks, Banks, and Monetary Policy: United States Loan-Level Evidence Since the 1990s

Discussants: FLORIAN HEIDER, European Central Bank ITAMAR DRECHSLER, University of Pennsylvania GREG BUCHAK, University of Chicago 


\section{Sunday $\cdot$ January 5}

\section{8:00 AM Manchester Grand Hyatt San Diego-Seaport F}

AFA

Finance and Development (G3)

Presiding: EMILY BREZA, Harvard University

JULIA FONSECA, Princeton University-Financial Development, Labor Markets, and Aggregate Productivity: Evidence from Brazil

YINGCONG LAN, Cornerstone Research, XIAOJI LIN, University of Minnesota, NENG WANG, Columbia University, and JINQIANG YANG, Shanghai University of Finance and Economics-Investor Protection, Corporate Investment, and Valuation

SHUO YAN, Southern University of Science \& TechnologyCorporate Political Connections and the Finance-Growth Nexus: Evidence from China

BHAVYA AGGARWAL, Reserve Bank of India, NIRUPAMA KULKARNI, Reserve Bank of India, and SUBATRA RITADHI, Reserve Bank of India-Cash Supply Shock, Formalization and Economic Development - Evidence from India's Demonetization Episode

Discussant: SEAN HIGGINS, University of California-Berkeley

\section{8:00 AM Manchester Grand Hyatt San Diego-Seaport G AFA}

\section{Measuring Bond Liquidity (G1)}

Presiding: PETER FELDHÜTTER, Copenhagen Business School

KURT LEWIS, Federal Reserve Board, and LUBOMIR PETRASEK, Federal Reserve Board-Corporate Bond Illiquidity: Evidence from Government Guarantees

MICHAEL REICHENBACHER, Karlsruhe Institute of Technology, and PHILIPP SCHUSTER, Karlsruhe Institute of TechnologySize-Adapted Bond Liquidity Measures and Their Asset Pricing Implications

JULES VAN BINSBERGEN, University of Pennsylvania, WILLIAM DIAMOND, University of Pennsylvania, and MARCO GROTTERIA, University of Pennsylvania-Risk Free Interest Rates 


\section{Sunday $\cdot$ January 5}

Discussants: JACK BAO, University of Delaware

JAEWON CHOI, University of Illinois

PIETRO VERONESI, University of Chicago

\section{8:00 AM Manchester Grand Hyatt San Diego-Seaport H AFA}

\section{Memory, Perception, and Asset Prices (G1)}

Presiding: CARY FRYDMAN, University of Southern California JESSICA WACHTER, University of Pennsylvania, and MICHAEL KAHANA, University of Pennsylvania-A Retrieved-Context Theory of Financial Decisions

KATRIN GÖDKER, Maastricht University, PEIRAN JIAO, Maastricht University, and PAUL SMEETS, Maastricht UniversityInvestor Memory

BEN MATTHIES, Yale University-Biases in the Perception of Covariance

Discussants: PEDRO BORDALO, University of Oxford

COLIN CAMERER, California Institute of Technology

VALENTIN HADDAD, University of California-Los Angeles

\section{8:00 AM Manchester Grand Hyatt San Diego-Harbor A}

AFA

\section{Mergers and Acquisitions (G3)}

Presiding: ISIL EREL, Ohio State University

TINGTING LIU, Iowa State University, and MICAH OFFICER, Loyola Marymount University-Inside the "Black Box" of Private Merger Negotiations

PAUL BEAUMONT, Paris Dauphine University, CAMILLE HEBERT, Tilburg University and Paris Dauphine University, and VICTOR LYONNET, Ohio State University-Build or Buy? Human Capital and Corporate Diversification

ULRICH HEGE, Toulouse School of Economics, and YIFEI ZHANG, Toulouse School of Economics and Yale UniversityActivism Pressure and the Market for Corporate Assets 


\section{Sunday $•$ January 5}

WILLIAM MANN, University of California-Los Angeles, SYED

WALID REZA, State University of New York-Binghamton, and RONG GUO, State University of New York-Binghamton-Are Acquisitions of Intangibles Less Subject to Agency Problems?

Discussants: DAVID BECHER, Drexel University

PAIGE OUIMET, University of North Carolina-Chapel Hill

ALEX EDMANS, London Business School

KAI LI, University of British Columbia

\section{8:00 AM Manchester Grand Hyatt San Diego-Seaport B AFA}

\section{Shareholder Activism (G3)}

Presiding: NADYA MALENKO, Boston College

MARCO BECHT, Free University of Brussels, JULIAN FRANKS, London Business School, and HANNES WAGNER, Bocconi University-Corporate Governance Through Voice and Exit

DRAGANA CVIJANOVIC, University of Warwick, AMIL DASGUPTA, London School of Economics, and KONSTANTINOS ZACHARIADIS, Queen Mary University of London-The Wall Street Stampede: Exit as Governance with Interacting Blockholders ADRIAN AYCAN CORUM, Cornell University-Activist Settlements

Discussants: MICHELLE LOWRY, Drexel University

DORON LEVIT, University of Pennsylvania JONATHAN COHN, University of Texas-Austin

\section{8:00 AM Manchester Grand Hyatt San Diego-Mission Beach AB AFE}

Finance, Money and Banking in India (G2)

Presiding: OMESH KINI, Georgia State University and Indian School of Business 


\section{Sunday $•$ January 5}

PRACHI MISHRA, Goldman Sachs, N. R. PRABHALA, Johns Hopkins University, and RAGHURAM RAJAN, University of Chicago-The Relationship Dilemma: Organizational Culture and the Adoption of Credit Scoring Technology in Indian Banking VIKAS RAMAN, Lancaster University, MICHEL A. ROBE, University of Illinois-Urbana-Champaign, and PRADEEP K. YADAV, University of Oklahoma-Man Versus Machine: Liquidity Provision and Market Fragility

GABRIEL CHODOROW-REICH, Harvard University, GITA GOPINATH, Harvard University and International Monetary Policy, PRACHI MISHRA, Goldman Sachs, and ABHINAV NARAYANAN, Reserve Bank Of India—Cash and the Economy: Evidence from India's Demonetization

SUMIT AGARWAL, National University of Singapore, SHASHWAT ALOK, Indian School of Business, PULAK GHOSH, Indian Institute of Management-Bangalore, TOMASZ PISKORSKI, Columbia University, and AMIT SERU, Stanford UniversityBanking the Unbanked: What Do 255 Million New Bank Accounts Reveal about Financial Access?

Discussants: JUSTIN MURFIN, Cornell University

KUMAR VENKATARAMAN, Southern Methodist University

ANJAN THAKOR, Washington University-St. Louis

ENRICHETTA RAVINA, Northwestern University

\section{8:00 AM Manchester Grand Hyatt San Diego-Cortez Hill A} AFEE

\section{Perspectives on Emergent Financial Systems (E5)}

Presiding: MATÍAS VERNENGO, Bucknell University

FARUK ÜLGEN, University of Grenoble-Alpes-An Institutionalist Framework for a Consistent Financial Regulation

MARIO SECCARECCIA, University of Ottawa, and ORSOLA COSTANTINI, Institute for New Economic Thinking-Income Distribution, Household Debt and Growth in Modern Financialized Economies 


\section{Sunday $\cdot$ January 5}

EUGENIA CORREA, National Autonomous University of Mexico (UNAM)-Mexico City, and ALICIA GIRON, National Autonomous University of Mexico (UNAM)-Mexico City-The Limits of "Progressive" Institutional Change: Migration and Remittance Experiences

WESLEY MARSHALL, Metropolitan Autonomous University (UAM)-Iztapalapa, and GREGORIO VIDAL, Metropolitan Autonomous University (UAM)-Iztapalapa-Public Knowledge and

Financial Regulation: Two Post-Crisis Periods

Discussants: FELIPE ALMEIDA, Federal University of Paraná

MATÍAS VERNENGO, Bucknell University

\section{8:00 AM Manchester Grand Hyatt San Diego-Regatta B AREUEA}

\section{Commercial Real Estate Prices and Cycles (R3)}

Presiding: ROBERT KURTZMAN, Federal Reserve Board

LIANG PENG, Pennsylvania State University-Quality, Deal Size, and Investment Returns of Commercial Real Estate

TOBIAS MUHLHOFER, University of Miami, and ROBERT CONNOLLY, University of North Carolina-Chapel Hill-Leverage Cycles in a Mature Asset Class: New Evidence from a Natural Laboratory

ANDREA CHEGUT, Massachusetts Institute of Technology, DANIEL FINK, Massachusetts Institute of Technology, CHRISTOPH REINHART, Massachusetts Institute of Technology, and IRMAK TURAN, Massachusetts Institute of Technology-The Value of Daylight in Office Spaces

KEVIN CHIANG, University of Vermont, CROCKER LIU, Cornell University, and ANDREY UKHOV, University of Vermont-The True Value of Green: Separating the Wheat from the Chaff

Discussants: ROBERT KURTZMAN, Federal Reserve Board TIMOTHY RIDDIOUGH, University of Wisconsin-Madison

SPENCER COUTS, University of Southern California

MILENA PETROVA, Syracuse University 


\section{Sunday $\cdot$ January 5}

\section{8:00 AM Manchester Grand Hyatt San Diego-Regatta C AREUEA}

\section{Investors, Purchasers, and House Prices (R3)}

Presiding: XUDONG AN, Federal Reserve Bank of Philadelphia

ROHAN GANDURI, Emory University, SERENA WENJING XIAO, University of Texas-Dallas, and STEVEN CHONG XIAO, University of Texas-Dallas-Tracing the Source of Liquidity for Distressed Housing Markets

ANDRE ANUNDSEN, Oslo Metropolitan University, ERLING ROED LARSEN, Oslo Metropolitan University, and DAG EINAR SOMMERVOLL, Statistics Norway-Getting More by Asking for Less?

LU HAN, University of Toronto, and SEUNG-HYUN HONG, University of Illinois-Financing Risk and Information Bias in Housing Markets

ATHENA TSOUDEROU, IE University, PEDRO GETE, IE University, and CARLOS GARRIGA, Federal Reserve Bank of St. Louis-The Dynamic Effects of Investors in Housing Markets

Discussants: W. BEN MCCARTNEY, Purdue University

MAGGIE HU, Chinese University of Hong Kong JOHN MONDRAGON, Northwestern University

CHRISTOS ANDREAS MAKRIDIS, Massachusetts Institute of Technology

\section{8:00 AM Manchester Grand Hyatt San Diego-Nautical AREUEA}

\section{Machine Learning in Real Estate (C4)}

Presiding: THIES LINDENTHAL, University of Cambridge

YAOPEI WANG, National University of Singapore, and YONG TU, National University of Singapore-Machine Learning and Housing Rent Index Construction: A State-Space Modeling Approach

YILDIRAY YILDIRIM, Baruch College, and ARKA BANDYOPADHYAY, Baruch College-Deep Learning for Risk in Commercial Mortgage 


\section{Sunday $•$ January 5}

BRENT AMBROSE, Pennsylvania State University, YIQIANG HAN, Clemson University, SANKET KORGAONKAR, Pennsylvania State University, and LILY SHEN, Clemson University-Contractual Completeness in the CMBS Market: Insights from Machine Learning

CAROLIN SCHMIDT, Centre for European Economic Research (ZEW), and THIES LINDENTHAL, University of CambridgeThe Odd One Out: Asset Uniqueness and Price Precision

Discussants: ALEXANDER VAN DE MINNE, Massachusetts Institute of Technology

DOMINIK REHSE, Centre for European Economic Research (ZEW)

TUGBA GUNES, University of Cambridge

CHRIS CUNNINGHAM, Federal Reserve Bank of Atlanta

\section{8:00 AM Manchester Grand Hyatt San Diego-Ocean Beach ARIA/AEA}

\section{Topics in Risk and Insurance (D8)}

Presiding: SHARON TENNYSON, Cornell University

A.J. A. BOSTIAN, University of Tampere, and CHRISTOPH HEINZEL, National Institute of Agronomic Research (INRA) Robustness of Inferences in Risk and Time Experiments to Lifecycle Asset Integration

KYEONGHEE KIM, Florida State University, TY LEVERTY, University of Wisconsin-Madison, and JOAN SCHMIT, University of Wisconsin-Madison-Regulatory Capital and Asset Risk Transfer BENJAMIN L. COLLIER, Temple University, TOBIAS HUBER, Ludwig Maximilian University of Munich, JOHANNES G. JASPERSEN, Ludwig Maximilian University of Munich, and ANDREAS RICHTER, Ludwig Maximilian University of Munich-Analyzing Severe Repetitive Loss Properties in the United States National Flood Insurance Program: Mitigation Efforts and Insurance Choices

MOSHE A. MILEVSKY, York University-Calibrating Gompertz in Reverse: Mortality-adjusted Biological Ages around the World 


\section{Sunday $\cdot$ January 5}

Discussants: LISA L. POSEY, Pennsylvania State University

MARTIN F. GRACE, Temple University

DAVID ECKLES, University of Georgia

DANIEL BAUER, University of Wisconsin-Madison

\section{8:00 AM Manchester Grand Hyatt San Diego-Cove}

ASE

\section{Seeing Red: Households Awash in Debt (B5)}

Presiding: STEVEN M. FAZZARI, Washington University-St. Louis

MARK SETTERFIELD, New School for Social Research, and YUN KIM, University of Massachusetts-Boston-How Financially Fragile Can Households Become?

MELANIE LONG, College of Wooster-Investing in the Future?

College Enrollment, Student Debt, and Household Financial Fragility after the Great Recession

STEVEN M. FAZZARI, Washington University-St. LouisHousehold Demand, Household Finances, and Secular Stagnation ORSOLA COSTANTINI, Institute for New Economic ThinkingThe American Dual Debt Economy

ROBERT SCOTT, Monmouth University, and STEVEN PRESSMAN, Colorado State University-Debt and the Well-Being of United States Households

\section{8:00 AM Manchester Grand Hyatt San Diego-Cortez Hill B ES}

\section{Exchange Rate Puzzles (G1)}

Presiding: NIKOLAI ROUSSANOV, University of Pennsylvania

PHILIPPE BACCHETTA, University of Lausanne, and ERIC VAN WINCOOP, University of Virginia-Puzzling Exchange Rate Dynamics and Delayed Portfolio Adjustment

HUSNU DALGIC, University of Mannheim-Financial Dollarization in Emerging Markets: An Insurance Arrangement 


\section{Sunday $\cdot$ January 5}

ZHENZHEN FAN, Nankai University, JUAN M. LONDONO, Federal Reserve Board, and XIAO XIAO, Erasmus University Rotterdam-What Can U.S. Equity Tail Risk Tell US about Exchange Rate Puzzles?

XIANG FANG, University of Pennsylvania, and YANG LIU, University of Hong Kong-Volatility, Intermediaries, and Exchange Rates

Discussants: ADRIEN VERDELHAN, Massachusetts Institute of Technology

LORENA KELLER, University of Pennsylvania

LUIGI BOCOLA, Stanford University

WENXIN DU, University of Chicago

\section{8:00 Ам Marriott Marquis San Diego-Del Mar ES}

\section{Industrial Organization and Financial Markets (L2)}

Presiding: VIVEK BHATTACHARYA, Northwestern University

GREG BUCHAK, University of Chicago, GREGOR MATVOS, University of Texas-Austin, TOMASZ PISKORSKI, Columbia University, and AMIT SERU, Stanford University-The Limits of Shadow Banks

RALPH KOIJEN, University of Chicago, and MOTOHIRO YOGO, Princeton University-The Fragility of Market Risk Insurance

DEANCORBAE, University of Wisconsin-Madison, and MICHAEL GOFMAN, University of Rochester-Interbank Trading, Collusion, and Financial Regulation

GAURAB ARYAL, University of Virginia, EDUARDO FAJNZYLBER, Adolfo Ibáñez University, MARIA FLORENCIA GABRIELLI, CONICET-UNCuyo, and MANUEL WILLINGTON, Adolfo Ibáñez University-Auctioning Annuities

VIVEK BHATTACHARYA, Northwestern University, and GASTON ILLANES, Northwestern University-Bargaining and the Design of Defined Contribution Plans

Discussant: GASTON ILLANES, Northwestern University 


\section{Sunday $\cdot$ January 5}

\section{8:00 AM Marriott Marquis San Diego-Balboa \\ ES}

\section{Information Effects and Decision under Uncertainty (D1)}

Presiding: AMIT GANDHI, University of Pennsylvania

LUCIANO POMATTO, California Institute of Technology, PHILIPP STRACK, University of California-Berkeley, and OMER TAMUZ, California Institute of Technology-Stochastic Dominance under Independent Noise

AMIT GANDHI, University of Pennsylvania, ANYA SAMEK, University of Southern California, and RICARDO SERRANOPADIAL, Drexel University-Information and Risk Preferences: The Case of Insurance Choice

JOSHUA SCHWARTZSTEIN, Harvard Business School—Relative Thinking and Risk Attitudes

LEVON BARSEGHYAN, Cornell University, JOSHUA TEITELBAUM, Georgetown University, and LIN XU, U.S. Joint Committee on Taxation-Different Contexts, Different Risk Preferences?

Discussants: CHARLES SPRENGER, University of California-San Diego

BENJAMIN HANDEL, University of California-Berkeley

MARK DEAN, Columbia University

AMANDA STARC, Northwestern University

\section{8:00 AM Marriott Marquis San Diego-Catalina ES}

\section{Macroeconometrics (C3)}

Presiding: LUTZ KILIAN, Federal Reserve Bank of Dallas

ATSUSHI INOUE, Vanderbilt University, and LUTZ KILIAN, Federal Reserve Bank of Dallas-The Uniform Validity of Impulse Response Inference in Autoregressions

JONAS ARIAS, Federal Reserve Bank of Philadelphia, JUAN RUBIO-RAMIREZ, Emory University, and DANIEL WAGGONER, Federal Reserve Bank of Atlanta-Inference Based on Bayesian Proxy-SVARs 


\section{Sunday $\cdot$ January 5}

ZHONGJUN QU, Boston University, and DENIS TKACHENKO, National University of Singapore-Using Arbitrary Precision Arithmetic to Sharpen Identification Analysis for DSGE Models

MIKKEL PLAGBORG-MOLLER, Princeton University, and CHRISTIAN WOLF, Princeton University-Local Projections and VARs Estimate the Same Impulse Responses

PETER PHILLIPS, Yale University, and ZHENTAO SHI, Chinese University of Hong Kong-Boosting the Hodrick-Prescott Filter

\section{8:00 AM Marriott Marquis San Diego—La Costa ES}

\section{Testing in Incomplete and Complete Models (C1)}

Presiding: HIROAKI KAIDO, Boston University

XU CHENG, University of Pennsylvania, WINSTON DOU, University of Pennsylvania, and ZHIPENG LIAO, University of California-Los Angeles-Conditional Inference for GMM Model Specification Test with Applications to Asset Pricing Models

GREGORY COX, Columbia University, and XIAOXIA SHI, University of Wisconsin-Madison-A Simple Uniformly Valid Test for Inequalities

CHRISTOPH BREUNIG, Humboldt University of Berlin, and XIAOHONG CHEN, Yale University-Adaptive Testing in Instrumental Variable Models

MATTHEW MASTEN, Duke University, and ALEXANDRE POIRIER, Georgetown University-Salvaging Falsified Instrumental Variable Models

BULAT GAFAROV, University of California-Davis-Inference in High-Dimensional Set-Identified Affine Models

HIROAKI KAIDO, Boston University, and YI ZHANG, Jinan University-Robust Likelihood-Ratio Tests for Incomplete Economic Models 


\section{Sunday $\cdot$ January 5}

\section{8:00 AM Manchester Grand Hyatt San Diego-Solana Beach AB HERO}

\section{Innovation in Healthcare Markets (I1)}

Presiding: M. KATE BUNDORF, Stanford University

ARIEL STERN, Harvard University, CRAIG GARTHWAITE, Northwestern University, and REBECCA SACHS, Harvard University-ACA-Era Medicaid Expansions and Pharmaceutical Innovation

LUCA MAINI, University of North Carolina-Chapel Hill, and JOSHUA FENG, University of Utah-The ACA Medicaid Rebate Rule Change: Impact on Pricing and Innovation

PIERRE AZOULAY, Massachusetts Institute of Technology, JENNIFER KAO, University of California-Los Angeles, and MISTY HEGGENESS, U.S. Census Bureau-Medical Progress and Health Care Financing: Evidence from Academic Medical Centers JOSHUA KRIEGER, Harvard University, MATTHEW HIGGINS, University of Utah, DANIELLE LI, Massachusetts Institute of Technology, and DIMITRIS PAPANIKOLAOU, Northwestern University-Paving the Way for Cures? Valuing Failures in Drug Development

Discussants: MATTHEW GRENNAN, University of Pennsylvania

WESLEY YIN, University of California-Los Angeles

\section{8:00 AM Marriott Marquis San Diego-Newport Beach HES}

The Cowles Commission at the Frontiers of Theoretical Economics (B2)

Presiding: LARRY SAMUELSON, Yale University

MICHAEL ASSOUS, Lumière University Lyon 2, and VINCENT CARRET, Lumière University Lyon 2-Instability at the Cowles Commission (1939-1948)

OLAV BJERKHOLT, University of Oslo-The Entangled Relations between the Econometric Society and the Cowles Commission in the Early Years and the Role of Ragnar Frisch 


\section{Sunday $\cdot$ January 5}

ROBERT W. DIMAND, Brock University, and SYLVIE RIVOT, University of Strasbourg-The Cowles Commission and the Emerging Chicago School

CATHERINE HERFELD, Ludwig Maximilian University of Munich, and MALTE DOEHNE, Ludwig Maximilian University of Munich-Let's Formalize Behavior! - Jakob Marschak and the Early Adoption of Game Theory at the Cowles Commission, 1944-1965

Discussant: LARRY SAMUELSON, Yale University

\section{8:00 AM Manchester Grand Hyatt San Diego-Harbor E LERA}

\section{Labor Market Power (J4)}

Presiding: ARINDRAJIT DUBE, University of Massachusetts-Amherst

DAVID BERGER, Northwestern University, KYLE HERKENHOFF, University of Minnesota, and SIMON MONGEY, University of Chicago_Labor Market Power

BRAD HERSHBEIN, W.E. Upjohn Institute for Employment Research, CLAUDIA MACALUSO, Federal Reserve Bank of Richmond, and CHEN YEH, University of Illinois-UrbanaChampaign-Concentration in United States Local Labor Markets: Evidence from Vacancy and Employment Data

AARON SOJOURNER, University of Minnesota, and YUE QIU, Temple University-Labor-Market Concentration and Labor Compensation

MATTHEW DEY, U.S. Bureau of Labor Statistics, and ELIZABETH WEBER HANDWERKER, U.S. Bureau of Labor Statistics-Which Occupations Are Most Affected by Labor Market Power Discussants: MARSHALL STEINBAUM, University of Chicago IOANA ELENA MARINESCU, University of Pennsylvania

8:00 AM Manchester Grand Hyatt San Diego-Harbor F LERA

Teacher Labor Markets and Student Achievement (J4)

Presiding: SETH GERSHENSON, American University 


\section{Sunday $\cdot$ January 5}

QUENTIN BRUMMET, NORC at the University of Chicago, EMILY K. PENNER, University of California-Irvine-After School: An Examination of the Career Paths and Earnings of Former Teachers

CARYCRUZ BUENO, Brown University, and TIM R. SASS, Georgia State University-The Effects of Differential Pay on Teacher Recruitment and Retention

DANIA V. FRANCIS, University of Massachusetts-Amherst, ELIZABETH O. ANANAT, Duke University and Barnard College, ANNA GASSMAN-PINES, Duke University, and CHRISTINA M. GIBSON-DAVIS, Duke University—The Effects of Localized Mass Layoffs on Academic Achievement Gaps

JING LIU, Brown University, MONICA LEE, Stanford University, and SETH GERSHENSON, American University-The Short- and Long-Run Impacts of Secondary School Absences

Discussants: CHRISTINA STACY, Urban Institute

BRIAN STACY, World Bank

\section{8:00 AM Marriott Marquis San Diego-Cardiff NEA}

\section{Crime, Financial Shock, Employee Ownership (K1)}

Presiding: OLUGBENGA AJILORE, Center for American Progress

SALVADOR CONTRERAS, University of Texas-Rio Grande Valley, and AMIT GHOSH, Illinois Wesleyan University-Local Financial Shocks and Its Effect on Crime

ROBYNN COX, University of Southern California-Crime, Employment, and Broad Based Employee Ownership Opportunities DAVID T. ROBINSON, Duke University, and ANGELINO C. G. VICEISZA, Spelman College-Media Influences on Entrepreneurship and Innovation

JEFFREY BURNETTE, Rochester Institute of Technology, and JAVIER ESPINOSA, Rochester Institute of Technology—Disparities in Homeownership and Mortgage Lending: Understanding the American Indian Experience from 2005-2017. 


\section{Sunday $\cdot$ January 5}

HANADI ALABAAD, Howard University, and ZHUN XU, Howard University-Trends in Global Female Labor Participation: 1990-2017

LISA COOK, Michigan State University, MAGGIE E. C. JONES, Michigan State University, TREVON LOGAN, Michigan State University, and DAVID ROSÉ, Michigan State UniversityThe Green Books and the Geography of Segregation in Public Accommodations

Discussants: ROBYNN COX, University of Southern California

SALVADOR CONTRERAS, University of Texas-Rio Grande Valley SAMUEL L. MYERS, University of Minnesota

\section{8:00 AM Marriott Marquis San Diego-Marriott Grand Ballroom 11 \\ NEA}

\section{Relationships among Health, Education and Inequality (I1)}

Presiding: ANDRIA SMYTHE, Howard University

KEISHA SOLOMON, Johns Hopkins University-State Mental Health Insurance Parity Laws and College Educational Outcomes

GERALD ERIC DANIELS, Howard University, and VENOO KAKAR, San Francisco State University-The Relationship between Student Debt and Health

REBECCA HSU, Howard University-Do Ethnic Enclaves Protect Foreign-Born Women from Intimate Partner Violence?

KENNETH WHALEY, Clemson University, PATRICK BAYER, Duke University, and PETER BLAIR, Harvard University-The Causes and Consequences of Neighborhood Sorting: Evidence from School Finance Reforms

ANDRIA SMYTHE, Howard University-Higher Education and Racial/Ethnic Differences in Intergenerational Mobility

KARL BOULWARE, Wesleyan University, and KENNETH N. KUTTNER, Williams College-Macroeconomic Aspects of Income Inequality 


\section{Sunday $\cdot$ January 5}

Discussants: JEVAY GROOMS, Howard University

MARCUS CASEY, Brookings Institution

E.J. UME, Miami University

OMARI SWINTON, Howard University

JAMEIN CUNNINGHAM, University of Memphis

\section{8:00 AM Manchester Grand Hyatt San Diego-Old Town B NTA}

Hot-Button Tax Policy Questions: A Session of New Insights and Evidence Organized by the National Tax Association (H2)

Presiding: MATTHEW WEINZIERL, Harvard Business School

STEFANIE STANTCHEVA, Harvard University-Taxation and Innovation in the 20th Century

MICHELLE HANLON, Massachusetts Institute of TechnologyTax Reform Made Me Do It!

DAMON JONES, University of Chicago-The Labor Market Impacts of Universal and Permanent Cash Transfers: Evidence from the Alaska Permanent Fund

BENJAMIN LOCKWOOD, University of Pennsylvania-What Is the Optimal Lottery Tax?

Discussants: OWEN ZIDAR, Princeton University

JOSHUA RAUH, Stanford University

ALEXANDER GELBER, University of California-San Diego

JACOB GOLDIN, Stanford University

\section{8:00 AM Manchester Grand Hyatt San Diego-Gaslamp C PSSI/AEA}

Ethnic Polarization, Displaced People, Governance, and War (F5)

Presiding: SOLOMON POLACHEK, State University of New YorkBinghamton

MICHAEL HUTCHINS, Freddie Mac-Political Ideologies \& Governmental Structure 


\section{Sunday $\cdot$ January 5}

JON ECHEVARRIA, University of the Basque Country, and JAVIER GARDEAZABAL, University of the Basque Country-A Spatial Model of Internal Displacement and Forced Migration

MICHELLE GARFINKEL, University of California-Irvine, and CONSTANTINOS SYROPOULOS, Drexel University-Choosing between War and Peace with and without Transfers

NICHOLAS SAMBANIS, University of Pennsylvania, STERGIOS SKAPERDAS, University of California-Irvine, and WILLIAM WOHLFORTH, Dartmouth College-External Intervention, Identity, and Civil War

Discussants: RAUL CARUSO, Catholic University of the Sacred Heart

CARLOS SEIGLIE, Rutgers University-Newark

OZLEM TONGUC, State University of New York-Binghamton

ELI BERMAN, University of California-San Diego

\section{8:00 AM Manchester Grand Hyatt San Diego-Mission Beach C SGE}

\section{Household Balance Sheet (E0)}

Presiding: MARTHA J. BAILEY, University of Michigan

JUSTIN R. FALK, U.S. Congressional Budget Office, and NADIA S. KARAMCHEVA, U.S. Congressional Budget Office-The Effect of the Employer Match and Defaults on Workers' TSP Saving Behavior DANIELLE H. SANDLER, U.S. Census Bureau, and NICHOLE SZEMBROT, U.S. Census Bureau-Maternal Labor Force Dynamics: Participation, Earnings, and Employer Changes

XIAOQING ZHOU, Bank of Canada, and KATYA KARTASHOVA, Bank of Canada-Mortgage Rate Refinancing and Household Balance Sheets: Evidence from Expansionary and Contractionary Monetary Policy Episodes

GRAY KIMBROUGH, American University-Moving Out? The Increasing Prevalence of Living with Parents

Discussants: YICHEN SU, Federal Reserve Bank of Dallas

ELENA PATEL, University of Utah

PHILIP OSTROMOGOLSKY, Federal Deposit Insurance Corporation

META BROWN, Stony Brook University 


\section{Sunday $\cdot$ January 5}

\section{8:00 AM Manchester Grand Hyatt San Diego-Old Town A URPE/IAFFE}

\section{Feminist Perspectives on Institutions, Norms and Agency (Joint with IAFFE) (B5)}

Presiding: SHAIANNE OSTERREICH, Ithaca College

ELLEN MUTARI, Stockton University-Feminist Institutional Economics: A Cross-Fertilization of Congruent Approaches

SARAH SMALL, Colorado State University-Hegemonic Masculinity under Capitalism: Women, Work, and Wellbeing

ANNA ZACHOROWSKA, Jagiellonian University-Exchange, Redistribution and Reciprocity in the Context of Provisioning Care in Contemporary Economies

NICOLE HERPAI, University of Manitoba-Selling Love in a State of Conflict

\section{8:00 AM Manchester Grand Hyatt San Diego—La Jolla B URPE}

Race, Gender, and Economic Security in the 21st Century: Entrepreneurship, Employment, and Retirement (J7)

Presiding: MARTHA JAIMES, New School for Social Research

RACHEL MARIE BROOKS ATKINS, New York UniversityBlack Entrepreneurship and the Business Cycle: Firm Entry During Economic Downturn

OFRONAMA BIU, New School, and DARRICK HAMILTON, Ohio State University-Black Workers and the Rise of Vulnerable Employment in the U.S.

JORDAN AYALA, University of Missouri-Kansas City, and MATTHEW ROBINSON, University of Missouri-Kansas CityEmployment Policy Considering Stratification and Subalternity: An Alternative Framing for Employment Disparities by Race, Gender, and Country of Origin

MARTHA JAIMES, New School for Social Research-Is the Social Security's Actuarial Adjustment Schedule Regressive? The Effect of Differential Mortality Rates 


\section{Sunday $\cdot$ January 5}

Discussants: FADHEL KABOUB, Denison University

OZGUR ORHANGAZI, Kadir Has University-Instanbul

\section{0:15 AM Manchester Grand Hyatt San Diego-Harbor D ACES}

\section{Markets and Health Care Quality in Low and Middle-Income Countries (I1)}

Presiding: HARSHA THIRUMURTHY, University of Pennsylvania

GUADALUPE BEDOYA, World Bank, JISHNU DAS, World Bank, and AMY DOLINGER, World Bank-Randomized Regulation: The Impact of Inspections on Health Markets

MANOJ MOHANAN, Duke University, ZACHARY WAGNER, RAND Corporation, and SOMALEE BANERJEE, NEERMAN Research-Does the Market Reward Quality? Evidence from India SOLÈNE DELECOURT, Stanford University, and ANNE FITZPATRICK, University of Massachusetts-Boston-The Baby Profit Gap: How Childcare Duties Impact Entrepreneurial Performance

SEAN SYLVIA, University of North Carolina-Chapel Hill, HAO XUE, Shaanxi Normal University, HONGMEI YI, Peking University, and GORDON LIU, Peking University-Civil Service and Motivation in Publicly-Provided Health Care: An Audit Study of Physicians in China

Discussants: SEBASTIAN BAUHOFF, Harvard University

JAY BHATTACHARYA, Stanford University

\section{0:15 AM Marriott Marquis San Diego-Marriott Grand} Ballroom 4

AEA

\section{Advanced Country Monetary Policy Spillovers to Emerging} Markets (F2)

Presiding: SEBNEM KALEMLI-OZCAN, University of Maryland

KRISTIN FORBES, Massachusetts Institute of Technology, and FRANK WARNOCK, University of Virginia-Capital Flow Waves-Or Ripples? Extreme Capital Flow Movements In an Era of Easy Monetary Policy 


\section{Sunday $\cdot$ January 5}

DANIEL DIAS, Central Bank of Columbia, and HELENE REY, London Business School-Monetary Policy Transmission and Capital Controls: Micro-Evidence from Colombia

STEFAN AVDJIEV, Bank for International Settlements, and LINDA GOLDBERG, Federal Reserve Bank of New York-Bank Global Liquidity Management and Monetary Policy

SEBNEM KALEMLI-OZCAN, University of Maryland-US Monetary Policy and International Risk Spillovers

Discussants: PIERRE DE LEO, University of Maryland

PIERRE-OLIVIER GOURINCHAS, University of CaliforniaBerkeley

MATTEO MAGGIORI, Harvard University

OZGE AKINCI, Federal Reserve Bank of New York

\section{0:15 AM Marriott Marquis San Diego—Solana} AEA

\section{Air Pollution: Exposure, Health, and the Labor Market (Q5)}

Presiding: PAULINA OLIVA, University of Southern California

MARK BORGSCHULTE, University of Illinois-UrbanaChampaign, DAVID MOLITOR, University of Illinois-UrbanaChampaign, and ERIC ZOU, University of Oregon-Air Pollution and the Labor Market: Evidence from Wildfire Smoke

KAREN CLAY, Carnegie Mellon University, JOSHUA LEWIS, University of Montreal, and EDSON SEVERNINI, Carnegie Mellon University-Air Pollution, Infectious Disease, and Health Care Access: Evidence from Influenza Pandemics in the United States, 1945-1981

OLIVIER DESCHENES, University of California-Santa Barbara, HUIXIA WANG, Hunan University, SI WANG, Hunan University, and PENG ZHANG, Hong Kong Polytechnic University-The Effect of Air Pollution on Body Weight and Obesity: Evidence from China

JANET CURRIE, Princeton University, JOHN VOORHEIS, U.S. Census Bureau, and REED WALKER, University of CaliforniaBerkeley-The Causes and Consequences of Racial Convergence in Pollution Exposure in the United States 


\section{Sunday $\cdot$ January 5}

Discussants: JOSEPH E. ALDY, Harvard University

BRIAN BEACH, Vanderbilt University

SHANJUN LI, Cornell University

RANDALL WALSH, University of Pittsburgh

10:15 AM Marriott Marquis San Diego-Torrey Pines 1

AEA

Banking Under Stress (G2)

Presiding: YULIYA DEMYANYK, University of Illinois-Chicago

NATASHA SARIN, University of Pennsylvania, and EMILY

WILLIAMS, Harvard Business School-Bank Adjustment

JAIRAJ GUPTA, University of Birmingham, and MARIACHIARA BARZOTTO, Newcastle University-Bankruptcy Resolution: Misery or Strategy

DEYAN RADEV, University of Bonn, THORSTEN BECK, City University of London, and ISABEL SCHNABEL, University of Bonn-Can Bank Resolution Regimes Increase Systemic Risk?

GARY RICHARDSON, University of California-Irvine, and BRIAN YANG, San Francisco State University_Origins of Too Big to Fail: Commercial Bank Stock Returns and the Banking Reforms of the 1930s

YUNZHI HU, University of North Carolina-Chapel Hill, and HANZHE ZHANG, Michigan State University-Overcoming Borrowing Stigma: The Design of Lending-of-Last-Resort Policies

DIANE PIERRET, University of Lausanne, and ROBERTO STERI, University of Lausanne-Stressed Banks

\section{0:15 AM Marriott Marquis San Diego-Presidio 2} AEA

Building Organizational Culture for Performance (D2)

Presiding: KATHRYN SHAW, Stanford University 


\section{Sunday $\cdot$ January 5}

NAVA ASHRAF, London School of Economics, ORIANA BANDIERA, London School of Economics, and ALEXIA DELFINO, London School of Economics-Value Dissonance and Firm Performance

ROBERT GIBBONS, Massachusetts Institute of TechnologyVisible Hands: Governance of Value Creation-In Firms and Beyond REBECCA HENDERSON, Harvard University, and GEORGE SERAFEIM, Harvard University-Climate Change and Corporate Purpose

MICHAEL IMPINK, New York University, ANDREA PRAT, Columbia University, and RAFFAELLA SADUN, Harvard University-Measuring Corporate Culture Through Communication Data

\section{0:15 AM Marriott Marquis San Diego—Point Loma} AEA

\section{Consumer Credit and Business Cycles (E2)}

Presiding: LUKASZ DROZD, Federal Reserve Bank of Philadelphia

LUKASZ DROZD, Federal Reserve Bank of Philadelphia, and MICHAL KOWALIK, Federal Reserve Bank of Boston-Credit Cards and the Great Recession: The Collapse of Teasers

MAKOTO NAKAJIMA, Federal Reserve Bank of Philadelphia, and JOSÉ-VÍCTOR RÍOS-RULL, University of PennsylvaniaCredit, Bankruptcy, and Aggregate Fluctuations

J. CARTER BRAXTON, University of Minnesota, KYLE HERKENHOFF, Federal Reserve Bank of New York, and GORDON PHILLIPS, Dartmouth College-Can the Unemployed Borrow? Implications for Public Insurance

CARLOS GARRIGA, Federal Reserve Bank of St. Louis, and AARON HEDLUND, University of Missouri-Mortgage Debt, Consumption, and Illiquid Housing Markets in the Great Recession

Discussants: JAROMIR NOSAL, Boston College

ERIC YOUNG, University of Virginia

LUKASZ DROZD, Federal Reserve Bank of Philadelphia NIKOLAI ROUSSANOV, University of Pennsylvania 


\section{Sunday $\cdot$ January 5}

\section{0:15 AM Marriott Marquis San Diego-Newport Beach}

AEA

Determinants of Academic Achievement (I2)

Presiding: ANDREW HILL, Montana State University

AIDAY SIKHOVA, University of Wisconsin-Madison, SVEN OSKARSSON, Uppsala University, and RAFAEL AHLSKOG, Uppsala University-Better Parents or Richer Parents: Understanding Intergenerational Transmission of Human Capital

MAULIK JAGNANI, Cornell University-Poor Sleep: Sunset Time and Human Capital Production

GARRETT WES AUSTIN, Georgia State University-School Bus Diesel Emissions and Academic Performance: A National Study

HYUNCHEOL BRYANT KIM, Cornell University, and SEONGHOON KIM, Singapore Management University-Teach Me in My Mother Tongue: Experimental Evidence on Mother Tongue Education from Primary Schools in Malawi

LAURENT BOSSAVIE, World Bank, and OHTO KANNINEN, Labour Institute for Economic Research-What Explains the Gender Gap Reversal in Educational Attainment?

\section{0:15 AM Marriott Marquis San Diego—Santa Rosa} AEA

\section{Economic Consequences of Immigration Policy (J6)}

Presiding: ANDREA VELASQUEZ, University of Colorado-Denver

ELIZABETH U. CASCIO, Dartmouth College, and ETHAN G. LEWIS, Dartmouth College-Chain Reaction? The Population Spillovers of Immigrant Legalization

MARCELLA ALSAN, Stanford University, KATHERINE ERIKSSON, University of California-Davis, and GREGORY NIEMESH, Miami University-The Rise and Fall of the KnowNothing Party

BRITTA GLENNON, University of Pennsylvania-How Do Restrictions on High-Skilled Immigration Affect Offshoring? Evidence from the H-1B Program 


\section{Sunday $\cdot$ January 5}

CHLOE N. EAST, University of Colorado-Denver, ANNIE HINES, University of California-Davis, PHILIP LUCK, University of Colorado-Denver, HANI MANSOUR, University of ColoradoDenver, and ANDREA VELASQUEZ, University of ColoradoDenver-The Labor Market Effects of Immigration Enforcement

Discussants: REBECCA LESSEM, Carnegie Mellon University

JOSÉ A. TESSADA, Pontifical Catholic University of Chile and Jameel Poverty Action Lab

GIOVANNI PERI, University of California-Davis

MICHAEL CLEMENS, Center for Global Development

\section{0:15 AM Marriott Marquis San Diego-Marriott Grand Ballroom 3 \\ AEA}

Gender Differences in Career Progression (J7)

Presiding: PAOLA GIULIANO, University of California-Los Angeles

SYDNEE CALDWELL, Massachusetts Institute of TechnologyMonopsony and the Gender Wage Gap: Experimental Evidence from the Gig Economy

RICARDO PEREZ-TRUGLIA, University of California-Los Angeles, and ZOE CULLEN, Harvard University-The Old Boys' Club: Measuring Gender Bias in the Corporate Ladder

BASIT ZAFAR, Arizona State University, and CHER LI, Colorado State University-Ask and You Shall Receive? Gender Differences in Regrading Requests

SIRI ISAKSSON, Harvard University-It Takes Two: Gender Differences in Group Work

Discussants: ROBERT METCALFE, Boston University

JESSICA PAN, National University of Singapore

BO COWGILL, Columbia University

LAURA GEE, Tufts University 


\section{Sunday $\cdot$ January 5}

\section{0:15 AM Marriott Marquis San Diego-Torrey Pines 3}

AEA

\section{Gender Effects (J1)}

Presiding: HEATHER ANTECOL, Claremont McKenna College

CARLOS FERNANDO AVENANCIO-LEON, Massachusetts Institute of Technology and Indiana University, and TAMMY SUNJU LEE, Massachusetts Institute of Technology—Do Financial Conditions Shape Gender Norms?: Gendered Labor Dynamics over the Credit Boom-Bust Cycle

ROBERT FAIRLIE, University of California-Santa Cruz, GLENN MILLHAUSER, University of California-Santa Cruz, DAN OLIVER, Tulane University, and RANDA ROLAND, University of California-Santa Cruz-Gender Bias and Academic Outcomes in STEM: Pairwise Gender Interactions in Gateway Chemistry Labs

KRISHNAPRIYA PARAMESWARAN PERUMBILLISSERY, Duke University, JENNIFER MEYER, Franklin \& Marshall College, SUBHRENDU K. PATTANAYAK, Duke University, and MARC JEULAND, Duke University-Gendered Demand for Modern Cook-Stoves and the Environmental Health Complementarities

ANNA KATHARINA PIKOS, Leibniz University Hannover, and ALEXANDER STRAUB, Leibniz University Hannover-In Youth We Learn; In Age We Understand - Gender-Specific Competitiveness over the Life Cycle

FRANZISKA BRASCHKE, Leibniz University Hannover-That Extra Edge Disadvantages of Potential Mothers in Contract Duration SIYING LIU, IMPAQ International-Workplace Breastfeeding Benefits and the Gender Wage Gap

\section{0:15 AM Marriott Marquis San Diego-Malibu} AEA

\section{Housing Markets (F3)}

Presiding: DON SCHLAGENHAUF, Federal Reserve Bank of St. Louis 


\section{Sunday $\cdot$ January 5}

ZHIMIN LI, Peking University, LESLIE SHENG SHEN, University of California-Berkeley and Federal Reserve Board, and CALVIN ZHANG, Federal Reserve Bank of Philadelphia-Capital Flows, Asset Prices, and the Real Economy: A "China Shock" in the United States Real Estate Market

SHIKONG (SCOTT) LUO, University of Alabama, and JUN MA, Northeastern University-Global Housing Markets and Monetary Policy Spillovers: Evidence from OECD Countries

HAYOUNG KIM, London School of Economics and Political Science-Housing Prices and Consumption: The Role of News Media

DANIEL GARCIA, Federal Reserve Board-Second-Home Buying and the Housing Boom and Bust

JUNHONG CHU, National University of Singapore, YIGE DUAN, University of British Columbia, XIANLING YANG, Lianjia Research Institute, and LI WANG, Lianjia Research Institute-The Last Mile Matters: Impact of Dockless Bike Sharing on Subway Housing Price Premium

DESEN LIN, University of Pennsylvania, and SUSAN M. WACHTER, University of Pennsylvania-Land Use Regulation and Housing Prices

\section{0:15 AM Marriott Marquis San Diego-Rancho Santa Fe 2 AEA}

\section{Job Polarization: Evidence and Possible Causes (J3)}

Presiding: ROBERTO PINHEIRO, Federal Reserve Bank of Cleveland

NICOLAS ROYS, Royal Holloway University of London, and CHRISTOPHER TABER, University of Wisconsin-MadisonSkills Prices, Occupations and Changes in the Wage Structure for Low Skilled Men

FATIH KARAHAN, Federal Reserve Bank of New York, SERDAR OZKAN, University of Toronto, and JAE SONG, Social Security Administration-Sources of Earnings Growth Heterogeneity

JAN EECKHOUT, Pompeu Fabra University, CHRISTOPH HEDTRICH, Pompeu Fabra University, and ROBERTO PINHEIRO, Federal Reserve Bank of Cleveland-Automation, Spatial Sorting, and Job Polarization 


\section{Sunday $\cdot$ January 5}

NIR JAIMOVICH, University of Zurich, ITAY SAPORTAEKSTEN, Tel Aviv University, HENRY SIU, University of British Columbia, and YANIV YEDID-LEVI, IDC Herzliya-A Tale of

Two Workers: The Macroeconomics of Automation

Discussants: FABIAN LANGE, McGill University

NICOLAS PETROSKY-NADEAU, Federal Reserve Bank of San Francisco

ENGHIN ATALAY, University of Wisconsin-Madison

ROBERTO PINHEIRO, Federal Reserve Bank of Cleveland

\section{0:15 AM Marriott Marquis San Diego-Marriott Grand} Ballroom 1

AEA

\section{Labor Unions in the United States (J5)}

Presiding: JOHN AHLQUIST, University of California-San Diego

JOHN AHLQUIST, University of California-San Diego, and MITCH DOWNEY, Stockholm IIES - Import Exposure and Unionization in the United States

JAMES FEIGENBAUM, Boston University, and ALEXANDER HERTEL-FERNANDEZ, Columbia University-The Effects of Union Membership on Political Participation: Evidence from Michigan Teachers Unions after Right to Work

NICOLE FORTIN, University of British Columbia, THOMAS LEMIEUX, University of British Columbia, and NEIL LLOYD, University of British Columbia-Union Spillover Effects and Changes in Wage Inequality

ELISA JÁCOME, Princeton University, ILYANA KUZIEMKO, Princeton University, and SURESH NAIDU, Columbia UniversityUnited States Intergenerational Mobility over the 20th Century: Evidence from Small Data 


\section{Sunday $•$ January 5}

\section{0:15 AM Marriott Marquis San Diego-Presidio 1}

AEA

\section{Long-Term Effects of Educational Interventions in Developing Countries (01)}

Presiding: EDWARD MIGUEL, University of California-Berkeley

KARTHIK MURALIDHARAN, University of California-San Diego-Long-Term Effects of Teacher Performance Pay: Experimental Evidence from India

DAVID EVANS, Center for Global Development, and MŨTHONI NGATIA, World Bank-School Costs, Short-Run Participation, and Long-Run Outcomes: Evidence from Kenya

EDWARD GLAESER, Harvard University, and MING LU, Shanghai Jiao Tong University-Human-Capital Externalities in China

RICHARD AKRESH, University of Illinois-Urbana-Champaign, DANIEL HALIM, World Bank, and MARIEKE KLEEMANS, University of Illinois-Urbana-Champaign-Long-Term and Intergenerational Effects of Education: Evidence from School Construction in Indonesia

Discussants: REBECCA THORNTON, University of Illinois-UrbanaChampaign

LAURA ZIMMERMANN, University of Georgia

GAURAV KHANNA, University of California-San Diego

RICHARD AKRESH, University of Illinois-Urbana-Champaign

\section{0:15 AM Marriott Marquis San Diego-Marina Ballroom D} AEA

\section{Minimum Wages, Taxes and Low Wage Labor Markets (J2)}

Presiding: DAVID CARD, University of California-Berkeley

CHRISTIAN DUSTMANN, University College London, ATTILA LINDNER, University College London, UTA SCHÖNBERG, University College London, MATTHIAS UMKEHRER, Institute for Employment Research-Nuremberg (IAB), and PHILIPP VON BERGE, Institute for Employment Research-Nuremberg (IAB) - Reallocation Effects of the Minimum Wage: Evidence from Germany 


\section{Sunday $\cdot$ January 5}

DARA LEE LUCA, Mathematica Policy Research, and MICHAEL LUCA, Harvard Business School-The Effects of Minimum Wage on Firm Practices and Management

THOMAS BREDA, Paris School of Economics, LUKE HAYWOOD, DIW Berlin, and HAOMIN WANG, University of Konstanz-Labor Market Responses to Payroll Tax Subsidies

SEBASTIAN LINK, Ifo Institute-The Price and Employment Response of Firms to the Introduction of Minimum Wages

Discussants: DAVID CARD, University of California-Berkeley

MICHAEL REICH, University of California-Berkeley

SUPHANIT PIYAPROMDEE, University College London

ATTILA LINDNER, University College London

\section{0:15 AM Marriott Marquis San Diego-Marriott Grand} Ballroom 5-6

AEA

Panel: Monetary Policy Frameworks in a World of Low Interest Rates (E5)

Presiding: AGUSTÍN CARSTENS, Bank for International Settlements

BEN R. BROADBENT, Bank of England

PHILIP R. LANE, Central Bank of Ireland

MASAZUMI WAKATABE, Bank of Japan

CAROLYN A. WILKINS, Bank of Canada

JOHN C. WILLIAMS, Federal Reserve Bank of New York

\section{0:15 AM Marriott Marquis San Diego-Torrey Pines 2} AEA

\section{Non-Price Collusion (L4)}

Presiding: CUICUI CHEN, State University of New York-Albany

CHRISTOPHER JOHN SULLIVAN, University of WisconsinMadison-The Ice Cream Split: Empirically Distinguishing Price and Product Space Collusion 


\section{Sunday $\cdot$ January 5}

JORGE ALE-CHILET, Bar-Ilan University, and JUAN PABLO ATAL, University of Pennsylvania-Trade Associations and Collusion among Many Agents: Evidence from Physicians

CUICUI CHEN, State University of New York-Albany, JORGE ALE-CHILET, Bar-Ilan University, and JING LI, Massachusetts Institute of Technology-Technological Cooperation Versus Technological Collusion: The Case of German Automakers

\section{0:15 AM Marriott Marquis San Diego-San Diego Ballroom A AEA}

\section{Panel: Rising Markups and Monopoly Power (L1)}

Presiding: MICHAEL KADES, Washington Center for Equitable Growth NANCY L. ROSE, Massachusetts Institute of Technology

JOHN MICHAEL VAN REENEN, Massachusetts Institute of Technology

JAN DE LOECKER, KU Leuven

FIONA SCOTT MORTON, Yale University

\section{0:15 Am Marriott Marquis San Diego-Marriott Grand}

Ballroom 2

AEA

\section{Societal Impacts of Policing and Incarceration (K4)}

Presiding: JENNIFER DOLEAC, Texas A\&M University

SIOBHAN O'KEEFE, University of California-Davis-Baby's Gone: The Effect of Increased Sentencing Severity on Fertility and Family Formation

SARAH KROEGER, University of Notre Dame, and GIULIA LA MATTINA, University of South Florida-Housing Security and Domestic Violence: Evidence from Nuisance Ordinances

NAYOUNG RIM, United States Naval Academy, BOCAR BA, Duke University, and ROMAN RIVERA, Columbia University-In-group Bias and the Police: Evidence from Award Nominations

EMILY WEISBURST, University of California-Los Angeles, and FELIPE GONCALVES, University of California-Los Angeles-Do Arrests Deter or Promote Offending? 


\section{Sunday $\cdot$ January 5}

Discussants: ANNE PIEHL, Rutgers University

ERDAL TEKIN, American University

BENJAMIN HANSEN, University of Oregon

JUSTIN MCCRARY, Columbia University

\section{0:15 Am Marriott Marquis San Diego-Marriott Grand Ballroom 13 \\ AEA}

Sources of the Transatlantic Productivity Slowdown (D2)

Presiding: DALE JORGENSON, Harvard University

DANY BAHAR, Brookings Institution, Harvard University, CESifo, and IZA, MARTIN NEIL BAILY, Brookings Institution, and BARRY BOSWORTH, Brookings Institution-The Productivity Slowdown in Germany, Japan, and the United States: Trends and Causes

JOHN FERNALD, INSEAD and Federal Reserve Bank of San Francisco, and ROBERT INKLAAR, University of GroningenDoes Disappointing European Productivity Growth Reflect a Slowing Trend? Weighing the Evidence and Assessing the Future ANTONIN BERGEAUD, Bank of France, GILBERT CETTE, Bank of France and AMSE, and REMY LECAT, Bank of FranceThe Circular Relationship between Productivity Growth and Real Interest Rates

ROBERT GORDON, Northwestern University and NBER, and HASSAN SAYED, Northwestern University-The Industry Anatomy of the Transatlantic Productivity Growth Slowdown

Discussants: DALE JORGENSON, Harvard University

MARSHALL REINSDORF, International Monetary Fund

DAN SICHEL, Wellesley College

BART VAN ARK, Conference Board 


\section{Sunday $•$ January 5}

\section{0:15 AM Marriott Marquis San Diego-Marriott Grand Ballroom 10 \\ AEA}

\section{The Puerto Rican Debt Crisis (H0)}

Presiding: JAY SHAMBAUGH, George Washington University and Brookings Institution

ROBERT CHIRINKO, University of Illinois-Chicago, RYAN CHIU, University of Illinois-Chicago, and SHAINA HENDERSON, University of Illinois-Chicago-What Went Wrong?: The Puerto Rican Debt Crisis, The "Treasury Put" and the Failure of Market Discipline

PABLO A. GLUZMANN, CEDLAS (FCE-UNLP) \& CONICET, MARTIN M. GUZMAN, Columbia University, and JOSEPH E. STIGLITZ, Columbia University-An Analysis of Puerto Rico's Debt Relief Needs to Restore Debt Sustainability

ZADIA M. FELICIANO, City University of New York and NBER, and ANDREW GREEN, City University of New York-United States Multinationals in Puerto Rico and the Repeal of Section 936 Tax Exemption for United States Corporations

ANUSHA CHARI, University of North Carolina-Chapel Hill and NBER, RYAN LEARY, Brattle Group, and TOAN PHAN, Federal Reserve Bank of Richmond-The Transmission of Quasi-Sovereign Default Risk: Evidence from Puerto Rico

Discussants: JAMES POTERBA, Massachusetts Institute of Technology

DANIEL GROS, Center for European Policy Studies (CEPS)

JAMES HINES, University of Michigan

LAURA ALFARO, Harvard Business School

\section{0:15 AM Marriott Marquis San Diego-Marina Ballroom E} AEA

\section{The Recent Consequences of Trade Wars and Trade Threats (F1)}

Presiding: NUNO LIMAO, University of Maryland

MARY AMITI, Federal Reserve Bank of New York, DAVID WEINSTEIN, Columbia University, and STEPHEN J. REDDING, Princeton University-The Impact of the 2018 Trade War on United States Prices and Welfare 


\section{Sunday $\cdot$ January 5}

PABLO FAJGELBAUM, University of California-Los Angeles, PINELOPI GOLDBERG, World Bank Group, PATRICK KENNEDY, University of California-Berkeley, and AMIT K. KHANDELWAL, Columbia University-The Return to Protectionism

OLIVER EXTON, University of Cambridge, MEREDITH CROWLEY, University of Cambridge, and LU HAN, University of Cambridge-Renegotiation of Trade Agreements and Firm Exporting Decisions: Evidence from the Impact of Brexit on UK Exports

ALEJANDRO GRAZIANO, University of Maryland, KYLE HANDLEY, University of Michigan, and NUNO LIMAO, University of Maryland-Brexit Uncertainty and Trade Disintengration

\section{0:15 AM Marriott Marquis San Diego-Marriott Grand Ballroom 11 \\ AEA}

Panel: Using Social Media and Blogging to Engage Economists (A2)

Presiding: DARSHAK PATEL, University of Kentucky

BRANDON SHERIDAN, Elon University-Moderator

JESSICA B. HOEL, Colorado College-Final Exam by Twitter:

Using social media to inspire intrinsic motivation to learn

N. GREGORY MANKIW, Harvard University-Blogging as a Pedagogical Tool

SCOTT CUNNINGHAM, Baylor University_Engaging Economists using Twitter

MARTHA L. OLNEY, University of California-BerkeleyEngaging our Students and Alums via Twitter

CLAUDIA SAHM, Federal Reserve Board-Blogging and Twitter to Promote Diversity and Inclusion

10:15 AM Marriott Marquis San Diego-Balboa AEA

Wage Dynamics and the Efficiency of Job Separations (E2)

Presiding: STEVEN J. DAVIS, University of Chicago 


\section{Sunday $\cdot$ January 5}

EKATERINA JARDIM, Amazon, GARY SOLON, University of Michigan, and JACOB VIGDOR, University of Washington-How Prevalent Is Downward Rigidity in Nominal Wages?

STEVEN J. DAVIS, University of Chicago, and PAWEL KROLIKOWSKI, Federal Reserve Bank of Cleveland-Wage Stickiness, Search Behavior, and Expectations of Laid-Off Workers LEENA RUDANKO, Federal Reserve Bank of Philadelphia—Firm Wages in a Frictional Labor Market

SIMON JAEGER, Massachusetts Institute of Technology, BENJAMIN SCHOEFER, University of California-Berkeley, and JOSEF ZWEIMÜLLER, University of Zurich-Marginal Jobs and Job Surplus: A Test of the Efficiency of Separations

Discussants: MARK SCHWEITZER, Federal Reserve Bank of Cleveland ANDREAS MUELLER, University of Texas-Austin CHRISTOPHER HUCKFELDT, Cornell University THIJS VAN RENS, University of Warwick

\section{0:15 AM Manchester Grand Hyatt San Diego-Gaslamp D AERE}

Natural Resources as Assets (Q3)

Presiding: DAVID KLING, Oregon State University

JESSE D. BACKSTROM, Texas A\&M University-Strategic Reporting and the Effects of Water Use in Hydraulic Fracturing on Local Groundwater Levels in Texas

ARIEL DINAR, University of California-Riverside, JOSE ALBIAC, University of Zaragoza, GILLES ERKENS, Utrecht University, ENCARNA ESTEBAN, University of Zaragoza, and GERARDO HERRERA, Geological Survey of Spain-Land Subsidence - The Forgotten Enigma of Groundwater (Over)Extraction

MARTINO PELLI, University of Sherbrooke, UJJAYANT CHAKRAVORTY, Tufts University, YAZHEN GONG, Renmin University of China, QIAN ZHANG, Chinese Academy of Science, and XIANGZHENG DENG, Chinese Academy of Science-A Tale of Two Roads: Groundwater Depletion in the North China Plains 


\section{Sunday $\cdot$ January 5}

JOSHUA ABBOTT, Arizona State University, ELI P. FENICHEL, Yale University, and SEONGDO YUN, Mississippi State UniversityValuing Multiple Natural Capital Stocks under Correlated Volatility Discussants: CYNTHIA LIN LAWELL, Cornell University

UJJAYANT CHAKRAVORTY, Tufts University

RHIANNON JERCH, Temple University

DAVID KLING, Oregon State University

\section{0:15 AM Manchester Grand Hyatt San Diego-Seaport A AFA}

\section{Analysts, News, and Intermediaries (G1)}

Presiding: ERIC SO, Massachusetts Institute of Technology

ELISABETH KEMPF, University of Chicago, and MARGARITA TSOUTSOURA, Cornell University-Partisan Professionals: Evidence from Credit Rating Analysts

SHIMON KOGAN, Massachusetts Institute of Technology, TOBIAS MOSKOWITZ, Yale University, and MARINA NIESSNER, AQR Capital Management—Fake News: Evidence from Financial Markets DANIEL BRADLEY, University of South Florida, RUSSELL JAME, University of Kentucky, and JARED WILLIAMS, University of South Florida-Non-Deal Roadshows, Informed Trading, and Analyst Bias

Discussants: ALOK KUMAR, University of Miami

ANASTASSIA FEDYK, University of California-Berkeley

JAY RITTER, University of Florida

\section{0:15 AM Manchester Grand Hyatt San Diego-Seaport DE AFA}

Asset Pricing: Frictions and Market Efficiency (G1)

Presiding: JOSEPH ENGELBERG, University of California-San Diego 


\section{Sunday $\cdot$ January 5}

XI DONG, City University of New York-Baruch College, NAMHO KANG, Bentley University, and JOEL PERESS, INSEAD—Fast and Slow Arbitrage: Smart Money, Dumb Money and Mispricing in the Frequency Domain

YUKUN LIU, University of Rochester, and XI WU, New York University-Labor Market Competitor Network and the Transmission of Shocks

WILLIAM GRIESER, Texas Christian University, JUNGHOON LEE, Tulane University, and MORAD ZEKHNINI, Tulane University-Ubiquitous Comovement

Discussants: DONG LOU, London School of Economics

ISAAC HACAMO, Indiana University

CHARLES CLARKE, University of Kentucky

\section{0:15 AM Manchester Grand Hyatt San Diego-Seaport C} AFA

\section{Corporate Culture and Socially Responsible Investing (G3)}

Presiding: CHRISTOPHER PARSONS, University of Washington

GARY GORTON, Yale University, and ALEXANDER ZENTEFIS, Yale University-Social Progress and Corporate Culture

RAJNA GIBSON BRANDON, University of Geneva, PHILIPP KRUEGER, University of Geneva and Swiss Financial Institute, PEDRO MATOS, University of Virginia, and TOM STEFFEN, University of Geneva-Responsible Institutional Investing Around the World

SOHNKE BARTRAM, University of Warwick, KEWEI HOU, Ohio State University, and SEHOON KIM, University of Florida-Real Effects of Climate Policy: Financial Constraints and Spillovers

Discussants: LUIGI ZINGALES, University of Chicago

PAUL SMEETS, Maastricht University

WILLIAM MULLINS, University of California-San Diego 


\section{Sunday $\cdot$ January 5}

10:15 AM Manchester Grand Hyatt San Diego-Seaport F AFA

\section{Entrepreneurial Finance: Risk and Return (G2)}

Presiding: ARTHUR KORTEWEG, University of Southern California

KATJA KISSELEVA, European School of Management and Technology, AKSEL MJØS, Norwegian School of Economics, and DAVID T. ROBINSON, Duke University-The Returns to EarlyStage Investment

OLEG GREDIL, Tulane University, MORTEN SORENSEN, Copenhagen Business School, and WILLIAM WALLER, Tulane University-Evaluating Private Equity Performance Using Stochastic Discount Factors

GUOJUN CHEN, Nanyang Technological University, JIANJUN MIAO, Boston University, and NENG WANG, Columbia University-Entrepreneurial Experimentation and Duration

RAVI JAGANNATHAN, Northwestern University, SHUMIAO OUYANG, Princeton University, and JIAHENG YU, Massachusetts Institute of Technology_Life Cycle Cash Flows of Ventures

Discussants: AYAKO YASUDA, University of California-Davis

ANISHA GHOSH, McGill University

CHRISTIAN OPP, University of Rochester

MORTEN SORENSEN, Copenhagen Business School

\section{0:15 AM Manchester Grand Hyatt San Diego-Seaport G} AFA

\section{Executive Compensation (G3)}

Presiding: EFRAIM BENMELECH, Northwestern University

BENJAMIN BENNETT, Ohio State University, GERALD GARVEY, BlackRock, TODD MILBOURN, Washington University-St. Louis, and ZEXI WANG, Lancaster University-The Role of Stock Price Informativeness in Compensation Complexity

DAEWOUNG CHOI, Louisiana State University-Shreveport, DAVID CICERO, Auburn University, and SHAWN MOBBS, University of Alabama-CEO Marketability, Employment Opportunities, and Compensation: Evidence from Compensation Peer Citations 


\section{Sunday $\cdot$ January 5}

KEE-HONG BAE, York University, SADOK EL GHOUL, University of Alberta, JISOK KANG, John Carroll University, and ALBERT TSANG, York University-Why Are CEOs of Public Firms Paid More Than CEOs of Private Firms? Evidence from the Effect of Board Reforms on CEO Compensation

Discussants: FILIPPO MEZZANOTTI, Northwestern University

KAI LI, University of British Columbia

CAROLA FRYDMAN, Northwestern University

\section{0:15 AM Manchester Grand Hyatt San Diego-Seaport H}

AFA

\section{Household Finance: Regulation and Intermediation (G2)}

Presiding: MOTOHIRO YOGO, Princeton University

WEILING LIU, Harvard Business School, and JESSICA LIU, Harvard University-The Effect of Political Frictions on Long Term Care Insurance

LAUREN COHEN, Harvard Business School, UMIT GURUN, University of Texas-Dallas, and DANIELLE LI, Massachusetts Institute of Technology_-Internal Deadlines, Drug Approvals, and Safety Problems

DENIZ AYDIN, Washington University-St. Louis-Decomposing Present Value Effects on Defaults

CHANGCHENG SONG, Singapore Management UniversityCan Partial Commitment Increase Pension Contribution? A Field Experiment in Sri Lanka

Discussants: CHRISTOPHER TONETTI, Stanford University

SABRINA T. HOWELL, New York University

PASCAL NOEL, University of Chicago

JAMES CHOI, Yale University

10:15 AM Manchester Grand Hyatt San Diego-Harbor A AFA

Intermediation and Asset Prices (G1)

Presiding: KATHY YUAN, London School of Economics 


\section{Sunday $\cdot$ January 5}

MING YANG, Duke University, and YAO ZENG, University of Washington-The Coordination of Intermediation

AYTEK MALKHOZOV, Federal Reserve Board, and GYURI VENTER, Copenhagen Business School-Financially Constrained Strategic Arbitrage

CHRISTIAN KUBITZA, University of Bonn, LORIANA PELIZZON, Goethe University Frankfurt, and MILA GETMANSKY SHERMAN, University of MassachusettsAmherst-Pitfalls of Central Clearing in the Presence of Systematic Risk

Discussants: CHONG HUANG, University of California-Irvine

JUNGSUK HAN, Stockholm School of Economics

JESSIE JIAXU WANG, Arizona State University

\section{0:15 AM Manchester Grand Hyatt San Diego-Seaport B}

AFA

\section{Liquidity Risk (G1)}

Presiding: RUI ALBUQUERQUE, Boston College

YAKOV AMIHUD, New York University, and JOONKI NOH, Case Western Reserve University-The Pricing of the Illiquidity Factor's Conditional Risk with Time-varying Premium

VINCENT BOGOUSSLAVSKY, Boston College, and PIERRE COLLIN-DUFRESNE, Swiss Federal Institute of TechnologyLausanne (EPFL) — Liquidity, Volume, and Volatility

ITAMAR DRECHSLER, University of Pennsylvania, ALAN MOREIRA, University of Rochester, and ALEXI SAVOV, New York University—Liquidity Creation as Volatility Risk

ANGELO RANALDO, University of St. Gallen, and PAOLO SANTUCCI DE MAGISTRIS, Guido Carli University (LUISS) Trading Volume, Illiquidity and Commonalities in FX Markets

Discussants: JEFFREY PONTIFF, Boston College

HAOXIANG ZHU, Massachusetts Institute of Technology

MARK WESTERFIELD, University of Washington

PASQUALE DELLA CORTE, Imperial College London 


\section{Sunday $•$ January 5}

\section{0:15 AM Manchester Grand Hyatt San Diego_Cortez Hill A AFEE/ASE}

Finance and Economic Transition (E0)

Presiding: THOMAS KEMP, University of Wisconsin-Eau Claire

BRIAN CHI-ANG LIN, National Chengchi University—Sustainable Growth: A Circular Economy Perspective

GAËLLE DESPIERRE CORPORON, University of GrenobleFinancing for Development: An Institutional Analysis

RICARDO CHI SEN SIU, University of Macau—Policy Dimensions of Progressive Institutional Change: Lessons from China's Construction of a Socialist Market Economy

HAO CHENG, Nanchang University-Chinese Experience of Advancing Financial Inclusion in Light of Foster's Three Limiting Conditions of Institutional Change

Discussants: THOMAS KEMP, University of Wisconsin-Eau Claire

CHARLES WHALEN, State University of New York-Buffalo

\section{0:15 AM Manchester Grand Hyatt San Diego-Nautical AREUEA}

\section{Institutional Issues in Mortgage Markets (R2)}

Presiding: JIA HE, Nankai University

JUNG-EUN KIM, Federal Reserve Bank of Richmond, and DONG BEOM CHOI, Seoul National University-Securitization and Screening Incentives: Evidence from Mortgage Processing Time YUNQI ZHANG, Nankai University, and YONG KYU GAM, Southwestern University of Finance and Economics—Dismembered Giants: Bank Mergers and Acquisitions, Branch Divestitures, and Housing Markets

LAUREN LAMBIE-HANSON, Federal Reserve Bank of Philadelphia, JULAPA JAGTIANI, Federal Reserve Bank of Philadelphia, and TIM LAMBIE-HANSON, Haverford CollegeFinTech Lending and Mortgage Credit Access 


\section{Sunday $\cdot$ January 5}

SHUANG ZHU, Kansas State University, and ABDULLAH YAVAS, University of Wisconsin-Madison-Misreporting of Second Liens in Residential Mortgages

Discussants: HAOYANG LIU, Federal Reserve Bank of New York

TONG YU, University of Cincinnati

XIANGYU GUO, Fudan University

WEI SHI, Jinan University

\section{0:15 AM Manchester Grand Hyatt San Diego-Regatta C AREUEA}

\section{Pricing (Dis)Amenities (R2)}

Presiding: SIQI ZHENG, Massachusetts Institute of Technology

MAGGIE HU, Chinese University of Hong Kong, SUMIT AGARWAL, National University of Singapore, and ADRIAN LEE, University of Technology Sydney—Street Name Fluency and Housing Prices

RONAN LYONS, Trinity College Dublin, TOM GILLESPIE, National University of Ireland Galway, and STEPHEN HYNES, National University of Ireland Galway-Picture and Playground: Valuing Coastal Amenities

RUCHI SINGH, University of Georgia, and JUAN MUÑOZ, University of Illinois-Urbana-Champaign-Do School Shootings Erode Property Values?

BENNIE WALLER, Longwood University, GEOFFREY TURNBULL, University of Central Florida, and VELMA ZAHIROVICHERBERT, University of Georgia-Self-Help Recovery Housing: The Effects of Sober Living Houses on Neighboring Properties

Discussants: WEN-CHI LIAO, National University of Singapore

DANIEL BROXTERMAN, Florida State University

JEFF ZABEL, Tufts University

SCOTT WENTLAND, U.S. Bureau of Economic Analysis 


\section{Sunday $•$ January 5}

\section{0:15 AM Marriott Marquis San Diego_La Costa \\ ES}

\section{Evolution of Monetary Policymaking (E5)}

Presiding: ULRIKE MALMENDIER, University of California-Berkeley

ADAM SHAPIRO, Federal Reserve Bank of San Francisco, and DANIEL J. WILSON, Federal Reserve Bank of San FranciscoTaking the Fed at Its Word: Direct Estimation of Central Bank Objectives Using Text Analytics

OLIVIER COIBION, University of Texas-Austin, MARC DORDAL i CARRERAS, University of California-Berkeley, YURIY GORODNICHENKO, University of California-Berkeley, and COOPER HOWES, University of Texas-Austin-What Do We Learn from Reading Every FOMC Transcript?

MICHAEL BORDO, Rutgers University, and KLODIANA ISTREFI, Bank of France-Perceived FOMC: The Making of Hawks, Doves and Swingers

ULRIKE MALMENDIER, University of California-Berkeley, STEFAN NAGEL, University of Chicago, and ZHEN YAN, University of Michigan-The Making of Hawks and Doves

\section{0:15 AM Marriott Marquis San Diego—Catalina ES}

\section{Pricing Algorithms, Competition, and Collusion (L1)}

Presiding: ALEXANDER MACKAY, Harvard University

JUSTIN JOHNSON, Cornell University, ANDREW RHODES, Toulouse School of Economics, and MATTHIJS WILDENBEEST, Indiana University_Platform Design when Sellers Use Pricing Algorithms

FRANCESCO DECAROLIS, Bocconi University, MARIS GOLDMANIS, Royal Holloway University of London, and ANTONIO PENTA, Pompeu Fabra University-Bidding through Intermediaries: Estimation of Sponsored Search Auctions

JASON O'CONNOR, University of Pittsburgh, and NATHAN WILSON, Federal Trade Commission-Reduced Demand Uncertainty and the Sustainability of Collusion: How AI Could Affect Competition 


\section{Sunday $\cdot$ January 5}

EMILIO CALVANO, University of Bologna, GIACOMO CALZOLARI, European University Institute, VINCENZO DENICOLO, University of Bologna, and SERGIO PASTORELLO, University of Bologna-Artificial Intelligence, Algorithmic Pricing and Collusion

ZACH BROWN, University of Michigan, and ALEXANDER MACKAY, Harvard University-Competition in Pricing Algorithms

Discussants: SCOTT DUKE KOMINERS, Harvard University

STEVEN TADELIS, University of California-Berkeley

JOSEPH HARRINGTON, University of Pennsylvania

MO XIAO, University of Arizona

MICHAEL SINKINSON, Yale University

\section{0:15 AM Marriott Marquis San Diego-Marina Ballroom F} ES

\section{Regression Discontinuity Designs (C1)}

Presiding: SEBASTIAN CALONICO, University of Miami

YINGYING DONG, University of California-Irvine, and YINGYING LEE, University of California-Irvine-Regression Discontinuity Designs with a Continuous Treatment

MATIAS CATTANEO, Princeton University, MICHAEL JANSSON, University of California-Berkeley, and XINWEI MA, University of California-San Diego-Simple Local Polynomial Density Estimators

HENG CHEN, Bank of Canada, HAROLD CHIANG, Vanderbilt University, and YUYA SASAKI, Vanderbilt University-Quantile Treatment Effects in Regression Kink Designs

YOICHI ARAI, Waseda University, YU-CHIN HSU, Academia Sinica, TORU KITAGAWA, University College London, ISMAEL MOURIFIE, University of Toronto, and YUANYUAN WAN, University of Toronto-Testing Identifying Assumptions in Fuzzy Regression Discontinuity Designs

SEBASTIAN CALONICO, University of Miami, MATIAS CATTANEO, Princeton University, and MAX FARRELL, University of Chicago-Optimal Bandwidth Choice for Robust Bias Corrected Inference in Regression Discontinuity Designs 


\section{Sunday $•$ January 5}

\section{0:15 AM Marriott Marquis San Diego_Carlsbad \\ ES}

\section{Reputation (C7)}

Presiding: HARRY PEI, Northwestern University

HARRY PEI, Northwestern University-Reputation Building with Endogenous Speed of Learning

LAURENT MATHEVET, New York University, DAVID PEARCE, New York University, and ENNIO STACCHETTI, New York University-Reputation and Information Design

BRUNO JULLIEN, Toulouse School of Economics, and IN-UCK PARK, University of Bristol-Communication, Feedback and Repeated Moral Hazard with Short-Lived Buyers

JACK FANNING, Brown University-Mediation in Reputational Bargaining

VOLKER NOCKE, University of California-Los Angeles, and ROLAND STRAUSZ, Humboldt University of Berlin-Collective Reputation

\section{0:15 AM Marriott Marquis San Diego-Del Mar ES}

\section{Stochastic Choice and Experiments on Decision Making (D8)}

Presiding: YORAM HALEVY, University of Toronto

KIRILL POGORELSKIY, University of Warwick, and MATTHEW SHUM, California Institute of Technology-News We Like to Share: How News Sharing on Social Networks Influences Voting Outcomes PATRICK KLINE, University of California-Berkeley, and CHRISTOPHER WALTERS, University of California-BerkeleyAudits as Evidence: Experiments, Ensembles, and Enforcement

FEDERICO ECHENIQUE, California Institute of Technology, TAISUKE IMAI, Ludwig Maximilian University of Munich, and KOTA SAITO, California Institute of Technology-Decision Making under Uncertainty: An Experimental Study in Market Settings

JAY LU, University of California-Los Angeles, and KOTA SAITO, California Institute of Technology_-Repeated Choice: A Theory of Stochastic Intertemporal Preferences 


\section{Sunday $\cdot$ January 5}

SIMONE CERREIA-VIOGLIO, Bocconi University, FABIO ANGELO MACCHERONI, Bocconi University, MASSIMO MARINACCI, Bocconi University, and ALDO RUSTICHINI, University of Minnesota-Law of Demand and Stochastic Choice LARRY EPSTEIN, Boston University, and YORAM HALEVY, University of Toronto-Hard-to-Interpret Signals

\section{0:15 AM Manchester Grand Hyatt San Diego_-Solana Beach AB HERO}

\section{Innovations in Medicare Regulations (I1)}

Presiding: MICHAEL CHERNEW, Harvard University

MARIKA CABRAL, University of Texas-Austin, COLLEEN CAREY, Cornell University, and SARAH MILLER, University of Michigan-The Impact of Insurance Generosity on the Healthcare Utilization of Low Income Medicare Beneficiaries

COLLEEN CAREY, Cornell University, SARAH MILLER, University of Michigan, and ETHAN M.J. LIEBER, University of Notre Dame-Drug Firms' Payments and Physicians' Prescribing Behavior in Medicare Part D

SETH RICHARDS-SHUBIK, Lehigh University, MARTIN GAYNOR, Carnegie Mellon University, and NIRAV MEHTA, University of Western Ontario-Optimal Contracting with Altruistic Agents: A Structural Model of Medicare Reimbursements for Dialysis Drugs

Discussants: MOLLY SCHNELL, Northwestern University

THUY NGUYEN, Indiana University

KATE HO, Princeton University

\section{0:15 AM Marriott Marquis San Diego-Mission Hills IAAE}

Advances in Panel Data Econometrics: Theory and Practice (C1)

Presiding: M. HASHEM PESARAN, University of Southern California 


\section{Sunday $•$ January 5}

VICTOR CHERNOZHUKOV, Massachusetts Institute of Technology, MERT DEMIRER, Massachusetts Institute of Technology, ESTHER DUFLO, Massachusetts Institute of Technology, and IVÁN FERNÁNDEZ-VAL, Boston University-Machine Learning Inference on Heterogeneous Effects in Panel Data

CHENG HSIAO, University of Southern California, ZHENTAO SHI, Chinese University of Hong Kong, and QIANKUN ZHOU, Louisiana State University-Transformed Estimation for Panel Interactive Effects Models

STEPHANE BONHOMME, University of Chicago, and THIBAUT LAMADON, University of Chicago-Variational Random-Effects for Panel Data

JOAKIM WESTERLUND, Lund University, and HANDE KARABIYIK, Vrije University Amsterdam-Forecasting Using Cross-Section Average-Augmented Time Series Regressions

\section{0:15 AM Manchester Grand Hyatt San Diego-Harbor F}

\section{LERA}

\section{The Evolution and Growth of Occupational Regulation and the Work Force (J4)}

Presiding: MORRIS M. KLEINER, University of Minnesota

JASON HICKS, University of Minnesota, ANDREW KARCH, University of Minnesota, and MORRIS M. KLEINER, University of Minnesota-The Origins and Evolution of Occupational Licensing in the United States

DAVUD ROSTAM-AFSCHAR, University of Hohenheim, and KURT SCHMIDHEINY, University of Basel-Occupational Licensing and Job Mobility in Europe

PAOLO BUONANNO, University of Bergamo, and MARIO PAGLIERO, University of Torino-Occupational Licensing, Labor Mobility, and the Unfairness of Entry Standards

ILYA KUKAEV, Saint Francis University, ROBERT J. THORNTON, Lehigh University, EDWARD J. TIMMONS, Saint Francis University, and PAVEL BARYSHNIKOV, Saratov State Law Academy-Occupational Regulation in Russia 


\section{Sunday $\cdot$ January 5}

Discussants: MARIA KOUMENTA, Queen Mary University of London RYAN NUNN, Brookings Institution MAURY GITTLEMAN, U.S. Bureau of Labor Statistics VICTORIA M. UDALOVA, U.S. Census Bureau

\section{0:15 AM Manchester Grand Hyatt San Diego-Harbor E LERA}

Worker Skills, Abilities and Labor Market Returns: Improving Measurement, Identification and Policy Responses (J2)

Presiding: MARCUS DILLENDER, W.E. Upjohn Institute for Employment Research

JOHN ERIC HUMPHRIES, Yale University-College Major Choice: Sorting and Differential Returns to Skills

MATTHEW DEY, U.S. Bureau of Labor Statistics, and MARK LOEWENSTEIN, U.S. Bureau of Labor Statistics-On Job Requirements, Skill, and Wages

ANDREW WEAVER, University of Illinois-Urbana-ChampaignSkills and Hiring Frictions in the IT Industry: Evidence from a National Survey

CAROLYN HEINRICH, Vanderbilt University, and SUSAN HOUSEMAN, W.E. Upjohn Institute for Employment ResearchWorker Hard and Soft Skills and Labor Market Outcomes: A Lens through the Temporary Help Industry over the Business Cycle

Discussant: BRAD HERSHBEIN, W.E. Upjohn Institute for Employment Research

\section{0:15 AM Marriott Marquis San Diego_-Vista} NAEE

Economic Education: Practices and Evidence (A2)

Presiding: PAUL GRIMES, Pittsburg State University

EVGENIYA DUZHAK, Federal Reserve Bank of San Francisco, K. JODY HOFF, Federal Reserve Bank of San Francisco, and JANE S. LOPUS, California State University-East Bay-The Effects of the Chair the Fed Simulation on High School Students' Knowledge and Attitudes 


\section{Sunday $\cdot$ January 5}

KELVIN WONG, Arizona State University—Giving Feedback to Students in a Large Lecture

KAREN GEBHARDT, University of Colorado Boulder-The Impacts of Adaptive Learning Courseware on Student Success

PAUL GRIMES, Pittsburg State University-Revealed Confidence, Self-Efficacy, and Stress in the Introductory Economics Classroom

Discussants: PAUL GRIMES, Pittsburg State University

JANE S. LOPUS, California State University-East Bay

KELVIN WONG, Arizona State University

KAREN GEBHARDT, University of Colorado-Boulder

\section{0:15 AM Marriott Marquis San Diego-Cardiff \\ NEA}

\section{Crime, Race, and Public Policy (K4)}

Presiding: MIESHA WILLIAMS, Morehouse College

ROBYNN COX, University of Southern California, and JAMEIN CUNNINGHAM, University of Memphis-Effect of Proposition 47 on Minority Labor Market Outcomes

BENJAMIN FEIGENBERG, University of Illinois-Chicago, and CONRAD MILLER, University of California-Berkeley-Racial Divisions and Criminal Justice: Evidence from Southern State Courts BOCAR BA, Duke University, JUSTIN HOLZ, University of Chicago, and ROMAN RIVERA, Columbia University-Network Effects in Police Use of Force

ANDREA M. HEADLEY, Ohio State University, and JAMES E. WRIGHT, Florida State University—Racial and Gender Congruence in Police Use of Force Encounters

LUISA BLANCO, Pepperdine University, ROBIN GRIER, Texas Tech University, KEVIN GRIER, Texas Tech University, and DANIEL HICKS, University of Oklahoma-Household Responses to the Escalation of Violent Crime in Mexico

OLUGBENGA AJILORE, Center for American Progress-Campus Carry Laws on Campus Violence 


\section{Sunday $\cdot$ January 5}

Discussants: SCOTT CUNNINGHAM, Baylor University

MARCUS CASEY, University of Illinois-Chicago

DAMON JONES, University of Chicago

JHACOVA WILLIAMS, Clemson University

LUISA BLANCO, Pepperdine University

\section{0:15 AM Manchester Grand Hyatt San Diego_-Old Town A URPE}

\section{Feminist Radical Political Economy: Reproduction and Production (B5)}

Presiding: JENNIFER COHEN, Miami University and University of the Witwatersrand

SIRISHA NAIDU, Wright State University—Climate Change and Feminist Radical Political Economy

PADDY QUICK, St. Francis College-Brooklyn-The Role of Household Production in the Determination and Wages and the Growth of Capitalist Production

JENNIFER COHEN, Miami University and University of the Witwatersrand-Precarity Beyond Paid Employment: Gender, Precariousness, and Life

ENITH FLORES CHAMBA, National University of General Sarmiento (UNGS)-The Work of Women within the Extended Reproduction of Life

\section{1:00 PM Manchester Grand Hyatt San Diego-Harbor D ACES}

\section{What Determines Women's Careers: Norms, Organizational Culture, and Institutions (L2)}

Presiding: GUIDO FRIEBEL, Goethe University Frankfurt

PAULINE GROSJEAN, University of New South Wales, RENEE ADAMS, University of Oxford, and ALI AKYOL, University of Melbourne-Corporate Gender Culture 


\section{Sunday $\cdot$ January 5}

JOHN S. EARLE, George Mason University, J. DAVID BROWN, U.S. Census Bureau, MEE JUNG KIM, George Mason University and U.S. Census Bureau, and KYUNG MIN LEE, George Mason University-The Gender Gap in Entrepreneurship

JESSICA PAN, National University of Singapore, KERWIN CHARLES, University of Chicago, and JONATHAN GURYAN, Northwestern University-The Effects of Sexism on American Women: The Role of Norms Versus Discrimination

GUIDO FRIEBEL, Goethe University Frankfurt, EMMANUELLE AURIOL, Toulouse School of Economics, and SASCHA WILHELM, Goethe University Frankfurt-Women in European Economics

Discussants: MARIASSUNTA GIANNETTI, Stockholm School of Economics ELIZABETH BRAINERD, Brandeis University

DEVESH RUSTAGI, Goethe University Frankfurt GHAZALA AZMAT, Sciences Po

\section{1:00 PM Marriott Marquis San Diego-Torrey Pines 2} AEA

\section{Analyzing Firm Behavior Using United States Tax-Returns Data (H3)}

Presiding: ERIC ZWICK, University of Chicago and NBER

ERIC ZWICK, University of Chicago and NBER, MATTHEW SMITH, U.S. Treasury Department, and OWEN ZIDAR, Princeton University and NBER-Top Wealth in the United States: New Estimates and Implications

BRETT COLLINS, Internal Revenue Service, ANDY GARIN, University of Illinois-Urbana-Champaign and NBER, EMILIE JACKSON, Stanford University, DMITRI K. KOUSTAS, University of Chicago, and MARK PAYNE, Internal Revenue Service-Is Gig Work Replacing Traditional Employment? Evidence from Two Decades of Tax Returns

MAX RISCH, University of Michigan-Sharing the Burden: Responses of Business Owners to Changes in the Top Personal Income Tax Rate 


\section{Sunday $\cdot$ January 5}

BIBEK ADHIKARI, Illinois State University, JAMES ALM, Tulane University, and TIMOTHY HARRIS, Illinois State UniversityTaxpayer Responses to Third-Party Income Reporting: Evidence from Spatial Variation Across the United States

\section{1:00 PM Marriott Marquis San Diego-Point Loma}

AEA

\section{Behavioral Market Design (D9)}

Presiding: SHENGWU LI, Harvard University

BNAYA DREYFUS, Hebrew University of Jerusalem, ORI HEFFETZ, Cornell University and Hebrew University, and MATTHEW RABIN, Harvard University-Expectations-Based Loss Aversion May Help Explain Seemingly Dominated Choices in Strategy-Proof Mechanisms

ALEX REES-JONES, Cornell University, RAN SHORRER, Pennsylvania State University, and CHLOE TERGIMAN, Pennsylvania State University-Correlation Neglect in Student-ToSchool Matching

MODIBO SIDIBE, Duke University, and KEHINDE AJAYI, World Bank-School Choice with Limited Attention

PETER TROYAN, University of Virginia, and THAYER MORRILL, North Carolina State University-Obvious Manipulations

\section{1:00 PM Marriott Marquis San Diego-Marriott Grand}

\section{Ballroom 10}

AEA

\section{Capital Flows, Sovereign Debt, and Risk (F3)}

Presiding: SERGIO SCHMUKLER, World Bank

GONZALO ASIS, University of North Carolina-Chapel Hill, ANUSHA CHARI, University of North Carolina-Chapel Hill and NBER, and ADAM HAAS, University of North Carolina-Chapel Hill-In Search of Distress Risk in Emerging Markets 


\section{Sunday $\cdot$ January 5}

JULIA BEVILAQUA, Federal Reserve Bank of San Francisco, GALINA HALE, Federal Reserve Bank of San Francisco, and ERIC TALLMAN, Federal Reserve Bank of San Francisco-Corporate Bond Spreads, Sovereign Spreads, and Crises

GRACIELA LAURA KAMINSKY, George Washington University and NBER, LEANDRO MEDINA, International Monetary Fund, and SHIYI WANG, George Washington University-Boom-Bust Capital Flow Cycles: Global or Regional?

LORENZO PANDOLFI, University of Naples Federico II and CSEF, and TOMAS WILLIAMS, George Washington UniversityConsequences of Capital Inflows to Sovereign Debt Markets for Firms: Evidence from the Stock Market

\section{1:00 PM Marriott Marquis San Diego-Rancho Santa Fe 2} AEA

\section{Causes of Populism and Its Related Political Preferences (H3)}

Presiding: FRANCESCO PASSARELLI, University of Turin and Bocconi University

FEDERICA LIBERINI, University of Bath, MICHELA REDOANO, University of Warwick, ANTONIO RUSSO, ETH Zurich, ANGEL CUEVAS, University Carlos III of Madrid, and RUBEN CUEVAS, University Carlos III of Madrid-Politics in the Facebook Era: Evidence from the 2016 United States Presidential Elections

ELLIOTT ASH, ETH Zurich, and SERGIO GALLETTA, ETH Zurich-Partisan Media and Fiscal Policy Choices: Evidence from United States Cable News Channels

ARNSTEIN AASSVE, Bocconi University, GIANMARCO DANIELE, Bocconi University, and MARCO LE MOGLIE, Bocconi University-Never Forget the First Time: The Persistent Effects of Corruption and the Rise of Populism in Italy

SHUAI CHEN, LISER-Unemployment, Immigration, and Populism: Evidence from Two Quasi-Natural Experiments in the United States

CARLO ALTOMONTE, Bocconi University, GLORIA GENNARO, Bocconi University, and FRANCESCO PASSARELLI, University of Turin and Bocconi University-Collective Emotions and Protest Vote 


\section{Sunday $\cdot$ January 5}

\section{1:00 PM Marriott Marquis San Diego-Balboa}

\section{AEA}

Changes in Family Structures and Consequences (J1)

Presiding: ALOYSIUS SIOW, University of Toronto

CAROLINA ARTEAGA, University of California-Los AngelesThe Cost of Bad Parents: Evidence from the Effects of Parental Incarceration on Children's Education

JUNJIAN YI, National University of Singapore, V. BHASKAR, University of Texas-Austin, and WENCHAO LI, National University of Singapore-High Sex Ratios and Premarital Investments: The Implications of Imperfect Commitment

XIAOYU XIA, Chinese University of Hong Kong, NAIJIA GUO, Chinese University of Hong Kong, and JUNSEN ZHANG, Chinese University of Hong Kong-A Matching Model of Co-Residence with a Family Network: Empirical Evidence from China

LAURA SALISBURY, York University, JEANNE LAFORTUNE, Catholic University of Chile, and ALOYSIUS SIOW, University of Toronto-A Century of Changes in American Family Formation

Discussants: JEANNE LAFORTUNE, Catholic University of Chile

ALOYSIUS SIOW, University of Toronto

V. BHASKAR, University of Texas-Austin

KIRSTEN CORNELSON, University of Notre Dame

\section{1:00 PM Marriott Marquis San Diego-Marriott Grand}

\section{Ballroom 2}

AEA

\section{Drivers of the Labor Share of Income (E2)}

Presiding: HILDE C. BJØRNLAND, BI Norwegian Business School

PHILIPPE AGHION, London School of Economics, ANTONIN BERGEAUD, Bank of France, TIMO BOPPART, Institute for International Economic Studies (IIES), PETER KLENOW, Stanford University, and HUIYU LI, Federal Reserve Bank of San Francisco-A Theory of Falling Growth and Rising Rents 


\section{Sunday $\cdot$ January 5}

MARC GIANNONI, Federal Reserve Bank of Dallas, and KAREL MERTENS, Federal Reserve Bank of Dallas-Outsourcing, Markups and the Labor Share

GERMÁN GUTIÉRREZ, New York University, and SOPHIE PITON, Bank of England-Are Institutional Investors Distorting Income Distribution?

DRAGO BERGHOLT, Norges Bank, FRANCESCO FURLANETTO, Norges Bank, and NICOLÒ MAFFEI FACCIOLI, Autonomous University of Barcelona and Barcelona GSE-The Decline of the Labor Share: New Empirical Evidence

Discussants: BENJAMIN MALIN, Federal Reserve Bank of Minneapolis

JOSEBA MARTINEZ, London Business School

AYSEGUL SAHIN, University of Texas-Austin

NICHOLAS TRACHTER, Federal Reserve Bank of Richmond

\section{1:00 PM Marriott Marquis San Diego-Presidio 1} AEA

\section{Economic Development in Africa (05)}

Presiding: MEREDITH STARTZ, Stanford University

RUSSELL D. TOTH, University of Sydney, CHRIS BARRETT, Cornell University, RICHARD BERNSTEIN, Cornell University, PATRICK CLARK, United States Department of Agriculture, CARLA GOMES, Cornell University, MOHAMED SHIBIA, University of Trier, ANDREW MUDE, International Livestock Research Institute, and BIRHANU TADDESSE, International Livestock Research Institute-Behavioural Substitution of Formal Risk Mitigation: Index Insurance in East Africa

HORATIU A. RUS, University of Waterloo, TEFERI MERGO, University of Waterloo, and ALAIN-DESIRE NIMUBONA, University of Waterloo-Ethnic Favoritism in the Provision of Public Goods: Theory and Evidence from Ethiopia

KELLY M. JONES, American University, and VIVIAN HOFFMANN, International Food Policy Research InstituteImproving Food Safety on the Farm: Experimental Evidence from Kenya on Agricultural Incentives and Subsidies as Public Health Investment 


\section{Sunday $\cdot$ January 5}

FORHAD SHILPI, World Bank, M. SHAHE EMRAN, Columbia University, BRIAN BLANKESPOOR, World Bank, and HAROLD COULOMBE, World Bank-Temporary Trade Shocks, Reallocation, and Persistence in Developing Countries: Evidence from a Natural Experiment in West Africa

JAMES BERRY, University of Delaware, HYUNCHEOL BRYANT KIM, Cornell University and Asia Development Bank, and HYUK SON, Cornell University-When Student Incentives Don't Work: Evidence from a Field Experiment in Malawi

\section{1:00 PM Marriott Marquis San Diego-Marriott Grand Ballroom 13}

AEA

Economic Implications of Longevity Risk in an Aging Society: Challenges and New Insights (G4)

Presiding: OLIVIA S. MITCHELL, University of Pennsylvania

SHLOMO BENARTZI, University of California-Los Angeles, DAVID FARO, London Business School, ANJA SCHANBACHER, Duke University, and SIMONA BOTTI, London Business SchoolThe Psychological Impact of Annuities: Can Pension Payout Choice Influence Health Behavior?

JEFFREY R. BROWN, University of Illinois-Urbana-Champaign, ARIE KAPTEYN, University of Southern California, ERZO F.P. LUTTMER, Dartmouth College, OLIVIA S. MITCHELL, University of Pennsylvania, and ANYA SAMEK, University of Southern California-Behavioral Impediments to Valuing Annuities: Evidence on the Effects of Complexity and Choice Bracketing

ABIGAIL HURWITZ, University of Pennsylvania and College of Management Academic Studies-Israel, and ORLY SADE, Hebrew University of Jerusalem-Is One Plus One Always Two? The Potential Effects of Multiple Savings Accounts on Retirement Payout Choices

IRINA GEMMO, ETH Zurich, RALPH ROGALLA, St. John's University, and JAN-HENDRIK WEINERT, Viridium GroupOptimal Lifecycle Portfolio Choice with Natural Tontines under Systematic Longevity Risk 


\section{Sunday $•$ January 5}

Discussants: JOHN CHALMERS, University of Oregon

LEE LOCKWOOD, University of Virginia

ANNAMARIA LUSARDI, George Washington University

GAL WETTSTEIN, Boston College

\section{1:00 PM Marriott Marquis San Diego-San Diego Ballroom A AEA}

Economics for Inclusive Prosperity (EfIP): Finance and Taxation (G0)

Presiding: DANI RODRIK, Harvard University

ANAT ADMATI, Stanford University-Towards a Better Financial System

ATIF R. MIAN, Princeton University-How to Think about Finance?

GABRIEL ZUCMAN, University of California-Berkeley, and EMMANUEL SAEZ, University of California-Berkeley-Taxing Multinational Corporations in the 21st Century

Discussants: SEBNEM KALEMLI-OZCAN, University of Maryland-College Park

STEFANIE STANTCHEVA, Harvard University

\section{1:00 PM Marriott Marquis San Diego-Marriott Grand} Ballroom 11

AEA

\section{Explaining Gender Gaps: Role of Competitiveness Versus} Perceptions (D9)

Presiding: LATA GANGADHARAN, Monash University

THOMAS BUSER, University of Amsterdam, MURIEL NIEDERLE, Stanford University, and HESSEL OOSTERBEEK, University of Amsterdam-Can Competitiveness Predict Education and Labor Market Outcomes? Evidence from Incentivized Choice and Survey Measures 


\section{Sunday $\cdot$ January 5}

LINA LOZANO, Maastricht University, and ERNESTO REUBEN, New York University Abu Dhabi-Is There a Preference for Competition?

NISVAN ERKAL, University of Melbourne, LATA GANGADHARAN, Monash University, and BOON HAN KOH, University of East Anglia-Gender, Attribution Biases and DecisionMaking under Risk

ANDREAS LEIBBRANDT, Griffith University-Gender Lens Investing: Experimental Evidence on Financing Mixed Gender Teams

Discussants: PATRICK NOLEN, University of Essex

MARIA RECALDE, University of Melbourne

OLGA STODDARD, Brigham Young University

SIRI ISAKSSON, Norwegian School of Economics

\section{1:00 PM Marriott Marquis San Diego-Solana} AEA

Foreign Exchange Intervention: Theory and Policy (F3)

Presiding: SEBNEM KALEMLI-OZCAN, University of Maryland

NICOLAS MAGUD, International Monetary Fund, and ALEJANDRO WERNER, International Monetary Fund-Foreign Exchange Intervention in Inflation Targeting Latin America

FABRIZIO PERRI, Federal Reserve Bank of Minneapolis, JAVIER BIANCHI, Federal Reserve Bank of Minneapolis, LUIGI BOCOLA, Stanford University, and MANUEL AMADOR, Federal Reserve Bank of Minneapolis-Foreign Reserves Management

ALESSANDRO REBUCCI, Johns Hopkins University, GIANLUCA BENIGNO, London School of Economics, and CHANGHUA YU, Peking University-Optimal FX Intervention for Macro-Financial Stability

OLIVIER JEANNE, Johns Hopkins University, and DAMIANO SANDRI, International Monetary Fund-Global Financial Cycle and Liquidity Management 


\section{Sunday $\cdot$ January 5}

Discussants: LAURA ALFARO, Harvard Business School

MATTEO MAGGIORI, Harvard University

JULIEN BENGUI, Bank of Canada

KINDA HACHEM, University of Virginia

\section{1:00 PM Marriott Marquis San Diego-Cardiff AEA}

Information and Sorting in Labor Markets (J3)

Presiding: BO COWGILL, Columbia University

DANIELLE LI, Massachusetts Institute of Technology, ALAN BENSON, University of Minnesota, and KELLY SHUE, Yale University-Promotions and the "Peter Principle"

KORY KROFT, University of Toronto, ISMAEL MOURIFIE, University of Toronto, and MONS CHAN, University of TorontoAn Empirical Framework for Matching with Imperfect Competition JUDD KESSLER, University of Pennsylvania, CORINNE LOW, University of Pennsylvania, and COLIN SULLIVAN, University of Pennsylvania-Incentivized Resume Rating: Eliciting Employer Preferences without Deception

AMANDA AGAN, Rutgers University, BO COWGILL, Columbia University, and LAURA GEE, Tufts University-The Effect of Observation and Deception in Field Experiments: Evidence from a Two-sided Audit Study

Discussants: PAUL OYER, Stanford University

ZOE CULLEN, Harvard Business School

WILLIAM KERR, Harvard Business School

JOHN MICHAEL VAN REENEN, Massachusetts Institute of Technology

\section{1:00 PM Marriott Marquis San Diego-Marriott Grand}

\section{Ballroom 12}

AEA

Local Shocks and Long-Run Persistence (R0)

Presiding: DONALD DAVIS, Columbia University 


\section{Sunday $\cdot$ January 5}

REMI JEDWAB, George Washington University, NOEL JOHNSON, George Mason University, and MARK KOYAMA, George Mason University—Pandemics, Places, and Populations: Evidence from the Black Death

DAVE DONALDSON, Massachusetts Institute of Technology, and DANIEL KENISTON, Louisiana State University-Dynamics of a Malthusian Economy: India in the Aftermath of the 1918 Influenza

LEAH BOUSTAN, Princeton University, MATTHEW KAHN, University of Southern California, PAUL RHODE, University of Michigan, and LUCIA YANGUAS, University of California-Los Angeles-The Effect of Natural Disasters on Economic Activity in United States Counties: A Century of Data

BRYAN STUART, George Washington University, and BRAD HERSHBEIN, W.E. Upjohn Institute for Employment ResearchRecessions and Local Labor Markets

Discussants: HOYT BLEAKLEY, University of Michigan

NANCY QIAN, Northwestern University

RICHARD HORNBECK, University of Chicago

KATHERINE ERIKSSON, University of California-Davis

\section{1:00 PM Marriott Marquis San Diego-Marriott Grand Ballroom 1} AEA

\section{Macroprudential Policies (E5)}

Presiding: JULIE GARIN, Claremont McKenna College

DAWID ZOCHOWSKI, European Central Bank, LUCA NOCCIOLA, Goethe University Frankfurt, and FABIO FRANCH, Reserve Bank of Australia-Cross-Border Effects of Prudential Regulation - Evidence from the Euro Area

ADRIAN ALTER, International Monetary Fund, GASTON GELOS, International Monetary Fund, ERLEND NIER, International Monetary Fund, MACHIKO NARITA, International Monetary Fund, and HEEDON KANG, International Monetary FundDigging Deeper - Evidence on the Effects of Macroprudential Policies from a New Database 


\section{Sunday $\cdot$ January 5}

SUMIT AGARWAL, National University of Singapore, CHANGCHENG SONG, Singapore Management University, MURIS HADZIC, Lake Forest College, and YILDIRAY YILDIRIM, City University of New York-Baruch CollegeLiquidity Constraints and Consumption: Evidence from MacroPrudential Policy in Turkey

RUSTOM IRANI, University of Illinois-Urbana-Champaign, SJOERD VAN BEKKUM, Erasmus University Rotterdam, MARC GABARRO, University of Mannheim, and JOSÉ-LUIS PEYDRÓ, ICREA, Pompeu Fabra University, CREI, Barcelona GSE, and Imperial College London-Macroprudential Policy and Household Leverage: Evidence from Administrative Household-Level Data

STEPHEN MILLARD, Bank of England, MARGARITA RUBIO, Nottingham University, and ALEXANDRA VARADI, University of Oxford-The Macroprudential Toolkit: Effectiveness and Interactions

\section{1:00 PM Marriott Marquis San Diego-Presidio 2}

\section{AEA}

\section{Political Economy (P1)}

Presiding: RUIXUE JIA, University of California-San Diego

GABOR NYEKI, Duke University-Does Hate Drive out Hate? Representation in Congress and (Non-)Violent Protests in the United States Civil Rights Movement

GAZI KARA, Federal Reserve Board, and YOUNGSUK YOOK, Federal Reserve Board-Policy Uncertainty and Bank Mortgage Credit

MAGGIE CHEN, George Washington University, and QIANG ZHENG, George Washington University-Political Polarization in Social Media

STEFAN EICHLER, Dresden University of Technology, JANTKE DE BOER, Dresden University of Technology, and INGMAR ROEVEKAMP, Dresden University of Technology-The Impact of United States Presidential Debates on Exchange Rates

CHRIS REDL, Bank of England-Uncertainty Matters: Evidence from Close Elections 


\section{Sunday $\cdot$ January 5}

1:00 PM Marriott Marquis San Diego-Marriott Grand Ballroom 3 AEA

Relocation and Price Effects of United States Trade Policy (F1)

Presiding: THOMAS HOLMES, University of Minnesota and Federal Reserve Bank of Minneapolis

AARON FLAAEN, Federal Reserve Board, ALI HORTACSU, University of Chicago, and FELIX TINTELNOT, University of Chicago_-The Production Relocation and Price Effects of United States Trade Policy: The Case of Washing Machines

THOMAS HOLMES, University of Minnesota and Federal Reserve Bank of Minneapolis_-Tariffs on Global Goods

CHAD P. BOWN, Peterson Institute for International EconomicsUnited States Special Protection in Historical Perspective: 1974-2018

\section{1:00 PM Marriott Marquis San Diego-Marriott Grand Ballroom 4} AEA

\section{Social Determinants of Health Disparities (I1)}

Presiding: JANET CURRIE, Princeton University

MARCELLA ALSAN, Stanford University, OWEN GARRICK, Bridge Clinical Research, and GRANT GRAZIANI, University of California-Berkeley-Does Diversity Matter for Health? Experimental Evidence from Oakland

DOUGLAS ALMOND, Columbia University, and YI CHENG, Columbia University-Perinatal Health among One Million Chinese-Americans

JUNE KIM, Purdue University-Fort Wayne, AJIN LEE, Michigan State University, and MAYA ROSSIN-SLATER, Stanford University-Extreme Heat during Pregnancy and Maternal and Child Health

DIANE ALEXANDER, Federal Reserve Bank of Chicago, and HANNES SCHWANDT, Northwestern University-Dirty Diesel: Emissions Cheating, Car Pollution, and Health 


\section{Sunday $•$ January 5}

Discussants: ADAM SACARNY, Columbia University

JESSAMYN SCHALLER, University of Arizona

BHASH MAZUMDER, Federal Reserve Bank of Chicago

NICHOLAS J. SANDERS, Cornell University

\section{1:00 PM Marriott Marquis San Diego-Carlsbad}

AEA

\section{Transportation (R4)}

Presiding: PATRICK MCCARTHY, Georgia Institute of Technology

ZACHARY LISCOW, Yale University, and LEAH BROOKS, George Washington University-Infrastructure Costs

GUSTAVO J. CANAVIRE-BACARREZA, Inter-American Development Bank, JUAN CARLOS DUQUE, EAFIT University, and JOAQUIN URREGO, Syracuse University-Moving Citizens and Deterring Criminals: Innovation in Public Transport Facilities

YENJAE CHANG, Washington State University-Route-Based Price Discrimination in the Ride-Hailing Industry

ROBERTO MOSQUERA, University of the Americas-Stuck in Traffic: Measuring Congestion Externalities with Negative Supply Shocks

ALEX ANAS, State University of New York-Buffalo, and HUIBIN CHANG, Dongbei University of Finance and Economics-When are the Vehicle-Miles-Traveled Tax and the Gasoline Tax Not Efficient?

\section{1:00 PM Marriott Marquis San Diego-Torrey Pines 1} AEA

\section{Wages (J3)}

Presiding: LAURA GIULIANO, University of California-Santa Cruz

STEFFEN ANDERSEN, Copenhagen Business School, PHILIPPE D'ASTOUS, HEC Montreal, JIMMY MARTINEZ-CORREA, Copenhagen Business School, and STEPHEN H. SHORE, Georgia State University-Are Educational Differences in the Gender Earnings Gap Causal? 


\section{Sunday $\cdot$ January 5}

INES HELM, Stockholm University, ALICE KÜGLER, University College London, and UTA SCHÖNBERG, University College London-Displacement Effects in Manufacturing: The Role of Firms

SABRINA T. HOWELL, New York University, and J. DAVID BROWN, U.S. Census Bureau-Do Cash Windfalls Affect Wages? Evidence from R\&D Grants to Small Firms

JORGEN HARRIS, Occidental College-Do Wages Fall When Women Enter an Occupation?

TRISTAN POTTER, Drexel University, and DAN BERNHARDT, University of Illinois-Urbana-Champaign-Wage Offers and On-the-Job Search

\section{1:00 PM Manchester Grand Hyatt San Diego-Gaslamp D AERE}

\section{Evolving Electricity Markets (Q4)}

Presiding: JIM BUSHNELL, University of California-Davis

DANIEL LLOYD SHAWHAN, Resources for the Future, ALAN KRUPNICK, Resources for the Future, REBECCA EPANCHINNEILL, Resources for the Future, PAUL PICCIANO, Resources for the Future, and ALEXANDRA THOMPSON, Resources for the Future-Your Money or Your Wildlife: Environmental and Economic Tradeoffs from Solar Siting Restrictions in Texas

JACKSON DORSEY, Indiana University, GAUTAM GOWRISANKARAN, University of Arizona, and ANDREW BUTTERS, Indiana University_Packing Power: Electricity Storage and Renewable Energy

MATT WOERMAN, University of Massachusetts-Amherst, DALLAS BURTRAW, Resources for the Future, and KAREN PALMER, Resources for the Future-Linking Carbon Markets with Different Initial Conditions

LINDA COHEN, University of California-Irvine, and KYLE KETTLER, University of California-Irvine-The Political Economy of Electricity Rates 


\section{Sunday $•$ January 5}

Discussants: STAN REYNOLDS, University of Arizona

ERIN MANSUR, Dartmouth College

GARTH HEUTEL, Georgia State University

JIM BUSHNELL, University of California-Davis

1:00 PM Manchester Grand Hyatt San Diego-Seaport A AFA

Asset Pricing: Cross-section of Returns and Investors (G1)

Presiding: ANNETTE VISSING-JORGENSEN, University of CaliforniaBerkeley

RALPH KOIJEN, University of Chicago, ROBERT RICHMOND, New York University, and MOTOHIRO YOGO, Princeton University-Which Investors Matter for Global Equity Valuations and Expected Returns?

DANIEL ANDREI, McGill University, JULIEN CUJEAN, University of Bern, and MATHIEU FOURNIER, HEC MontrealThe Low-Minus-High Portfolio

ASSAF EISDORFER, University of Connecticut, KENNETH FROOT, Harvard Business School, GIDEON OZIK, EDHEC Business School, and RONNIE SADKA, Boston CollegeCompetition Links and Stock Returns

Discussants: JOHN CAMPBELL, Harvard University

SERHIY KOZAK, University of Maryland

CHRISTOPHER POLK, London School of Economics

\section{1:00 PM Manchester Grand Hyatt San Diego-Seaport B} AFA

Corporate Disclosure and Incentives (G3)

Presiding: IVAN MARINOVIC, Stanford University

PAUL POVEL, University of Houston, and GÜNTER STROBL, Frankfurt School of Finance \& Management-Lying to Speak the Truth: Selective Manipulation and Improved Information Transmission 


\section{Sunday $\cdot$ January 5}

THOMAS BOURVEAU, Columbia University, GUOMAN SHE, Hong Kong University of Science and Technology, and ALMINAS ZALDOKAS, Hong Kong University of Science and TechnologyCorporate Disclosure as a Tacit Coordination Mechanism: Evidence from Cartel Enforcement Regulations

SHIMING FU, Shanghai University of Finance and Economics, and GIULIO TRIGILIA, University of Rochester-Voluntary Disclosure, Moral Hazard and Default Risk

Discussants: MARTIN SZYDLOWSKI, University of Minnesota

JOHN KEPLER, Stanford University

FELIPE VARAS, Duke University

\section{1:00 PM Manchester Grand Hyatt San Diego-Seaport C AFA}

Financial Crises and Transmission of Shocks (G2)

Presiding: TYLER MUIR, University of California-Los Angeles

AGOSTINO CAPPONI, Columbia University, ALLEN CHENG, Columbia University, STEFANO GIGLIO, Yale University, and RICHARD HAYNES, Commodity Futures Trading CommissionThe Collateral Rule: An Empirical Analysis of the CDS Market

WENHAO LI, Stanford University—Public Liquidity and Financial Crises

VALENTINA BRUNO, American University, and HYUN SONG SHIN, Bank for International Settlements-Dollar Exchange Rate as a Credit Supply Channel: Evidence from Firm-Level Exports

ALEXANDER JUNG, European Central Bank, and HARALD UHLIG, University of Chicago-Monetary Policy Shocks and the Health of Banks

Discussants: GEORGY CHABAKAURI, London School of Economics

MORITZ LENEL, Princeton University

ZHENGYANG JIANG, Northwestern University

MATTHEW PLOSSER, Federal Reserve Bank of New York 


\section{Sunday $•$ January 5}

1:00 PM Manchester Grand Hyatt San Diego-Seaport F

AFA

\section{Household Debt and Savings (G1)}

Presiding: GREGOR MATVOS, University of Texas-Austin

FRANCESCO D'ACUNTO, Boston College, THOMAS RAUTER, University of Chicago, CHRISTOPH SCHEUCH, Vienna University of Economics and Business, and MICHAEL WEBER, University of Chicago-Perceived Precautionary Savings Motives: Evidence from FinTech

EMILY GALLAGHER, University of Colorado-Boulder, RADHAKRISHNAN GOPALAN, Washington University-St. Louis, MICHAL GRINSTEIN-WEISS, Washington University-St. Louis, and JORGE SABAT, Washington University-St. LouisMedicaid and Household Savings Behavior: New Evidence from Tax Refunds

HOLGER MUELLER, New York University, and CONSTANTINE YANNELIS, University of Chicago-Reducing Barriers to Enrollment in Federal Student Loan Repayment Plans: Evidence from the Navient Field Experiment

Discussants: GREG BUCHAK, University of Chicago

TIMOTHY MCQUADE, Stanford University

TIM LANDVOIGT, University of Pennsylvania

\section{1:00 PM Manchester Grand Hyatt San Diego-Seaport G}

AFA

\section{Information Trading in Networks (G1)}

Presiding: ZHIGUO HE, University of Chicago

SELMAN EROL, Carnegie Mellon University, and MICHAEL LEE, Federal Reserve Bank of New York-Insider Networks

DAVID HIRSHLEIFER, University of California-Irvine, LIN PENG, City University of New York-Baruch College, and QIGUANG WANG, Hong Kong Baptist University-Social Interaction and Market Reaction to Earnings News 


\section{Sunday $\cdot$ January 5}

PAT AKEY, University of Toronto, VINCENT GREGOIRE, HEC Montreal, and CHARLES MARTINEAU, University of TorontoPrice Revelation from Insider Trading: Evidence from Hacked Earnings News

SERGEI GLEBKIN, INSEAD—Liquidity Versus Information Efficiency

Discussants: PETER KONDOR, London School of Economics

ASAF MANELA, Washington University-St. Louis

EMILIANO PAGNOTTA, Imperial College London

EDUARDO DAVILA, Yale University

\section{1:00 PM Manchester Grand Hyatt San Diego-Seaport H AFA}

\section{Labor Markets and Firm Performance (G3)}

Presiding: MARGARITA TSOUTSOURA, Cornell University

MURILLO CAMPELLO, Cornell University and NBER, JANET GAO, Indiana University, and QIPING XU, University of Notre Dame-Local Taxes and the Demand for Skilled Labor: Evidence from Job Postings

YUE ZHANG, Catholic University of Louvain, and JIAPING QIU, McMaster University_Wage Rigidity and Debt Financing: Evidence from Labor Contract Renewal during the Financial Crisis

KYEONG H. LEE, Norwegian School of Economics, KARIN THORBURN, Norwegian School of Economics, and EMMA QIANYING XU, University of Texas-El Paso-Local Employment Opportunities and Corporate Retention Policies

Discussants: XAVIER GIROUD, Columbia University

ELENA SIMINTZI, University of North Carolina-Chapel Hill HYUNSEOB KIM, Cornell University 


\section{Sunday $•$ January 5}

1:00 PM Manchester Grand Hyatt San Diego-Harbor A AFA

\section{Risk Premia Dynamics in Treasury Bond Markets (G1)}

Presiding: ANH LE, Pennsylvania State University

GURDIP BAKSHI, Temple University, JOHN CROSBY, University of Maryland, and XIAOHUI GAO BAKSHI, Temple UniversityUnspanned Risks, Negative Local Time Risk Premiums, and Empirical Consistency of Models of Interest-Rate Claims

ROBERT CZECH, Bank of England, SHIYANG HUANG, University of Hong Kong, DONG LOU, London School of Economics, and TIANYU WANG, Tsinghua University-Predicting Interest Rates

DANIELE BIANCHI, University of Warwick, MATTHIAS BUCHNER, University of Warwick, and ANDREA TAMONI, Rutgers University_-Bond Risk Premia with Machine Learning

GEERT BEKAERT, Columbia University, ERIC ENGSTROM, Federal Reserve Board, and ANDREY ERMOLOV, Fordham University-Macro Risks and the Term Structure of Interest Rates

Discussants: SCOTT JOSLIN, University of Southern California

GIANG NGUYEN, Pennsylvania State University

JINGZHI HUANG, Pennsylvania State University

GREG DUFFEE, Johns Hopkins University

\section{1:00 PM Manchester Grand Hyatt San Diego-Cortez Hill A AFEE}

\section{Public Policy toward Business (L1)}

Presiding: RICHARD ADKISSON, New Mexico State University KOSTA JOSIFIDIS, University of Novi Sad, and NOVICA SUPIC, University of Novi Sad-Innovation and Income Inequality in the United States of America: Ceremonial Versus Institutional Adjustment

AVRAHAM IZHAR BARANES, Elmhurst College-Automation, Financialization, and Institutional Change: Challenges for Progressive Industrial Policy 


\section{Sunday $\cdot$ January 5}

MATÍAS VERNENGO, Bucknell University-From Regulation to Deregulation: Old Institutionalist Versus Chicago School Views of Law and Economics

MARY V. WRENN, University of West England-From Mad to Mindful: Corporate Control through Corporate Mindfulness

CHRISTOPHER BROWN, Arkansas State University-Will the Green Kondratieff Wave be Stillborn?

Discussants: RICHARD ADKISSON, New Mexico State University

ANNA KILIMNA, University of Saskatchewan

\section{1:00 PM Manchester Grand Hyatt San Diego—Regatta C AREUEA}

\section{Housing and Cyclical Dynamics (R2)}

Presiding: LU HAN, University of Toronto

LARA LOEWENSTEIN, Federal Reserve Bank of ClevelandConsumption of Housing During the 2000s Boom: Evidence and Theory

C.Y. CHOI, University of Texas-Arlington, and SOOJIN JO, Bank of Canada-Do Housing Markets Affect Local Consumer Prices? Evidence from United States Cities

PAVEL KRIVENKO, City University of New York-Baruch College-Unemployment and the United States Housing Market during the Great Recession

ELLIOT ANENBERG, Federal Reserve Board, and DANIEL

RINGO, Federal Reserve Board-The Propagation of Demand Shocks Through Housing Markets

Discussants: EDWARD KUNG, University of California-Los Angeles

LIANG PENG, Pennsylvania State University

JACK FAVILUKIS, University of British Columbia

ERIC SMITH, University of Essex 


\section{Sunday $•$ January 5}

\section{1:00 PM Manchester Grand Hyatt San Diego-Nautical}

AREUEA

\section{REITs (G1)}

Presiding: EVA STEINER, Cornell University

MANUELA PEDIO, Bocconi University, and MASSIMO GUIDOLIN, Bocconi University-How Smart is the Real Estate Smart Beta? Evidence from Optimal Style Factor Strategies for REITs

BING ZHU, University of Reading, and DAVID DOWNS, Virginia Commonwealth University_Property Market Liquidity and REIT Liquidity

MARIYA LETDIN, Florida State University, STACE SIRMANS, Auburn University, and STACY SIRMANS, Florida State University—NAV Premiums and Betting against the Sentiment

KIMBERLY LUCHTENBERG, American University-REIT Unit Investment Trusts and Fund Manager Skill

Discussants: CHONGYU WANG, University of Florida

SHAUN BOND, University of Queensland

WALLY BOUDRY, Cornell University

MOUSSA DIOP, University of Wisconsin-Madison

\section{1:00 PM Marriott Marquis San Diego-Catalina \\ ES}

\section{Advances in Phillips Curve Research (E2)}

Presiding: OLIVIER COIBION, University of Texas-Austin

RUPAL KAMDAR, University of California-Berkeley-The Inattentive Consumer: Sentiment and Expectations

HASSAN AFROUZI, Columbia University, and CHOONGRYUL YANG, University of Texas-Austin-Dynamic Inattention, the Phillips Curve, and Forward Guidance

EMI NAKAMURA, University of California-Berkeley_A Plucking Model of Business Cycles 


\section{Sunday $\cdot$ January 5}

JANE RYNGAERT, Wake Forest University, OLIVIER COIBION, University of Texas-Austin, YURIY GORODNICHENKO, University of California-Berkeley, and SATEN KUMAR, Auckland University of Technology-Anticipating the Phillips Curve: Firms' Joint Expectations of Unemployment and Inflation

\section{1:00 PM Marriott Marquis San Diego—La Costa ES}

\section{Business Cycles and Labor Markets (J2)}

Presiding: CYNTHIA DONIGER, Federal Reserve Board

PATRICK KEHOE, Stanford University, PIERLAURO LOPEZ, Bank of France, VIRGILIU MIDRIGAN, New York University, and ELENA PASTORINO, Stanford University-Asset Prices and Unemployment Fluctuations

HIE JOO AHN, Federal Reserve Board, and JAMES HAMILTON, University of California-San Diego-Measuring Labor-Force Participation and the Incidence and Duration of Unemployment

CYNTHIA DONIGER, Federal Reserve Board-Do Greasy Wheels Curb Inequality?

RYAN CHAHROUR, Boston College, KRISTOFFER NIMARK, Cornell University, and STEFAN PITSCHNER, Uppsala University and Stockholm School—Sectoral Media Focus and Aggregate Fluctuations

CHRISTIAN MOSER, Columbia University, FARZAD SAIDI, Boston University, BENJAMIN WIRTH, Bavarian State Office for Statistics, and STEFANIE WOLTER, IAB Nuremberg-Credit Supply, Firms, and Earnings Inequality

\section{1:00 PM Marriott Marquis San Diego-Del Mar ES}

\section{Identification and Estimation in Causal Models (C2)}

Presiding: VICTOR AGUIRREGABIRIA, University of Toronto

KIRILL BORUSYAK, Princeton University, and PETER HULL, University of Chicago-Combining Quasi-Experimental Shocks with Endogenous Exposure: A General Framework 


\section{Sunday $\cdot$ January 5}

YUSUKE NARITA, Yale University-(Non)Randomization: A Theory of Quasi-Experimental Evaluation of School Quality

BRANTLY CALLAWAY, Temple University, TONG LI, Vanderbilt University, and IRINA MURTAZASHVILI, Drexel UniversityQuantile Treatment Effects with Two-Sided Measurement Error HIROYUKI KASAHARA, University of British Columbia, and KATSUMI SHIMOTSU, University of Tokyo-Identification of Regression Models with a Misclassified and Endogenous Binary Regressor

YINGYAO HU, Johns Hopkins University, and YI XIN, California Institute of Technology-Identification and Estimation of Dynamic Structural Models with Unobserved Choices

VICTOR AGUIRREGABIRIA, University of Toronto-Structural Models of Competition with Firms' Flexible Beliefs

\section{1:00 PM Marriott Marquis San Diego-Newport Beach ES}

\section{Information in Contests (C7)}

Presiding: MARCO OTTAVIANI, Bocconi University

JINGFENG LU, National University of Singapore, and ZIJIA WANG, National University of Singapore-Optimal Disclosure of Value Distribution Information in All Pay Auction

ALEJANDRO MELO PONCE, Nazarbayev University-The Secret behind The Tortoise and the Hare: Information Design in Contests ZHUOQIONG CHEN, Harbin Institute of Technology-ShenzhenInformation Disclosure in Contests: Private Versus Public Signals MARCO OTTAVIANI, Bocconi University-Proportional Allocation across Fields, Demand Relativity, and Benchmarking

\section{1:00 PM Manchester Grand Hyatt San Diego-Cortez Hill B ES}

\section{Rare Events (G1)}

Presiding: WINSTON WEI DOU, University of Pennsylvania 


\section{Sunday $\cdot$ January 5}

LARS KUEHN, Carnegie Mellon University, DAVID SCHREINDORFER, Arizona State University, and FLORIAN SCHULZ, University of Washington-Credit and Option Risk Premia

CLAUDIA MOISE, Duke University—Flights to Safety and Volatility Pricing

NICOLE BRANGER, University of Muenster, RENÉ FLACKE, University of Muenster, and FREDERIK MIDDELHOFF, University of Muenster-Jumps and the Correlation Risk Premium: Evidence from Equity Options

HUIDI LIN, Northwestern University, and VIKTOR TODOROV, Northwestern University-Aggregate Asymmetry in Idiosyncratic Jump Risk

Discussants: BORIS NIKOLOV, University of Lausanne and Swiss Finance Institute

ALAN MOREIRA, University of Rochester

DAVID WEINBAUM, Syracuse University

METE KILIC, University of Southern California

\section{1:00 PM Manchester Grand Hyatt San Diego-Harbor F} LERA

\section{Causes and Consequences of Performance Pay (J3)}

Presiding: SUSAN R. HELPER, Case Western Reserve University

JED DEVARO, California State University-East Bay, and JOHN PENCAVEL, Stanford University-Working Hours, Health and Absenteeism, and Performance Pay

JEFFREY H. KEEFE, Rutgers University-The Decline of Incentive Wage Rates: Evidence from the American Machinery Industry

BENJAMIN ARTZ, University of Wisconsin-Oshkosh, COLIN P. GREEN, Norwegian University of Science and Technology, and JOHN S. HEYWOOD, University of Wisconsin-Milwaukee-Does Performance Pay Increase Alcohol and Drug Use?

Discussants: MICHAEL GIBBS, University of Chicago

MORRIS M. KLEINER, University of Minnesota

DANIEL PARENT, HEC Montreal 


\section{Sunday $•$ January 5}

1:00 PM Manchester Grand Hyatt San Diego-Harbor E LERA

Using Online Job Vacancy Data to Study Labor Market Dynamics (J6)

Presiding: MARY BURKE, Federal Reserve Bank of Boston

SUSAN VROMAN, Georgetown University, JIM ALBRECHT, Georgetown University, and BRUNO DECREUSE, Aix-Marseille University-Directed Search with Phantom Vacancies

STEVEN J. DAVIS, University of Chicago, and BRENDA SAMANIEGO DE LA PARRA, University of California-Santa Cruz-Application Flows

MARTHA GIMBEL, Schmidt Futures, and TARA SINCLAIR, George Washington University and Indeed Hiring Lab-Mismatch in Online Job Search

MARY BURKE, Federal Reserve Bank of Boston, ALICIA MODESTINO, Northeastern University, RACHEL SEDERBERG, Bowdoin College, and BLEDI TASKA, Burning Glass Technologies-No Longer Qualified? Changes in the Supply and Demand for Skills within Occupations

Discussants: TARA SINCLAIR, George Washington University and Indeed Hiring Lab

JIM ALBRECHT, Georgetown University

\section{1:00 PM Marriott Marquis San Diego-Mission Hills NEA}

\section{Factors Impacting Emerging African Nations (01)}

Presiding: JULIET ELU, Morehouse College

OLADELE OMOSEGBON, Indiana Wesleyan University and Indiana University-Purdue University Indianapolis-A Dynamic Path to Infrastructural Development in Africa: The Role of Economic Integration

JOHN CHIWUZULUM ODOZI, University of Ibadan, and RUTH UWAIFO OYELERE, Agnes Scott College and IZA-The Effects of Recent Violent Conflict Exposure on Labor Supply of Agricultural Households in Nigeria 


\section{Sunday $\cdot$ January 5}

JULIET ELU, Morehouse College, and MIESHA J. WILLIAMS, Morehouse College-Development Funding in Africa: The Case of West Africa

J. O. SAKA, Lagos State University-Nigeria, and DOUGLASON G. OMOTOR, West African Institute For Financial and Economic Management-Financing Electricity and Transportation Infrastructure in Selected Sub-Saharan African Countries

EMMANUEL OBI, Morehouse College-Economic Development and Challenges in Sub-Saharan Africa

AKPAN H. EKPO, University of Uyo-Nigeria and Foundation for Economic Research and Training (FERT) - Governance, Growth and Development in Sub-Saharan Africa: A Revisit of the Evidence Discussants: JOHN NED, Loyola University Maryland

CRUZ BUENO, State University of New York-New Paltz

JAMEIN CUNNINGHAM, University of Memphis

LINDA LOUBERT, Morgan State University

JAN CHRISTOPHER, Delaware State University

\section{1:00 PM Manchester Grand Hyatt San Diego_-Old Town A URPE}

\section{Ecology, the Environment, and Energy (Q5)}

Presiding: PAUL COONEY, National University of General Sarmiento and URPE

PAUL COONEY, National University of General Sarmiento (UNGS)-Marxism and Ecological Economics: An Assessment of the Past, Present, and Future

LYNNE CHESTER, University of Sydney-Energy and Social Reality: Can Social Ontology Provide Insight?

ANN E. DAVIS, Marist College- - "Home on the Range": Integrating the Household and Ecology

CEREN SOYLU, University of Massachusetts-Amherst-The Political Economy of Environmental Conflicts: Collective Action as Informal Regulation 


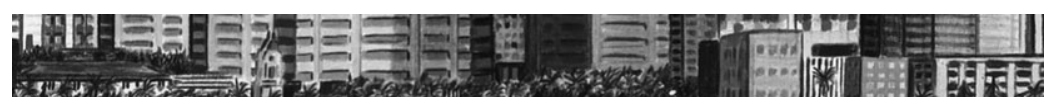

\section{Subject Area Index}

A1 General Economics 90, 133, 140, 174, 205, 226, 234

A2 Economic Education and Teaching of Economics 60, 69, 96, 124, 148, $167,185,235,270,359,373$

B0 History of Economic Thought, Methodology, and Heterodox Approaches:

General 78, 87, 119, 164

B2 History of Economic Thought since 1925 145, 338

B3 History of Economic Thought: Individuals 269

B4 Economic Methodology 87, 122, 243, 260, 278

B5 Current Heterodox Approaches 81, 114, 128, 134, 154, 157, 203, 221, 241 , 261, 263, 289, 292, 334, 344, 375

C1 Econometric and Statistical Methods and Methodology: General 82, 119, 131, 161, 211, 248, 251, 294, 295, 315, 337, 369, 371

C2 Single Equation Models • Single Variables 162, 208, 397

C3 Multiple or Simultaneous Equation Models • Multiple Variables 336

C4 Econometric and Statistical Methods: Special Topics 332

C5 Econometric Modeling 103

C6 Mathematical Methods • Programming Models • Mathematical and Simulation Modeling 264

C7 Game Theory and Bargaining Theory 209, 370, 398

C8 Data Collection and Data Estimation Methodology • Computer Programs 298

C9 Design of Experiments 181, 228, 296

D1 Household Behavior and Family Economics 69, 82, 97, 120, 248, 292, 336

D2 Production and Organizations 232, 281, 347, 357

D3 Distribution 141, 163, 249, 268

D4 Market Structure, Pricing, and Design 83, 182

D6 Welfare Economics 311

D7 Analysis of Collective Decision-Making 85, 170, 175, 207, 314

D8 Information, Knowledge, and Uncertainty 100, 116, 117, 136, 160, 246, $323,333,370$

D9 Micro-Based Behavioral Economics 85, 147, 163, 219, 273, 377, 382 
E0 Macroeconomics and Monetary Economics: General 82, 169, 180, 220, $251,253,320,343,366$

E1 General Aggregative Models 169, 279

E2 Consumption, Saving, Production, Investment, Labor Markets, and Informal Economy 102, 178, 265, 267, 280, 302, 317, 348, 359, 379, 396

E3 Prices, Business Fluctuations, and Cycles 59, 99, 115, 256, 319

E4 Money and Interest Rates 154

E5 Monetary Policy, Central Banking, and the Supply of Money and Credit $59,71,99,104,210,274,321,330,355,368,385$

E6 Macroeconomic Policy, Macroeconomic Aspects of Public Finance, and General Outlook 103, 125, 127, 133, 175, 322

E7 Macro-Based Behavioral Economics 231

F0 International Economics: General 136, 216, 302

F1 Trade 114, 142, 166, 214, 303, 358, 387

F2 International Factor Movements and International Business 80, 144, 174, 345

F3 International Finance 66, 91, 165, 179, 233, 351, 377, 383

F4 Macroeconomic Aspects of International Trade and Finance 295

F5 International Relations, National Security, and International Political Economy 301, 342

F6 Economic Impacts of Globalization 218, 226, 265

G0 Financial Economics: General 63, 68, 110, 149, 187, 236, 257, 284, 382

G1 General Financial Markets 72, 74, 75, 76, 83, 107, 108, 121, 149, 151, $153,177,198,199,201,202,210,236,238,240,286,287,288,325,327$, $328,334,361,364,365,390,392,394,396,398$

G2 Financial Institutions and Services 77, 92, 102, 106, 113, 129, 144, 151, $164,199,200,204,214,229,237,238,260,277,284,303,308,326,329$, $347,363,364,391$

G3 Corporate Finance and Governance 73, 74, 75, 106, 109, 110, 150, 152, 200, 201, 237, 239, 250, 275, 285, 288, 297, 317, 327, 328, 329, 362, 363, 390,393

G4 Behavioral Finance 381

H0 Public Economics: General 141, 159, 255, 358

H1 Structure and Scope of Government 58, 216, 223

H2 Taxation, Subsidies, and Revenue 277, 281, 342

H3 Fiscal Policies and Behavior of Economic Agents 308, 376, 378

H4 Publicly Provided Goods 130, 158, 205, 230

H6 National Budget, Deficit, and Debt 279 
I0 Health, Education, and Welfare: General 60, 101, 124

I1 Health 86, 121, 138, 146, 183, 202, 206, 215, 228, 243, 262, 267, 296, $338,341,345,371,387$

I2 Education and Research Institutions 62, 135, 173, 224, 313, 349

I3 Welfare, Well-Being, and Poverty 58, 68, 101, 270, 275

J0 Labor and Demographic Economics: General 96, 299

J1 Demographic Economics 64, 176, 177, 181, 206, 247, 250, 252, 316, 321 , 351,379

J2 Demand and Supply of Labor 88, 118, 139, 166, 252, 299, 309, 354, 373, 397

J3 Wages, Compensation, and Labor Costs 123, 217, 221, 282, 318, 352, 384, 388,399

J4 Particular Labor Markets 254, 339, 372

J5 Labor-Management Relations, Trade Unions, and Collective Bargaining 132,353

J6 Mobility, Unemployment, Vacancies, and Immigrant Workers 61, 70, 305, $319,349,400$

J7 Labor Discrimination 65, 89, 133, 179, 184, 224, 227, 344, 350

K1 Basic Areas of Law 168, 340

K2 Regulation and Business Law 219, 253, 300

K4 Legal Procedure, the Legal System, and Illegal Behavior 66, 94, 312, 356, 374

L1 Market Structure, Firm Strategy, and Market Performance 117, 165, 167, $222,254,310,315,356,368,394$

L2 Firm Objectives, Organization, and Behavior 90, 335, 375

L4 Antitrust Issues and Policies 264, 355

L8 Industry Studies: Services 276

L9 Industry Studies: Transportation and Utilities 122, 126, 134, 257, 304

M5 Personnel Economics 217

N0 Economic History: General 313

N2 Financial Markets and Institutions 245

N3 Labor and Consumers, Demography, Education, Health, Welfare, Income, Wealth, Religion, and Philanthropy 116, 143, 208, 261

N4 Government, War, Law, International Relations, and Regulation 131, 246

O0 Economic Development, Innovation, Technological Change, and Growth $78,139,183,258$

O1 Economic Development 64, 111, 168, 222, 233, 240, 276, 283, 354, 400 
O3 Innovation - Research and Development - Technological Change •

Intellectual Property Rights 62, 67, 92, 98, 126, 128, 135, 138, 146, 225, 231,273

O4 Economic Growth and Aggregate Productivity 293

O5 Economywide Country Studies 380

P1 Capitalist Systems 386

P2 Socialist Systems and Transitional Economies 80, 306

P3 Socialist Institutions and Their Transitions 172

Q0 Agricultural and Natural Resource Economics • Environmental and Ecological Economics: General 172

Q2 Renewable Resources and Conservation 105, 235

Q3 Nonrenewable Resources and Conservation 360

Q4 Energy 137, 185, 249, 263, 297, 323, 389

Q5 Environmental Economics 72, 93, 148, 158, 186, 258, 268, 283, 300, 310, $324,346,401$

R0 Urban, Rural, Regional, Real Estate, and Transportation Economics:

General 155, 384

R2 Household Analysis 84, 156, 290, 366, 367, 395

R3 Real Estate Markets, Spatial Production Analysis, and Firm Location 79, $112,242,290,331,332$

R4 Transportation Economics 104, 118, 291, 388

R5 Regional Government Analysis 293

Z0 Other Special Topics: General 244

Z1 Cultural Economics • Economic Sociology • Economic Anthropology 95, 266 


\section{Index of Participants}

A

Aaronson, Daniel 143

Aassve, Arnstein 147, 378

Abadie, Alberto 119

Abbott, Joshua 105, 361

Abdelbary, Islam 266

Abdi, Farshid 194

Abdul Aziz, Nor Izzatina

219

Abraham, Katharine G. 89, 123,145

Abramitzky, Ran 181

Abreu, Dilip 209

Acemoglu, Daron 62, 143, 249, 282

Acharya, Avidit 85

Acharya, Sushant 137

Acharya, Viral 238

Ackerberg, Daniel 166

Acolin, Arthur 290

Adams, Abi 247

Adams, Renee 111, 205, 375

Adao, Rodrigo 180, 208

Adda, Jerome 101

Addison, John 132

Addoum, Jawad 97

Adhikari, Bibek 377

Adkisson, Richard 111, 394, 395

Admati, Anat 382

Adrian, Tobias 149, 322

Adusumilli, Karun 295

Afrouzi, Hassan 396

Agan, Amanda 67, 95, 179, 278, 384

Agarwal, Neha 95

Agarwal, Sumit 113, 157, 178, 191, 304, 324, 330, 367,386

Agarwal, Vikas 153

Ager, Philipp 143

Agerton, Mark 185

Aggarwal, Bhavya 327

Aggarwal, Shilpa 276

Agha, Leila 86
Aghabarari, Leila 265

Aghion, Philippe 67, 379

Agostinelli, Francesco 275

Agranov, Marina 163, 296

Agrawal, Anup 192

Agte, Patrick 100

Aguero, Jorge 183

Aguiar, Mark 165

Aguiar, Victor 161

Aguirregabiria, Victor 255, 397,398

Agur, Itai 60

Ahamed, Mostak 129

Ahern, Kenneth 288

Ahlfeldt, Gabriel 55

Ahlquist, John 353

Ahlskog, Rafael 349

Ahlstrom, Laura J. 61

Ahmadizadeh, Mohammad 300

Ahmadpoor, Mohammad 98

Ahmed, Tanima 205

Ahn, Daniel 249

Ahn, Hie Joo 266, 397

Ahnert, Toni 297

Aikman, David 144

Aiura, Hiroshi 139

Aizer, Anna 66, 143, 294

Ajayi, Kehinde 377

Ajilore, Olugbenga 125, 340,374

Ajzenman, Nicolas 174

Akbarpour, Mohammad 182

Akcigit, Ufuk 67, 117, 220, 232, 293

Akee, Randall 61, 140, 206

Aker, Jenny C. 276

Akerlof, George 259

Akerlof, Robert 281

Akey, Pat 75, 393

Akhtari, Mitra 167

Akinci, Ozge 346

Akresh, Richard 354

Aksoy, Billur 220

Aksoy, Cevat Giray 93, 174
Akyol, Ali 375

Alabaad, Hanadi 341

Alam, Md Rafayet 51

Alazzawi, Shireen 253, 266

Albelda, Randy 218

Albiac, Jose 360

Albouy, David 113

Albrecht, Jim 400

Albuquerque, Rui 325, 365

Aldana, Ursula 183

Alderucci, Dean 146

Aldy, Joseph E. 93, 347

Ale-Chilet, Jorge 356

Alesina, Alberto 181, 234

Alexander, Diane 387

Alexopoulou, Ioana 33

Alfaro, Laura 216, 358, 384

Ali, Ayesha 32, 51

Ali, Fahd 169

Ali, Mona 157

Aliprantis, Dionissi 112

Allcott, Hunt 225

Allemand, Denis 300

Allen, Bradley J. 51

Allen, Craig 219

Allen, Lindsay 244

Allen, Roy 161

Allen, Treb 231

Allende, Claudia 84, 100

Alm, James 377

Almeida, Felipe 155, 331

Almeida, Heitor 285

Almond, Douglas 143, 387

Alok, Shashwat 330

Alpanda, Sami 256

Alpert, Abby 244

Alsabah, Khaled 194

Alsan, Marcella 349, 387

Alston, Mackenzie 89

Altavilla, Carlo 326

Alter, Adrian 385

Altindag, Duha Tore 89

Altomonte, Carlo 378

Alves, Carolina 128

Alves, Romulo 196 
Amador, Manuel 125, 165, 383

Amaral, Sofia 120

Ambrocio, Gene Paul Gerard 35

Ambrose, Brent 156, 290, 333

America, Richard 168

Amihud, Yakov 365

Amin, Modhurima Dey 104

Amiti, Mary 358

Ammann, Manuel 188

Amponsah, Samuel 171, 203

Amuedo-Dorantes, Catalina 206, 254

An, Xudong 332

An, Zhiyong 282

Anadu, Kenechukwu 73

Ananat, Elizabeth O. 340

Anas, Alex 388

Andersen, Steffen 388

Anderson, Alyssa 77

Anderson, D. Mark 208

Anderson, Gareth 99

Ando, Tomohiro 30

Andolfatto, David 68

Andor, Mark 323

Andrade, Sandro 41

Andrei, Daniel 390

Andreoni, James 158, 323

Andrew, Alison 247

Andrews, Isaiah 211

Anenberg, Elliot 395

Angeletos, George-Marios 161

Angelov, Nikolay 45

Angelucci, Manuela 60, 183

Angner, Erik 122

Annan, Francis 203

Antecol, Heather 351

Antipa, Pamfili 245

Antman, Francisca M. 313

Anton, Miguel 75

Antoniades, Alexis 115

Antoniou, Constantinos 188

Antonovics, Kate 256

Antras, Pol 214

Anukriti, S. 172

Anundsen, Andre 242, 332

Aragon, George 153

Arai, Yoichi 369

Arbel, Yuval 177
Arce, Fernando 137

Archakov, Ilya 212

Archibald, Thomas 39

Archibong, Belinda 89, 131, 203, 241

Arcidiacono, Peter 313

Arcila, Andres 159

Arefeva, Alina 242

Arellano, Cristina 295

Arellano Gonzalez, Jesus 259

Ari, Anil 60

Arias, Jonas 336

Arkhangelsky, Dmitry 119

Armey, Laura 301

Armitage, Sarah 93

Arnold, Marc 40

Arnould, Guillaume 30

Arold, Benjamin 62

Arslan-Ayaydin, Ozgur 191

Artavanis, Nikolaos 29

Arteaga, Carolina 94, 379

Arteaga, Irma A. 45, 47

Artuc, Erhan 226

Artz, Benjamin 271, 399

Aryal, Gaurab 335

Asad, Sher Afghan 89

Asai, Yukiko 217

Ash, Elliott 378

Ashenfelter, Orley 139

Ashraf, Nava 90, 348

Asis, Gonzalo 377

Asiseh, Fafanyo 125

Aslan, Hadiye 106

Assaad, Ragui 174

Assous, Michael 338

Astier, Nicolas 263

Atal, Juan Pablo 356

Atalay, Enghin 146, 353

Ates, Sina 117, 220, 232, 293

Athey, Susan 119, 149, $215,224,298$

Atkins, Rachel Marie Brooks 344

Atkinson, Glen 289

Attanasio, Orazio 163, 270

Atwood, Alicia 244

Aucejo, Esteban 313

Auclert, Adrien 180

Auerbach, Alan 175, 279

Auh, Jun Kyung 240

Auriol, Emmanuelle 376

Austin, Garrett Wes 349

Autor, David 96, 282
Avdis, Efstathios 210

Avdjiev, Stefan 346

Avenancio-Leon, Carlos

Fernando 351

Avetisyan, Misak 134

Avilova, Tatyana 69, 70

Avraham, Ronen 49

Avramov, Doron 149

Avsar, Veysel 265

Ayala, Jordan 344

Aydin, Deniz 364

Aygun, Aysun 218

Ayres, Andrew 235

Ayromloo, Shalise 176, 177

Ayyagari, Meghana 286

Azar, Jose 75, 106, 139

Azevedo, Viviane 304

Azimi, Mehran 192

Aziz, Ahmed Tariq 36

Azmat, Ghazala 376

Azoulay, Pierre 98, 138, 338

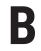

Ba, Bocar 356, 374

Babenko, Ilona 202

Babina, Tania 109

Babus, Ana 178

Bacchetta, Philippe 334

Bachas, Natalie 199

Bachas, Pierre 64, 304

Bachmann, Rudi 136

Back, Kerry 287

Bäckman, Claes 290

Backstrom, Jesse D. 360

Backus, Ann 216

Backus, Matthew R. 165, 212, 310, 311

Badgett, Lee 184

Badruddoza, Syed 104

Bae, Chang Suk 192

Bae, Kee-Hong 364

Baghai, Ramin 109

Baghban Ferdows, Soroosh 45

Bagues, Manuel 321

Bahar, Dany 175, 357

Bai, Jennie 240

Bai, Yan 227, 295

Bailey, James 45

Bailey, Martha J. 66, 94, 275,343 
Bailey, Michael C. 231

Baily, Martin Neil 357

Baiman, Ron 127, 134

Baird, Sarah 215

Baires, Wilber 95

Bajari, Patrick 167

Bajgar, Matej 232

Baker, Erin 263

Baker, Lawrence 86

Baker, Malcolm 200

Baker, Scott 136

Bakoush, Mohamed 99

Bakshi, Gurdip 394

Bakyono, Richard 177

Balaban, Rita 96

Balasubramanian, Natarajan 218

Balasubramanian, Sriram 79

Balboni, Clare 283

Balcilar, Mehmet 266

Baldassi, Carlo 117

Bali, Turan 151, 196, 236

Baliamoune-Lutz, Mina 125, 203, 241

Balisacan, Arsenio 269

Balistreri, Edward 72

Ballensiefen, Benedikt Fabian 41

Balliester Reis, Thereza 81

Balter, Anne 255

Banal-Estanol, Albert 106, 311

Bandiera, Oriana 283, 348

Bandyopadhyay, Arka 332

Banerjee, Abhijit 233

Banerjee, Simanti 205

Banerjee, Snehal 288

Banerjee, Somalee 345

Baniya, Suprabha 142

Bannier, Christina E. 189

Banuri, Sheheryar 220, 266

Bao, Jack 328

Bar-El, Ronen 177

Baranes, Avraham Izhar 394

Baranov, Victoria 65

Barberis, Nicholas 239

Barendse, Sander 212

Barillas, Francisco 326

Barnes, Spencer 193

Barnett, Michael L. 86

Barnichon, Regis 265

Barofsky, Jeremy 46

Baron, E. Jason 60
Barr, Tavis 52

Barrage, Lint 93, 259

Barreira, Paul 314

Barrero, Jose Maria 117, 231

Barrett, Chris 380

Barseghyan, Levon 161, 311,336

Barth, Daniel 73

Bartlett, Robin 221

Bartley, Alan 176

Bartos, Vojtech 86

Bartram, Sohnke 362

Baryshnikov, Pavel 372

Barzotto, Mariachiara 347

Basilico, Matthew 314

Baskaran, Thushyanthan 316

Baslandze, Salomé 67

Basteck, Christian 163

Basten, Christoph 121, 187

Bastian, Jacob 278

Bastianello, Francesca 194

Bastos, Paulo 226

Basu, Sanjukta 31, 50

Basu, Sudipta 169

Batabyal, Amit 78, 79

Batista, Catia 276

Battigalli, Pierpaolo 246

Bau, Natalie 167

Bauer, Daniel 334

Bauer, Michael 210

Bauer, Michal 86

Bauer, Rob 193

Baughman, Reagan 278

Bauhoff, Sebastian 345

Baum, Charles L. 219

Bauman, Yoram 149, 307

Bauner, Christoph 222

Bayer, Amanda 96, 176, 235, 272

Bayer, Patrick 341

Baylis, Patrick 186

Bazzi, Samuel 62

Beach, Brian 208, 256, 347

Beaumont, Paul 328

Beblo, Miriam 250

Bech, Morten L. 230

Becher, David 329

Becht, Marco 329

Beck, Sedefka 272

Beck, Thorsten 347

Becker, Anke 234

Becker, Bo 152
Becker, Sascha O. 62, 174, 175, 244

Beckmeyer, Heiner 196

Bednarek, Peter 121

Bedoya, Guadalupe 345

Beede, David 146

Beegle, Kathleen 215

Beer, Sebastian 281

Begenau, Juliane 200, 251, 322

Beghin, John 37

Begley, Jaclene 80

Begley, Taylor 129, 284

Behbahani, Amirhossein Amini 300

Behrer, Patrick 299

Bekaert, Geert 394

Beladi, Hamid 79, 128

Belavina, Elena 118

Bell, Adrian 197

Bellak, Christian 91

Bellani, Luna 46

Belleflamme, Paul 40

Bellégo, Christophe 176

Belley, Philippe 176

Bellofiore, Riccardo 78, 128

Bellucci, Davide 43

Belman, Dale 300

Belo, Frederico 74

Beltrame, Giacomo 33

Beltramo, Theresa 223, 312

Ben-David, Itzhak 76, 200

Ben-Rephael, Azi 191

Ben-Shahar, Danny 80

Bena, Jan 239

Benartzi, Shlomo 236, 381

Benchimol, Jonathan 40, 59

Benetton, Matteo 83, 99

Bengoa, Marta 216, 265

Bengui, Julien 137, 384

Benigno, Gianluca 383

Benjamin, Dwayne 96

Benmelech, Efraim 363

Bennedsen, Morten 317

Bennett, Benjamin 152, 363

Benson, Alan 384

Bento, Antonio 137

Bento, Pedro 118

Bentzen, Jeanet 245

Benzell, Seth 279

Berg, Claudia 53

Berg, Peter 88 
Berg, Tobias 107

Bergant, Katharina 238

Bergbauer, Annika B. 224

Bergeaud, Antonin 67, 357,379

Berger, Allen 169, 298

Berger, David 115, 339

Berger, Elizabeth 285

Bergholt, Drago 380

Bergman, Peter 230

Bergstrand, Jeffrey 214

Berik, Günseli 263

Berk, Jonathan 240

Berkes, Enrico G. 262

Berlingieri, Giuseppe 232

Berman, Eli 159, 343

Bernanke, Ben 306

Bernard, Benjamin 178

Bernard, Sabine 195

Berndt, Antje 113, 288

Berndt, Ernst 58

Bernhardt, Dan 85, 389

Bernheim, B. Douglas 182, 296

Bernstein, Richard 380

Bernstein, Shai 239

Berry, James 381

Bertoldi, Moreno 267

Bertrand, Marianne 170, 217,312

Berzins, Janis 38

Besley, Tim 163

Bessen, James 62, 63

Betancourt, Roger R. 80, 81

Betsey, Charles 168

Bevilaqua, Julia 378

Bevis, Leah 222

Bhandari, Anmol 199

Bhanot, Syon 96

Bharadwaj, Prashant 233, 276

Bharati, Tushar 48

Bhaskar, V. 379

Bhatt, Monica 312

Bhattacharya, Haimanti 274

Bhattacharya, Jay 345

Bhattacharya, Vivek 335

Bhattarai, Saroj 248

Bhutta, Neil 130

Biais, Bruno 237

Bian, Bo 142

Bianchi, Daniele 394

Bianchi, Javier 137, 383
Bianconi, Marcelo 215

Biasi, Barbara 179

Bielecki, Marcin 256

Bieler, John 320

Biguri, Kizkitza 75

Bilir, Kamran 231

Billio, Monica 193

Bilmes, Linda 246

Bindal, Shradha 106

Bindseil, Ulrich 33

Bird, Daniel 209

Bird, Robert 189

Birke, David 278

Birkeland, Kathryn 271, 272

Biroli, Pietro 95

Bisiere, Christophe 237

Biswas, Rumpa 189

Bitler, Marianne 262

Biu, Ofronama 344

Bivens, Josh 88, 166

Bjerkholt, Olav 338

Bjorkegren, Daniel 231

Bjørnland, Hilde C. 256, 379

Blaauw, Duane 184

Black, Sandra E. 96, 227 , 282

Blackwell, Calvin 272

Blair, Peter 341

Blalock, Garrick 223

Blanchard, Olivier 175 , 320

Blanco, Luisa 97, 206, 374,375

Blankespoor, Brian 53, 381

Blascak, Nathan 45

Blattman, Christopher 312

Blattner, Laura 200

Blau, Francine 227

Bleakley, Hoyt 385

Blevins, Jason 255

Blickle, Kristian 277

Block, Fred L. 204

Bloem, Jeffrey 223

Bloom, Nicholas 66, 117, 220

Blume, Lawrence 182

Blumenstock, Joshua 159

Blundell, Richard 163

Blundell, Wesley 324

Bluwstein, Kristina 103

Boberg-Fazlic, Nina 262

Boccanfuso, Jeremy 33
Bocola, Luigi 295, 335, 383

Boerner, Lars 52

Bofinger, Yannik 189

Bogan, Vicki 97, 205

Bogousslavsky, Vincent 365

Bohn, Jim 73

Bojilov, Raicho 52

Boldrin, Michele 35

Bole, Velimir 308

Bollen, Nicolas 153

Boller, Lysle 311

Bollinger, Bryan 324

Bolotnyy, Valentin 179, 314

Bolt, Wilko 214

Bolte, Lukas 141

Bonaime, Alice 75

Bonaldi, Pietro 213

Bonatti, Alessandro 209

Bond, Shaun 396

Bond, Timothy N. 173

Bonfiglioli, Alessandra 142

Bonfim, Diana 93, 214

Bonhomme, Stephane 211, 372

Bonin, John 91, 308

Boppart, Timo 280, 379

Bordalo, Pedro 232, 328

Bordo, Michael 145, 368

Borgschulte, Mark 73, 346

Borio, Claudio 71

Borker, Girija 104, 105

Borochin, Paul 42, 189

Borusyak, Kirill 397

Boskin, Michael 279

Bossavie, Laurent 349

Bostian, A. J. A. 333

Bostic, Raphael 113

Bosworth, Barry 357

Botero Degiovanni, Hernan 50

Bottan, Nicolas 323

Bottasso, Anna 39

Botti, Simona 381

Bottone, Marco 115

Boudreau, Kevin 98

Boudreau, Laura 283

Boudry, Wally 396

Boukidis, Constantine M. 219

Boulware, Karl 341

Boumans, Marcel 87

Bourassa, Steven 113, 242 
Bourveau, Thomas 391

Boushey, Heather 61, 134, 322

Boustan, Leah 181, 385

Bouvard, Matthieu 237

Bouwman, Christa H.S. 229, 230

Bowblis, John R. 207

Bowles, Samuel 226

Bown, Chad P. 303, 387

Boxell, Levi 116

Boyer, Kenneth D. 127

Boyson, Nicole 153

Bozou, Caroline 40

Bracha, Anat 229

Brada, Josef C. 91, 308

Bradley, Daniel 50,361

Brady, Gordon 164

Braghieri, Luca 225

Brahma, Dweepobotee 104

Brailly, Julien 135

Brailovskaya, Valentina 276

Brainard, Lael 104

Brainerd, Elizabeth 376

Brandao Marques, Luis 35

Brandt, Loren 207

Brandt, William G. 300

Branger, Nicole 193, 196, 399

Branstetter, Lee 146

Braschke, Franziska 351

Bräuer, Konstantin 188

Braunstein, Elissa 221, 252, 263

Bravo, Monica Martinez 168

Braxton, J. Carter 348

Breda, Thomas 355

Bredtmann, Julia 48

Breeden, Sarah 104

Breig, Zachary 274

Brennecke, Claire 169

Breon-Drish, Bradyn 201

Breugem, Matthijs 107

Breunig, Christoph 337

Breunig, Ian 267

Breza, Emily 233, 327

Brick, Ivan 192

Bridges, Jonathan 144

Briukhova, Olga 187

Broadbent, Ben R. 355

Broda, Philippe 289

Brodeur, Abel 278
Brogaard, Jonathan 202, 325

Bronchetti, Erin 96

Broner, Fernando 165

Brooks, Benjamin 160, 209

Brooks, Chris 197

Brooks, Leah 388

Brookshire, Michael 253

Brown, Caitlin 283

Brown, Christopher 154, 155, 395

Brown, Clair 299

Brown, Gregory 108, 153

Brown, J. David 254, 376, 389

Brown, Jeffrey R. 69, 381

Brown, Jenny 221

Brown, Meta 343

Brown, Zach 369

Broxterman, Daniel 367

Brueckner, Jan 292

Bruehler, James R. 270, 272

Bruich, Gregory 148

Brumm, Johannes 279

Brummet, Quentin 340

Brunetti, Celso 178

Brunnermeier, Markus 237, 277

Bruno, Ellen Marie 235

Bruno, Valentina 391

Bryan, Gharad T. 62

Bryan, Kevin 224

Brynjolfsson, Erik 146, 225

Bryzgalova, Svetlana 108

Brzoza-Brzezina, Michal 256

Bubb, Ryan 200

Buchak, Greg 130, 326, 335,392

Buchanan, Joy 70

Bucheli, José R. 254

Buchholz, Nicholas 119

Buchner, Matthias 394

Buckles, Kasey 70, 94

Buckmann, Marcus 103

Budish, Eric 83, 84, 100

Bueno, Carycruz 340

Bueno, Cruz 401

Buffa, Andrea 108

Buffington, Cathy 146

Builes, Martha Susana Jaimes 123

Bullard, Sam 34

Bullinger, Lindsey 88
Bundorf, M. Kate 243, 338

Buonanno, Paolo 372

Burchardi, Konrad 71

Burgess, Robin 283

Burke, Mary 400

Burkhardt, Jesse 324

Burkhauser, Richard V. 68

Burlig, Fiona 123, 279

Burlon, Lorenzo 326

Burn, Ian 184

Burnette, Jeffrey 340

Burstein, Ariel 118

Bursztyn, Leonardo 168, 323

Burtraw, Dallas 389

Buser, Thomas 382

Bushnell, Jim 389, 390

Bushong, Ben 292

Buss, Adrian 107

Busse, Jeffrey 193

Bustamante, M. Cecilia 199

Butera, Luigi 323

Butler, Julianna 61

Butters, Andrew 389

Button, Kenneth 134

Button, Patrick 89

Byambadalai, Undral 207

Byers, Deborah 297

\section{C}

Caballero, Ricardo 302

Cabral, Marika 371

Cabus, Sofie 44

Caetano, Gregorio 84

Caglio, Cecilia 100

Cahill, Kevin E. 254, 301

Cai, Gaoyang 32

Cai, Jinghan 41

Cai, Ning 36

Cai, Xiangshang 187

Cakir, Metin 222

Calani, Mauricio 216

Caldwell, Sydnee 218, 318, 319,350

Calice, Giovanni 169

Callaway, Brantly 398

Callen, Mike 58

Calligaris, Sara 232

Calomiris, Charles W. 245

Calonico, Sebastian 369

Calub, Renz Adrian T. 257

Calvano, Emilio 369 
Calvi, Rossella 283

Calzolari, Giacomo 369

Camacho, Maximo 256

Camera, Gabriele 142

Camerer, Colin 122, 181, 328

Campa, Pamela 321

Campano, Fred 268

Campbell, Jeffrey 249

Campbell, John 390

Campbell, William D. 270

Campello, Murillo 393

Canavire-Bacarreza, Gustavo J. 388

Canay, Ivan 209

Canayaz, Mehmet 73

Candela, Rosolino 120

Canning, David 203, 241

Cannonier, Colin 89, 271

Cantet, Natalia 60, 177

Cantillo, Andres 169

Cantore, Cristiano 99

Cao, Dan 220

Cao, Hao-Yu 56

Cao, Jianfei 209

Cao, Jie 190, 198

Cao, Jin 47, 214

Cao, Linyi 33

Cao, Ruiqing 140

Capitán, Tabaré 43

Cappelen, Alexander 142

Capponi, Agostino 178, 238, 287, 391

Capra, Monica 182

Carattini, Stefano 72

Carbó Valverde, Santiago 298

Card, David 174, 354, 355

Carey, Colleen 371

Carlana, Michela 66

Carlin, Wendy 226

Carlson, Deven 314

Carlson, Mark 313

Carneiro, Pedro 44

Carpenter, Christopher Scott 184

Carpio, Lucia Del 321

Carr, Jillian 67

Carr, Michael 218, 300

Carrell, Scott 313

Carrera, Mariana 183

Carret, Vincent 338

Carrillo-Tudela, Carlos 310

Carroll, Caitlin 262

Carroll, Daniel 112
Carson, Richard 72

Carson, Scott Alan 241

Carstens, Agustín 355

Carstensen, Kai 136

Carter, Andrew 209

Caruso, Raul 343

Carvalho, Carlos 71

Carvalho, Jean-Paul 245

Carvalho, Leandro 86

Carvalho, Vasco 118

Casamatta, Catherine 237

Cascio, Elizabeth U. 173, 349

Case, Anne 88, 275

Casey, Marcus 89, 113, 342,375

Casolari, Amber 186

Castellanos, Kenneth 310

Castex, Gonzalo 176

Castillo, Marco 158

Castro, Pedro 36

Catan, Emiliano 200

Cattaneo, Matias 211, 369

Cavallo, Alberto 115, 217

Caviglia-Harris, Jill 284

Cazes, Sandrine 252

Celentano, Francesco 40

Celil, Hursit 41

Cerra, Valerie 78, 79, 303

Cerreia-Vioglio, Simone 117,371

Cesa-Bianchi, Ambrogio 66, 99

Cesur, Resul 160

Cetemen, Esat Doruk 209

Cette, Gilbert 249, 357

Chabakauri, Georgy 391

Chaboud, Alain 286

Chaderina, Maria 285

Chahrour, Ryan 397

Chairassamee, Nattanicha 49

Chakravorty, N.N. Tarun 54

Chakravorty, Ujjayant 360, 361

Chalmers, John 382

Chamba, Enith Flores 375

Chamberlain, Gary 248

Chambers, Robert 258

Chan, David 146, 147

Chan, Eric 230

Chan, Mons 318, 384

Chan, Nathan W. 148, 220

Chan, Sewin 291
Chandrasekhar, Arun 233, 323

Chaney, Thomas 71

Chang, Ha-Joon 176

Chang, Huibin 388

Chang, Ya-Ting 29

Chang, Yenjae 388

Chang, Yoosoon 265, 266

Chapman, Jonathan 208, 293

Chari, Anusha 216, 226, 358, 377

Chari, Varadarajan 125

Charles, Kerwin 208, 376

Charles, Loïc 87

Charoenwong, Ben 33

Chassang, Sylvain 295

Chassonnery-Zaigouche, Cleo 227

Chatterjee, Anomitro 130

Chatterjee, Bibaswan 30

Chatterjee, Somdeep 315

Chatterji, Pinka 228

Chauvet, Marcelle 256

Chauvin, Kyle 30

Che, Xiaogang 52

Che, Yeon-Koo 117, 298

Chegut, Andrea 331

Chemmanur, Thomas 196, 197

Chen, Alice 147

Chen, Cheng 318

Chen, Chunda 91

Chen, Cuicui 355, 356

Chen, Feng 46

Chen, Guojun 363

Chen, Heng 85, 369

Chen, Hui 150, 236

Chen, Jennjou 271

Chen, Jianhao 319

Chen, Jiaying 30

Chen, Joyce 172, 268

Chen, Juan 190

Chen, Kaiji 248

Chen, Liang 212

Chen, Liwen 132

Chen, Maggie 386

Chen, Mary 280

Chen, Mingli 162

Chen, Qianying 35

Chen, Shiqi 190

Chen, Shiyi 47

Chen, Shuai 378

Chen, Stacey H. 138

Chen, Tao 159 
Chen, Xiaohong 337

Chen, Yan 163

Chen, Yi 209

Chen, Zhiyao 287

Chen, Zhuo 236

Chen, Zhuoqiong 398

Chen Peraza, Juliana 32

Cheng, Allen 391

Cheng, Cheng 67, 255

Cheng, Chunli 41

Cheng, Hao 366

Cheng, Ing-Haw 151

Cheng, Shuyi 189

Cheng, Si 214

Cheng, Xin 36

Cheng, Xu 337

Cheng, Yi 387

Cheng, Yuan 35

Cherif, Reda 297

Chernew, Michael 86, 371

Chernov, Mikhail 77, 109

Chernozhukov, Victor 167, 251, 294, 372

Cherrier, Beatrice 122, 227

Chester, Lynne 87, 260, 401

Chetty, Raj 148, 182

Chevalier, Arnaud 319

Chevalier, Judith 205, 265

Chi, W. Edward 186

Chia, Wai Mun 192

Chiang, Harold 369

Chiang, Kevin 331

Childers, David 212

Childs, Brad D. 271

Chinco, Alexander 109, 325

Chirikov, Igor 135

Chirinko, Robert 358

Chiteji, Ngina 97

Chiu, Jonathan 68

Chiu, Li-Ting 195

Chiu, Ryan 358

Cho, Caleb 320

Cho, Heepyung 113

Cho, Thummim 150

Chodorow-Reich, Gabriel 175, 295, 322, 330

Choi, C.Y. 79, 395

Choi, Daewoung 363

Choi, Dong Beom 366

Choi, Eleanor Jawon 49

Choi, Jaewon 237, 328

Choi, Jaewoo 49

Choi, James J. 62, 364
Choi, Jay Pil 298

Choi, Michael 68

Chou, Shin-Yi 207

Choudhury, Sanchari 30

Christensen, Darin 101

Christensen, Garret 278

Christensen, Peter 105

Christopher, Jan 401

Chu, Junhong 352

Chu, Yongqiang 80, 113, 157

Chuang, Hongwei 138

Chuku, Chuku 240

Chulkov, Dmitriy 272

Chung, Kim Sau 30

Chyn, Eric 94, 156

Chytilová, Julie 86

Ciancio, Alberto 176

Ciani, Andrea 318

Cicala, Steve 123

Cicero, David 363

Cieslak, Anna 131, 274

Cihak, Martin 280

Cinar, Mine 300

Cingolani, Massimo 292

Cinnirella, Francesco 143

Cipullo, Davide 314

Cisternas, Gonzalo 209

Claessens, Stijn 280

Clancy, Daragh 165

Clancy, Matthew 92

Clapp, John 79

Clarida, Richard 180

Clark, Charles M. 81

Clark, Damon 230

Clark, Patrick 380

Clarke, Charles 362

Clausing, Kimberly 166

Clay, Karen 186, 346

Clayton, Jim 112

Clemens, Michael 181, 350

Clements, Douglas H. 173

Clements, Mark 151

Clerici-Arias, Marcelo 186

Clithero, John 181

Cocco, Joao 107, 294

Cochran, Howard H. 271

Coelho, Maria 281

Coen, Jamie 144

Coffman, Katherine 229, 321

Coglianese, John 322

Cohen, Avi J. 96

Cohen, Jeffrey 126, 127, 292
Cohen, Jennifer 375

Cohen, Lauren 364

Cohen, Linda 389

Cohn, Alain 142

Cohn, Jonathan 329

Coibion, Olivier 115, 161, 232, 266, 274, 368, 396, 397

Coker, David 164

Colangelo, Kyle 294

Coles, Jeff 264

Collier, Benjamin L. 333

Collier, Paul 301

Collin-Dufresne, Pierre $107,287,365$

Collins, Brett 376

Collinson, Robert 293

Collis, Avinash 32, 225

Collis, Manuela 229

Colmer, Jonathan 94

Colonnelli, Emanuele 109

Compiani, Giovanni 83

Cong, Lin William 260

Cong, Will 201, 237

Conklin, James 130, 157, 290

Conlon, Christopher T. 165,311

Connolly, Robert 331

Conrad, Cecilia 140, 263

Contreras, Salvador 340, 341

Converse, Nathan 36, 145

Conway, Patrick 96

Conzo, Pierluigi 43, 147

Cook, Lisa 65, 235, 341

Cook, Nikolai 278

Cookson, J. Anthony 303

Cooney, Paul 169, 401

Cooper, Daniel 88

Cooper, Jasper 183

Cooper, Russ 68

Copeley, Leto 272

Coppola, Antonio 233

Corbae, Dean 335

Corhay, Alexandre 199

Corinth, Kevin 68

Cornaggia, Jess 73, 109

Cornaggia, Kimberly 73

Cornelson, Kirsten 67, 379

Corno, Lucia 95

Cornwall, Gary 267

Cororaton, Anna 309

Corradi, Valentina 213

Corrado, Carol 225 
Correa, Eugenia 241, 242, 331

Correa, Ricardo 38, 121, $214,233,280$

Correia, Sergio 313

Cortes, Gustavo 56

Cortes, Kalena E. 60

Cortes, Patricia 217

Corum, Adrian Aycan 329

Costantini, Orsola 330, 334

Cotelioglu, Efe 196

Coughlin, Maura 161

Coulibaly, Louphou 136, 137

Coulombe, Harold 381

Coulson, Edward 243, 291

Couts, Spencer 331

Covert, Thomas R. 123, 185

Cowgill, Bo 179, 224, 225, $323,350,384$

Cox, Gregory 337

Cox, James 219, 296

Cox, Robynn 89, 340, 341, 374

Coyle, Diane 126

Craig, Stuart 86

Crane, Leland 280

Crinò, Rosario 142

Criscuolo, Chiara 232

Crosby, John 394

Crosignani, Matteo 238

Croson, Rachel 227

Crouzet, Nicolas 106, 286

Crowley, Meredith 359

Cruz, Cesi 234

Cuartas, Alejandro Puerta 129

Cuciniello, Vincenzo 59

Cuculiza, Carina 97, 188, 196

Cuéllar, Mariano-Florentino 273

Cuesta, Jose Ignacio 77

Cuevas, Angel 378

Cuevas, Ruben 378

Cui, Xiaomeng 259

Cujean, Julien 390

Cullen, Joseph 257

Cullen, Zoe 323, 350, 384

Cumbers, Andrew 87

Cummins, Joe 215

Cunat, Vicente 110

Cunha, Flavio 270

Cunningham, Chris 333
Cunningham, Colleen 264

Cunningham, Jamein 125, $342,374,401$

Cunningham, Scott 359, 375

Curfman, Christopher J. 230

Curiel, Claudia 44

Currie, Helen 249

Currie, Janet 65, 67, 101, $138,227,262,315$, 346, 387

Custodio, Claudia 74, 238

Cutler, David 262

Cvijanovic, Dragana 112, 256, 329

Czech, Robert 394

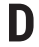

D'Acunto, Francesco 64, 106, 178, 392

d'Astous, Philippe 388

D'Errico, Marco 264

D'Exelle, Ben 177

da Nechio, Fernanda 71

Da, Zhi 192

Dahiya, Sandeep 210, 289

Dai, Ruochen 207

Dalgic, Husnu 334

Dalton, John T. 116

Daly, Mary C. 104, 133, 250

Dang, Tri Vi 193

Daniel, Kent 288

Daniele, Gianmarco 378

Danieli, Oren 218, 319

Daniels, Gerald Eric 341

Dannreuther, Charlie 170

Dao, Hoang 56

Darity, William 125, 168, 235

Da Rocha Lima Filho, Roberto Ivo 43

Darst, Matt 100

Das, Jishnu 345

Das, Monica 37

Das, Ram Upendra 129

Das, Tirthatanmoy 302

Dasgupta, Amil 329

Dastrup, Sam 267

Daumas, Louis 157

Dauth, Wolfgang 54

Davidson, Andrew 271
Davies, Richard 148

Davila, Eduardo 169, 277, 325, 393

Davis, Ann E. 154, 203, 204, 305, 401

Davis, C. Austin 312

Davis, Donald 384

Davis, Jesse 288

Davis, John 87

Davis, Mike 305

Davis, Morris 80

Davis, Scott 136

Davis, Steven J. 359, 360, 400

Davydenko, Sergei 289

Davydiuk, Tetiana 260

Dawid, Herbert 254, 255

de Almeida, Rafael Galvão 164

de Azevedo, Andre Filipe 36

de Bodt, Eric 75

de Boer, Jantke 386

de Boyrie, Maria E. 265

de Cornière, Alexandre 298

De Figueiredo Silva, Felipe 92

De Giorgi, Giacomo 312

De Haas, Ralph 65, 93, 304

de la Cruz, Juan 206

De Leo, Pierre 346

De Loecker, Jan 117, 265, 311, 356

de Marcellis, Nathalie 216

De Neve, Jan-Emmanuel 282

de Oliveira, Angela C. M. 219

de Oliveira Souza, Thiago 40

de Paula, Aureo 82

de Roux, Nicolas 314

Deadman, Erica 226

Dean, Mark 336

Deaner, Ben 212

DeAngelo, Greg 182

Dearing, Adam 255

Deaton, Angus 58, 101, 163, 248, 275

Deb, Saikat Sovan 198

Decarolis, Francesco 368

Dechter, Evgenia 176

DeCicca, Phil 44

Decker, Ryan A. 220, 303

Decreuse, Bruno 400 
Dedola, Luca 115

Deere, Carmen Diana 263

DeFusco, Anthony 130

Degryse, Hans 191

Deininger, Matthew 280

Del Boca, Daniela 275

Del Viva, Luca 196

Delecourt, Solène 140, 345

Delfino, Alexia 348

Delgado, Mercedes 65

Delgado, Miguel A. 213

Delhommer, Scott 184

Della Corte, Pasquale 76, 286, 365

Dell'Aqua, Fabrizio 225

Dell'Ariccia, Giovanni 60

Della Vigna, Stefano 279

Dellachiesa, Alejandro E. 61

DeMarco, Laurie Pounder 38

DeMartino, George 243

Deming, David 63, 96, 182,282

Demiral, Elif 229

Demirer, Mert 372

Demirguc-Kunt, Asli 214, 286

Demiroglu, Cem 285

Demyanyk, Yuliya 121, 347

Denes, Matthew 75

Deng, Guoying 56

Deng, Hai-Anh 312

Deng, Xiangrong 40

Deng, Xiangzheng 360

Deng, Xiaohu 316

Deng, Yongheng 113

Deng, Yuanyuan 83

Denicolo, Vincenzo 369

Derenoncourt, Ellora 61, 318

Derwall, Jeroen 193

Desari, Amedeo De 187

Deschenes, Olivier 235, 236, 305, 346

DeShazo, J. R. 149

Deshpande, Manasi 118

Despierre Corporon, Gaëlle 81,366

Devaney, Steven 112

DeVaro, Jed 399

Devereux, John 81, 302

Devereux, Michael 136

Devos, Erik 112

Dew-Becker, Ian 239
Dey, Matthew 339, 373

Deyo, Darwyyn 70

Dhuey, Elizabeth 166

Di Maro, Vincenzo 219

Di Tella, Sebastian 302

Di Vita, Fabio 52

Di Vita, Giuseppe 52

Diamond, Douglas 99, 277

Diamond, Rebecca 67, 293

Diamond, William 152, 327

Dianat, Ahrash 163

Dias, Daniel 346

Dibeh, Ghassan 300

Dick-Nielsen, Jens 200

Dickert-Conlin, Stacy 244

Dicks, David 73

Diette, Timothy 89

Dietz, Simon 310

Diewert, W. Erwin 225

Dildar, Yasemin 120

Dillender, Marcus 373

DiMaggio, Marco 179

Dimand, Robert W. 339

Dinar, Ariel 360

DiNardi, Michael 46

Dinarte, Lelys 312

Dindo, Pietro 35

Dinerslov, Emin 146

Ding, Jing 193

Ding, Lei 113

Ding, Xiang 215

Dinger, Valeriya 196, 214

Dinlersoz, Emin 220

Diop, Moussa 157, 396

Dippel, Christian 70

Dissanayake, Ruchith 39

Disyatat, Piti 71

Dittmar, Robert 210

Dituri, Philip 271

Do, Quoc-Anh 202, 245

Doan, Bao 189

Doehne, Malte 339

Doerr, Sebastian 63, 187

Dolado, Juan 212

Dold, Malte 119

Doleac, Jennifer 94, 179, $225,312,356$

Dolfsma, Wilfred 87, 111

Dolinger, Amy 345

Domadenik, Polona 308

Domini, Giacomo 54

Dominko, Miha 308

Donaldson, Dave 385

Donangelo, Andres 74
Dong, Mengming 107

Dong, Michell Yoonjei 44, 48

Dong, Xi 362

Dong, Yingying 369

Dong, Zhi 30, 53

Doniger, Cynthia 397

Donohue, John 312

Donovan, Kevin 64

Doraszelski, Ulrich 255

Dordal i Carreras, Marc 368

Dorinski, Suzanne M. 254

Dorman, Peter 127, 306

Dorner, Matthias 98

Dorsey, Jackson 122, 389

dos Reis, Magnus 36

Doss, Cheryl 250

Döttling, Robin 150

Dou, Winston Wei 289, 337, 398

Douglas, Reed 193

Doval, Laura 119, 160

Dovis, Alessandro 125, 126

Dow, William H. 88

Downey, Mitch 353

Downs, David 396

Doyle, Joseph 138, 297

Doytch, Nadia 91

Drabek, Zdenek 91

Dräger, Lena 160

Drechsel-Grau, Moritz 34, 190

Drechsler, Itamar 211, 326, 365

Drenik, Andres 318

Dreschel, Thomas 100

Drexler, Alejandro 199

Dreyfus, Bnaya 377

Driscoll, John C. 264

Droes, Martijn 80, 113

Drouard, Joeffrey 176

Drozd, Lukasz 348

Du, Qingjie 193

Du, Songzi 160

Du, Wenxin 77, 100, 153, 233, 286, 335

Du, Xiaoxue 135

Duan, Kun 79

Duan, Yige 352

Duarte, Fernando 322

Dube, Arindrajit 96, 339

Dube, Oeindrila 101

Dubois, Dimitri 31

Duchene, Sebastien 39 
Duchin, Ran 74, 264, 317

Duffee, Greg 394

Duflo, Esther 372

Dufour, Alfonso 193

Dugar, Subhasish 79, 274

Dugoua, Eugenie 310

Dumas, Bernard 77

Dumas, Marion 310

Duncan, Brian 206

Dunn, Abe 147

Dupas, Pascaline 122, 227

Duprey, Thibaut 34

Duque, Juan Carlos 388

Duranton, Gilles 155

Durdu, Bora 35

Dustmann, Christian 354

Dutt, Devika 91, 92

Dutta, Nabamita 114, 128, 129

Duygan-Bump, Burcu 145

Duzhak, Evgeniya 373

Dworczak, Piotr 182

Dymski, Gary 78, 170, 204, 257, 305

Dynan, Karen 69, 101, 175

Dynarski, Susan 60, 135, 227

Dyrda, Sebastian 280

\section{E}

Earle, John S. 376

East, Chloe N. 278, 350

Eberly, Janice 102, 175

Echenique, Federico 370

Echevarria, Jon 343

Eckbo, B. Espen 75, 289

Eckel, Catherine 65

Eckles, David 334

Eckrote, Marissa 88

Edelberg, Wendy 175

Ederer, Florian 264

Edmans, Alex 73, 329

Edwards, Eric 235

Edwards, José 87

Eeckhout, Jan 117, 352

Effenberger, Alexandra 35

Egan, Mark 152, 200

Eggers, Felix 32, 225

Eggertsson, Gauti 199

Eggleston, Karen N. 121, 273

Egorov, Georgy 168

Ehsani, Sina 74
Eichacker, Nina 257

Eichengreen, Barry 303

Eichler, Stefan 36, 386

Eichmeyer, Sarah 225

Eid Jr., William 192

Eilat, Ran 160

Einav, Liran 86, 251

Eisdorfer, Assaf 390

Eisert, Tim 238

Eisfeldt, Andrea 199, 285

Eizenberg, Alon 165

Ekhator-Mobayode, Uche 203

Ekpo, Akpan 203, 240, 401

Ekponon, Adelphe 41

Elamin, Mahmoud 297

Elder, Todd 244

Eldridge, Lucy 302

El Ghoul, Sadok 364

El Hefnawy, Menatalla 196

El-Gamal, Mahmoud 249

El-Shal, Amira 203, 241

Eli, Shari 143

Eliaz, Kfir 160

Ellen, Ingrid Gould 156, 243

Elliot, Amanda 87

Elliott, David 326

Ellison, Sara 106

Elmendorf, Douglas 175

Elsayed, Ahmed 48

Elsby, Michael 281

Elshawa, Rasha 266

Elsner, Benjamin 319

Elu, Juliet 400, 401

Elul, Ronel 129

Elwell, James 68

Emanuel, Natalia 179

Emerson, Tisha Lin Nakao 61,97

Emin, Mustafa 197

Emmett, Ross 164, 269

Emran, M. Shahe 53, 381

Engelberg, Joseph 237, 361

Engelke, Carola 29

Engstrom, Eric 394

Enikolopov, Ruben 168

Enke, Benjamin 234

Epanchin-Neill, Rebecca 389

Epstein, Gerald 258

Epstein, Larry 371

Eraker, Bjorn 151

Eraslan, Hulya 84, 162

Erce, Aitor 165
Erel, Isil 152, 328

Eren, Egemen 153

Erfle, Stephen 270

Ericson, Keith Marzilli 86, 296

Erik, Burcu 180

Eriksen, Mike 290

Eriksson, Katherine 181, 319, 349, 385

Erkal, Nisvan 383

Erkens, Gilles 360

Ermolov, Andrey 394

Erol, Selman 238, 392

Erten, Bilge 120

Espinola-Arredondo, Ana 324

Espinosa, Javier 340

Espinosa, Salvador 43

Esposito, Federico 215, 318

Esteban, Encarna 360

Evans, Charles 104

Evans, David 354

Evans, Richard 76, 110, 279

Evans, William N. 244

Evdokimov, Kirill 162, 212

Evgeniou, Theodoros 211

Ewens, Michael 109

Exley, Christine 182

Exton, Oliver 359

F

Faber, Jasper 134

Fabisik, Kornelia 198

Fack, Gabrielle 231

Fackler, Paul 105

Fadeev, Evgenii 214

Fafchamps, Marcel 283

Faggio, Giulia 155

Faia, Ester 211

Fairlie, Robert 351

Fajgelbaum, Pablo 359

Fajnzylber, Eduardo 335

Fakih, Ali 300

Falato, Antonio 199, 238

Falch, Ranveig 142

Falk, Armin 234

Falk, Justin R. 343

Falvey, Ryan 236

Fan, Manyi Yu 41

Fan, Yi 80, 291

Fan, Ying 315

Fan, Zhenzhen 77, 335 
Fang, Hanming 83, 127, 291

Fang, Lilly 255

Fang, Xiang 286, 335

Fang, Ximeng 324

Fang, Ying 158

Fanning, Jack 370

Fantino, Davide 99

Farahati, Farah 267

Fares Gibb, Lygia Sabbag 221

Farhi, Emmanuel 322

Farmand, Aida 89

Faro, David 381

Farolfi, Stefano 31

Farrell, Diana 226

Farrell, Max 369

Fast, Don 320

Favilukis, Jack 107, 248, 285, 395

Fayissa, Bichaka 203, 240

Fazzari, Steven M. 334

Fedyk, Anastassia 73, 108, 361

Feenstra, Robert 115, 320

Fehr, Dietmar 85, 142

Fei, Chengcheng J. 46

Feigenbaum, James 208, 353

Feigenberg, Benjamin 374

Feir, Donna 208

Feiveson, Laura 69

Feldhütter, Peter 288, 327

Feliciano, Zadia M. 358

Feng, Jinlu 36

Feng, Josh 140

Feng, Joshua 338

Feng, Kai 103

Feng, Xueliang 40

Fenichel, Eli P. 361

Fenner, Arved 121

Ferdows, Nasim B. 45

Ferguson, John-Paul 65

Fernald, John 357

Fernandez, Linda 37

Fernández-Val, Iván 162, 372

Fernandez-Villaverde, Jesus 294

Ferreira, Daniel 152, 201

Ferreira, Joao 296

Ferreira, Miguel 255

Ferreiro, Jesus 81

Ferrero, Andrea 71

Ferroni, Filippo 99
Fetter, T. Robert 185

Fetzer, Thiemo R. 63, 313

Fichtner, Jason 69

Field, Alexander J. 262

Field, Erica 104, 183, 247

Figart, Deborah 292

Figlio, David 70

Figueiredo Walter, Torsten 64

Findeisen, Sebastian 54

Fink, Daniel 331

Fink, Gunther 85

Finkelstein, Amy 86

Fischer, Marcel 42, 156, 193

Fishback, Price 94

Fisher, Lynn 157

Fisman, Raymond 75

Fitzgerald, Timothy 185

Fitzpatrick, Anne 345

Flaaen, Aaron 387

Flacke, René 193, 399

Flandreau, Marc 71

Flannery, Mark 238

Flatnes, Jon Einar 268

Fleck, Susan 303, 320

Fleckenstein, Matthias 202

Flikkema, Clio Bryant 229

Flinn, Christopher 247, 275

Florentsen, Bjarne 76

Florig, Stephan 150

Foad, Hisham 116, 218

Fofack, Hippolyte 171

Fohlin, Caroline 131

Folbre, Nancy 205, 263

Fomenko, Olesya 44

Fong, Christina 141

Fonseca, Julia 327

Fontana, Giuseppe 81

Fontanier, Paul 194

Foote, Chris 80

Forbes, Kristin 179, 233, 345

Forget, Evelyn 87

Fornaro, Luca 137

Forstater, Mathew 127

Fort, Teresa C. 214, 215

Forte, Francesco 164

Fortin, Nicole 179, 282, 353

Fossen, Frank M. 49

Foster, Diana 94

Foster, Dylan 251

Foster, Lucia 146, 227
Fouka, Vasiliki 70, 138, 223

Fourakis, Stelios 165

Fournier, Mathieu 198, 390

Fowles, Richard 134

Fowlie, Meredith 93, 304

Fox, Jeremy 84

Fox, Kevin 225

Fox, Liana 69

Fracassi, Cesare 202

Frame, W. Scott 130, 204

Franch, Fabio 385

Francis, Dania V. 89, 125, $168,254,340$

Franco, Juan Pablo 181

Frank, Eyal 105

Franks, Julian 329

Fraumeni, Barbara M. 255

Frederiksen, Anders 217

Freedman, Matthew 67, 155

Freeman, Patricia 262

Freeman, Richard 63, 132

Friebel, Guido 205, 375, 376

Fried, Stephie 148, 284

Friedman, Benjamin 71

Friedman, John N. 182

Friedrich, Christian 35

Friedt, Felix 126

Frisancho, Veronica 183

Friscia, Bronwyn Lewis 149

Frisvold, David 228

Froot, Kenneth 390

Frug, Alex 209

Frydman, Carola 364

Frydman, Cary 239, 328

$\mathrm{Fu}$, Danying 191

$\mathrm{Fu}$, Shihe 157

$\mathrm{Fu}$, Shiming 391

$\mathrm{Fu}$, Zhe 53

Fudenberg, Drew 116, 181

Fuentes-Medel, Yuly 65

Fulghieri, Paolo 73

Fullerton, Don 283

Fungáčová, Zuzana 93

Funk, Russell 98

Furceri, Davide 66, 249

Furlanetto, Francesco 33, $34,256,380$

Furman, Jason 82, 166, 293

Furman, Jeff 65

Füss, Roland 193

Fuster, Andreas 130 
Gabaix, Xavier 180

Gabarro, Marc 386

Gabriel, Stuart 80

Gabrielli, Maria Florencia 335

Gadea-Rivas, Marıa

Dolores 144, 256

Gadenne, Lucie 64

Gadgil, Salil 52

Gaessler, Fabian 98

Gafarov, Bulat 337

Gagnon-Bartsch, Tristan 296

Gailes, Arthur 141

Gaither, Sarah E. 125

Galanis, Giorgos 261

Galasso, Vincenzo 316

Galbraith, James 246

Gale, William 69

Galimberti, Jaqueson Kingeski 29

Gallagher, Emily 392

Gallagher, Justin 156, 284

Gallardo, Karina 135

Gallego, Francisco 84

Galletta, Sergio 378

Gallier, Carlo 130

Gallus, Jana 64

Galor, Oded 234

Galperti, Simone 246

Gam, Yong Kyu 37, 366

Gammans, Matthew 259

Gancia, Gino 142

Gandhi, Amit 336

Gandhi, Priyank 202

Ganduri, Rohan 332

Ganelli, Giovanni 36

Gangadharan, Lata 382, 383

Ganguli, Ina 63, 98

Ganong, Peter 294

Gans, Joshua 224, 225, 298

Gantchev, Nickolay 110

Gao Bakshi, Xiaohui 394

Gao, Chen 46

Gao, Janet 393

Gao, Lei 316

Gao, Ning 187

Gao, Pengjie 202

Gao, Wayne Yuan 209

Garcia, Daniel 352

Garcia-Jimeno, Camilo 176
Garcia-Perez, Monica 81, 206

Garcia-Ramos, Aixa 50

García-Suaza, Andrés F. 213

Gardeazabal, Javier 343

Garfinkel, Michelle 343

Garin, Andy 376

Garin, Julie 385

Garmann, Sebastian 42

Garner, Thesia 69, 267

Garratt, Rod 68

Garrick, Owen 387

Garriga, Carlos 248, 332, 348

Gartenberg, Claudine 90

Garthwaite, Craig 338

Garvey, Gerald 363

Gassman-Pines, Anna 340

Gatti, Silvia 46

Gautam, Sanghmitra 44

Gau, Yin-Feng 29

Gautier, Kate 52

Gavazza, Alessandro 77

Gavris, Maria 257

Gaynor, Martin 371

Gazmuri, Ana 314

Ge, Muyang 235

Gebhardt, Karen 167, 374

Gechter, Michael 279

Gee, Laura 179, 350

Geelen, Thomas 150

Geiecke, Friedrich 295

Gelber, Alexander 342

Gelfond, Hilary 69

Gelos, Gaston 385

Gemmo, Irina 381

Geng, Heng 309

Genicot, Garance 95

Gennaioli, Nicola 232

Gennaro, Gloria 378

Gentzkow, Matthew 211, 225

Getmansky Sherman, Mila 365

Georg, Co-Pierre 178

Georgarakos, Dimitris 274

Georges, Luise 250

Georgiadis, George 160

Gerakos, Joseph J. 106, 311

Gerarden, Todd 263

Gerardi, Kristopher 130, 204

Gerken, William 153
Geromichalos, Athanasios 33

Gersbach, Hans 85

Gershenson, Seth 339, 340

Gerster, Andreas 323, 324

Gertler, Mark 321

Gertler, Paul 304

Gete, Pedro 204, 248, 332

Getmansky Sherman, Mila 365

Gevorkyan, Aleksandr V. 38,81

Ghaderi, Mohammad 195

Ghanbari, Negar 189

Ghandi, Amit 166

Ghanem, Dalia 72

Ghani, Tarek 159

Ghatak, Maitreesh 283

Ghent, Linda S. 272

Ghilarducci, Teresa 57, 89,123

Ghosh, Amit 340

Ghosh, Anisha 363

Ghosh, Pulak 330

Ghysels, Eric 108

Giannetti, Mariassunta 110, 152, 326, 376

Giannoni, Marc 380

Gibbons, Robert 90, 147, 223, 224, 281, 348

Gibbs, Holly 284

Gibbs, Michael 399

Gibson Brandon, Rajna 362

Gibson-Davis, Christina M. 340

Gibson, Matthew 139, 274

Gicheva, Dora 217

Giesecke, Matthias 49

Giglio, Stefano 108, 202, 391

Gihleb, Rania 229

Gil-Vásquez, Karol 154

Gilbert, Scott Dale 301

Gilbukh, Sophia 79

Gill, Balbinder Singh 189

Gillen, Ben 182

Gillen, David 134

Gillespie, Tom 367

Gillingham, Kenneth 137, 324

Gimbel, Martha 400

Gine, Mireia 75

Gine, Xavi 304

Ginn, Thomas 174 
Ginther, Donna 227

Giovannini, Massimo 37

Girardi, Gherardo 51

Giron, Alicia 331

Girotra, Karan 118

Giroud, Xavier 393

Gissler, Stefan 63, 102

Gittleman, Maury 373

Giuliano, Laura 60, 388

Giuliano, Paola 70, 234, 350

Glaeser, Edward 354

Glebkin, Sergei 393

Glennon, Britta 98, 349

Glewwe, Paul 135, 223

Glosser, Stuart 253

Gluzmann, Pablo A. 358

Gneezy, Ayelet 296

Gödker, Katrin 328

Godoy, Anna 88

Goedde-Menke, Michael 164

Goerlach, Joseph-Simon 84

Goette, Lorenz 83, 323, 324

Goetz, Daniel 115

Goffe, William 185, 186, 270

Gofman, Michael 335

Golan, Roni 80

Goldberg, Linda 144, 214, 346

Goldberg, Pinelopi 163, 359

Golden, Lonnie 252

Goldfarb, Avi 63, 225

Goldin, Claudia 70, 145, 282

Goldin, Jacob 296, 342

Goldmanis, Maris 368

Goldschlag, Nathan 146

Goldsmith-Pinkham, Paul 180

Goldstein, Itay 76, 277

Goldstein, Jonathan 170

Golosov, Mikhail 302

Golub, Benjamin 233, 323

Gomes, Armando 84

Gomes, Carla 380

Gomes, Francisco 72, 107

Gomes, Joao F. 255

Gomez, Carmen 81

Gomez, Matthieu 59, 211, 277

Goncalves, Andrei 74, 326
Goncalves, Felipe 356

Gong, Yazhen 159, 186, 360

Gong, Yifan 290

Gong, Yujing 195

Gonzales, Mariella 314

Gonzalez-Lozano, Heriberto 206

Gonzalo, Jesus 212

Goos, Maarten 63

Gopalan, Radhakrishnan 392

Gopinath, Gita 330

Gordon, Robert 259, 357

Gormsen, Niels 74, 198

Gornall, Will 111, 317

Gorodnichenko, Yuriy 64, 161, 175, 274, 368, 397

Gorrin, Jesus Andres 37

Gorsuch, Marina Mileo 89

Gorton, Gary B. 102, 250, 362

Gosnell, Greer 263

Gottlieb, Joshua 86, 147

Goulart, Gustavo 155

Goulet Coulombe, Philippe 294

Gourinchas, Pierre-Olivier $71,295,346$

Gowrisankaran, Gautam 389

Goyal, Amit 109

Grabka, Markus 114

Grace, Martin F. 334

Graff, Gregory 92

Graff Zivin, Joshua 55, 299

Graham, John 73, 187

Grandjean, Julien 164

Granja, Joao 199

Grant, Alan P. 270, 272

Grant, Laura 325

Granziera, Eleonora 256

Grassi, Basile 118

Grauman, Kristen 251

Gray, Clark 268

Gray, Gary 64

Gray, Rowena 262

Graziani, Grant 387

Graziano, Alejandro 359

Grazzi, Marco 54

Gredil, Oleg 108, 153, 363

Green, Alan 186

Green, Andrew 358

Green, Colin P. 399

Green, Donald P. 183
Greenhalgh-Stanley, Nadia 291

Greenland, Andrew 115

Greenstein, Shane 225

Greenwood, Jeremy 220

Greenwood, Robin 107

Gregoire, Vincent 393

Gregory, Jesse 156

Gregory, Neil 301

Greig, Fiona 226

Greimel, Fabian 34, 190

Grenet, Julien 49, 50, 231

Grennan, Matthew 338

Gretz, Richard T. 51

Grieco, Paul 165

Grier, Kevin 374

Grier, Robin 374

Grieser, William 362

Griffin, John 236

Grillo, Edoardo 85

Grimes, Paul 61, 373, 374

Grinstein-Weiss, Michal 392

Grodzicki, Daniel 276

Grogger, Jeffrey 275

Groll, Thomas 271

Gronqvist, Hans 49, 50

Grooms, Jevay 124, 252, 342

Grooms, Katherine 325

Gros, Daniel 358

Grosfeld, Irena 174

Groshen, Erica 217, 319

Grosjean, Pauline A. 65, 174, 375

Grotteria, Marco 327

Gruber, Jonathan 44, 147

Grünthaler, Thomas 196

Gu, Yizhen 157

Guadalupe, Maria 90, 281, 321

Guenzel, Marius 73

Guerci, Eric 39

Guernsey, Scott 188

Guettler, Andre 199

Guidolin, Massimo 213, 396

Guinan, Eva 64

Gul, Faruk 117

Guldi, Melanie 94

Gulen, Huseyin 232

Gunduz, Yalin 40, 191

Gunes, Tugba 333

Gunnsteinsson, Snaebjorn 46 
Gunsilius, Florian 213

Guo, Audrey 220

Guo, Chuanyi 46

Guo, Hongye 239

Guo, Huiyi 160

Guo, Mengmeng 158

Guo, Naijia 44, 379

Guo, Rong 329

Guo, Xiangyu 367

Gupta, Abhimanyu 113

Gupta, Apoorv 106

Gupta, Deeksha 129, 260

Gupta, Jairaj 347

Gupta, Sudip 106

Gupta, Sumedha 262

Guren, Adam 130, 180, 293

Gurevich, Tamara 141

Guriev, Sergei 174

Gurun, Umit 284, 364

Guryan, Jonathan 376

Gustafson, Matthew 109

Gutiérrez, Germán 380

Gutknecht, Daniel 213

Guven, Baris 128

Guzmán, Jorge 225

Guzman, Martin M. 358

Gyimah-Brempong,

Kwabena 203

Gyntelberg, Jacob 200

Gyöngyösi, Gyozo 63

\section{H}

Haas, Adam 377

Hacamo, Isaac 121, 362

Hachem, Kinda 165, 230, 384

Hacioglu Hoke, Sinem 33

Hackbarth, Dirk 287

Hackethal, Andreas 188, 195

Hadad, Vitor 298

Haddad, Valentin 154, 201, 328

Hadzic, Muris 386

Hagedorn, Marcus 103

Hahn, Youjin 53

Hahnel, Robin 306

Hajda, Jakub 150

Hajdu, Tamas 228

Hakamada, Mai 78

Hake, Eric 289

Hakimov, Rustamdjan 163

Hakobyan, Shushanik 214
Halac, Marina 125

Hale, Galina 298, 378

Halevy, Yoram 370, 371

Halim, Daniel 354

Halket, Jonathan 113

Hall, Anne 267

Hall, John 78, 242

Hall, Robert 145, 302

Haltiwanger, John 68, 225, 293

Hamermesh, Dan 250

Hamersma, Sarah E. 223

Hamilton, Darrick 97, 254, 344

Hamilton, Dennis 197

Hamilton, Gillian 96

Hamilton, James D. 71, 133, 256, 397

Hamilton, Stephen 222

Hamjediers, Maik 250

Hamman, Mary 88

Hammond, Robert 163

Hamory Hicks, Joan 215

Han, Jianlei 316

Han, Jungsuk 365

Han, Lu 332, 359, 395

Han, Munhee 264

Han, Shu 111

Han, Sukjin 251

Han, Xuehui 35

Han, Yaeeun 122

Han, Yiqiang 333

Hanaki, Nobuyuki 39

Hancock, Diana 250

Handa, Sudhanshu 268

Handbury, Jessie 84, 156

Handel, Benjamin 146, 336

Handel, Michael 63

Handley, Kyle 115, 136, 359

Hands, Wade 87

Handwerker, Elizabeth Weber 339

Hanemann, Michael 235

Hanewald, Katja 83

Hanlon, Michelle 342

Hanlon, Walker 208

Hanousek, Jan 308

Hansen, Anne 198

Hansen, Benjamin 67, 357

Hansen, Christian 209, 211,251

Hansen, Lars 248

Hansen, Peter 212

Hansen, Stephen 274, 294
Hanson, Gordon 249

Hanson, Samuel 107, 274

Hanspal, Tobin 188

Hanushek, Eric A. 173, 224, 303

Hao, Stephanie 181

Harhoff, Dietmar 98

Harrell, Stephen 223

Harrington, Joseph 298, 311,369

Harrington, Rachel 244

Harris, Adrienne 236

Harris, Jeffrey H. 178

Harris, Jorgen 389

Harris, Mathew 244

Harris, Timothy 377

Harter, Cynthia 61, 124

Harter, John 124

Hartley, Daniel 80, 156, 284

Hartmann, Sven 148

Hartung, Benjamin 103

Hartwell, Christopher Andrew 313

Hartwig, Benny 191

Harvison, Thuong 194

Hasan, Iftekhar 319

Hasanhodzic, Jasmina 279

Hasanov, Fuad 297

Hasbrouck, Joel 325

Haselmann, Rainer 264

Hassan, Tarek 71, 136

Hastings, Justine 230

Hattori, Takahiro 35

Haupert, Michael 131

Haushofer, Johannes 101, 183

Hausman, Jerry 294

Hawash, Ronia 266

Hayden, F. Gregory 155, 289

Haynes, Richard 391

Haynie, Alan 105

Haywood, Luke 355

$\mathrm{He}$, Ai 108

He, Alex 317

$\mathrm{He}$, Guanming 41

He, Guojun 55

He, Jia 366

$\mathrm{He}, \mathrm{Pu} 118$

He, Xuezhong 32

He, Yinghua 84, 163, 231

He, Zhiguo 151, 236, 260 , 285,392 
He, Zhongzhi (Lawrence) 109

Headley, Andrea M. 374

Hean, Oudom 49

Heath, Rachel 95, 183

Hebert, Benjamin 153

Hebert, Camille 328

Heblich, Stephan 70, 266

Heckman, James J. 145, 270

Hedlund, Aaron 348

Hedtrich, Christoph 352

Heffetz, Ori 292, 377

Hege, Ulrich 328

Heggeness, Misty 338

Heider, Florian 298, 326

Heikensten, Emma 64

Heining, Joerg 132

Heinisch, Katja 29

Heinrich, Carolyn 373

Heinzel, Christoph 333

Heisey, Paul 92

Heitz, Amanda 202

Heldring, Leander 58

Heller, C.-Philipp 163

Heller, Sara 312

Helm, Ines 389

Helper, Susan R. 63, 146 , 399

Henderson, Rebecca 348

Henderson, Shaina 358

Hendricks, Kenneth 185

Hennessy, David 135

Henriksson, Matthew 189

Henry, Peter Blair 97, 226

Herfeld, Catherine 122, 339

Herkenhoff, Kyle 339, 348

Hernandez de Benito, Maria 95

Hernandez-Cata, Ernesto 81

Hernandez, Manuel 56

Herndon, Thomas 292

Herpai, Nicole 344

Herrenbrueck, Lucas 33

Herrera, Gerardo 360

Herrera-Almanza, Catalina 172

Herrerias, Renata 39

Hershbein, Brad 123, 282, 339, 373, 385

Herskowitz, Sylvan 159

Hertel-Fernandez, Alexander 132, 353
Hertweck, Matthias Sebastian 29

Hessami, Zohal 316

Heutel, Garth 93, 284, 310, 390

Heyerdahl-Larsen, Christian 210

Heyes, Anthony 278

Heywood, John S. 399

Hicks, Daniel 374

Hicks, Jason 372

Hidalgo, Cesar A. 216

Higgins, Matthew 338

Higgins, Sean 231, 304, 327

Hill, Andrew 349

Hill, Jeffrey 320

Hill, Ryan 316

Hiller, R. Scott 50

Hilmi, Nathalie 300

Hilpert, Christian Martin 41

Hines, Annie 350

Hines, James 358

Hinzen, Franz 237

Hirschey, Nicholas 236

Hirschfeld, Mary 269

Hirshleifer, David 128, 236, 307, 392

Hizmo, Aurel 130, 290

Hjort, Jonas 224, 318

Ho, Chun-Yu 276, 277

Ho, Kate 265, 371

Ho, Steven Wei 192, 194

Ho, Sy Ha 192

Hoberg, Gerard 75, 239, 285

Hochfellner, Daniela 88

Hockenberry, Jason 207

Hoddinott, John 268

Hoderlein, Stefan 161

Hodgson, Charles 185

Hodler, Roland 301

Hodson, James 73

Hoekstra, Mark 67

Hoel, Jessica B. 359

Hoesli, Martin 113

Hoff, K. Jody 373

Hoff, Karla 224

Hoffmann, Manuel 228

Hoffmann, Vivian 380

Hofmann, Boris 233

Hogan, Thomas 99

Hohberger, Stefan 37

Hoisl, Karin 98
Holladay, J. Scott 310

Hollander, Stephen 136

Hollingsworth, Alex 186, 244

Holmes, Thomas 155, 387

Holmlund, Marcus 44

Holst, Elke 250

Holtemöller, Oliver 269

Holton, Sarah 326

Holz, Justin 374

Homanen, Mikael 93

Hombert, Johan 200

Hong, Han 103

Hong, Ji Yeon 131

Hong, Seung-Hyun 332

Hoover, Gary 176, 177, 235

Hoover, Kevin 87

Hopkins, Barbara 111

Horn, Henrik 91

Hornbeck, Richard 155, 385

Horner, Stephen 219

Hornuf, Lars 148

Horowitz, Andrew W. 129

Hortacsu, Ali 387

Horvath, Balint 214

Horvath, Krisztina 50

Hottman, Colin 115

Hou, Dexin 187

Hou, Kewei 202, 362

Hou, Yu-Qi 56

Hovy, Ed 146

Houde, Jean-Francois 123

Houde, Sebastien 137

Houenou, Boris 203, 240

Houseman, Susan 123, 253, 373

Houston, Mark B. 51

Howell, Sabrina T. 109, $239,260,317,364,389$

Howes, Cooper 368

Howse, Robert 91

Hoynes, Hilary 262, 322

Hoyt, Eric 252

Hsiao, Cheng 372

Hsieh, Chang-Tai 173

Hsieh, Chih-Sheng 207

Hsu, Alex 210

Hsu, Chih-Chiang 29

Hsu, David 239

Hsu, Po-Hsuan 239

Hsu, Rebecca 341

Hsu, Yu-Chin 369

Hu, An (Allen) 195 
Hu, Grace Xing 198

Hu, Jiafei 154

Hu, Jianfeng 197

$\mathrm{Hu}, \mathrm{Lin} 85$

$\mathrm{Hu}$, Maggie 80, 332, 367

Hu, Peicong 247

Hu, Yingyao 398

Hu, Yunzhi 309, 347

Hu, Yutong 194

Hua, Jian 192

Huang, Alan 73

Huang, Chao 39

Huang, Chong 365

Huang, Dashan 108

Huang, Jingzhi 194, 287, 394

Huang, Ling 105

Huang, Naqun 290

Huang, Qianqian 188

Huang, Rongbing 109

Huang, Sean Sheng-Hsiu 207

Huang, Shiyang 194, 288, 394

Huang, Wenqian 188

Huang, Zhangkai 190

Huber, Kilian 77

Huber, Stefanie Jeanette 44

Huber, Tobias 333

Huckfeldt, Christopher 360

Hughes, Joseph 309

Hughes-Cromwick, Ellen 146

Hugonnier, Julien 211

Huh, Sahn-Wook 109

Huisman, Kuno 255

Huizinga, Harry 214

Hull, Peter 397

Humphries, Jane 263

Humphries, John Eric 148, 275, 294, 373

Hung, Chih-Ching 192

Hungerman, Daniel 130, 158

Hurtado, Carlos 155

Hurwitz, Abigail 381

Hussain, Syed Muhammad 34

Hussam, Reshmaan 283

Huszar, Zsuzsa R. 41

Hutchins, Michael 342

Huttunen, Kristiina 176

Huynh, Kim P. 277

Hwang, Ilwoo 298

Hyatt, Henry 220
Hynes, Stephen 367

Hyun, Yeseul 299, 309

Iannaccone, Laurence

R. 62

Ibarra, Imanol 298

Ibert, Markus 240

Iercosan, Diana 238

Igami, Mitsuru 315

Iizuka, Toshiaki 273

Illanes, Gaston 123, 335

Illeditsch, Philipp 210

Imai, Masami 34

Imai, Taisuke 370

Imas, Alex 296

Imazeki, Jennifer 186

Imbens, Guido 82, 119,

167, 180, 248, 298,

315,316

Imbert, Clement 282

Imhof, Stephan 230

Immorlica, Nicole 100, 141

Impink, Michael 348

Imura, Yuko 36

Indarte, Sasha 200

Infante, Sebastian 102, 152

Ingermann, Peter-Hendrik 164

Inklaar, Robert 357

Innes-Gawn, Siobhan S. 50

Inoue, Atsushi 336

Ion, Mihai 115, 232

Iqbal, Azhar 34

Irani, Mohammad (Vahid) 39

Irani, Rustom 386

Isaksson, Siri 350, 383

Islam, Asad 53, 283

Islam, Emdad 38

Issabayev, Murat 265

Istrefi, Klodiana 368

Ivashina, Victoria 77, 110

Iverson, Terrence 148

Iwasaki, Keiko 43

Izhak, Olena 53

Izhakian, Yehuda 273

Izquierdo, Sergio Camara 128
Jabri, Ranae 104

Jacewitz, Stefan 169

Jacho-Chavez, David 129

Jack, B. Kelsey 85

Jackson, Emilie 376

Jackson, Matthew O. 85, 141, 178, 246

Jacobson, Mireille 244

Jacoby, Sanford M. 299

Jácome, Elisa 353

Jaeger, Simon 103, 132, 318,360

Jaffe, Adam B. 98

Jaffe, Amy 250

Jagadeesan, Ravi 182

Jagannathan, Ravi 363

Jäger, Philipp 49

Jagnani, Maulik 349

Jagtiani, Julapa 309, 366

Jahnson, Daniel 49

Jaimes, Martha 344

Jaimovich, Nir 353

Jain, Radhika 122

Jakiela, Pamela 86, 95, 142, 215

Jalali, Ali 120

Jame, Russell 361

James, Christopher 285

James, Zoe 223

Jamilov, Rustam 195

Jamison, Julian 215

Jamison, Mark 305

Jana Gallus 158

Jansen, David-Jan 280

Jansen, Kristy 193

Jansen, Mark 164

Jansson, Joakim 44

Jansson, Michael 369

Jaravel, Xavier 140

Jardim, Ekaterina 360

Jardine, Sunny 105

Jaremski, Matthew 245

Jaroszewicz, Ania 296

Jarvis, Stephen 305

Jaspersen, Johannes G. 333

Javadekar, Apoorva 108

Javdani, Mohsen 176, 177

Jayachandran, Seema 66, 95

Jayanetti, Kalana 219

Jeanne, Olivier 383

Jeanneret, Alexandre 41, 286 
Jedwab, Remi 385

Jeffers, Esther 170, 257, 258

Jeffords, Chris 261

Jena, Anupam 262

Jenkins, Jade 206

Jenkinson, Tim 191

Jens, Candace 285

Jensen, Anders 64

Jensen, Bjarne Astrup 42

Jensen, Christian Skov 198

Jenter, Dirk 201, 237

Jerch, Rhiannon 361

Jessen, Lasse 142

Jessoe, Katrina 72, 235, 324

Jeuland, Marc 351

Jha, Akshaya 123, 305

Jha, Anup Kumar 129

Jha, Saumitra 71

Ji, Yongjie 92

Ji, Yunan 86

Jia, Jian 167

Jia, Jingyi 91

Jia, Ruixue 172, 386

Jia, Yuanyuan 172

Jiang, Haibin 49

Jiang, Lei 193

Jiang, Shenzhe 83

Jiang, Yi 257

Jiang, Zhengyang 76, 154, 391

Jianyu Lu, Will 64

Jiao, Peiran 328

Jiao, Wei 37

Jin, Dunhong 76

Jin, Ginger 167

Jin, Lawrence 107, 147, 211, 239

Jin, Xin 314

Jo, Soojin 395

Jo, Tae-Hee 111, 260

Johan, Sofia 121, 256

Johansson, Per 45

John, Kose 237, 288

Johnson, David S. 68, 69

Johnson, Justin 368

Johnson, Marianne 271, 272

Johnson, Noel 385

Johnson, Richard W. 88

Johnson, Rucker 97

Johnson, Stephanie 113

Johnson, Travis 151, 200

Johnston, Drew 231
Jonathan, Puigvert 53

Jones, Benjamin F. 98, 138, 316

Jones, Chad 259, 282

Jones, Damon 97, 342, 375

Jones, Daniel B. 256

Jones, Kelly M. 47, 215, 380

Jones, Maggie 208

Jones, Maggie E. C. 341

Jones, Maggie R. 206, 278

Jones, Stacey 133

Jorda, Oscar 144, 256

Jorgenson, Dale 58, 357

Joseph, Andreas 103

Josifidis, Kosta 111, 394

Joskow, Paul 263

Joslin, Scott 394

Ju, Jiandong 114

Juarez-Torres, Miriam 53

Jullien, Bruno 370

Jung, Alexander 391

Jung, Hye Ryoung 142

Jung, Hyeyoon 197

Jung, Jinho 222

Jung, Philipp 103

Junior, Ildo 101

Juraqulova, Zarrina 221

Juselius, John Mikael 71

Jylhä, Petri 40

1

Kabas, Gazi 187

Kaboub, Fadhel 127, 345

Kacperczyk, Marcin 76, 108, 288

Kacperczyk, Olenka 140

Kades, Michael 356

Kadiyala, Padma 79

Kadyrzhanova, Dalida 308

Kahana, Michael 328

Kahn, George A. 133

Kahn, Matthew 385

Kahn, R. Jay 256

Kahn, Shulamit 299, 309

Kahraman, Bige 76, 232

Kaido, Hiroaki 337

Kaila, Martti 176

Kaiser, Tim 124

Kakar, Venoo 341

Kalamara, Eleni 59, 280
Kalemli-Ozcan, Sebnem $100,165,232,272,345$, $346,382,383$

Kalenkoski, Charlene Marie 32

Kalesnik, Vitali 151

Kali, Raja 129

Kaliski, Daniel 228

Kalmi, Panu 124

Kalnina, Ilze 212

Kaltenberg, Mary 98

Kamal, Jai 315

Kamdar, Rupal 396

Kamei, Kenju 220

Kaminsky, Graciela Laura 378

Kamrad, Bardia 210

Kanczuk, Fabio 217

Kandpal, Eeshani 122

Kandrac, John 230

Kane, John 301

Kang, Heedon 385

Kang, Jisok 364

Kang, Namho 362

Kang, Sang Baum 39

Kang, Shulong 47

Kang, Ya 194

Kanik, Zafer 141

Kanninen, Ohto 349

Kantak, Preetesh 153

Kanzig, Diego R. 256

Kanz, Martin 234

Kao, Jennifer 338

Kapadia, Sujit 59, 103, 280

Kapetanios, George 59, 208, 280

Kaplan, Cameron 45

Kaplan, Ethan 314

Kaplan, Greg 280

Kaplan, Robert S. 133

Kaplan, Steven 110

Kapor, Adam 100, 230, 231

Kapteyn, Arie 381

Kapustin, Max 312

Kara, Gazi 386

Karabarbounis, Loukas 295

Karabiyik, Hande 372

Karahan, Fatih 103, 352

Karakaş, Oğuzhan 110

Karamcheva, Nadia S. 343

Karampatsas, Nikolaos 189

Karch, Andrew 372

Kargar, Mahyar 151

Karim, Suzana 314

Karlan, Dean 62 
Karmaziene, Egle 321

Karnani, Mohit 70

Karpoff, Jonathan 74

Karra, Mahesh 172

Karra, Soumya 29

Kar, Saibal 128

Kartashova, Katya 343

Kasahara, Hiroyuki 398

Kashaev, Nail 161

Kashyap, Anil K. 144, 285, 322

Kastl, Jakub 119

Katayama, Hajime 52

Kato, Takao 217

Katz, Lawrence 101, 145 , 174, 282, 316

Kauppinen, Ilpo 141

Kaur, Supreet 85

Kaymak, Baris 249

Kazandjian, Romina 31

Kazinnik, Sophia 59

Kazumori, Eiichiro 271

Ke, Xiao 53

Kearney, Melissa 282

Kedagni, Desire 212

Keefe, Jeffrey H. 399

Kehoe, Patrick 397

Kehrig, Matthias 249

Kekre, Rohan 295

Kelcey, Ben 30

Keller, Lorena 154, 335

Kellermann, Kim Leonie 314

Kelly, Bryan 198, 302

Keloharju, Matti 325

Kemp, Thomas 366

Kempf, Elisabeth 361

Keniston, Daniel 385

Kennedy, Patrick 359

Kepler, John 391

Kerkhoff, Allison 306

Kermani, Amir 201

Kerola, Eeva 93

Kerr, Sari Pekkala 138

Kerr, William 138, 384

Kertesi, Gabor 228

Kessel, Dany 229

Kessler, Judd 384

Kesternich, Martin 130

Kettler, Kyle 389

Kezdi, Gabor 228

Khalifa, Ahmed Ali 130

Khalil, Fahad 283

Khan, Mahreen 132
Khan, Muhammad Aamir 269

Khanal, Kalpana 154, 242

Khandelwal, Amit K. 359

Khanna, Gaurav 95, 159, $234,305,354$

Khorunzhina, Natalia 156, 290

Kichkha, Areerat 270

Kick, Thomas 264

Kiel, Katherine 242

Kieren, Pascal 42

Kigabo, Thomas 304

Kikuchi, Tomoo 269

Kiley, Michael 177

Kilian, Lutz 336

Kilic, Mete 195, 399

Kilimna, Anna 395

Kim, Chang-Jin 131

Kim, Dasol 169

Kim, Dawoon 73

Kim, Hayoung 352

Kim, Hugh Hoikwang 32, 39

Kim, Hwagyun (Hagen) 188

Kim, Hyuncheol Bryant $122,349,381$

Kim, Hyunseob 73, 393

Kim, Incheol 319

Kim, J. Daniel 138

Kim, Jinwoo 117

Kim, Ju Hyun 188

Kim, Jun Sung 53

Kim, June 387

Kim, Jung-Eun 112, 366

Kim, Jungmin 111

Kim, Kyeonghee 333

Kim, Kyungmin 298

Kim, Marlene 221

Kim, Mee Jung 376

Kim, Mina 318

Kim, Moon Joon 228

Kim, Ryan 182

Kim, Sanghyun (Hugh) 264

Kim, Sehoon 362

Kim, Seonghoon 349

Kim, Sunghyun Henry 36

Kim, Yun 334

Kimball, William Thomas 132

Kimbrough, Gray 343

Kincaide, Laura 95

Kind, Axel 196
Kini, Omesh 329

Kinias, Zoe 281

Kinnan, Cynthia 234

Kirdar, Murat 218

Kirilova, Antonia 197

Kirpalani, Rishabh 126

Kisseleva, Katja 363

Kitagawa, Kota 289

Kitagawa, Toru 369

Kitamura, Tomoki 43

Kitamura, Yuichi 162

Kitenge, Erick 241

Kiyotaki, Nobuhiro 321

Klaes, Matthias 122

Klasjna, Marko 142

Kleemans, Marieke 354

Klein, Mathias 35

Klein, Philipp 121

Kleinberg, Jon 225

Kleiner, Morris M. 372, 399

Klemens, Ben 47

Klenow, Peter 251, 379

Klimina, Anna 155

Kline, Patrick 61, 370

Kling, David 105, 360, 361

Klopfer, John B. 173, 224

Kluehs, Theres 31

Knetsch, Andreas 187

Kniesner, Thomas 301

Knill, April 74

Knopf, John 189

Knüpfer, Samuli 107

Knyazeva, Anzhela 111

Knyazeva, Diana 111

Koch, Andrew 75

Koch, Melanie 31

Kochan, Thomas A. 132

Kocherlakota, Narayana 274

Kock, Anders 213

Koebel, Kourtney 167

Koehl, Lorraine 249

Koeppl, Thorsten 68

Koetter, Michael 297

Koga, Kyoko 203, 241

Kogan, Leonid 326

Kogan, Shimon 361

Koh, Youngwoo 117

Kohl, Tristan 214

Kohler, Karsten 157

Kohlhase, Janet 204, 292

Kohn, Donald 144

Koijen, Ralph 180, 335, 390 
Kojevnikov, Denis 162

Kokoreva, Maria 42

Kolasa, Marcin Pawel 256

Kolb, Aaron 209

Kolesar, Michal 208

Kolev, Julian 64, 65

Kollmann, Robert 37

Kolotilin, Anton 247

Kolstad, Jonathan 146, 297

Komi, Mohamed El 266

Kominers, Scott Duke 182, 369

Kondor, Peter 201, 393

Kondylis, Florence 105

Kong, Xiangwen 222

Koning, Rembrand 65, 139,140

Koo, Bonsoo 212

Koo, Minjae 190

Koopman, Robert 303

Kopiec, Pawel 34

Korankye, Thomas 32

Korgaonkar, Sanket 333

Korinek, Anton 96

Kort, Peter M. 255

Korteweg, Arthur 201, 363

Kosack, Edward 261

Kosonen, Tuomas 176

Koster, Hans 80

Kotlikoff, Laurence 279

Kotter, Jason 109

Kotz, David 306

Koulayev, Sergei 276, 277

Koumenta, Maria 373

Koustas, Dmitri K. 217, 376

Koutout, Kristine 309

Kovrijnykh, Natalia 285

Kowalik, Michal 348

Kowalski, Amanda Ellen 213, 297

Koyama, Mark 385

Kozak, Serhiy 325, 390

Kozbur, Damian 209

Kozhan, Roman 40

Kraemer-Mbula, Erika 265

Kraft, Ben 146

Krainer, John 112

Kramarz, Francis 252

Kramer, Anica 319

Krasa, Stefan 85

Krause, Thomas 316

Kreindler, Gabriel 118

Krekel, Christian 30

Kremens, Lukas 286
Kremer, Michael 101, 215

Kricheli-Katz, Tamar 49

Krieger, Joshua 338

Krishnamurthy, Arvind 151

Krivenko, Pavel 395

Kroeger, Sarah 356

Kroetz, Kailin 105

Kroft, Kory 384

Krohn, Ingomar 286

Krolikowski, Pawel 360

Kronies, Alexander 196

Krueger, Alan B. 139

Krueger, Philipp 362

Krupnick, Alan 186, 389

Krusell, Per 280

Kruttli, Mathias 102, 153

Kuang, Weida 157

Kuang, Zhonghong 31

Kubitza, Christian 365

Kubler, Felix 279

Kuchler, Theresa 231

Kucinskas, Simas 274

Kuebler, Dorothea 163

Kuehn, Lars 399

Kuenn, Steffen 55

Kuerschner Rauck, Kathleen 319

Kügler, Alice 84, 389

Kuhnen, Camelia 238

Kuhn, Moritz 103

Kukaev, Ilya 372

Kulkarni, Leena 229

Kulkarni, Nirupama 327

Kumar, Alok 97, 188, 361

Kumar, Amit 45

Kumar, Anil 291

Kumar, Kaushalendra 47

Kumar, Rishabh 79

Kumar, Santosh 47

Kumar, Saten 397

Kung, Edward 395

Kung, Howard 199

Kurino, Morimitsu 163

Kurtzman, Robert 331

Kury, Theodore J. 305

Kutan, Ali 91

Kuttner, Kenneth N. 341

Kuwayama, Yusuke 236

Kuziemko, Ilyana 353

Kuzmina, Olga 321

Kvasnicka, Michael 319

Kwon, Sungjoung 192

Kyle, Albert 287

Kyriazis, Anna E. 175
La Croix, Sumner 116 , 132, 208

La Ferrara, Eliana 95

La Mattina, Giulia 120, 356

La Vecchia, Davide 212

Laarits, Toomas 74, 198

Labonne, Claire 121, 290

Lachman, Margie E. 98

Lade, Gabriel 324

Ladika, Tomislav 150

Laeven, Luc 100, 144

Lafontaine, Francine 90

Lafortune, Jeanne 304, 379

Lagarde, Mylene 122, 184

Lai, Ernest 207

Lai, Rose 204

Laibson, David 128

Lakdawala, Aeimit 210

Lake, James 214

Lakhani, Karim 64

Lakićević, Milan 308

Lalé, Etienne 252

Lalibert, Jean-William 167

Lallour, Antoine 30

LaLumia, Sara 278

Lama, Ruy 78

Lamadon, Thibaut 372

Lamadrid, Alberto J. 263

Lamberova, Natalia 54

Lambert, Thomas 40

Lambie-Hanson, Lauren 80,366

Lambie-Hanson, Tim 366

Lambrecht, Bart 190

Lamers, Martien 164

Lamla, Michael 160, 161

Lan, Chunhua 73

Lan, Yingcong 327

Landais, Camille 103

Landefeld, Steve 58

Landesmann, Michael 308

Landsman, Rachel 229

Landvoigt, Tim 392

Lane, Julia 98

Lane, Philip R. 355

Lang, Kevin 173

Lange, Andreas 130

Lange, Fabian 353

Langer, Ashley 122, 136

Langworthy, Melissa 241

Larrimore, Jeff 68

Larsen, Benjamin 273 
Larsen, Vegard Høghaug 59,115

Lau, Sau-Him Paul 42

Laubach, Thomas 71

Lautenbacher, Stefan 136

Lavie, Shay N. 49

Lavrutich, Maria 255

Lavy, Victor 62

Laxminarayan, Ramanan 47

Layton, Tim 296

Lazar, Emese 191

Lazarev, John 213

Lazarus, Eben 74

Lazear, Edward 181

Le, Anh 394

Le, Thao 204, 243

Le Barbanchon, Thomas 315

Le Moglie, Marco 378

Leard, Benjamin 137

Leary, Ryan 358

Leatham, David J. 46

Lecat, Remy 357

Leduc, Sébastien 281

Leduc, Sylvain 322

Lee, Adrian 367

Lee, Ajin 387

Lee, Edgar 110

Lee, Eunhee 226, 266

Lee, Heon Yeong 146

Lee, Hyojung 113

Lee, Hyunju 266

Lee, Jae Joon 181

Lee, Jongwook 223

Lee, Junghoon 362

Lee, Keyoung H. 143

Lee, Kyeong H. 393

Lee, Kyung Min 376

Lee, Michael 392

Lee, Monica 340

Lee, Peter 52

Lee, Robin 84

Lee, Seung Jung 280

Lee, Sokbae 298

Lee, Stefan 192

Lee, Sukjoon 33

Lee, Tammy Sunju 351

Lee, Tomy 287

Lee, Won Fy 47

Lee, Ying-Ying 294, 369

Lee, Yong Suk 135, 273

Lee, Yoonseok 211

Leeffers, Stefan 219

Leeth, John 301
Legovini, Arianna 105

Leibbrandt, Andreas 383

Leibrecht, Markus 91

Leigh, Nancy Green 146

Lelarge, Claire 62

Lemi, Adugna 241

Lemieux, Thomas 179, 353

Lemoine, Derek 105, 136

Lemont, Bethany 244

Lemus, Jorge 54

Lenel, Moritz 391

Leningston, Oliver 92

Leon, Gianmarco 314

Leon-Ledesma, Miguel 99

Leone, Samuel 311

Lepine, Aurelia 177

Lepore, Caterina 144

Lerner, Josh 255

Leroux, Maxime 294

Leshno, Jacob 100

Leslie, Gordon 305

Lessem, Rebecca 350

Letdin, Mariya 204, 396

Letourneau, Pascal 39

Leung, Charles Ka Yui 80, 290

Leung, Michael 162

Leung, Tommy 116

Leuz, Christian 199

Levely, Ian 86

Leverty, Ty 333

Levin, Jonathan D. 101, 251

Levine, David I. 223

Levin, Sarah 91

Levinson, Arik 137

Levit, Doron 110, 329

Levonyan, Vardges 42

Levy, David M. 120

Levy Paluck, Elizabeth 278

Levy-Yeyati, Eduard 180

Lewbel, Arthur 162

Lewellen, Stefan 113, 169

Lewis, Daniel 59

Lewis, Ethan G. 138, 349

Lewis, Joshua 346

Lewis, Kurt 327

Lewis, Logan 114

Lewis, Ryan 287

Li, Andy Tao 52

Li, Anqi 85

Li, Bangxi 258

Li, Bin Grace 276

Li, Bo 289

Li, Bruce 239
Li, Changtai 192

Li, Cher Hsueh-Hsiang 70, 184,350

Li, Danielle 65, 239, 338, 364, 384

Li, Dongmei 197

Li, Fei 246, 247

Li, Hongbin 173

Li, Hongchang 127

Li, Hongxiu 55

Li, Huiyu 379

Li, J. Frank 136

Li, Jiacui 76

Li, Jian 285

Li, Jie 187

Li, Jin 201

Li, Jing 123, 290, 356

Li, Josefina 127

Li, Jun 326

Li, Kai 107, 210, 289, 329, 364

Li, Ming 209

Li, Shanjun 186, 347

Li, Shengwu 377

Li, Shi 269

Li, Tao 260

Li, Tong 398

Li, Wenchao 379

Li, Wendy Chuen-Yueh 126

$\mathrm{Li}$, Wenhao 152, 391

Li, Xiaodi 156, 243

Li, Xin 194

Li, Xuan 318

$\mathrm{Li}$, Ye 237

Li, Yuexin 42

Li, Zhi 159

Li, Zhimin 352

Lian, Weicheng 34, 35

Liang, Annie 181

Liang, Nellie 144, 279 , 321,322

Liao, Chen-Hsuan 271

Liao, Gordon 233

Liao, Jingchi 239

Liao, Li 187, 196

Liao, Wen-Chi 367

Liao, Yanjun 72

Liao, Yuan 108, 251

Liao, Zhipeng 337

Liberini, Federica 378

Lichand, Guilherme 86

Lichter, Andreas 319

Lieber, Ethan M. J. 244, 371 
Liebman, Benjamin H. 36

Lien, Jaimie 147

Limao, Nuno 115, 358, 359

Lin, Brian Chi-Ang 258, 366

Lin, Desen 243, 290, 352

Lin, Haizhen 262

Lin, Hsien-Chang 207

Lin, Huang 158

Lin, Huidi 399

Lin, Jeffrey 292

Lin, Justin Yifu 53, 133

Lin, Luca Xianran 75, 191

Lin, Tse-Chun 194

Lin, Tsui-Fang 271

Lin, Tzu-Hsin 138

Lin, Xiaoji 285, 327

Lin, Xu 207

Lin, Yatang 291

Lin, Zhenguo 290

Lin Lawell, Cynthia 361

Lindahl, Mikael 45

Lindenthal, Thies 332, 333

Lindenthal, Volker 62

Lindner, Attila 354, 355

Lindo, Jason M. 94, 177

Ling, David 112

Link, Sebastian 355

Linn, Joshua 137

Linnainmaa, Juhani 74, $151,240,325$

Linthon, Diego 157

Linton, Oliver 212

Lipsitz, Michael 139

Liscow, Zachary 388

Litan, Huiyi 51

Littlejohn, Maximillian 188

Littman, Rebecca 278

Liu, Baixiao 74

Liu, Canyao 73

Liu, Chong 258

Liu, Chunbo 37

Liu, Clark 237

Liu, Crocker 261, 331

Liu, Emily 42

Liu, Ernest 199

Liu, Gordon 345

Liu, Haiyong 131

Liu, Han 242

Liu, Haoyang 130, 367

Liu, Jessica 364

Liu, Jianping 52

Liu, Jing 340

Liu, Jinyu 236

Liu, Jun 210
Liu, Lin 34

Liu, Liyan 241

Liu, Lu 191

Liu, Maggie 268

Liu, Mengdi 159

Liu, Qing 308

Liu, Shida 197

Liu, Shimeng 155

Liu, Sitian 247

Liu, Siying 351

Liu, Taoxiong 52

Liu, Tingting 328

Liu, Tong 55

Liu, Tracy 84

Liu, Weiling 364

Liu, Xiangshi 228

Liu, Xiaotian 194

Liu, Xin 38

Liu, Xuan 131

Liu, Yan 131

Liu, Yang 77, 288, 335

Liu, Yanran 197

Liu, Yijiao 113

Liu, Yingchun 290

Liu, Yixin 50

Liu, Yong 36

Liu, Yu 50

Liu, Yukun 189, 362

Lleras-Muney, Adriana 143, 211

Lloyd, Neil 353

Lo, Irene 100

Lochstoer, Lars 107, 288

Lockwood, Benjamin 342

Lockwood, Lee 118, 382

Loeb, Peter D. 134

Loeb, Susanna 62

Loewenstein, Lara 80, 395

Loewenstein, Mark 373

Lof, Matthijs 38, 40

Logan, Trevon 116, 140, 254, 341

Loge, Frank 324

Loken, Katrine 143, 275

Lombardi, Marco 180

Lomys, Niccolo 213

Londono, Juan M. 77, 280, 335

Long, Melanie 334

Long, Wang 157

Long, Ying 157

Longfield, Chuck 158

Loos, Benjamin 195

Lopes, Paula 107

Lopez, Luis 290
Lopez, Mark Hugo 254

Lopez, Mary 206

Lopez, Pierlauro 397

López-Peña, Paula 312

Lopresti, John 115

Lopus, Jane S. 167, 373, 374

Lorenzoni, Guido 322

LoSasso, Anthony 122

Löschel, Andreas 55, 130

Loscos, Ana Gomez 256

Lott, John 75

Lotti, Francesca 67

Loualiche, Erik 326

Loubert, Linda 401

Louçã, Francisco 78

Lou, Dong 74, 362, 394

Loungani, Prakash 79

Loutskina, Elena 164

Low, Corinne 229, 384

Low, Hamish 118

Lowenstein, Christopher 88

Lowery, John 222

Lowes, Sara 95

Lowry, Michelle 110, 329

Loyalka, Prashant 135

Lozano, Fernando 206

Lozano, Lina 383

Lu, Fangwen 228

Lu, Haitian 289

Lu, Jay 370

Lu, Jingfeng 398

Lu, Liang 135

Lu, Lina 30, 73

Lu, Ming 354

Lu, Xiaolan 159

Lu, Yiqing 110

Lu-Andrews, Ran 79

Luca, Dara Lee 65, 355

Luca, Michael 167, 355

Luchtenberg, Kimberly 396

Lucier, Brendan 100

Luck, Philip 350

Luck, Stephan 277, 313

Lucking, Brian 220

Ludema, Rodney 115

Ludvigson, Sydney 180

Ludwig, Jens 225, 312

Luengo-Prada, Maria 88

Luintel, Kul 129

Lukens, Gideon F. 126

Lundberg, Shelly 70

Luo, Jianbo 48

Luo, Shikong (Scott) 352

Luo, Yao 213 
Luo, Yilei 228

Luo, Zijun 159

Lurie, Ithai 296

Lusardi, Annamaria 382

Lustig, Hanno 77, 202, 233

Luts, Maarten 282

Luttmer, Erzo F.p. 142, 381

Lutz, Chandler 243

Luz, Manuel Ramon De Souza 242, 261

Lybbert, Travis 92

Lyn, Gary 72

Lynch, Devon 271

Lynch, Lisa 58, 174

Lyonnet, Victor 200, 328

Lyons, Angela 269

Lyons, Elizabeth 140

Lyons, Ronan 242, 367

\section{M}

Ma, Ching-To Albert 206, 207

Ma, Han 193

Ma, Hong 114, 308

Ma, Jun 131, 192, 352

Ma, Lala 324, 325

Ma, Luchun 189

Ma, Marshall 42

Ma, Sai 180, 286

Ma, Song 195

Ma, Xianlei 56

Ma, Xinwei 369

Ma, Yiming 102, 152

Ma, Yueran 232, 277

Mabeu, Marie Christelle 203

Mabille, Pierre 248

Macaluso, Claudia 339

Maccheroni, Fabio Angelo $116,117,371$

Ma, Chang 121

Machelett, Margarita 179

MacKay, Alexander 368, 369

Mackey, Timothy K. 246

MacLeod, W. Bentley 138

Mader, Nicholas 294

Madland, David 132

Maffei Faccioli, Nicolò 380

Maggiori, Matteo 233, 346, 384

Magnac, Thierry 163

Magne, Tiphanie 90
Magnolfi, Lorenzo 213

Magud, Nicolas 383

Mahadevan, Meera 324

Maheshri, Vikram 84

Mahon, David 61

Mahoney, Neale 86

Maier, Mark 185

Maingi, Raman Quinn 309

Maini, Luca 338

Majbouri, Mahdi 300

Makarin, Alexey 168

Makowsky, Michael 67

Makridis, Christos Andreas 59, 242, 332

Maksimovic, Vojislav 255, 285, 286

Malak, Natalie 44

Malamud, Semyon 153, 274

Malek, Abdul 53, 283

Malenko, Nadya 288, 329

Malhi, Fareena 205

Malikov, George 201

Malin, Benjamin 380

Malkhozov, Aytek 365

Malladi, Suraj 246

Malliaris, Anastasios 267

Mallick, Sushanta K. 79, 129

Mallucci, Enrico 36

Malm, James 272

Malmendier, Ulrike 73, 259, 368

Mamaysky, Harry 325

Mamica, Lukasz 111

Mamun, Khawaja Saeed 283

Manchester, Colleen F. 217

Mandel, Michael 126

Manela, Asaf 393

Manfra, Pellegrino 268

Mani, Anandi 86

Maniloff, Peter 185

Mankad, Shawn 178

Mankiw, N. Gregory 133, 279, 359

Mann, William 286, 329

Manova, Kalina 227

Manovskii, Iourii 103

Manresa, Elena 82

Manso, Gustavo 239

Mansour, Hani 350

Mansur, Erin 324, 390

Manzella, Julia 227

Mao, Connie 50
Marcel Te Kaat, Daniel 121

Marchingiglio, Riccardo 70

Marie, Olivier 48

Marinacci, Massimo 117, 371

Marinescu, Ioana Elena $139,218,339$

Marinovic, Ivan 390

Markowsky, Eva 250

Marktanner, Marcus 266

Marley-Payne, Jack 271

Marmer, Vadim 162

Marquardt, Kelli 94

Marrouch, Walid 300

Marsh, W. Blake 169

Marshall, Emily 59

Marshall, Wesley 292, 331

Martell, Michael 184

Martin, Alberto 165

Martin, David 225

Martin, Ian 239

Martin, Philippe 295

Martin, Ralf 324

Martin-Flores, Jose M. 93

Martineau, Charles 393

Martinez Hernandez, Catalina 34

Martinez, Joseba 380

Martinez, Luis Roberto 314

Martinez-Correa, Jimmy 388

Martins, Igor 116

Martins, Pedro 139

Martorell, Paco 230

Marx, Julie 156

Mas, Alexandre 174

Maseland, Robbert 313

Mask, Joshua 47

Mason, Charles F. 127, 134

Mason, Joe 132

Massa, Massimo 191, 214

Masten, Matthew 337

Mast, Evan 156

Maswana, Jean-Claude 202, 203, 241

Matar, Ghida 300

Mateer, G. Dirk 271

Matejka, Filip 119

Mathevet, Laurent 370

Matos, Pedro 362

Matouschek, Niko 281

Matray, Adrien 239

Matson, Erik 120

Matsumoto, Brett 320

Matsusaka, John 110 
Matthies, Ben 328

Mattioli, Francesco 147

Matumoto, Akira 78

Matvos, Gregor 335, 392

Matzkin, Rosa 248

Maurel, Arnaud 313

Maurer, Thomas 76

Mayer, Erik J. 38

Maynard, Norman 272

Mayo, John 257

Mazier, Jacques 170, 258

Mazin, Felipe 71

Mazrekaj, Deni 44

Mazumder, Bhash 143, 227, 388

Mazumder, Shom 138

Mazumder, Soumyajit 70

Mazurek, Jakub 308

McAdams, David 246

McAndrews, James 276

McCain, Robert A. 114

McCann, Fergal 39, 121, 238

McCarthy, Ian 262

McCarthy, Patrick 134, 388

McCartney, W. Ben 332

McCloskey, Deirdre 269

McCluskey, Jill J. 104, 135,184

McCollum, Meagan 204, 303

McConnell, John 74

McConnell, Margaret 86

McConnell, Scott 154

McCoy, Daire 263

McCrary, Justin 357

McCubbin, Janet 296

McDermott, Eric M. 61

McDermott, Grant 257, 305

McDougal, Topher 246

McElheran, Kristina 146, 273

McEntarfer, Erika 227

McEvoy, David 307

McFadden, Daniel 248

McGarry, Kathleen 69

McGoldrick, Kim Marie 61, 96, 235

McGuire, Erin 59

McHenry, Peter 309

McIntyre, Adrianna 296

McKay, Alisdair 180

McKenzie, David 279, 317

McLaughlin, Kenneth J. 48
McLean, David 196

McMahon, Michael 160, 161,274

McManus, T. Clay 318

McMaster, Robert 87

McQuade, Timothy 129, 392

McRae, Shaun D. 122, 257, 263

Meardon, Stephen 87

Meder, Martin 272

Medina, Carlos 95, 159

Medina, Leandro 378

Megginson, William L. 50

Meghir, Costas 182

Mehrotra, Anurag 204

Mehrotra, Vikas 39

Mehta, Nirav 371

Mehtab, Ayesha 218

Meier, Armando N. 184

Meier, Felix 149

Meierrieks, Daniel 114

Meinerding, Christoph 191

Meisenzahl, Ralf 132, 326

Meissner, Christopher M. 245

Meister, Alexander 161

Melentyeva, Valentina 321

Melnikov, Nikita 312

Meltzer, Rachel 156

Mendes, Diogo 238

Mendez, Lizethe 157

Mendez, Rodolfo 81

Méndez-Carbajo, Diego 61, 167

Meng, Chong 190

Menkhoff, Lukas 124

Menkveld, Albert 188, 237, 287

Mensah, Justice Tei 159

Merel, Pierre 259

Mergo, Teferi 380

Merkel, Almut 266

Mertens, Karel 380

Messer, Todd 295

Mesters, Geert 265

Metcalf, Gilbert 93

Metcalfe, Robert 323, 350

Metrick, Andrew 102

Metzger, Daniel 238

Meyer, Bruce 69

Meyer, Jennifer 351

Meyer, Steffen 195

Meyer-Ter-Vehn, Moritz 323
Mezzanotti, Filippo 106, $179,239,364$

Mian, Atif R. 382

Miao, Jianjun 83, 363

Michael, Robert T. 101

Michaelides, Alex 72

Michaels, Ryan 281

Michelmore, Katherine 278

Middelhoff, Frederik 193, 399

Midrigan, Virgiliu 397

Miethe, Jakob 310

Miguel, Edward 140, 215, $278,311,354$

Mihaljek, Dubravko 180

Mikhail, Diana 195

Mikhed, Slava 45

Mikusheva, Anna 82

Milazzo, Annamaria 95

Milberg, Will 243

Milbourn, Todd 363

Milcheva, Stani 112

Milevsky, Moshe A. 333

Millard, Stephen 386

Miller, Conrad 374

Miller, Laurie A. 61, 167

Miller, Nathan 264, 315

Miller, Sarah 94, 371

Millhauser, Glenn 351

Millogo, Doslalo 218

Mimiroglu, Nagihan 189

Minoiu, Camelia 304

Miquel, Gerard Padró I 168,224

Miranda-Agrippino, Silvia 179,180

Miranda, Javier 138

Miri Lavasani, Aidin 41

Mishra, Mrinal 195

Mishra, Prachi 180, 330

Mishra, Tapas 79, 99

Mistree, Dinsha 135

Mitchell, Olivia S. 69, 381

Mitman, Kurt 103

Mitrosky, Micah 299

Mittelhammer, Ron 184

Mjøs, Aksel 363

Mobarak, Ahmed Mushfiq 283,312

Mobbs, Shawn 363

Mocanu, Tatiana 44, 80

Modena, Andrea 35

Modestino, Alicia 45, 227 , 299, 309, 400

Mody, Ashoka 59 
Moerke, Mathis 188

Moessinger, Carina 121

Moffette, Fanny 284

Moffitt, Robert 101

Mogstad, Magne 119

Mohanan, Manoj 345

Mohnen, Paul 309

Mohrenweiser, Jens 48

Moise, Claudia 399

Mokyr, Joel 262

Molavi, Pooya 116

Molina, Renato 235

Molinari, Francesca 161

Molitor, David 346

Mollah, Shirin 41

Mollerstrom, Johanna 229

Monarch, Ryan 114

Mondragon, John 332

Mones, Patricia 44

Mongey, Simon 117, 339

Monin, Phillip 153

Monnet, Cyril 230

Monnet, Eric 229

Montalvao, Joao 104

Moon, Choon-Geol 309

Moon, Hyungsik Roger 251

Moon, Terry 281

Moore, Charity 247

Moore, Christopher C. 105

Moore, Frances 259

Moos, Katherine 134, 221

Mora, Marie T. 60, 140

Morales, Daniel R. 44

Morales, Eduardo 208

Morales, Jose 37

Morck, Randall 33

Moreira, Alan 365, 399

Moreira, Diana 224

Moreira, Fernando 39

Morellec, Erwan 150

Morgan, Ash 307

Morjaria, Ameet 58

Morkoetter, Stefan 190

Morrill, Thayer 377

Morris, Stephen 57, 147, 274

Morse, Adair 83

Morshed, Akm Mahbub 51

Morsy, Hanan 171, 203, 241

Mortágua, Mariana 78

Mortimer, Julie Holland 165

Moschella, Daniele 54
Moschini, Gian Carlo 92

Moser, Christian 397

Moser, Petra 138

Moskowitz, Tobias 150, 361

Mosquera, Roberto 388

Mostagir, Mohamed 163

Mota, Lira 195

Motameni, Alireza 90

Mougin, Elisa 32

Mourad, Frederico 298

Mourifie, Ismael 369, 384

Moussa, Racha 226

Moussawi, Rabih 110

$\mathrm{Mu}$, Xiaosheng 160

Mude, Andrew 380

Muehlenbachs, Lucija 185

Mueller, Andreas 360

Mueller, Holger 392

Mueller, Philippe 210, 286

Mueller, Valerie 172, 268

Mueller-Dethard, Jan 42

Mueller-Smith, Michael 67, 294

Muhlhofer, Tobias 331

Mui, Preston 280

Muir, Tyler 233, 391

Mukand, Sharun 62

Mukharlyamov, Vladimir 77

Mukherjee, Abhiroop 107

Mukherjee, Debasri 104

Mukherjee, Priya 234, 313

Mukhin, Yaroslav 213

Mukhopadhyay, Kakali 269

Mukoyama, Toshi 220

Mullainathan, Sendhil 85, 225

Mullen, Kirsten 168

Müller, Karsten 63

Mullins, William 362

Mumford, Kevin 155

Munasinghe, Lalith 52

Mundaca, Gabriela 281

Mundra, Kusum 128

Munneke, Henry 204

Muñoz, Juan 69, 367

Munoz-Garcia, Felix 324

Muralidharan, Karthik 295, 354

Muravyev, Dmitriy 198

Murciano-Goroff, Raviv 98, 251

Murfin, Justin 284, 330

Murphy, Alvin 291
Murphy, Bonnie 320

Murphy, Daniel 175

Murray, Fiona 65

Murray, Michael 127

Murray, Scott 151

Murry, Charles 165

Murtazashvili, Irina 398

Music, Almedina 45

Musse, Isabel 45

Mussio, Irene 220

Musto, David 129, 237

Mutari, Ellen 241, 344

Muz, Jennifer 215

Myers, Erica 149

Myers Jr., Samuel L. 341

Mykyta, Laryssa 69

Mylovanov, Tymofiy 247

\section{N}

Naecker, Jeffrey 181, 182

Naef, Alain 91, 92

Nagel, Stefan 368

Naidu, Sirisha 375

Naidu, Suresh 96, 226, 353

Nair, Gautam 234

Nair-Reichert, Usha 129

Nakajima, Akiko 51

Nakajima, Makoto 348

Nakamura, Emi 145, 180, 320, 396

Nakashima, Kunio 43

Nalebuff, Barry 201

Nanda, Anupam 112

Nanda, Ramana 140, 317

Nanda, Vikram 153, 264

Nandi, Arindam 47

Nannicini, Tommaso 316

Narajabad, Borghan Nezami 102

Narayanan, Abhinav 330

Narita, Futoshi 34

Narita, Machiko 385

Narita, Yusuke 231, 398

Naughton, Barry 269

Nave, Gideon 181

Naveen, Lalitha 111

Nawas, Mike 195

Ndikumana, Léonce 171

Ned, John 401

Nedeljkovic, Milan 59

Neggers, Yusuf 234

Negi, Akanksha 119 
Negrete Garcia, Ana Karen 120

Neidell, Matthew 72

Neier Beran, Stacy 300

Neilson, Christopher 84, 100

Neilson, Elijah 309

Neiman, Brent 233

Nelissen, Dagmar 134

Nelson, Charles R. 131

Nelson, Julie 172

Nemzer, Louis R. 52

Nersisyan, Yeva 82

Neuenkirch, Matthias 280

Neuhierl, Andreas 150, 325

Nevoux, Sandra 252

Newbold, Stephen C. 105

Newey, Whitney 251, 294

Newham, Melissa 106

Neymotin, Florence 52

$\mathrm{Ng}$, Odyssia 140

$\mathrm{Ng}$, Serena 180, 248

Ngatia, Mũthoni 354

Nguyen, Anh 247

Nguyen, Bang 202

Nguyen, David 126

Nguyen, Genevieve 135

Nguyen, Giang 394

Nguyen, Huong 325

Nguyen, Quyen 273

Nguyen, Thai Vu Hong 38

Nguyen, Thuy 244, 262 , 371

Nguyen, Tung 189

Nguyen-Van, Phu 31

Nicholls, Gradon 277

Nichols, Austin 267

Nichols, Joseph 112

Niedergall, Sarah 320

Niederle, Muriel 227, 382

Nielsen, Eric 224

Nielsson, Ulf 76

Niemesh, Gregory 349

Niepmann, Friederike 42, 100,145

Nier, Erlend 385

Niessen-Ruenzi, Alexandra 152

Niessner, Marina 361

Niknami, Susan 50

Nikolov, Boris 399

Nikolova, Stanislava 151

Nikolowa, Radoslawa 201

Nimark, Kristoffer 115, 397
Nimubona, Alain-Desire 380

Nini, Gregory 285

Nirei, Makoto 126

Nix, Emily 176

Nizovtsev, Dmitri 272

Nobuyuki, Hanaki 296

Nocciola, Luca 385

Nocke, Volker 370

Noel, Pascal 294, 364

Noelke, Clemens 318

Noell, Edd 269

Noh, Joonki 365

Nolen, Patrick 383

Nomura, Koji 302

Norden, Lars 297

Nordstrom, Jonas 43

Norman, Peter 247

Nosal, Jaromir 107, 348

Notowidigdo, Matthew 118, 179, 294

Noureldin, Diaa 253

Noussair, Charles 38, 39

Novan, Kevin 148

Novta, Natalija 35

Nozawa, Yoshio 287

Nsiah, Christian 240

Nugent, Jeffrey 266

Nunn, Ryan 373

Nüß, Patrick 114

Nyberg, Henri 38

Nyberg, Peter 325

Nyeki, Gabor 386

Nyshadham, Anant 95, 159

O'Connell, Stephen 96

O'Connor, Jason 368

O'Donnell, Charles 39

O'Flynn, Kuchulain 191

O'Keefe, Siobhan 356

O'Malley, Terry 121

Obermeyer, Ziad 184

Obi, Emmanuel 401

Obikili, Nonso 131

Oblak, Ana 308

Ockenfels, Axel 296

Odermatt, Reto 30

Odozi, John Chiwuzulum 400

Oduro, Abena D. 263

Oehmke, Martin 277

Officer, Micah 328
Ofosu, George 279

Oh, Seungjoon 41

Oh, Suanna 85

Okunade, Albert 31

Oladi, Reza 235

Oladipo, Oluwasheyi 250, 316

Olafsson, Arna 178

Olbert, Marcel 40

Olenski, Andrew 86

Oliva, Paulina 346

Oliver, Dan 351

Olmstead, Sheila 236

Olney, Martha L. 97, 235, 359

Olsson, Jonna 280

Omosegbon, Oladele 400

Omotor, Douglason G. 401

Önder, Ali Sina 29

Ongena, Steven 121, 191, 195,200

Oosterbeek, Hessel 100, 382

Opoku-Agyemang, Kweku 159

Opp, Christian 151, 363

Oremus, Kimberly 105

Orhangazi, Ozgur 345

Orlowski, Lucjan 268

Ormaechea, Emilia 260

Orozco-Aleman, Sandra 206

Orsini, Kristian 267

Orszag, Peter 293

Ortega, Alberto 124, 125

Ortiz-Bobea, Ariel 72, 259

Ortiz-Molina, Hernan 239

Ortoleva, Pietro 116

Oskarsson, Sven 349

Oslington, Paul 269

Osman, Adam 105

Osmani, Ahmad Reshad 31

Ossandon Busch, Matias 39

Osterreich, Shaianne 344

Ostromogolsky, Philip 343

Ostry, Jonathan 303

Otchia, Christian 241

Otis, Nicholas 279

Ottaviani, Marco 398

Ottonello, Giorgio 40

Ottonello, Pablo 137, 251

Ottoni-Wilhelm, Mark 205

Ouimet, Paige 164, 286, 329 
Ouyang, Alice 34

Ouyang, Shumiao 363

Owens, Emily 312

Owusu, Abena 191

Oyelere, Ruth Uwaifo 223, 400

Oyer, Paul 384

Ozak, Omer 71, 234

Ozdenoren, Emre 288

Ozek, Umut 70

Ozgur, Gokcer 170

Ozier, Owen 95

Ozik, Gideon 390

Ozkan, Serdar 352

Ozkul, Olgu 54

Özler, Berk 215

\section{P}

Pabilonia, Sabrina Wulff 267, 303

Packham, Analisa 67, 94, 177

Paczos, Marta 126

Pagán, Lorissa 60

Page, Beau 285

Page, Lionel 163

Page, Scott E. 90

Pagel, Michaela 82, 107, 178

Pagliero, Mario 372

Pagnotta, Emiliano 68, 237, 288, 393

Paige, Jerome S. 168

Pakrashi, Debayan 283

Pakzad-Hurson, Bobby 323

Palacios, Juan 55

Palazzo, Berardino 251

Palia, Darius 192

Palmer, Christopher 130

Palmer, Karen 284, 389

Palvia, Ajay 200

Pan, Jessica 217, 350, 376

Pan, Jun 198

Pan, Shin-Ren 54

Pandalai-Nayar, Nitya 226

Pande, Rohini 247, 272

Pandolfi, Lorenzo 378

Panebianco, Fabrizio 246

Pang, Hao 131

Panizza, Ugo 217

Pankratov, Andrey 192

Pankratz, Nora 310

Paolin, Po 246
Papadopoulos, Michael 123

Papamichalis, Theofanis 38

Papanikolaou, Dimitris 109, 153, 302, 338

Parajuli, Bharat 197

Paravisini, Daniel 199

Parent, Daniel 399

Parey, Matthias 309

Park, Heungju 188

Park, In-Uck 370

Park, Jisung 299

Park, Jooyoun 318

Park, Seollee 122

Park, Seongkyu (Gilbert) 197

Park, Sujeong 45

Park, Sunkyoung 131

Parker, Brian 320

Parker, Jonathan 88

Parker, Susan 205

Parks, Byung Yul 37

Parlatore, Cecilia 287, 325

Parman, John 116, 313

Parro, Fernando 115

Parsons, Christopher 74, 149,362

Partridge, Mark D. 49, 155

Paschall, Stephen 289

Paserman, Daniele 71

Passarelli, Francesco 378

Pastorello, Sergio 369

Pastor, Lubos 73, 202

Pastor, Manuel 305

Pastorino, Elena 397

Patel, Darshak 359

Patel, Dev 224

Patel, Elena 343

Patel, Saurin 108

Patel, Tarun 188

Patelli, Ella 286

Pathak, Parag 230

Pathak, Praveen 172

Patrick, Carlianne 155

Pattanayak, Subhrendu K. 325,351

Patton, Andrew 212

Paul, Mark 125, 292

Paule-Paludkiewicz, Hannah 44

Pauly, Nathan 244

Pavcnik, Nina 226, 227

Pavel, Md Tanvir 300

Pavlova, Anna 285

Payne, Abigail 62, 205

Payne, Mark 376
Paz, Lourenco S. 36

Peach, James T. 111, 261

Pearce, Brittany 219

Pearce, David 370

Peart, Sandra J. 120

Pedio, Manuela 213, 396

Pei, Harry 370

Pekkarinen, Tuomas 143

Pelger, Markus 150

Pelizzon, Loriana 35, 40, 150,365

Pelli, Martino 360

Pelli, Michele 187

Pelster, Matthias 40

Pély, Désirée-Jessica 193

Pelzman, Joseph 216, 265

Pena, Anita 114

Pencavel, John 399

Pence, Karen 205

Penciakova, Veronika 220

Peng, Cameron 239

Peng, Cong 55

Peng, Liang 331, 395

Peng, Lin 192, 236, 392

Peng, Ni 187

Peng, Sida 212

Peng, Yushi 193

Pengfei, Liu 159

Penglase, Jacob 283

Penn, Mary H. 50

Penner, Emily K. 340

Penta, Antonio 368

Peoples, James 134

Perego, Jacopo 246

Pereira dos Santos, Joao 255

Pereira Vieceli, Cristina 221

Peress, Joel 107, 362

Perez, Francisco 238

Perez, M. Fabricio 91

Perez, Maria Francisca 317

Perez, Santiago 116

Perez-Quiros, Gabriel 144

Perez-Truglia, Ricardo 323, 350

Peri, Giovanni 71, 312, 350

Pernoud, Agathe 178

Perotti, Enrico 150

Perri, Fabrizio 383

Perumbillissery, Krishnapriya

Parameswaran 351

Pesaran, M. Hashem 66, 208, 213, 371 
Pesendorfer, Wolfgang 117

Pestel, Nico 55, 319

Petach, Luke 114, 158, 271

Peterman, William 148

Peters, Florian 274

Peters, Jorg 323

Peters, Ryan 109

Peterson, Janice 155

Peterson, Paul E. 173

Petit, Pascal 170, 258

Petitclerc, Amelie 88

Petmezas, Dimitris 189

Petrasek, Lubomir 327

Petrie, Ragan 158, 228

Petrosky-Nadeau, Nicolas 353

Petrova, Maria 168

Petrova, Milena 331

Pettit, Luke 233

Peydró, José-Luis 63, 99, 326, 386

Pezzo, Luca 76

Pfaff, Steve 244

Pfajfar, Damjan 160

Pfeifer, Christian 48

Pflueger, Carolin 286

Phan, Duc Thi Hong 38

Phan, Toan 358

Phelan, Chris 125

Philippon, Thomas 149 , 232,249

Phillips, David 67, 156

Phillips, Gordon 106, 190, 239, 348

Phillips, Michelle A. 305

Phillips, Peter 337

Pianta, Mario 170

Piazzalunga, Daniela 114

Picciano, Paul 389

Piehl, Anne 357

Pieper, Paul J. 87

Pieralli, Simone 259

Pierce, Lamar 82

Pierret, Diane 347

Pieters, Gina 216

Pihl, Ariel 45

Pikos, Anna Katharina 351

Pikulina, Elena 296

Pilkauskas, Natasha 278

Pilny, Adam 43

Pineda, Jose 81

Pineda Torres, Mayra

Belinda 177

Pinheiro, Roberto 352, 353

Pinter, Gabor 201
Pinto, Santiago 50

Pires, Luiza Nassif 221

Pirozhenko, Yakym 84

Pisciotta, Kevin 109

Piskorski, Tomasz 64, 238, 330, 335

Pistaferri, Luigi 118

Piszczek, Matthew 88

Piton, Sophie 380

Pitschner, Stefan 397

Piyapromdee, Suphanit 355

Plagborg-Moller, Mikkel 337

Plassmann, Florenz 43

Platt, Kasia 316

Plihon, Dominique 170, 258

Ploegmakers, Huub 56

Plosser, Matthew 391

Pogach, Jonathan 169

Pöge, Felix 98

Pogorelskiy, Kirill 370

Poirier, Alexandre 337

Polachek, Solomon 342

Polivka, Anne 252

Polk, Christopher 390

Poltera, Marco 196

Pomatto, Luciano 336

Pomfret, Richard 142

Ponce, Alejandro Melo 398

Pongou, Roland 203

Ponticelli, Jacopo 289

Pontiff, Jeffrey 196, 365

Pope, Devin G. 184

Popescu, Andreea 38

Popko, David 320

Popov, Sergey V. 29

Porat, Haggai 49

Porter, Sonya R. 206

Porzio, Tommaso 64

Posen, Adam 321

Posey, Lisa L. 334

Posmanick, Benjamin 316

Posner, Daniel 279

Posso, Christian 95

Poterba, James 69, 145, 358

Poti, Valerio 210

Potochnick, Stephanie 206

Potter, Tristan 33, 389

Poutvaara, Panu 141, 174, 175

Povel, Paul 390

Powell, David 45, 244

Powell, Michael 160
Pozo, Susan 206

Pozsar, Zoltan 102

Prabhala, N. R. 330

Prager, Elena 314

Prašnikar, Janez 308

Prat, Andrea 348

Pratt, Ryan 285

Preinerstorfer, David 213

Preonas, Louis 123

Presbitero, Andrea 304

Presidente, Giorgio 53

Press, Charles 102

Pressman, Steven 57, 172 , 243, 334

Prest, Brian 186

Prestipino, Andrea 321

Prettyman, Alexa 48

Price, Michael 130, 324

Prieto, Rodolfo 211

Prilmeier, Robert 284

Prina, Silvia 276

Pritsker, Matthew 73

Profeta, Paola 321

Prusak, Laurence 281

Pugacheva, Evgenia 35

Pugatch, Todd 70

Pukthuanthong, Kuntara 187

Pulvino, Todd 110

Puri, Manju 199

Purnanandam, Amiyatosh 284

Purseigle, François 135

Pursiainen, Vesa 38, 187

Putnam, Robert D. 275

Putnins, Talis 325

Putterman, Louis 220

Pyle, William 135

Pyles, Mark 272

\section{Q}

Qazi, Ihsan Ayyub 32, 51

Qi, Hao 221

Qian, Nancy 168, 385

Qian, Wenlan 156, 178

Qian, Xuechao 49

Qian, Yiwei 48

Qiang, Hanlin 258

Qiao, Yankuo 192

Qin, Yu 191, 291

Qiu, Jiaping 393

Qiu, Yue 339

Qiu, Zhesheng 33 
Qu, Guangjun 43

Qu, Xi 162

Qu, Zhongjun 337

Quick, Paddy 128, 258, 375

Quincy, Sarah 245

\section{$\mathbf{R}$}

Raahauge, Peter 76

Rabin, Matthew 292, 377

Rachel, Łukasz 71

Radev, Deyan 347

Radpour, Siavash 89

Raehsler, Rod D. 272

Ragoussis, Alexandros 301, 318

Ragunathan, Vanitha 111

Rahko, Jaana 124

Raissian, Kerri 88

Rajan, Raghuram 71, 99, $180,199,275,330$

Ramalingam, Abhijit 219

Raman, Vikas 330

Ramazzotti, Paolo 154, 261

Rambachan, Ashesh 225

Ramey, Valerie A. 102, 175

Ramirez, Carlos A. 40, 178

Ramirez Nieto, Katerine 172

Ramos-Pastrana, Julio Alberto 90

Rampini, Adriano 151

Ranaldo, Angelo 40, 41, 365

Randrianarisoa, Laingo M. 134

Ranehill, Eva 321

Rangvid, Jesper 76

Ransom, Tyler 313

Ranu, Hardeep 64

Rao, Gautam 224

Raphael, Steven 312

Rapson, David 137

Raschky, Paul 301

Rassier, Dylan 126

Rasul, Imran 101, 141, 142, 259

Ratner, David 281

Ratto, Marco 37

Rau, Hannes 142

Rauch, Christian 191

Rauh, Joshua 342

Raut, Lakshmi K. 267
Rauter, Thomas 178, 392

Raval, Devesh 165, 220

Ravid, S. Abraham 111

Ravina, Enrichetta 330

Rayo, Luis 281

Reardon, Thomas 135

Rebucci, Alessandro 66, 121, 137, 383

Recalde, Maria 229, 383

Redding, Stephen J. 215, 266, 358

Redfearn, Chris 242

Redl, Chris 59, 280, 386

Redoano, Michela 378

Reed, Adam 110

Rees, Daniel 208

Rees-Jones, Alex 82, 377

Reese, Simon 208

Regev, Tali 49

Reguant, Mar 122

Rehbeck, John 161

Rehbein, Oliver 29, 164

Reher, Michael 112

Rehse, Dominik 333

Reich, Michael 88, 355

Reichenbacher, Michael 327

Reilly, Christopher 196

Reimer, Matthew 105

Reinhart, Carmen 216

Reinhart, Christoph 331

Reinsdorf, Marshall 126, 357

Reisel, Natalia 110

Remer, Marc 315

Rempel, Mark 40

Ren, Mengbing 41

Ren, Xiao 198

Ren, Yuan 178

Renneboog, Luc 42

Renwick, Trudi 69

Reslow, André 314

Restrepo, Pascual 62, 146, 249, 282

Restuccia, Diego 118

Reuben, Ernesto 383

Reuter, Jonathan 76

Rey, Helene 71, 144, 180, 346

Reynolds, Lockwood 291

Reynolds, Stan 390

Reza, Syed Walid 329

Rhee, Jennifer 216

Rho, Deborah 89

Rho, Hye Jin 218, 299
Rhode, Paul 385

Rhodes, Andrew 368

Ribarsky, Jennifer 126

Ribeiro, Ruy 36

Ricca, Bernardo 37

Richards, Michael 262

Richards, Timothy 222

Richards-Shubik, Seth 371

Richardson, David P. 69

Richardson, Gary 347

Richione, Marco 41

Richmond, Robert 76, 390

Richter, Andreas 333

Ricks, Judith 113

Riddiough, Timothy 331

Ridley, David 122

Riedel, Max 150

Rieder, Kilian 245

Rieger, Marc 148

Riehl, Evan 314

Rigol, Natalia 247

Riise, Julie 184

Rim, Nayoung 356

Ringdal, Charlotte 183

Ringo, Daniel 113, 395

Ríos-Rull, José-Víctor 33, 280, 348

Risch, Max 376

Rishi, Meenakshi 129

Rising, James 310

Ritadhi, Subatra 327

Ritter, Jay 109, 361

Riutort, Julio 304

Rivera, Roman 356, 374

Rivers, David 175

Rivot, Sylvie 339

Rizzo, Mario J. 119

Robb, Alicia 317

Robe, Michel A. 330

Roberts, Daniel 230

Roberts, Michael 285

Robinson, David T. 340, 363

Robinson, Jonathan 276

Robinson, Matthew 344

Robotti, Cesare 109

Robson, Denise 271

Robstad, Ørjan 33, 34

Rocha, Nadia 142

Rocheteau, Guillaume 68

Rochon, Louis-Philippe 292

Rock, Bjoern 189

Rock, Daniel 63

Rockoff, Hugh 145 
Rodems, Rick 278

Rodgers III, William M. 123

Rodnyansky, Alexander 115

Rodriguez, Jorge 275

Rodríguez, Juan Felipe Riaño 245

Rodrik, Dani 166, 226, 382

Roed Larsen, Erling 242, 332

Roeger, Werner 37

Roesel, Felix 43

Roevekamp, Ingmar 36, 386

Rogalla, Ralph 381

Rogers, William H. 300

Rogoff, Kenneth 102, 275

Rohlin, Shawn 156, 242

Rojon, Isabelle 134

Roland, Randa 351

Roll, Richard 75, 187

Rolleston, Caine 223

Roman, Raluca 290

Romer, Christina 145

Romer, David 145, 315

Romero Cortés, Kristle 283, 284

Romero Haaker, Javier 183

Romeu, Rafael 81

Romley, John 267

Roncoroni, Camilla 213

Roney, Thomas 219

Rong, Ke 51

Rong, Zhao 44, 159

Ropele, Tiziano 232

Rosé, David 341

Rose, Jonathan 245, 280

Rose, Nancy L. 235, 264, 356

Rosen, Samuel 37, 260

Rosenbaum, David 219

Rosenthal, Jean-Laurent 116

Rosenzweig, Mark 172

Rosolia, Alfonso 115

Ross, Amanda 113, 290

Ross, Chase 102, 195

Ross, Matthew B. 98

Ross, Steve 290

Rossi, Alberto G. 106, 179

Rossi, Andrea 76

Rossi, Barbara 66

Rossi, Stefano 232
Rossi-Hansberg, Esteban 220

Rossin-Slater, Maya 67, 387

Rostam-Afschar, Davud 372

Rostom, Ahmed Mohamed Tawfick 265

Roth, Anja 48

Roth, Duncan H. W. 55

Roth Tran, Brigitte 310

Rother, Simon 164

Rothstein, Jesse 66, 96

Rotz, Dana 65

Rouchier, Julliette 31

Roukny, Tarik 264

Rouse, Cecilia 273

Roussanov, Nikolai 75, $240,334,348$

Roussellet, Guillaume 210

Roy, Dooti 30

Roy, Jayjit 30

Royer, Heather 60

Roys, Nicolas 352

Rozelle, Scott D. 173, 270, 306

Rozo, Sandra 174, 311

Ru, Hong 36, 201

Ruan, Hongxun 76, 240

Ruan, Tianyue 226

Ruane, Cian 303

Rubalcaba, Joaquin Alfredo-Angel 125, 254

Rubin, Edward 257, 304

Rubin, Jared 52, 62, 244, 245

Rubio, Margarita 33, 386

Rubio-Ramirez, Juan 336

Rudanko, Leena 360

Ruder, Phil 185

Rudik, Ivan 72, 149, 186

Ruenzi, Stefan 153

Ruhm, Christopher 244

Ruijs, Nienke 46

Ruiz Junco, Pablo 72

Ruiz-Tagle, Jaime 304

Rungcharoenkitkul, Phurichai 71

Runge, Andrew 146

Rus, Horatiu A. 55, 380

Rusche, Felix 31

Russ, Katheryn 214

Russo, Antonio 378

Russo, Natalie 41

Rustagi, Devesh 223, 376
Rustichini, Aldo 371

Ruta, Michele 142

Rutledge, Matthew 123

Rutskiy, Vladislav N. 54

Ryngaert, Jane 397

Rysman, Marc S. 276

Ryu, Doojin 197

Rzayev, Khaladdin 194

S

Saadon, Yossi 59

Saar, Gideon 287

Saavedra, Martin 208

Sabat, Jorge 392

Sabbatucci, Riccardo 149

Sabelhaus, John 69

Sabia, Joseph 160, 184, 244

Sacarny, Adam 86, 296, 388

Sachs, Rebecca 338

Sacks, Daniel 244

Sade, Orly 381

Sadiraj, Vjollca 219

Sadka, Ronnie 390

Sadun, Raffaella 348

Saez, Emmanuel 382

Safaa, Alain 300

Sagaya, Takuo 315

Sager, Erick 220

Sager, Lutz 137

Saglam, Mehmet 194

Sahin, Aysegul 380

Sahm, Claudia 322, 359

Sahni, Herman 240

Saidi, Farzad 397

Saito, Kota 370

Saka, J. O. 401

Saka, Orkun 93

Sakakibara, Mariko 218

Salarpour Goodarzi, Leila 302

Saleh, Fahad 237, 260

Saleh, Mohamed 174

Salgado, Sergio 318

Salisbury, Laura 379

Sall, Mohamadou 122

Sallee, James 137

Salomao, Juliana 232

Salomons, Anna 63

Salvanes, Kjell 143

Salvatore, Dominick 102, 267, 268, 303 
Salz, Tobias 118, 119

Samaniego de la Parra, Brenda 400

Sambanis, Nicholas 343

Samek, Anya 158, 205, $229,336,381$

Samila, Sampsa 65

Sammon, Marco 215

Samsura, Ary Adriansyah 56

Samuels, Jon D. 302

Samuelson, Larry 163, 338, 339

San, Shmuel 138

Sanchez, Alison 323

Sanchez de la Sierra, Raul 58

Sand, Ben 243

Sand, Edith 62

Sandefur, Justin 224

Sanders, Nicholas J. 186, 388

Sandler, Danielle H. 227, 343

Sandri, Damiano 383

Sandro, Ambuehl 296

Sannikov, Yuliy 209

Sansone, Dario 104, 184

Sant'Anna, Pedro H. C. 212, 213

Sant'Anna, Vinicios 56

Santangelo, Gabriela 64

Santiago, Melanie 320

Santillano, Robert 206

Santos, Andres 209

Santos, Toni 298

Santosh, Shrihari 326

Santucci de Magistris, Paolo 365

Sapienza, Paola 70, 234

Saporta-Eksten, Itay 353

Sarama, Julie 173

Sarangi, Sudipta 129

Saravay, Zack 102

Saretto, Alessio 151

Sarferaz, Samad 34

Sarid, Assaf 234, 262

Sarin, Natasha 77, 347

Sarkar, Asani 230

Sarkissian, Sergei 108

Saros, Daniel 306

Sarr, Ibrahima 312

Sarsons, Heather 140, 179, 318

Sarte, Pierre-Daniel 220
Sarvimäki, Matti 143

Sarzosa, Miguel 184

Sasaki, Yuya 213, 369

Sass, Tim R. 340

Sastry, Karthik 161

Sauvagnat, Julien 315

Savor, Pavel 75, 238

Savov, Alexi 365

Sawyer, Malcolm 81

Saxell, Tanja 53

Saydaliyev, Hayot Berk 265

Sayed, Hassan 357

Schaanning, Eric 144

Schaefer, Maximilian 51

Schaefer, Mick 41

Schaffner, Patrick 40

Schaller, Jessamyn 94, 186, 278, 388

Schanbacher, Anja 381

Schaner, Simone 247

Schanzenbach, Diane Whitmore 174, 322

Scharlemann, Tess 113

Schaur, Georg 97, 318

Scheinkman, Jose 277

Schepens, Glenn 230

Scherbina, Anna 202

Scherer, Thomas 159

Scheuch, Christoph 178, 392

Schilbach, Frank 85

Schiller, Christoph Maximilian 310

Schilter, Claudio 295

Schiozer, Rafael 298

Schlaepfer, Alain 223

Schlagenhauf, Don 351

Schloderer, Florian 281

Schlusche, Bernd 77

Schmacker, Renke 281

Schmid, Lukas 199, 288

Schmid, Markus 152

Schmidheiny, Kurt 372

Schmidt, Alex 314

Schmidt, Carolin 333

Schmidt, Christian 196

Schmidt, Christoph 323

Schmidt, Lawrence 154

Schmidt-Eisenlohr, Tim 42,100

Schmidt-Padilla, Carlos 44,312

Schmit, Joan 333
Schmitt-Grohé, Stephanie 137, 295

Schmukler, Sergio 303, 377

Schnabel, Isabel 347

Schnabl, Philipp 77

Schneck, Stefan 141

Schneider, Geoffrey E. 260

Schneider, Helen 271

Schneider, Martin 136, 199

Schneider, Michael 40

Schneider, Will 88

Schnell, Molly 371

Schoar, Antoinette 149, 237

Schoch, Daniela 189

Schoeb, Samuel 324

Schoefer, Benjamin 103, $132,280,318,360$

Schoellman, Todd 64

Schoenherr, David 84

Scholz, Sibylle 168

Schomaker, Rahel M. 218

Schönberg, Uta 354, 389

Schonholzer, David 58

Schori, Tobias 190

Schott, Immo 249

Schott, Peter K. 115, 215

Schreft, Stacey 238

Schreger, Jesse 217, 233

Schreindorfer, David 74, 399

Schreyer, Paul 58

Schrimpf, Andreas 274

Schroeder, Elizabeth 70

Schubert, Jens 60, 61

Schueler, Yves 191

Schuerman, Til 144

Schuetz, Jenny 112

Schulkind, Lisa 262

Schult, Christoph 29

Schulz, Florian 75, 399

Schulze, Tatjana 196

Schuster, Philipp 327

Schutz, Nicolas 257

Schwabish, Jonathan 148

Schwandt, Hannes 387

Schwartzman, Felipe 248

Schwartzstein, Joshua 336

Schwarz, Chris 153

Schweitzer, Mark 360

Schweitzer, Sascha 29

Schwellnus, Cyrille 249

Schwenkler, Gustavo 201

Schwert, Michael 151

Schwienbacher, Armin 40 
Schwirplies, Claudia 130

Scott, Erin 65

Scott Morton, Fiona 311, 356

Scott, Robert 334

Seamans, Robert 63, 273

Seasholes, Mark 201

Seccareccia, Mario 292, 330

Sederberg, Rachel 49, 400

Sedrakyan, Gohar S. 42

Segal, Gill 199

Seguino, Stephanie 252

Seidel, Tobias 55

Seidenfeld, David 268

Seiglie, Carlos 81, 301, 343

Seira, Enrique 304

Sekhposyan, Tatevik 66

Seko, Miki 291

Selcuk, Cemil 118

Seldeslachts, Jo 106, 311

Selim, Tarek H. 270

Selvam, Srinivasan 41

Semenova, Alla 154

Semenova, Vira 294

Sen, Basav 299

Sen, Ishita 190

Sen, Ruchira 154

Sengupta, Rajdeep 169

Seo, Sang Byung 195

Sepulveda, Alberto 77

Serafeim, George 348

Serra, Danila 70, 219

Serra-Garcia, Marta 158

Serrano-Padial, Ricardo 336

Seru, Amit 236, 302, 330, 335

Sesmero, Juan 222

Setterfield, Mark 334

Sevastyanova, Elena P. 54

Severgnini, Battista 52

Severin, Peter Heinz 40

Severinov, Sergei 117

Severnini, Edson 346

Sevinc, Orhun 48

Shachar, Or 230

Shachmurove, Yochanan 36

Shadmehr, Mehdi 85, 147

Shah Goda, Gopi 69

Shah, Manisha 95, 215

Shahin, Wassim 253

Shaikh, Azeem 209, 295

Shaliastovich, Ivan 77

Shambaugh, Jay 322, 358
Shamdasani, Yogita 268

Shams, Amin 260

Shamshur, Anastasiya 308

Shangi, Xueying 41

Shapiro, Adam 368

Shapiro, Jeremy P. 183

Shapiro, Jesse M. 211

Shapiro, Matthew 281

Shapiro, Steven J. 253, 254

Shappo, Mariya 113

Sharma, Varun 190

Sharp, Paul 262

Sharpe, Rhonda Vonshay 243

Shastry, Gauri Kartini 229

Shaver, Myles 217

Shaw, Kathryn 317, 347

Shawhan, Daniel Lloyd 389

Shayo, Moses 62

Shcherbakov, Oleksandr 257, 277

She, Guoman 391

Sheen, Albert 75

Sheiner, Louise 58, 126, 320

Sheldon, Tamara L. 149

Shemyakina, Olga 120

Shen, Leslie Sheng 145, 165,352

Shen, Lily $157,243,333$

Shen, Zuchao 30

Sheng, Jinfei 189

Sheng, Shuyang 211

Shepard, Mark 147, 297

Sheridan, Brandon 97, 359

Sheriff, Glenn 186, 324

Sheu, Gloria 264

Shi, Guang 186

Shi, Lei 32

Shi, Ruoyao 212

Shi, Wei 367

Shi, Xiaoxia 337

Shi, Xuezhu 147

Shi, Yu 83

Shi, Zhan 287

Shi, Zhentao 337, 372

Shibia, Mohamed 380

Shiferaw, Leah 60

Shikher, Serge 36, 141

Shilian, Dalia 165

Shiller, Robert J. 102

Shilpi, Forhad 381

Shim, Hyoung Suk 316

Shim, John 84
Shimotsu, Katsumi 398

Shin, Donghwa 260

Shin, Hyun Song 100, 133, $149,180,233,274,391$

Shishkin, Denis 116

Shive, Sophie 109

Shkilko, Andriy 264

Shleifer, Andrei 232

Shoair, Kareman M. 270

Shonchoy, Abu 283

Shore, Stephen H. 204, 388

Shorrer, Ran 100, 377

Shourideh, Ali 125

Shrader, Jeffrey 274

Shrestha, Prabal 191

Shu, Pian 140

Shu, Tao 237

Shue, Kelly 107, 200, 384

Shughart, William 164

Shukralla, Elias 240

Shum, Matthew 370

Shurchkov, Olga 229

Shy, Oz 311

Sialm, Clemens 202, 240

Siani, Kerry 187

Sichel, Dan 58, 357

Sicilian, Martin 280

Siddiqi, Bilal 101

Siddique, Akhtarur 210

Sidibe, Modibo 377

Siebert, Ralph 222

Siegel, Stephan 106

Siegert, Caspar 144, 280

Siemers, Sarinda Taengnoi 271

Sierminska, Eva 114

Sikhova, Aiday 141, 349

Silva, Andre F. 304

Silva, Olmo 155

Silva, Rui 109

Silver, David 147

Silverman, Daniel 89

Silz-Carson, Katherine 186

Simasek, Peter 210

Simeonova, Emilia 206

Simintzi, Elena 239, 286, 317,393

Simkins, Scott 185

Simmons, Lakisha 271

Simon, Curtis 302

Simon, David 278

Simon, Kosali 207, 244, 262

Simon, Zorka 41, 150

Simonovska, Ina 145, 227 
Simons, Andrew M. 223

Simonyan, Karen 196

Simpasa, Anthony 240

Sims, Christopher 248

Sims, Eric 60

Simsek, Alp 302

Simsek, Oezguer 103

Simutin, Mike 317

Sina, Ana 193

Sinclair, Tara 400

Sing, Tien Foo 191

Singh, Amanjot 198

Singh, Harminder 198

Singh, Mandeep 38

Singh, Rahul 251

Singh, Ruchi 367

Singla, Shikhar 264

Singleton, John 227

Singleton, Kenneth 236

Sinkinson, Michael 165, 311,369

Siow, Aloysius 379

Sirman, Stace 396

Sirmans, Stacy 396

Sissoko, Yaya 271

Sitorus, Romora 195

Siu, Henry 353

Siu, Ricardo Chi Sen 366

Siuda, Fabian 47

Sivadasan, Jagadeesh 218

Skaperdas, Stergios 343

Skeie, David 264

Skidmore, Marin 284

Skoog, Gary 219

Skrastins, Janis 84

Skreta, Vasiliki 160

Slavov, Sita 291

Slesnick, Frank L. 253

Slivko, Olga 31

Sloane, Carolyn M. 141

Sloboda, Brian W. 271

Slotwinski, Michaela 48

Slusky, David 94

Slutzky, Pablo 304

Small, Sarah 344

Smed, Sinne 281

Smeeding, Timothy 69

Smeets, Paul 142, 328, 362

Smets, Frank 99

Smith, Alec 181, 182

Smith, Barbara A. 143

Smith, Ben 97

Smith, Candis Watts 125

Smith, David C. 289

Smith, Dominic 220
Smith, Emma 311

Smith, Eric 395

Smith, Imari 125

Smith, Julie K. 59

Smith, Matthew 376

Smith, Nina 217

Smith, Noah 322

Smith, Stephen 222

Smith, Steven M. 235

Smith, Tony 273

Smith, Tristan 134

Smythe, Andria 166, 341

Snowberg, Erik 293

Snyder, Christopher M. 101

Snyder, Marcia 272

So, Eric 361

Sobel, Joel 247

Sockin, Jason 52

Söderlind, Paul 197

Soetevent, Adriaan 158

Sofie Beck Knudsen, Anne 244

Sojourner, Aaron 166, 339

Solari, Stefano 261

Solis Alonso, Agueda 33

Solnick, Sara 250

Solomon, Keisha 341

Solomon, Steven 152

Solon, Gary 360

Somerville, Tsur 242

Sommervoll, Dag Einar 332

Somogyi, Fabricius 197

Son, Hyelim 49

Son, Hyuk 381

Song, Changcheng 364, 386

Song, Hongwei 129

Song, Hyojin 298

Song, Jae 352

Song, Kyungchul (Kevin) 162

Song, Shiyun 325

Song, Xiaojun 212

Song, Yan 30

Song, Yang 76

Song, Yingquan 55

Song, Ze 43

Song, Zhaogang 237

Song, Zheng Michael 165

Sonin, Konstantin 301

Sorensen, Morten 363

Sorgner, Alina 49

Sorkin, Isaac 180

Sorrenti, Giuseppe 275
Sosyura, Denis 317

Soupre, Matthieu 66

Sovago, Sandor 100

Sovero, Veronica 211

Soylu, Ceren 401

Spady, Richard 212

Spang, Edward 324

Spinnewijn, Johannes 103, 282

Spitzer, Yannay 116

Spizman, Lawrence M. 301

Spletzer, James R. 253

Sposi, Michael 114

Sprenger, Charles 82, 182, 292, 293, 336

Sprengholz, Maximilian 250

Spriggs, Bill 252

Springborn, Michael 105

Springel, Katalin 137

Spruk, Rok 313

Sraer, David 232

Srinivasan, Kandarp 129

Stacchetti, Ennio 370

Stacy, Brian 340

Stacy, Christina 340

Staehr, Karsten 308

Stahl, Jörg 75

Staiger, Becky 183

Staiger, Douglas O. 173, 231

Stanley, Denise 223

Stantcheva, Stefanie 181, 234, 342, 382

Starc, Amanda 86, 336

Starnawska, Sylwia E. 271

Starr, Evan 139, 218, 300

Startz, Meredith 380

Stathopoulou, Eleni 324

Steck, Andrew 185

Steffen, Sascha 298

Steffen, Tom 362

Stegmann, Andreas 58

Stehle, Simon 193

Steigerwald, Douglas 208, 209

Steinbaum, Marshall 339

Stein, Carolyn 316

Stein, Howard 111

Stein, Jeremy 110, 274

Stein, Wiebke 31

Steiner, Eva 396

Steingrimsdottir, Herdis 46

Steinsson, Jon 145, 180

Stenbacka, Rune 311 
Stepanova, Anastasia 42

Steri, Roberto 347

Stern, Ariel 338

Stern, Lea 152

Stevanovic, Dalibor 294

Stevens, Andrew W. 177

Stevens, Ann Huff 278

Stevens, Jack 65

Stevens, Reid 46

Stevenson, Betsey 227

Stevenson, Megan 225

Stiglitz, Joseph E. 166, 178,358

Stinson, Martha 143

Stock, James 93

Stock, Wendy 97, 148

Stockhammer, Engelbert 157

Stoddard, Olga 316, 383

Stoerk, Thomas 310

Stojkov, Aleksandar 216

Stouli, Sami 212

Stoye, Joerg 161, 162

Strack, Philipp 336

Strahan, Philip 77

Strand, Jon 281

Strange, William 155

Strassmann, Diana 263

Straub, Alexander 351

Strausz, Roland 370

Strebulaev, Ilya 287, 317

Street, Brittany 312

Strenio, Jacqueline 120, 243

Strittmatter, Anthony 301

Strobl, Günter 390

Stroebel, Johannes 231

Stuart, Bryan 385

Stulz, Rene 109, 200, 250, 284

Sturm, Daniel M. 266

Su, Yaqin 255

Su, Yichen 343

Su, Zhongxing 132

Suarez, Gustavo 121

Suárez Serrato, Juan Carlos 223, 273

Subrahmanyam, Marti G. 40, 150

Suedekum, Jens 54

Suen, Wing 85

Sugaya, Takuo 85

Sugden, Robert 219

Sukeda, Akatsuki 33

Sukhatme, Neel U. 316
Sukhtankar, Sandip 86

Sulaeman, Deserina 47

Sulaeman, Johan 237, 291

Sullivan, Christopher John 315, 355

Sullivan, Colin 384

Sullivan, Ryan 301

Sumita, Kazuto 291

Summerfield, Fraser 310

Summers, Lawrence 71, $102,175,321$

Sun, Chang 318

Sun, Jian 287

Sun, Shuqiao 275

Sun, Yanmei 53

Sun, Yufeng 31

Sun, Yukun 43

Sun, Zhen 51, 52

Sunding, David 236

Sung, Ilmo 320

Sunstein, Cass 225

Suntheim, Felix 76

Supic, Novica 394

Suri, Tavneet 276

Surprenant, Stephane 294

Svejnar, Jan 308

Sviatschi, Maria Micaela $65,95,312$

Svorenčík, Andrej 87

Swallow, Stephen 159

Swanson, Eric 210

Swanson, Nicholas 278

Sweeney, Richard L. 123, 185

Swem, Nathan 200

Swenson, Deborah 115

Swiecki, Tomasz 115

Swift, Henry 180

Swinton, Omari 307, 342

Sylvia, Sean 270, 345

Sylwester, Kevin 43

Syrgkanis, Vasilis 251

Syropoulos, Constantinos 343

Syverson, Chad 220, 293

Szabo-Morvai, Agnes 228

Szekely, Istvan P. 308

Szembrot, Nichole 343

Szydlowski, Martin 391

Szymanowska, Marta 196

Szymborska, Hanna 157, 221
Ta, Chi Lan 283

Tabellini, Marco 70, 138

Taber, Christopher 211, 295, 352

Taddesse, Birhanu 380

Taddy, Matt 302

Tadelis, Steven 369

Tadesse, Bedassa 203, 240

Tahbaz-Salehi, Alireza 178

Tahoun, Ahmed 136

Takahashi, Shingo 289

Takaku, Reo 139

Takalo, Tuomas 53

Takats, Elod 145

Takeda, Yosuke 50

Tallman, Ellis 245

Tallman, Eric 378

Talpey, Laura M. 173

Tamayo, Jorge 95, 159

Tamer, Elie 211

Tamoni, Andrea 74, 394

Tamuz, Omer 336

Tan, Rose 293

Tan, Sook Rei 192

Tan, Teck Yong 247

Tang, Heiwai 114

Tang, Ke 103, 202

Tang, Qu 55

Tang, Rui 147

Tang, Susan Xu 219

Tang, Tianze 51

Tang, Xun 162

Tang, Yi 236

Tang, Yihong 143

Tangeras, Thomas 91

Tangvatcharapong, Meradee 31

Tannenbaum, Daniel 294

Tao, Ran 197

Tapsoba, Ludovic 177

Taraz, Vis 268

Tarquinio, Lisa 71

Tarroux, Benoit 296

Taska, Bledi 63, 400

Taskin, Ahmet Ali 199

Tasneem, Sakiba 53

Tasoff, Joshua 181

Tate, Geoffrey 152, 317

Taubinsky, Dmitry 323

Tavani, Daniele 158

Taylor, Greg 298

Taylor, Lucian A. 240, 289

Taylor, Mark 40, 76 
Tebaldi, Pietro 147

Teitelbaum, Joshua 161, 336

Teixeira, Paulino 132

Tejada, Oriol 85

Tejeda, Hernan 135

Tekin, Erdal 66, 357

Teltser, Keith 244

Temesvary, Judit 145

Temnyalov, Emil 176, 177

Tena, Vincent 190

Tennyson, Sharon 333

Teo, Ho Pin 291

Teodorescu, Andrew 131

Teodoridis, Florenta 63

Teplitskiy, Misha 64

Tergiman, Chloe 296, 377

Terrier, Camille 230

Terry, Stephen J. 71, 199, 232

Tervala, Juha 36

Teryoshin, Yevgeniy 34

Tessada, José A. 304, 350

Thakor, Anjan 330

Thakral, Neil 82

Tham, Eric 187

Theissen, Erik 196

Theloudis, Alexandros 32

Théré, Christine 87

Thesmar, David 231, 232, 326

Thewissen, James 191

Thiede, Brian 172

Thijssen, Jacco 255

Thimsen, Christoffer 200

Thirumurthy, Harsha 345

Thomas, Betty 177

Thomasson, Melissa 143

Thompson, Alexandra 389

Thompson, Peter 185

Thompson, William 320

Thorburn, Karin 393

Thornton, Rebecca 354

Thornton, Robert J. 372

Thorsrud, Leif Anders 59, 115

Thunstrom, Linda 43, 147

Tibbitts, Joshua 184

Tideman, Nicolaus 43

Timmer, Yannick 35

Timmins, Christopher 185

Timmis, Jonathan 232

Timmons, Edward J. 372

Timpe, Brenden 275

Tindall, Greg 194
Tintelnot, Felix 214, 387

Tissen, Colin 193

Titman, Sheridan 149, 190

Tkachenko, Denis 337

Tkalec, Marina 313

Tô, Linh 82

To, Thuy 99

Tobol, Yossef 177

Todd, Petra 247

Todorov, Viktor 399

Todorova, Zdravka 82 , 154,260

Toikka, Juuso 209

Tolotti, Marco 32

Toloui, Ramin 273

Tomoeda, Kentaro 30

Tonetti, Christopher 231, 364

Toney, Jermaine 97

Tong, Matthew 274

Tonguc, Ozlem 343

Tookes, Heather 152

Toomet, Ott 159

Topalova, Petia 35

Toporowski, Jan 78

Torbat, Akbar 253

Torgovitsky, Alexander 119

Torsin, Wouter 191

Toth, Russell D. 223, 380

Touzet, Chloe 252

Townsend, Rick 111

Townsend, Robert 83, 284

Trachter, Nicholas 220, 380

Traeger, Christian 149

Trako, Iva 65

Tran, Kevin Ducbao 51

Tran, Ngoc-Khanh 99

Tran, Trang Thu 318

Trautmann, Stefan 142

Tregenna, Fiona 265

Treibich, Tania 54

Trejo, Stephen 206

Tremacoldi-Rossi, Pedro 80,190

Tresl, Jiri 308

Trevino, Isabel 273

Trias, Julieta 45

Trigeorgis, Lenos 196

Trigilia, Giulio 391

Trojette, Ines 218

Troyan, Peter 377

Truskinsovsky, Yulya 218

Tsang, Albert 364

Tsankova, Teodora 282

Tseng, Kevin 197
Tsiaras, Argyris 150

Tsigas, Marinos 141

Tsomocos, Dimitrios 38, 196

Tsou, Chi-Yang 107

Tsouderou, Athena 204, 248, 332

Tsoukalas, Gerry 237

Tsoutsoura, Margarita 152, $317,361,393$

Tu, Hong 156

Tu, Yong 332

Tudoreanu, Mihnea 306

Tumen, Semih 175

Tungodden, Bertil 142

Turan, Irmak 331

Turkel, Eray 85

Turnbull, Geoffrey 367

Turner, Bryce 326

Turrell, Arthur 59, 280

Tut, Daniel 188

Tuzemen, Didem 299

Twinam, Tate 256

Tybout, James 317

Tyran, Jean-Robert 220

Tyrefors, Bjorn 44

Tyrowicz, Joanna 308

Tzur-Ilan, Nitzan 113

U

Uchida, Ichihiro 50

Uchida, Shinsuke 72

Udalova, Victoria M. 373

Uddin, Syed Al-Helal 36

Udell, Gregory F. 297

Ueberfeldt, Alexander 34

Ufier, Alexander B. 169

Uhlig, Harald 68, 180, 391

Uhr, Charline 195

Ukhov, Andrey 331

Ülgen, Faruk 330

Ulrich, Maxim 150

Ulrych, Urban 194

Ulvedal, Pål Bergset 33

Ume, E. J. 342

Umkehrer, Matthias 354

Uppal, Raman 108

Upton Jr., Gregory B. 48, 263, 303

Uribe, Martin 295

Urrego, Joaquin 388 
Valchev, Rosen 77

Valencia Caicedo, Felipe 245

Valkanov, Rossen 108

Valletta, Robert 252

Van Ark, Bart 357

van Bekkum, Sjoerd 386

van Benthem, Arthur A.

137

van Binsbergen, Jules 74, 150, 199, 286, 327

van Breemen, Vivian 195

van de Minne, Alexander 112,333

van den Berge, Wiljan 63

van der Beek, Karine 262

van der Klaauw, Bas 100

van der Krabben, Erwin 56

van der Linden, Clifton 216

Van Dijk, Dorinth 242

van Dijk, Winnie 294

Van Doornik, Bernardus 84

van Lelyveld, Iman 264

van Lent, Laurence 136

Van Nieuwerburgh, Stijn 108, 248

van Oordt, Maarten R.C. 68

Van Order, Robert 204

Van Reenen, John Michael 67, 136, 232, 282, 356, 384

van Rens, Thijs 360

Van Tassel, Peter 151

van Veldhuizen, Roel 229

Van Wesep, Edward 152, 307

van Wincoop, Eric 334

Vandenbussche, Jerome 35

Varadi, Alexandra 386

Varas, Felipe 309, 391

Vardoulakis, Alexandros 152

Varela, Liliana 216

Vargas, Juan F. 95, 174

Vari, Miklos 229

Varian, Hal R. 273, 320

Varneskov, Rasmus 150

Varotto, Simone 193

Vasconcello, Carlos 221

Vasigh, Bijan 134

Vasiljević, Nikola 194

Vasios, Michalis 40
Vasquez, Aurelio 151, 198

Velasquez, Andrea 94, 349, 350

Veld, Klaas Van't 43

Veldkamp, Laura 74, 152, 201, 266

Velikova, Marieta V. 271

Velioglu, Guner 285

Veliyev, Bezirgen 213

Vellore, Arthi 262

Venancio, Ana 255

Veneziani, Roberto 261

Venkataraman, Kumar 330

Venkateswaran, Venky 136

Venter, Gyuri 365

Verbrugge, Randal 243

Verdelhan, Adrien 77, 335

Verme, Paolo 311, 312

Vermeulen, Stan 46

Vernengo, Matías 330, 331,395

Verner, Emil 63

Veronesi, Marcella 72

Veronesi, Pietro 202, 328

Verriest, Ewout 275

Vertova, Giovanna 111

Vespa, Emanuel 296

Vesterlund, Lise 229

Viceisza, Angelino C. G. 340

Vicente, Pedro 219, 276

Vicquery, Roger 37

Vidal, Gregorio 331

Vielma, Nicole Cerpa 305

Vig, Vikrant 75, 264

Vigdor, Jacob 360

Villa, Kira 222

Villacorta, Lucciano 209

Villamizar-Villegas, Mauricio 233, 304

Vincent, Nicolas 249

Vink, Dennis 195

Vinogradov, Dmitri 161

Violette, William 269

Virag, Gabor 117

Visschers, Ludo 310

Vissing-Jorgensen, Annette 274, 390

Vitanza, Justin 169

Vivalt, Eva 279

Vives, Xavier 139, 311

Vo, Nguyen Ngoc Thao 38

Voena, Alessandra 95

Vogel, Jonathan 182

Voigtländer, Nico 174
Volchkova, Natalya 321

Volkov, Nikanor I. 219

Volpp, Kevin 184

von Berge, Philipp 354

von Hirschhausen, Christian 249, 297

von Meyerinck, Felix 152

Voorheis, John 346

Voors, Maarten 101

Vossmeyer, Angela 245

Voth, Hans-Joachim 63

Vroman, Susan 400

Vu, Khoa 223

Vyborny, Kate 104, 105

W

Wachtel, Paul 92

Wachter, Jessica 151, 239, 328

Wachter, Susan M. 204, 290, 352

Waggoner, Daniel 336

Wagman, Liad 167

Wagner, Gernot 310

Wagner, Hannes 329

Wagner, Jamie 124

Wagner, Zachary 345

Waichman, Israel 130

Wakatabe, Masazumi 355

Waldinger, Daniel 83

Waldinger, Fabian 62

Waldock, Katherine 288

Walker, Brigham 46

Walker, Reed 346

Wall, Larry 164

Waller, Bennie 367

Waller, William 155, 260, 363

Walmsley, Terrie 269

Walsh, Randall 256, 347

Walstad, William B. 124

Walter, Jason 50

Walters, Christopher 119, 231, 370

Wamboye, Evelyn 203

Wan, Sirui 173

Wan, Xinwei 80, 291

Wan, Yuanyuan 369

Wan, Zhixi 84

Wanamaker, Marianne 143, 227

Wang, Baolian 239, 260

Wang, Chaojun 287 
Wang, Chongyu 112, 396

Wang, Daniel 320

Wang, Emily 222

Wang, Feng 43

Wang, Gang 30

Wang, Guanghua 132

Wang, Hao 197

Wang, Haomin 355

Wang, Huixia 346

Wang, Jessie Jiaxu 365

Wang, Jiang 198

Wang, Jingyuan 103

Wang, Junbo 187

Wang, Li 352

Wang, Liang Choon 48, 53

Wang, Long 127, 291

Wang, Lucy Xiaolu 121

Wang, Neng 237, 285, 327,363

Wang, Qiguang 392

Wang, Sean 109

Wang, Shiyi 378

Wang, Shuangxin 44

Wang, Si 346

Wang, Teng 214, 297

Wang, Tianyu 394

Wang, Tracy 75, 152

Wang, Wanyi 189

Wang, Wei 169, 289

Wang, Wenjun 55

Wang, Wenxiao 143

Wang, Wenyu 289

Wang, Xiao Yu 183, 223

Wang, Yajun 287

Wang, Yaopei 332

Wang, Ye 75, 191

Wang, Yenan 191

Wang, Yifei 326

Wang, Yiren 186

Wang, Yong 32, 35, 51

Wang, Yonglin 113

Wang, Youan 193, 202

Wang, Yu 196, 197

Wang, Yulong 211, 213

Wang, Zenan 278

Wang, Zexi 152, 363

Wang, Zhengwei 196

Wang, Zhu 276, 277

Wang, Zi 114

Wang, Zigan 54, 99, 193, 202

Wang, Zijia 398

Wang Huber, Amy 153

Ward, John O. 253

Ward, Zachary 208
Warin, Thierry 216

Warnecke, Tonia 241

Warnock, Frank 345

Warren, Lawrence 254

Warren, Lewis H. 267

Warrinnier, Nele 270

Washington, Ebonya 140, 176

Wasserman, Melanie 217

Waters, Brian 152

Watkins, John 82

Watson, Philip 135

Watt, Andrew 170

Watugala, Sumudu 153

Weagley, Daniel 284

Weaver, Andrew 299, 373

Webb, Anthony 88, 89

Webb, Michael 273

Webb, Stuart 97

Weber, Marko 238

Weber, Martin 42

Weber, Michael 106, 161, 274, 325, 326, 392

Weber, Paige 263

Weber, Roberto A. 321

Wei, Hongcen 90

Wei, Lili 56

Wei, Mengxin 158

Wei, Shang-Jin 76

Wei, Yanhao 240

Wei, Zuobao 50

Weidner, Martin 162

Weigert, Florian 153

Weil, David 318

Weill, Laurent 93

Weinandt, Mandie 271, 272, 307

Weinbaum, David 399

Weinberg, Matthew 106, $166,264,315$

Weinert, Jan-Hendrik 381

Weinstein, David 358

Weinzierl, Matthew 342

Weisbach, Michael 201

Weisbrot, Mark 246

Weisburst, Emily 356

Welch, C. Jamilah 276

Wen, Hefei 207

Wentland, Scott 367

Wermers, Russell 72

Werner, Alejandro 383

Werner, Ingrid 325

Werthschulte, Madeline 55

West, Colin 205

Westerfield, Mark 365
Westerlund, Joakim 372

Wettstein, Gal 382

Whalen, Charles 289, 366

Whaley, Kenneth 341

Whang, Yoon-Jae 211

Wheelock, David C. 245

Whelan, Paul 286

Wherry, Laura 94

Whillans, Ashley 205

Whinston, Michael 146

White, Eugene 245

White, T. Kirk 302

Whited, Toni 232, 285, 326

Whitehead, John C. 307

Wicks-Lim, Jeannette 252

Wieber, Anna 250

Wiemer, Calla 268

Wiemers, Emily 218

Wiesen, Daniel 207

Wilcher, Britni 47, 125

Wilcox, David 273

Wildenbeest, Matthijs 368

Wilhelm, Mark 130, 158

Wilhelm, Sascha 376

Wilke, Anna 183

Wilkins, Carolyn A. 104, 355

Willage, Barton 184, 262

Willen, Alexander L.P. 184

Willen, Paul 204, 290

Willett, Thomas 34

Williams, Emily 347

Williams, Geoffrey 176

Williams, Heidi 316

Williams, Jared 361

Williams, Jhacova 375

Williams, John C. 355

Williams, Jonathan 166

Williams, Joseph 79, 243

Williams, Miesha J. 133, 374,401

Williams, Robert 125

Williams, Roberton 93, 149

Williams, Tomas 304, 378

Willington, Manuel 335

Willis, Jonathan 68

Wilson, Daniel J. 310, 368

Wilson, Jarnickae 301

Wilson, Nathan 368

Wilson, Riley 277, 278

Wilson, Wesley W. 127, 257

Winberry, Thomas 302

Winkler, Erwin 143

Winter, Simon 314 
Wirth, Benjamin 397

Wischnewsky, Arina 280

Wiswall, Matthew 230, 275

Witte, Mark 272

Wittry, Michael 150

Wiwattanakantang, Yupana 33

Woerman, Matt 123, 389

Woessmann, Ludger 62, 173, 224

Woessner, Nicole 54

Wohlforth, William 343

Wolak, Frank A. 257

Wolcott, Erin 145

Woldemichael, Andinet 203

Wolf, Christian 337

Wolf, Zoltan 293

Wolfe, Barbara L. 314

Wolfe, Simon 79, 99

Wolfenzon, Daniel 317

Wolfers, Justin 136, 205, 227

Wolfolds, Sarah 32

Wolfskeil, Isabella 197

Wolitzky, Alexander 85, 246

Wolla, Scott 272

Wollmann, Thomas 264

Wolter, Stefanie 397

Wong, Anna 145

Wong, Arlene 231

Wong, Kelvin 374

Woo Chang, Jin 218

Woodbury, Stephen A. 267

Wood, Justine 78, 79

Wooldridge, Jeffrey 72 , 119

Wozniak, Abigail 299

Wray, Randall 82

Wrenn, Douglas H. 185

Wrenn, Mary V. 395

Wright, Austin 301

Wright, Brian 92

Wright, Catherine 304

Wright, Ian 117, 241

Wright III, James E. 374

Wright, Randall 68

Wu, Botao 194

Wu, Chaopeng 255

Wu, Derek 69

Wu, Eliza 325

Wu, Hong 110

Wu, Jiashan 38

Wu, Jing 156
Wu, Jing Cynthia 60, 131

Wu, Ke 193

Wu, Qianfan 225

Wu, Shijia 197

Wu, Xi 362

Wu, Yanhui 39

$\mathrm{Wu}$, Yufeng 326

Wu, Zhonghua 112

Wuchte, Christian 150

Wydick, Bruce 223

Wynter, Matthew 39

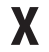

Xi, Tianyang 207

Xia, Lingjun (Lotus) 229

Xia, Xiaoyu 30, 379

Xiang, Hong 194

Xiao, Kairong 326

Xiao, Mo 369

Xiao, Ruli 213

Xiao, Serena Wenjing 332

Xiao, Steven Chong 332

Xiao, Xiao 77, 151, 198, 335

Xiao, Yizhou 201

Xiaolan, Mindy 199, 251, 286

Xie, Danxia 32

Xie, Jia 290

Xie, Jin 106, 311

Xie, Peichu 35

Xie, Rengming 236

Xin, Yi 398

Xing, Jianwei 137, 207

Xiong, Qiaoqin 51

Xiong, Qizhou 38

Xiong, Wei 173

Xiong, Yan 288

Xiu, Dacheng 108

$\mathrm{Xu}$, Chenggang 172, 173

$\mathrm{Xu}$, Chenjie 107

Xu, Chenzi 144, 245

Xu, Dafeng 49, 50

Xu, David Xiaoyu 188

Xu, Emma Qianying 393

$\mathrm{Xu}, \mathrm{Li} 276$

$\mathrm{Xu}$, Lin 336

$\mathrm{Xu}$, Menghan 32

$\mathrm{Xu}$, Ming 318

$\mathrm{Xu}$, Mingzhi 115

$\mathrm{Xu}$, Minhong 55

$\mathrm{Xu}$, Nancy 66, 150, 286

Xu, Qi 40, 212
Xu, Qiping 393

$\mathrm{Xu}$, Weibiao 156

$\mathrm{Xu}$, Yilan 55

$\mathrm{Xu}$, Yilong 142

$\mathrm{Xu}$, Yujing 30, 32

$\mathrm{Xu}$, Zhun 258, 341

Xue, Hao 345

Xue, Jinming 193

Xue, Shan 34

Xue, Xiaohan 191

Y

Yadav, Pradeep K. 330

Yagan, Danny 249, 281

Yamada, Hiroyuki 54

Yamada, Takahiro 54

Yamana, Kazufumi 126

Yan, Jianye 53

Yan, Jubo 291

Yan, Shuo 327

Yan, Zhen 368

Yang, Bin 188

Yang, Brian 347

Yang, Chenyu 84

Yang, Chloe Chunliu 76

Yang, Choongryul 248, 396

Yang, Cynthia 213

Yang, David 168

Yang, Endong 36

Yang, Ge 192

Yang, He 245, 323

Yang, Hee-Seung 48, 53

Yang, Hyunjoo 131

Yang, Jialun 190

Yang, Jinqiang 327

Yang, Liyan 236, 288

Yang, Lizhengbo 188

Yang, Ming 365

Yang, Ron 287

Yang, Wenhao 32

Yang, Xi 155

Yang, Xianling 352

Yang, Yang (Zoe) 127, 157, 291

Yang, Ying 56

Yang, Yuhao 61

Yanguas, Lucia 385

Yannelis, Constantine 199, 392

Yao, Chen 325

Yao, Fang 33

Yao, Yang 168

Yared, Pierre 125 
Yariv, Leeat 163

Yaron, Amir 288

Yassin, Shaimaa 253

Yasuda, Ayako 363

Yavas, Abdullah 261, 367

Ye, Han 147

Ye, Kailei 286

Ye, Zihan 192

Yeckehzaare, Iman 163

Yedid-Levi, Yaniv 353

Yegen, Eyub 188

Yeh, Chen 339

Yellen, Janet 140, 170, 259, 306, 321

Yemba, Boniface 203, 241

Yett, Donald 296

Yeung, Bernard 178

Yeung, Eric 237

Yeung, Kelvin 237

Yi, Hongmei 345

Yi, Junjian 147, 379

Yi, Moises 254

Yildirim, Yildiray 332, 386

Yin, Rujun 34

Yin, Wesley 338

Yip, Winnie Chi-Man 122

Yoder, Jonathan 184

Yog, Motohiro 335

Yogo, Motohiro 200, 364, 390

Yoo, Jungsoo 156

Yoo, Sunny (Seung Yeon) 189

Yook, Youngsuk 386

Yoruk, Baris K. 228

Yoshida, Jiro 35, 291

Yoshida, Masahiro 78

Young, Christopher 301

Young, Eric 112, 348

Young, Michael 110

Young, Sabrina 244

Young, Samuel 103

Younkin, Peter 140

Yu, Chan 319

Yu, Changhua 383

Yu, Chu (Alex) 72

Yu, Haiyue 47

Yu, Han 48

Yu, Jiaheng 363

Yu, Ko Chiu 41

Yu, Luping 54, 99

Yu, Shihao 188

Yu, T. Edward 126

Yu, Tong 367

Yu, Zhi 115
Yuan, Haishan 154

Yuan, Kathy 288, 364

Yuan, Xiaojing 319

Yucel, Mine 297

Yuchtman, Noam 58, 168, 173

Yun, Jeonghwan 48

Yun, Seong Do 361

Yurukoglu, Ali 165

\section{Z}

Zabcyzk, Pawel 322

Zabel, Jeff 367

Zabin, Carol 299

Zachariadis, Konstantinos 329

Zachorowska, Anna 344

Zadeh, Ali 90

Zafar, Basit 217, 350

Zaffaroni, Paolo 108, 212

Zahirovic-Herbert, Velma 367

Zaia, Johannes 196

Zakharenko, Roman L. 47

Zaldokas, Alminas 38, 391

Zalewski, David 204, 289, 307

Zamarripa, Guillermo 39

Zandberg, Jonathan 190

Zapechelnyuk, Andriy 247

Zecchetto, Franco 204

Zekhnini, Morad 362

Zelleke, Almaz 205

Zellweger, Thomas 190

Zender, Jaime 273

Zeng, Yao 365

Zentefis, Alexander 362

Zerbib, Olivier David 187

Zetlin-Jones, Ariel 125

Zettelmeyer, Jeromin 35

Zhan, Xintong 190, 198

Zhang, Ally 210

Zhang, Anming 127

Zhang, Bing 159

Zhang, Bohui 202

Zhang, Calvin 352

Zhang, Cathy 68

Zhang, Cheng 309

Zhang, Chi 50

Zhang, Daiqiang 51, 276

Zhang, Donghang 298

Zhang, Hanzhe 31, 347

Zhang, Harold 326
Zhang, Hong 187, 214

Zhang, Hongwei 190

Zhang, Hongyong 318

Zhang, Hongzhong 287

Zhang, Jialiang 291

Zhang, Jiaming 40

Zhang, Jing 56, 114

Zhang, Junfu 159

Zhang, Junsen 379

Zhang, Kaida 51

Zhang, Lei 251

Zhang, Melanie 112

Zhang, Mingrui 192

Zhang, Mu 117

Zhang, Peng 55, 346

Zhang, Qi 255

Zhang, Qian 360

Zhang, Qilin 42

Zhang, Renbin 37

Zhang, Shaojun 286

Zhang, Shengxing 230, 288

Zhang, Shuang 223

Zhang, Teng 113

Zhang, Tengfei 187

Zhang, Terry 72

Zhang, Tingting 166

Zhang, Tongbin 37

Zhang, Wei 258

Zhang, Weilong 247

Zhang, Weiming 190

Zhang, Xiaobo 207

Zhang, Xiaoqian 41

Zhang, Xiaoyu 191

Zhang, Xin 284

Zhang, Yanqun 269

Zhang, Yi 337

Zhang, Yifei 328

Zhang, Yue 393

Zhang, Yunqi 366

Zhang, Yuxin 50, 72

Zhang, Yuzhe 83

Zhao, Aidong 56

Zhao, Daxuan 157

Zhao, Guihai 39

Zhao, Haibei 153

Zhao, Hangcheng 31, 147

Zhao, Tianyue 194

Zhao, Weihua 291

Zhao, Xiaofei 285

Zhao, Yanhui 42

Zhao, Yijia (Eddie) 298

Zhen, Ying 261

Zheng, Fanyin 118

Zheng, Hannan 201

Zheng, Jie 31, 52, 147 
Zheng, Lu 108

Zheng, Qiang 386

Zheng, Siqi 367

Zheng, Xiang 196

Zheng, Xiaoting 257

Zhong, Molin 35

Zhong, Songfa 147

Zhong, Weijie 298

Zhong, Xiao 194

Zhou, Anming 127

Zhou, Changyun 191

Zhou, Christy 137

Zhou, Congyi 196

Zhou, Di 51

Zhou, Frank 309

Zhou, Guofu 108

Zhou, Hao 83

Zhou, Jin 270

Zhou, Junjie 246

Zhou, Kris 51

Zhou, Qiankun 372

Zhou, Tingyu 79, 112
Zhou, Tong 239

Zhou, Xiaoqing 343

Zhou, Xiaoxia 157

Zhou, Yinggang 36

Zhou, Zhengyi 127

Zhu, Bing 396

Zhu, Haoxiang 198, 287, 325,365

Zhu, Jialiang 31

Zhu, Lijun 33, 35

Zhu, Shuang 367

Zhu, Wu 83

Zhu, Xiaodong 114

Zhu, Yinchu 251

Zhu, Ying 103

Zhulanova, Julia 115

Zhuravskaya, Ekaterina 174

Zia, Bilal 238

Zidar, Owen 342, 376

Ziedonis, Arvids 239

Ziegert, Andrea 221
Zierow, Larissa 62

Zikes, Filip 144, 178, 238

Zimmermann, Laura 354

Zimran, Ariell 116

Zingales, Luigi 64, 147, 226, 362

Zlate, Andrei 73

Zochowski, Awid 33

Zochowski, Dawid 385

Zolas, Nikolas 92, 146

Zongwu, Cai 131

Zotti, Roberto 43

Zou, Eric 346

Zubairy, Sarah 175, 256

Zucman, Gabriel 226, 382

Zuo, Luo 237

Zviadadze, Irina 108

Zwager, Astrid 105

Zweimüller, Josef 103, 360

Zwick, Eric 376 


\section{Need a break from looking for the good swag* in the Exhibit Hall?}

\section{Join ASSA and the Exhibitors for a coffee \& tea break every morning from 9-10}

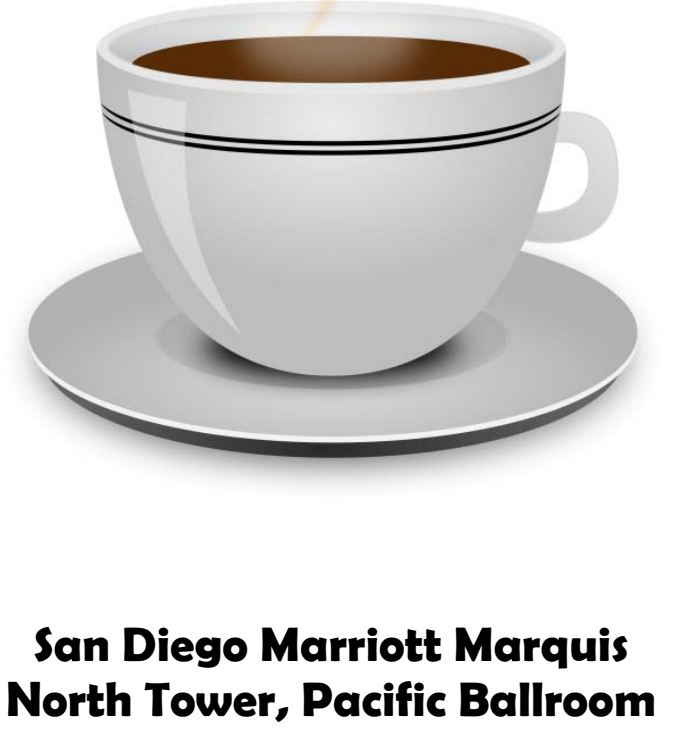

*Swag: A slang term for free promotional items given away by exhibitors at a convention. 


\section{ANALYSIS GROUP}

\section{Providing expertise in economics,}

finance, health care analytics, and strategy to top law firms,

Fortune Global 500 companies, and government agencies

worldwide.

For more information, please contact

Martha Samuelson, CEO and Chairman, at 6174258000 , or visit www.analysisgroup.com

Boston Chicago Dallas Denver Los Angeles

Menlo Park New York San Francisco Washington, DC

Beijing - Brussels - London - Montreal - Paris 


\section{LOOKING FOR A RESEARCH GRANT?}

\section{Steven H. Sandell Grant Program}

Opportunity for junior or non-tenured scholars to pursue projects on retirement or disability issues.

$\$ 45,000$ grants awarded to researchers with a Ph.D. or comparable credentials.

Program guidelines at: crr.bc.edu/about-us/grant-programs Application deadline: January 31, 2020

\section{Dissertation Fellowship Program}

Opportunity for the next generation of scholars to pursue quality research on retirement or disability issues.

$\$ 28,000$ fellowships awarded to doctoral candidates enrolled in a U.S. university's accredited program.

Program guidelines at: crr.bc.edu/about-us/grant-programs Application deadline: January 31, 2020

Sponsored by the U.S. Social Security Administration

\section{Manage your ASSA schedule here!}

- DOWNLOAD THE FREE APP

- LOG IN WITH YOUR REGISTRATION ID

(CLICK ON THE ASSA 2020 MEETING PAGE ON OUR HOMEPAGE, OR GO TO ANY PREFERRED APP STORE LOCATION)

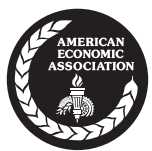

Download App

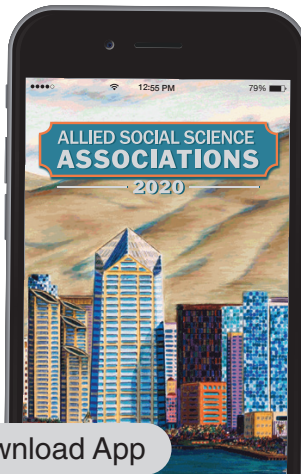

www.aeaweb.org

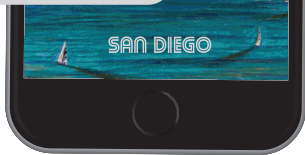




\section{AEA CONTINUING EDUCATION PROGRAM STAY CURRENT on the Latest Developments in Economics Teaching and Research}

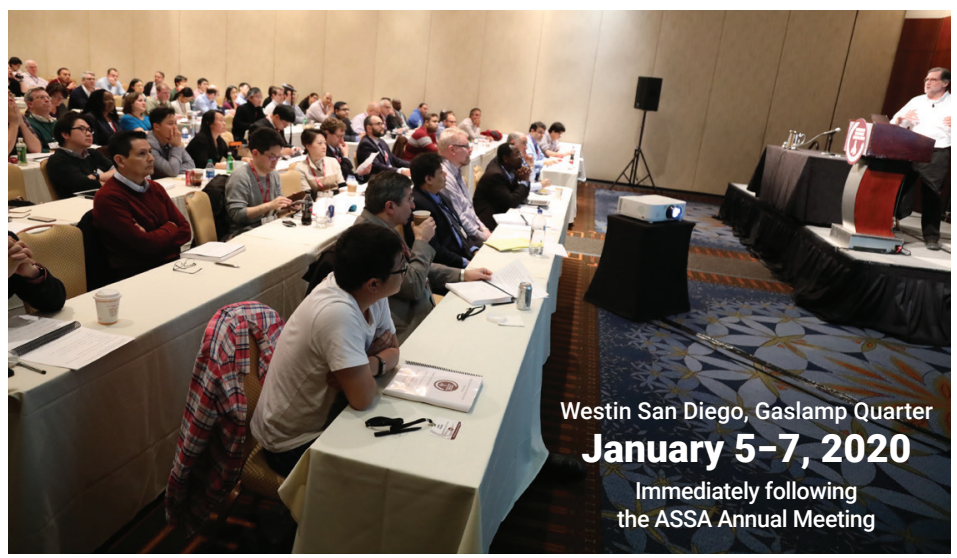

\section{THREE CONCURRENT PROGRAMS}

\section{Mastering Mostly Harmless Econometrics}

Alberto Abadie

Massachusetts

Institute of Technology

\section{Joshua Angrist \\ Massachusetts}

Institute of Technology
Christopher Walters University of California-Berkeley
Gauti B. Eggertsson

Monetary Policy
Jon Steinsson

University of

California-Berkeley

University

Gilbert E. Metcalf Tufts University

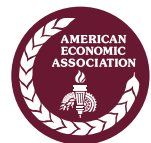

Registration is required. www.aeaweb.org/conference/cont-ed 
Kauffman

Networking Reception for Entrepreneurship Research

\author{
January 4, 2020 \\ 6:30 to 9:00 p.m. \\ Marriot Marquis \\ San Diego \\ Grand Ballroom 12
}

The Kauffman Foundation invites you and your colleagues to join us for an informal and interactive networking reception to engage scholars who are studying entrepreneurship.

Cocktails and hors d'oeuvres will be served.

Learn more about the Kauffman Foundation at Kauffman.org.

FOUNDATION

THINK. DO. BE UNCOMMON . 


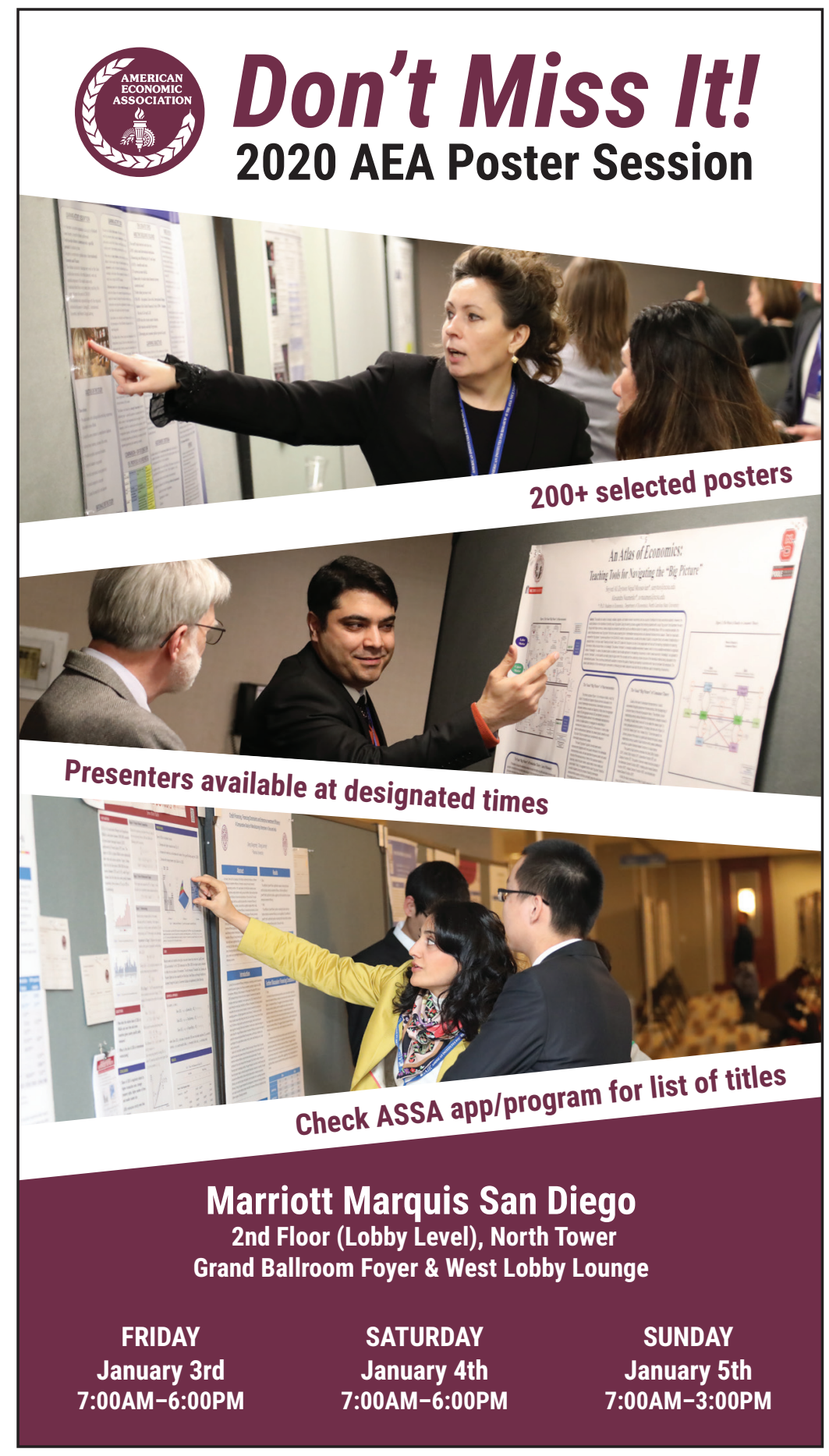




\section{FEC Call for Papers}

Frontiers of Economics in China (FEC) is a double-blind peer-reviewed economics journal edited at Shanghai University of Finance and Economics and published by Higher Education Press. With $600+$ institutional subscribers worldwide and indexed in $10+$ databases including EBSCO, EconLit, ESCI, ProQuest, RePEc and SCOPUS, the journal was ranked as one of "The Highest International Impact Academic Journals of China" in 2016. FEC welcomes submissions of theoretical and empirical papers from all fields of economics, particularly those with an emphasis on the Chinese economy and other emerging, developing or transition economies.

Editor: Guoqiang Tian, Texas A\&M University

Executive Editor: Zhiqi Chen, Carleton University

Co-Editors: Chunrong Ai, University of Florida

Kevin X. D. Huang, Vanderbilt University

Neng Wang, Columbia University

Quan Wen, University of Washington

\section{Selected Papers Published in 2019}

An Agenda for Reforming Economic Theory..........Joseph E. Stiglitz Where Are We in the Economics of Industrial Policies?...Dani Rodrik Research on the Education of Migrant Children in China: A Review of the Literature .........Yuanyuan Chen, Shuaizhang Feng, Yujie Han Multi-dimensional Product Differentiation

Qihong Liu, Jie Shuai

Tackle China's Economic Complexities by Deepening Reform and Opening Up: Macroeconomic Outlook, Policy Simulations, and Reform Implementation - A Summary of the Annual SUFE Macroeconomic Report (2018-2019)

Kevin X. D. Huang, Guoqiang Tian, Yuqin Wang

China's Growth Deceleration: Causes and Future Growth Prospect...... Justin Yifu Lin

Website: http://journal.hep.com.cn/fec Online Submission: http://mc.manuscriptcentral.com/fec 


\section{Harvard University Press}

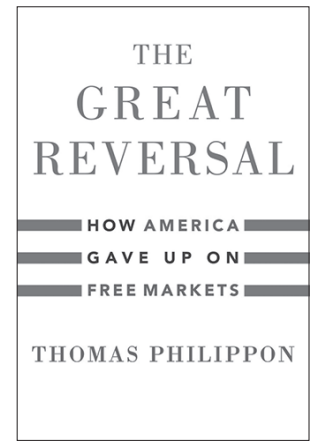

The Great Reversal

How America Gave Up on Free Markets

\section{Thomas Philippon}

Belknap Press \$29.95

Bloc by Bloc

How to Build a Global

Enterprise for the New

Regional Order

\section{Steven Weber}

$\$ 35.00$

Shadows of Doubt

Stereotypes, Crime, and the Pursuit of Justice

\section{Brendan O'Flaherty}

Rajiv Sethi

$\$ 27.95$

\section{Open}

The Progressive Case for Free Trade, Immigration, and Global Capital

\section{Kimberly Clausing}

$\$ 27.95$

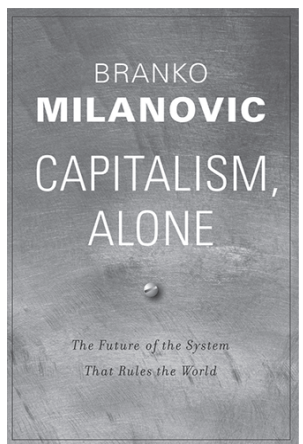

\section{Capitalism, Alone}

The Future of the System That Rules the World

\section{Branko Milanovic}

Belknap Press \$29.95

The Enchantments of Mammon

How Capitalism Became

the Religion of Modernity

\section{Eugene McCarraher}

Belknap Press \$39.95

VC

An American History

\section{Tom Nicholas}

$\$ 35.00$

Growth and

Distribution

Second Edition

\section{Duncan K. Foley}

Thomas R. Michl

Daniele Tavani

$\$ 60.00$

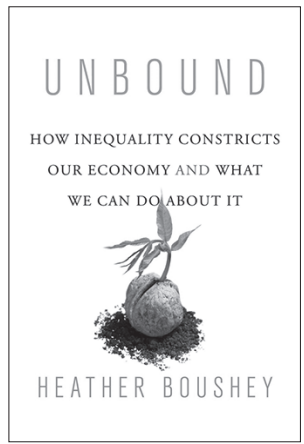

\section{Unbound}

How Inequality Constricts Our Economy and What We Can Do about It

\section{Heather Boushey}

$\$ 27.95$

\section{NEW IN PAPER}

The Great

Convergence

Information Technology and the New Globalization

\section{Richard Baldwin}

Belknap Press \$16.95

\section{Virtual Competition}

The Promise and Perils of the Algorithm-Driven Economy

\section{Ariel Ezrachi}

Maurice E. Stucke

$\$ 18.95$

\section{Finding Time}

The Economics of Work-Life Conflict

\section{Heather Boushey}

$\$ 17.95$ 


\section{Visit MF in Booth \#222}

\section{Global economic}

knowledge at your fingertips

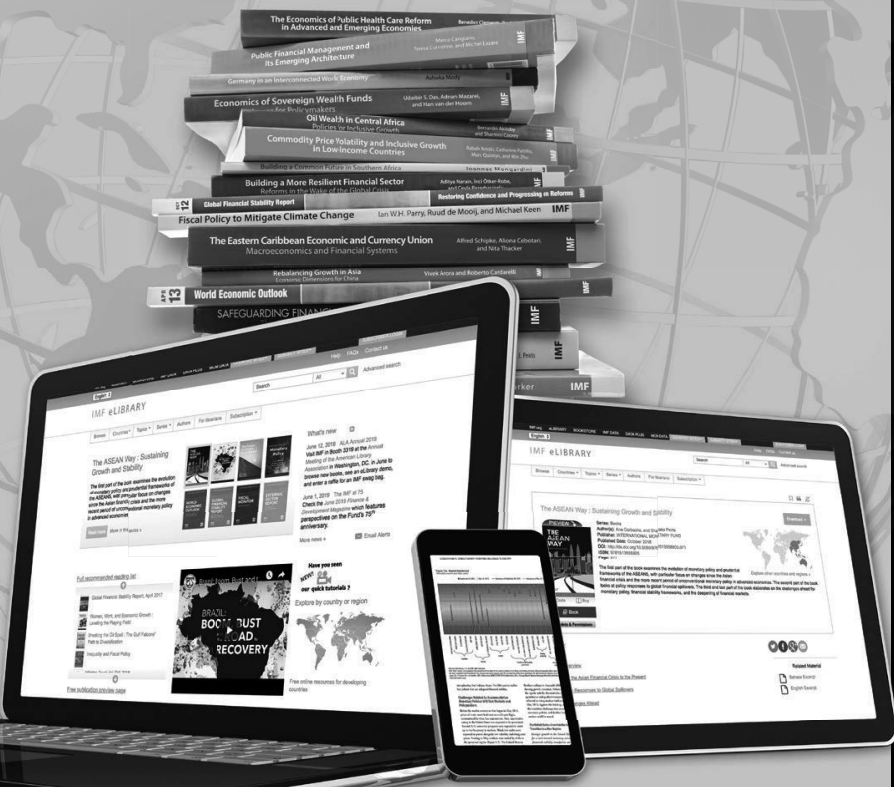

Browse new books and ask how to access free digital content elibraryolMForg 


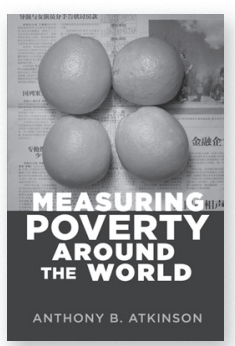

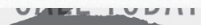

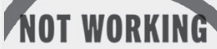

Where Have All the Good Jobs

Gone?

$\star$ DAVID G. $\star$ BLANCHFLOWER

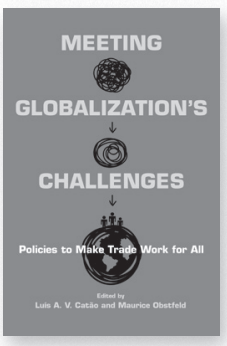

MARKETS, STATE, AND PEOPLE
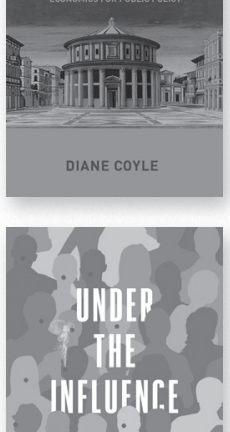

SHAPING THESOCIAL FORCLS THAT GUIDE OURCHOICES

Mobent H.FRAM

\section{NEW FROM PRINCETON}

Measuring Poverty around the World

Anthony B. Atkinson

Cloth $\$ 29.95$

\section{The Handbook of}

\section{Economic Development} and Institutions

Edited by Jean-Marie Baland, François

Bourguignon, Jean-Philippe Platteau, \& Thierry Verdier

Cloth $\$ 99.95$

\section{Taking the Floor}

Models, Morals, and

Management in a

Wall Street Trading Room

Daniel Beunza

Cloth $\$ 35.00$

\section{Not Working}

Where Have All the

Good Jobs Gone?

David G. Blanchflower

Cloth $\$ 29.95$

\section{Democratic Capitalism at the Crossroads}

Technological Change and the Future of Politics

Carles Boix

Cloth $\$ 27.95$

\section{Digital Cash}

The Unknown History

of the Anarchists, Utopians, and Technologists Who

Created Cryptocurrency

Finn Brunton

Cloth $\$ 26.95$

\section{Meeting}

\section{Globalization's}

\section{Challenges}

Policies to Make Trade

Work for All

Edited by Luís A. V. Catão

\& Maurice Obstfeld

With a foreword by

Christine Lagarde

Cloth $\$ 35.00$

\section{Markets, State, and People}

Economics for Public Policy

Diane Coyle

Cloth $\$ 39.95$

\section{Globalizing Capital}

A History of the International

Monetary System, Third Edition

Barry Eichengreen

Paper $\$ 29.95$
Under the Influence

Putting Peer Pressure

to Work

Robert H. Frank

Cloth $\$ 24.95$

The Technology Trap

Capital, Labor, and Power in the Age of Automation

Carl Benedikt Frey

Cloth $\$ 29.95$

\section{Going the Distance}

Eurasian Trade and

the Rise of the Business

Corporation, 1400-1700

Ron Harris

The Princeton Economic History

of the Western World

Cloth $\$ 39.95$

\section{Markets, Games,} and Strategic Behavior

An Introduction to

Experimental Economics,

Second Edition

Charles A. Holt

Cloth $\$ 85.00$

\section{Patient Capital}

The Challenges and Promises of Long-Term Investing

Victoria Ivashina \& Josh Lerner Cloth $\$ 29.95$

\section{Chicago Price Theory}

Sonia Jaffe, Robert Minton,

Casey B. Mulligan,

\& Kevin M. Murphy

Cloth $\$ 60.00$

\section{Patient Care}

under Uncertainty

Charles F. Manski

Cloth $\$ 39.95$

\section{Darkness by Design}

The Hidden Power in Global Capital Markets

Walter Mattli

Cloth $\$ 29.95$

The Wealth of Religions The Political Economy of Believing and Belonging

Rachel M. McCleary \& Robert J. Barro Cloth $\$ 29.95$

\section{The Code of Capital}

How the Law Creates

Wealth and Inequality

Katharina Pistor

Cloth $\$ 29.95$

(9) 

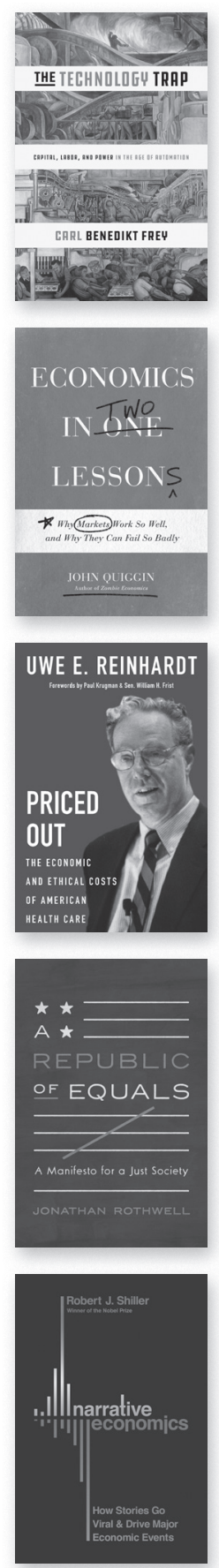

\section{Economics in Two Lessons}

Why Markets Work So Well, and Why They Can Fail So Badly

John Quiggin

Cloth $\$ 29.95$

\section{American Bonds}

How Credit Markets

Shaped a Nation

Sarah L. Quinn

Princeton Studies in American

Politics: Historical, International,

and Comparative Perspectives

Cloth $\$ 35.00$

\section{Priced Out}

The Economic and Ethical

Costs of American Health Care

Uwe E. Reinhardt

Forewords by Paul Krugman

\& Sen. William H. Frist

Cloth $\$ 27.95$

\section{A Republic of Equals}

A Manifesto for a Just Society

Jonathan Rothwell

Cloth $\$ 29.95$

\section{Narrative Economics}

How Stories Go Viral and Drive Major Economic Events

Robert J. Shiller

Cloth $\$ 27.95$

\section{New in Paper}

\section{The End of Theory}

Financial Crises, the Failure of Economics, and the Sweep

of Human Interaction

Richard Bookstaber

Paper $\$ 18.95$

\section{The Origins of Happiness}

The Science of Well-Being

over the Life Course

Andrew E. Clark, Sarah Flèche,

Richard Layard,

Nattavudh Powdthavee

\& George Ward

With a new preface by the authors

Paper $\$ 24.95$

\section{American Default}

The Untold Story of FDR, the Supreme Court, and the Battle over Gold

Sebastian Edwards

Paper $\$ 19.95$

\section{How Global Currencies Work}

Past, Present, and Future

Barry Eichengreen, Arnaud Mehl,

\& Livia Chițu

Paper $\$ 24.95$

\section{Beating the Odds}

Jump-Starting

Developing Countries

Justin Yifu Lin \& Célestin Monga

Paper $\$ 22.95$

\section{Adaptive Markets}

Financial Evolution at the Speed of Thought

Andrew W. Lo

With a new afterword

by the autho

Paper $\$ 22.9$

\section{The Nobel Factor}

The Prize in Economics,

Social Democracy, and the Market Turn

Avner Offer \& Gabriel Söderberg Paper \$27.95

\section{Efficiently Inefficient}

How Smart Money Invests and Market Prices Are Determined

Lasse Heje Pedersen Paper $\$ 24.95$

\section{Radical Markets}

Uprooting Capitalism and Democracy for a Just Society Eric A. Posner \& E. Glen Weyl

With a new foreword by

Vitalik Buterin \& Jaron Lanier and a new afterword by the authors Paper $\$ 18.95$

\section{Straight Talk on Trade}

Ideas for a Sane

World Economy

Dani Rodrik

Paper $\$ 18.95$

\section{Economics for the} Common Good

Jean Tirole

Paper $\$ 18.95$

\section{Unelected Power}

The Quest for Legitimacy

in Central Banking and the Regulatory State

Paul Tucker

With a new preface by the author Paper $\$ 24.95$

\section{Forthcoming March 2020}

Deaths of Despair and the Future of Capitalism

Anne Case \& Angus Deaton Cloth $\$ 29.95$ 


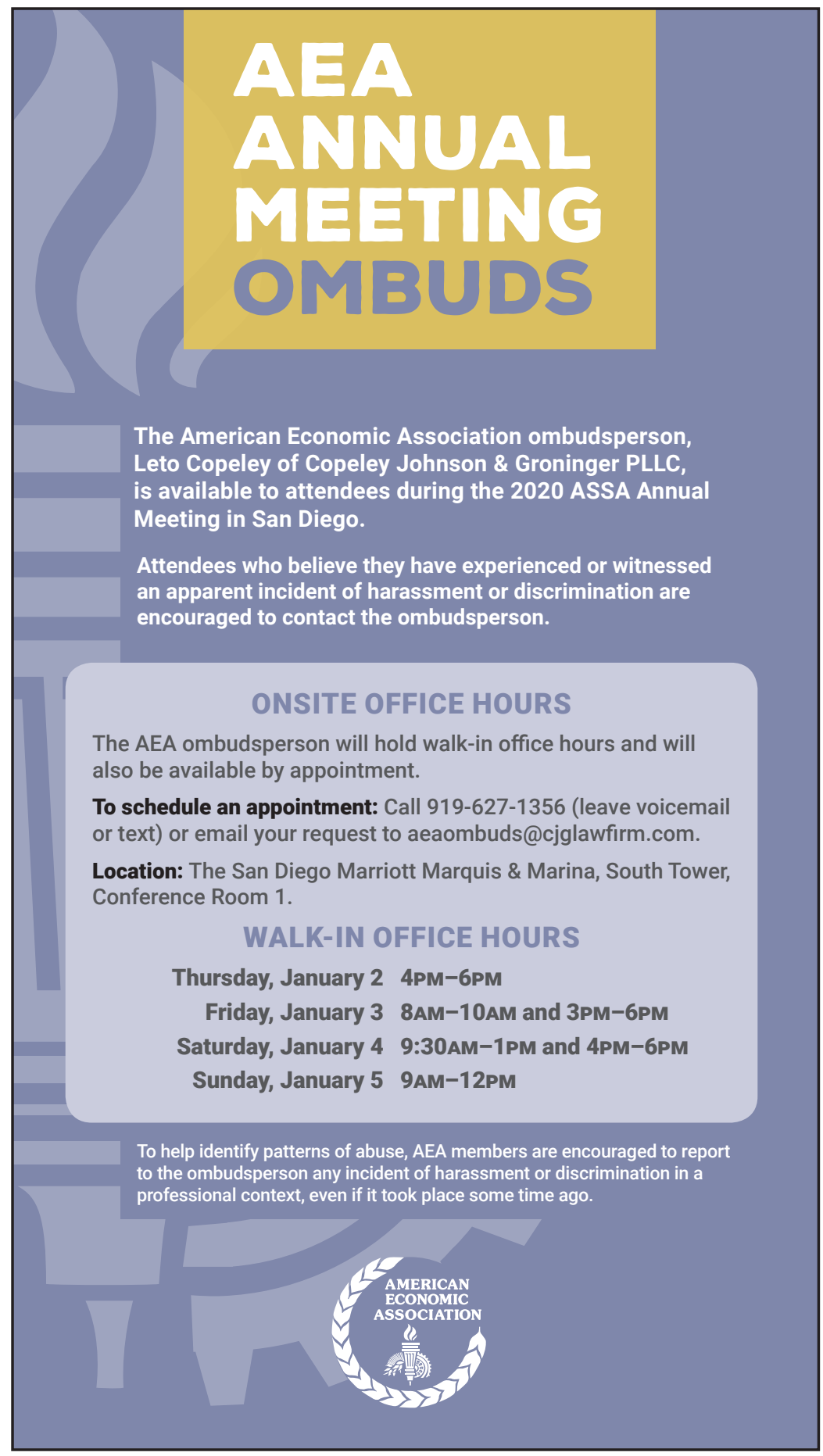




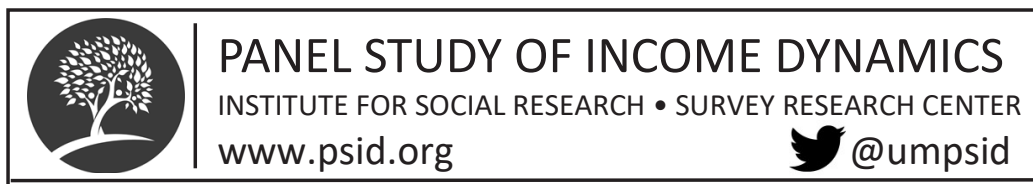

The Panel Study of Income Dynamics (PSID) is the world's longest running national household panel survey. Begun in 1968, the PSID has collected 41 waves of data from the same families and their descendants for over 50 years. More than 11,000 families participate in the PSID, including a refresher sample of new immigrant families added in 2017. Because PSID follows descendants of original sample members, it is a unique source for studying the intergenerational transmission of health and economic wellbeing.

\section{Current Questionnaire Content}

Employment \& Wages

Income \& Wealth

Expenditures

Education

Mortgage Distress \&

Foreclosures

Pensions

Philanthropy
Marriage \& Fertility

Health Status \& Behaviors

Health Insurance

Mortality

Program Participation

Computer \& Internet Use

Housing Characteristics

Time Use

Interested in learning more about PSID data? Please see our Getting Started page to learn about the study and sample, supplemental studies, and how to download data through our online Data Center.

\section{Child Development Supplement (CDS) \& Transition into Adulthood Supplement (TAS)}

-Measures of child/adolescent cognitive, physical, social and behavioral development as well as unique comprehensive national time-use information on children and youth of all ages.

Original CDS \& TAS: Three waves of CDS data on 3,500 children aged 0-12 from PSID families who were first interviewed in 1997, re-interviewed in 2002 at ages 5-18, and again in 2007 at ages 10-18.

- Six waves of TAS data were collected biennially from 2005-2015 for CDS young adults ages 18-28.

Ongoing CDS \& TAS: A new round of CDS (CDS-2014) with data from over 4,300 children and caregivers is now available. CDS-2019 is being collected in 2019-2020 from sample children ages 0-17.

- TAS-2017 has been released and the 8th wave of TAS is being collected in 2019-2020 from young adults ages 18-28 in all PSID families, regardless of Original or Ongoing CDS participation.

The vast majority of data are freely accessible through the web-based Data Center which provides customized datasets

Main sponsorship is provided by the National Science Foundation, the National Institute on Aging, and the Eunice Kennedy Shriver National Institute of Child Health \& Human Development 


\section{RUSSELL SAGE FOUNDATION}

New and Noteworthy Books in the Social Sciences

GOLDEN YEARS?

Social Inequality in Later Life

Deborah Carr

$\$ 35.00$ | January 2019

THE HANDBOOK OF RESEARCH SYNTHESIS AND META-ANALYSIS Third Edition

Harris Cooper, Larry V. Hedges, and Jeffrey C. Valentine, eds. $\$ 99.95$ | June 2019

IMMIGRATION AND THE REMAKING OF BLACK AMERICA Tod G. Hamilton $\$ 35.00$ | May 2019

ADMINISTRATIVE BURDEN Policymaking by Other Means

Pamela Herd and Donald P. Moynihan $\$ 37.50$ | December 2018

CYCLES OF SEGREGATION Social Processes and Residential Stratification Maria Krysan and Kyle Crowder $\$ 35.00$ | December 2017
THE GOVERNMENT-CITIZEN DISCONNECT

Suzanne Mettler

$\$ 29.95$ | June 2018

\section{WRECKED}

How the American Automobile Industry Destroyed Its Capacity to Compete Joshua Murray and Michael Schwartz $\$ 35.00$ | June 2019

STARVING THE BEAST

Ronald Reagan and the Tax Cut Revolution Monica Prasad

$\$ 35.00$ | November 2018

STATUS

Why Is It Everywhere? Why Does It Matter? Cecilia L. Ridgeway

$\$ 35.00$ | November 2019

HOMEWARD

Life in the Year After Prison

Bruce Western

$\$ 29.95$ | May 2018

CREDIT WHERE IT'S DUE Rethinking Financial Citizenship Frederick F. Wherry, Kristin S. Seefeldt, and Anthony S. Alvarez $\$ 29.95$ | April 2019

RSF: THE RUSSELL SAGE FOUNDATION JOURNAL OF THE SOCIAL SCIENCES

FREE online at rsfjournal.org

CHANGING JOB QUALITY: CAUSES, CONSEQUENCES, AND CHALLENGES David R. Howell and Arne L. Kalleberg, eds. I Volume 5, Issue 4 | September 2019 Cofunded with the W.K. Kellogg Foundation

IMPROVING EMPLOYMENT AND EARNINGS

IN TWENTY-FIRST CENTURY LABOR MARKETS

Erica L. Groshen and Harry J. Holzer, eds. | Volume 5, Issue 5 | Fall 2019

Copublished with the Alfred P. Sloan Foundation 


\section{COLLABORATE ON AN AEA \\ SESSION PROPOSAL}

Complete session

proposals have a higher acceptance rate than individual papers!

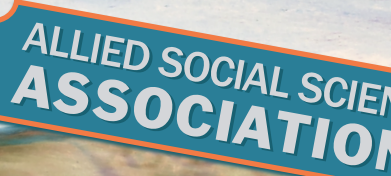

CONOAN ECONOMIC
ASSOCIATION EconHarmony OPENS FEBRUARY 1, 2020

www.aeaweb.org/econ-harmony 


\section{Society of Government Economists}

\section{www.sge-econ.org}

The Society of Government Economists (SGE) is a professional organization that provides conference, research, and publication opportunities to government economists and other researchers interested in public policy and economics. SGE promotes educational and scholarly exchange on the many facets of economic affairs, encourages the free exchange of ideas, and abides by ethical guidelines of our profession.

Professional activities include:

- SGE@ASSA - conference sessions are competitively selected for presentation at the January ASSA meetings

- Seminars on current policy topics in Washington, DC

- Collaborative activities with National Economists Club

- SGE Annual Conference in Washington DC

\section{SGE Annual Conference}

March 27, 2020

US Bureau of Labor Statistics' Conference Center Washington, DC

See call for papers at

\section{www.sge-econ.org}

Deadline for abstract submission is February 1, 2020.

Students attend for free.

Contact conferencechair@sge-econ.org for more information.

SGE is a nonprofit 501(c)3 and membership-supported organization based in Washington, DC. SGE does not tolerate harassment or discrimination in any of its activities and abides by the AEA Code of Professional Conduct. 


\section{STANFORD UNIVERSITY PRESS}

\section{ENJOY 30\% OFF ALL SUP TITLES ON DISPLAY IN THE EXHIBIT HALL}

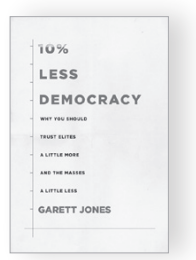

10\% Less Democracy

Why You Should Trust Elites a Little

More and the Masses a Little Less

Garett Jones

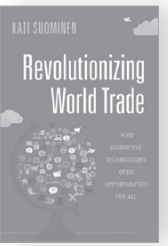

Revolutionizing World Trade

How Disruptive Technologies Open

Opportunities for All

Kati Suominen

EMERGING FRONTIERS IN THE

GLOBAL ECONOMY

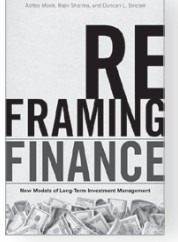

Reframing Finance

New Models of Long-Term

Investment Management

Ashby Monk, Rajiv Sharma, and

Duncan L. Sinclair

NOW IN PAPERBACK

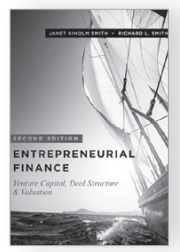

Entrepreneurial Finance

Venture Capital, Deal Structure E

Valuation, Second Edition

Janet Kiholm Smith and

Richard L. Smith

MEASURING

SOCIAL

Measuring Social Change

Performance and Accountability in a

Complex World

Alnoor Ebrahim

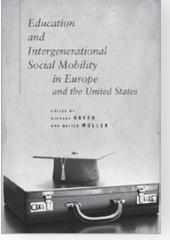

Education and Intergenerational

Social Mobility in Europe

and the United States

Edited by Richard Breen and

Walter Müller

STUDIES IN SOCIAL INEQUALITY 


\section{Upjohn Institute Publications}

\section{Making Sense of Incentives}

Taming Business Incentives to Promote Prosperity

Timothy J. Bartik

*A WEfocus book

Strengths of the Social Safety Net in the Great Recession Supplemental Nutrition Assistance and Unemployment Insurance

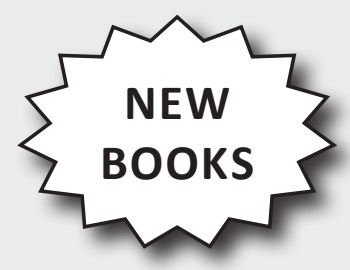

Christopher J. O'Leary, David Stevens, Stephen A. Wandner, and Michael Wiseman, editors

Food Stamps and the Working Poor Peter Mueser, David Ribar, and Erdal Tekin

\section{Pathways to Careers in Health Care} Christopher T. King and Philip Young P. Hong, editors
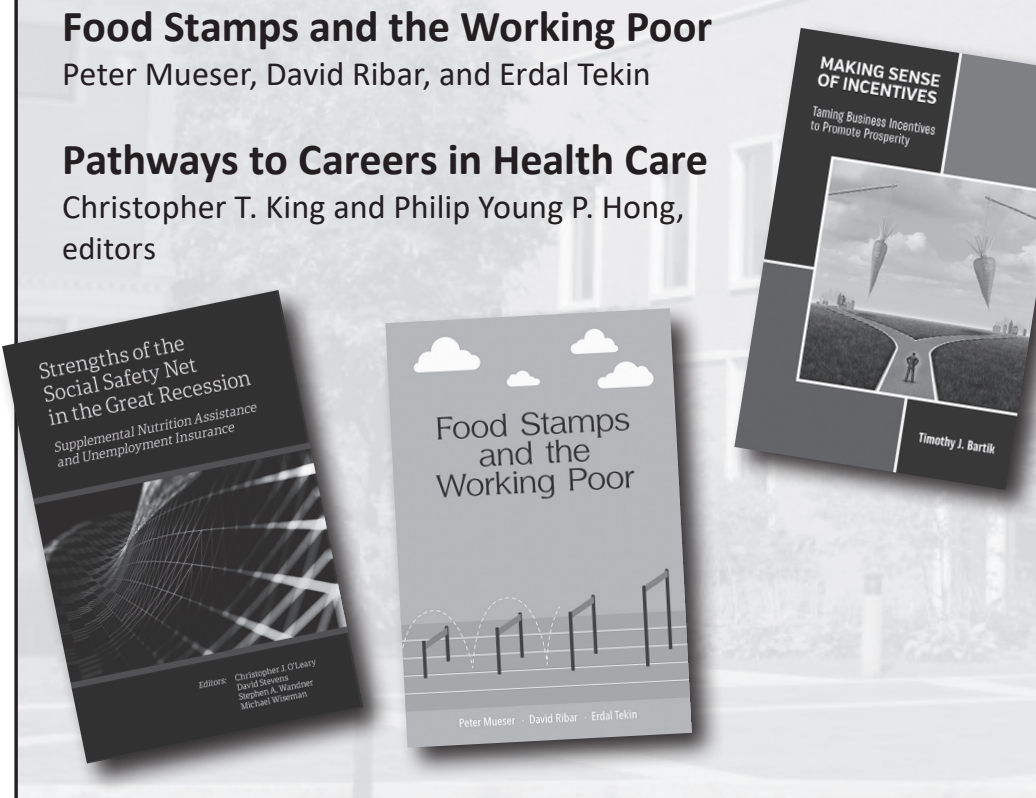

*WEfocus books are available for free download at https://research.upjohn.org.

W.E. Upjohn Institute Publications (888) 227-8569 • https://www.upjohn.org Booth 309 publications@upjohn.org @UpjohnInstitute 


\section{Dissertation Award Winners}

The W.E. Upjohn Institute for Employment Research is pleased to announce the winner of its annual Dissertation Award:

\section{Sydnee Caldwell}

Massachusetts Institute of Technology

"Essays on Imperfect Competition

in the Labor Market"

Advisor: Daron Acemoglu

\section{HONORABLE MENTION}

\author{
Sarah Bana \\ University of California, \\ Santa Barbara \\ "Three Essays on \\ Vulnerable Workers" \\ Advisor: Peter Kuhn
}

\author{
Giulia Giupponi \\ London School of Economics \\ and Political Science \\ "Essays in Labor \\ and Public Economics" \\ Advisor: Camille Landais
}

The establishment of this award further pursues the mission of the Upjohn Institute: to support and conduct policy-oriented research on issues related to employment and unemployment. Dissertations were judged by a panel of economists on the basis of policy relevance, technical quality of research, and presentation.

\section{PRIZES}

The winner of the W.E. Upjohn Institute Dissertation Award receives a prize of $\$ 2,500$. The honorable mention recipients each receive a $\$ 1,000$ prize.

\section{DEADLINE}

The deadline for submission for the 2020 W.E. Upjohn Institute for Employment Research Dissertation Award is July 6, 2020. Any individual whose dissertation has been accepted during the 24-month period of July 1,2018 , to June 30,2020 , is eligible for the 2020 prize. Contact the Institute for more information.

W.E. Upjohn Institute for Employment Research 300 South Westnedge Ave., Kalamazoo, Michigan 49007-4686 communications@upjohn.org Phone (269) 343-5541 • https://www.upjohn.org 


\section{ECONOMICS JOURNALS FROM CHICAGO}

$\star$ NEW TO CHICAGO IN 2020

AMERICAN JOURNAL of HEALTH ECONOMICS

journals.uchicago.edu/ajhe | Published for ASHEcon

\section{$\star$ NeW JOURNal IN 2020}

ENVIRONMENTAL and ENERGY POLICY and the ECONOMY journals.uchicago.edu/eepe | Published for NBER

ECONOMIC DEVELOPMENT and CULTURAL CHANGE journals.uchicago.edu/edcc

INNOVATION POLICY and the ECONOMY

journals.uchicago.edu/ipe

JOURNAL Of HUMAN CAPITAL

journals.uchicago.edu/jhc

JOURNAL of LABOR ECONOMICS

journals.uchicago.edu/jole

The JOURNAL of LAW and ECONOMICS

journals.uchicago.edu/jle

$\star$ PUBLISHING 12 ISSUES/YYEAR BEGINING IN 2020

JOURNAL of POLITICAL ECONOMY

journals.uchicago.edu/jpe

JOURNAL of the ASSOCIATION of

ENVIRONMENTAL and RESOURCE ECONOMISTS

journals.uchicago.edu/jaere

MARINE RESOURCE ECONOMICS

journals.uchicago.edu/mre

NBER MACROECONOMICS ANNUAL

journals.uchicago.edu/ma

SUPREME COURT ECONOMIC REVIEW

journals.uchicago.edu/scer

TAX POLICY and the ECONOMY

journals.uchicago.edu/tpe

\section{THE UNIVERSITY OF CHICAGO PRESS JOURNALS}

Save $20 \%$ on new individual subscriptions with promo code ASSA20. Offer expires 3/31/20. Discounts apply to new individual subscriptions. Taxes \& shipping may apply. 


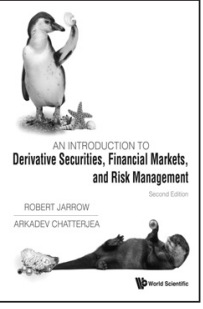

by Robert Jarrow

(Cornell University, USA) \&

Arkadev Chatterjea (Indiana

University Bloomington, USA)

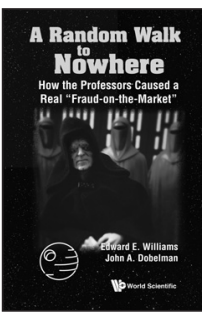

by Edward E Williams, John A Dobelman

(Rice University, USA)

Jan 2020 | 978-981-120-835-5(pbk) US\$28 / £25

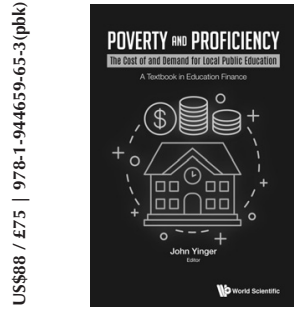

edited by John Yinger

(Syracuse University, USA)

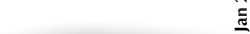
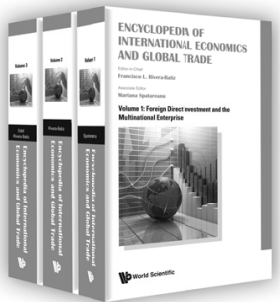

Editor-in-chief:

Francisco L Rivera-Batiz

(Columbia University, USA) Editors: Mariana Spatareanu (Rutgers University, USA) \& Can Erbil (Boston College, USA)

Mar 2020 | 978-981-120-053-3 | US\$980/ $£ 860$

Introductory Offer till May 31, 2020 Introductory Offer till Dec 31, 2020 US\$850 / $\mathbf{E 7 5 0}$

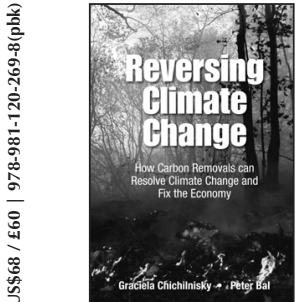

by Graciela Chichilnisky (Columbia University, USA) \& Peter Bal (Millemont Institute, USA

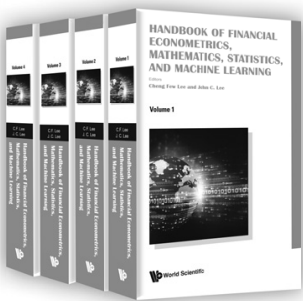

Editors: Cheng Few Lee (Rutgers University, USA) \& John C Lee (Center for PBBEF Research, USA)

Mar 2020 | 978-981-120-238-4 US\$1950/£1715

US\$1399 / £1230

* Discount code cannot be used in conjunction with any other ongoing promotions.

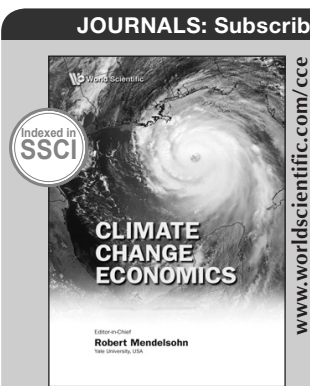

Editor-in-Chief Robert Mendelsohn (Yale University, USA)

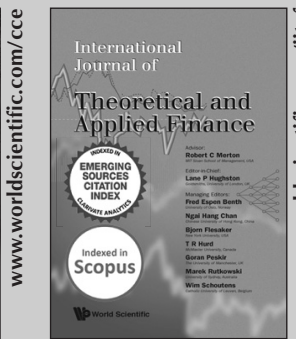

Editor-in-Chief: Lane P Hughston (Goldsmiths College,

University of London, UK)

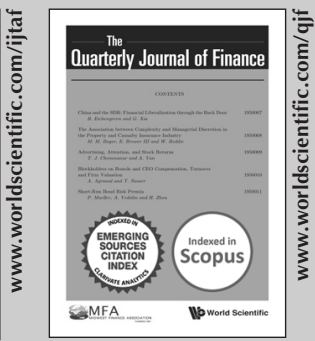

Editors: Jean Helwege (University of California, Riverside, USA) \& Fernando Zapatero (University of Southern California, USA) 

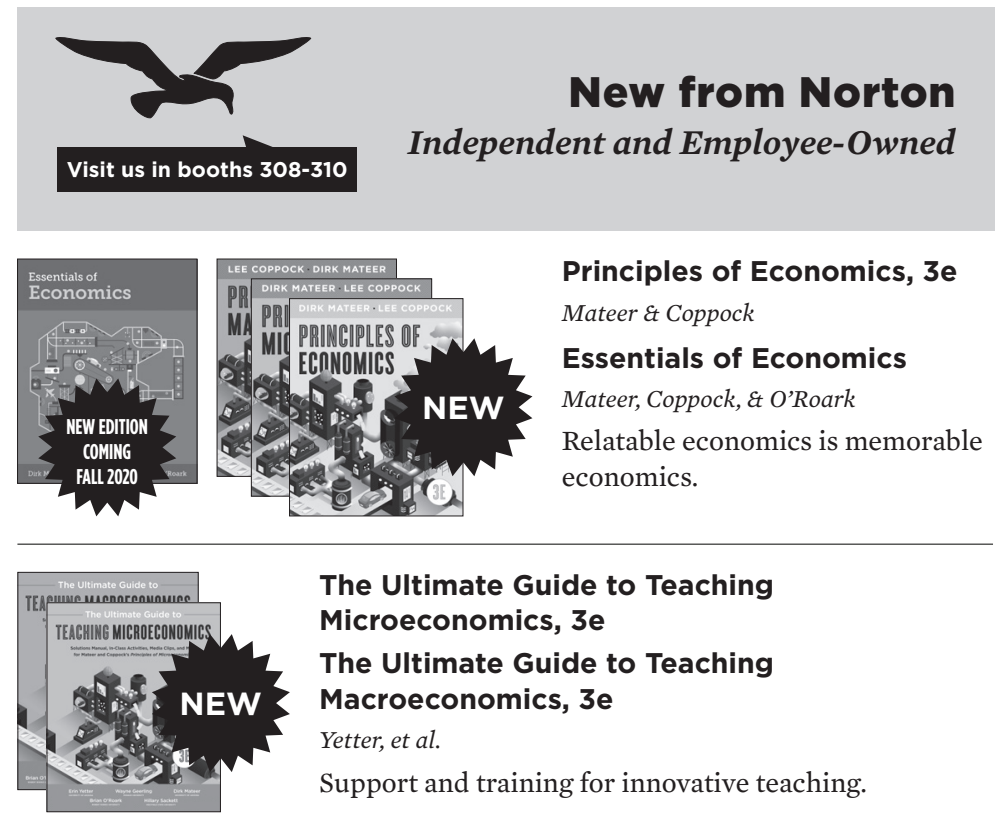

The Ultimate Guide to Teaching Microeconomics, $3 e$

The Ultimate Guide to Teaching

Macroeconomics, $3 e$

Yetter, et al.

Support and training for innovative teaching.

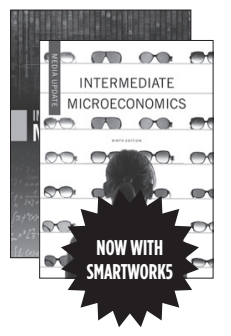

Intermediate Microeconomics, 9e, Media Update Intermediate Microeconomics with Calculus, Media Update

Varian

Now supported by Smartwork 5 online homework and Graphing Interactives (included with the purchase of any Media Update Edition).

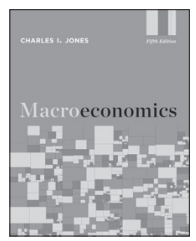

\section{NEW!}

Macroeconomics, 5 e

Jones

Modern and practical macroeconomics.

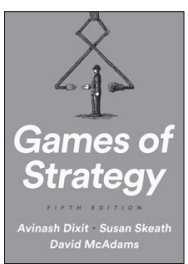

NEW! Games of Strategy, 5e Dixit, Skeath, McAdams Comprehensive, clear, and approachable, with examples that motivate students.

\section{JET SET \\ Be a part of the JET SET! \\ January 24-25 - Le Meridien, New Orleans, LA \\ Norton and the Journal of Economic Teaching present the 2020 Symposium on Economics Teaching.}




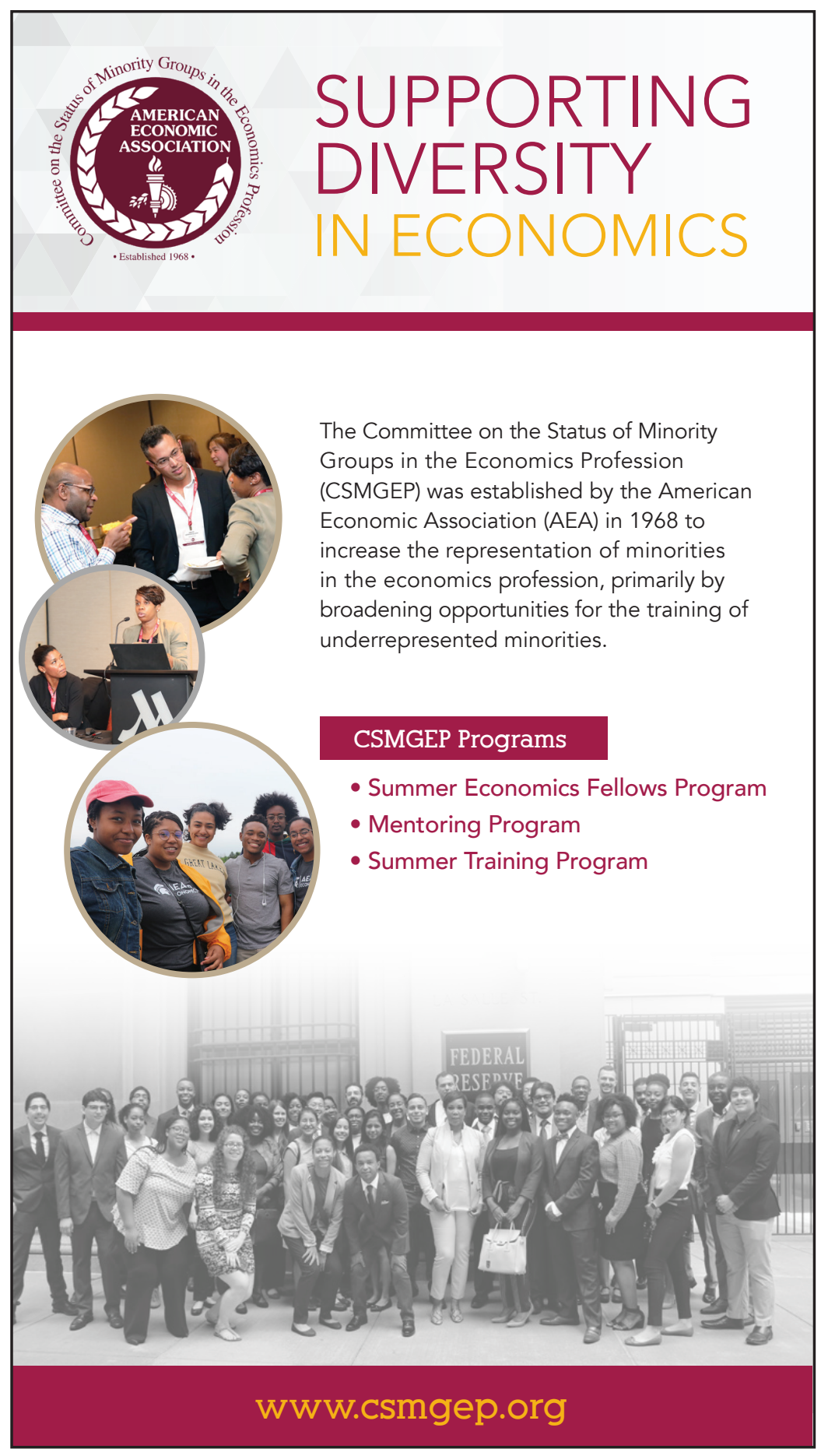




\section{Yale UnIVERSITY PRESS}
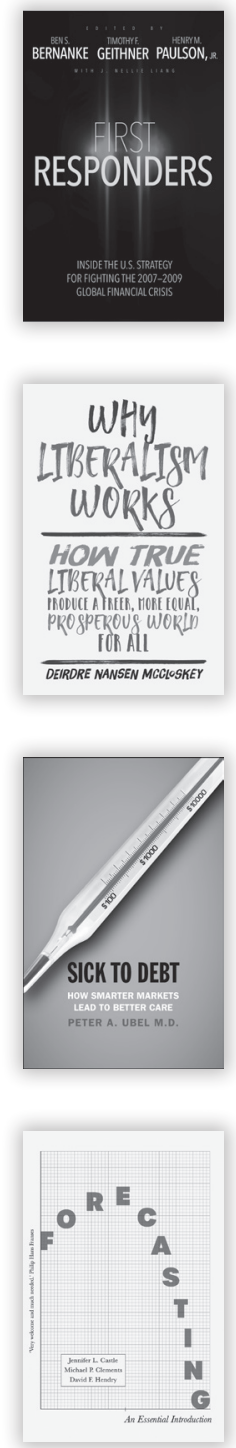

First Responders

Inside the U.S.

Strategy for Fighting

the 2007-2009 Global

Financial Crisis

Edited by

Ben S. Bernanke,

Timothy F. Geithner,

and Henry M. Paulson,

Jr., with J. Nellie Liang

\section{Economists}

Photographs by

Mariana Cook

Edited with an

introduction by

Robert M. Solow

Why Liberalism

\section{Works}

How True Liberal

Values Produce a

Freer, More Equal,

Prosperous World

for All

Deirdre Nansen

McCloskey

What's Wrong with

Economics?

A Primer for the

Perplexed

Robert Skidelsky

\section{Sick to Debt}

How Smarter Markets Lead to Better Care

Peter A. Ubel, M.D.

\section{Russia's Crony \\ Capitalism}

The Path from Market

Economy

to Kleptocracy

Anders Åslund

\section{Forecasting}

An Essential

Introduction

Jennifer Castle,

Michael Clements and

David Hendry
Software Rights

How Patent Law

Transformed Software

Development in

America

Gerardo Con Diaz

\section{A Better Planet}

Forty Big Ideas for a

Sustainable Future

Edited by Daniel C. Esty

Foreword by

Ingrid C. Burke

\section{Free Enterprise}

An American History

Lawrence B. Glickman

The Underground

On the Capitalist

Origins of Silver

Mining, A.D.

1150-1450

Jeannette Graulau

Yale Series in Economic and Financial History

\section{Willful}

How We Choose What We Do

Richard Robb

How We Cooperate

A Theory of Kantian

Optimization

John E. Roemer

The Marginal

Revolutionaries

How Austrian

Economists Fought

the War of Ideas

Janek Wasserman

FORTHCOMING

IN 2020

\section{Slowdown}

The End of the Great

Acceleration-and

Why It's Good for the

Planet, the Economy,

and Our Lives

Danny Dorling
Trade Wars Are Class Wars

How Rising

Inequality Distorts

the Global Economy

and Threatens

International Peace

Matthew C. Klein and

Michael Pettis

\section{New Money}

Currency, Community, and the Future of

Payment

Lana Swartz

NOW IN PAPERBACK

\section{Twilight of the}

\section{Elites}

Prosperity, the Periphery, and the

Future of France

Christophe Guilluy

Translated from

the French by

Malcolm DeBevoise

With a new preface

\section{They Were Her}

Property

White Women as

Slave Owners in the

American South

Stephanie E.

Jones-Rogers

\section{Red Flags}

Why Xi's China Is in Jeopardy

George Magnus

\section{Money and}

\section{Government}

The Past and Future of Economics

Robert Skidelsky

\section{The Fragile Middle}

\section{Class}

Americans in Debt

Teresa A. Sullivan,

Elizabeth Warren,

and Jay Lawrence

Westbrook

With a new preface 


\section{AMERICAN FINANCE ASSOCIATION}

\section{Publisher of The Journal of Finance

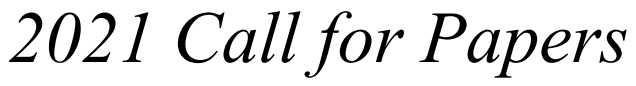

The Annual Meeting of the American Finance Association will be held January 35, 2021 in Chicago, Illinois. Papers presented at the Annual Meeting traditionally include both submitted papers and papers solicited by the session chairs in order to promote both broad participation and a high quality program. I encourage you to submit your best paper for this meeting.

Submissions must be made by March 15, 2020, via the program website, which is accessed from a link on the Annual Meeting page at www.afajof.org. The paper submission website will open in mid-February. Authors of selected papers will be notified by May 31 .

All papers must be accompanied by an abstract of at least 200 words, but no more than 600 words. All papers must be submitted as PDF files. Complete papers will be given preference, but extended abstracts of several pages may also be submitted. Please include in your submission the emails, phone numbers and addresses for every author.

Note: Submitted papers should not have been accepted for publication. The author submitting the paper to the Annual Meeting must be a member of the American Finance Association for the paper to be considered. To enable wider participation, please submit only one paper and do not submit the same paper to other associations that meet at the same time as the AFA/ASSA.

\section{John Graham}

Program Chair of the 2021 Meeting

of the American Finance Association
Fuqua School of Business

Duke University

Durham, NC 27708 


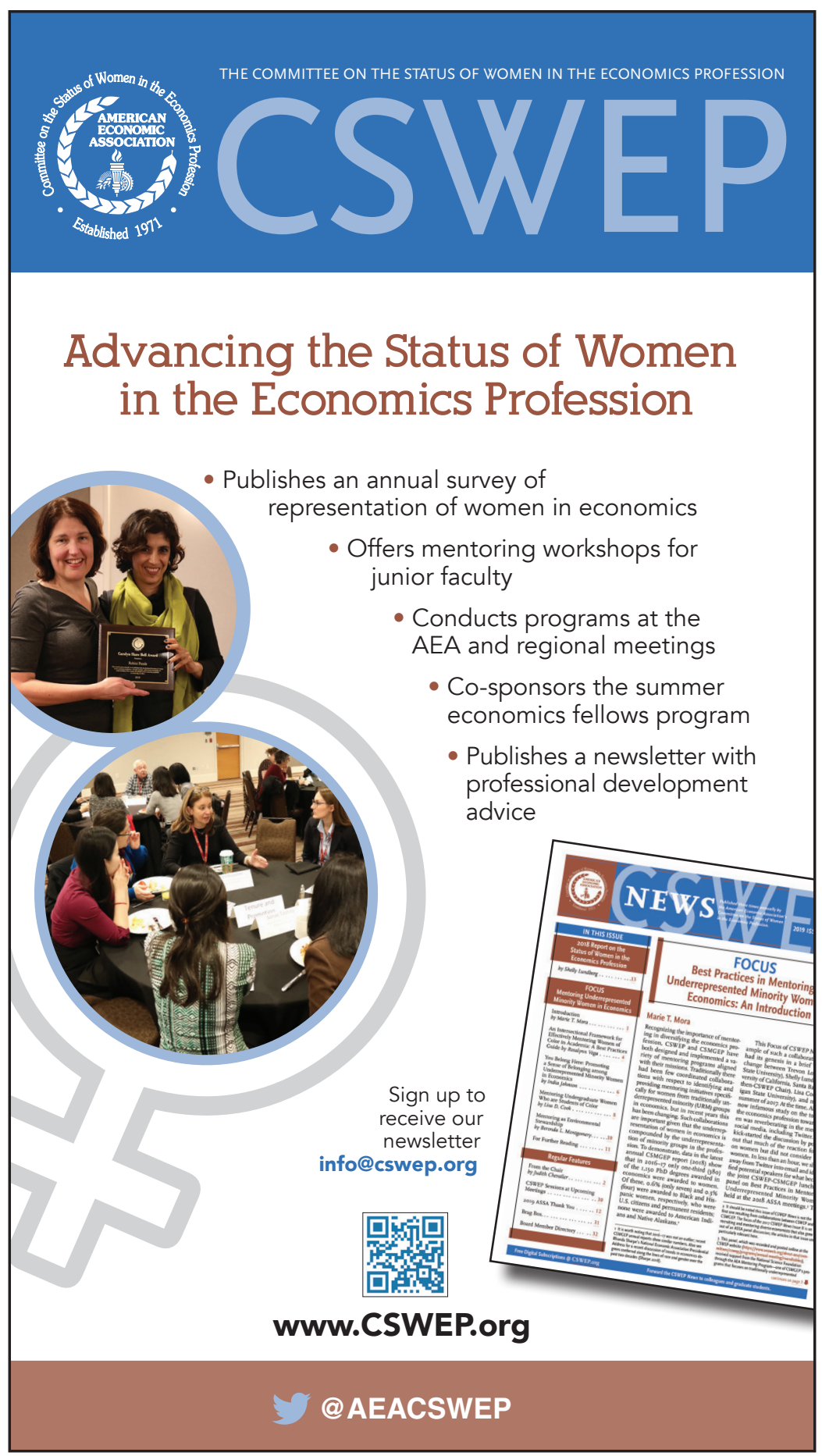




\section{$12^{\text {th }}$ World Congress of the Econometric Society 17 - 21 AUGUST 2020 Bocconi University, Milano, Italy}

Bocconi University, located in Milano, is delighted to invite you to participate in the $12^{\text {th }}$ World Congress of the Econometric Society, which will feature the work and findings of the leading scholars in theoretical and applied economics and in econometrics and provide an excellent forum to present your own research results.

For all information regarding the Congress, paper submission and registration, please visit www.eswc2020.org

PROGRAM CHAIRS

Victor Chernozhukov MIT Johannes Hörner Yale University Eliana La Ferrara Bocconi University

\section{- IMPORTANT DATES}

15 November 2019 Paper Submission Opens

31 January 2020 Paper Submission Closes

31 March 2020 Notification of Paper Outcome

30 April 2020 Early Registration Deadline

Deadline for Presenting Authors

17 August 2020 Congress Begins

21 August 2020 Congress Ends

\section{Join the conversation!}

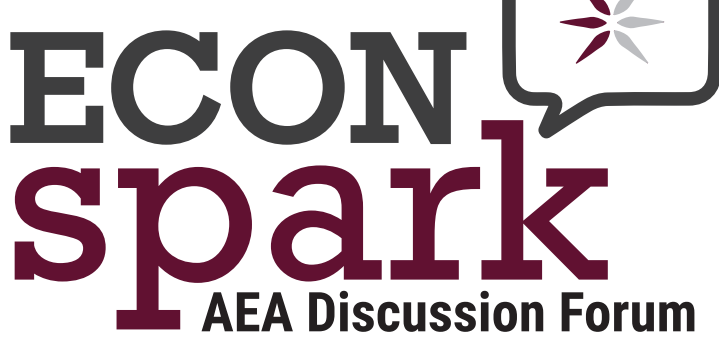

www.aeaweb.org/econspark 


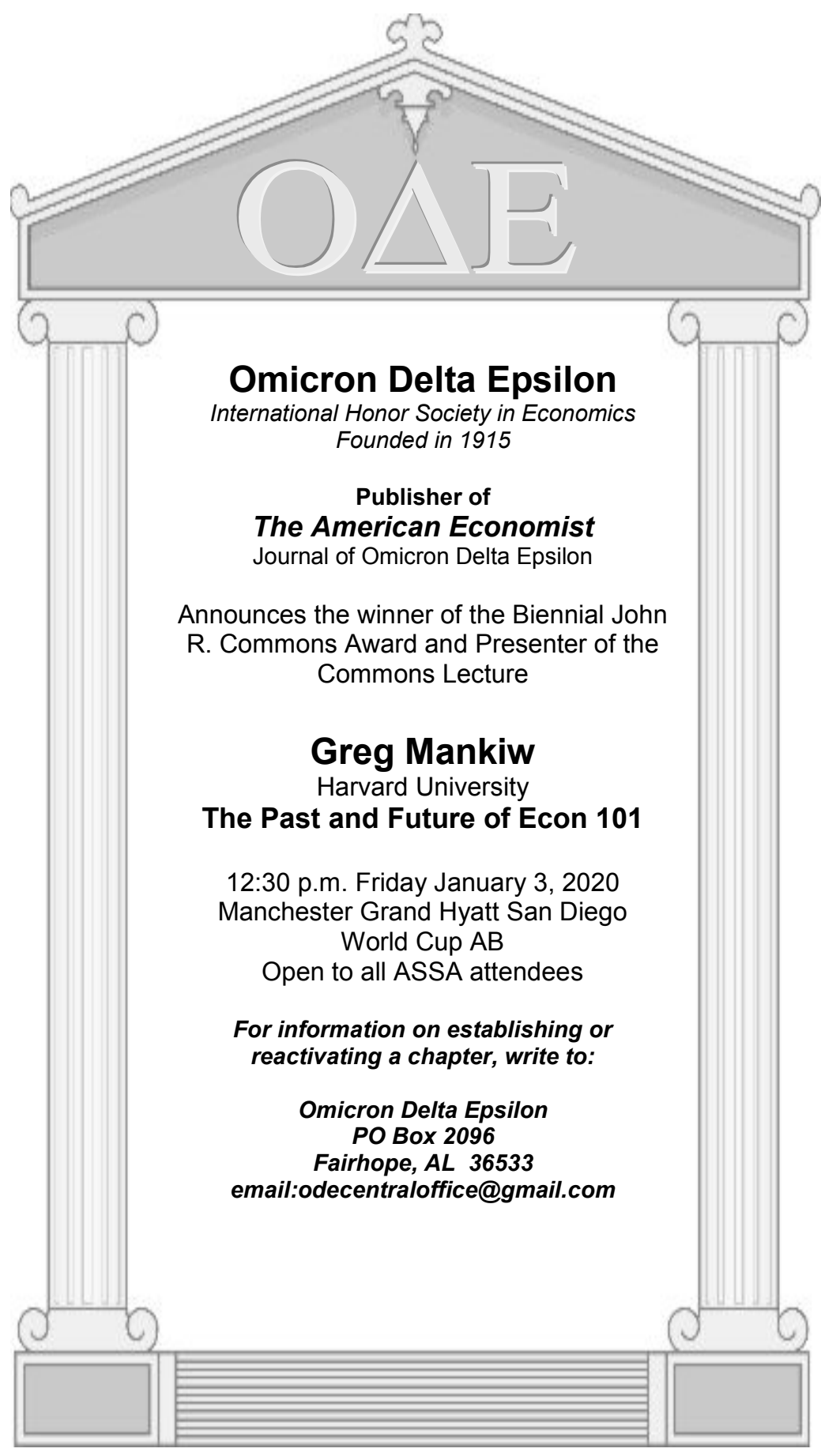




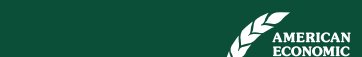 ECONOMIC
ASSOCIATION

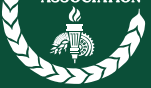 \\ MICHIGAN STATE \\ UN IVERS I TY \\ AEA SUMMER TRAINING \& SCHOLARSHIP PROGRAMS}

\section{May 28-July 26, 2020}

Intensive 2-month

residential program

Two levels of study

Targeted training in math, microeconomics, econometrics, and research methods

Presented in collaboration with

Western Michigan University
"The program is a catapult to success."

Patrick Collard AEASP 2018

"I love watching the AEASP students gain confidence and get inspired about the possibilities of their future careers in Economics." AEASP 2019

\section{APPLICATION DEADLINE: January 31, 2020}

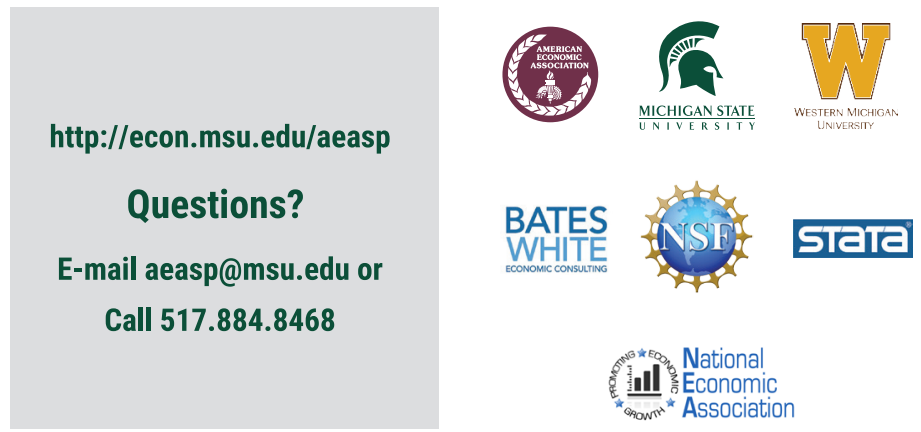




\section{Set Students Up for Success with Mankiw, 9E}

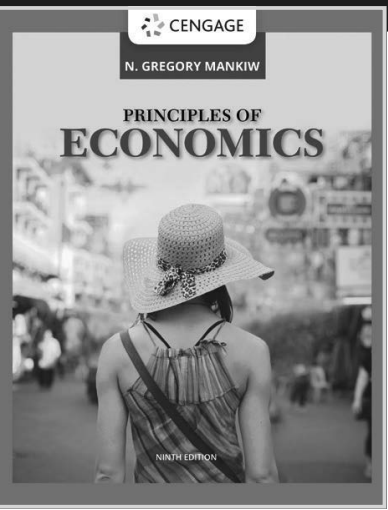

Mankiw's market leading introductory text continues to set the standard in Principles of Economics courses, thanks to its clear, accessible prose and focused content. Now in its 9th edition, it continues to help students build a strong understanding of Economics concepts - the ideal foundation for future success in and out of the classroom.

\section{MINDTAP}

MindTap, the leading online solution for the Mankiw texts, now comes with MobLab at no additional charge. This exciting partnership offers students access to games and experiments that immerse them in higher-concept learning activities.

\section{OSENGAGE UNLIMITED}

MINDTAP | WEBASSIGN | OPENNOW | SAM | CNOW ${ }^{\mathrm{v} 2}$ | OWL $\mathrm{OW}^{\mathrm{v} 2}$

Even better: your Economics students can access all the aboveand more-for one price with Cengage Unlimited. Students subscribe and save on all their Cengage online textbooks, platforms and study tools, including Mankiw's 9th edition and MindTap.

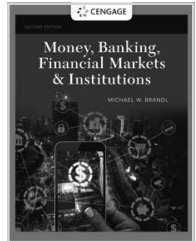

\section{Also in a New Edition} this Semester:

Money, Banking, Financial Markets \& Institutions, 2e Brandl 


\section{Western Economic Association International \\ weai.org}
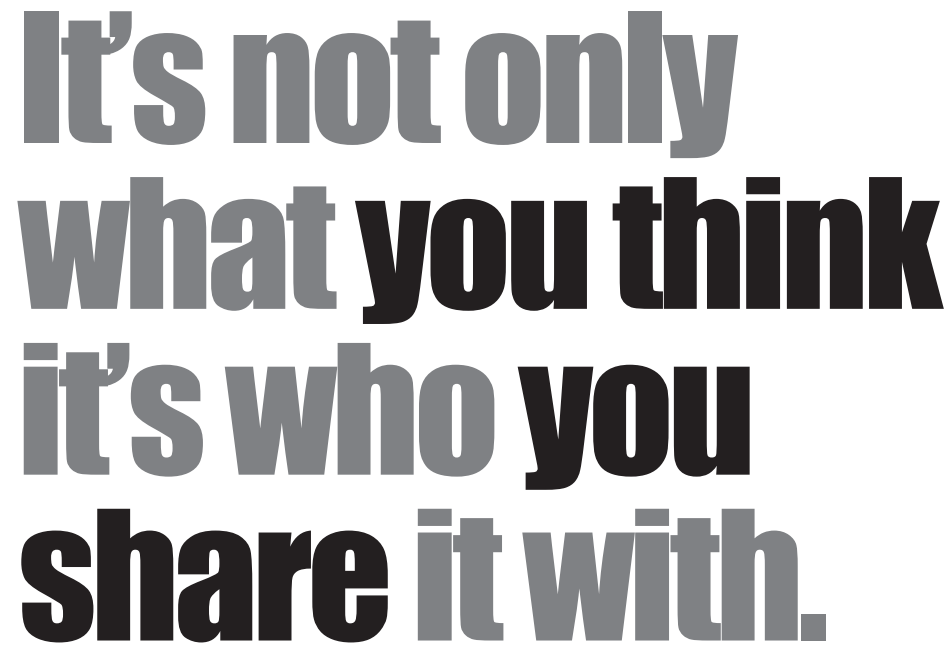

\section{Contemporary Economic Policy}

Published since 1982, CEP features research and analysis on issues of vital concern to business, government, and other decision makers.

\section{Economic Inquiry}

A general-interest journal published since 1962, EI authors include over 20 Nobel Laureates. Its Editorial Board features highly-regarded specialized field co-editors.

\section{Allied Societies}

Whether your group is longestablished or simply part of an emerging specialty, WEAI can help bring your members together and increase your visibility within the discipline.
Upcoming Conferences

Present or Discuss a Paper, Organize or Chair a Session

- 16th International Conference Shanghai, March 19-22, 2020

- 95th Annual Conference Denver, Colorado June 26-30, 2020

Upcoming sites include Honolulu, Melbourne, Portland, San Diego, Seattle, and more.

\section{Graduate Student Workshop}

Sixteen top Ph.D. candidates selected each year for hands-on experience in job-market paper presentation skills and interview techniques. 


\section{EDL China Data Instifute}

Booth: 508

http:// chinadatacenter.net/ http:// china-data-online.com/

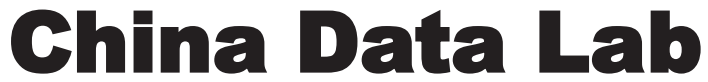

The New Platform for China Studies http://chinadatalab.net

*

$*$

*

\section{China Data Online Statistics - Census - GIS}

The China Data Online has a new look with many new features:

- Statistical Datasheets provides about 270,000 statistical tables from all provincial yearbooks and some other sources with full text search function and metadata.

- Census Maps covers more than 7 million census maps with data by province, city, county or even township, including population census 2000 and 2010, economic census 2004 and 2008, basic unit census 2001, and industrial census 1995.

- Statistical Charts provides a rich collection of statistical charts for those monthly and yearly statistics at country, province, prefecture city and county levels with full text search function and metadata.

- Updated data in China Geo-Explorer, including yearly statistics, census data, land use and night-time light data. 